UNIVERSIDADE DE SÃO PAULO

FACULDADE DE FILOSOFIA, LETRAS E CIÊNCIAS HUMANAS

DEPARTAMENTO DE HISTÓRIA

PROGRAMA DE PÓS-GRADUAÇÃO EM HISTÓRIA SOCIAL

LUIZ CARLOS VILLALTA

Reformismo Ilustrado, Censura e Prática de Leitura:

Usos do Livro na América Portuguesa 
UNIVERSIDADE DE SÃO PAULO

FACULDADE DE FILOSOFIA, LETRAS E CIÊNCIAS HUMANAS

DEPARTAMENTO DE HISTÓRIA

PROGRAMA DE PÓS-GRADUAÇÃO EM HISTÓRIA SOCIAL

\title{
Reformismo Ilustrado, Censura e Prática de Leitura: Usos do Livro na América Portuguesa
}

Luiz Carlos Villalta

\begin{abstract}
Tese apresentada ao Programa de Pós-Graduação em História Social do Departamento de História da Faculdade de Filosofia, Letras e Ciências Humanas da Universidade de São Paulo, para a obtenção do título de Doutor em História.
\end{abstract}

Orientador: Profa. Dra. Laura de Mello e Souza

São Paulo

1999 


\section{Resumo}

\section{Reformismo Ilustrado, Censura e Prática de Leitura: Usos do Livro na América Portuguesa}

Esta tese propõe-se a investigar os usos do livro na América Portuguesa, fazendo referências também a Portugal. Embora concentre-se nos anos compreendidos entre 1750 e 1822, para compreender as especificidades deste mesmo período, recua quando necessário ao século XVI. Primeiramente, apresenta um quadro das referências culturais e dos alvos de ataque da censura portuguesa e dos leitores no período do Reformismo Ilustrado: de um lado, as teorias corporativas de poder da Segunda Escolástica, os milenarismos e o anti-cientificismo e, de outro, a Ilustração e, ainda, as linhas gerais do Reformismo Ilustrado português, de Pombal ao Príncipe Regente D. João VI. Em segundo lugar, focaliza a atuação da censura e da Coroa em relação aos livros, isto é, os usos prescritos e interditados, avaliando os parâmetros censórios e suas modificações sob o Reformismo Ilustrado; acompanhando as práticas de controle e, inversamente, de difusão que afetaram a circulação e a posse de livros; e, ainda, examinando as concessões de licença para a leitura de livros proibidos. Por fim, aborda os usos do livro no mundo luso-brasileiro, através da análise da distribuição da posse de livros e da composição das bibliotecas; depois, da identificação das concepções de uso formuladas pelos próprios leitores; e, em seguida, examinando as práticas de leitura que acompanharam a formulação de proposições heréticas e, de forma mais particularizada, a Conjuração de Minas Gerais, avaliando os pesos respectivos da influência das Luzes e de outras referências culturais.

PALAVRAS-CHAVE: Reformismo Ilustrado; Censura; Bibliotecas; Práticas de Leitura Brasil-Portugal, 1750-1822. 


\section{Abstract \\ Enlightened Reformism, Censorship and Reading Practices: The Uses of Books in Portuguese America}

This thesis proposes a research about the uses of books in Portuguese-America with reference to Portugal also. Although it concentrates in the years between 1750 and 1822, it goes back to the sixteenth Century to understand particular characteristics of the later period. Firstly, it presents a series of cultural references and some practices of the Portuguese censorship with readers during the period of the Enlightened Reformism. On one hand, there were the corporate theories of power from the Second Scholastic, the millennium beliefs and the anti-scientificism, and, on the other hand, the Enlightenment and the main characteristics of the Portuguese Enlightened Reformism, since the rule of marquis of Pombal until that of the Regent Prince D. João VI. Secondly, it focuses on the practices censorship and the Crown in relation to books - that is, the prescribed and prohibited use which evaluated the parameters that established censorship and their modifications under the Enlightened Reformism. Also it accompanies the controlling practices and the diffusion practices that affected the circulation and the possession of books and examines the concession of licenses for the reading of prohibited books. Finally, it incorporates the uses of books in the Portuguese-Brazilian world through, the analysis, lastly, of the distribution of the possession of books and the composition of libraries and the conceptions identified and formulated by the readers themselves. Concluding, the practices that accompanied the formulation of heretic proposals and the Inconfidência Mineira are examined and specifically the different influences of the Enlightenment and other cultural influences.

KEYWORDS: Enlightened Reformism; Censorship; Libraries; Reading Practices Brazil-Portugal, 1750-1808. 


\section{Luiz Carlos Villalta}

\section{Reformismo Ilustrado, Censura e Práticas de Leitura: Usos do Livro na América Portuguesa}

Tese de Doutoramento apresentada ao Departamento de História da Faculdade de Filosofia, Letras e Ciências Humanas da Universidade de São Paulo.

Orientadora: Prof ${ }^{\mathrm{a}}$. Dra ${ }^{\mathrm{a}}$. Laura de Mello e Souza

São Paulo

Universidade de São Paulo

Faculdade de Filosofia, Letras e Ciências Humanas

Departamento de História

1999 
Tese de Doutorado defendida e aprovada em 12 de agosto de 1999, pela banca examinadora constituída pelos professores:

$\overline{\text { Prof }^{\mathrm{a}} \text {. Dr }}{ }^{\mathrm{a}}$. Laura de Mello e Souza (Orientadora)

Prof $^{\mathrm{a}}$. Dr ${ }^{\mathrm{a}}$. Marisa Lajolo (Unicamp)

Prof ${ }^{\mathrm{a}}$. Dra ${ }^{\mathrm{a}}$. Lúcia Bastos Pereira das Neves (UERJ)

Prof. Dr. Fernando Antônio Novais (USP)

Prof $^{\mathrm{a}}$. Dr ${ }^{\mathrm{a}}$. Eni de Mesquita Samara (USP) 
Ao meu avô, Francisco de Faria, e a meus pais, Milton e Alba, com quem descobri o prazer de ler os livros e o mundo

Para Laura, sempre minha mestra

Ao meu irmão Kico e aos amigos-leitores Dora, Fábio, Fernanda, Ítalo, João e Lucinha 


\section{Agradecimentos}

Em primeiríssimo lugar, gostaria de registrar meus agradecimentos à $\operatorname{Prof}^{\mathrm{a}} \operatorname{Dr}^{\mathrm{a}}$ Laura de Mello e Souza, orientadora e amiga, que não poupou esforços no sentido de incentivar a consecução desta tese, abrindo-me caminhos e oportunidades, bem como sugerindo-me rumos, retificações e ricos veios a serem explorados. À Prof ${ }^{a}$ Laura, devoto imensa gratidão - ao que se soma a profunda admiração -; devo-lhe, com a mais absoluta certeza, todos os acertos desta tese; seu trabalho, por fim, constituiu um paradigma que sempre tive no horizonte.

Quero agradecer também ao Professor Doutor Luís Reis Torgal, da Faculdade de Letras da Universidade de Coimbra, cujas sugestões precisas guiaram-me no mundo dos livros e das leituras em Portugal, fornecendo-me informações valiosas a respeito de fontes, bibliografia e, ainda, revendo com minúcia o meu projeto de pesquisa.

À CAPES, sou grato pela bolsa do PICD. Ao Professor Dr. José Jobson Arruda e à Cátedra Jaime Cortesão, do Instituto de Estudos Avançados da USP e do Instituto Camões, quero agradecer muitíssimo pelo auxílio que me foi concedido durante dois meses em Portugal. À administração da UFOP, nas pessoas das professoras Célia Maria Fernandes Nunes, chefe do departamento de Educação; Deisa Chamahum Chaves, vice-diretora do ICHS; Heliana Maria Brina Brandão, Diretora do mesmo instituto; e do professor Danton Heleno Gameiro, pró-reitor de pesquisa e pós-graduação, devo auxílios para estadias em Lisboa e Paris.

Sou muitíssimo grato às professoras Ana Maria de Almeida Camargo e Raquel Glezer, que me iniciaram na pesquisa histórica e que me distinguiram com sua sapiência no exame de qualificação, trazendo-me críticas e sugestões para a conclusão da tese. Tenho débitos enormes também com os professores Carlos Alberto Lombardi Filgueiras (IQUFRJ), Lúcia Maria Bastos Pereira das Neves (UERJ), Luiz Mott (Universidade Federal da Bahia), Rita Marquilhas (Faculdade de Letras, Universidade de Lisboa), Guilherme Pereira das Neves (UFF), Alcir Pécora (IEL-UNICAMP), Márcia Abreu (IEL-UNICAMP), István Jancsó (FFLCH-USP), Heloísa Helena de Jesus Paulo (Universidade Fernando Pessoa, do Porto), Bruno Feitler (doutorando na Ecole des Hautes Etudes en Sciences Sociales (EHESS), Marisa Lajolo (IEL-UNICAMP), João Adolfo Hansen (FFLCH-USP), David Higgs (University of Toronto), Júnia Furtado (FAFICH-UFMG), Carla Anastasia (FAFICH-UFMG), Olímpia Maria Loureiro (Universidade Portucalense), José de Oliveira (Universidade Portucalense), João Luís Lisboa (Universidade Nova de Lisboa), Maria Beatriz Nizza da Silva (FFLCH-USP e Universidade Portucalense); Luciano Raposo de Almeida Figueiredo (UFF), Maria da Guia Barata, Tânia Bessone (UERJ), José Guilherme Ribeiro (UFOP), Adriana Romeiro (UFMG), Marina Massimi (USP-Ribeirão Preto), Glória Guiné de Mello Carvalho (UFOP), Maria Lúcia Jacob Dias de Barros (FALE-UFMG), Álvaro de Araujo Antunes, Anete e João Alves Alegria. Rita Marquilhas e Márcia Abreu, além de indicarem inúmeros textos, de fornecerem e de lerem meus escritos, abriram-me as portas da Europa: a primeira, com sua generosidade lusitana, "adotou-me" prontamente, tornando a estadia na "Corte" portuguesa motivo de saudades permanentes; a segunda, introduziu-me na Torre do Tombo e, juntamente com Antônio Macedo, amenizou os tons opressivos da imponência de Paris num final de inverno. João Luís Lisboa, Olímpia Loureiro, Marina Massimi e Maria da Guia Barata ofereceram-me gentilmente suas teses e escritos, o mesmo fazendo com suas publicações os professores Carlos Filgueiras, Lúcia e Guilherme Pereira das Neves e Marisa Lajolo, referências fundamentais para o meu trabalho. Rita Marquilhas e Heloísa Helena de Jesus Paulo socorreram-me quando, já iniciada a redação, constatei que havia algumas lacunas na pesquisa, exigindo novamente um retorno às fontes. Alcir Pécora muito gentilmente solucionou minhas dúvidas sobre Vieira e passou-me indicações bibliográficas. E István Jancsó instruiu-me sobre a 
Inconfidência Baiana, indicando-me caminhos e cedendo-me generosamente muitos artigos e livros. Júnia Furtado, Carla Anastasia, Lúcia P. das Neves e Luiz Mott passaram-me transcrições de fontes e inúmeros textos. Lúcia Pereira das Neves, ademais, foi minuciosa leitora, acompanhando muito de perto a feitura desta tese, sendo à finalização da mesma indissociável de suas contribuições. Maria Beatriz Nizza da Silva encorajou-me vivamente na fase conclusiva da tese. Bruno Feitler ofereceu-me gentilmente inúmeras informações inéditas sobre a censura inquisitorial, colhidas no Instituto dos Arquivos Nacionais da Torre do Tombo. Glória Guiné de Mello Carvalho e Lúcia Jacob auxiliaram-me na tradução, respectivamente, de textos em inglês e francês. Álvaro Antunes leu a versão final da tese; Lúcia Jacob corrigiu pacientemente as citações em francês. Anete e João Alegria, anfitriões tão gentis no Rio de Janeiro, desdobraram-se para fotocopiar uma tese.

Ao longo de todo o processo de feitura desta tese, alguns parentes e amigos foram fundamentais, pelo que muito lhes agradeço. Meus pais, Milton e Alba, e os amigos Maria Lúcia Jacob Dias de Barros, Ítalo Brener de Carvalho e Maria Auxiliadora Vieira de Carvalho ajudaram-me em ínumeros momentos e souberam compreender minhas ausências e falhas. Mariana de Campos Mendonça foi um apoio inestimável na fase da redação. Arnaldo Franco Júnior, amigo querido de tantos anos, fez-se sempre presente. Fábio Faversani, Yara Caetano e Ana Maria Pechilo Faversani hospedaram-me em São Paulo, contemplando-me com demonstrações de afeto e consideração por quase um ano. Dulce Leiria, Isabel Leiria e Ivo Castro, os dois últimos professores da Faculdade de Letras da Universidade de Lisboa, cederam-me um apartamento nos Olivais Norte, em Lisboa. Heloísa Helena de Jesus Paulo, com seu coração generoso, hospedou-me em várias circunstâncias em Coimbra e pôs-me a par do mundo acadêmico luso.

Fábio Faversani, João Pinto Furtado e Fernanda Borges de Moraes foram solidários em incontáveis momentos, interlocutores sempre de plantão, consultores para todos os assuntos. Íris Kantor e Andréa Lisly Gonçalves mostraram-se leitoras ávidas e disponíveis. Os brasileiros Rogério Ribas, Bruno Feitler, Helen Osório, Janaína Amado, Márcia Abreu, Priscilla Leal Mello e Caio Boschi; e os portugueses Luís Antunes e Francisco José da Silva Gomes, foram companheiros de pesquisa na Torre do Tombo, compartilhando descobertas acadêmicas, muitos risos, deliciosos pastéis de nata, boemias e algumas angústias. Ana Luísa Janeiro (Faculdade de Ciências da Universidade de Lisboa) abriu-me às portas do CICTSUL (Centro Interdisciplinar de Ciência, Tecnologia e Sociedade da Universidade de Lisboa). Ida Lewkovicz, amiga de todas as horas, acompanhou de perto todo o processo de pesquisa e elaboração da tese, dando-me sempre seu inestimável apoio e trazendo-me alegria nos momentos mais difíceis.

Sou grato também aos funcionários do Instituto dos Arquivos Nacionais da Torre do Tombo - Dra. Célia, Dra. Albertina, Dr. Penteado e donas Bárbara, Augusta, Gertrudes, Céu, Lucinda, Margarida, Paula e Cândida - ; do Arquivo da Casa Setecentista de Mariana - Kátia Napoleão e Vânia Santos —; da Biblioteca do Palácio Episcopal de Mariana; do Instituto de Estudos Brasileiros da USP - Maritália, Flora, Diva, Izilda, amigas desde meus tempos de graduação - e ao Monsenhor Flávio Carneiro Rodrigues, diretor do Arquivo Episcopal da Arquidiocese de Mariana.

Por fim, quero agradecer vivamente a Natália Guiné de Mello Carvalho pela revisão técnica das notas e da bibliografia e aos orientandos de iniciação científica e auxiliares de pesquisa Maria do Carmo Pires, Sônia Maria de Magalhães, Margareth Veisac Marton, Maria Tereza Gonçalves Pereira, Karla Leal Luz e Taciana Bodega Tavares. Devo, ainda, agradecimentos especiais, a Rosimeire Chagas de Assis e Karla Leal Luz pelos seus préstimos como digitadoras. A Roberval Araújo e Coreen Jacobs agradeço pela tradução do resumo para o inglês. 


\section{SUMÁRIO}

Introdução

13

\section{Parte I}

Usos do Livro sob o Reformismo Ilustrado: parâmetros e alvos

Cap. 1 - Teorias Corporativas de Poder, Milenarismos e Anti-Cientificismo

1. Segunda Escolástica e Teorias Corporativas de Poder 24

2. Milenarismos e anti-cientificismo 37

2.1 Anti-cientificismo 40

2.2 Milenarismos cristãos na Europa e América: das origens ao século XVIII 47

2.3 Milenarismos cristãos no mundo ibero-americano 53

2.4 Milenarismo, Segunda Escolástica e realismo: o padre Antônio Vieira 61

2.5 Gusmão, o "Voador", e Rocha Pitta: eruditos milenaristas no Setecentos 74

Cap. 2 - A Ilustração 78

1. Luzes: história, origens sociais e idéias 78

2. Portugal e "Brasil" na ótica da Ilustração Européia 95

Cap. 3 - O Reformismo Ilustrado Português 110

1. Luzes, Catolicismo, Tradições e Luís Antônio Verney 111

2. Reinado Josefino e Reformismo Ilustrado 115

3. Sob Dona Maria I e D. João 123 


\section{Parte II}

Usos prescritos e interditados: a Censura

Cap. 4 - A Censura sob o Reformismo Ilustrado

146

1. Antecedentes: a Censura Tríplice (1517-1768) 146

2. Reformas do Aparato Censório (1768-1808) 154

3. Parâmetros de Censura e Obras Proibidas 162

Cap. 5 - O Controle e a Difusão da Circulação e da Posse de Livros

1. Linhas Gerais 191

2. Censura Tríplice e Fiscalização 193

3. Fiscalização e Difusão de Livros sob o Reformismo Ilustrado 201

3.1 Alfândegas e Entrada de Livros 202

3.2 Autoridades Coloniais e Posse de Livros 216

Cap. 6 - As Licenças para Posse e Leitura de Livros Proibidos 226

1. Regras de concessão 226

2. Limites e possibilidades da documentação 228

3. Práticas de concessão 234

3.1 Clérigos, leigos e tipos de licenças 236

3.2 Tipos de licenças e proibições mantidas e suspensas 240

3.3 Regalias, origem e perfil dos beneficiários em sua variação no tempo $\quad 254$

\section{Parte III}

Usos do Livro pelos Leitores: Leitura e Ordem Religiosa e Política

Cap. 7 - Dos Usos em Geral à Inventividade e à Heresia

1. Do Medo ao Prestígio do Saber 276

2. Posse e composição das bibliotecas na América: usos implícitos dos livros 281

$\begin{array}{ll}2.1 \text { Séculos XVI e XVII } & 281\end{array}$ 
3. Utilidades dos livros, no dizer dos leitores luso-brasileiros 311

4. Leituras inventivas e heresia 319

4.1 Antecedentes Quinhentistas e Seiscentistas na América 319

4.2 Luzes e proposições heréticas e iconoclastas no mundo luso-brasileiro $\quad 330$

Cap. 8 - Leituras e Inconfidência Mineira (1789) 362

1. Historiografia e Inconfidência: das Luzes à Lusitânia 363

2. Tensões e perspectivas sob Dona Maria I: apropriações possíveis 367

3. Escritos Inconfidentes: das "potências" aos "atos" 375

4. Leituras da Conjuração 384

4.1 Boêmias literárias $\quad 384$

4.2 Apropriações sediciosas dos livros e das histórias 390

4.3 "Modo[s] de se fazerem os levantes" 398

$\begin{array}{ll}\text { Conclusões } & 410\end{array}$

$\begin{array}{ll}\text { Fontes Primárias e Bibliografia } & 417\end{array}$

$\begin{array}{ll}\text { Fontes manuscritas } & 418\end{array}$

$\begin{array}{ll}\text { Fontes impressas } & 424\end{array}$

$\begin{array}{ll}\text { Bibliografia } & 428\end{array}$

Artigos e Capítulos de livros $\quad 428$

$\begin{array}{ll}\text { Livros e Teses } & 437\end{array}$ 


\section{Lista de Tabelas}

Tabela I - Posse de Livros no Rio de Janeiro (1751-1822) 285

Tabela II - Posse de Livros em Mariana (1714-1822) 287 


\section{Lista de Figuras}

Gráfico I - Requerimentos para Leitura de Livros Proibidos 230

Gráfico II - Provisões de Licenças (1775-1794) 232

Gráfico III - Requerimentos e Licenças para Leitura de Livros Proibidos (1770-1808) 235

Gráfico IV - Licenças dadas a Clérigos (1770-1808) 237

Gráfico V - Licenças dadas a Leigos (1770-1808) 237

Gráfico VI - Tipos de Provisões dadas a Clérigos (1775-1794) 238

Gráfico VII - Tipos de Provisões dadas a Leigos (1775-1794) 239

Gráfico VIII - Proibições Fixadas em Editais e de Obras Mantidas (M) e Suspensas (S) nas Provisões (1770-1771) e Licenças (1772-1790) 243

Gráfico IX - Proibições Fixadas em Editais e de Obras Mantidas (M) e Suspensas (S) $\begin{array}{ll}\text { nas Provisões (1775-1777) } & 248\end{array}$

Gráfico X - Proibições Fixadas em Editais e de Obras Mantidas (M) e Suspensas (S) nas Provisões de Licença (1790-1794) 251

Gráfico XI - Tipos de Licenças dadas nos Requerimentos (1770-1808) e Provisões $\begin{array}{ll}(1770-1771) & 255\end{array}$

Gráfico XII - Tipos de Licenças Registrados nos Livros de Provisões (1775-1794) 256

Gráfico XIII - Evolução da Posse de Livros entre Inventariados de Mariana (1714-1822) 291 


\section{ABREVIATURAS}

ACSM - Arquivo da Casa Setecentista de Mariana

ADBA - A Inconfidência da Bahia - Devassas e Seqüestros

ADIM - Autos de Devassa da Inconfidência Mineira

ADRJ - Autos de Devassa - Prisão dos Letrados do Rio de Janeiro (1794)

AEAM - Arquivo Episcopal da Arquidiocese de Mariana

AN - Arquivo Nacional do Rio de Janeiro

APM - Arquivo Público Mineiro (Belo Horizonte)

BN - Biblioteca Nacional (Rio de Janeiro)

BNL - Biblioteca Nacional (Lisboa)

BPM - Biblioteca do Palácio Episcopal de Mariana (Museu do Livro)

IANTT - Instituto dos Arquivos Nacionais da Torre do Tombo (Lisboa) 


\section{INTRODUÇ̃̃O}

Esta tese de doutoramento inscreve-se no campo do que hoje se denomina história do livro e das práticas de leitura. Tendo como seus maiores expoentes na atualidade Roger Chartier e Robert Darnton, esse campo vem chamando a atenção de inúmeros outros historiadores e também de pesquisadores de diferentes áreas, mormente sob o prisma da literatura, ou da lingüística, ou ainda da educação, todos eles engajados na construção de uma história do livro e da leitura. No exterior, dentre os estudiosos que se voltam para o livro e a leitura na Época Moderna, podem-se citar historiadores como Carlo Ginzburg e Natalie Zemon Davis e, mais precisamente em Portugal, a lingüista Rita Marquilhas. No Brasil, às historiadoras Maria Beatriz Nizza da Silva, Lúcia Maria B. P. das Neves, Tânia Bessone Ferreira e Leila Mezan, juntam-se às pesquisadoras da literatura Marisa Lajolo, Regina Zilberman e Márcia Abreu.

Dessa produção acadêmica sobre o livro e as práticas de leitura, emerge um elemento mais ou menos comum, sintetizado com muita clareza por Roger CHARTIER: a compreensão de que a história dos livros e da leitura requer que se focalize atentamente a tensão entre o poder do livro sobre o leitor e a liberdade e inventividade deste último na produção de sentidos no contato com os textos ${ }^{1}$. Assim, Robert DARNTON, em sua "história dos livros", interessa-se pelo circuito de comunicação que vai do autor ao editor (ou ao livreiro), ao impressor, ao distribuidor, ao vendedor e chega ao leitor, o qual encerra o circuito (na medida em que o autor, o ponto de partida, também é um leitor) ${ }^{2}$. Cada fase deste processo, suas inter-relações e o processo como um todo, em suas variações no tempo e no espaço, e em suas relações com outros sistemas (econômico, social, cultural, político), constituem objeto de interesse da história dos livros. No Brasil, Maria Beatriz Nizza da SILVA adota posição bastante similar, pois toma o livro como fato social — isto

\footnotetext{
${ }^{1}$ CHARTIER, Roger. A história cultural: entre práticas e representações. Lisboa: Difel; Rio de Janeiro: Bertrand Brasil, 1990. p. 121.

${ }^{2}$ DARNTON, Robert. O beijo de Lamourette: mídia, cultura e revolução. São Paulo: Companhia das Letras, 1990.
} 
é, objeto de escrita e leitura mas também de venda, compra, colecionamento; motivo de censura, crítica e classificação; vítima de esquecimento ou algo retido pela memória coletiva ${ }^{3}$.

Roger CHARTIER entende que as investigações devem seguir duas linhas: uma, sobre as estratégias usadas pelos autores e editores para impor uma ortodoxia do texto, uma leitura forçada; e outra, sobre a diversidade de leituras antigas ${ }^{4}$. Investigar a imposição da ortodoxia do texto, no contexto da Época Moderna, envolve a abordagem das normas e dos procedimentos através dos quais o Estado e a Igreja procuravam controlar a impressão e a circulação dos livros, isto é, exige que se focalize o funcionamento do aparato censório. Requer também que se atente para as distâncias e tensões existentes entre a ação de autores e editores, entre o texto, o que foi escrito pelos autores, e o impresso, aquilo produzido pelos editores - estes, muitas vezes, para se aproximarem do que julgavam serem as expectativas dos leitores ou para atenderem às determinações da Igreja e do Estado, censuravam as alusões tidas como contrárias aos interesses dos últimos ou como blasfemas e heréticas, e alteravam substantivamente os livros, encurtando-os, suprimindo trechos e capítulos supérfluos, simplificando enunciados, modificando a estruturação dos períodos e parágrafos, acrescentando títulos e resumos ${ }^{5}$; os tradutores, em Portugal, não apenas vertiam os textos estrangeiros para o vernáculo, como adaptavam-nos, modificando-os às vezes sensivelmente ${ }^{6}$. Os autores, por sua vez, procuravam controlar a publicação de seus trabalhos ${ }^{7}$, enquanto a pirataria, prática rotineira ${ }^{8}$, ampliava o fosso existente entre autores e editores. Para analisar a imposição da ortodoxia do texto há que considerar, ainda, as identificações por meio das quais as obras se classificavam, os gêneros em que eram enquadradas e os indicadores

\footnotetext{
${ }^{3}$ SILVA, Maria Beatriz Nizza da. Livro e Sociedade no Rio de Janeiro (1808-1821). Revista de História, São Paulo, 46 (94): 441-457, 1973.

${ }^{4}$ CHARTIER, Roger, op. cit., p. 123.

5 DARNTON, Robert. Edição e sedição: o universo da literatura clandestina no século XVIII. São Paulo: Companhia das Letras, 1992; CHARTIER, Roger, op. cit., p. 129-300; e ALCALÁ, Angel. La censura inquisitorial de la literatura del siglo de oro en España y en Portugal: comparación de sus 'indices' y sus resultados. In: NOVINSKY, Anita, CARNEIRO, Maria Luiza Tucci (org.). Inquisição: ensaios sobre mentalidade, heresias e arte. Rio de Janeiro: Expressão e Cultura; São Paulo: EDUSP, 1992, p. 423-424.

${ }^{6}$ CARREIRA, Laureano. O teatro e a censura em Portugal na segunda metade do século XVIII. Lisboa: Imprensa Nacional, 1988, p. 115-123.

${ }^{7}$ CHARTIER, Roger. A ordem dos livros: leitores, autores e bibliotecas na Europa entre os séculos XIV e XVIII. Brasília: UnB, 1994, p. 54.

${ }^{8}$ DARNTON, Robert. Boemia literária e revolução: o submundo das letras no Antigo Regime. São Paulo: Companhia das Letras, 1989, p. 184.
} 
formais e materiais dos livros, destacando-se as ilustrações, a "aeração da página pela multiplicação dos parágrafos", as subdivisões e os formatos que impunham ou propunham significados distintos e formas de leitura ${ }^{9}$.

Pesquisar a diversidade de leituras antigas passa, inicialmente, pelo arrolamento das obras em circulação, aquelas vendidas pelos livreiros - tal como fizeram DARNTON ${ }^{10}$, Sara NALLE ${ }^{11}$, G. BERGER ${ }^{12}$ e Maria Beatriz Nizza da SILVA $^{13}$ —, ou ainda, encontradas em bibliotecas públicas, e/ou possuídas por particulares, e/ou enviadas de Portugal para a América - como realizaram, respectivamente, Nizza da SILVA ${ }^{14}$, VILLALTA ${ }^{15}$ e ABREU ${ }^{16}$. A identificação dos títulos das obras, de seus autores, e sua classificação e quantificação são procedimentos úteis ${ }^{17}$. Na classificação, devem-se evitar os anacronismos, não se colocando "curiosidades do século XX" no meio das categorias de classificação do passado $^{18}$, ou, inversamente, o "passadismo", não adotando os mesmos critérios de catalogação presentes na documentação compulsada, cujo resultado seria a produção de um quadro desconcertante ${ }^{19}$. Trata-se de um trabalho árido e controverso, pois se verifica uma variedade de critérios e de formas de classificação. A quantificação das obras possuídas, do número de bibliotecas e de livros que as constituíam permite avaliar a incidência da venda e da posse de livros, a distribuição desta entre os indivíduos e os diversos agrupamentos sociais (de classe, ofício, gênero, religião etc.). Possibilita também verificar as inter-relações existentes entre sua distribuição

${ }^{9}$ CHARTIER, Roger. A ordem dos livros, op. cit., p. 18-20.

${ }^{10}$ DARNTON, Robert. Edição e sedição, op. cit.

${ }^{11}$ NALLE, Sara Nalle. Litteracy and culture in Early Modern Castile. Past \& Present. Oxford, (125): 65-96, nov. 1989.

${ }^{12}$ BERGER, G. Littérature et lecteurs à Grenoble aux XVII $\underline{\text { e }}$ et XVIII $\underline{\mathrm{e}}$ siècles: le public littéraire dans une capitale provinciale. Revue d'Histoire Moderne et Contemporaine. Paris, (33): 114-132, jan./mar. 1986.

${ }^{13}$ SILVA, Maria Beatriz Nizza da, op. cit., p. 449-454.

${ }^{14}$ SILVA, Maria Beatriz Nizza da. "A Livraria Pública da Bahia em 1818: obras de História". Revista de História, São Paulo, 43 (87): 225-239, 1971.

${ }^{15}$ VILLALTA, Luiz Carlos. O que se fala e o que se lê: língua, instrução e leitura. In: SOUZA, Laura de Mello e (coord.). História da vida privada no Brasil: cotidiano e vida privada na América Portuguesa. São Paulo: Companhia das Letras, 1997, p. 331-385.

16 ABREU, Márcia. Leituras Coloniais. CONGRESSO LUSO-BRASILEIRO DE HISTÓRIA DA EDUCAÇÃO, 2, 1998, São Paulo. Anais, São Paulo, [1999]. (Inédito).

17 Leila Mezan Algranti fez um estudo sobre o conteúdo e a composição de bibliotecas nos recolhimentos carmelitas no Brasil. Seu propósito era identificar a ortodoxia do texto e as condutas que se queriam impor às mulheres; ao mesmo tempo ambicionava aproximar-se da diversidade das leituras. (ALGRANTI, Leila Mezan. Os livros de devoção e a religiosa perfeita: normatização e práticas religiosas nos recolhimentos femininos no Brasil colonial. In: SILVA, Maria Beatriz Nizza da (coord.). Cultura portuguesa na Terra de Santa Cruz. Lisboa: Editorial Estampa, 1995, p. 109-124).

${ }^{18}$ SILVA, Maria Beatriz Nizza da. Livro e Sociedade no Rio de Janeiro (1808-1821), op. cit., p. 138. 
pelos indivíduos e grupos, e sua variação numérica pelas áreas de conhecimento, em tempos e espaços distintos. Desse modo, com a quantificação logra-se apreender os aspectos mais repetitivos e redutíveis da apropriação dos livros.

A quantificação, no entanto, é insuficiente. Primeiro, por deixar de fora os modos diferenciados pelos quais os grupos e os indivíduos utilizavam os livros, que, às vezes, eram os mesmos ${ }^{20}$. Em segundo lugar, pelo fato de que nem todas as pessoas liam todos os livros que possuíam e de que, no período que se estende do século XVI ao século XVIII, muita gente lia livros que jamais comprara ${ }^{21}$, ou mesmo, tinha contatos com escritos que, por seu escasso valor, escapavam de serem registrados pelas fontes ${ }^{22}$. Por isso, é preciso ir além da análise quantitativa, chegando até as formas de leitura, isto é, aos modos efetivos pelos quais os textos eram lidos, terreno que, segundo DARNTON, coloca as maiores dificuldades dentro da história dos livros ${ }^{23}$. Da constatação da posse de um livro não se pode deduzir que ele foi lido; da leitura do mesmo, por seu turno, não é possível concluir que as idéias nele contidas foram 'imediatamente absorvidas e propagadas 'tais como eram' originariamente" ${ }^{24}$. Há, portanto, que se verificar não apenas os conteúdos dos livros, mas também a existência ou não de distâncias entre aqueles textos que foram lidos e as idéias que sobre eles se fizeram, identificando os fatores possivelmente intervenientes na ocorrência de um maior ou menor distanciamento entre as últimas e os primeiros.

$\mathrm{O}$ acesso às formas de leitura — isto é, às práticas de leitura e aos modos de apropriação dos textos - pode-se dar por diferentes formas. Primeiro, acompanhando-se as estratégias editoriais e os textos dos próprios livros, que, por terem sempre em mira atingir o leitor, oferecem informações preciosas sobre as

${ }^{19}$ DARNTON, Robert. O beijo de Lamourette, op. cit., p. 175-176.

${ }^{20}$ CHARTIER, Roger. Lectures et lecteurs dans la France d'Ancien Régime. Paris: Éditions du Seuil, 1987, p. 12.

${ }^{21}$ Ibidem, p. 167 e VILLALTA, Luiz Carlos. Bibliothèques privées et pratiques de lecture au Brésil colonial. In: MATTOSO, Katia, SANTOS, Idellete Muzart Fonseca dos, ROLLAND, Denis (org.). Naissance du Brésil moderne (1500-1808). Paris: Presses de L'Université de Paris-Sorbonne, 1998, p. 334.

${ }^{22}$ CHARTIER, Roger. As práticas da escrita. In: ARIÈS, Philipe, Idem. História da vida privada: da Renascença à epoca das Luzes. São Paulo: Companhia. das Letras, 1991, p. 113-167.

${ }^{23}$ DARNTON, Robert. O beijo de Lamourette, op. cit., p. 121.

${ }^{24}$ FALCON, Francisco Calazans. O imaginário republicano do século XVIII e Tiradentes. In: TIRADENTES hoje: imaginário e política na república brasileira. Belo Horizonte: Fundação João Pinheiro, 1994, p. 132. 
práticas de leitura ou mesmo as retratam ${ }^{25}$. Um segundo modo de se aproximar da diversidade de leituras é debruçar-se sobre a circulação: a compra, a venda e os empréstimos de livros registram a movimentação e as inquietações do mercado livreiro bem como a apropriação do livro pelo público leitor ${ }^{26}$. Outro meio, além disso, é o exame das práticas de censura ${ }^{27}$, as quais indicam a situação da circulação e da veiculação das idéias. A análise dos processos desenvolvidos pelo aparato repressivo (inquisição e justiças civil e eclesiástica, por exemplo) contra os heterodoxos da fé, da moral e da política constitui também um modo de verificar como as idéias dos livros eram apreendidas e transformadas ${ }^{28}$. Uma quinta forma seria pesquisar, no caso de homens de letras, as obras produzidas por estes e os escritos que porventura tenham legado no exercício de cargos públicos, o que também permite compreender como os textos eram "reelaborados" 29 . Por fim, podese fazer inferências sobre as práticas de leitura a partir dos próprios elementos materiais e formais dos livros ${ }^{30}$.

A historiografia, além de trazer todas essas contribuições teóricometodológicas - ressaltando-se, no caso brasileiro especificamente, o apontamento de rumos para novas pesquisas, a possibilidade de correlacionar a composição das bibliotecas às idéias políticas dos agentes históricos, as potencialidades de uma análise que junte o quantitativo ao qualitativo - oferece sugestões preciosas a respeito das fontes a serem empregadas em investigações sobre a história do livro e

${ }^{25}$ LAJOLO, Marisa, ZILBERMAN, Regina. A leitura rarefeita: livro e literatura no Brasil. São Paulo: Brasiliense, 1991, p. 59-86. Lúcia Maria Bastos Pereira das Neves, por exemplo, a partir dos artifícios de retórica observados em um conjunto de impressos (panfletos, folhetos políticos e periódicos) publicados entre 1821 e 1822, infere que os mesmos foram redigidos segundo uma perspectiva oral e que se dirigiam a um público restrito (NEVES, Lúcia Maria Bastos Pereira das. Corcundas e constitucionais: a cultura política no mundo Luso-Brasileiro - 1820-1822. In: SILVA, Maria Beatriz Nizza da (coord.). Cultura portuguesa na Terra de Santa Cruz, op. cit., p. 268).

${ }^{26}$ NEVES, Lúcia Maria Bastos Pereira das. Comércio de livros e censura de idéias no Brasil. Ler História, Lisboa, (23): 61-78, 1992, p. 69-74 e GUEDES, Fernando. O livro e a leitura em Portugal: subsídios para a sua história, séculos XVIII e XIX. Lisboa/ São Paulo: Verbo, 1987, p. 83-116.

${ }^{27}$ NEVES, Lúcia Maria Bastos Pereira das, FERREIRA, Tânia Marta T. Bessone da C. O medo dos 'abomináveis princípios franceses': a censura dos livros nos inícios do século XIX no Brasil. Acervo: revista do Arquivo Nacional, Rio de Janeiro, 4 (1):113-119, jan./jun. 1989.

${ }^{28}$ GUINZBURG, Carlo. O queijo e os vermes: o cotidiano e as idéias de um moleiro perseguido pela inquisição. São Paulo: Companhia das Letras, 1986 e MATTOSO, Katia de Queiroz. Presença francesa no movimento democrático baiano de 1798. Salvador: Editora Itapuã/ Secretaria de Educação e Cultura do Estado da Bahia, 1969.

${ }^{29}$ BOSCHI, Caio César. Debate da conferência 'O Imaginário Republicano do Século XVIII e Tiradentes'. In: TIRADENTES hoje: imaginário e política na república Brasileira. Belo Horizonte: Fundação João Pinheiro, 1994, p. 143.

${ }^{30}$ DARNTON, Robert. O grande massacre de gatos e outros episódios da história cultural francesa. 2 ed. Rio de Janeiro: Paz e Terra, 1986, p. 288. 
da leitura no Brasil: os seqüestros dos bens das pessoas envolvidas nas Conjurações do século XVIII; os depoimentos prestados pelos diversos conjurados nas devassas; os inventários post mortem; os catálogos de livros e as listas de obras encaminhadas ao aparato censório português após 1768; os róis de livros retidos nas alfândegas; as obras literárias; os relatos de viajantes; as denúncias encaminhadas ao Santo Ofício; os relatórios governamentais; as propagandas em jornais; os manuais de confissão etc. $^{31}$. Tais testemunhos permitem investigações sobre um amplo leque de temas e relações referentes à história do livro e da leitura: na linha da imposição da ortodoxia do texto, as práticas de censura; os gêneros e as formas de classificação dos livros empregados por editores, livreiros e censores; e os aspectos materiais dos impressos; e, na vertente da diversidade de leituras antigas, o comércio livreiro, a distribuição social da posse dos livros, as bibliotecas, as práticas de leitura e as formas de apropriação dos textos, correlacionando livros e idéias professadas pelos leitores.

Aliando as possibilidades das fontes enumeradas àquelas novas perspectivas trazidas pela historiografia sobre o livro e as práticas de leitura, esta tese de doutoramento propõe-se a investigar os usos do livro: de um lado, a imposição da ortodoxia do texto e, de outro, a diversidade das leituras, isto é, as práticas de leitura e os usos atribuídos aos livros pelos leitores, no conjunto da América Portuguesa, particularmente sob o Reformismo Ilustrado Português, da ascensão de D. José I até o estabelecimento da Família Real no Rio de Janeiro, em 1808. Embora privilegie estes marcos cronológicos, isto é, 1750-1808, esta tese abarcará, quando necessário, todo o período colonial, recuando-se aos inícios do século XVI e estendendo-se até

\footnotetext{
${ }^{31}$ Veja, dentre outros, não se atendo apenas à historiografia brasileira, mas abrangendo também estudos portugueses: MARQUILHAS, Rita. A faculdade das letras: leitura e escrita em Portugal no século XVII. Lisboa: Faculdade de Letras, 1996 (Tese de doutorado); LOUREIRO, Olímpia Maria da Cunha. O livro e a leitura no Porto no século XVIII. Porto: Centro de Estudos D. Domingos de Pinho Brandão/ Fundação Eng. ${ }^{\circ}$ António de Almeida, 1994; Idem. Bibliotecas e leituras do clero do Porto (1769-1770). Actas do Congresso de História no IV Centenário do Seminário de Évora. Évora, 1994; JOBIM, Leopoldo Collor. O Santo Ofício da inquisição no Brasil setecentista: estudo de uma denúncia. Revista de Estudos IberoAmericanos, Porto Alegre, 13 (2): 195-213; LIMA, Lana Lage da Gama. Aprisionando o desejo: confissão e sexualidade. In: VAINFAS, Ronaldo (org.). História e sexualidade no Brasil. Rio de Janeiro: Graal, 1986, p. 67-88; LESSA, Clado Ribeiro de. As bibliotecas brasileiras dos tempos coloniais: apontamentos para um estudo histórico. Revista do Instituto Histórico e Geográfico Brasileiro, Rio de Janeiro, (191): 339-345, 1946; MACHADO, Alcântara. Vida e morte do bandeirante. Belo Horizonte: Itatiaia; São Paulo: Edusp, 1980, p. 99-105; FRIEIRO, Eduardo. O Diabo na livraria do cônego. 2 ed. rev. e aum. São Paulo: EDUSP; Belo Horizonte: Itatiaia, 1981; SILVA, Maria Beatriz Nizza da. A Livraria Pública da Bahia em 1818: obras de história, op.cit.; LEITE, Paulo Gomes. A maçonaria, o Iluminismo e a Inconfidência Mineira. Revista Minas Gerais. Belo Horizonte, (33): 18-23, jan. 1991; e SILVA, Maria Beatriz Nizza da. Cultura e Sociedade no Rio de Janeiro (1808-1821). 2 ed. São Paulo: Companhia Editora Nacional, 1978.
} 
1822, para identificar as principais permanências e rupturas produzidas dentro do período do Reformismo Ilustrado.

A Parte I - Usos do Livro sob o Reformismo Ilustrado: Parâmetros e Alvos, assim, volta-se para a imposição da ortodoxia do texto, identificando os principais textos, idéias e práticas que constituíram as referências culturais e os alvos de ataque da censura portuguesa e dos leitores no período do Reformismo Ilustrado: as teorias corporativas de poder da Segunda Escolástica, os milenarismos e o anticientificismo (Capítulo 1); a Ilustração (Capítulo 2) e o Reformismo Ilustrado Português, de Pombal ao Príncipe Regente D. João (Capítulo 3). Pretende-se na Parte I, enfim, passar em revista o legado de livros e de idéias presentes na cultura luso-brasileira, legado referendado ou combatido no período, pela censura e/ ou pelos próprios leitores.

A Parte II - Usos Prescritos e Interditados: a Censura também se volta para a imposição da ortodoxia no texto, agora restrita unicamente à censura, principalmente entre 1768 e 1808, mas também no período anterior, de 1517 a 1568, avaliando as modificações e os parâmetros censórios sob o Reformismo Ilustrado (Capítulo 4); as práticas de censura que incidiam sobre a circulação, a posse e a leitura de livros, com especial atenção para o que se referia à América Portuguesa (Capítulo 5); e, por fim, as concessões de licença para a leitura e a posse de livros proibidos em Portugal e na América (Capítulo 6). Quer-se, portanto, na segunda parte da tese, fixar as linhas gerais da ação censória e as conexões existentes entre ela, o legado de livros e as idéias existentes na cultura luso-brasileira e a política reformista ilustrada seguida pela Coroa portuguesa.

A Parte III - Usos do Livro e Ordem Religiosa e Política dedica-se à diversidade das leituras na América Portuguesa, privilegiando-se o século XVIII e os inícios do século XIX. Inicialmente, procurar-se-á apreender as visões que Estado e sociedade constituíram a respeito do livro; depois, os usos implícitos dos livros, aqueles inferidos a partir do exame da distribuição da posse de livros na América Portuguesa e de alguns dados sobre a circulação livreira, avançando-se até 1822; e em seguida, os usos explícitos, abordando-se as utilidades que os próprios leitores atribuíam aos livros, nos dois lados do Atlântico, no período do Reformismo Ilustrado; e, por fim, as práticas de leitura, as apropriações feitas pelos leitores dos conteúdos dos textos, marcadamente aquelas em que se evidenciam heterodoxias 
religiosas, recuando-se até o século XVI e chegando até 1808 , de tal sorte a apreender as formas pelas quais se amalgamaram, às idéias da Ilustração, tradições culturais iconoclastas e milenaristas, algumas delas de origem cristã-nova (Capítulo 7). No último capítulo, far-se-á o exame das relações entre práticas de leitura e contestação política, analisando-se as apropriações feitas pelos Inconfidentes de Minas Gerais, destacando se a junção das Luzes e, mais ainda, da Independência dos Estados Unidos da América, às idéias da Segunda Escolástica, a princípios milenaristas laicizados e à história da Restauração Portuguesa de 1640 (Capítulo 8).

Às Conclusões Gerais, nas quais se passará em revista a tensão entre a imposição da ortodoxia do texto e a diversidade de leituras na América Portuguesa, seguem-se as indicações das Fontes Primárias e a Bibliografia consultada. 


\section{PARTE I:}

\section{Usos do Livro sob o Reformismo Ilustrado Português:}

\section{Parâmetros e Alvos}

"Trazei, sabios illutres, á memoria

"Aquelle tempo em que contentes visteis

"Entrar nesta Cidade triumphante

"O grande, invicto, o immortal Carvalho,

"As vezes de seu Rei representando,

"Daquelle sabio Rei, cujo retrato

"Inda agora me anima, e me dá forças,

"Para que em seu favor, em sua gloria

"Derramando o meu sangue exhale a vida.

"Visteis ao gran Marquez, qual sol brilhante

"De escura noite dissipando as trevas,

"A frouxa Estupidez lançar ao longe,

"E erigir á Sciencia novo throno

"Em sabios estatutos estribado.

"Das vossas mesmas bocas retumbárão

"Canticos de louvor nestas paredes."

(FRANCO, Francisco de Mello. Reino da Estupidez, poema. 1820). 
A partir da ascensão de D. José I, "o sábio rei” do poema em epígrafe ${ }^{1}$, ao trono português, em 1750, Sebastião José de Carvalho e Mello, “o immortal Carvalho", Conde de Oeiras e, depois, Marquês de Pombal, tornou-se uma espécie de cônsul, nos moldes romanos. E, com este "sol brilhante", a Coroa portuguesa ingressou na Era das Luzes, desenvolvendo uma política reformista em várias áreas, da economia à educação, passando pela censura. A Coroa portuguesa, sob o Reformismo Ilustrado, fez uma incorporação seletiva das idéias das Luzes, rechaçando aquelas que ameaçavam as prerrogativas absolutistas do trono, o domínio colonial e a religião. Com isso, a Ilustração constituiu, ao mesmo tempo, referência e alvo de ataque.

O Reformismo buscava conciliar a valorização da Razão e das ciências à anteposição de obstáculos ao que soava como ameaça ao absolutismo monárquico, à religião católica e à manutenção do Império Colonial, cerceando a influência das vertentes mais radicais da Ilustração. O Reformismo Ilustrado, além disso, procurava romper com o panorama cultural estabelecido, atacando especificamente os milenarismos, o anti-cientificismo e as teorias de poder corporativas.

Se o Reformismo Ilustrado contagiou o governo, forneceu-lhe elementos para definir medidas e alterações no mundo luso-brasileiro, seduziu os leitores no geral. Esses, no entanto, muitas vezes mostraram-se profundamente marcados por um legado cultural anterior, particularmente pelos milenarismos, pelo anti-cientificismo e pelas teorias corporativas de poder da Segunda Escolástica.

Nessa primeira parte da tese, será focalizado esse conjunto de elementos que serviram de parâmetros e de alvos para a censura e os leitores sob o Reformismo Ilustrado português, nos dois lados do Atlântico, no Reino e na América. Assim, o Capítulo 1 trata das Teorias Corporativas de Poder, dos Milenarismos e do AntiCientificismo; o Capítulo 2 tem como tema a Ilustração e, por fim, o Capitulo 3 versa sobre o Reformismo Ilustrado Português, de seus inícios, com a ascensão de Dom José I e de seu ministro Sebastião José de Carvalho e Melo, até a regência do príncipe Dom João.

\footnotetext{
${ }^{1}$ FRANCO, Francisco de Mello. Reino da Estupidez, poema. Hambourg: 1820, p. 38-39.
} 


\section{Capítulo 1:}

\section{Teorias Corporativas de Poder, Milenarismos e Anti- Cientificismo}

\section{Segunda Escolástica e Teorias Corporativas de Poder}

Portugal e Espanha na Época Moderna apresentavam uma configuração intelectual peculiar em relação ao Além-Pireneus, especialmente a França, tendo esta situação perdurado do Quinhentos até o século das Luzes.

Segundo Richard MORSE, durante a Idade Média, os ibéricos acompanharam as inovações intelectuais que floresciam no Ocidente Europeu e, até o século XVII, conseguiram apresentar fórmulas alternativas a essas opções ${ }^{1}$. Nos séculos XV e XVI, através das navegações e descobrimentos, Portugal - e também a Espanha forneceu dados importantes para que o pensamento europeu elaborasse novos conceitos $^{2}$ e ofereceu contribuições para as ciências aplicadas ${ }^{3}$. Ao mesmo tempo, a reforma protestante e a revolução científica levaram os lusos e espanhóis a retomarem, no umbral da Modernidade, orientações culturais da Baixa Idade Média. Em solo ibérico, assim, a teologia teve um desenvolvimento notável com a chamada Segunda Escolástica ou Neo-escolástica, a qual formulou teorias corporativas de poder e construiu as bases da jurisprudência internacional ${ }^{4}$. Essa firme orientação teológica permitiu que a alta cultura espanhola se mantivesse integrada à sociedade, desfrutando de um amplo consenso, o qual passava por alguns pontos referentes à natureza do governo: "suas fontes de legitimidade, o alcance exato do seu poder, sua responsabilidade de assegurar justiça e eqüidade, sua missão 'civilizatória' em face

\footnotetext{
${ }^{1}$ MORSE, Richard M. O espelho de Próspero: cultura e idéias nas Américas. Trad. Paulo Neves. São Paulo: Companhia das Letras, 1995, p. 28-29 e 72.

${ }^{2}$ CARVALHO, Rômulo de. História do ensino em Portugal: desde a fundação da nacionalidade até o fim do Regime de Salazar-Caetano. Lisboa: Fundação Calouste Gulbenkian, 1986, p.369-370.

${ }^{3}$ É o caso, por exemplo, dos textos de Garcia de Orta sobre as propriedades terapêuticas da flora oriental. As contribuições portuguesas, no entanto, não envolveram especulações científicas mais vastas (MORSE, Richard M., op. cit., p. 44).

${ }^{4}$ TORGAL, Luís Reis. Ideologia política e teoria do Estado na Restauração. Coimbra: Biblioteca
} 
dos povos não-cristãos de seu território e de ultramar",

As concepções corporativas de poder da Segunda Escolástica predominaram na Península Ibérica até meados do século XVII e tiveram bastante força até o século XVIII, quando ainda impregnavam a doutrinação política, constituindo-se como as premissas do pensamento político luso-brasileiro e hispano-americano. Nos domínios portugueses especificamente, nem as reformas pombalinas, nem a expulsão dos jesuítas lograram eliminá-las, com o que elas sobreviveram até o período da Independência ${ }^{6}$.

Tais concepções, derivadas em parte da reinterpretação dos escritos de São Tomás, repudiavam o maquiavelismo e as heresias luteranas e ora incorporavam, ora refutavam as idéias de Guilherme de Ockham e seus discípulos ${ }^{7}$. As teorias corporativas são encontradas em obras de autores como o cardeal italiano Roberto Belarmino (1542-1621), o holandês Becanus (1563-1624) e, entre os espanhóis, o jurista Azpilcueta Navarro (1592-1586), os dominicanos Francisco de Vitoria (14851546) e Domingo de Soto (1595-1560), os jesuítas Luís de Molina (1536-1600), Francisco Suárez (1548-1617) e Juan de Mariana (1536-1624). Em Portugal, os baluartes da cultura escolástica espanhola exerceram grande influência, chegando mesmo a lecionar: Molina, em Évora; Navarro, em Coimbra; e Suárez, na mesma cidade, onde ocupou uma cátedra a partir do fim do século $\mathrm{XVI}^{8}$.

Para São Tomás, o universo seria regido por uma hierarquia de leis: primeiro, a "lei eterna", pela qual age o próprio Deus; em seguida, a "lei divina", aquela que Deus comunica aos homens através da escritura; em terceiro lugar, a "lei da

Geral da Universidade, 1981, vol. 1, p. 110 e MORSE, Richard M., op. cit., p. 29.

${ }^{5}$ MORSE, Richard M., op. cit., p. 38-39.

${ }^{6}$ MACEDO, Jorge Borges de. Formas e premissas do pensamento Luso-Brasileiro. Revista da Biblioteca Nacional, Lisboa, 1(1): 76-7, jan./jun. 1981; MORSE, Richard M., op. cit., p. 64 e 92-93; e TORGAL, Luís Reis, op. cit., vol. 1, p. 127 e 132-133.

${ }^{7}$ TORGAL, Luís Reis, op. cit., vol. 1, p. 197; MORSE, Richard M., op. cit., p. 42 e 47; e SKINNER, Quentin. As fundações do pensamento político moderno. Trad. Renato Janine Ribeiro e Laura Teixeira Motta. São Paulo: Companhia das Letras, 1996, p. 417 e 450-451. Ockham atribuía pouca importância à razão em matéria teológica, na medida em que considerava que os dogmas da religião revelada, a existência e os atributos de Deus não podem ser conhecidos pela fé, sendo somente provados " "na teologia supondo-se a fé"” (SKINNER, Quentin, op. cit., p. 305); a razão seria apenas o meio pelo qual Deus notifica sua vontade ao homem (FASÓ, Guido. Jusnaturalismo. In: BOBBIO, Norberto, MATTEUCCI, Nicola, PASQUINO, Gianfranco. Dicionário de política. 9 ed. Brasília: Universidade de Brasília, vol. 1, p. 657). Este ceticismo da escolástica de Ockham, em relação aos poderes do raciocínio humano, era recusado pelos pensadores da Segunda Escolástica (SKINNER, Quentin, op. cit., p. 425-426).

${ }^{8}$ TORGAL, Luís Reis, op. cit., vol. 1, p. 110, 188, 191 e 197. 
natureza", que Deus inscreve nos homens para que eles sejam capazes de compreender Seus desígnios; e, por fim, a "lei positiva" (chamada de lex humana, lex civilis ou ius positivum) $)^{9}$. A "lei eterna" existiria no homem como "lei natural", princípio regulador e normativo da atividade deste, levando-o a fixar na sociedade a "lei humana". A "lei humana", assim, participa, de um lado, do "direito natural", princípio essencial e imutável e, de outro, do "direito positivo", sua parte secundária, modificável. Esta circunscrição da esfera humana na esfera divina faz-se presente igualmente na visão tomista de Estado. Deus é a fonte primeira do direito e do Estado. Este último é concebido como expressão da condição natural do homem enquanto "ser social", a qual, por sua vez, subordina-se à "lei eterna". O Estado se originaria de um "pacto social", através do qual o povo, enquanto comunidade, detendo o poder derivado de Deus, buscaria realizar o "bem comum", definido em consonância com os fins eternos do homem, fins estes que, por sua vez, pertenceriam à jurisdição da igreja. Deste modo, em última instância, o Estado teria como fim o bem comum, tornando-se ilegítimo se o esquecesse, violando o direito natural e, com isto, o divino. Nestes casos, nas situações em que existisse tirania, São Tomás admitia o direito do "povo", da comunidade, de resistir ativamente, mas não o tiranicídio. São Tomás, com tais idéias, abriu espaço para que se legitimasse a deposição de governos que afrontassem os interesses do papado ${ }^{10}$.

As teorias da Segunda Escolástica se pautaram pela defesa de dois princípios básicos: primeiro, a capacidade do homem de compreender a lei natural - negando, deste modo, a idéia herética de que Deus ordenaria diretamente o estabelecimento da sociedade política - e, em segundo lugar, a compreensão de que o estado natural do homem é de liberdade, igualdade e independência, tese esta defendida por Vitoria, Soto, Suárez e pelos teóricos jesuítas do período posterior ${ }^{11}$. No estado natural, os homens seriam governados, em todos os momentos, por uma lei, a "lei da natureza", do que os escolásticos deduziam que, antes mesmo da constituição da sociedade política, os ditames desta lei estariam presentes " "no coração dos homens""12. Neste

\footnotetext{
${ }^{9}$ SKINNER, Quentin, op. cit, p. 426.

${ }^{10}$ TORGAL, Luís Reis, op. cit., vol. 2, p. 6-8.

${ }^{11}$ SKINNER, Quentin, op. cit., p. 432-433.

${ }^{12}$ MOLINA. Apud. Ibidem, p. 434-435.
} 
mesmo estado, além disso, entendiam que os homens já viveriam em sociedade ${ }^{13}$.

Os escolásticos jesuítas explicavam a passagem do estado da natureza - isto é, o das comunidades naturais pré-políticas - para o da sociedade política como uma questão de sobrevivência e de interesse pessoal: Molina e Suárez afirmavam que, se os homens tivessem persistido no primeiro estado, ver-se-iam degradados por uma crescente injustiça e incerteza, mal conseguindo sobreviver. Por isso, então, teriam aberto mão da sua liberdade natural em favor da imposição da lei positiva, dando seu consentimento para a instituição da sociedade política ${ }^{14}$.

Vitoria, Suárez e Bellarmino circunscreviam a realidade humana na divina, mas, ao mesmo tempo, consideravam distintas as esferas de atuação eclesiástica e secular, dando-lhes uma especificidade e, ainda, concluindo disto que o papa não teria um poder coercitivo direto sobre as repúblicas ${ }^{15}$. O "direito das gentes", embora derivado de Deus, seria elaborado pelo homem; Estado e comunidade internacional, apesar de presididos por Deus, seriam igualmente realidades humanas. Suárez considerava que o poder político é legítimo, procede de Deus e recai diretamente na natureza humana, não transitando diretamente do Criador para o governante. $O$ Estado seria, assim, um “corpo místico" — isto é, pactum subjectionis, "unidade de uma vontade coletiva que se aliena do poder e o transfere para a 'pessoa mística' do Rei, que se torna a 'cabeça' do corpo político do Estado subordinado, submetido ou súdito" ${ }^{\text {— }}$, exigindo a articulação das diversas forças existentes. O papa constituiria a única entidade que representa Deus e o seu poder espiritual; os assuntos espirituais pertenceriam ao papa, que poderia mandar, coagir e castigar clérigos e leigos em matérias eclesiásticas ${ }^{17}$, tendo o poder temporal, neste campo especificamente, que se sujeitar ao espiritual. O papa, além disso, teria poderes indiretos bastante extensos sobre os assuntos temporais, embora nem todos os tomistas estivessem convictos

\footnotetext{
${ }^{13}$ SKINNER, Quentin, op. cit., p. 435.

${ }^{14}$ Ibidem, p. 436-439. Quentin Skinner afirma que a questão dos porquês da passagem do estado da natureza para o das sociedades políticas não foi resolvida pelos teóricos dominicanos, mas sim pelos que os sucederam, isto é, os jesuítas (ibidem, p. 436). A idéia de que o organismo político legítimo originava-se num ato de consentimento, por seu turno, não seria uma peculiaridade dos jesuítas, mas um lugar comum, tanto para os seguidores de São Tomás como para os discípulos de Guilherme de Occam (ibidem, p.439).

${ }^{15}$ Ibidem, p. 451.

${ }^{16}$ HANSEN, João Adolfo. Teatro da memória: monumento barroco e retórica. Revista do IFAC, Ouro Preto, (2): 44, dez. 1995.

${ }^{17}$ TORGAL, Luís Reis, op. cit., v. 2, p. 18.
} 
disto: Bellarmino entendia que estes poderes indiretos eram limitados, enquanto Vitoria e Suarez davam-lhe maior abrangência. Para Bellarmino, o papa não teria um poder temporal fora de seu Estado (motivo pelo qual sua obra foi colocada no Índex pelo Papa Sixto V), mas estaria no seu direito opor-se a um domínio político que pusesse em risco a cristandade ${ }^{18}$. Vitória entendia que o sumo pontífice poderia agir diretamente se estivessem em jogo assuntos fundamentais da esfera espiritual. Para Suárez, o papa estaria autorizado a exercer seu poder coercitivo em relação aos príncipes e reis heréticos, podendo excomungá-los ou interditá-los, ou mesmo, tirarlhes o reino, privando-os do exercício do poder, para evitar que prejudicassem seus súditos $^{19}$. Essas posições, embora refutassem um romanismo radical, favoreciam o uso do poder temporal pelo papado ${ }^{20}$.

Outro aspecto a ser considerado nas teorias de poder dos tomistas é a existência de perspectivas democráticas, avant la lettre, convivendo com opiniões favoráveis ao absolutismo ${ }^{21}$. Os teóricos tomistas, por um lado, abraçavam uma perspectiva contratualista para explicar a origem da instituição do poder político, chegando por isto a admitir, em certos casos, a insurgência do povo-comunidade contra seus soberanos - por defenderem esses princípios, os neotomistas foram vistos como fundadores do constitucionalismo e da democracia moderna. O jurista Azpilcueta Navarro, quanto à origem do poder, desse modo, partia da distinção entre o poder in actu e o poder in habitu: o rei deteria o poder in actu, mas o povocomunidade continuaria a deter este 'habitualmente', isto é, potencialmente, mesmo após o 'pacto de sujeição'. "Por isso no caso de manifesta tirania régia o poder político pode ser assumido pelo povo" ${ }^{, 2}$. Suárez e Belarmino são tributários dessa teoria de Azpilcueta Navarro: para ambos, o poder pertenceria naturalmente ao povocomunidade, que o transmitiria ao governante de uma forma que ele não deixaria de existir em si; o povo conservaria o poder in habitu, podendo readquiri-lo em certas circunstâncias definidas com clareza nos documentos e nos costumes. Porém, isso não significava que, para Suárez, o rei estaria sujeito ao povo-comunidade no exercício do poder: no que se refere ao exercício do poder, o pensador espanhol fazia

\footnotetext{
${ }^{18}$ Ibidem, vol. 1, p. 189.

${ }^{19}$ SKINNER, Quentin, op. cit., p. 453-454.

${ }^{20}$ TORGAL, Luís Reis, op. cit., v. 2, p. 19.

${ }^{21}$ SKINNER, Quentin, op. cit., p. 450 e 454.
} 
uma defesa do absolutismo. O rei teria recebido o poder de maneira “"plena e absoluta", sendo assim independente ${ }^{23}$. O ato de um povo livre de instituir um governante não seria apenas um "ato de transferência, mas também de ab-rogação de sua soberania original",24.

A retomada do poder do rei pelo povo, contudo, era admitida tanto por Suárez, quanto por Soto, Azpilcueta Navarro, Bellarmino, João Azor, Mariana e Molina, nos casos em que o rei viesse a se tornar tirânico ou herético (deixando de ser católico), contrariando o direito natural e divino, desrespeitando determinados fundamentos ético-religiosos ${ }^{25}$. Para Suárez, uma república tinha o direito de resistir a seu príncipe, podendo até mesmo matá-lo, se não houvesse outro meio para se preservar; porém, quando a sua existência não estivesse ameaçada, deveria sofrer em silêncio $^{26}$. Para depor um rei apropriadamente, seria necessário fazer uma assembléia representativa de toda a república, deliberando-se sobre uma linha de ação e ouvindose os cidadãos mais ilustres ${ }^{27}$. O jesuíta Juan de Mariana foi tão ou mais longe. No capítulo VI do seu livro De rege et regis institutione, defendeu o controle eclesiástico sobre os reis e o regicídio, afirmando que um rei poderia ser assassinado em certas circunstâncias, quando abusasse do seu $\operatorname{poder}^{28}$. Outros jesuítas, posteriores a Mariana, insistiram na tese do direito de resistência da comunidade: o alemão Hermann Busembaum (1600-1688) e Cláudio Lacroix (1652-1714) ${ }^{29}$. Portanto, os tomistas postulavam “a origem 'popular' do poder régio, que o 'povo' poderia, com a

\footnotetext{
${ }^{22}$ TORGAL, Luís Reis, op. cit., v. 1, p. 245.

${ }^{23}$ Ibidem, v. 2, p. 17.

${ }^{24}$ SKINNER, Quentin, op. cit., p. 459-460.

${ }^{25}$ TORGAL, Luís Reis, op. cit., v. 1, p. 191 e 270; e MACEDO, Jorge Borges de, op. cit., p. 76.

${ }^{26}$ SKINNER, Quentin, op. cit., p. 452-453.

${ }^{27}$ Ibidem, p. 453.

${ }^{28}$ TORGAL, Luís Reis, op. cit., vol. 1, p. 192. Muito tempo antes da criação da real mesa censória, à época do domínio espanhol, Felipe II já se inquietara com estas posições (BASTOS, José Timóteo da Silva. História da censura intelectual em Portugal: ensaio sobre a compreensão do pensamento português. 2 ed. Lisboa: Moraes Editores, 1983, p. 61-62). Na França, em 1610, condenaram-se as idéias de Mariana sobre a oportunidade do regicídio, "sob o argumento de que elas teriam inspirado Jean-François Ravaillac, assassino de Henrique IV (1553-1610)”. O jesuíta Cláudio Acquaviva (15811615) determinou aos seus subordinados que evitassem defender, até mesmo em conversas íntimas, qualquer espécie de resistência à autoridade real (MIRANDA, Tiago Costa Pinto dos Reis. "Ervas de ruim qualidade”: a expulsão da Companhia de Jesus e a aliança anglo-portuguesa: 1750-1763. São Paulo: FFLCH-USP, 1991, p. 256-257 (Dissertação de mestrado)). Com essa proibição, enfim, vedava-se aos padres defender "a legitimidade, em determinadas circunstâncias, de movimentos tendentes a afastar um tirano do poder, acrescentando que os reincidentes ficariam sujeitos à excomunhão, suspensão, inabilitação para qualquer posto e outras penalidades" (HOLANDA, Sérgio Buarque de. Capítulos de literatura colonial. São Paulo: Brasiliense, 1991, p. 447-448).

${ }^{29}$ MIRANDA, Tiago Costa Pinto dos Reis, op. cit., p. 257.
} 
aquiescência papal, depor o rei herético, e defendiam, em certas condições, até mesmo a legitimidade do regicídio" 30 . E exatamente neste ponto residia a objeção que faziam a Maquiavel: não se tratava de uma repulsa ao absolutismo, mas de oposição à ameaça de tirania. O Estado era concebido, enfim, pelos neotomistas como "um todo ordenado em que as vontades da coletividade e do príncipe se harmonizam à luz da lei natural e no interesse da felicitas civitatis ou bem comum"31. Esta concepção, embora não fosse refratária ao absolutismo, impunha-lhe limites: fazer o bem comum e a justiça, seguindo a religião católica e obedecendo à lei natural (e, por conseguinte, à divina).

Se em Portugal, é importante repetir, lecionaram os grandes pensadores espanhóis Suarez, Molina e Navarro, houve, além disso, a incorporação das idéias corporativas da Segunda Escolástica nas obras de juristas e canonistas. Dentre estes, destacam-se Manuel Álvares Pegas, com Commentaria in Ordinationes Regni Portugalliae, de 1669-1759, com que granjeou, segundo a Bibliotheca Lusitana, "immortal gloria ao seu nome",32; e Melchior Phebo, também do século XVII, que reiterava a representação medieval de sociedade dividida em três estados e que distinguia, dentro do povo, os "estados vis" (o daqueles que exerciam ofícios mecânicos) e os estados "limpos" "33.

A tese da Segunda Escolástica que consagrava a origem popular do poder régio era extremamente freqüente na literatura portuguesa seiscentista, mas possuía certas especificidades: por um lado, o princípio da origem pactícia do poder subordinava-se ao princípio hereditário (havia que respeitar a descendência do sangue real) e, por outro, este último sujeitava-se ao bem comum, com o que se permitia o afastamento tanto de herdeiros desprovidos das qualidades necessárias para o governo, como de reis que governassem mal. Os vassalos, além disso, teriam o direito de exigirem do rei o respeito dos jura aquisita por pactos subseqüentes, de denunciarem o pacto de sujeição nos casos em que o rei não cumprisse gravemente

\footnotetext{
${ }^{30}$ TORGAL, Luís Reis, op. cit., vol. 1, p. 190-191 e 196.

${ }^{31}$ MORSE, Richard M., op. cit., p. 58.

${ }^{32}$ MACHADO, Diogo Barbosa. Bibliotheca lusitana. Lisboa: Biblioteca Nacional, [1998], v. 3, p. 174 (CD-ROM).

${ }^{33}$ XAVIER, Ângela Barreto, HESPANHA, Antônio Manuel. A representação da sociedade e do poder. In: HESPANHA, Antônio Manuel (coord.). História de Portugal. Lisboa: Editorial Estampa, 1998, vol. 4, p. 127 e 131-132
} 
seus deveres, resistindo e privando-o de seu poder, podendo até mesmo matá-1o ${ }^{34}$.

João Salgado de Araújo, em Ley regia de Portugal, impressa em 1627, invocando a autoridade do cardeal Bellarmino, de Francisco de Vitória e de Azpilcueta Navarro, apresentava a teoria do pacto, por meio do qual os povos teriam delegado ao rei o poder que lhes competiria por direito natural. Os reis, por seu turno, ficariam obrigados a subordinar-se a Deus, a obedecerem ao Papa, a respeitarem os privilégios eclesiásticos, devendo praticar a justiça e assegurar o respeito à religião ${ }^{35}$. Segundo Araújo, portanto, o poder absoluto do rei tinha limites; e, caso desrespeitasse às finalidades ético-políticas que lhe seriam inerentes, tornar-se-ia ilegítimo $^{36}$.

Em Justa acclamação do Sereníssimo Rey de Portugal D. João o IV, editada em Lisboa em 1644, Francisco Velasco de Gouvea, à semelhança de Belarmino e Suárez, entende que o poder, em última instância, residiria em Deus; como atributo humano, no entanto, derivaria "imediatamente" da divindade para a comunidade. A comunidade, por sua vez, transferiria todo o seu poder e império aos reis, mas isto “ “debaixo de uma tacita condição de os regerem, e mandarem, com justiça e sem tyrania", tendo os povos, nestes casos, o direito de "'prival-os dos Reinos, em sua legitima e natural defensão",37. Como Azpilcueta Navarro, Belarmino e Suárez, Velasco distingue o poder dos reis, in actu, do poder do povo, in habitu, admitindo que, em certas circunstâncias, o povo naturalmente poderia reassumir o poder in actu que lhe pertenceria, inclusive elegendo um novo príncipe para o governar. Assim, embora não defendesse o tiranicídio, apresentava argumentos que o apoiavam. Velasco, por fim, recusava a necessidade de interferência papal para a deposição do rei, invocando em seu apoio Navarro, Bellarmino e Molina: o pontífice teria apenas o poder espiritual, usando o temporal apenas quando estivesse em jogo o espiritual nos Estados $^{38}$.

A teoria da origem popular do poder régio propugnada pelos pensadores neoescolásticos e por Francisco Velasco de Gouvea, considerados "monarcômacos" por José de Seabra da Silva, figura de proa do governo português após a ascensão de D.

\footnotetext{
${ }^{34}$ Ibidem, p. 128.

${ }^{35}$ Ibidem, loc. cit. e TORGAL, Luís Reis, op. cit., vol. 1, p. 229-230.

${ }^{36}$ TORGAL, Luís Reis, op. cit., vol. 1, p. 231.

${ }^{37}$ Ibidem, vol. 2, p. 25-28 e XAVIER, Ângela Barreto, HESPANHA, Antônio Manuel, op. cit., p. 128.
} 
José I, encontrou ressonância entre juristas portugueses importantes, como Antônio de Souza Macedo, Manoel Rodrigues Leitão ${ }^{39}$, Gabriel Pereira de Castro e Pedro Barbosa Homem. Macedo - que escreveu Eva, ou Ave Maria triumphante: Teatro de erudição e philosophia christã, de 1676; Perfectus doctor in quacumque scientia, de 1643, "um verdadeiro compêndio da auto-representação dos juristas, contendo normas que vão da alimentação e vestuário até às leituras"; e que já se supôs ser o autor de Arte de Furtar -, em Anti-Caramuel e Lusitania Liberata, contestava os que proclamavam a ilegitimidade da Restauração Portuguesa de 1640, dizia ser o rei de Espanha um tirano, defendia o absolutismo britânico e acreditava que o poder régio dependeria do povo em termos de sua eleição primeira e da finalidade de sua ação ${ }^{40}$. Leitão, em Balidos e no Tratado analítico, embora defendesse a soberania do rei, limitando-a pelas leis fundamentais que ele próprio estabeleceu, advogava a origem popular do poder régio. Pedro Barbosa Homem defendia igualmente a tese segundo a qual o poder passa de Deus ao povo, que o depositaria no rei, a quem competiria usálo "moralmente"; enquanto Pereira de Castro dizia que a "'jurisdição temporal"' havia sido dada aos reis "'imediatamente por Deus e mediatamente pelas gentes"'11.

Dom Luís de Menezes, $3^{\circ}$ conde da ERICEIRA, em História de Portugal Restaurado $(1697)^{42}$, endossou também a tese da origem popular do poder régio. A adesão de Ericeira a esta proposição, entretanto, foi demasiado sutil; apesar disso, sua obra receberá aqui atenção especial, uma vez que ela parece ter sido apropriada para fins sediciosos na América, no último quartel do século XVIII, como se mostrará no Capítulo 8. ERICEIRA, primeiramente, ao procurar legitimar a Restauração, referendou palavras pronunciadas pelo Duque de Bragança, marido de D. Catarina, a

\footnotetext{
${ }^{38}$ TORGAL, Luís Reis, op. cit., vol. 2, p. 28-31.

39 SILVA, José de Seabra da. Dedução chronologica e analytica. Lisboa: Officina de Miguel Menescal de Costa, 1767, vol. 1, p. 407.

${ }^{40}$ TORGAL, Luís Reis, op. cit., vol. 1, p. 138-139, 142 e 215 e vol. 2, p. 23, 58, 105, 301 e 303; e XAVIER, Ângela Barreto, HESPANHA, Antônio Manuel, op. cit., p. 131.

${ }^{41}$ TORGAL, Luís Reis, op. cit., vol. 2, p. 23, 58 e 40. Velasco de Gouvea, é importante frisar, parece de fato ter desfrutado de prestígio nos meios intelectuais portugueses, recebendo entusiásticos elogios de autores como Nicolau Monteiro, que escreveu Vox Tortur., livro proibido pela censura pombalina; João Soares de Brito; Antônio Figueira Durão; e Dom Francisco Manoel de Melo (MACHADO, Diogo Barbosa, op. cit., vol. 2, p. 278).

42 ERICEIRA, Conde [D. Luís de Menezes]. História de Portugal restaurado. Lisboa: Livraria Civilização Editora, 1945, 4 v. Dom Luís de Menezes devotava uma paixão pelas artes fabris e industriais, tendo tentado impulsionar sua introdução em Portugal, motivo pelo qual ficou conhecido como o Colbert português. Nas intrigas que cercaram a deposição de Afonso XVI, tomou partido de D. Pedro, irmão deste. Suicidou-se em 1690 (SILVA, Innocencio Francisco da. Diccionario
} 
qual, próximo à morte de El-Rei D. Henrique, disputava o trono português com D. Antônio, o prior do Crato, e Felipe II, rei de Espanha. O Duque de Bragança, então, compreendia que as Cortes de Lamego, supostamente celebradas em 1145, teriam estabelecido as leis fundamentais do Reino, dentre elas, as leis de sucessão, as quais excluiriam os estrangeiros, caso em que se encontrava Felipe II, o que tornava justa a pretensão ao trono por parte sua esposa, Dona Catarina. As normas de sucessão citadas mostravam, além disso, que se "instituíam Príncipes para a República e não República para os Príncipes, porque a sucessão dos Reis só devia atender à sua conservação e liberdade"43. Desta forma, subordinava-se o princípio sucessório à “conservação e liberdade" do Reino, fim da "República", à qual os Príncipes deviam servir (e não o contrário) ${ }^{44}$. Segundo o mesmo duque, às cortes pertenceria o direito de decidir quem seria o rei.

Após apresentar essas "razões" do Duque de Bragança, ERICEIRA acrescenta que as mesmas foram depois corroboradas pela "notícia mais clara das leis de Lamego, que a política de Castela pretendeu tirar da publicidade dos livros impressos" $"$. Ou seja, ERICEIRA admitia que o povo, reunido em Cortes, possuía o direito de decidir quem seria seu rei, fazendo valer as deliberações das Cortes de Lamego, por meio das quais se formalizaram o pacto e as regras de sujeição ao governante. Essa teoria de poder, implícita na interpretação de Ericeira, fica mais clara quando o autor explica a rebelião contra Felipe IV, associando-a à questão tributária. Segundo Dom Luís de Menezes, nos capítulos assinados por Felipe II, ficou estabelecido que "os Três Estados do reino não seriam obrigados a estar pela concórdia, e poderiam livremente negar-lhes sujeição, vassalagem e obediência, sem por este respeito incorrerem em crime de lesa-majestade, nem outro mau caso", cláusula esta que teria sido suprimida quando da impressão do documento pelos castelhanos ${ }^{46}$. Felipe IV, no entanto, ainda conforme ERICEIRA, sem "chamar Cortes, acrescentou os tributos em Portugal, com tal excesso, que vieram a ser intoleráveis" 47 , constituindo uma situação de "tirania"48.

bibliographico portuguez. Lisboa: Imprensa Nacional- Casa da Moeda, 1987 (fac-simile)).

${ }^{43}$ ERICEIRA, Conde [D. Luís de Menezes], op. cit., vol. 1, p. 37.

${ }^{44}$ Ibidem, vol. 1, p. 38.

${ }^{45}$ Ibidem, vol. 1, p. 41-42.

${ }^{46}$ Ibidem, vol. 1, p. 48.

${ }^{47}$ Ibidem, vol. 1, p. 66. 
Ao lado da larga difusão dessas teorias corporativas de poder, havia em Portugal uma tradição juspolítica de caráter 'popular': em 1385, as Cortes, reunidas em Coimbra, escolheram o Mestre de Avis entre os pretendentes ao trono; em 1580, se pretendeu que de novo o povo deveria escolher o seu rei; em 1640, na Restauração Portuguesa, se apeou Felipe IV e se colocou no trono o Duque de Bragança, Dom João IV; e, ainda, em 1667, se destronou Afonso VI, filho de Dom João IV, e se coroou Dom Pedro II. Esses três últimos movimentos, é importante frisar, foram acompanhados de um esforço de legitimação por meio do emprego de concepções corporativas de $\operatorname{poder}^{49}$. Se isto é perceptível nas obras já mencionadas anteriormente, o mesmo ocorre em escritos como o Assento feito em cortes [...] da aclamação [de D. João IV], impresso na capital portuguesa em 1641; Allegações de direito [...] por parte da Senhora Dona Catarina..., 1581; e Cortes do reyno de Portugal, de $1668^{50}$. Se, ainda, apenas a "tese da origem popular do poder régio poderia, com efeito, justificar a deposição de Felipe IV - considerado tirano pelo direito e pela atuação - e a eleição de D. João IV",51, o mesmo ocorreu em relação à deposição de Afonso VI, em 1667. Nesta ocasião, D. Pedro II tomou-lhe o poder, justificando sua iniciativa pelo "mau governo" do rei seu irmão e apelando para as Cortes tomarem a decisão que lhes aprouvessem ${ }^{52}$.

A defesa da legitimidade da Restauração Portuguesa de 1640, com base no direito legítimo dos Bragança à Coroa e no caráter tirânico do domínio espanhol, pode ser encontrada em Histoire des Révolutions de Portugal, do Abbé VERTOT (1655-1735), obra francesa publicada pela primeira vez em 1689, editada por várias vezes na Europa a partir de então ${ }^{53}$ e que circulou no Reino e na América Portuguesa

\footnotetext{
${ }^{48}$ Ibidem, vol. 1, p. 52.

49 TORGAL, Luís Reis, op. cit., vol. 1, p. 198.

${ }^{50}$ XAVIER, Ângela Barreto, HESPANHA, Antônio Manuel, op. cit., p. 128.

${ }^{51}$ TORGAL, Luís Reis, op. cit., vol. 2, p. 24.

${ }^{52}$ A autoridade das Cortes, para julgar um rei, e do Reino, para depor o Príncipe, foi debatida por duas juntas teológicas, não tendo seus membros chegado a uma unanimidade, havendo apenas concordância da metade deles em relação aos pontos assinalados (XAVIER, Ângela Barreto, HESPANHA, Antônio Manuel, op. cit., p. 128-129).

${ }^{53}$ Segundo o Webster's Biographical Dictionary (1 ed. Springfield [Mass.]: G. \& C. Merriam, 1943. p. 1517), o Abbé René Aubert de Vertot (1655-1735) era um "French historian; historiographer of Knights of Malta, or Hospitalers (1715); author of Histoire des Révolutions de Portugal (1689), Histoire des Révolutions de la République Romaine (1719), etc." (sou grato a Guilherme Pereira das Neves por esta informação). No Emílio, Rousseau, após criticar os historiadores que se dedicavam à "história moderna" por só pensarem "em fazer retratos muito coloridos e que não raro nada representam", denunciando esta história como fruto da fantasia dos mesmos historiadores, tece elogios
} 
no século XVIII. Tanto no próprio texto do abade, como nos prefácios elaborados para as diferentes edições, nota-se o uso da supracitada justificativa. Há de se sublinhar que para Vertot, como para outros historiadores seus contemporâneos, "a história é uma escola de moral, um tribunal soberano, um teatro para os bons príncipes, um cadafalso para os maus" ${ }^{~} 54$, sendo, portanto, sua apreciação sobre a Restauração Portuguesa algo que se encaixava perfeitamente na sua visão de história.

No prefácio da edição inglesa de 1721, faz-se um apanhado da história portuguesa, de Dom Sebastião a Dom Pedro II e, quanto à Restauração propriamente dita, percebe-se a preocupação em legitimar o movimento, classificando-se o domínio espanhol como "pesado jugo" e Felipe IV como "tirano usurpador" e insinuando-se, a partir disto, que seria impróprio chamar o movimento de "conspiração" diferentes idades, qualidades e interesses e que, pela coragem e espírito público de poucos, ocorreu uma Revolução gloriosa e feliz ${ }^{56}$. No mesmo prefácio, ainda, compreende-se o governo de Afonso VI como tirânico e apresenta-se D. Pedro II, o irmão que o destronou, de forma positiva: enquanto o primeiro teria vícios odiosos, o último possuiria "virtudes famosas" ${ }^{\circledR}$. Conclui-se o prefácio, enfim, com a frase latina Ita Imperium semper ad optumum quem; ab minus bono transfertur ${ }^{58}$, ou seja, “Assim o poder 'tende' sempre para os melhores; é transferido do menor para o maior" ${ }^{, 59}$. Esta afirmação pode ser intepretada, à luz das teorias corporativas de poder, como reafirmação da finalidade da república, uma vez que o bem triunfa sobre o mal,

a Vertot: ele "é quase o único que sabia pintar sem fazer retratos" (ROUSSEAU, J.-J. Emílio ou da educação. Trad. Roberto Leal Ferreira. São Paulo: Martins Fontes, 1995, p. 316). Em bibliotecas brasileiras, foram localizadas várias edições desta obra, feitas na França, Inglaterra e Holanda.

${ }^{54}$ HAZARD, Paul. La crise de la conscience européenne: 1680-1715. Paris: Fayard, 1994, p. 38.

55 A Restauração portuguesa, ao que parece, suscitou interesse de outros autores europeus, não escapando entre esses de ser rotulada como "sublevação". O padre Antônio Vieira conta ter conhecimento de um "autor alemão, que escreveu as histórias de nossos tempos, e tirando o que ele chama sublevação do duque de Bragança, não fala mais palavra de Portugal, como se o não houvera no mundo" (VIEIRA, Antônio. Cartas. Lisboa: Editores J. M. C. Seabra \& T. Q. Antunes, 1854-5, tomo 1, p. 182).

56 "We shall see a People, who, no longer able to bear a heavy yoke, resolve to shake it off, and venture their Lives and their Fortunes for their Liberty: a Conspiracy prevail (if an Intent to revolt from an Usurping Tyrant may be call'd a Conspiracy) in which so many Persons, Persons, whole Age, Quality and Interest were very different, are engag'd; and by the Courage and Publick Spirit of a few, a happy and glorious Revolution brought about" (VERTOT, L'Abbé. The revolutions of Portugal written in French by the... London: William Chetwood, 1721, p. XIV).

57 Afirma-se sobre Pedro II, em relação a Afonso VI: "his brother, a Prince whose Virtues were as famous, as the other's Vices were odious, to preserve the Crown in their Family" (Ibidem, p. XV).

${ }^{58}$ Ibidem, loc. cit. 
que o tirano é apeado do poder em nome do bem comum, ou mesmo, num raciocínio que não exclui o primeiro, como reiteração da hierarquia que deve existir nas repúblicas entre o príncipe, "o maior de todos os seus membros", e o conjunto do povo $^{60}$.

Nas edições holandesa e inglesa, respectivamente, de 1749 e 1765, ambas em francês, há um mesmo prefácio, no qual a argumentação sobre a legitimidade da Restauração passa também pela discussão sobre qual seria o melhor termo para classificá-la: esclarece-se que se substituiu o título "Conspiração" por "Revolução", porque o primeiro termo seria menos conveniente para uma empresa que teve por objetivo restituir a Coroa ao seu legítimo herdeiro ${ }^{61}$, no que se vê uma concepção implícita de revolução como sinônimo de "restauração", isto é, como retorno a uma situação anterior compreendida como legítima. O próprio abade VERTOT, no interior da obra, lida com os dois argumentos legitimadores (tirania e direito ao trono). De um lado, afirma que os Felipes trataram "les Portugais moins comme de sujets naturels que comme des peuples soumis par les armes et par le droit de la guerre", de tal sorte que Portugal "devenoit insensiblement province d'Espagne", explicando que, sob o conde-duque Olivares, primeiro-ministro de Felipe IV, os portugueses "n'ayant plus rien à perdre et ne pouvant espérer de fin ni d'adoucissement à l'état, songèrent à s'affranchir d'une domination qui leur avoit toujours paru injuste, et que devenoit tyrannique et insupportable (1640)"62. De outro, VERTOT sublinha o direito de Dom João IV ao trono português, ao reproduzir o discurso de um arcebispo numa reunião preparatória da rebelião. Nesta ocasião,

\footnotetext{
${ }^{59}$ Sou grato a Fábio Faversani pela tradução deste período.

${ }^{60}$ Suárez e Vitoria refletem sobre a diferença existente entre o governante e o povo, embora pareçam estar mais preocupados com o tratamento que o último deve ao primeiro, e não tanto com a qualidade do governante. Sobre isto, veja: SKINNER, Quentin, op. cit., p. 458. Outra possibilidade seria interpretar tal afirmação à luz de Maquiavel. Isto deslocaria a explicação para a habilidade do Príncipe na arte de governar, na defesa da razão de Estado, sendo a relação com o povo descolada de qualquer fundamento ético. Neste sentido, valendo-se o poder pelo poder, Pedro II seria mais capacitado que Afonso VI.

${ }^{61}$ Conspiração seria "moins convenable dans une entreprise, dont les Chefs n'avoient pour object que de rendre la Couronne à un Prince, qu'ils regardoient comme l'hérétier légitime” (VERTOT, L' Abbé. Histoire des révolutions de Portugal par... sixiéme edition, revue \& augmentée par l'auteur. Londres: Jean Nourse, 1765, p. 3). As referências da edição holandesa são: VERTOT, L' Abbé. Histoire des révolutions de Portugal par... Amsterdã: Etienne Roger, 1749.

${ }^{62}$ VERTOT, L' Abbé. Histoire des révolutions de Portugal par... continuée jusqu'au tems présent, Enrichie de Notes Historiques et Critiques, d'une Table Historique et Chronologique des Rois de Portugal, et d'une Description du Brésil par Louis de Boisgelin, chevalier de Malthe. Londres: R. Juigné, 1809, p. 15-17.
} 
alguns nobres aventaram a possibilidade de instaurar uma república, à semelhança da Holanda, ao invés de uma monarquia, tendo, então, retrucado o arcebispo:

\begin{abstract}
"que le choix du gouvernement n'étoit point arbitraire; qu'ils ne pouvoient en conscience rompre le serment de fidélité qu'ils avoient fait au roi d'Espagne, se ce n'étoit pour rendre justice à l'héritier légitime de la couronne; que tout le monde savoit qu'il appartenoit au duc de Bragance; et ainsi qu'il falloit se déterminer ou à le reconnoître pour leur roi, ou à rester pour jamais sous la domination d'Espagne",63
\end{abstract}

Portanto, segundo o arcebispo, a legitimidade do movimento estava indissociavelmente ligada ao seu propósito de restituir a Coroa portuguesa ao seu legítimo herdeiro, o duque de Bragança: só o direito deste ao trono justificava a ruptura do juramento de fidelidade feito ao rei de Espanha.

É importante dizer que a visão de VERTOT sobre o domínio espanhol e a Restauração Portuguesa não era algo excepcional entre os historiadores estrangeiros da passagem do século XVII para o século XVIII. Outros historiadores pareciam admitir a legitimidade de uma rebelião contra um governo tirânico, sobretudo quando se tinha em vista restituir o trono ao seu "Príncipe legítimo". O também francês Mr. Nicolas de LA CLÈDE, em sua Histoire Générale de Portugal, provavelmente publicada pela primeira vez em 1735, não é nada lisonjeiro com os reinados dos Felipes, caracterizando-os como "de rapina, de terror, e de estrago", período em que "Gemeo Portugal 61 annos escravo": antes "Reino florescente, cuja gloria se estendia até aos extremos do Mundo", Portugal converteu-se em "huma Provincia opprimida",64. Inversamente, com a Restauração, segundo LA CLÈDE, “os Portuguezes sacodem o jugo, e repoem no Throno o seu Principe legitimo, e lhe firmão a Coroa na cabeça, com huma serie de victorias alcançadas contra os seus

\footnotetext{
${ }^{63}$ Ibidem, p. 32.

${ }^{64}$ LA CLĖDE, [Nicolas de]. História geral de Portugal. traduzida em vulgar e illustrada com muitas notas históricas, geograficas, e criticas; e com algumas dissertações singulares. Lisboa: Typografia Rollandiana, 1781-1790, vol. 1, p. 37. No Tomo XIII, editado em português em 1790, o reinado de Felipe III, é comparado com o de seu pai. Felipe II é descrito como "mais avarento, cruel, mas doble, e dissimulado, buscava honrosos pretextos para as desgraças, com que opprimia seus novos vassalos; e seu filho, que naturalmente não sabia dissimular, nem fingir tanto, deixava ver a todos claramente que seus intentos só se dirigião a abater tanto os Portuguezes, que nunca podessem arredar o dominio Hespanhol". Qualifica-se como odioso o Conde Duque de Olivares, o poderoso ministro de Felipe IV, e diz-se que ele teve dois auxiliares em seu empenho de oprimir os portugueses: Diogo Soares, secretário do Conselho de Despachos, em Lisboa; e Miguel de Vasconcelos, filho de Pedro Barbosa (Ibidem, p. 7-8 e 27).
} 
oppressores" ${ }^{\prime 65}$.

Em Portugal, enfim, desde os inícios da fundação do Reino havia uma prática juspolítica que consagrava a soberania popular e, nos séculos XVI, XVII e XVIII, circulavam teorias de poder com a mesma orientação ${ }^{66}$, fossem aquelas de Bellarmino e dos pensadores escolásticos espanhóis ou de autores de outras nacionalidades, como o abade Vertot e, de modo mais discreto, La Clède, fossem as produzidas pelos próprios lusos que se inspiravam nos primeiros. Essa tradição juspolítica e parte desse universo literário foram alvos da ofensiva absolutista e reformista iniciada por D. José I e continuada por seus sucessores, Dona Maria I e o Príncipe Regente. Tais elementos, como se verá no Capítulo 8, foram apropriados por alguns sediciosos da América Portuguesa de fins do século XVIII, constituindo a epistemè que os mesmos usaram contra o domínio português, o que demonstra a clarividência do aparato censório em procurar interditá-los. Mas, é importante adiantar, tal epistemè aliou-se às novas perspectivas trazidas pelas Luzes, sendo ambas amalgamadas pelos sediciosos luso-americanos de fins do século XVIII.

\section{Milenarismos e Anti-Cientificismo}

Na mentalidade européia, até o início do século XVIII, como assinala Sérgio Buarque de HOLANDA, considerava-se que o espetáculo terreno fornecia, "em sua própria evanescência, lições de eternidade": a natureza era "o livro da Natureza", escrito por Deus e, como a Bíblia, encerrava sentidos ocultos, além do literal; através de toda a Criação, portanto, falaria a própria voz do Criador ${ }^{67}$. Essa visão simbólica da natureza, presente desde os momentos iniciais do cristianismo, incidia sobre a natureza inorgânica, os animais e as plantas ${ }^{68}$. Nem mesmo a França foi refratária a esta visão, embora neste país alguns a tenham atenuado, secularizando a apreciação do mundo natural, como, por exemplo, La Fontaine, que, ao invés de ver lições

\footnotetext{
${ }^{65}$ Ibidem, vol. 1, p. 37-38.

${ }^{66}$ TORGAL, Luís Reis, op. cit., vol. 1, p. 199.

67 HOLLANDA, Sérgio Buarque de. Visão do paraíso: os motivos edênicos no descobrimento e colonização do Brasil. 3 ed. São Paulo: Ed. Nacional; Secretaria de Cultura, Ciência e Tecnologia, 1977, p. 64.

${ }^{68}$ Ibidem, p. 191-192.
} 
divinas nos bichos, projetou neles sentimentos e ressentimentos humanos ${ }^{69}$.

Os ibéricos, longe de refutarem essa visão sacralizada de mundo, vieram a acentuá-la. Contudo, os portugueses, diferentemente dos seus vizinhos espanhóis, conjugaram-na a um certo realismo. Tratava-se de um realismo de caráter medieval, de um pragmatismo que os levava a concederem primado à experiência, ao quotidiano e a hostilizarem a fantasia; que os conduzia a resignarem-se ao imediato, ao real $^{70}$. Assim, se nas apreciações construídas pelos espanhóis sobre o Novo Mundo imperavam portentosos motivos edênicos, nas constituídas pelos lusitanos, estes mesmos motivos encontravam-se descoloridos, plausivelmente atenuados, de tal sorte que o maravilhoso era admitido apenas quando se achasse além da órbita do saber empírico, sobretudo "quando servissem para contentar seu apetite de bens materiais" ${ }^{71}$. Os portugueses, ademais, renunciaram à transfiguração da realidade por meio da obediência a "códigos de postura e regras formais" ${ }^{\text {,72 }}$. Esse realismo guiou a postura de alguns intelectuais luso-brasileiros, levando-os a tergiversar em matéria de princípios e a priorizar a ação em detrimento da especulação, inclusive a científica. Até mesmo as autoridades coloniais deixaram-se contaminar por tal flexibilidade, afrouxando regras e conduzindo suas práticas com base numa avaliação cuidadosa da oportunidade das mesmas, dos seus possíveis efeitos, das reações que iriam desencadear ${ }^{73}$.

Marcada pela sacralização, pelo realismo-pragmatismo e pelos topoi edênicos plausivelmente atenuados, a mentalidade portuguesa deu guarida também ao anticientificismo e, à semelhança do que sucedia em outros países europeus como a Inglaterra, acolheu os milenarismos. Aos milenarismos portugueses foi essencial a profecia - que teve no padre Antônio Vieira seu maior propagador — de instauração de um Quinto Império, com capital em Lisboa, misto de Reino temporal e espiritual de Cristo (ou Vice-Cristo) na Terra ${ }^{74}$. Tal profecia sobreviveu ao tempo e

\footnotetext{
${ }^{69}$ Ibidem, p. 218-219.

${ }^{70}$ Ibidem, p. 103 e 304

${ }^{71}$ Ibidem, p. 5, 103, 126 e 143.

72 Idem, Raízes do Brasil. 19 ed. Rio de Janeiro: José Olympio, 1987, p. 76.

${ }^{73}$ VILLALTA, Luiz Carlos. O cenário urbano em Minas Gerais setecentista: outeiros do sagrado e do profano. In: TERMO de Mariana: história e documentação. Belo Horizonte: BDMG; Ouro Preto: UFOP, 1998, p. 67-85. Sobre isso veja, a título de exemplo, algumas passagens de: COELHO, José João Teixeira. Instrução para o governo da capitania de Minas Gerais. Belo Horizonte: Fundação João Pinheiro, Centro de Estudos Históricos e Culturais, 1994, p. 135, 137-138 e 147.

${ }^{74}$ Sobre Vieira e o Quinto Império, veja principalmente: PÉCORA, Alcir. Teatro do sacramento: a
} 
atravessou o Atlântico, encontrando na América inspiração e adeptos. Enquanto na América Inglesa, os milenarismos secularizaram-se, tendo a utopia da propagação da fé sido substituída pela da liberdade; no mundo luso-brasileiro, observou-se a difusão da utopia da constituição de um "Império Florente" na América Portuguesa. Império religioso-secular para alguns, como, por exemplo, no século XVIII, o herético Pedro Rates Henequim ${ }^{75}$, transformou-se em "poderoso império" laico na concepção de Ilustrados como D. Luís da Cunha, Dom Rodrigo de Souza Coutinho, o cônego inconfidente mineiro Luís Vieira da Silva; e, avançando até o século XIX, o jornalista Hipólito José da Costa ${ }^{76}$.

O que havia de específico nos milenarismos portugueses face aos outros europeus? Até que ponto o anti-cientificismo imperava na cultura luso-brasileira? Em que medida o Reformismo Ilustrado Português se contrapôs ao anti-cientificismo? Encontrar respostas a estas questões é essencial para compreender não só os parâmetros da censura portuguesa sob o Reformismo Ilustrado Português, mas também para acompanhar as resistências movidas pelos leitores que enfrentavam as interdições e se contrapunham às novas diretrizes governamentais. Por isto, neste capítulo, abordar-se-ão, primeiro, a presença do anti-cientificismo em Portugal e, depois, a configuração dos milenarismos. No Capítulo 3, referente ao Reformismo Ilustrado em Portugal, ver-se-á como os Ilustrados e a Coroa portuguesa apreenderam e se posicionaram face a esta herança.

\subsection{Anti-cientificismo}

unidade teológico-retórico-política dos sermões de Antônio Vieira. São Paulo: Edusp; Campinas: Editora da Universidade de Campinas, 1994, p. 213-258; Idem, Prefácio: Tópicas políticas dos escritos de Antônio Vieira. In: PÉCORA, Alcir (org.). Escritos históricos e políticos. São Paulo: Martins Fontes, 1995, p. XXI-XXIII; CIDADE, Hernâni. Antônio Vieira. Lisboa: Editorial Presença, 1985, p. 24-26, 28-32 e 73-93; e SARAIVA, Antônio J.. Padre Antônio Vieira. In: DICIONÁRIO da História de Portugal. Porto: Inic. Edit., 1970, vol. 6, p. 298-302. Sobre o sebastianismo, veja principalmente: HERMANN, Jacqueline. No Reino do desejado: a construção do sebastianismo em Portugal (séculos XVI e XVII). São Paulo: Companhia das Letras, 1998.

${ }^{75}$ A profecia da edificação de um Império na América portuguesa será detalhada mais à frente. Sobre sua presença no pensamento de Henequim, veja: ROMEIRO, Adriana. Um visionário na corte de D. João V: revolta e milenarismo em Minas Gerais., Campinas: Unicamp, 1996, p. 73-74 (Tese de doutorado), e GOMES, Plínio Freire. Um herege vai ao paraíso: cosmologia de um ex-colono condenado pela Inquisição (1680-1744). São Paulo: Companhia das Letras, 1997, p. 124-126.

${ }^{76}$ Sobre a utopia de um Império no pensamento de D. Luís da Cunha, D. Rodrigo de Souza Coutinho e Hipólito José da Costa, veja: LYRA, Maria de Lourdes Viana Lyra. A utopia do poderoso império. Rio de Janeiro: Sette Letras, 1994, p. 110-111 e 124-131 e MAXWELL, Kenneth. Pombal: paradox of the enlightenment. Cambridge [UK]: Cambridge University Press, 1995, p. 16. 
O anti-cientificismo se inscrevia num quadro maior de reações da Ibéria aos grandes movimentos intelectuais ocorridos no Além-Pirineus. Tais reações marcaram-se por uma certa negatividade, cujos contornos, no entanto, precisam ser delimitados com cuidado. Pensando-se especificamente sobre Portugal, cumpre evitar resumir a situação cultural - e isto vale também para a economia e a sociedade - em termos como "atraso" ou em interpretações que postulem a existência de uma barreira intransponível em relação ao que sucedia no AlémPirineus. A aplicação do modelo transpirinaico de forma apriorística e, mais do que isto, excludente, conduz a preconceitos e implica fazer tábua rasa das especificidades do mundo português. Por isto, deve-se atentar para a dinâmica das permanências e das transformações que afetaram Portugal, sobretudo a partir do segunda metade do século XVIII ${ }^{77}$.

Portugueses e espanhóis, é bem verdade, por um lado, desconheceram alguns dos movimentos culturais que ocorreram no Além-Pirineus; incorporaram outros, anexando-os à cultura dominante; e, ainda, viram a cultura oficial repudiar pura e simplesmente inúmeras manifestações ${ }^{78}$. Enquanto na Ibéria usava-se uma epistemologia racional formal-objetiva, que "vai de um dado concreto a uma classe

\footnotetext{
${ }^{77}$ MIRANDA, Tiago Costa Pinto dos Reis (op. cit., p. 31-42) examina como a historiografia tratou a idéia de "atraso" cultural e científico de Portugal face aos países do Além-Pirineus. Neste balanço, identifica algumas constantes (a contraposição de uma Europa desenvolvida a um Portugal "atrasado", a articulação entre "atraso cultural" e "análises econômicas estritamente negativas", e a identificação dos "estrangeirados" como os protagonistas de tentativas de ruptura com a "indolência" portuguesa), apresenta os questionamentos historiográficos recentes (Portugal participou dos movimentos de renovação que ocorriam na Europa; não houve no século XVIII a alegada crise do setor industrial português "como um todo"; o conceito de "estrangeirado" precisa ser repensado em bases econômicas e sociais; e a idéia de atraso, uma criação do romantismo, era estranha aos portugueses do século XVIII) e, ainda, sugere alguns rumos para as investigações futuras (recusar as dicotomias, ver o que os portugueses setecentistas pensavam e avaliar a difusão dos projetos dos estrangeirados). Vale lembrar também o trabalho de Valentim Alexandre, que se atém à situação econômica portuguesa na passagem do século XVIII para o século XIX, abalando alguns dos pilares sobre os quais se assentou a historiografia recente para falar do "atraso" de Portugal: mostra que os historiadores fizeram uma sistematização e uma leitura "defeituosas" do conjunto das balanças do comércio exterior português, avaliando, por conseguinte, de forma equivocada o papel da metrópole e da Inglaterra no período. No entendimento do autor supracitado, Portugal não seria um mero entreposto de bens europeus destinados às suas possessões americanas, mas também produtora dos artigos exportados para a Colônia, havendo na província do Entre-Douro-e-Minho e na Beira Litoral uma expressiva indústria artesanal de linho e ferragens. Já a Inglaterra não teria um papel predominante no consumo de produtos coloniais portugueses, como alegam os historiadores (ALEXANDRE, Valentim. Os sentidos do império: questão nacional e questão colonial na crise do antigo regime português. Porto: Edições Afrontamento, 1993, p. 19, 27, 36 e 46).

${ }^{78}$ TORGAL, Luís Reis, op. cit., vol. 1, p. 66.
} 
de coisas, e então retorna para interpretar o dado", e que recorre essencialmente à dedução, via-se entre os protestantes e os occamistas uma epistemologia ditada pela racionalidade "dialético pessoal”, em que a "discussão alimenta-se do 'sim' e do 'não' que surgem nos encontros entre pessoas distintas" e na qual as afirmações são generalizadas "a partir de vários encontros do informante", extraindo-se, portanto, a partir da indução ${ }^{79}$.

Se no restante da Europa Ocidental, no seu tempo, as diversas correntes protestantes, o jansenismo, o augustinianismo oratoriano, o laicismo, o cientismo, o racionalismo, o ceticismo e o libertinismo fizeram-se representados, em Portugal e Espanha, tais correntes se mostraram inexistentes, ou apareceram como produtos de importação, encontrando oposição de variada $\operatorname{ordem}^{80}$. A sociedade portuguesa manteve-se "sacral", com o que todos os setores da existência ficaram impregnados de religiosidade, enquanto os povos do Norte da Europa iam-se secularizando sob a influência do humanismo e do protestantismo ${ }^{81}$. O racionalismo não logrou afetar profundamente a consciência portuguesa ${ }^{82}$.

Nos colégios dos jesuítas prevaleceu uma situação pouco favorável às ciências exatas e naturais. Elas eram abordadas no Curso de Filosofia: algumas noções elementares de matemática, na Lógica, na Aritmética, na Geometria, na Perspectiva e na Esfera; conteúdos de física, astronomia e cosmografia, na Física; e, ainda, tópicos de biologia, na Metafísica. Todos esses conteúdos, acrescente-se, ficaram durante muito tempo só no plano programático ${ }^{83}$. Na matemática, os jesuítas mostraram-se mais progressistas, mesmo assim principalmente a partir dos inícios do século XVIII; na América, só se criou uma Faculdade de Matemática em 1726, no

\footnotetext{
${ }^{79}$ MORSE, Richard M., op. cit., p. 47-48. O autor sublinha que se trata de "duas epistemologias divergentes e não apenas de dois artifícios lógicos representados pela dedução e a indução" (Ibidem, p. 47).

${ }^{80}$ TORGAL, Luís Reis, op. cit., loc. cit.

${ }^{81}$ BESSELAAR, José van den. O sebastianismo: história sumária. Lisboa: Ministério da Educação e Cultura/ ICALP, 1987, p. 26. Trevor-Roper, embora apreenda a Espanha de forma extremamente pejorativa (para ele, foi uma infelicidade o fato desse país ter estendido à Europa o Estado da ContraReforma), vê como menos "progressistas" não apenas as sociedades ibéricas, mas o conjunto das sociedades católicas: comparativamente, as sociedades protestantes seriam mais progressistas, em termos econômicos e intelectuais (TREVOR-HOPER, H. R. De la Réforme aux Lumières. Trad. Laurence Ratier. Paris: Éditions Gallimard, 1996, p. 46 e 81).

${ }^{82}$ DOMINGUES, Francisco Contente. Ilustração e catolicismo: Teodoro de Almeida. Lisboa: Edições Colibri, 1994, p. 27.

${ }^{83}$ CARVALHO, Rômulo de, op. cit., p. 343-350.
} 
Colégio da Bahia ${ }^{84}$. O autor fundamental no ensino das ciências era Aristóteles; este e são Tomás de Aquino foram objeto de defesa cautelosa nos colégios, tendo sido recomendado aos mestres, pelo Ratio Studiorum, que se evitasse qualquer suspeita contra as doutrinas dos mesmos ${ }^{85}$. Vários de seus escritos foram lidos, compostos, recompostos e reunidos por Manuel de Góis, Cosme de Magalhães, Baltazar Álvares e Sebastião do Couto, a partir do que surgiu, ao final do século XVI, a obra conhecida como Curso Conimbricense, usada em Portugal e seus domínios, inclusive por colégios de outras ordens religiosas, e também nos países europeus ${ }^{86}$. Na Universidade de Coimbra, um axioma conformava o programa de todas as faculdades: "Que não se apartem de Aristóteles em coisa alguma",87.

A dialética de Aristóteles confundia-se com sua tópica e constituía a "base da árvore dos saberes", a fonte de todas as formas de conhecimento, da ciência e das artes em geral, dominando o ensino nas escolas e na universidade. A tópica era um método de raciocínio assentado numa lógica da argumentação cuja ordem era a seguinte: primeiro, proposição-problema, etapa inicial em que se apresentava uma proposição que, ao mesmo tempo, se convertia em problema; num segundo momento, o dos tópicos, o dialético pesquisava os pontos de vista sob os quais podiam ser analisados os problemas; na etapa seguinte, dos argumentos / razões, aquele reunia os argumentos encontrados na pesquisa favoráveis a uma ou outra solução; depois, na ponderação das razões, o dialético avaliava as soluções; e, por fim, na última etapa, da solução mais provável, optava-se pela solução mais provável $^{88}$. No direito e na política, o uso da tópica adquiriu traços pragmáticos, com o que se transformou numa técnica mediante a qual se resolviam problemas em consonância com interesses políticos de um determinado contexto ${ }^{89}$. A tópica, além disso, ensejou a formulação de repertórios de mais diversa natureza (de tópicos

\footnotetext{
${ }^{84}$ Ibidem, p. 378 e 390; e FILGUEIRAS, Carlos Alberto Lombardi. Bartolomeu de Gusmão - um eco da Revolução Científica no Brasil Colonial. In: GOLDFARB, Ana Maria, MAIA, C. A.(org.). História e Ciência: o mapa do conhecimento. São Paulo: Expressão e Cultura/ Edusp, 1995, p. 383-385.

${ }^{85}$ CARVALHO, Rômulo de, op. cit., p. 344-345. Nesta situação, com certeza, encontrava-se também o ensino jesuítico na América Portuguesa - LEITE, Serafim. O curso de Filosofia e tentativas para se criar a universidade do Brasil no século XVII. Verbvm, revista trimestral, Rio de Janeiro, 2 (5): 134, jun./1948.

${ }^{86}$ CARVALHO, Rômulo de, op. cit., p. 348-249 e 376-377.

${ }^{87}$ XAVIER, Ângela Barreto. "El Rei aonde póde, \& não aonde quér": Razões da política no Portugal seiscentista. Lisboa: Colibri, 1998, p. 102.

${ }^{88}$ Ibidem, p. 84-87.

${ }^{89}$ Ibidem, p. 86.
} 
jurídicos, históricos, gramaticais, literários e de imagens), impressos ou manuscritos, de onde os letrados retiravam pontos de vista e argumentos para construírem seus raciocínios. Com isso, a tópica, ao invés de estimular a flexibilidade do raciocínio, “fixava 'opiniões', que de tanto usadas e consideradas, se transformavam em dogmas inabaláveis", transformando-se em fonte de conhecimento. Deixava, assim, de ser um 'modo de discorrer sobre as coisas', para ser um 'modo de discorrer sobre os discursos 90 .

Por outro lado, o panorama cultural do mundo luso-brasileiro do período moderno mostrou-se menos fechado, sacral e negativo em relação ao Além-Pirineus do que se pode imaginar. No próprio Curso Conimbrence havia passagens que contradiziam São Tomás $^{91}$ e, no Brasil, isso era percebido por mestres e discípulos ainda nos inícios do século XVII ${ }^{92}$. Além disso, se as idéias de Galileu Galilei, Descartes e Newton tiveram ou um atraso notório na sua divulgação em Portugal, ou um desvirtuamento, ou uma difusão por outras vias que não as originais ${ }^{93}$, elas se fizeram presentes em território luso. Os jesuítas estiveram a par da revolução científica, conhecendo as novas metodologias propostas, o método experimental nas Ciências da Natureza e as descobertas astronômicas. A divulgação dessas novas idéias pelos inacianos, no entanto, foi restrita. Alguns manuais usados nos colégios jesuíticos faziam apenas pequenas concessões à modernidade, como o Cursus Philosophicus (1651), de Francisco Soares Lusitano ${ }^{94}$, autor que defendia a tese da circulação do sangue - afirmando, neste aspecto, preferir o que diziam os médicos ao que afirmava são Tomás - e que citava nominalmente Harvey, seu contemporâneo, de quem tirara a prova experimental. Este livro, é importante frisar, deve ter sido de largo uso no Brasil: à época da expulsão dos jesuítas, havia 84 tomos no colégio do Rio de Janeiro ${ }^{95}$. No geral, porém, os inacianos mantiveram todo este saber restrito ao seu uso privado, ao consumo dos seus pares, nunca comunicando-o nas aulas, exceto aqui e ali, pela ousadia de um ou outro mestre ${ }^{96}$.

Essa tolerância relativa dos jesuítas face a algumas inovações científicas

\footnotetext{
${ }^{90}$ Ibidem, p. 89-92.

${ }^{91}$ CARVALHO, Rômulo de, op. cit., p. 375-376.

${ }^{92}$ LEITE, Serafim, op. cit., p. 124-140.

${ }^{93}$ DOMINGUES, Francisco Contente, op. cit., p. 40.

${ }^{94}$ CARVALHO, Rômulo de, op. cit., p. 376-377.

${ }^{95}$ LEITE, Serafim, op. cit., p. 139-142.
} 
possivelmente ligava-se à influência que o probabilismo exerceu sobre eles. Doutrina casuística cujo advento pode ser situado na segunda metade do século $\mathrm{XVI}^{97}$, o probabilismo discorre sobre as situações particulares em que existe uma incerteza sobre a aplicação de regras morais, estabelecendo que, nesses casos, para não errar, seria suficiente seguir uma opinião provável, ainda que não fosse a mais recomendável em termos de "estrita doutrina" 98 . Assim, ao pecador, para não ser faltoso, bastaria agir de acordo com uma opinião plausível e que contasse com defensores respeitáveis, mesmo que ela fosse menos provável do que a opinião contrária $^{99}$.

O probabilismo encontrou no jesuíta Francisco Suárez e no dominicano Medina seus iniciadores, sendo associado freqüentemente aos jesuítas e atacado duramente por religiosos de outras ordens - e também por políticos que se opunham aos inacianos. Os probabilioristas, adversários do probabilismo, julgavam que entre duas opiniões, uma menos provável e segura e outra mais provável e mais segura, a escolha deveria recair sobre a última; por isto, os probabilioristas viam o probabilismo como sinônimo de laxismo, de moral relaxada, considerando-o um incentivo para condutas não condizentes com os critérios morais da igreja ${ }^{100}$. Jean DELUMEAU sublinha que, "se o probabilismo constituiu a infra-estrutura intelectual do laxismo", contribuiu para "modelar uma moral mais bem adaptada que a do passado à ascensão da civilização ocidental”, na medida em que sublinhava "o respeito devido às consciências e a necessidade de limitar a esfera da obrigação para proteger a da liberdade" $" 101$.

\footnotetext{
${ }^{96}$ CARVALHO, Rômulo de, loc. cit. e p. 386.

${ }^{97}$ DELUMEAU, Jean. A confissão e o perdão. São Paulo: Companhia das Letras, 1991, p. 99. O probabilismo, segundo o mesmo autor, entretanto, teria uma pré-história que remonta à Idade Média, encontrando nas idéias de Guilherme de Ockham sobre a liberdade do homem um de seus fundamentos. Segundo Ockham, a liberdade é o bem próprio e original do homem, e a moralidade consiste no encontro da liberdade e da lei; não havendo moralidade sem lei, nem sem liberdade. Para o mesmo, a lei não tem a mesma conotação que para São Tomás: se para este a lei natural vem de Deus e se interioriza na natureza humana, para Ockham ela é exterior ao homem; bem e mal são decisões divinas; um ato é bom porque Deus prescreve e, por fim, a razão pode ditar ao homem alguma coisa, mas a vontade pode a não querer (Ibidem, p. 100 e 105-106).

${ }^{98}$ CHIARAMONTE, José Carlos. Ciudades, provincias, estados: orígenes de la nación Argentina 1800-1846. Buenos Aires: Ariel Historia, 1997, p. 33.

99 DELUMEAU, Jean, op. cit., p. 97-117 e ALMEIDA, Ângela Mendes de. O gosto do pecado: casamento e sexualidade nos manuais de confessores dos séculos XVI e XVII. Rio de Janeiro: Rocco, 1992, p. 19-30.

${ }^{100}$ CHIARAMONTE, José Carlos, loc. cit. e DELUMEAU, Jean, op. cit., p. 115.

${ }^{101}$ DELUMEAU, Jean, op. cit., p. 108.
} 
Richard MORSE afirma que a estratégia probabilista expressava um "espírito pluralista e não concludente" em relação aos "fenômenos observados ou experimentados" ${ }^{\prime 102}$. Isto reforça a idéia de que é um equívoco adjetivar os jesuítas e o panorama intelectual português simplesmente como "atrasados".

A "liberdade" e o "pluralismo" consagrados pelo probabilismo parecem ter sido exercitados pelos jesuítas em relação ao heliocentrismo de Copérnico e Galileu. Assim, o padre Cristóvão Bruno, professor de esfera no Colégio de Santo Antão, por volta de 1625 , divulgava a teoria heliocêntrica, mas a refutava em vários pontos ${ }^{103}$. Num momento primeiro da divulgação do heliocentrismo de Copérnico, os jesuítas revelaram uma certa indiferença, não atribuindo importância aos riscos doutrinários que lhe eram inerentes, pois ele se assentava unicamente em razões matemáticas e metafísicas, e o probabilismo lhes permitia, no caso de se defrontarem com duas hipóteses contrárias, acomodar-se àquela que mais atendesse às suas necessidades ${ }^{104}$. Quando Galileu comprovou a citada teoria com o telescópio, porém, os jesuítas mudaram de posição, vindo a rejeitá-la de modos diferentes: alguns passaram a considerar dispensáveis as idéias de Copérnico e Galileu; outros, as repudiaram como falsas; e, por fim, o já mencionado padre Cristóvão Bruno e o padre Antônio Vieira procuraram conciliar a escolástica às novas descobertas. $\mathrm{O}$ primeiro condenava $\mathrm{o}$ sistema de Ptolomeu, mas ao mesmo tempo, em conformidade com a física aristotélica, discordava da existência de um movimento de rotação por parte da Terra, como postulava Galileu, concluindo que as teorias heliocêntrica e de Ptolomeu davam conta das aparências observadas no céu, mas não eram uma representação real do Universo; e Vieira, que teve contato com as novas idéias ainda no Brasil, de modo similar mostrava desinteresse em avaliar "se o Sol se move, ou nós”, pois “"tudo acaba'", não importando o ângulo sob o qual examinássemos os fatos ${ }^{105}$. Num e

\footnotetext{
${ }^{102}$ MORSE, Richard M., op. cit., p. 35.

103 ALBUQUERQUE, Luís de. Para a história da ciência em Portugal. Lisboa: Horizonte, 1973, p. 140. Bruno discorria sobre o assunto em audiências públicas, não apenas diante de membros da Companhia. Revelava em Portugal as descobertas astronômicas de Galileu, mesmo tendo travado com este uma disputa para descobrir um processo seguro para determinar a longitude no alto mar (DOMINGUES, Francisco Contente, op. cit., p. 35).

${ }^{104}$ ALBUQUERQUE, Luís de, op. cit., p. 122-125.

105 Ibidem, p. 135 e 140-141. O mesmo Padre Antônio Vieira, ainda em 1675, demonstrando seu interesse e atualização em matéria de ciência, teceu comentários sobre o livro "História Natural de Pernambuco", "com as estampas dos animais, peixes e plantas" — na realidade, História Natural do Brasil, de Jorge Marcgrave e Guilherme Piso, publicado em 1648 na Holanda (FILGUEIRAS, Carlos Alberto Lombardi. Origens da ciência no Brasil. Química Nova, São Paulo, 13 (3): 224, 1990). Tomou
} 
noutro raciocínio, enfim, as verdades celestes - respectivamente, representação real do Universo e finitude da matéria - mantinham-se incólumes e amorteciam o impacto das novas descobertas. Por fim, demonstrando a existência de aberturas entre os jesuítas às novas idéias científicas, tentou-se, no Colégio das Artes de Coimbra, em 1712, enveredar pelos novos caminhos das ciências, introduzindo-se alterações nos seus estatutos, iniciativa esta abortada por D. João V. Em 1746, ao tempo do mesmo monarca, no referido colégio, proibiu-se o recurso às lições de Descartes, Gassendi e Newton ${ }^{106}$.

$\mathrm{Na}$ corte joanina, com o estímulo do próprio rei, desenvolveu-se, no entanto, um gosto pelas novidades científicas, particularmente quando envoltas na dimensão de espetáculo, como as atividades de execução e observação de experiências com utilização de instrumentos apropriados, em cursos públicos extra-escolares de Física Experimental, à semelhança do que sucedia em outros países ${ }^{107}$. Com isso, sob D. João $\mathrm{V}$, enquanto nos colégios jesuíticos mantinha-se o acesso às ciências reservado aos mestres individualmente, a Corte e a nobreza inscreviam as inovações científicas numa cultura do espetáculo e da ostentação. O rei interessava-se avidamente pela aquisição de livros para a biblioteca do palácio real, encarregando os representantes diplomáticos da compra de obras nos países em que se encontravam ou por onde andavam. Suspeita-se, no entanto, que este interesse nada mais expressava do que uma ânsia de ostentar e celebrar seu próprio nome ${ }^{108}$.

Em Portugal, enfim, de um lado, predominava uma perspectiva escolástica, contrária à experimentação e, em grande medida, ao livre-pensamento, mas, por outro, inexistia um completo isolamento em relação ao que sucedia no AlémPirineus, recebendo-se ecos da revolução científica, ecos muitas vezes mantidos reservados a poucos, outras vezes amenizados pelo predomínio de uma perspectiva sacral de mundo, ou ainda, sufocados pela autoridade régia. O probabilismo jesuítico talvez tenha sido um elemento importante para as aberturas encontradas na cultura

\footnotetext{
como seu autor um "médico holandês" e lamentou ver divulgadas as riquezas do Brasil: "por sinal que me pesou muito de ver tão público um secreto que podia acrescentar a cobiça daquelas terras que nós tão pouco sabemos estimar" (Padre Antônio Vieira, op. cit., tom. 4, p. 47). Marcgrave, como um sinal dos tempos, reproduziu o topos edênico que consagrava a grande longevidade dos brasis (HOLLANDA, Sérgio Buarque de. Visão do paraíso, op. cit., p. 249).

${ }^{106}$ CARVALHO, Rômulo de, op. cit., p. 389.

${ }^{107}$ Ibidem, p. 393-397.

${ }^{108}$ ALMEIDA, Luís Ferrand de. D. João V e a Biblioteca Real. Revista da Universidade de Coimbra,
} 
lusitana, embora seja necessário reunir mais evidências empíricas para sustentar esta conjectura.

Nesse ambiente cultural português, até meados do século XVIII eivado de sacralização, de pragmatismo, de topoi edênicos atenuados e de anti-cientificismo, os eruditos mantiveram uma convivência estreita com os messianismos e os milenarismos (ambos no plural, porquanto compreenderam no seu interior movimentos heterogêneos). Como se mostrará a seguir, os milenarismos e messianismos grassaram por boa parte do continente europeu, não sendo propriamente uma especificidade portuguesa ou mesmo ibérica. Em Portugal, no entanto, milenarismos e messianismos, muitas vezes, por mais paradoxal que possa parecer, aliavam-se a um extremo pragmatismo. Tal convivência, ao lado de outros elementos, parece ser uma particularidade do mundo português.

\subsection{Milenarismos cristãos na Europa e América: das origens ao século XVIII}

Os milenarismos-messianismos têm em comum a espera de um tempo de felicidade, de um reino geralmente terrestre. Os milenarismos aparecem entre povos cujas religiões aceitam a existência de uma idade primeira, perfeita, uma idade do ouro desaparecida, manifestando-se tanto em religiões que vêem a história como um vetor (por exemplo, judaísmo, cristianismo e islamismo), quanto entre aquelas que admitem uma renovação cíclica do universo (por exemplo, a religião dos guaranis do século XVI) ${ }^{109}$.

Milenarismos e messianismos não são sinônimos. Os messianismos compreendem a espera de um messias, que pode ou não ter vindo anteriormente como, por exemplo, acontece entre os judeus -, mas não definem uma duração determinada para essa espera e para o reino do messias. Os milenarismos, por sua vez, não comportam necessariamente a crença na vinda de um messias. Os milenarismos cristãos, especificamente, se distinguem dos messianismos por conceberem que o advento do "reino" reatualiza as condições anteriores à Queda e, além disso, por entenderem que o Redentor já veio e que se aguarda o seu retorno.

Coimbra, (36): 418-421, 1991.

109 DELUMEAU, Jean. Mil anos de felicidade: uma história do paraíso. São Paulo: Companhia das Letras, 1997, p. 17-18. 
São nucleares nos milenarismos cristãos, ainda, três elementos: primeiro, a "crença num reino terrestre vindouro de Cristo e de seus eleitos", com a duração de mil anos, literais ou simbólicos; segundo, a idéia de que o advento do milênio situa-se entre a ressurreição dos mortos já eleitos e uma segunda ressurreição, que ocorrerá na ocasião do julgamento dos demais homens; e, em terceiro lugar, a concepção de um milênio demarcado por dois momentos de provação (o reino do Anticristo, ao que se seguirá a instalação do reino de paz; e, depois, "uma nova liberação das forças demoníacas, que serão vencidas num último combate") ${ }^{110}$.

O milenarismo cristão surgiu nos primeiros séculos da nossa Era com a seita que lhe deu o nome. Os milenaristas ou quiliastas aguardavam a inauguração do Reino de Cristo na Terra, prognosticando-o para um futuro próximo ${ }^{111}$. As primeiras comunidades cristãs da Ásia abraçaram crenças milenaristas vindas de meios judaicos, entre os quais circulavam promessas de um futuro de felicidade, encontradas em textos do Velho Testamento, como os dos profetas canônicos Isaías e Daniel. Dessas comunidades teve origem o Apocalipse de São João (20, 1-15), que fixa a duração de mil anos para o Reinado de Cristo ${ }^{112}$.

Nos primeiros séculos da nossa Era, crenças milenaristas foram defendidas por alguns autores: no século II, o Pseudo-Barnabé, o bispo Pápio, de Hierápolis, Justino e Santo Irineu; no século III, Tertuliano e Metódio; e, no século IV, Lactâncio. Já Santo Agostinho (354-430) considerava que o milênio seria o reinado da Igreja Cristã e, devido à forte influência que exerceu sobre esta, o milenarismo passou a ser marginalizado pela mesma, sobrevivendo até o século $\mathrm{X}$ sobretudo através das sibilas cristãs, uma espécie de literatura profética ${ }^{113}$. As sibilas influenciaram alguns cruzados e, no século XII, estiveram por trás de movimentos de rebelião ocorridos na França ${ }^{114}$.

\footnotetext{
${ }^{110}$ Ibidem, p. 18-19.

${ }^{111}$ BESSELAAR, José van den, op. cit., p. 14-16.

${ }^{112}$ DELUMEAU, Jean. Mil anos de felicidade: uma história do paraíso, op. cit., p. 22.

113 Ibidem, p. 22-32.

${ }^{114}$ Ibidem, p. 36-37.
} 
No século XII, os milenarismos foram reforçados pelo pensamento de Joaquim de Fiore, monge cisterciense calabrês. Fiore abandonou sua ordem por julgar-se insuficientemente fiel ao ideal monástico e fez críticas às ordens religiosas e à Igreja, contudo, jamais refutou a ortodoxia, manifestando, pelo contrário, vontade de conformar suas idéias ao ensinamento dos papas ${ }^{115}$.

Em seu pensamento destaca-se, primeiro, a distinção de três idades ao longo da história, o tempo da lei natural e mosaica anterior a Cristo, o tempo definido pela vinda de Jesus e o tempo futuro em que triunfaria a "inteligência espiritual"”. Em segundo lugar, postula-se uma correspondência entre estas três idades e o Antigo e Novo Testamento, entre os quais Fiore via uma concordância, de tal sorte que as idades sucederiam uma a outra, reproduzindo-se, numa escala de progressiva perfeição, elementos do Antigo no Novo Testamento e, por conseguinte, também no tempo da "inteligência espiritual". Além disso, anuncia-se um período de repouso na terra, mediação entre o tempo das agruras de história e o início da eternidade posterior ao juízo final. Por fim, identificam-se dois tempos de provação (antes da instauração do reinado do espírito e, depois, entre o término deste e o juízo final) e de dois Anti-Cristos ${ }^{116}$.

Fiore, é importante ressaltar, não prognosticou nem a vinda de um Messias, nem um Reino com duração de mil anos, não podendo, por conseguinte, ser considerado messianista ou milenarista ${ }^{117}$.

No século XVI, sob a influência de Santo Agostinho, os mais qualificados representantes do protestantismo e do catolicismo se posicionaram contra as idéias milenaristas. Porém, essas, em ambos os lados da cristandade, vieram a encontrar adeptos, ainda que marginalmente.

No mundo protestante, indo do século XVI aos inícios do Setecentos, Joris, Servet, Curione e Comenius (célebre autor da Didática Magna), atingindo um espectro de países e regiões que iam da Transilvânia aos Países Baixos, da Suíça à Suécia; mais precisamente na França, manifestaram crenças milenaristas Georges Pacard, Pierre de Launay, Pierre Serrurier, Antoinette Bourignon, Pierre Poiret,

\footnotetext{
${ }^{115}$ Ibidem, p. 40-47.

${ }^{116}$ Ibidem, p.42-44.

${ }^{117}$ Ibidem, p. 43.
} 
Pierre Jurieu e Jacques Massard ${ }^{118}$; e, por fim, na Inglaterra, destacaram-se os nomes de Arthur Dent (falecido em 1707), do matemático John Napier (1550-1617), do presbiteriano Thomas Brightam (1562-1607) e do anglicano John Mede (1586-1638). Todos esses eruditos ingleses foram popularizadores do livro de Daniel e do Apocalipse, defendendo a idéia segundo a qual o Papa era o Anticristo e Roma, a Babilônia, e, portanto, ajustando o milenarismo ao protestantismo ${ }^{119}$.

Do lado católico, nos séculos XVI e XVII, foram eminentes partidários do milenarismo: Guillaume Postel, com passagem pela França e pela Itália; Cosme Damian Hortolá, na Espanha; Nicolas Charpy; na França; e Tommaso Campanela, na Itália $^{120}$. Algumas das personalidades citadas — Serrurier, Curione, Poiret e Jurieu entendiam que haveria no milênio a conversão dos judeus ${ }^{121}$. Na Itália, na segunda metade do século XVII, encontrava-se ainda Piscatore di Chiaravalle, "um grão matemático", o qual - a acreditar-se no que escreveu o padre Antônio VIEIRA, em 1673 - defendia idéias que cheiravam se não a milenarismo, ao menos a profetismo. Em “um livrinho estampado" em Milão no ano mencionado ou no que o antecedeu, segundo palavras do padre VIEIRA, Chiaravelle prognosticava "extraordinaria mutatione", relacionada a "nuove pretentioni d'un principe relegato", tudo isto na “cita metropoli d'una provincia maritima”, "no fim do juízo deste inverno" ${ }^{22}$.

De todos os nomes mencionados, com certeza Joaquim de Fiore, a rigor um não-milenarista, foi o que exerceu maior influência sobre os milenarismos. As idéias de Fiore difundiram-se pela Itália e além dos Alpes ainda durante sua vida. Os franciscanos e os dominicanos contribuíram para a difusão do joaquiminismo, tendo alguns intelectuais divisado nos frades menores os "espirituais" que renovariam a Igreja e a governariam em seu último período, proposição condenada pelo papa Alexandre IV em 1255. Ganhando o mundo dos leigos, o joaquiminismo, radicalizado e simplificado, deu origem a movimentos proféticos na Itália nos séculos XIII e XIV e difundiu-se pela França, Alemanha e Países Baixos neste mesmo período, levando ao surgimento da heresia do livre espírito, que reunia a promessa de um reino messiânico, a vontade de destruir as riquezas do mundo

\footnotetext{
${ }^{118}$ Ibidem, p. 156 e 163-175.

${ }^{119}$ Ibidem, p. 218.

${ }^{120}$ Ibidem, p. 158-163.

${ }^{121}$ Ibidem, p. 165, 169 e 173.
} 
pecador e a proposição segundo a qual todos os bens possuídos por outrem pertenciam aos "espirituais" e que nada seria pecado para os mesmos, desencadeando roubos e excessos eróticos ${ }^{123}$.

Esses seguidores de Joaquim de Fiore, com o radicalismo e a violência que suscitaram, traíram as idéias deste último e trouxeram elementos não contidos originalmente no pensamento do mesmo: a crença na existência de um imperador leigo, reinando sobre a cristandade regenerada e aplicando castigos severos à Igreja por suas faltas e torpezas, e a espera de um papa "angélico", graças ao qual haveria um só rebanho e um só pastor. Ao mesmo tempo, insistiram num ponto não privilegiado por Fiore: as provações que marcariam o início do reinado do Imperador $^{124}$.

Nos séculos XV e XVI, idéias milenaristas prosperaram na Alemanha, na França e na Itália, sendo identificados como o imperador dos últimos dias soberanos alemães e franceses de nome Frederico e Carlos, aureolados pela ascendência comum de Carlos Magno ${ }^{125}$. Ao mesmo tempo, nos países tchecos e na Boêmia, no século XV; na Alemanha, no século XVI; e na Inglaterra, no século XVII, aconteceram insurreições de tendências milenaristas ${ }^{126}$. A Inglaterra foi o país do Ocidente europeu que, entre o final do século XVI e 1660, debateu com maior paixão o milênio. A espera do milênio difundiu-se entre os teólogos, ganhando, portanto, os meios eruditos, e contagiou também ativistas religiosos, alcançando extremo radicalismo. As idéias milenaristas chegaram à América Inglesa, estabelecendo-se uma circulação mútua entre a Inglaterra e suas possessões Norte-Americanas, sendo as pessoas de John Cotton (1584-1652) e John Elliot (1604-1690), exemplos de eruditos que influenciaram os dois lados do Atlântico ${ }^{127}$.

Dos ativistas ingleses, deve-se falar dos grupos que se envolveram nas lutas político-religiosas de meados do século XVII: os niveladores, que eram contrários ao abuso do poder pelo rei, parlamento, igreja e a todos os ricos, defendendo uma democracia pluralista e cujo líder John Lilburne usava um jargão com referências

\footnotetext{
${ }^{122}$ VIEIRA, Antônio, op. cit., tomo 3, p. 188-189.

${ }^{123}$ DELUMEAU, Jean. Mil anos de felicidade: uma história do paraíso, op. cit., p. 57-63.

${ }^{124}$ Ibidem, p. 49, 66 e 80.

125 Ibidem, p. 66-75.

${ }^{126}$ Ibidem, p. 92, 95-97, 108-110, 123 e 128-147.

${ }^{127}$ Ibidem, p. 13, 116 e 223-225.
} 
milenaristas (identificava o papado e a igreja anglicana com o Anticristo, prognosticava o Apocalipse, o fim da Babilônia); os cavadores, que ocupavam terras incultas segundo princípios comunistas, liderados por Gerard Winstanley, que fazia fé no estabelecimento de um reino de Deus na terra; os batistas, que acreditavam no estabelecimento do milênio; os quakers, que faziam também prognósticos milenaristas, mas que, após a punição de um de seus propagandistas por Cromwell, James Nayler, transformaram a crença na vinda à terra do rei da Quinta Monarquia em acesso de Cristo às almas que assim o permitiam; e, por fim, os "Homens da Quinta Monarquia", que se destacaram na cena político-religiosa britânica após a morte de Carlos I, em 1549. Os "Homens da Quinta Monarquia" viram na execução do rei o prenúncio da queda de todos os reis da terra e de que a Inglaterra havia sido escolhida por Deus para promover, até mesmo com o recurso às armas, as alterações necessárias para o advento do Senhor ${ }^{128}$.

$\mathrm{Na}$ América Inglesa, os milenaristas aliavam a apreensão da nova terra como paraíso à crença de que os índios ou eram pagãos a serem convertidos antes dos últimos tempos, ou seriam descendentes das dez tribos perdidas de Israel. Compreendiam também que a Santa Igreja seria transferida para o outro lado do Atlântico. Para alguns emigrados, no entanto, a América seria um deserto, um lugar selvagem não atingido pela corrupção, constituindo-se por isto mesmo como um espaço mais apropriado para a edificação da nova igreja e instalação por Deus de seu Reino terrestre. Dentre os defensores de princípios milenaristas que migraram para a América destacam-se o já mencionado John Cotton e Jonatham Edwards, que, como alguns milenaristas britânicos, entendiam que o milênio se inauguraria sem a vinda de Cristo. Na América do Norte, a partir de meados do século XVIII, o milenarismo progressivamente laicizou-se, passando do combate à heresia romana para a luta pela liberdade, contra a tirania, com o que se substituía a piedade pela liberdade, vista como causa divina. Ao mesmo tempo, firmava-se a crença no papel reservado às colônias inglesas na redenção do mundo: Timothy Dwight (1757-1821), discorrendo sobre a Guerra da Independência, prognosticava o estabelecimento de um novo Éden, de um império “de paz, de justiça e de liberdade”, de um milênio que teria na

\footnotetext{
${ }^{128}$ Ibidem, p. 226-236.
} 
república americana seu agente e motor ${ }^{129}$.

Proposições semelhantes a essas, misturadas a topoi e referências específicas do milenarismo português, fizeram-se presentes também entre os Inconfidentes Mineiros, como se mostrará no Capítulo 8.

\subsection{Milenarismos cristãos no mundo ibero-americano}

Nos século XIII e XIV, a Espanha foi atingida pelas idéias milenaristas, especialmente de inspiração joaquimita e franciscana, exercendo particular influência os escritos de Arnauld de Villeneuve, que denominava "Novo Davi" o imperador dos tempos de felicidade, e Jean de Roquetaillade ${ }^{130}$.

No século XIV o joaquimismo parece ter entrado em Portugal e, nos séculos XVI, XVII e XVIII, se constituiu neste país um "vasto repertório de crenças profético-messiânicas" e, de resto, milenaristas, em torno da idéia de um Quinto Império controlado pelos portugueses ${ }^{131}$.

A existência em si, na Ibéria, dos milenarismos cristãos não pode ser considerada uma peculiaridade da cultura portuguesa ou espanhola, uma vez que, como se viu, os mesmos se desenvolveram também nos outros países da Europa, com destaque especial para a Inglaterra. A especificidade lusa não está também no enraizamento dos milenarismos nos círculos eruditos portugueses: se não bastassem os exemplos de intelectuais de vários países europeus anteriormente citados que tiveram o mesmo comportamento, cumpriria lembrar os casos de Galileu Galilei e Newton. O primeiro, patrocinou a edição da obra milenarista-messianista Anacephaleosis da monarquia lusitana, do português Manuel Bocarro Francês, o que sugere uma simpatia pelo tema ${ }^{132}$. Já Newton, um dos símbolos da ciência moderna, em 1727 (portanto, no século XVIII), antes de morrer, escrevera Observations upon the prophecies of Daniel and the Apocalypse of Saint John, livro no qual afirma que “"o Evangelho será pregado a todas as nações antes da grande tribulação do fim do mundo"” e, então, “"os reinos do mundo se tornarão o reino de Cristo", tempo

\footnotetext{
${ }^{129}$ Ibidem, p. 223-224 e 237-245.

${ }^{130}$ Ibidem, p. 191.

${ }^{131}$ ROMEIRO, Adriana, op. cit., p. 79. Besselaar afirma que os séculos mencionados assistiram ao apogeu dos profetismos em terras lusitanas (BESSELAAR, José van den, op. cit., p. 17, 25 e 33).
} 
último que julgava próximo ${ }^{133}$.

As especificidades dos milenarismos em Portugal residem em outros aspectos. Os portugueses, primeiramente, talvez tenham sido os únicos europeus a se apropriarem, por séculos, do mito do Encoberto, a realimentarem-no ${ }^{134}$. Constituíram, ainda, como se mostrará a seguir, o único povo em que os milenarismos tiveram como núcleo original formulações tecidas por um artesão - o sapateiro Gonçalo Annes Bandarra, ele próprio um mediador cultural - e difundidas entre pessoas de amplos segmentos sociais, atingindo de forma decisiva letrados, alguns de renome internacional, como o padre Antônio Vieira. Se a longevidade pode ter sido traço distintivo de Portugal em matéria de milenarismos, na Península Ibérica como um todo, estes últimos possuíram particularidades em seu conteúdo e em suas proveniências cultural e sócio-econômica. Naquilo que se refere às bases sócioeconômicas, isto é, à materialidade, enquanto na Inglaterra os milenarismos desenvolviam-se em meio à corrosão do feudalismo e às transformações de cunho capitalista; enquanto na Alemanha, eram reações à segunda servidão; na Península Ibérica tratava-se de formulações elaboradas sob o impacto dos descobrimentos, em meio à presença forte da cultura judaica e ao colonialismo (fator que talvez tenha influído de forma equiparável o milenarismo inglês) ${ }^{135}$.

A etnia judaica fazia-se presente em Portugal e na Espanha desde o período romano. Em Portugal, se os judeus foram perseguidos violentamente no século XII e convertidos ou expulsos no final do século XV, viveram neste intervalo sem maiores restrições, cultivando uma mística escatológica ${ }^{136}$. Ao final do século XV e XVI, alguns judeus ou elementos de origem judaica apresentaram formulações messiânicas e/ou milenaristas: Isaac Abravanel, judeu convicto, compreendia que o sofrimento do povo judeu em Portugal de fins do século XV indicava o advento do Messias, prevendo-o para o ano de 1503 ou para o intervalo 1490-1573; em Trás-os-Montes, dois "rabinos", Diogo de Leão de Costanilha e Antônio de Valença, prognosticavam a vinda de um messias judeu; e o próprio D. João III, para justificar a instalação do

\footnotetext{
${ }^{132}$ DELUMEAU, Jean. Mil anos de felicidade: uma história do paraíso, op. cit., p. 215.

${ }^{133}$ Apud. Ibidem, p. 279.

${ }^{134}$ HERMANN, Jacqueline, op. cit., p. 61-62.

135 Jacqueline Hermann propõe esses elementos como específicos dos messianismos ibéricos - a autora, neste ponto, portanto, não usa o termo milenarismo (Ibidem, p. 37 e 234).

${ }^{136}$ Ibidem, p. 35-36.
} 
Santo Ofício diante do Papa, mencionou o levantamento de um messias entre os cristãos-novos ${ }^{137}$. Convém sublinhar, entretanto, que o milenarismo judaico, mais forte na Ibéria, não se fez completamente ausente nos demais países europeus. $\mathrm{Na}$ segunda metade do século XVII, por exemplo, viu-se, para além das fronteiras portuguesas e espanholas, a difusão do sabatainismo: o rabino Sabatai Tzvi se anunciava como o messias esperado para o ano de 1666, o número da besta, ganhando a adesão da maioria dos rabinos, à exceção da Polônia, deflagrando uma onda de fervor entre judeus e não judeus ${ }^{138}$.

Johan Alamany, frade menor; Francisco Eximenis, franciscano catalão; Rodrigo Ponce de Léon, chefe militar; e Cristóvão Colombo, o descobridor da América, destacam-se como autores que, nascidos ou com passagem pela Espanha, deixaram escritos milenaristas. Alamany entendia que um "pastor angélico", um papa, reformaria a Igreja, e que um imperador, o "encubierto", dirigiria os pobres contra "os muçulmanos, os judeus e os maus cristãos da Espanha, para em seguida conquistar Jerusalém, combater o Anticristo e instaurar o milênio"139.

Eximenis acreditava que um mau imperador e um antipapa perseguiriam a igreja, ao mesmo tempo em que, involuntariamente, iriam purificá-la. Ponce de León tomou os temas do "Novo Davi" e do "Encubierto" a favor de Fernando de Aragão, o rei Católico. Se esses temas prestaram-se à propaganda da monarquia, foram usados por insurretos valencianos, já no século XVI, em 1522-3, que chamavam a seus líderes de "encubiertos"140.

O genovês Colombo, embora não fosse um milenarista no sentido estrito, defendia algumas idéias que se aproximam da tradição milenarista: a existência de uma era de paz antes do fim dos tempos, a ocorrência de uma reconciliação e conversão geral da humanidade, com a eliminação da ameaça muçulmana. O navegador, ademais, tributário das sibilas cristãs e do joaquimismo, acreditava nas profecias relativas ao soberano dos últimos dias, interpretando-as a favor dos reis de Espanha, e, ainda, tomava a descoberta da América como confirmação de que

\footnotetext{
${ }^{137}$ Ibidem, p. 39.

${ }^{138}$ ROMEIRO, Adriana, op. cit., p. 163.

${ }^{139}$ DELUMEAU, Jean. Mil anos de felicidade: uma história do paraíso, op. cit., p. 192.

${ }^{140}$ Ibidem, p. 191-193.
} 
chegara o momento do Evangelho ser pregado em toda a terra ${ }^{141}$. Na Espanha, a espera de um "encubierto", de um "Novo Davi", fez-se presente em outras manifestações individuais e coletivas nos séculos XVI e XVII, e ligava-se à “espiritualidade hebraica marcada pelo modelo messiânico dadívico e pela noção de "povo eleito""142. Esse país, além disso, abrigou uma série de profecias rimadas (coplas, trovas etc. $)^{143}$.

As idéias milenaristas alcançaram a América espanhola nos princípios da colonização, misturando-se aos topoi edênicos projetados nas visões construídas sobre o Novo Mundo e suas gentes: os primeiros frades franciscanos que desembarcaram no México em 1524 eram tributários de concepções escatológicas, misturando fórmulas joaquimitas (a crença numa “"última idade do mundo", em que haveria paz, reconciliação e conversão geral ao cristianismo, precedendo isto tudo ao fim da história; e a conversão à pobreza, que assinalaria a passagem aos tempos escatológicos) ${ }^{144}$. Dentre estes frades destacou-se Motolinia, frei Toribio de Benavente, adversário de Las Casas no que concernia à necessidade da conversão dos índios, promessa por ele considerada apocalipítica, sendo pois sinal do fim dos tempos: este autor era partidário da pobreza evangélica, da restauração da pureza da igreja primitiva e, por conseguinte, da separação física e material em relação à igreja de Roma, deixando a igreja e os índios na América unicamente dependentes do rei de Espanha, sob os cuidados dos franciscanos, instalados em missões e sem contato com espanhóis ${ }^{145}$. Jerônimo de Mendieta, outro franciscano, estabelecido no México em 1554, mostrou-se defensor de idéias muito similares às de Motilinia: movido pela crença de que se encontrava nos tempos próximos ao fim do mundo, momento de fazer entrar no seio da igreja “"todas as nações, línguas e povos"”, defendia a aceleração da história através da conversão dos mesmos índios (que entendia serem descendentes das "dez tribos perdidas" de Israel), em comunidades indígenas separadas; atribuía esta missão aos reis católicos; e manifestava a pretensão de

\footnotetext{
${ }^{141}$ Ibidem, p. 198.

${ }^{142}$ Ibidem, p. 193-194.

${ }^{143}$ BESSELAAR, José van den, op. cit., p. 17 e 25.

${ }^{144}$ Ibidem, p. 201-205.

${ }^{145}$ Delumeau levanta a hipótese de que o primeiro bispo do México, Juan de Zumarraga, chegado em 1528 , tenha sido partidário da constituição dessas comunidades indígenas separadas, proposta de Motilinia, e que se deixou influenciar nisto pela obra Utopia, de Thomas Morus, que trouxera em sua bagagem (Ibidem, p. 205-207).
} 
restaurar a pureza da igreja primitiva na América ${ }^{146}$.

No Peru, o dominicano Francisco de la Cruz, queimado pela inquisição em 1578, defendia proposições em parte convergentes com as de Motilinia e Mendieta e, que, sobretudo, transpiram influências de várias correntes milenaristas: dividia a história em três períodos, nos moldes de Joaquim de Fiore; esperava a vinda de um rei salvador e de um papa angélico, como se postulava nas sibilas; na esteira dos franciscanos, entendia que os turcos destruiriam Roma e a cristandade européia, que a igreja seria transportada para Lima e, por fim, certamente sob a influência do "encubiertismo", dizia que ele próprio seria ao mesmo tempo papa e Rei do Novo Mundo, qualificando-se a si mesmo como o terceiro Davi, cujo antecessor teria sido Jesus Cristo $^{147}$.

No século XVII, também no Peru, viveu outro seguidor de idéias milenaristas: o franciscano Gonzalo Tenorio. Este, guiando-se pelo esquema joaquimita das três idades, achava que a descoberta da América não anunciava o fim dos tempos, mas, pelo contrário, assinalava a implantação da monarquia cristã, sendo as Índias o ponto de partida para a expansão do reinado universal de Cristo, para a derrota do AntiCristo e início, enfim, do período escatológico. Caberia à monarquia espanhola unir os príncipes cristãos, levar o Evangelho a todas as partes do mundo e firmar o dogma da Imaculada Conceição; o "encubierto" descenderia dos reis de Espanha, mas poderia vir da América; o Papa teria que deixar Roma, refugiando-se no Peru. Estes autores, todos, enfim, mostram que havia uma tendência a enaltecer a América em detrimento da Europa ${ }^{148}$.

Gonçalo Anes Bandarra, sapateiro de Trancoso nascido por volta de 1500, é um marco fundamental para as crenças milenaristas surgidas em Portugal; em plano muito inferior está Simão Gomes, o Sapateiro Santo, membro da companhia de Jesus, lendário personagem que teria exercido influência na corte de D. João III e de D. Sebastião ${ }^{149}$. Bandarra, um artesão, estabeleceu laços com outros artesãos, alguns deles cristãos-novos, os quais mantinham freqüentemente uma estreita convivência com os cristãos-velhos e que, comparados a estes, tinham maior intimidade com os

\footnotetext{
${ }^{146}$ Ibidem, p. 208-210.

${ }^{147}$ Ibidem, p. 211-213.

${ }^{148}$ Ibidem, p. 214-215.

${ }^{149}$ CIDADE, Hernani, op. cit., p. 25 e HERMANN, Jacqueline, op. cit., p. 193.
} 
textos escritos. Nesse ambiente cultural que congregava artesãos, cristãos-novos e cristãos-velhos, letrados e não-letrados, de um lado, havia a presença de formulações escatológicas, marcadas pela oralidade, como explicação para as transformações que então atingiam a sociedade portuguesa, e, de outro lado, observava-se grande circulação de papéis sobre vidas de santos e príncipes. O sapateiro de Trancoso, imerso nessa cultura artesã-apocalítptica, dizia-se intérprete das Escrituras e, de fato, agia como um mediador cultural, integrando elementos judaicos e cristãos, transitando entre o grupo de letrados e não-letrados, eruditos e não-eruditos ${ }^{150}$.

Bandarra entendia que algumas maldades afligiam o Reino Luso - o uso da simonia pelo clero, a venalidade dos juízes, a ostentação de títulos comprados pelos fidalgos, a leviandade e frivolidade das mulheres e a falta de coragem das autoridades para agir e reagir ${ }^{151}$. E, a partir da leitura da Bíblia, de profecias atribuídas a santo Isidoro e das Coplas do castelhano Pedro Frias e de outros versejadores espanhóis, convenceu-se de que viria um Rei Encoberto, predestinado a destruir o Império Otomano e a estabelecer a Monarquia Mundial, expressando tais profecias em trovas $^{152}$. As trovas do sapateiro difundiram-se no país a partir da década de 1530 , apesar de proibidas pela inquisição já em 1541 e de serem editadas pela primeira vez apenas em 1603, em Paris ${ }^{153}$. Circulando oralmente e em cópias manuscritas, causaram alvoroço e foram interpretadas diferentemente conforme a conjuntura e os grupos culturais em questão ${ }^{154}$. Bandarra, então, "andou tanto nas bocas de grandes e pequenos", sendo canonizado "pelos mesmos que o proibiram"155. Os cristãos-novos leram-no em sentido judaico, vendo no Rei Encoberto o messias prometido aos povos de Israel; sentidos os mais diversos foram atribuídos por outros grupos às palavras do sapateiro de Trancoso.

À influência de Bandarra é preciso somar a tradição celta centrada no rei Arthur. Ainda no século XIII, surgia em Portugal a Demanda do Santo Graal, em que se cristianizavam as lendas que tinham por protagonista o rei cavaleiro, figura que juntava bravura e imortalidade e que teria se refugiado numa ilha Afortunada em que

\footnotetext{
${ }^{150}$ HERMANN, Jacqueline, op. cit., p. 19, 43 e 46.

${ }^{151}$ BESSELAAR, José van den, op. cit., p. 54.

152 Ibidem, p. 49-51.

153 Ibidem, p. 52-53.

${ }^{154}$ Ibidem, p. 56 e ROMEIRO, Adriana, op. cit., p. 80-81.

${ }^{155}$ VIEIRA, Antônio, op. cit., tomo IV, p. 117.
} 
se tinha uma sobrevivência eterna. Em 1567, o novelista e comediógrafo Jorge Ferreira de Vasconcelos, publicou uma releitura da obra supracitada: o Memorial das proezas da segunda Távola Redonda, livro no qual narra os feitos do neto do rei Arthur, Sagramor. Essas obras atestam a circulação de lendas do ciclo arturiano em Portugal, as quais influenciaram as formulações milenaristas de mulheres pertencentes às camadas populares, presas pelo Santo Ofício em meados do século XVII, não parecendo ter a mesma repercussão entre os letrados ${ }^{156}$.

Com a morte de El-Rei Dom Sebastião em Alcácer Quibir, em meio ao clima de fervor nacional extremado surgido sob a dominação espanhola, recebendo influências da tradição celta centrada na figura do rei Artur e do messianismo judaico, muitos intelectuais e populares passaram a identificar o monarca morto ao Encoberto, surgindo, então, no país uma nova versão milenarista e/ ou messianista: os sebastianismos ${ }^{157}$. Populares e intelectuais sebastianistas, a partir das trovas de Bandarra, de passagens da Sagrada Escritura, da interpretação milagrosa e profética de alguns acontecimentos, da lenda do milagre de Ourique (Cristo teria aparecido a D. Afonso Henriques, às vésperas da Batalha de Ourique contra os mouros, fundando em pessoa o Reino de Portugal), da conjugação de certos astros ${ }^{158}$ e, até mesmo, da interpretação cabalística dos números que constituíam certas datas, concluíam que os portugueses eram o segundo "povo escolhido" de Deus ${ }^{159}$. Eles haviam sido

\footnotetext{
${ }^{156}$ HERMANN, Jacqueline, op. cit., p. 185-186 e 275 e SOUZA, Laura de Mello e. Inferno atlântico: demonologia e colonização (séculos XV e XVII). São Paulo: Companhia das Letras, 1993, p. 117121.

157 HERMANN, Jacqueline, op. cit., p. 181 e 186. Optou-se pela classificação milenarista e/ ou messianista porque nem sempre entre os sebastianistas fica clara a idéia de que o rei-messias instauraria um milênio. Usam-se sebastianismos, no plural, devido à heterogeneidade observada nas formulações sebastianistas, acompanhando às análises de Jacqueline Hermann (Idem, op. cit., p. 187) e Adriana Romeiro (Idem, op. cit., p. 80-81).

${ }^{158}$ Os prognósticos sobre o devir assentados na observação do movimento de cometas e astros eram comuns não apenas em Portugal. O próprio Bacon não rejeitava inteiramente a astrologia, embora a censurasse e postulasse a necessidade de depurá-la (HOLANDA, Sérgio Buarque de. Visão do Paraíso, op. cit., p. 4). No mundo luso-brasileiro, o padre jesuíta morávio Valentim Estancel, exmestre de matemática (esfera) no colégio de Santo Antão, com passagem pela América Portuguesa, era useiro da astrologia: nos idos de 1665, num "famoso papel sobre os dois cometas", cheios "de metáforas e enigmas de nomes gregos", Estancel inferia que os cometas anunciavam "mudanças dos tempos e das coisas, e todos para bem, e bem de todos" (VIEIRA, Padre Antônio, op. cit., tomo 2, p. 36). Na correspondência do padre Antônio Vieira, vê-se recorrentemente a feitura de prognósticos do gênero (Ibidem, tom. 3, p. 28 e ROMEIRO, Adriana, op. cit., p. 171, 177 e 180); a astrologia, além disso, sempre comparece nas alegorias construídas pelo mesmo nos seus Sermões (CIDADE, Hernâni, op. cit., p. 19). A crença na astrologia foi um dos pontos enfatizados nas críticas pombalinas a Antônio Vieira e aos milenaristas-sebastianistas (veja: SILVA, José de Seabra da, op. cit., p. 216-217).

${ }^{159}$ TORGAL, Luís Reis, op. cit., vol. 1, p. 302-303.
} 
castigados em 1580 pelas suas faltas, mas iriam libertar-se da Espanha e cumpririam a suma missão de evangelizar o mundo, vindo D. Sebastião a instaurar o reino de Cristo, temporal e espiritual, na Terra ${ }^{160}$. De grande aceitação e impacto popular, esta crença, que expressa uma concepção providencialista de história e da vida, foi dirigida e explorada por alguns intelectuais, destacando-se D. João de Castro, Manuel Bocarro Francês e o padre Antônio Vieira ${ }^{161}$. Os jesuítas estiveram, ao que parece, entre seus principais divulgadores.

D. João de Castro, nobre de formação jesuítica, quando da disputa travada pelo trono português entre Felipe II, Dona Catarina de Bragança e o Prior do Crato, engrossou as fileiras dos partidários deste último, de quem se desligou ao constatar as dificuldades de vencer o poderoso inimigo da Espanha. Dos 22 manuscritos que se sabe ter escrito, D. João de Castro teve publicados apenas dois. O primeiro foi o Discvrso da uida do sempre bem vindo et apparecido Rey Dom Sebastião, editado em Paris em 1602, primeiro texto - e primeira manifestação sebastianista da cultura letrada - explicitamente messiânico, referente a Dom Sebastião ${ }^{162}$. O segundo manuscrito foi Parapharase et concordançia de alguas Prophecias de Bãdarra, çapateiro de Trancoso, editado em 1603, obra que constitui a primeira edição das Trovas de Bandarra e que revela a importância consagrada por um letrado a trovas compostas por um reles sapateiro, demonstrando a circularidade existente entre eruditos e populares. Manuel Bocarro Francês, cristão-novo, médico formado em Alcalá e Montpellier, publicou em 1634 o poema Anacephaleosis da monarquia lusitana, vítima de severa reprovação por parte da censura filipina — e, como se verá no Capítulo 4, também dos órgãos censórios criados a partir de Pombal —, em que se procura, dentre outras coisas, demonstrar a partir da astrologia que Portugal haveria de ser a última e mais poderosa monarquia ${ }^{163}$.

\subsection{Milenarismo, Segunda Escolástica e realismo: o Padre Antônio Vieira}

O mais notável dentre os muitos eruditos que, no Reino e na Colônia,

\footnotetext{
${ }^{160}$ Ibidem, loc.cit..

${ }^{161}$ Ibidem, loc. cit. e HERMANN, Jacqueline, op. cit., p. 188.

162 HERMANN, Jacqueline, op. cit., p. 189-191.

${ }^{163}$ Ibidem, p. 199, 204-206 e 209-216.
} 
abraçaram o milenarismo foi, no entanto, o padre Antônio Vieira, cujos sermões, segundo seus próprios detratores, enchiam "de admiração a Corte, e o Reyno: Que nas Igrejas, onde elle pregava, era preciso que os ouvintes se antecipassem muitas horas, para acharem lugar" ${ }^{264}$. As formulações deste assinalam, no que se refere ao milenarismo, uma notável coincidência cronológica com os anúncios feitos na América espanhola por Motilinia e Mendieta, mostrando, portanto, que a efervescência escatalógica sobrevivia ainda no século XVII ${ }^{165}$. Suas idéias, no geral, constituem um emblema da mentalidade portuguesa, que combinava sacralizaçãoprofetismo, realismo e um certo anti-cientificismo.

Vieira teve, de fato, suas veleidades científicas: além de dar demonstrações de interesse pela matéria, como já se indicou anteriormente, compôs uma "Filosofia própria”, isto é, um livro de Filosofia, redigido durante o seu Curso de Artes, entre 1629-1632, ainda no Brasil ${ }^{166}$. Seus interesses científicos, contudo, subordinavam-se à sua compreensão mística do mundo, tanto assim que, por mais de uma vez, condenou o "desejo de saber", a "maior gula de natureza racional", que teria feito Eva e muitos estudantes da Companhia de Jesus perecerem ${ }^{167}$. A isto contrapunha a salvação das almas, universidade a que se dedicara Cristo, obra que compreendia dever realizar-se entre os gentios do Maranhão. Por isto mesmo, acusava os que tinham apreço imoderado pela ciência de serem "idólatras", recomendando-lhes a leitura do seguinte salmo de David: Porque não conheci letras, entrarei nas potências de Deus ${ }^{168}$. Vieira, portanto, valorizava a ação, mas uma ação impregnada pelo divino, inscrevendo-a numa sacramentalidade que dava "unidade" às suas ações e aos seus escritos.

Segundo Alcir PÉCORA, Vieira seria marcado por um "humanismo" aristotélico-tomista e inaciano (portanto, não um humanismo no sentido técnico, isto é, renascentista), que conjugava a pressuposição de uma analogia entre o mundo natural e o divino ao entendimento de que a salvação estaria ao alcance de todos os que se dispusessem a praticar determinados exercícios da alma e, ainda, a desenvolver uma ação afirmativa no mundo dos acontecimentos, unindo, assim,

\footnotetext{
${ }^{164}$ SILVA, José de Seabra da, op. cit., p. 208-209.

${ }^{165}$ DELUMEAU, Jean. Mil anos de felicidade: uma história do paraíso, op. cit., p. 215.

${ }^{166}$ LEITE, Serafim, op. cit., p. 136.

${ }^{167}$ Ibidem, p. 122.
} 
vontade e ação ${ }^{169}$. Deste modo, Vieira ia ao encontro daquela perspectiva geral dos homens de seu tempo, indicada anteriormente, segundo a qual a natureza portaria verdades celestes, mensagens divinas, a serem decifradas: para ele, era preciso vê-las através e apesar da natureza, reconhecer o invisível sob o visível, o espiritual no corpóreo $^{170}$. Ao mesmo tempo, no entanto, procurava descobrir a "penumbra sobre os contornos fronteiriços" da ordem natural e divina, de forma a "ampliar a linha em que a ação humana é indistinta do beneplácito e da presença divina”. Neste ponto, descolava-se da escolástica e retirava da teologia mística a questão da "união mística" entre Deus e o homem ${ }^{171}$, uma "união" que, ao contrário de ser individual, direta e extática, como se propunha na sua origem (isto é, na teologia mística), tornava-se algo mediado pela Igreja, com suas práticas litúrgicas e sacramentais, sua hierarquia etc. ${ }^{172}$. A ordenação eclesiástica, para o célebre orador, era a perfeita representação da vontade divina, de tal sorte que, se submetendo a ela, o homem faria com que sua vontade coincidisse com a do Criador. Disto, decorreu a valorização, por um lado, da obediência e, por outro, do dom sobrenatural da igreja de atualizar a manifestação terrena da transcendência divina através dos sacramentos, fundamentalmente o da eucaristia ${ }^{173}$.

Da comunhão entre homem e Deus consumada na eucaristia, Vieira extraiu um modelo, um "modo sacramental" de união entre o humano e o divino, um modo que ele aplicou a várias situações, com o intuito de encontrar, sob o visível, o divino, sinalizado ou escondido, encoberto ou invisível ${ }^{174}$. Este modo sacramental incidiu na visão que Vieira construiu sobre o rei e o Estado portugueses: ele advogava para estes a probabilidade de celebração da união entre homem e Deus, superando a antinomia existente entre um e outro por uma unidade a ser consumada no seio da história ${ }^{175}$. O rei seria portador de uma condição dual: por um lado, depositário do poder da comunidade, alienado voluntariamente pelas ordens, transferido para a potência de um só, como propugnava a teologia política de Suárez; e, por outro lado,

\footnotetext{
${ }^{168}$ CIDADE, Hernâni, op. cit., p. 15.

${ }^{169}$ PÉCORA, Alcir. Teatro do sacramento, op. cit., p. 72-76 e 84.

${ }^{170}$ HOLLANDA, Sérgio Buarque de. Visão do paraíso, op. cit., p. 223-235.

${ }^{171}$ PÉCORA, Alcir. Teatro do sacramento, op. cit., p. 84 e 87.

172 Ibidem, p. 91.

${ }^{173}$ Ibidem, p. 94 e $97-98$.

${ }^{174}$ Ibidem, p. 98-99 e 101.

${ }^{175}$ Ibidem, p. 106-107.
} 
pessoa mística, cristológica, livre das leis; era pois, finito e infinito ${ }^{176}$. Esta dualidade era o fundamento sobre o qual Vieira constituía sua visão milenarista e sua profecia do Quinto Império - os anteriores seriam os impérios dos caldeus, dos persas, de Alexandre Magno e o romano - , para o que encontrava apoio tanto em seus colegas de ordem, como em muita gente do seu tempo ${ }^{177}$.

Para VIEIRA, Nação e Estado portugueses eram uma mesma coisa, tinham uma mesma substância, marcada pela eleição divina e da qual ele próprio desejaria ser guardião. No seu entendimento, nos tempos modernos, Portugal ocupava o lugar que fora perdido por Israel com a crucificação de Cristo; a aliança definitiva entre Deus e a nação portuguesa encontrava-se no já citado milagre de Ourique, em que Cristo selou ao rei Afonso Henriques a promessa de sucessão dinástica, com o que o poder transitou-se diretamente de Deus ao rei $^{178}$. Aqui, portanto, Vieira ia na contramão do que afirmavam Vitória e os téologos da companhia, destacando-se dentre eles Suárez, defensores da mediação da comunidade e, inversamente, mostrava-se adepto de uma concepção de poder providencialista ${ }^{179}$. Mais do que o rei, era o Estado português que se providencializava na perspectiva de Vieira: Estado único ao qual caberia o papel de ser causa segunda da atualização da semelhança entre o mundo criado e o Criador ${ }^{180}$. O Encoberto seria, assim, aquele predestinado que conduziria a história do homem a "um ajuste com a verdade que Deus designa para ela"181.

A identidade do Encoberto foi algo controverso entre os milenaristas portugueses. Ele foi identificado diferentemente, acompanhando as alterações da conjuntura política ou os interesses dos diversos grupos culturais. Para os judeus, tratava-se do Messias prometido aos povos de Israel; havia mesmo quem se autoproclamasse o próprio Encoberto das trovas do Bandarra ou da tradição bíblicaprofética. Os sebastianistas acreditavam ser o rei D. Sebastião, desaparecido em Alcácer-Quibir, como já se comentou ${ }^{182}$; esta crença foi depois substituída, entre outros milenaristas, pela crença no regresso de um rei — geralmente identificado em

\footnotetext{
${ }^{176}$ HANSEN, João Adolfo. Prefácio. In: PÉCORA, Alcir. Teatro do sacramento, op. cit., p. 15-16.

${ }^{177}$ PÉCORA, Alcir. Teatro do sacramento, op. cit., p. 225.

${ }^{178}$ Ibidem, p. 218, 224 e 238-239.

${ }^{179}$ XAVIER, Ângela Barreto, HESPANHA, Antônio Manuel, op. cit., p. 135.

${ }^{180}$ PÉCORA, Alcir. Teatro do sacramento, op cit., p. 241-242.

${ }^{181}$ Ibidem, p. 249.
} 
termos vagos como "o Encoberto" — que salvaria Portugal, tornando-lhe a concederlhe a independência e a dignidade.

Da polêmica constituída em torno da identificação do Encoberto participaram intelectuais coimbrãos como o padre Francisco Guedes, que, nos idos de 1664, "tomou por problema dos futuros contingentes, se havia de vir ou não el-rei D. Sebastião. E depois de o disputar com aplauso por uma e outra parte, resolveu que o verdadeiro encoberto profetizado" era D. Afonso VI ${ }^{183}$.

$\mathrm{O}$ padre Vieira entrou nessa controvérsia sobre o Encoberto quando ainda estava no Brasil e, no transcorrer dos anos, veio a formular várias hipóteses sobre sua identidade. Um mês após a Restauração, num sermão pronunciado em louvor a Felipe IV, ao mesmo tempo em que aprovava as medidas da Coroa espanhola contra a revolta da Catalunha, tratava como quimera o regresso de Dom Sebastião; anos antes, em 1634, no "Sermão de S. Sebastião", rebatera esta mesma proposição ${ }^{184}$. Depois, anteviu o Encoberto em mais de um monarca lusitano: veio a identificá-lo sucessivamente em D. João IV, Afonso VI, D. Pedro II e Teodósio ${ }^{185}$. As diferentes hipóteses que Vieira formulou a respeito da identidade do Encoberto embasaram-se no modo pelo qual ele construía suas interpretações da história, o que, por sua vez, esteve ligado estreitamente à sua hermenêutica bíblica.

Vieira, primeiramente, acreditava que nas Escrituras Sagradas não havia “"palavra, nem sílaba, nem ainda uma só letra, que seja supérflua, ou careça de mistério"”; valorizava, ademais, os algarismos dos textos proféticos na atividade de interpretação; e buscava nas variantes do texto bíblico, nas suas antigas versões, explicações para o mistério oculto em cada letra, pois compreendia que as diferentes versões enriqueciam a Verdade revelada, ao invés de serem contraditórias ${ }^{186}$. Usando os quatro princípios de interpretação das Escrituras estabelecidos por são Boaventura (literal, moral, alegórico e analógico) e juntando-lhes o "sentido histórico", considerava a Sagrada Escritura a verdadeira fonte da história ${ }^{187}$ e compreendia haver uma correspondência entre o Novo e o Velho Testamento, de tal sorte que o Novo

\footnotetext{
${ }^{182}$ ROMEIRO, Adriana, op. cit., p. 81.

${ }^{183}$ VIEIRA, Antônio. Cartas, op. cit., tomo I, p. 106.

${ }^{184}$ AZEVEDO, J. Lúcio de. História de Antônio Vieira. 2 ed. Lisboa: Livraria Clássica Editora, 1931, v. 1, p. 54 e SARAIVA, Antônio J., op. cit., p. 301.

${ }^{185}$ HANSEN, João Adolfo. Prefácio, op . cit., p. 29.

${ }^{186}$ ROMEIRO, Adriana, op. cit., p. 82-83.
} 
estaria oculto na história, enquanto o Velho estaria descoberto no Novo ${ }^{188}$. Salientava, na História do Futuro, que a exegese da Bíblia era um empreendimento no qual as descobertas não resultavam necessariamente do tempo gasto pelo intérprete, podendo suceder que "“os que vêm na última hora, por felicidade da mesma hora, acabem e descubram com poucas enxadadas o que muitos em muito tempo e com muito trabalho, cavando muito mais, não descobriram"”,189.

A partir disso, extraía da Bíblia passagens que previam acontecimentos que se passaram ou que iriam se passar" ${ }^{190}$ e estabelecia uma "especularidade histórica entre dois eventos distanciados no tempo, compondo-os como signos na ordem da história", signos na ordem da revelação, encontrando nas "matérias mundanas do tempo" a "prefiguração e a pós-figuração proféticas da finalidade transcendente do reino guiado por um príncipe fatal" ${ }^{\text {"191 }}$. Procedendo desta forma, pôde formular diferentes hipóteses sobre a identidade do Encoberto, migrando de um nome para outro conforme o momento em que se encontrava, o que não significa propriamente um engano, na medida em que, de acordo com sua visão, o essencial era que o Encoberto seria um monarca português, verdade prefigurada desde Ourique, recuando desde Adão e que vinha sempre, numa atualidade eterna ${ }^{192}$.

O Encoberto não seria Cristo, mas um Vice-Cristo ${ }^{193}$. Seu reino duraria 1000 anos, durante os quais desapareceriam o pecado e as guerras. Encerrado o milênio, apareceria o Anticristo, haveria uma Batalha Final, e depois, ocorreria o Dia do Juízo $^{194}$. O Quinto Império para Vieira teria sido profetizado por Daniel e Ezequiel, sucedendo ao Quarto, o Império romano, então sobrevivente com a Casa de Áustria. Possuiria um caráter simultaneamente temporal e espiritual e, diferentemente dos impérios que o precederam, gozaria de uma maior graça divina. Nele, haveria o encontro e a incorporação das Doze Tribos perdidas de Israel, assim como de todos os hereges, judeus e pagãos ${ }^{195}$, os quais seriam convertidos graças ao poder espiritual do Pontífice, à Primeira Pessoa da Trindade, à Virgem Maria, à virtude dos

\footnotetext{
${ }^{187}$ TORGAL, Luís Reis, op. cit., vol. 1, p. 308.

${ }^{188}$ HANSEN, João Adolfo. Prefácio, op. cit., p. 17.

${ }^{189}$ Padre Antônio Vieira. Apud. ROMEIRO, Adriana, op. cit., p. 82.

190 TORGAL, Luís Reis, op. cit., vol. 1, p. 309.

${ }^{191}$ HANSEN, João Adolfo. Prefácio, op. cit., p. 17.

192 Ibidem, p. 29.

${ }^{193}$ PÉCORA, Alcir. Teatro do sacramento, op. cit., p. 234.

${ }^{194}$ Ibidem, p. 236-237 e 257.
} 
Pregadores, ao Espírito Santo e, ainda, ao uso da força pelo Imperador ${ }^{196}$. Esta temporalidade do Quinto Império tinha evidente proximidade com o que advogavam os judeus - e o próprio Vieira o admitia, pois afirmava tê-la aceito em conversa com o rabino Manassés Ben Israel, com quem ele se encontrara em Amsterdã ${ }^{197}$ — e mereceu o pronto repúdio da Inquisição, quando a mesma processou o famoso orador.

O Vieira milenarista, como já se afirmou anteriormente, foi também um pragmático, um realista. Embora o realismo de Vieira não pareça ter sido o alvo principal do ataque que lhe foi desferido pela censura pombalina, constituiu elemento importante de sua atuação, principalmente em relação à América Portuguesa, onde, é preciso dizer, circularam não apenas suas idéias milenaristas, mas também suas refinadas análises políticas, muitas vezes mais realistas do que a própria realidade. $\mathrm{O}$ Padre Antônio Vieira, embora estivesse longe de propugnar levante contra os tiranos, tecera em seus sermões corrosivas análises sobre a administração colonial, discorrera nos mesmos sobre o bom governo e, mais do que isso, se metera numa ousada proposta de separar o Brasil de Portugal, estabelecendo cá El-Rei Dom João IV (as apropriações que se fizeram dessas análises, serão objeto de análise nos capítulos 7 e 8 desta tese).

Nos pronunciamentos, recorrendo a tópicas presentes em coleções iconográficas de ditames políticos para a educação dos príncipes produzidas por autores castelhanos, como Diego de Saavedra Fajardo (1548-1648) e Juan de Sólorzano y Pereira (1575-1653) - concórdia das gentes e ordens do reino; suavidade e proporcionalidade dos impostos; honestidade e proficiência dos ministros; exemplaridade dos atos do governo - defendeu a distribuição proporcional dos impostos entre os três estados, com o intuito de garantir à Coroa recursos para enfrentar Castela. Advogou também uma "espécie de profissionalização da máquina do Estado absolutista, imprescindível para a defesa eficaz de sua soberania": que o rei utilizasse menos o sangue do que as inclinações e competências dos indivíduos ao fazer as nomeações para cargos e mercês ${ }^{198}$.

\footnotetext{
195 CIDADE, Hernâni, op. cit., p. 79.

${ }^{196}$ Ibidem, p. 84.

${ }^{197}$ Ibidem, p. 80.

${ }^{198}$ PÉCORA, Alcir. Prefácio: tópicas políticas dos escritos de Antônio Vieira, op. cit., p. XI-XII.
} 
Em sermão pronunciado aos 02 de julho de 1640, em homenagem ao Marquês de Montalvão, D. Jorge Mascarenhas, que chegava à Bahia como Vice-Rei ${ }^{199}$, em meio às interpretações e às profecias baseadas em analogias com os fatos narrados na Bíblia, VIEIRA, inicialmente, compara a situação da Bahia e do Brasil à época com a da casa de Zacarias, onde reinavam enfermidades antes da entrada de Jesus Cristo. Se, na casa de Zacarias, a chegada de Cristo trazia alegria, no Brasil, o mesmo se dava com a vinda do vice-rei; com ela, no "enfermo Brasil", se via "também cumprida em si aquela profecia, que havia de vir um Sol de justiça a restaurá-lo, que traria a saúde nas asas",200.

O Brasil, então, estaria "enfermo", "morto"201. E a principal razão desta enfermidade teria sido "o tolher-se-lhe a fala: muitas vezes se quis queixar justamente, muitas vezes quis pedir o remédio de seus males, mas sempre lhe afogou as palavras na garganta, ou o respeito, ou a violência",202. A "enfermidade do Brasil", por sua vez, seria "pecado original", a "falta de devida justiça, assim da justiça punitiva, que castiga maus, como da justiça distributiva, que premia bons". Para VIEIRA, é importante sublinhar:

"Prêmio e castigo são os dois pólos em que se revolve e
sustenta a conservação de qualquer monarquia e porque
ambos estes faltaram sempre ao Brasil, por isso se arruinou
e caiu [...] Que a causa por que os reinos e as monarquias se
não conservam debaixo do mesmo Senhor, a causa porque
andam passando inconstantemente de umas nações a outras,
como vemos, é proper injustitias, por injustiças"

Por isto mesmo, VIEIRA queria remediar a enfermidade do Brasil "senão fazendo justiça", pois "se por injustiças" Deus entrega "os estados do mundo" a nações estrangeiras, para "conservar o nosso" era preciso não perdê-lo, condição sem a qual não havia como restaurá-1o ${ }^{204}$.

No Brasil, segundo VIEIRA, "por falta de justiça chegou ao miserável estado em que vemos. Houve roubos, houve homicídios, houve desobediências, houve

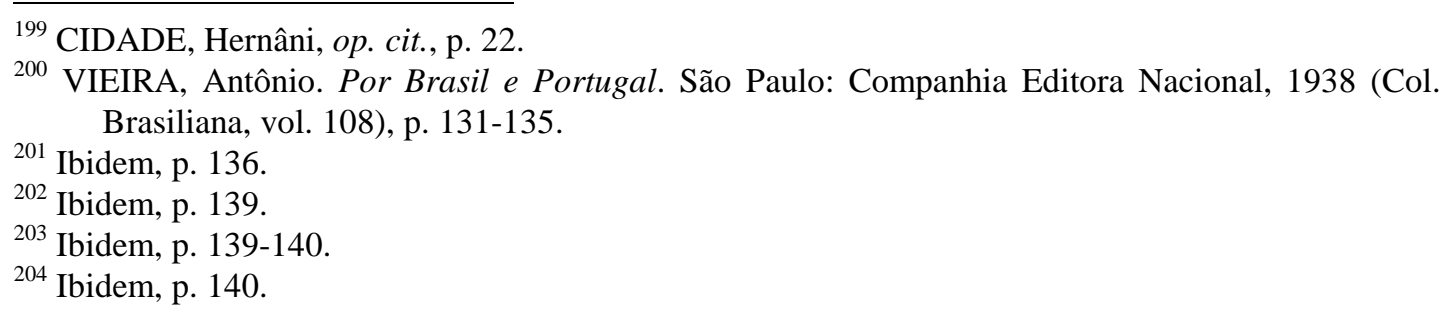


outros delitos, muitos e enormes, que não sei se chegaram a tocar na religião; mas nunca houve castigo, nunca houve um rigor que fizesse exemplo"205. Era necessária também não apenas "esta justiça punitiva, que castiga malfeitores, senão a outra parte da justiça distributiva, que premie liberalmente os beneméritos"206. Os prêmios urgiam para que existissem soldados ${ }^{207}$, mesmo porque no Brasil sucedia o oposto:

"os valerosos levam as feridas, e os venturosos os prêmios. Na Philosophia bem ordenada primeiro é a potência e o ato, depois o hábito; cá se olharmos para os peitos dos homens, acharemos muitos hábitos e mui pensionados, onde nunca houve ato, nem ainda potência. Desta desigualdade se segue, que o efeito dos prêmios militares vem a ser contrário a si mesmo, porque em vez de com elles se animarem os soldados, antes se desanimam e desalentam" 208 .

VIEIRA, em seguida, retoma a questão da causa da enfermidade do Brasil, tecendo considerações extremamente corrosivas sobre a administração colonial. Estabelece uma analogia entre a Queda, o pecado original, e a enfermidade do Brasil:

"A causa da enfermidade do Brasil bem examinada é a mesma que a do pecado original. Pôs Deus no paraíso terreal a nosso pai Adão, mandando-lhe que o guardasse $\mathrm{e}$ trabalhasse: Ut operatur, et custodiret: e ele parecendo-lhe melhor o guardar que o trabalhar, lançou mão à árvore vedada, tomou o pomo que não era seu, e perdeu a justiça, em que vivia para si, e para o gênero humano. Esta foi a origem do pecado original, e esta é a causa original das doenças do Brasil, tomar o alheio, cobiças, interesses, ganhos, e conveniências particulares, por onde a justiça se não guarda, e o estado se perde. Perde-se o Brasil, senhor (digamô-lo em uma palavra), porque alguns ministros de sua majestade não vêm cá buscar nosso bem, vêm cá buscar nossos bens. Assim como dissemos que se perdeu o mundo, porque Adão fez só metade do que Deus lhe mandou, em sentido inverso, guardar sim, trabalhar não; assim podemos dizer, que se perde também o Brasil, porque alguns de seus ministros não fazem mais que a metade do que el-rei lhes manda [...].Toma nesta terra o ministro da justiça? Sim, toma. Toma o ministro da fazenda? Sim, toma. Toma o ministro da República? Sim, toma. Toma o ministro da milícia? Sim, toma. Toma o ministro do estado? Sim, toma. E como tantos sintomas lhe sobrevem ao pobre enfermo, e todos acometem à cabeça, e ao coração, que são as partes mais vitais, e todos são atrativos e contrativos do dinheiro,

\footnotetext{
${ }^{205}$ Ibidem, p. 141.

${ }^{206}$ Ibidem, p. 143.

${ }^{207}$ Ibidem, p. 144.

${ }^{208}$ Ibidem, p. 144-145.
} 
que é o nervo dos exércitos e das repúblicas, fica tomado todo o corpo e tolhido de pés e mãos, sem haver mão esquerda que castigue, nem direita que premie; e faltando a justiça punitiva para expelir os humores nocivos, e a distributiva para alentar e alimentar o sujeito, sangrando-o por outra parte os tributos em todas veias, milagre é que não tenha expirado",209.

Portanto, se o "tomar o alheio", protagonizado por Adão, fora motivo da "perda" do mundo, no Brasil, o "tomar o alheio, cobiças, interesses, ganhos, e conveniências particulares" produziam o mesmo efeito destrutivo, contaminando o "corpo" da Colônia, sem que houvesse quem o punisse, nem quem premiasse os que o merecessem. A isto, se aliavam os tributos, que sangravam ainda mais o enfermo o Brasil. Com efeito, salienta VIEIRA:

"Desfazia-se o povo em tributos, e mais tributos, em imposições, e mais imposições, em donativos e mais donativos, em esmolas, e mais esmolas (que até a humildade deste nome se sujeitava a necessidade, ou se abatia a cobiça), e no cabo nada aproveitava, nada luzia, nada aparecia. Por quê? Porque o dinheiro não passava das mãos por onde passava. Muito deu em seu tempo Pernambuco: muito deu, e dá hoje a Bahia, e nada se logra; porque o que se tira do Brasil, tira-se do Brasil; o Brasil o dá; Portugal o leva" 210 .

Os tributos tirariam para Portugal o que daria o Brasil - e VIEIRA, na seqüência, insiste em retomar a ação dos governadores, seu papel na transferência de riquezas do então miserável Brasil para Portugal e Espanha. Para retratar a situação, recorre a uma bela metáfora:

"Com terem tão pouco do céu os ministros que isto fazem, temo-los retratados nas nuvens. Aparece uma nuvem no meio daquela Bahia, lança uma manga ao mar, vai sorvendo por oculto segredo da natureza grande quantidade de água, e depois que está bem cheia, depois que está bem carregada, dá-lhe o vento, e vai chover daqui a trinta, daqui a cincoenta léguas. Pois, nuvem ingrata, nuvem injusta, se na Bahia tomaste essa água, se na Bahia te encheste, porque não choves também na Bahia? Se a tiraste de nós, porque a não despendes conosco? Se a roubaste a nossos mares, porque a não restitues a nossos campos? Tais como isto são muitas

\footnotetext{
${ }^{209}$ Ibidem, p. 153-154.

${ }^{210}$ Ibidem, p. 156.
} 
vezes os ministros que vêm ao Brasil, e é fortuna geral as partes ultramarinas. Partem de Portugal estas nuvens, passam as calmas da linha, onde se diz que também refervem as consciências, e em chegando, verbi gratia, a esta Bahia, não fazem mais que chupar, adquirir, ajuntar, encher-se (por meios ocultos, mais sabidos), e ao cabo de três ou quatro anos, em vez de fertilizarem a nossa terra com água que era nossa, abrem as asas do vento, e vão chover a Lisboa, esperdiçar a Madrid. Por isso nada lhe luz ao Brasil, por mais que dê, nada lhe monta, e nada lhe aproveita, por mais que faça, por mais que desfaça. E o mal para sentir de todos é, que a água que por lá chovem e esperdiçam as nuvens, não é tirada da abundância do mar, como noutro tempo, senão nas lágrimas do miserável, e dos suores do pobre, que não sei mais como atura já tanto a constância e fidelidade destes vassalos" ${ }^{\prime 211}$.

Os ministros-governadores, que de três em três anos desembarcavam no Brasil, assim, agiam como "nuvens", "chupando" as riquezas da Colônia por "meios ocultos”, carreando-as para Lisboa e Madrid, sem trazerem benefício à terra, mas sim tirando-as de um povo que então se achava miserável. Vieira, em seguida, expressa sua esperança de que o Vice-Rei desse cabo a esta situação e, em conclusão, vaticina: "desta vez se há de restaurar o Brasil". "Tudo o que der a Bahia para a Bahia há de ser: tudo o que se tirar do Brasil, com o Brasil se há de gastar"212.

Após a Restauração, durante o reinado de D. João IV, a situação diplomática de Portugal tornou-se bastante complexa, pois o país ficou quase sem apoio dos países europeus em sua luta contra a inimiga Espanha ${ }^{213}$. Nesse contexto, Vieira fez pronunciamentos e tomou iniciativas em que seu pragmatismo, mais do que sua

\footnotetext{
${ }^{211}$ Ibidem, p. 156-157.

212 Ibidem, p. 158. Segundo J. Lúcio de Azevedo (Idem, op. cit., vol. 1, p. 53), este sermão lembra o livro Arte de Furtar, cuja autoria foi atribuída a Vieira. De fato, neste livro aparecem alguns termos, imagens e interpretações que, embora não se refiram restritamente ao universo colonial, são bastante próximos aos encontrados no sermão em destaque, especialmente: a oposição entre a pobreza e opulência dos grandes, identificados a uma "esponja" que, como "sanguessugas" que "chupam o sangue" do doente fazendo-lhe mal, aniquilam os pequenos se servindo do suposto "benefício" que fazem ao soberano (Arte de Furtar/ Anônimo Século XVIII. Ap. de João Ubaldo Ribeiro. 2 ed. Rio de Janeiro: Nova Fronteira, 1992, p. 43). Outras idéias comuns aos dois textos são: Portugal sustentar-seia de suas "conquistas"; governadores seguiriam as "leis da cobiça" (Ibidem, p. 43-44); e haveria a necessidade dos reis estabelecerem uma correspondência "nos pagamentos e remunerações dos serviços que lhes" fizessem os seus vassalos (Ibidem, p. 33). De acordo com Azevedo, o sermão, ainda, tem pontos de convergência com escritos de dois autores baianos, mais ou menos coevos do pregador: a História do Brasil, do Frei Vicente Salvador, publicada apenas no século XIX, na qual se diz que, "após D. João III não houve outro rei que do Brasil curasse senão para receber suas rendas $e$ direitos"; e alguns "versos chocarreiros" de Gregório de Matos (“... os brasileiros são bestas/ E estarão a trabalhar/ Toda a vida por manterem/ Maganos de Portugal”) — AZEVEDO, J. Lúcio de, loc. cit..

213 AZEVEDO, J. Lúcio de, op. cit., p. 95.
} 
clarividência, é indiscutível. Compreendendo que para a conservação de Portugal era imprescindível "muito dinheiro", não havendo para tanto "meio mais eficaz que o do comércio" e, por conseguinte, gente com mais "cabedal" e "indústria" que os da "nação" (leiam-se cristãos-novos), propugnou a eliminação da distinção entre cristãos-velhos e cristãos-novos e a mudança dos "estilos" da Inquisição, tornando públicas as acusações feitas aos réus, isentando-os do confisco de bens ${ }^{214}$. O padre propôs também a D. João IV que em "Portugal, à imitação de Holanda, se levantassem duas companhias mercantis, uma oriental, e outra ocidental", para que se desenvolvessem, respectivamente, o comércio com a Índia e o Brasil, depositando nestas empresas a esperança de que, sendo "menores os seus gastos e maiores os seus lucros", elas "naturalmente chamariam e trariam a Portugal o dinheiro mercantil de todas as nações, e muito particularmente dos Portugueses" estabelecidos na Holanda e em Castela; isto requereria que os investidores ficassem isentos do fisco, "por quanto de outra maneira, nem os mercadores, nem os do mesmo reino que o trazem divertido por outras partes o quereriam" aplicar nas companhias ${ }^{215}$. A preocupação de Vieira com o desenvolvimento mercantil converge com o imperialismo presente nos seus escritos proféticos, na medida em que o comércio, na concepção do padre, seria o instrumento de que se serviam os portugueses para evangelizar o mundo. Nas reformas executadas pelo Marquês de Pombal, adversário implacável dos jesuítas que se empenhou em perseguir e atacar a memória e as idéias do ilustre orador, como se comprovará no Capítulo 3, é possível reconhecer as propostas pragmáticas apresentadas por Vieira a D. João IV assinaladas anteriormente: a constituição de companhias de comércio, a eliminação da distinção entre cristãos-novos e cristãosvelhos e a mudança dos "estilos" da Inquisição ${ }^{216}$.

Tendo em vista às dificuldades de Portugal logo após a Restauração, Vieira propôs a entrega de Pernambuco à Holanda, outra demonstração do realismo do orador, tão extremo que suplantou a realidade, ou, nos termos propostos por Alcir PÉCORA, "foi desmontado pelo fantástico dos acontecimentos" "217. Assim, no denominado "Papel Forte", escrito em 1648, Vieira defendeu a entrega de

\footnotetext{
${ }^{214}$ PÉCORA, Alcir. Prefácio: tópicas políticas dos escritos de Antônio Vieira, op. cit., p. XIV e TORGAL, Luís Reis, op. cit., vol. 1, p. 404-405.

${ }^{215}$ VIEIRA, Antônio. Cartas, op. cit., tomo 2, p. 170-171.

216 TORGAL, Luís Reis, op. cit., vol. 1, p. 429-430 e BESSELAAR, José van den, op. cit., p. 157.
} 
Pernambuco à Holanda, para que assim se encerrassem os conflitos com este país, podendo Portugal concentrar-se na guerra contra Espanha ${ }^{218}$; e D. João IV enviou-o a Amsterdã e Haia para negociar um acordo nesses termos com os holandeses. No entanto, os revoltosos de Pernambuco, às suas próprias expensas e com suas fraquezas, não se deixando levar pela desigualdade das forças em embate na guerra, lograram expulsar os flamengos, anulando o acordo de paz pretendido ${ }^{219}$ - a vitória foi tão surpreendente, que nela Ericeira viu a intercessão do céu, o qual, "olhando, como sua, para esta causa, deu mais favorável sentença por este reino" de Portugal ${ }^{220}$. Vieira, então, passou a ser tratado por seus inimigos como o "Judas do Brasil"221.

Outro projeto "pragmático" em que se engajou Antônio Vieira foi o plano secreto de casar D. Teodósio, filho de D. João IV, com a sobrinha de Luís XIII, a Duquesa de Montpensier, filha do Duque de Orleans, sob a condição de que houvesse uma aliança entre Portugal e França ${ }^{222}$. Este projeto foi acalentado por D. João IV desde 1643, quando dele se incumbiu a missão de Luís Pereira de Castro à França, sem, porém, obter sucesso. Em 1647, o projeto foi retomado, tendo o rei enviado instruções ao Marquês de Niza sobre o negócio e mandado o padre Antônio Vieira a Paris para cuidar dele. Pela proposta, a aliança entre França e Portugal, que se buscava alcançar pelo casamento de D. Teodósio com Mlle. de Montepensier ou com outra princesa francesa, envolveria, de um lado, a retirada de D. João IV para o Brasil, onde o rei constituiria um reino autônomo, junto com os Açores, e, de outro lado, a transferência do trono português para D. Teodósio, ficando como regente do trono o pai da noiva (o Duque de Orleans ou outro nobre). Vieira foi, senão cúmplice do projeto, ao menos seu mediador; o Marquês de Nizza colocou obstáculos e o Cardeal Mazarino impediu que as negociações avançassem, contando com aval da rainha de França ${ }^{223}$. O Conde da ERICEIRA, em História de Portugal Restaurado, critica a atuação de Vieira no episódio, sem explicitar o conteúdo do acordo proposto à França, deixando entrever que ele teria pecado pela incompetência: "como o seu

\footnotetext{
${ }^{217}$ PÉCORA, Alcir. Prefácio: tópicas políticas dos escritos de Antônio Vieira, op. cit., p. XVI.

${ }^{218}$ Ibidem, p. XV.

${ }^{219}$ Ibidem, loc. cit.

${ }^{220}$ ERICEIRA, Conde [D. Luís de Menezes], op. cit., vol. 2, p. 311.

${ }^{221}$ PÉCORA, Alcir. Prefácio: tópicas políticas dos escritos de Antônio Vieira, op. cit., loc. cit.

${ }^{222}$ RIBEIRO, Ângelo. De Montijo à morte de D. João IV. In: PERES, Damião, CERDEIRA, Eleutério (dir.). História de Portugal. Barcelos: Portucalense, 1934, vol. 6, p. 69.

${ }^{223}$ Ibidem, p. 70; J. AZEVEDO, Lúcio de, op. cit., p. 96 e 119-121; e TORGAL, Luís Reis de, op. cit.,
} 
juízo era superior e não igual aos negócios, muitas vezes se lhe desvaneceram por querer tratá-los mais sutilmente do que os compreendiam os Príncipes e Ministros, com quem comunicou muitos de grande importância"224.

As concepções milenaristas de Vieira, ao que parece, tiveram maior repercussão do que as "realistas" na cultura letrada. Quando Vieira ainda vivia, nos idos de 1672, deixou circular inacabado "um livro intitulado o Quinto Império, ou Império consumado de Christo, que vem a ser a Clavis Prophetarum". Ele próprio, em carta escrita em 1695, dizia que o livro estava por terminar, tendo, por isto mesmo, que prosseguir em sua escritura ${ }^{225}$. A acreditar-se em seu autor, ninguém o lia "sem admiração, e sem o julgar por importantíssimo à inteligência das escrituras proféticas",226.

vol. 1, p. 322.

${ }^{224}$ ERICEIRA, Conde [D. Luís de Menezes], op. cit., vol. II, p. 243. Vieira, por sua vez, respondeu às críticas de Ericeira, encaminhando-lhe duas cartas, ambas da Bahia: uma, mais curta, aos 18 de agosto de 1688 (VIEIRA Padre Antônio. Cartas, op. cit., vol. 2, p. 159-161) e outra, mais longa, aos 23 de maio de 1689 (Idem, Escritos Históricos e Políticos, op. cit., p. 265-280). Nesta carta, embora Vieira não entre - e, sequer, o mencione - no mérito do plano, contra-argumenta da seguinte maneira: "por que ordenou S. M [D. João IV] que o Marquês de Nizza a nenhuma audiência da Rainha Regente, e do Cardeal Mazarino, fosse sem eu assistir juntamente com ele a tudo o que se tratava, se eu não havia de ser entendido da Rainha, nem do Cardeal seu primeiro Ministro?" (Ibidem, p. 279).

${ }^{225}$ VIEIRA, Antônio. Cartas, op. cit., tomo 2, p. 220.

${ }^{226}$ Ibidem, tomo 2, p. 97. 


\subsection{Gusmão, o "Voador", e Rocha Pitta: eruditos milenaristas no Setecentos}

As idéias milenaristas, vieiristas ou não, na verdade, tiveram grande fôlego, até mesmo nos círculos que valorizavam a ciência. Se na Inglaterra Newton tinha arroubos milenaristas, em Portugal os seguidores da fé num milênio parecem ter sido mais numerosos. O já citado matemático Estancel é um exemplo. Em 1695 com cerca de oitenta anos, concluiu uma obra sobre um dos livros proféticos da Bíblia, o livro de Daniel (que versa sobre a escatologia e o milenarismo), intitulando-o Commentarium in Danielem, obra que criticava as formulações de Vieira e que foi censurada e apreendida pelos revisores da Companhia de Jesus em Roma ${ }^{227}$. Outro que parece ter nutrido simpatias por crenças milenaristas, embora não seja possível afiançá-lo, foi o padre Bartolomeu de Gusmão. Nascido em Santos, ex-estudante do Seminário jesuítico da Cachoeira, na Bahia, Gusmão foi um matemático que se imiscuiu nos domínios da física: revelou um certo domínio sobre essa área, "conhecendo as propriedades de empuxo dos fluidos, estudados por Arquimedes no caso da água", e estendidos por ele ao ar; familiarizando-se, ainda, com a variação da densidade dos gases com a temperatura, a partir do que pôde projetar balões de ar quente, lançados ao ar em três ocasiões no ano de 1709. Tais experimentos tiveram êxitos moderados e, por causa deles e de uma projetada máquina de andar pelos ares, a Passarola, Gusmão obteve por alvará régio o monopólio da navegação aérea, tornando-se conhecido como o "Voador". Os experimentos e a excentricidade tornaram o padre alvo de acirrada zombaria, em função do que ele veio a abandonar as experiências com balões e a passar à mecânica e hidráulica, não mais com sucesso $^{228}$. Gusmão — no que se pode vislumbrar um escorregão milenarista prometeu a D. João V dilatar o Império Colonial Português e "dominar todos os reinos do mundo e estabelecer um único império universal", graças à Passarola ${ }^{229}$. Nem Império, nem Passarola se concretizaram e, sem que seja possível precisar as

\footnotetext{
${ }^{227}$ ROMEIRO, Adriana, op. cit., p. 180.

${ }^{228}$ FILGUEIRAS, Carlos Alberto Lombardi. Bartolomeu de Gusmão: um eco da revolução científica no Brasil colonial, op. cit., p. 384-390.

${ }^{229}$ ROMEIRO, Adriana, op. cit., p. 171 e 177.
} 
razões, o padre "Voador" acabou sendo exilado, morrendo precocemente em $1724^{230}$. A biografia do padre Bartolomeu de Gusmão, assim, mostra a promiscuidade entre ciência e milenarismos prevalecente no mundo luso-brasileiro até meados do século XVIII; ao mesmo tempo, pelas resistências que se moveram aos experimentos do padre, apresenta mais um indício de que havia uma letargia científica em território luso. A história de Gusmão revela igualmente que o anti-cientificismo, se reinava, não era absoluto, na medida em que houve quem valorizasse as ciências —e, talvez por isto mesmo, tenha vivido numa situação delicada —; além disso, confirma o desenvolvimento da Matemática e, ainda, o aprisionamento da ciência por uma civilidade das aparências em Portugal ao tempo de D. João V.

Como as ciências naturais - ou, melhor dizendo, "filosofia natural", evitando-se anacronismos —, a história não ficou imune aos milenarismos. Exemplo de contágio foi Sebastião da Rocha PITTA, intelectual da virada do século XVII para o XVIII, autor da obra História da América Portuguesa desde o ano de MD até o de MDCCXXIV, apresentada à Academia Real da História Portuguesa, editada pela primeira vez em $1730^{231}$. PITTA acreditava no "milagre de Ourique", no "Encoberto" e no Quinto Império e, ainda, construiu uma interpretação providencialista sobre a Restauração Portuguesa. Para este autor, o ano de 1640 seria o fim das "desgraças de Portugal" e ponto em que "principiavam as suas felicidades; limite prescrito das profecias do nosso Encoberto; termo dilatado e apetecido das nossas esperanças e tempo da segunda cláusula da promessa de Deus Nosso Senhor, feita a el-rei D. Afonso Henriques" ${ }^{232}$. A monarquia portuguesa, além disso, segundo Pita, haveria "de ser o único permanente e maior império de todos os quatro tão opulentos e inconstantes que teve o mundo" ${ }^{\text {233 }}$. Por fim, no dia da Aclamação de ElRei D. João IV, Jesus Cristo "despregou o braço direito da cruz que precedia ao arcebispo de Lisboa nos vivas de tão aplaudida ação", concluindo PITTA que este despregamento da cruz e a aclamação tinham "prodigiosa congruência", pois "a empresa que conseguiram os Lusitanos" só podia ser obra "da mão onipotente, pela

\footnotetext{
${ }^{230}$ FILGUEIRAS, Carlos Alberto Lombardi, loc. cit.

${ }^{231}$ MORAES, Rubens Borba de. Bibliografia brasileira do período colonial: catálogo comentado das obras dos autores nascidos no Brasil e publicadas antes de 1808. São Paulo: IEB, 1969, p. 290.

${ }^{232}$ PITTA, Sebastião da Rocha. História da América portuguesa desde o ano MD. até o de MDCCXXIV. 2 ed. rev. Lisboa: Livraria Guimarães \& C. ${ }^{\text {a }}, 1880$, p. 139.

${ }^{233}$ Ibidem, loc. cit.
} 
debilidade de forças em que se achava o reino [...] para proclamar liberdade"234.

No mundo luso-brasileiro da Época Moderna, em resumo, alguns livros, textos, movimentos e correntes político-culturais marcavam-se pela defesa de concepções corporativas de poder, pelo anti-cientificismo, pelos milenarismos e pelo realismo. Assim, primeiramente, sob a sombra da Segunda Escolástica, fixavam-se limites ético-políticos ao poder absoluto e, em graus variáveis, defendia-se a legitimidade da resistência à tirania, subordinando-a ao respeito aos direitos hereditários da dinastia reinante. Em segundo lugar, a influência do aristotelismo escolástico, de seu método tópico e dedutivo, do probabilismo "jesuítico", conduzia a um distanciamento de Portugal em relação à revolução científica então em andamento no Além-Pirineus, embora não impedisse que fossem assimilados, aqui e acolá, os novos conhecimentos e metodologias, que na maioria das vezes eram cultivados em círculos privados e restritos da sociedade, acomodados à ordem política e cultural vigente. Sem haver anti-cientificismo absoluto, além disso, em Portugal e seus domínios, assistiu-se à proliferação da crença na constituição de um Quinto Império, liderado por um príncipe lusitano, inaugurando um tempo de felicidade.

Sob o Reformismo Ilustrado, no governo de D. José I e de seus sucessores imediatos, como se mostrará nos Capítulos 3, 4, 5 e 6, porém, foram perseguidos o anti-cientificismo, as idéias milenaristas e as teorias corporativas de poder, ao mesmo tempo em que se repudiaram as posturas mais radicais da Ilustração, como o anticolonialismo, o anti-despotismo e a irreligiosidade. A coroa não conseguiu, contudo, suprimir as manifestações contrárias à fé católica, ou mesmo, as idéias milenaristas; não logrou impedir que as mesmas fossem assimiladas com tons sediciosos na América, laicizadas e mitigadas, misturadas a proposições Ilustradas, conectadas com as teorias corporativas de poder e suas aplicações à interpretação da Restauração Portuguesa de 1640.

Para encerrar este capítulo e dar vez às Luzes presentes nessa mencionada amalgamação de idéias, cumpre dizer que o abade RAYNAL, Ilustrado de grande repercussão no mundo luso-brasileiro, não poupava elogios ao nosso mais célebre milenarista, o padre Antônio Vieira, em sua Histoire philosophique et politique des

\footnotetext{
${ }^{234}$ Ibidem, p. 141.
} 
établissements et du commerce des européens dans les deux Indes ${ }^{235}$. Mencionando-o por mais de uma vez ao discorrer sobre a derrota dos holandeses no ataque à Bahia, RAYNAL conta que:

"Ce fut dans ces circonstances qu'un jésuite éloquent, Antoine Vieira, pronnonça dans un des temples de Bahia, le discours de plus vehément et le plus extraordinaire qu'on ait peut-être jamais entendu dans aucune chaire chrétienne. La singuralité de ce sermon fera peut-être excuser la longue analyse que nous en allons donner",236.

Após transcrever esse "mais extraordinário e mais veemente sermão jamais ouvido em nenhum púlpito cristão", no qual Vieira pede a Deus a intercessão a favor dos portugueses, RAYNAL associa seus efeitos à Restauração de 1640 nos seguintes termos:

"Je ne sais si le Seigneur fut sensible à l'apostrophe de l'orateur Vieira; mais très peu de temps après, les Hollandais virent interrompre leurs conquêtes par une révolution que toutes les nations désiraient, sans qu'aucune l'êut prévue" 237 , a Restauração Portuguesa.

Raynal não soube se o Senhor sensibilizou-se diante dos reclamos de Vieira, apesar de relacioná-los a uma "revolução que todas as nações desejavam". Aqui, pode-se tentar perceber como os Ilustrados dirigiram seus olhos ao próprio Deus e à fé cristã, à América e à colonização, para compreender como as Luzes se imbricaram aos milenarismos, ao anti-cientificismo, às teorias corporativas de poder e às aplicações dessas na interpretação da Restauração Portuguesa de 1640, fomentando heresias e engendrando não uma revolução esperada por "todas as nações", mas uma conspiração abortada em seu desiderato, a Inconfidência Mineira.

\footnotetext{
${ }^{235}$ RAYNAL, G. T.. Histoire philosophique et politique des établissements et du commerce des européens dans les deux Indes... nouvelle édition, corrigée et augmentée d'après les manuscrits autographé de l'auteur... par M. Peuchet. Paris: Amable Costes et C.ie., 1820, tomo 5. Esse volume foi recentemente publicado em português, com prefácio da historiadora Berenice Cavalcante: RAYNAL, Guillaume-Thomas François. $O$ estabelecimento dos portugueses no Brasil. Trad. Mônica F. Campos de Almeida e Flávia Roncari Gomes. Rio de Janeiro: Arquivo Nacional; Editora Universidade de Brasília, 1998.

${ }^{236}$ Ibidem, p. 36-37.

${ }^{237}$ Ibidem, p. 45.
} 


\section{Capítulo 2:}

\section{A Ilustração}

A Ilustração influenciou as ações da coroa portuguesa a partir da ascensão de D. José I e de seu poderoso ministro Sebastião de Carvalho e Mello, levando à realização de uma série de reformas, inclusive no aparato censório. Na própria ação desse último, além disso, assim como nas práticas de leitura, a sombra das Luzes é inconfundível.

Com o objetivo de compreender com maior clareza as transformações patrocinadas pelo Reformismo Ilustrado português, bem como seus limites e suas incidências sobre a censura literária e as práticas de leitura, primeiramente, buscarse-á identificar as linhas gerais da Ilustração, definindo em seguida o que constituiu seus elementos centrais. Depois, mostrar-se-á como os grandes filósofos viam Portugal, com destaque para as considerações que teceram sobre as relações entre o reino lusitano e sua vasta colônia na América.

\section{Luzes: história, origens sociais e idéias}

Desde o século XVIII a Ilustração vem motivando a preocupação das ciências humanas $^{1}$ e sendo objeto de polêmica na historiografia. Das análises e do debate emergem três perspectivas de abordagem das Luzes: "enquanto um movimento de idéias, enquanto uma questão histórica, enquanto uma dimensão sociológica" 2. Enquanto um problema histórico, trata-se de buscar as conexões da Ilustração com as transformações econômicas e sociais que foram suas contemporâneas; enquanto problema sociológico, cumpre identificar o lugar social e o perfil do intelectual que se encontra ligado à produção, circulação e apropriação das idéias ilustradas; e enquanto movimento de idéias, deve-se buscar entender o conteúdo de suas propostas e a postura intelectual que as engendrou. Em qualquer uma dessas

\footnotetext{
${ }^{1}$ OUTRAM, Dorinda. The Enlightenment. Cambridge: Cambridge University Press, 1995, p. 1.

${ }^{2}$ NEVES, Guilherme Pereira das. O Seminário de Olinda: educação, cultura e políica nos tempos modernos. Universidade Federal Fluminense: Niterói, 1984, vol. 1, p. 66-73 (Dissertação de
} 
perspectivas, constata-se que, sob o termo Ilustração, na realidade, oculta-se uma diversidade de idéias e processos, que compreenderam espaços e tempos também variados.

Analisando a Ilustração enquanto problema histórico, percebe-se, inicialmente, que a mesma teve um raio geográfico de influência bem amplo, não se restringindo ao "centro" da Europa (França, Inglaterra, Alemanha e Itália), mas atingindo a "periferia" do Velho Continente, de Portugal até a Rússia, e também as Américas. Além disso, não foi coetânea nos vários países em que se difundiu ${ }^{3}$. Podese dizer mesmo que a Ilustração variou conforme as diferenças de nacionalidade, de credo e de região, havendo, portanto, diferentes Ilustrações, vividas por homens e mulheres, por brancos e também sob a influência das tradições indígenas ${ }^{4}$. A variação das idéias dos filósofos deu-se, além disso, em consonância com os diferentes modos de pensar a religião e as táticas políticas, chegando mesmo a haver hostilidades entre pensadores católicos, luteranos e anglicanos ${ }^{5}$.

A ampla difusão das Luzes e sua diversidade, no entanto, foram permeadas por dois processos correlatos: industrialização e homogeneização cultural. Com o aumento da divisão do trabalho, o crescimento da produção e do consumo (inclusive de livros, panfletos, jornais etc.) e o desenvolvimento do comércio, entrelaçaram-se regiões, países, continentes; as transformações estruturais, portanto, permitiram a difusão ampla de idéias, valores, hábitos, rompendo-se barreiras, estabelecendo-se intercâmbios, produzindo-se impactos nos vários sistemas culturais, engendrando homogeneização ${ }^{6}$. Os impressos, quando não a capacidade de ler, tornaram-se mais

\footnotetext{
mestrado).

${ }^{3}$ OUTRAM, Dorinda, op. cit., p. 6-7. A autora sublinha que há pouco acordo entre os historiadores quanto à definição dos limites cronológicos e espaciais das Luzes, hoje estabelecendo-se contudo a compreensão de que entre Ilustração e Revolução Francesa, ao invés de ruptura, existiria uma continuidade (Ibidem, p. 8). Veja também: GOMES, Joaquim Ferreira. Para a história da educação em Portugal. Porto: Porto Editora, 1995, p. 66.

${ }^{4}$ OUTRAM, Dorinda, op. cit., p. 12. Peter Gay afirma que os filósofos não eram uma disciplinada legião ou mesmo uma escola fechada de pensamento, mas, pelo contrário, encerraram uma experiência política diversa, acompanhando a geografia (GAY, Peter. The Enlightenment: the rise of modern paganism. New York: Norton, 1995, p. 4).

${ }^{5}$ GAY, Peter, op. cit., p. 24.

${ }^{6}$ OUTRAM, Dorinda, op. cit., p. 15-17 e NEVES, Guilherme Pereira das. O Seminário de Olinda: educação, cultura e política nos tempos modernos, op. cit., vol. 1, p. 49. Esse último autor, ao realizar um balanço das posições historiográficas sobre as Luzes enquanto problema histórico, mostra como as interpretações que as associam à burguesia vêm sendo questionadas. Cita Lucien Goldmann como um dos autores criticados por fazer tal associação: representante da linhagem historiográfica marxista, Goldmann entende que contrato, igualdade, universalidade, tolerância, liberdade e propriedade, as principais categorias da Ilustração, corresponderiam aos elementos essenciais à troca, atividade burguesa por excelência. Essa interpretação é criticada porque, primeiro, na Inglaterra, epicentro da
} 
difundidos e, especialmente as classes mais elevadas passaram a ter acesso a um maior volume de material de leitura, cuja variedade de caráter também se ampliava ${ }^{7}$. As gazetas, os panfletos e as revistas destacavam-se em meio a esse material de leitura, encurtando distâncias intelectuais e criando uma atmosfera cosmopolita na Europa $^{8}$ e, pode-se dizer, também na América.

$\mathrm{Na}$ França especificamente, a par dessas transformações econômicas centradas na indústria e na homogeneização cultural que as acompanhou, as Luzes interligaram-se ainda à Revolução. Luzes e Revolução, na verdade, foram duas manifestações ou epifenômenos de um processo maior pelo qual se afirmou "uma sociedade de homens independentes, sem mitos nem religião (no sentido tradicional do termo), sociedade 'moderna', melhor dizendo, sociedade sem passado nem tradição, do presente, e inteiramente aberta na direção do porvir"; sociedade que se conhece independente de toda mítica tradicional ou da ordem sobrenatural da revelação, que desintegra as autoridades políticas e religiosas; sociedade ainda que substitui Deus pela natureza, uma natureza desmistificada na qual se observa a força do homem, sujeito que crê no progresso e se lança à procura das leis e dos princípios que ordenam a realidade ${ }^{9}$. Portanto, na França, Luzes, industrialização, Revolução e homogeneização cultural fizeram parte de um conjunto de transformações históricas que puseram abaixo o Antigo Regime, seus privilégios e a visão sacral-tradicional de mundo em que o mesmo se embasava.

Essa perspectiva de compreensão das Luzes - um tanto teleológica, é bem verdade, na medida em que se avalia o fato "Ilustração" a partir de seus desdobramentos futuros - associada a outras transformações, todas elas convergindo para o solapamento do Antigo Regime e a constituição da sociedade

revolução industrial, a efervescência das Luzes teria sido pequena, embora se fizesse presente na vizinha Escócia. Em segundo lugar, porque na França a nobreza participou amplamente do movimento; porque, ainda, no mesmo país, os filósofos cultivaram suas relações com o poder e mantiveram-se favoráveis à preservação das distinções sociais. E, por último, na medida em que ao menos um monarca assimilou o ideário Ilustrado. Pereira das Neves conclui, então, que apenas numa perspectiva teleológica seria possível atribuir um caráter burguês à Ilustração (Ibidem, p. 67-69).

${ }^{7}$ OUTRAM, Dorinda, op. cit., p. 20.

${ }^{8}$ NEVES, Guilherme Pereira das. O seminário de Olinda: educação, cultura e política nos tempos modernos, op. cit., p. 61 e OUTRAM, Dorinda, op. cit., p. 17-18.

9 DUPRONT, Alphonse. Qu'est-ce que les Lumières? Paris: Gallimard, 1996, p. 32-35 e 50-53. Segundo Dorinda Outram, a associação entre Ilustração e o desencantamento do mundo foi feita também por filósofos e comentadores políticos, destacando-se as figuras de Theodor Adorno e Max Horkheimer. Segundo esses, tendo o homem conquistado a supremacia sobre a natureza e sobre os outros seres humanos, controlando-os racionalmente, tecnologicamente, desconectou conhecimento e ética, conhecimento e verdade, resultando no totalitarismo (OUTRAM, Dorinda, op. cit., p. 9-11). 
moderna, no entanto, precisa ser matizada. As diferentes transformações relacionadas com as Luzes não se processaram num mesmo tempo, num mesmo ritmo, em todos os países e regiões. Além disso, se a Revolução Francesa afetou as estruturas políticas da Europa e da América, levando no caso de Portugal à transferência da corte para o Rio de Janeiro, a via revolucionária - entendendo-se por revolução não apenas alterações nas estruturas políticas, mas também no âmbito da sociedade e da economia —, não se generalizou. Em Portugal e suas possessões da América, assistiu-se, como se mostrará no Capítulo 3, a uma série de reformas ilustradas conduzidas pelos monarcas; a essas reformas sucederam a chamada Revolução do Porto, em 1820, e a Independência do Brasil, em 1822: esses movimentos políticos não tiveram nada de verdadeiramente revolucionário, levando, no primeiro caso, à limitação dos poderes régios e, no segundo, à ruptura dos vínculos políticoadministrativos entre Portugal e sua colônia americana ${ }^{10}$.

As Luzes, ainda enquanto problema histórico, envolveram importantes descobertas científicas. Tais descobertas deram-se paralelamente aos progressos da técnica relacionados à revolução industrial. Entretanto, tratava-se de dois mundos relativamente distintos: de um lado, o mundo dos gabinetes de física e astronomia, onde pesquisadores solitários realizavam suas experiências e, de outro, o mundo das artes mecânicas, das técnicas, de homens de negócio, dos inventores, que empenhavam seu gênio na construção de máquinas ${ }^{11}$. Tais transformações das ciências e das técnicas, é certo, afetaram umas às outras, tendo havido interferências mútuas entre elas, mas o que é mais importante nas afinidades entre ciência e técnica está nos seus resultados e nas forças que as moviam. Do ponto de vista dos resultados, vê-se que com os avanços da ciência organizavam-se uma visão e um sistema do mundo; enquanto com os progressos técnicos ampliavam-se os meios de apropriação da realidade, criando uma atmosfera extraordinária de descobertas, dentro da qual tudo era possível. A efervescência das técnicas e das ciências ensejava

\footnotetext{
${ }^{10}$ A "Revolução do Porto" foi uma "reação ao estado de colônia a que o reino se vira reduzido, após a partida da corte, pensada ainda nos quadros das mitigadas Luzes portuguesas e articulada por meio dessa nova forma de sociabilidade do período, a maçonaria" - NEVES, Guilherme Pereira das. Do Império Luso-brasileiro ao Império do Brasil (1789-1822). Ler História, Lisboa (27-28): 95, 1995. Assim sendo, a "Revolução", se servia para domesticar o absolutismo e, portanto, punha em xeque um elemento do Antigo Regime, tinha também em vista o reforço do sistema colonial, peça essencial do mesmo Antigo Regime. Isso demonstra como as Luzes, apreendidas como um problema histórico, abrigaram diferentes vias e possibilidades de transformação, não sendo a revolução uma fatalidade.

${ }^{11}$ DUPRONT, Alphonse, p. 40-42.
} 
a publicação de tratados, sintoma de um grande interesse coletivo e de uma vontade de aprender; neste ponto, assim, percebe-se um motor comum às técnicas e às ciências: uma pulsão por dissolver os mistérios e por afastar os fantasmas, uma crença na capacidade do homem ${ }^{12}$.

Descobertas científicas, avanços técnicos e eventos revolucionários, quando confrontados em sua cronologia, revelam, além disso, notável coincidência. Em 1767, quando James Watt construía a máquina a vapor, J. B. Priestley publicava sua Histoire de l'Électricité e, quatro anos mais tarde, Monge definia a geometria analítica e Lavoisier, a análise da composição do ar. Em 1774, Priestley estudava o oxigênio, enquanto Herschel construía seu grande telescópio; em 1776, Jouffroy d'Abbans tentava fazer navegar seu barco a vapor. Em 1778, Buffon publicava sua obra Époques de Nature; neste mesmo ano, Lamarck começava a editar sua Flore française; de 1787 a 1792, publicavam-se os grandes tratados definidores das novas ciências: Mécanique analytique de Lagrante (1782); Traité de statistique de Monge (1788); Traité de chimie de Lavoisier (1789); e De viribus electricitatis, do italiano Galvani $^{13}$. As descobertas científicas e as invenções técnicas, como se pode observar, ocorreram antes ou durante a Revolução Francesa ${ }^{14}$. Essa coincidência temporal relativa entre os avanços técnicos e científicos promovidos pelas Luzes e a Revolução, contudo, segreda especificidades de ordem espacial, mais uma vez apontando para a diversidade que marca a Ilustração enquanto um problema histórico: a França, um dos principais territórios dos avanços científicos, acompanhou muito lentamente as transformações da revolução industrial, enquanto a Inglaterra foi o berço desta última e espaço privilegiado das inovações técnicas ${ }^{15}$. Em suma, as Luzes, enquanto problema histórico, associam-se com transformações econômicas, sociais e culturais oriundas da industrialização e com mudanças político-culturais suscitadas por movimentos revolucionários ou reformistas; conjunto de transformações este que, variando no tempo e no espaço, pôs abaixo o Antigo Regime ou elementos dele, desencantou o mundo e afirmou a capacidade do homem de controlar a natureza e os outros homens, dissolvendo ou amenizando a força das tradições e da religião sobre a vida social.

\footnotetext{
${ }^{12}$ Ibidem, p. 45-46.

${ }^{13}$ Ibidem, p. 43-44.

${ }^{14}$ Ibidem, loc. cit.. Para Dupront, as descobertas científicas e as invenções técnicas desenvolveram-se cada qual de forma autônoma, embora houvesse influências recíprocas.
} 
Avaliando a Ilustração como um problema sociológico, percebe-se que suas bases sociais marcaram-se igualmente pela diversidade. O próprio modo como os diferentes grupos sociais participaram do debate e se posicionaram diante das questões trazidas pela Ilustração também foi plural. As Luzes, assim, seduziram a elite educada e chegaram também às classes subalternas, atingindo camponeses e aprendizes de impressores, homens e mulheres, a cidade e o campo (sobre este aspecto há grande discordância entre os historiadores, é preciso salientar) ${ }^{16}$. Esses diferentes grupos, que se integraram às Luzes em meio ao processo de transformações econômicas assentadas na industrialização e na progressiva homogeneização cultural, fizeram-no, contudo, de forma variada. No seio das elites, o interesse comum pelas questões e debates suscitados pela Ilustração foi capaz de unificar, passando por cima das diferenças, donos de manufaturas, homens de ciência e intelectuais locais. A maçonaria é um exemplo de instituição em que se vislumbrou essa ênfase na igualdade ${ }^{17}$. Na França, homens de finanças costumavam, além disso, praticar o mecenato, favorecendo o desenvolvimento das artes ${ }^{18}$. Na França e na Itália, seções das velhas e novas elites uniram-se nas academias de ciências: aristocratas, membros dos altos escalões da administração eclesiástica e régia, grandes comerciantes e, ainda, médicos e militares abastados, congregaram-se em torno das Luzes. Os debates, além disso, estenderam-se para além dos muros da academia e das lojas maçônicas, atingindo a população urbana e até mesmo rural, tendo como mediadores culturais os trabalhadores domésticos. Na Europa, esses trabalhadores constituíam um grupo ocupacional dos mais amplos; por serem freqüentemente provenientes do meio rural e, além disso, por participarem da intimidade dos seus empregadores, os empregados domésticos estavam em condições privilegiadas para agirem como mediadores culturais ${ }^{19}$.

Realidade sociologicamente multifacetada, unificando as elites, alcançando as camadas populares, as Luzes envolveram debates intensos e a defesa de idéias diametralmente opostas. Assim, ao se analisar a Ilustração enquanto um movimento

\footnotetext{
${ }^{15}$ Ibidem, p. 45.

${ }^{16}$ OUTRAM, Dorinda, op. cit., p. 25-29. A própria autora reconhece que historiadores como Roger Chartier e Robert Darnton entendem que a população rural manteve-se insensível às Luzes (Ibidem, p. 28-29). Para Alphonse Dupront, as Luzes, na França, foram um fenômeno essencialmente urbano (DUPRONT, Alphonse, op. cit., p. 59-60).

${ }_{17}$ OUTRAM, Dorinda, op. cit., p. 25.

${ }^{18}$ DUPRONT, Alphonse, op. cit., p. 58.

${ }^{19}$ OUTRAM, Dorinda, op. cit., p. 26-29.
} 
de idéias, logo se evidencia a existência de diferentes posições. As Luzes não constituíram algo tão homogêneo como se supunha e muito menos podem ser apreendidas, nos moldes propostos por Peter Gay, como movimento que instituiu o moderno paganismo ${ }^{20}$. Mesmo sob uma ótica tradicional de apreensão das idéias da Ilustração - isto é, a partir de seus grandes pensadores - constata-se a heterogeneidade do movimento. O próprio Peter GAY — historiador cuja apreciação sobre o conteúdo das Luzes é considerada tradicional e que identifica um programa comum aos diferentes ilustrados, postulando, portanto, a existência de uma unidade entre os mesmos - estabelece uma cronologia identificando três gerações de pensadores, nas quais seria perceptível um crescente radicalismo: a primeira, que vai até 1750, dominada por Montesquieu e Voltaire, quando os escritos de Locke e Newton eram ainda recentes e controversos, marcada pelo anti-clericalismo e pela especulação científica; a segunda, que organizou o anti-clericalismo e o cientificismo num coerente e moderno modo de conceber o mundo, iniciada a partir de meados do século XVIII, em que pontificavam Franklin, Buffon, Hume, Rousseau, Diderot, Condillac, Helvétius e d'Alembert; e, por fim, a terceira geração, que foi aplaudida, encorajada e irritada pelas gerações precedentes, voltada para questões de mitologia científica e metafísica materialista, para reformas políticas, econômicas e legais e, ainda, para a política prática, a geração de Holbach, Beccaria, Lessing, Jefferson, Kant, Wieland e Turgot ${ }^{21}$. O mesmo historiador, além disso, reconhece que não havia entre os Ilustrados uma unanimidade e que, algumas vezes, eles vieram a se atritar uns com os outros ${ }^{22}$. As diferenças multiplicam-se quando, ainda seguindo a ótica que privilegia os grandes pensadores, se penetra nas idéias referentes a temas e aspectos particulares. As Luzes, assim, implicaram uma variedade de respostas em relação à religião, sendo possível apenas apontar a tolerância religiosa como a mais característica idéia da Ilustração, idéia em torno da qual se congregaram muitos pensadores, de diferentes posições ${ }^{23}$.

\footnotetext{
${ }^{20}$ Ibidem, p. 6-7. Veja também: GOMES, Joaquim Ferreira, op. cit., p. 66.

${ }^{21}$ GAY, Peter, op. cit., p. 17-18.

${ }^{22}$ Ibidem, p. 4.

${ }^{23}$ OUTRAM, Dorinda, p. 35-37.
} 
A perspectiva anti-religiosa dominou os pensadores da Ilustração Francesa. Os deístas, muito fortes na Inglaterra e na França, negavam que o homem pudesse obter algum conhecimento do Criador que fosse além do mero fato de sua (de Deus) existência. Alguns deístas reinterpretavam as idéias de Isaac Newton, publicadas em Mathematical Principles of Natural Philosophy (1687), sobre a relação entre Deus e o cosmos. Segundo Newton, o cosmos seria uma prova da existência de Deus e da continuidade de sua intervenção, na medida em que a ordem nele visível sujeitava-se a leis matemáticas, não apenas estabelecidas originalmente pelo Criador, mas também derivadas de sua intervenção para corrigir irregularidades e fornecer energia. Popularizadores do eminente pensador inglês, como, por exemplo, Voltaire, no entanto, deturparam o sentido original das suas idéias, utilizando-as para defender princípios caros ao deísmo: a distância entre o Criador e a criação, a crença somente em Deus como criador do universo, a identificação do Criador às próprias leis da natureza ${ }^{24}$.

$\mathrm{Na}$ Inglaterra, Pope, pupilo do aristocrata deísta Bolingbroke, ensaiou um deísmo tímido, poético, em seu Ensaio sobre o Homem (1733) e em The Universal Prayer (1738), obras em que de algum modo apresentava Deus, o pai de toda a criação, como ser adorado indistintamente pelos sábios, santos e selvagens, tendo assim nomes variados. No mesmo país, alguns deístas iam mais longe, como Tindall em Christianity as old as the Creation, or the Gospel a Republication of the Law of Nature (1730). Tais deístas substituíam a revelação pela razão, pregando um regresso à religião natural, isto é, a religião que emanava unicamente da natureza, que seguia o instinto depositado em nós por esta última, permitindo-nos distinguir entre o bem e o mal, o verdadeiro e o falso; religião que obedecia à lei da natureza, dentro da qual se inscreveria a felicidade; religião que prescindia da mediação divina. Essa religião não implicava qualquer ato de fé, resumindo-se a uma operação intelectual que consistia em afirmar a existência de Deus e admirar seus efeitos sobre a criação ${ }^{25}$.

Na Alemanha, Johann Salomo Semler defendia que a religião era moralidade, vida interior, mais ou menos intensa conforme a qualidade do indivíduo, força espontânea, força livre, sendo a autoridade sua inimiga, na medida em que alterava

\footnotetext{
${ }^{24}$ Ibidem, p. 34 e 39-41. A necessária derivação divina das leis naturais era refutada pelo historiador escocês David Hume (Ibidem, p. 41).

${ }^{25}$ HAZARD, Paul. O pensamento europeu no século XVIII. Lisboa: Editorial Presença, 1989, p. 65$67,111 \mathrm{e}, 367-369$.
} 
sua energia e contrariava a expansão desta. Os livros bíblicos, no seu entender, continham informações contrárias às verdades da revelação eterna, não tendo sido escritos para revelar uma religião ${ }^{26}$.

Na França, em fins do século XVII, Pierre Bayle, em seu Dictionnaire historique critique, lançara-se ao combate à superstição, à defesa da tolerância religiosa e à opção pelos ensinamentos da moral, nos casos em que ela colidisse com as interpretações literais da Bíblia ${ }^{27}$. Montesquieu, à semelhança de Bayle, comungava de princípios deístas, louvando a Deus como o criador do gênero humano, combatendo os preconceitos e a intolerância e desdenhando a importância política do cristianismo ${ }^{28}$. O deísmo de Voltaire apropriou-se dessa crítica bíblica de caráter moral proposta por Bayle. Voltaire, como os demais deístas, acreditava na existência de um Criador, negava-se a averiguar as formas como este agiria, entendendo apenas que o faria com justiça; opunha-se à adesão a qualquer das "seitas" (isto é, religiões), vistas como contraditórias umas em relação às outras; defendia a religião natural, mais antiga que todas as religiões e por ele considerada capaz de irmanar os povos, de Pequim a Caiena, não excluindo nenhum deles; e movia, por conseguinte, uma intensa cruzada contra a religião organizada, contra a Igreja e contra o antropomorfismo ${ }^{29}$. Um dos seus alvos principais era a superstição, inimigo em função do qual Voltaire construiu uma visão e uma periodização da história em que contrapunha, dentro de cada período e entre uma e outra épocas, a luta entre a superstição e os filósofos ${ }^{30}$. Outro alvo que se consolidou para Voltaire com o passar dos anos foi o cristianismo: a Bíblia, segundo o grande deísta francês, só trouxera infelicidade; a Igreja, loucura e corrupção; e os que professavam a fé cristã, particularmente os clérigos, o fanatismo ${ }^{31}$.

Houve filósofos que disseram ser a observância religiosa tolerada apenas porque fazia-se útil para a estabilidade social, mas não por haver verdades em seus fundamentos. Outros pensadores foram declaradamente ateístas, como Alberto

\footnotetext{
${ }^{26}$ Ibidem, p. 76-77.

${ }^{27}$ CASSIRER, Ernst. Filosofia de la Ilustración, Trad. Eugenio Ímaz. 2 ed. Madrid: Fondo de Cultura Económica, 1993, p. 185-186 e 190-191.

${ }^{28}$ VIGUERIE, Jean de. Histoire et dictionnaire du temps des Lumières. Paris: Robert Laffont, 1995, p. 1209-1210.

${ }^{29}$ OUTRAM, Dorinda, op. cit., p. 34; CASSIRER, Ernst, op. cit., p. 156; e HAZARD, Paul. $O$ pensamento europeu no século XVIII, op. cit., p. 371-374.

${ }^{30}$ GAY, Peter, op. cit., p. 32-34.

${ }^{31}$ HAZARD, Paul. O pensamento europeu no século XVIII, op. cit., p. 380-382.
} 
Radicati de Passerano, para quem não haveria justiça neste mundo, nem vida eterna, nem início, nem fim, sendo a morte apenas o meio de que a natureza se serviria para fabricar novos seres. Esse ateísmo cheirava a materialismo, o qual, por sua vez, assentou-se freqüentemente em interpretações das idéias de Locke, um cristão declarado, sobre os limites das possibilidades do conhecimento humano e sobre a associação entre matéria e pensamento no homem. Essas idéias de Locke, à sua revelia, tornaram-se, muitas vezes, o ponto de partida para a defesa da materialidade da alma. Materialistas como Julien de la Mettrie negavam sua existência e diziam que todo o conhecimento provinha das impressões sensoriais do mundo físico. $\mathrm{O}$ barão de Holbach, outro materialista, autor de Le Système de la Nature (1770) dentre outros livros, entendia que a religião fazia os homens temerosos e covardes diante de tiranos invisíveis; por essa razão, Holbach defendia o abandono de toda religião para que os homens se reconciliassem com a natureza e combatia violentamente os clérigos. Diderot, para quem o mundo era matéria e somente matéria, considerava necessário o abandono da fé, não importando qual fosse ela, para que o homem se libertasse do preconceito e da servidão, abrindo com isso o caminho para a sua verdadeira felicidade. Sylvain Maréchal, compilador de um Dictionnaire des athées, reunia na categoria de ateus inúmeros homens ilustres do presente e do passado e, ainda, povos inteiros, dentre esses os brasileiros ${ }^{32}$.

Desenvolveu-se, entretanto, uma Ilustração cristã e, mesmo, católica. Se Locke ofereceu involuntariamente argumentos para os defensores da materialidade da alma, publicou um livro chamado The Reasonableneness of Christianity, em 1695, empenhando-se no sentido de construir um cristianismo racional, no que encontrou seguidores ${ }^{33}$. Alguns pensadores chegaram a usar o materialismo filosófico na defesa da religião cristã, sendo exemplo disso o químico Priestley, partidário do cristianismo racional, para quem a alma era material, sendo esta materialidade capaz de pensar graças ao desígnio do próprio Deus ${ }^{34}$. Da Ilustração católica são exemplos Benito Feijoo, Antonio Genovesi e Muratori ${ }^{35}$. Benito Feijoo,

\footnotetext{
${ }^{32}$ OUTRAM, Dorinda, op. cit., p. 34; CASSIRER, Ernst, op. cit., p. 156-157; VIGUERIE, Jean de, op. cit., p. 906-907; e HAZARD, Paul. O pensamento europeu no século XVIII, op. cit., p. 116-125.

${ }^{33}$ Ao mesmo tempo, ocorreram movimentos de sentido oposto (por exemplo, o metodismo, o Grande Despertar e o Pietismo), que rejeitavam as tentativas de "racionalizar" o cristianismo e, pelo contrário, apegavam-se à fé, à confiança na revelação e aos testemunhos pessoais de experiência religiosa (OUTRAM, Dorinda, op. cit., p. 43-45).

${ }^{34}$ HAZARD, Paul. O pensamento europeu no século XVIII, op. cit., p. 119-120.

${ }^{35}$ GOMES, Joaquim Ferreira, op. cit., p. 67.
} 
Ilustrado espanhol, teólogo e historiador que admirava Bacon e Newton, escrevia contra os nobres e, embora combatesse o aristotelismo e considerasse que a religião aviltava-se devido às crenças nos falsos milagres e às práticas pueris, mantinha-se cristão, defendendo os dogmas contra tudo aquilo que os conspurcasse ${ }^{36}$. Antonio Genovesi, o Genuense, foi o mais notável Ilustrado católico e teve grande influência em Portugal. Dizia: “'Adoro o Evangelho, cuja essência é amor. Como é doce essa palavra, amor! E como a nossa vida seria feliz se fosse ela a única a reinar'“. $\mathrm{Na}$ defesa do cristianismo, estudou todos os que o atacavam, leu também os apologistas e, ao mesmo tempo, enfrentou problemas colocados pelas Luzes tais como: a origem das idéias, o racionalismo, o empirismo e o otimismo. Aconselhava seus alunos a não aceitar passivamente as palavras dos mestres, a examinar as crenças racionalmente e a não confundi-las com beatice, que servia apenas para sufocar a chama interior ${ }^{37}$.

Jean-Jacques Rousseau é, dos grandes filósofos, talvez aquele que seja mais original no que se referia à religião. Ele se mostrava contrário às religiões estabelecidas, classificando-as em três tipos, todos eles reputados como danosos: o primeiro, o das religiões que se fundam no culto interno de Deus e nas obrigações de moralidade, traria o risco de tornar as pessoas indiferentes ao bem-estar terreno e, assim, à segurança e prosperidade dos seus semelhantes; o segundo tipo de religião refere-se àquelas codificadas num só país, dando-lhe seus deuses e seus tutores, cujo perigo estaria em tornar os homens tirânicos e exclusivistas; o terceiro tipo, finalmente, é o da "'religião do sacerdote'“, em que há uma teologia separada do sistema político, tipo este que seria danoso na medida em que dividiria soberania e poder, "destruindo assim o Estado pela sujeição dos homens a deveres contraditórios" ${ }^{\prime 38}$. Rousseau, além disso, colidia com os ensinamentos cristãos referentes ao pecado original. Embora concordasse que o homem vivia num estado de queda e, por isso, valorizava o amor próprio e a vaidade e empenhava-se em dominar os seus semelhantes, Rousseau negava a idéia do pecado original: a degeneração humana não teria sido um desígnio divino, mas o resultado do abandono do estado de natureza pelo homem, ingressando na cultura e sujeitando-se a uma forma coercitiva de sociedade, que o entregara aos vícios. Se Rousseau postulava a

\footnotetext{
${ }^{36}$ HAZARD, Paul. O pensamento europeu no século XVIII, op. cit., p. 89-90.

${ }^{37}$ Ibidem, p. 90-91.

38 DENT, N. J. H. Religião (civil). In: Idem, Dicionário Rousseau. Trad. Álvaro Cabral, Rio de Janeiro: Jorge Zahar Editor, 1996, p. 195.
} 
existência de uma queda-culpa construída neste mundo (e não anterior à existência histórico-empírica da própria humanidade), ao mesmo tempo negava a possibilidade da salvação fora dele: nenhum Deus a poderia trazer, mas apenas a própria sociedade, que, na medida em que fosse transformada, curaria as feridas por ela criadas $^{39}$. A salvação, assim, estava no terreno da política e, por isso mesmo, o filósofo defendia a necessidade de uma religião civil, que teria como um dos dogmas a proibição da intolerância e cujo propósito consistiria em "formar, consolidar e perpetuar os vínculos entre todos os membros da sociedade civil", fazendo-os respeitar, como religiosos, princípios fundamentais da lei: a honra e o bem dos $\operatorname{outros}^{40}$.

As Luzes, pode-se dizer, valorizavam o conhecimento científico, principalmente as ciências exatas e naturais, então circunscritas na "filosofia natural" e concebidas como essenciais para a felicidade dos homens por trazerem inventos e descobertas úteis para a sociedade ${ }^{41}$. Segundo Ernst CASSIRER, o pensamento ilustrado caracterizar-se-ia pela renúncia à dedução sistemática, isto é, àquela que, partindo de um ser supremo ou de uma certeza fundamental, máxima, expandia a luz desta a todos os seres e saberes derivados através do método da demonstração e da consequiência rigorosa, enlaçando aqueles à certeza primordial de modo imediato ${ }^{42}$. No pensamento ilustrado, o ponto de partida teria sido deslocado da certeza fundamental para a experiência e a observação, invertendo-se, pois, a hierarquia metodológica: procurar-se-ia descobrir a lógica dos fatos, através da qual, primeiro, apreendiam-se os fenômenos; depois, buscar-se-ia cada uma das condições que originaram esses últimos, revelando a dependência que os ligava; e, finalmente, com base nestas descobertas, chegar-se-ia às regularidades comuns a cada tipo de fenômeno, formulando princípios ou leis ${ }^{43}$. Portanto, segundo CASSIRER, o pensamento ilustrado combinaria os métodos resolutivo e compositivo; nele, a função mais importante da razão consistiria, pois, em separar e juntar ${ }^{44}$.

Essa inversão metodológica identificada por CASSIRER, em que se vê a indução substituir a dedução, fez-se presente nos textos Ilustrados, mais

\footnotetext{
${ }^{39}$ CASSIRER, Ernst, op. cit., p. 177-181.

${ }^{40}$ DENT, N. J. H., op. cit., p. 194-195.

${ }^{41}$ GAY, Peter, op. cit., p. 18 e DIAS, Maria Odila Leite Silva. Aspectos da Ilustração no Brasil. Revista do Instituto Histórico e Geográfico Brasileiro, Rio de Janeiro, (278): 106, jan./mar. 1968.

${ }^{42}$ CASSIRER, Ernst, op. cit., p. 21.

${ }^{43}$ Ibidem, p. 22-26.
} 
particularmente naqueles de cunho científico, de "filosofia natural". No século XVII, Bacon criticara a lógica formal, afirmara que o silogismo levava a desinteligências e aconselhara a mudança de método: o apelo à observação e à experiência ${ }^{45}$. Mas foi Newton, físico que viveu entre a segunda metade do século XVII e o primeiro quartel do Setecentos, quem se tornou o modelo e objeto de veneração entre os Ilustrados ${ }^{46}$. Sua física partia de fatos devidamente constatados, extraía leis da natureza, pondo a matemática a seu serviço, furtando-se, porém, a tomar como pontos de partida abstrações e axiomas. A inversão metodológica tinha, então, o seu modelo e, além disso, levava muitos Ilustrados a rejeitarem a primazia da matemática e da geometria e a entusiasmarem-se com a física e com as ciências naturais em geral ${ }^{47}$. Com isso, de fato, instalou-se uma efervescência que levou à proliferação de curiosos: homens de ciência, grandes senhores e reis, dentre eles o já citado D. João $\mathrm{V}$, lançaram-se à observação, à experiência e ao estudo da natureza, em razão do que investigadores abandonaram suas províncias e reinos rumo a outros continentes ${ }^{48}$. Botânicos, como Lineu, procuravam encontrar uma classificação das plantas apenas a partir da observação de fatos. Rompendo-se com verdades pré-estabelecidas, os novos cientistas rejeitavam a autoridade inquestionável da Bíblia. Buffon, em Les Époques de la Nature, por exemplo, rompia com uma concepção estática de ciência e a substituía por uma noção evolutiva; partia da observação dos aspectos caóticos da superfície da Terra para captar, graças à geologia, suas profundezas ${ }^{49}$; a natureza tinha, do seu ponto de vista, uma história, o seu estado presente não era o estado em que Deus a criara ${ }^{50}$.

A inversão metodológica citada, porém, não aconteceu sempre, não se verificava em todos os pensadores: não foi absoluta. Cientistas e filósofos, muitas vezes, "tentavam integrar o universo, e os produtos desse universo, num plano preestabelecido", submetendo, portanto, os fatos, a um a priori ${ }^{51}$ : a inversão metodológica identificada por Cassirer, por conseguinte, tem aqui sua límpida negação; se ela existiu, de fato, para muitos pensadores, não valeu para todos, nem

\footnotetext{
${ }^{44}$ Ibidem, p. 37.

${ }^{45}$ HAZARD, Paul. O pensamento europeu no século XVIII, op. cit., p. 128.

${ }^{46}$ Ibidem, loc. cit. e CASSIRER, Ernst, op. cit., p. 61-64.

${ }^{47}$ HAZARD, Paul. O pensamento europeu no século XVIII, op. cit., p. 127-128.

${ }^{48}$ Ibidem, p. 129-130.

${ }^{49}$ Ibidem, p. 139 e CASSIRER,Ernst, op. cit., p. 66.

${ }^{50}$ OUTRAM, Dorinda, op. cit., p. 59.

${ }^{51}$ HAZARD, Paul. O pensamento europeu no século XVIII, op. cit., p. 132-134.
} 
foi absoluta. Além disso, ainda do ponto de vista das ciências, a Ilustração foi palco de outras diversidades. Houve, assim, uma Ilustração racionalista, como a de Descartes e Leibniz; outra, empirista, fundamentalmente de raiz inglesa, com Bacon, Locke e Newton, cada uma oferecendo respostas diferentes a problemas como as relações entre homem e natureza, a possibilidade do conhecimento do mundo externo e o melhor modo de organizar tal conhecimento, optando entre "observação" e "experiência" "52. Mesmo a valorização do conhecimento científico, em si, não era algo absoluto, sem reticências, entre os filósofos. Se VOLTAIRE era um apreciador da ciência - por exemplo, no Cândido, na passagem referente ao país do Eldorado, país imaginário situado na América do Sul, depois de fazer o protagonista constatar a inexistência de tribunais de justiça, apresenta o Palácio das Ciências, motivo de maior surpresa e o que "maior prazer lhe [a Cândido] deu [...], onde viu uma galeria de dois mil passos, cheia de instrumentos de matemática e física" ${ }^{53}$ —, ROUSSEAU era anti-intelectualista, associando o florescimento das artes e ciências à decadência das sociedades. O autor de Emílio devotava ojeriza aos inventores e cientistas; à investigação erudita, cujo sentido fosse apenas satisfazer a vaidade dos seus praticantes; e à medicina, reputada por ele como "arte mentirosa", "funesta para o gênero humano" 54 . Enquanto isso, La Mettrie alçava o médico à categoria de único filósofo de verdade, o único que falaria em nome da experiência, corrigindo a natureza sempre que ela errava, curando os males da vida ${ }^{55}$.

Outro campo em que se podem vislumbrar diferenças sensíveis entres os filósofos é a política. A Ilustração, como um todo, é certo, renegava a razão de Estado como o princípio de governo (condenando, por isto, Maquiavel e, nesse ponto preciso, aproximando-se da Segunda Escolástica), definia a virtude como o princípio e o fim da política, concebia a existência de uma lei natural anterior a qualquer convenção humana, compreendendo a liberdade como um direito natural inalienável de todos os homens, assim como o direito à propriedade, à igualdade diante da lei e à participação de cada cidadão na legislação e, ainda, postulava a idéia de um contrato social inicial, ideal ou tácito, entre os indivíduos e o governante, pelo qual os primeiros abdicavam de parte dos seus direitos para instituir um poder, abdicação

\footnotetext{
${ }^{52}$ GOMES, Joaquim Ferreira, op. cit., p. 67 e OUTRAM, Dorinda, op. cit., p. 48 e 61-62.

${ }^{53}$ VOLTAIRE. Cândido. Lisboa: Publicações Europa-América, s/d., p. 79.

${ }^{54}$ ROUSSEAU, J-J., op. cit., p. 33-34 e DENT, N. J. H. Discurso sobre as ciências e as artes. In: Idem, Dicionário Rousseau, op. cit., p. 110-112.
} 
esta revogável nos casos em que o governante faltasse com seus deveres ${ }^{56}$. Do ponto de vista das relações entre as nações, os Ilustrados condenavam a guerra, sendo, portanto, anti-belicistas: o abade Saint Pierre, buscando a paz duradoura, acalentou o projeto de instituir uma sociedade das nações ${ }^{57}$. John Locke (1632-1704), por exemplo, referência para vários pensadores Ilustrados, rejeitava o poder absoluto das monarquias, julgando-o incompatível com a sociedade civil e defendendo a existência de poderes com atribuições distintas (executivo e legislativo); Montesquieu, inspirando-se em Locke, preconizava a divisão dos poderes do Estado em executivo, legislativo e judiciário, atingindo com isto os fundamentos do absolutismo monárquico ${ }^{58}$.

Se havia unanimidades entre os filósofos, eles também tinham divergências no que se referia à política. Primeiro, quanto aos limites da igualdade. Em sua maioria, os filósofos não iam além da igualdade política, condenado, assim, a igualdade social: d'Alembert entendia que essa última era uma quimera; Holbach considerava que a natureza estabelecia uma desigualdade necessária e legítima entre os seus membros, sendo insensato, portanto, igualar as classes sociais, bastando a igualdade jurídica; Voltaire julgava a imutabilidade da diferença de classes necessária à conservação da própria sociedade. No entanto, Morelly, em seu Código da Natureza, qualificava a propriedade como a origem de todos os crimes do mundo, defendendo sua supressão; Mably defendia a igualdade social e privada, a "feliz comunidade de bens"; na Inglaterra, Thomas Spence ansiava por transformar cada paróquia numa espécie de célula igualitária, enquanto William Ogilvie defendia a concessão a cada pessoa de uma parte do solo ${ }^{59}$.

Os pensadores da Ilustração, além da defesa da liberdade de pensamento e de expressão, da liberdade religiosa e da liberdade de circulação, posicionavam-se contrariamente ao despotismo, equiparando-o à morte. Fizeram-no claramente homens como Montesquieu, Helvetius, Voltaire, o barão de Holbach, Rousseau e Raynal $^{60}$. Rousseau considerava a liberdade um direito inalienável do homem,

\footnotetext{
${ }^{55}$ HAZARD, Paul. O pensamento europeu no século XVIII, op. cit., p. 135-136.

${ }^{56}$ Ibidem, p. 167-169 e CASSIRER, Ernst, op. cit., p. 278-280.

${ }^{57}$ HAZARD, Paul. O pensamento europeu no século XVIII, op. cit., p. 178-179.

${ }^{58}$ LYRA, Maria de Lourdes Viana, op. cit., p. 26-30.

${ }^{59}$ HAZARD, Paul. O pensamento europeu no século XVIII, op. cit., p. 167-173.

${ }^{60}$ NOVAIS, Fernando Antônio. Portugal e Brasil na crise do antigo sistema colonial (1777-1808). 2 ed. São Paulo: Hucitec, 1981, p. 147; LEITE, Paulo Gomes. A maçonaria, o Iluminismo e a Inconfidência Mineira. Revista Minas Gerais, Belo Horizonte, (33): 20, jan. 1991; e ROUANET,
} 
concebendo a existência de uma vontade geral, expressão da soberania do povo, como reguladora do corpo moral e coletivo, como base da constituição do Estado ${ }^{61}$. Rousseau e Raynal foram além dos outros filósofos num ponto: defendiam a legitimidade da rebelião de um povo contra um poder despótico. RAYNAL estendia esse direito até mesmo àqueles que não vivessem sob o despotismo - afirmava que, se "os povos são felizes sob a forma de seu governo, eles o conservarão"; e que "revolta" é o nome que o opressor dá "ao exercício legítimo de um direito inalienável e natural do homem que se oprime, e mesmo do homem que não é oprimido"62 - e assinalava a transitoriedade das formas de governo - para o abade, "nenhuma forma de governo tem a prerrogativa de ser imutável"; não há "nenhuma autoridade política criada ontem ou há mil anos, que não possa ser ab-rogada em dez anos ou amanhã, ${ }^{, 63}$. Se eram, no geral, anti-despóticos e se não eram unânimes em relação ao direito do povo à rebelião, os Ilustrados não tinham uma mesma idéia sobre a forma de governo a ser adotada, oscilando entre a monarquia e a república; defendiam apenas que o governo não levasse nenhum elemento a dominar os outros, devendo haver um equilíbrio entre os chefes, que não deveriam abusar do poder, e os súditos (na realidade, cidadãos), cuja responsabilidade era evitar a anarquia: para muitos deles, a Inglaterra afigurava-se claramente como o país que tinha a forma de governo ideal ${ }^{64}$.

Os "filósofos" dividiam-se ainda em relação a outro problema: a capacidade das mulheres, a posição dessas diante dos homens. Dentro do grupo de escritores independentes de mecenas, houve, é bem verdade, muitas mulheres; existiram também mulheres oriundas das elites que propugnaram idéias próprias, tal como a marquesa Emilie du Châtelet, companheira de Voltaire. Todavia, ao mesmo tempo, houve muitos filósofos que atacaram a capacidade das mulheres em geral de contribuir para a acumulação de idéias e para as discussões, todos eles freqüentemente baseados nas idéias de Rousseau, no Emílio, segundo as quais as mulheres conduzir-se-iam pela emoção, ao invés da racionalidade. Devido à sua biologia, em que era onipresente a função de reprodução, à sua dependência em relação aos homens e às suas obrigações familiares, as mulheres não estariam em

Sérgio Paulo. As Minas iluminadas: a Ilustração e a Inconfidência. In: NOVAES, Adauto (org.). Tempo e História. São Paulo: Companhia das Letras: Secretaria Municipal de Cultura, 1992, p. 336.

${ }^{61}$ LYRA, Maria de Lourdes Viana, op. cit., p. 29-30 e CASSIRER, Ernst, op. cit., p. 292-294.

${ }^{62}$ RAYNAL, Guillaume - Thomas François. A Revolução da América. Trad. Regina Clara Simões Lopes. Rio de Janeiro: Arquivo Nacional, 1993, p. 75.

${ }^{63}$ Ibidem, p. 76. 
condições de serem independentes e autônomas; sua participação entre os "filósofos", portanto, retiraria a legitimidade da República das Letras no que se referia à construção de uma opinião pública ${ }^{65}$.

Heterogênea no espaço, no tempo e nos temas; marcada pela presença de contradições evidentes nas posições de seus grandes pensadores; não compreendendo um programa intelectual coerente e preciso, a Ilustração é melhor definida, tal como propõe Dorinda OUTRAM, enquanto "uma série de problemas e debates, de 'pontosrelâmpago', característicos do século XVIII, ou de 'bolsões' em que projetos de expansão intelectual influenciavam e mudavam, em âmbito mundial, a natureza dos fatos na sociedade e no governo", destacando-se, dentre os problemas, "a contradição entre a investigação irrestrita e a necessidade de garantir a estabilidade do Estado e da sociedade" $" 66$. As Luzes seriam, assim, como uma "cápsula, contendo conjuntos de debates, pressões e preocupações que, independentemente de serem formuladas de maneira diversa ou de provocarem reações diferentes, parecem constituir, de fato, uma característica da maneira pela qual as idéias, opiniões e estruturas políticas e sociais interagiam e mudavam no século XVIII"67. Enfim, a Ilustração não seria um projeto intelectual fechado e homogêneo, mas um amplo leque de idéias e debates que se fizeram presentes no século XVIII, afetando a vida cultural, política e social em suas transformações, ocupando um papel de relevo, dentro das mesmas idéias e debates, o problema dos limites da investigação e do pensamento e a estabilidade dos Estados e da ordem social. Associando-se a outras transformações históricas e congregando forças sociais díspares, as Luzes não instituíram propriamente o "moderno paganismo", mas colaboraram para o desencantamento do mundo, para a afirmação da capacidade do homem de controlar a natureza e seus semelhantes, diminuindo a força da religião e das tradições sobre a vida social.

\footnotetext{
${ }^{64}$ HAZARD, Paul. O pensamento europeu no século XVIII, op. cit., p. 174-175.

${ }^{65}$ OUTRAM, Dorinda, op. cit., p. 23-24.

${ }^{66}$ No original: "a series of problems and debates, of 'flash-points', characteristic of the eighteenth century, or of 'pockets' where projects of intellectual expansion impacted upon and changed the nature of developments in society and government on a world-wide basis. Some of the most important of these problems have already been touched upon, in particular the contradiction between unrestricted inquiry and the need to assure stability in state and society" (OUTRAM, Dorinda, op. cit., p. 3). Agradeço a Glória Guiné de Carvalho e Mello pela tradução desses trechos.

67 No original: "capsule containing sets of debates, stresses and concerns, which however differently formulated or responded to, do appear to be characteristic of the way in which ideas, opinions and social and political structures interacted and changed in the eighteenth century" (Ibidem, p. 12).
} 


\section{Portugal e "Brasil" na ótica da Ilustração Européia}

O pensamento ilustrado, como se viu, comportava opiniões contraditórias e, mesmo, ambigüidades a respeito de certos temas. As apreciações que os grandes filósofos construíram a respeito de Portugal e da suas possessões na América, no conjunto, porém, possuem uma certa unidade. Não se pretende aprofundar a análise dessas apreciações, mas tão somente apontar as críticas feitas a aspectos da vida luso-brasileira que foram objeto de intervenções do Reformismo Ilustrado português, ou motivo de inquietação dos leitores no Reino e na Colônia, a saber: a religião, a inquisição e a colonização da América lusitana.

Voltaire foi um dos grandes filósofos que se interessou pelo mundo lusobrasileiro. Como outros pensadores, chegou a questionar os ensinamentos cristãos sobre um criador onipotente e amável a partir do trágico terremoto de Lisboa: se Deus era bom e onipotente, como pôde permitir que algo tão terrível e mau acontecesse ${ }^{68}$ Outro aspecto que chamou a atenção do grande filósofo foi a situação do cristianismo em Portugal, ou melhor, dos cristãos-novos acusados de judaísmo. Assim, no Dicionário Filosófico, mais precisamente no verbete "Cristianismo", ao discorrer sobre uma dissimulação feita por São Paulo, VOLTAIRE denuncia as incoerências do Deus judaico-cristão; da conduta de São Paulo; e da perseguição movida contra os judeus, em nome do cristianismo, em Portugal, Espanha e Itália:

"Foi pois deste modo que Paulo, a princípio encarniçado e sanguinário perseguidor da seita fundada por Jesus; Paulo, que depois quis governar essa seita nascente; Paulo, um cristão, pratica atos de culto judaico, judaíza, para que todos saibam que estão a caluniá-lo quando dizem que é cristão; Paulo faz o que hoje se considera um crime abominável, crime que é punido pela morte na fogueira em Espanha, em Portugal e na Itália; e procede assim a conselho do apóstolo Jaime e depois de ter recebido o Espírito Santo, isto é, após ter sido instruído pelo próprio Deus que se deve renunciar a todos os ritos judaicos, outrora instruídos pelo próprio Deus ${ }^{\prime \prime 69}$.

Na realidade, portanto, a situação dos cristãos-novos em Portugal, Espanha e Itália, sendo somada às palavras de Paulo e às ordens contraditórias do Deus cristão, servia

${ }^{68}$ OUTRAM, Dorinda, op. cit., p. 43.

${ }^{69}$ VOLTAIRE. Cristianismo. In: Idem, Dicionário Filosófico. Trad. de Bruno da Ponte, João Paulo Alves e Marilena Chaú. São Paulo: Nova Cultural, 1988, p. 50-51. 
ao filósofo para o questionamento da intolerância que permeava o cristianismo em geral.

A situação dos cristãos-novos em Portugal mereceu a reflexão de BIELFELD, que apontava os prejuízos que a intolerância para com os mesmos trazia ao reino lusitano e a incongruência entre essa posição e o desenvolvimento de relações comerciais com os protestantes. Segundo o autor,

"Un Juif Portugais, qui ne peut plus se cacher, fait passer secrétement ses richesses en Hollande ou en Angleterre, il s'embarque sur un vaisseau, quitte à jamais sa patrie, \& prive l'Etat de tous ses biens. D'autres font découvertes, ons les brûle, \& leurs biens confisqués passent à Rome. Au reste, ces riches Portugais ne doivent pas être considérés comme nos Juifs Allemands ou Polonois, stupides dans leur Religion, sales \& crapuleux dans leur façon de vivre, sourbes en faisant le commerce de la friperie. Au contraire, ce sont des gens de mise, simples, Deïstes dans le fonds, \& que suivent avec beaucoup de modifications les loix cérémoniales \& politiques que Moïse a dictées à leurs ancêtres, autant que ces loix paroissent applicables au temps présent; vivant d'ailleurs en grands Sei Seigneurs. Quant aus Protestans, la nécessité du Commerce les fait tolérer ouvertement en Portugal, l'Inquisition n'a aucune autorité sur eux, ils vont tête levée, sans avoir cependant l'exercice libre de leur Religion, si ce n'est pas ches les Ministres ou Cônsuls des Puissances commerçantes, Luthériennes ou Réformées" ${ }^{70}$.

No Candide, VOLTAIRE consagra outro espaço a Portugal. Primeiro, deixa entrever a estupidez da imaginária decisão dos "sábios" da Universidade de Coimbra de realizar um auto-de-fé após o terremoto de Lisboa - “o espetáculo de algumas pessoas queimadas a fogo lento, em grande cerimonial, era um meio infalível de impedir a terra de tremer". Depois, mostra que a ação do inquisidor-mor deixava-se guiar também por interesses profanos e privados, na medida em que além de "afastar o flagelo dos tremores de terra", prestava-se para intimidar o banqueiro judeu Issacar, cuja concubina lhe interessava ${ }^{71}$. A inquisição portuguesa, símbolo da intolerância religiosa, é vítima de outros ataques voltaireanos. No já citado Dicionário Filosófico, no verbete "Inquisição", VOLTAIRE traça um histórico do tribunal inquisitorial, considerado por ele "uma invenção admirável e absolutamente cristã destinada a tornar o papa e os monges mais poderosos e a tornar todo um reino

\footnotetext{
${ }^{70}$ BIELFELD, Baron de. Institutions politiques, par monsieur... Leide: Samuel et Jean Luchtmans, 1772 , tomo 3, p. 18-19.
} 
mais hipócrita"; uma instituição cuja paternidade encontra-se em São Domingos ${ }^{72}$. Para Voltaire, o estabelecimento da inquisição em Portugal foi o resultado de uma farsa protagonizada por "um malandrim chamado Saavedra"; este sujeito, sabendo "imitar todas as escritas, fabricar e apor falsos selos e falsos sinetes", apareceu em Lisboa como plenipotenciário do papa em 1539, dizendo-se encarregado de “estabelecer a Santa Inquisição sob fundamentos inabaláveis", trazendo para tanto cartas de Roma para o rei João III e para os funcionários da Corte. O rei, embora admirado de "que o papa lhe enviasse um legado a latere sem o previnir", acabou por aceitá-lo, tendo o mesmo se estabelecido como "um grande inquisidor, mandou cobrar dízimos por toda a parte; e, antes que a Corte pudesse receber respostas de Roma, já fizera queimar duzentas pessoas e arrecadara mais de duzentos mil escudos". Saavedra, no entanto, era um farsante e o papa "Paulo IV confirmou depois tudo o que fora estabelecido pelo intrujão", do que conclui VOLTAIRE que, com isto, ratificara com a "plenitude de seu poder divino todas as pequenas irregularidades processuais" e tornara "sagrado o que fora puramente humano"

Esse mesmo histórico crítico sobre a inquisição portuguesa aparece em outro livro publicado pela primeira vez em inglês, entre os anos 1735 e 1765, com o título de Universal History from the earliest account of time, to the present, e também editado em francês, em Amsterdã entre 1742 -1792, com o título Histoire Universelle depuis le commencement du monde jusqu'a présent, traduite de l'Anglais par une Socièté de Gens de Lettres. Numa nota de rodapé desta obra - que, em 1788, seria traduzida e publicada para o português por Antônio de Morais [SILVA] ${ }^{74}$ —, citam-se um livro francês (Mémoire pour servir à l'Histoire de l'Inquisition) e outro espanhol (Chronica del Caldinal Tavera) e explica-se a introdução da inquisição em Portugal da seguinte forma:

"Dizem que hum Religioso chamado João Peres de Sávedra, natural de Cordova, fingindo-se Cardeal Legado de Paulo III, trouxe huma Bulla, pela qual creava certos Inquisidores, que inquirissem contra os hereges, e fautores de doutrinas perigosas. Esta Bulla acompanhada de todos os caracteres de authenticidade foi feita com grande circunspecção [...] Mas por algumas suspeitas, que houverão, examinando-se melhor a Bulla, veio a descobrir-se que era falsa, e supposta, e o

\footnotetext{
${ }^{71}$ VOLTAIRE. Cândido, op. cit., p. 30 e 36-37.

${ }^{72}$ Idem, Inquisição. In: Idem, Dicionário filosófico, op. cit., p. 138.

${ }^{73}$ Ibidem, p. 139-140.

${ }^{74}$ MORAES, Rubens Borba de. Bibliografia brasileira do período colonial, op. cit., p. 355.
} 
Religiozo, que a trouxe, foi condemnado a galés por toda a vida, e solto alguns annos depois a rogos do Summo Pontifice" ${ }^{\text {, }}$.

Se a mordacidade e a ironia caracterizam esse histórico da implantação da inquisição em Portugal, a indignação é a marca da apreciação feita por outro filósofo Ilustrado sobre o tribunal inquisitorial português: BIELFELD. Em seu livro Institutions Politiques, esse autor, primeiro, avalia a inquisição como ofensiva à clemência divina, aos preceitos do cristianismo, à autoridade do soberano e ao direito dos homens; motivo de consternação e rebaixamento geral dos espíritos; depois, prega sua abolição, a destruição de seu palácio sede pelo fogo e, ainda, o envio à Roma de todos seus oficiais ${ }^{76}$. O autor avalia também a possibilidade de abolir o tribunal, sem que com isso se colocasse em risco o monarca e se suscitasse a reação dos fanáticos:

\begin{abstract}
“c'est un Problême à proposer aux plus habiles Politiques, comment le Monarque pourroit s'y prendre pour abolir cette horrible Inquisition, sans risquer sa vie \& sa couronne contre des milliers de Sujets fanatiques qui auroient les bras levés sur lui, à la première démarche qu'il pourroit faire pour exécuter un si glorieux dessein?"77.
\end{abstract}

Após considerar a existência de razões políticas para a manutenção da inquisição em Portugal — “il est des personnes instruites, qui prétendent que le Roi de de Portugal

\footnotetext{
${ }^{75}$ SILVA, Antônio de Moraes. História de Portugal composta em inglez por huma sociedade de litteratos, trasladada em vulgar, com as addições da versão franceza, e notas do traductor portuguez, Antonio de Moraes Silva. Lisboa: Typografia da Academia Real das Sciencias de Lisboa, 1802, vol. 2, p. 286-287.

${ }^{76}$ Seus termos são exatamente os seguintes: "Qui n'eût dit que dans un temps de détresse aussi grande, le Gouvernment auroit profité de la première consternation \& de l'abaissement général des esprits, pour appaiser da Colère céleste en lui sacrifiant cet horrible Tribunal qui blesse également la clémence divine, les préceptes du Christianisme, l'autorité du Souverain \& tous les droits des hommes? On sent bien que je veux parler de l'abolition de l'Inquisition. Sans vouloir répéter ici des idées que j'ai expliquées ailleurs, ni m'étendre en vaines déclamations, je ne puis m'empêcher de remarquer, que c'eût été le vrai moment de l'à propos, pour faire mettre secrètement le feu au Palais \& aux Prisons de l'Inquisition, \& détruire ce que le tremblement de terre en avoit épargné, en saisant saisir tous les Officiers de ce Tribunal, \& les noyer ou les renvoyer à Rome, pour délivrer ainsi le Prince \& ses sujets d'un joug affreux que leur fait porter la superstition la plus aveugle \& la plus honteuse pour l'humanité" (BIELFELD, Baron de, op. cit., tomo 3, p. 15-16). O Editor, em nota, se pronuncia contra a maneira proposta por Bielfeld para abolir a inquisição: "Cette manière d'abolir l'Inquisition, ne me paroit pas sensée. Au sort de la plus grande Catastrophe, l'augmenter em mettant le feu volontairement à des édifices, ç'auroit été une occupation bien odieuse \& bien indigne d'un Monarche. M. De Bielefeld [sic] s'est laissé emporter à un premier mouvement d'indignation, en écrivant ceci: \& s'il avoit consulté son coeur, ses arrêts auroient cassé ceux de l'esprit. Note de l'Editeur".
} 
tolère \& soutient même l'Inquisition par des raisons politiques, fondées sur le grand nombre de Juifs cachés qui se trouvent répandus dans ce Royaume" —, BIELFELD indaga se a existência do tribunal inquisitorial, independente do poder régio, não é mais perigosa ao rei do que todos os judeus em conjunto: "Un pareil Tribunal, indépendant du Souverain, n'est-il pas plus dangereux au Roi, que tous les Juifs ensemble; \& chaque sujet a-t-il un moment de fureté pour sa vie, son honneur, sa liberté \& ses biens? Qu'arrive-t-il d'ailleurs?",78.

O abade RAYNAL, em sua Histoire philosophique et politique des deux Indes, obra publicada inicialmente em 1770, combate a inquisição e discute a questão dos cristãos-novos em Portugal. Depois de falar sobre a perseguição aos judeus na Península Ibérica, mencionando, entre outros fatos, o banimento por D. Manuel dos que se recusaram a se tornar cristãos em 1496, insinua a existência de interesses econômicos por trás das ações contra os cristãos novos: "L'établissement de l'inquisition ralentit, em 1548, leur activité; les confiscations que se permettait ce tribunal odieux, et les taxes que le gouvernement leur arrachait de temps en temps, augmentaient la défiance". Cita, em seguida, o fornecimento de dinheiro pelos cristãos-novos para Dom Sebastião realizar sua expedicão à África; fala sobre as regras estabelecidas por Filipe II quanto à inadmissibilidade dos cristãos-novos para o estado eclesiástico e os cargos civis; e, ainda, avalia as conseqüências que tais medidas trouxeram a Portugal, isto é, a transferência dos capitais dos cristãos-novos para Anvers, Hambourg e outras cidades e a ocorrência de uma revolução contra a indústria, a qual teria privado Espanha e Portugal das “avantages que l'un tirait des Indes Orientales, et l'autre des Indes Occidentales"79. RAYNAL salienta, ademais, que anteriormente estes cristãos-novos haviam migrado em grande número para a América Portuguesa e, por fim, adverte que na Colônia não estiveram ao abrigo da ferocidade inquisitorial, tendo os clérigos, os agentes desta, se nutrido de suas máximas sanguinárias, seu fanatismo, trazendo prejuízos para a atividade agrícola:

"Sans avoir proprement l'inquisition, le Brésil n'est pas à l'abri des attentats de cette invention féroce. Les ecclésiastiques de la colonie que ce tribunal choisit pour ses

\footnotetext{
${ }^{77}$ Ibidem, p. 16-17.

${ }^{78}$ Ibidem, p. 19.

79 RAYNAL, G. T. Histoire philosophique et politique des établissements et du commerce des européens dans les deux Indes... nouvelle édition, corrigée et augmentée d'après les manuscrits autographes de l'auteur... par M. Peuchet. Paris, Amable Costes et C.ie., 1820, tomo 5, p. 9-10.
} 
agens, se nourrissent tous de ses maximes sanguinaires: leur fanatisme s'est quelquefois porté à des excés incroyables; l'accusation de judaïsme est celle qui provoque le plus souvent leur impitoyable sévérité. Les fureurs en ce genre furent poussées si loin depuis 1702 jusqu'en 1718, que tous les esprits se remplirent de terreur, et que la plupart des cultures restèrent négligées" ${ }^{" 80}$.

O abade, ao apresentar uma série de medidas visando tirar Portugal e a Colônia de "sua lassidão", afirma que a aceleração das vantagens das reformas exigiria "apagar até o menor traço da Inquisição, desse tribunal horrível, cujo nome faz estremecer as nações que não inteiramente à sua razão". Logo, portanto, segundo RAYNAL, a inquisição, mais do que um obstáculo para a ruptura com a "lassidão", para a execução de reformas no mundo luso-brasileiro, era uma ofensa à "razão" das nações ${ }^{81}$.

A inquisição não escapou à crítica de Cesare Beccaria, que, no livro Dei Delitti e delle Pene (1764), condena o recurso à tortura, seja porque sendo secreta não se revestia da virtude de exemplo, seja porque permitia aos culpados fugir dos castigos (dado que a resistência do réu à tortura era vista como prova de inocência), seja porque punia os justos que, não resistindo aos suplícios, confessavam culpas que não tinham. A tortura inquisitorial era, assim, insensata, criminosa; a tortura em geral deveria desaparecer de todo Estado que se pretendesse civilizado ${ }^{82}$.

No Cândido, VOLTAIRE retrata o "país do Eldorado", situado na América do Sul, não propriamente em território português, reino americano imaginário que teria sobrevivido incólume aos ataques dos espanhóis por estar rodeado de "rochedos inacessíveis e de precipícios". Como de costume, VOLTAIRE fustiga os clérigos, pondo a personagem Cândido a interrogar um velho sobre a religião no país do Eldorado e, diante das respostas, a repetir uma das perguntas: "Não tendes frades que ensinem, disputem, governem, intriguem e mandem queimar as pessoas que não são da sua opinião?". Ao que o velho, reiterando sua resposta, afirma: "Seria preciso que fôssemos loucos" ${ }^{\prime \prime 3}$. Novamente, portanto, o olhar sobre uma porção imaginária da América do Sul, ainda livre do domínio lusitano ou castelhano, presta-se à pregação

\footnotetext{
${ }^{80}$ Ibidem, p. 81-82.

81 RAYNAL, G. T. Histoire philosophique et politique des établissements et du commerce des européens dans les deux Indes, op. cit., tomo 5, p. 160.

${ }^{82}$ HAZARD, Paul. O pensamento europeu no século XVIII, op. cit., p. 153.

${ }^{83}$ VOLTAIRE. Cândido ou o otimismo, op. cit., p. 75-77.
} 
anti-clerical e pró-tolerância do grande filósofo. Diderot adota procedimento similar, engastando sua visão sobre os "outros" em sua estratégia de combate à religião: ateísta declarado, na sua intervenção na Histoire Philosophique do abade Raynal, vê os índios brasileiros como um "povo de ateus felizes" ${ }^{\circ 4}$.

Se as visões supracitadas de VOLTAIRE e de Diderot sobre os índios brasileiros, inscrevendo-se numa estratégia, respectivamente, de combate à igreja católica e de defesa do ateísmo, revestem-se de uma positividade em relação aos nossos aborígenes, é importante salientar, tal posição não foi uma constante nas Luzes. Houve mesmo a construção de um discurso em que se afirma a inferioridade do homem e da natureza da América. Montesquieu, assim, relacionava climas, instituições e costumes, compreendendo a escravidão, a poligamia e o despotismo como característicos de países quentes; ROUSSEAU compreendia que a "região não é indiferente à cultura dos homens; eles só são tudo o que podem ser nos climas temperados [...] Nem os negros nem os lapões têm a inteligência dos europeus" ${ }^{\text {"85 }}$. Buffon, em sua Histoire Naturelle, considerava as populações indígenas as mais fáceis vítimas de epidemias e compreendia que as doenças contagiosas e as baixas taxas de natalidade dos guaranis do Paraguai se deviam ao clima tórrido e insalubre, havendo o mesmo efeito entre os europeus e criollos lá estabelecidos. Raynal adotava a mesma posição, não a estendendo contudo aos criollos e europeus ${ }^{86}$. $\mathrm{O}$ próprio Voltaire considerava que o “'o brasileiro é um animal que não alcançou ainda o complemento de sua espécie, um pássaro que adquire suas penas muito tarde, uma lagarta fechada na sua fava, que só se tornará borboleta dentro de alguns séculos'“687.

A Ilustração, malgrado sua visão desfavorável ao homem americano, promoveu uma crítica contundente do colonialismo mercantilista, não poupando os feitos lusitanos nesta área. VOLTAIRE, no Cândido, insinua que as nações da Europa moviam-se por uma rapacidade incomensurável, por um "furor inconcebível", para cuja satisfação não se titubeava em ceifar a vida dos nativos da

\footnotetext{
${ }^{84}$ MOUREAU, François. L'épisode brésilien dans l'histoire philosophique et politique des deux Indes de l'abbé Raynal: un éclairage des Lumières. In: MATTOSO, Katia de Queiros, SANTOS, Idelette Muzart - Fonseca dos, ROLLAND, Denis (org.). Naissance du Brésil moderne: 1500-1808, op. cit., p. 120. Na edição de 1780 da mesma obra, acrescentava que os mesmos viviam numa anarquia que respondia à sua ignorância de toda força sobrenatural (Ibidem, p. 124).

${ }^{85}$ VENTURA, Roberto. Leituras do Abade Raynal na América Latina. In: COGGIOLA, Osvaldo (org.). A Revolução Francesa e o seu impacto na América Latina. São Paulo: Edusp/ Novastela; Brasília: CNPq, 1990, p. 170-171 e ROUSSEAU, J.-J. Emílio ou da educação, op. cit., p. 30.

${ }^{86}$ VENTURA, Roberto, op. cit., loc. cit., p. 171.

${ }^{87}$ Voltaire. Apud. MOUREAU, François, op. cit., p. 127.
} 
América $^{88}$. Em Essai sur les Moeurs, publicado em 1761, Voltaire, por um lado, reproduz uma série de topos presentes desde o século XVI nos escritos europeus sobre a terra e a gente da América portuguesa - grande longevidade dos homens, primaveras eternas, habitantes que vivem sem religião e leis - e, por outro lado, denuncia a exploração desenvolvida pelos colonizadores portugueses, aos quais se seguiram os espanhóis durante a União Ibérica, os holandeses e, devido a dependência de Portugal em relação à Inglaterra, por via indireta, também os ingleses ${ }^{89}$. Por causa do ouro, o Brasil deixara de se dedicar à agricultura e às manufaturas, verdadeiras fontes de riqueza ${ }^{90}$. Na Encyclopédie, o verbete monopólio, situação em que se encontravam os mercadores metropolitanos nas colônias, é apresentado como "tráfico ilícito"; já os fisiocratas e Adam Smith consideram-no um entrave para o crescimento da riqueza, defendendo a liberdade do comércio. RAYNAL, porém, vai mais longe: em sua Histoire Philosophique, o primeiro clássico francês do anti-colonialismo, toma o monopólio como um direito exercido por uns, do qual outros se vêem privados; fixa a máxima da liberdade comercial, propõe a substituição do colonialismo de violência por outro de razão e chega a incitar os habitantes da Índia, submetidos aos privilégios da companhia inglesa, a se rebelarem. Voltaire, Montesquieu e Marmontel denunciam veementemente as violências contra os indígenas da América; Montesquieu condena, em princípio, a escravidão, a qual é ferozmente combatida por Raynal. Burke ataca os defeitos da administração colonial $^{91}$.

RAYNAL, ademais, narra um feito, então recentemente ocorrido na América do Norte e cuja repercussão foi muito grande na América Ibérica: a Independência das Treze Colônias Inglesas. Ao mesmo tempo, convida os outros povos do continente americano a seguirem seu exemplo:

"Sacerdotes do Novo Mundo, é chegada a hora; expiai o antigo fanatismo que devastou e desolou a América, por um fanatismo mais feliz, nascido da política e da liberdade. Não, não estareis enganando os vossos concidadãos. Deus, que é o princípio da justiça e da ordem, odeia os tiranos. Deus imprimiu no coração dos homens este amor sagrado da

\footnotetext{
${ }^{88}$ VOLTAIRE. Cândido ou o otimismo, op. cit., p. 76.

${ }^{89}$ ROUANET, Sérgio Paulo. Voltaire e a modernidade. Revista Tempo Brasileiro, Rio de Janeiro, 5 (24): 6-7, jul./dez. 1994.

${ }^{90}$ Ibidem, loc. cit.

${ }^{91}$ MOUREAU, François, op. cit., p. 120 e 126; NOVAIS, Fernando Antônio, op. cit., p. 146-148 e 154-157 e LEITE, Paulo Gomes. A maçonaria, o Iluminismo e a Inconfidência Mineira, op. cit., p. 1823.
} 
liberdade; Ele não quer que a servidão avilte e desfigure a sua mais bela obra. Se a apoteose é destinada ao homem, é, sem dúvida, àquele que combate e morre por seu país. Entronizai a sua imagem nos vossos templos, aproximai-a dos altares. Será o culto da pátria", ${ }^{92}$.

Além disso, não foge à sua explicação da Independência Americana, nem ao chamamento dos outros povos da América para a revolução, uma percepção dual, que toma o Novo Mundo, ao mesmo tempo, como rico e pobre, atribuindo-se a pobreza à espoliação colonial, isto é, aos impostos, à proibição de manufaturas, ao monopólio comercial. A "unidade" entre as metrópoles e as colônias é identificada como "aquela dos imbecis animais da fábula, entre os quais" as metrópoles reservaram para si "o papel do leão",93. Conclui, por fim, que:

"O novo hemisfério deve, um dia desligar-se do velho. Esta grande cisão é preparada na Europa pela fermentação e pelo choque de nossas opiniões [...] Na América, é preparada pelo crescimento da população, das culturas, da indústria e das luzes. Tudo leva a essa cisão, os progressos do mal em um mundo, como os progressos do bem no outro" ${ }^{\circ 4}$.

Um dos volumes da Histoire Philosophique é dedicado ao Brasil. Nesse volume, RAYNAL aponta uma série de características positivas da geografia brasileira - um clima salutar, muitos portos, um litoral de fácil acesso e fértil, um grande número de rios navegáveis, terras produtivas - , concluindo que nada lhe faltava para ser "uma das mais belas colônias do globo"95. Além disso, cita as várias riquezas minerais do "pays de l'or et des diamans”, isto é, de Minas Gerais, e também de outras regiões: ferro, estanho, enxofre, chumbo etc., riquezas, no seu entender, jamais exploradas. Fala da fertilidade do solo e aponta as vantagens dessa rica colônia para as rendas públicas em Portugal: o pagamento do transporte dos

\footnotetext{
92 Ibidem, p. 84.

${ }^{93}$ Ibidem, p. 83.

${ }^{94}$ Ibidem, p. 131.

95 LEITE, Paulo Gomes. A propagação do Iluminismo em Minas Gerais, Revista Minas Gerais, Belo Horizonte, 2 (13): 23-7, jan. 1989. Nos termos do próprio abade, o Brasil: "C'est un continent immense, borné au nord par la rivière des Amazones; au sud, par la rivière de la Plata; à l'est par la mer; au couchant, par une multitude de marais, de lacs, de torrents, de rivières et de montagnes qui les séparent des possessions Espagnoles" (RAYNAL, G. T. Histoire philosophique et politique des établissements et du commerce des européens dans les deux Indes, op. cit., tomo 5, p. 4). Páginas adiante, depois de tratar da expulsão dos holandeses e do tratado celebrado entre Portugal e Holanda, diz Raynal que o Brasil era "une cônquete qui pouvait devenir la plus riche des colonies européennes $\mathrm{du}$ Nouveau-Monde, et donner à la republique une consistance qu'elle [=a Holanda] ne pouvait obtenir de son propre territoire" (Ibidem, p. 52).
} 
metais, o comércio exclusivo dos diamantes, a venda de monopólios. Em tudo isso, havia o peso do fisco que, insaciável na Europa, na América ia muito mais longe em matéria de "vexações":

"Dans les pays de l'or et des diamants, on trouve encore des améthystes, des topazes très imparfaites, et des chrysolites d'une assez grande beauté [...].Ces riches contrées offrent aussi des mines de fer, de soufre, d'antimoine, d'étain, de plomb, de vif-argent, qui se retrouvent dans quelques autres provinces du Brésil, sans qu'on se soit jamais occupé d'en ouvrir aucune. La nature paraît n'avoir refusé que le cuivre à cette vaste et fertile région du nouvel hémisphère [...].

Une colonie si intéressante a été utile au Portugal de plusieurs manières: l'augmentation de son revenu public, par le Brésil, paraît le genre d'avantage qui, jusqu'ici, a le plus occupé ses administrateurs; l'obligation de payer la voiture de métaux, réservée aux vaisseaux de guerre, le commerce exclusif des diamants, la vente d'un grand nombre de monopoles, la surchage des douanes: telles sont en Europe même les principales veines que s'est ouvertes un fisc insatiable. Les vexations ont été poussées plus loin encore en Amérique" ${ }^{, 96}$.

O abade compreende a situação portuguesa como de grande degradação, vendo sua origem no Tratado de Methuem (1703), estabelecido entre Portugal e Inglaterra, que teria trazido benefícios apenas a esta última, arruinando as manufaturas portuguesas; graças a ele, a Inglaterra teria conseguido assenhorear-se do comércio interno e inter-colonial lusitanos e consumindo o ouro do Brasil:

"Les avantages de cette stipulation [o Tratado de Methuem], bien réels pour l'une des deux parties contractantes, n'étaient qu'apparents pour l'autre. L'Angleterre, qui obtenait privilège exclusif pour ses manufactures, puisqu' on laissait subsister l'interdiction pour celles des autres nations, n'accordait rien de son côté, ayant déjà établi pour son intérêt particulier, ce qu'elle montrait à son allié sous l'aspect d'une faveur tout-à-fait signalée.

[...] Les manufactures portugaises ne purent soutenir la concurrence anglaise: elles disparurent. La Grande-Bretagne habilla son nouvel allié; et comme ce qu'elle achetait de vin, d'huile, de sel, de fruits, n'était presque rien en comparaison de ce qu'elle vendait, il fallut lui livrer l'or du Brésil. La balance pencha de plus en plus de son côté, et il n'était guère possible que cela fût autrement [...] la Grande-Bretagne parvint à envahir tous les produits du Portugal et de ses colonies.

[...] Cést ainsi que sans avoir prodigué ni sang, ni travaux, sans avoir éprouvé aucun des maux qu'entraînent les

${ }^{96}$ Ibidem, p. 132-133 e 135-136. 
conquêtes, ils se rendirent bien plus maîtres du Portugal, que celui-ici ne l'était des mines du Brésil ${ }^{97}$.

Ao discorrer sobre a mineração no Brasil e o comércio entre Portugal e suas colônias, RAYNAL dá continuidade à visão entusiástica da riqueza mineral brasileira, aliando-a aos outros recursos também existentes no Brasil, no sentido de tornar esse último uma das Colônias mais belas do globo. Pronuncia-se, então, veementemente contra o monopólio (um sistema destruidor que, em pleno século das Luzes, canalizaria para pequena parte do corpo político todos os princípios do movimento e da vida, gerando morte e inércia) e a favor da livre-concorrência (vista como capaz de produzir vantagens inestimáveis):

"C'est sur cette mauvaise base que portaient les rapports des possessions portugaises de l'ancien et du Nouveau-Monde, lorsque la découverte des mines d'or et de diamants fixa sur le Brésil, dès le commencement du siècle [XVIII], les yeux de toutes les nations. On pensa géneralement que ces richesses, ajoutées à celles d'un autre genre que donnait la colonie, en feraient un des plus beaux établissements du globe. L'Europe n'était pas encore entièrement détrompée, lorsqu'elle apprit avec surprise que la plus importante partie de cette région venait d'être mise sous le joug du monopole. Le Portugal avait fait, sans le secours d'aucune compagnie, des découvertes immenses en Afrique et dans les deux Indes. Ce fut l'ouvrage de quelques associations que formaient passagèrement entre eux les rois, les nobles, les négociants, et qui expédiaient des flottes plus ou moins considérables pour ces trois parties du monde. On ne serait pas attendu qu'un peuple qui, dans des temps de barbarie, avait saisi les avantages inestimables de la concurrence, finirait par adopter, dans un siècle de lumière, un système destructeur, qui, rassemblant dans une petite partie du corps politique tous les principes du mouvement et de la vie, ne laisse dans tout le reste que l'inertie et la mort" $"$.

Portanto, dualidade entre riqueza e pobreza; opressão fiscal e comercial, elementos válidos para o Novo Mundo em geral, são vistos pelo abade RAYNAL também em referência específica à América Portuguesa. Mas a crítica do abade não pára aí: atinge as próprias alterações tributárias feitas pela coroa portuguesa e o descuido desta com as atividades econômicas não-mineratórias após a descoberta das minas. Expressando uma visão fisiocrática, RAYNAL toma a agricultura como a verdadeira fonte da riqueza, concebe o ouro como ilusão e acentua o papel do

\footnotetext{
${ }^{97}$ Ibidem, p. 140-142.
} 
monopólio no sentido de dissipar essa mesma ilusão; entende ainda que as guerras entre Portugal e Espanha trouxeram danos para a economia colonial, aumentando a vexação fiscal e desviando homens do trabalho para a guerra, classificando esta situação como "bárbaro despotismo":

La découverte des mines fit négliger des objets qui parurent dès-lors moins intéressants qu'ils ne l'etaient.

L'or et les diamants, ces trésors, de convention, nuisirent eux-mêmes aux cultures qu'ils auraient pu encourager. L'espoir de faire une fortune brillante, en ramassant ces richesses fugitives et précaires, détermina un grand nombre de propriétaires à abandonner leurs plantations.

Cette illusion funeste commençait à se dissiper, lorsque les monopoles arrêtèrent le penchant qu'on montrait généralement pour rentrer dans une carrière plus sûre, et même plus lucrative que celle qui avait d'abord enflammé tant d'imaginations.

Enfin les derniers démêlés avec l'Espagne furent une nouvelle source de désolation pour la colonie. On arracha violemment les citoyens à leurs travaux; on en exigea, sans intérêt, des prêts dont ils ne sont pas encore remboursés; on ne leur épargna aucun des outrages du plus barbare despotisme",99.

Considerando que os obstáculos relacionados à ilusão do ouro e à guerra entre Espanha e Portugal haviam sido em sua maior parte superados, RAYNAL insiste novamente nas potencialidades dadas pelas riquezas naturais da Colônia, inutilmente oferecidas durante três séculos de colonização. O único senão da natureza colonial seriam as formigas; no mais, tudo seria positivo para que o Brasil se tornasse uma das "plus beaux établissements du globe":

Maintenant que ces obstacles à tout bien sont la plupart levés, il ne faut plus repousser les richesses qu'offre inutilement le Brésil depuis trois siècles. Le climat est sain dans cette partie du Nouveau-Monde; les ports y sont multipliés; ses côtes, d'un accès facile, sont généralement fertiles; l'intérieur du pays, encore plus productif et coupé par un grand nombre de fleuves navigables, peut être cultivé pour les besoins ou les délices de l'Europe; les productions particulières à l'Amérique y prospèrent toutes, malgré les dégâts des fourmis, sans qu'il faille craindre de les voir détruites par ces terribles ouragans, par ces sécheresses dévorantes qui désolent si souvent LES MEILLEURES ILES DE CET HEMISPHERE; on y est encouragé au travail par l'abondance et le bon marché des subsistances, des bestiaux, des esclaves: Rien n'y manque

\footnotetext{
${ }^{98}$ Ibidem, p. 74-75.

${ }^{99}$ Ibidem, p. 157-158.
} 
pour en faire un des plus beaux etablissements du globe" ${ }^{, 100}$.

O otimismo de RAYNAL quanto às potencialidades de desenvolvimento da rica colônia portuguesa na América, contudo, implica uma pré-condição: seria preciso livrá-la dos impostos e dos arrematantes destes que a humilhavam e oprimiam; seria necessário suprimir também os monopólios que aprisionavam as atividades econômicas e as taxas que encareciam as mercadorias importadas; seria imprescindível, ademais, permitir-lhe uma livre comunicação com outras possessões, abrindo-lhe, inclusive, o livre-acesso às Índias Orientais; não faltariam braços na colônia para desenvolver seus trabalhos, podendo-se, no entanto, permitir a entrada de estrangeiros da América e da Europa:

"Il le deviendra, lorsqu'on l'aura déchargé de cette multitude d'impôts, de cette foule de traitants qui l'humilient et qui l'oppriment; lorsque d'innombrables monopoles n'enchaîneront plus son activité; lorsque le prix des marchandises qu'on lu porte ne sera pas doublé par les taxes dont on les accable, lorsque ses productions ne paieront plus de droits ou n'en paieront pas de plus considérables que celles de ses concurrents; lorsque sa communication avec les autres possessions nationales aura été débarrassee des entraves qui la gênent; lorsqu'on lui aura ouvert les Indes orientales, et permis de tirer de son propre sein l'argent qu' exigerait cette liaison nouvelle.

La colonie a des bras suffisants pour multiplier, pour étendre ses travaux. Au temps où nous écrivons, elle compte cent soixante-seixe mille vingt-huit blancs, trois cent quarantesept mille huit cent cinquante-huit esclaves, deux cent soixante-dix-huit mille trois cent quarante-neuf Indiens, ce qui lui forme une population de huit cent deux mille deux cent trente-cinq personnes [...]

Un moyen plus sûr d'augmenter la masse des productions serait de recevoir, au Brésil, tous les étrangers qui voudraient en entreprendre la culture. Une infinité d'Américains, Anglais, Français, Hollandais, dont les plantations sont épuisées; beaucoup d'Européens qui ont la manie, devenue si commune, de faire promptement fortune, y porteraient leur activité, leur industrie et leurs capitaux" ${ }^{\prime 101}$.

${ }^{100}$ Ibidem, p. 158-159.

${ }^{101}$ Ibidem, p. 159-160. 
Neste ponto, o abade incluía a aludida supressão da inquisição e a diminuição da influência desmesurada dos clérigos ${ }^{102}$. Essas idéias do famoso "livrinho" do abade RAYNAL, convidando a uma recolonização do Brasil segundo os princípios da economia de mercado e de livre-troca de mercadorias e homens, como se verá no Capítulo 3, foram apropriadas, com alterações e supressões, por D. Rodrigo de Souza Coutinho. O mesmo se deu na América, onde elas afetaram profundamente os Inconfidentes de Minas Gerais, como será mostrado no Capítulo 8 (os conjurados de Minas Gerais não mencionaram apenas a recolonização, a abertura da colônia ao povoamento por estrangeiros, a supressão da inquisição e a diminuição da influência dos clérigos). Dentre eles, destacou-se Joaquim José da Silva Xavier, o Tiradentes.

Avaliando a Ilustração sob o ângulo de seus possíveis efeitos no mundo lusobrasileiro, primeiramente, deve-se pensar na questão da autoridade: na medida em que as Luzes punham em xeque toda "autoridade exterior, não justificada pela razão", "na política, na estética, no direito ou na moral"103, percebe-se que elas constituíam uma ameaça às verdades estabelecidas e aos poderes constituídos. $\mathrm{O}$ mesmo efeito tinha a inversão metodológica presente, ainda que parcialmente, no pensamento ilustrado: a abolição das certezas fundamentais como pontos de partida e a proposição da experiência e da observação como marco inicial, chegando-se, ao final, à descoberta de regularidades, jogavam cal sobre a idéia de um domínio régio ou colonial inquestionável e imutável, estimulando os súditos e os colonos a olharem criticamente sua realidade. A Ilustração, além disso, ao promover, de uma forma geral, uma rediscussão do passado e de elementos do Antigo Regime, como um todo ou isoladamente, estimulava transformações. No caso específico do mundo lusobrasileiro, os Ilustrados, dentre os quais se destaca o abade Raynal, ao mesmo tempo em que confrontavam as imensas riquezas do Brasil à degradação em que se encontrava Portugal, arrolavam uma série de medidas, que iam da supressão da inquisição às modificações nas relações entre Portugal e suas possessões na América, rompendo-se com o exclusivismo metropolitano, diminuindo a opressão fiscal, dinamizando o comércio inter-colonial com as Índias Orientais. As vertentes mais radicais das Luzes, ademais, fustigavam a religião católica, denunciando as instituições que esmagavam as massas populares, a intolerância religiosa — dentro

\footnotetext{
102 Ibidem, p. 160.

${ }^{103}$ FALCON, Francisco Calazans. A Época pombalina (política econômica e monarquia Ilustrada).
} 
do que se situava a crítica contumaz à Inquisição -, o fanatismo, a escritura sagrada, as exorbitâncias do poder real, os privilégios do rei e da nobreza e a infalibilidade papal, o monopólio comercial, o escravismo, o peso fiscal; houve mesmo, dentre os pensadores ilustrados, quem apoiasse o deísmo, o ateísmo, o materialismo. Por fim, ameaçando o absolutismo monárquico e o sistema colonial, alguns Ilustrados defendiam a insurgência dos vassalos contra seus soberanos e dos colonos contra as metrópoles ${ }^{104}$. O Reformismo Ilustrado português, como se verá a seguir, apropriouse seletivamente das idéias trazidas pelas Luzes, refutando aquelas que possuíam um caráter mais radical.

São Paulo: Ática, 1982, p. 100.

${ }^{104}$ BASTOS, José Timóteo da Silva. História da censura intelectual em Portugal: ensaio sobre a compreensão do pensamento português. 2 ed. Lisboa: Moraes Editores, 1983, p. 61 e Instituto dos Arquivos Nacionais da Torre do Tombo (IANTT), Real Mesa Censória, Caixa 1 e Livro 9. 


\section{Capítulo 3: \\ O Reformismo Ilustrado Português}

No século XVIII, a Península Ibérica estava na condição de uma mera consumidora intelectual ${ }^{1}$; em Portugal mais precisamente, além disso, até o consulado pombalino manteve-se uma resistência relativa à Revolução Científica. A medicina luso-brasileira, por exemplo, no início do Setecentos, encontrava-se distante das discussões que agitavam alguns dos países da Europa, mas ao mesmo tempo aproximava-se das suas congêneres européias ao apegar-se ao "maravilhoso". Assim, como as últimas, convivia, em pleno Século das Luzes, com o curandeirismo, com a magia e com a interferência da religião, mostrando-se prisioneira de uma visão de mundo regido por forças ocultas, sobrenaturais ${ }^{2}$. Desde o final do século XVII, contudo, a medicina lusitana assistiu à introdução de algumas mudanças, como a incorporação da iatroquímica, não no curso de medicina em Coimbra, mas apenas entre alguns médicos em particular ${ }^{3}$. Na medicina, portanto, conjugavam-se sobrevivência do "maravilhoso" (o que não era peculiaridade de Portugal) e incorporação de inovações fora do âmbito da instituição universitária — daí ser relativo o "isolamento português".

\footnotetext{
${ }^{1}$ MORSE, Richard M., op. cit., p. 72.

2 FILGUEIRAS, Carlos Alberto Lombardi. Saberes acadêmicos e populares na prática médica do século XVIII em Portugal e em Minas Gerais. In: CONGRESSO LATINO-AMERICANO DE HISTÓRIA DA CIÊNCIA E DA TECNOLOGIA, 5, 1998, Rio de Janeiro, p. 4 e RIBEIRO, Márcia Moisés. A ciência dos trópicos: a arte médica no Brasil do século XVIII. São Paulo: Hucitec, 1997, p. 43-44 e 134-136. Segundo a última autora, na Colônia, a assistência médica deficiente - faltavam médicos formados e os práticos freqüentemente demonstravam poucos conhecimentos -, colaborava para a grande interferência do maravilhoso na medicina; tanto aqui como em Portugal, ademais, a Ilustração não logrou modificar o panorama de modo substancial (RIBEIRO, Márcia Moisés, op. cit., p. 132-133).

3 No cotidiano da América Portuguesa, como mostra Márcia Moisés Ribeiro, nas elites e entre os populares, era muito forte a concepção de doença (e, por conseguinte, da cura) "como elemento sujeito à ação das forças sobrenaturais", tal como em grande parte da Europa do Antigo Regime, o que fez com que as gentes conferissem importância aos indivíduos que dominassem as artes da cura, com ou sem a intercessão de rituais mágicos (Ibidem, loc. cit.).
} 


\section{Luzes, Catolicismo, Tradições e Luís Antônio Verney}

A partir do consulado pombalino, Portugal passou a consumir idéias da Ilustração, que se difundiram no país, ainda que num círculo social restrito, filtradas por elementos específicos da mentalidade luso-brasileira ${ }^{4}$. À semelhança do sucedido na Itália e Espanha, países em que o catolicismo era muito forte, em território luso a Ilustração assumiu uma feição predominantemente católica ${ }^{5}$, prevalecendo, assim, a tentativa de harmonizar num todo coerente "elementos na aparência inconciliáveis: a fé e a ciência, a tradição filosófica e a inovação racional e experimental, o teocentrismo e o antropocentrismo"6. Isso, no entanto, não impediu que a Ilustração portuguesa comportasse, ao menos entre alguns poucos pensadores e mesmo populares, um conteúdo contrário à igreja ou à fé cristã. O que se quer sublinhar, enfim, é que a Ilustração Ibérica, sendo objeto de uma "releitura" feita em sintonia com as condições ali reinantes, assumiu contornos singulares, articulando-se com elementos culturais anteriores: alguns princípios Ilustrados não foram de todo inéditos em Portugal e, com certeza, também na Espanha. Isto é notório no que diz respeito às idéias sobre a religião, as quais, como sublinha Anita NOVINSKY, foram apenas "reforçadas com a leitura das obras proibidas dos pensadores franceses", mas não teriam origem neles: a sua fonte seria uma "mentalidade subterrânea", um "fenômeno de descristianização interior", constituída ao longo de séculos, remontando até mesmo aos tempos medievais, em resposta à repressão inquisitorial ${ }^{7}$.

${ }^{4}$ NEVES, Guilherme Pereira das. Do império luso-brasileiro ao império do Brasil (1789-1822), op. cit., p. 83.

${ }^{5}$ GOMES, Joaquim Ferreira, op. cit., p. 66-67.

${ }^{6}$ FALCON, Francisco José Calazans. A época pombalina (política econômica e monarquia ilustrada). São Paulo: Ática, 1982, p. 430-1.

${ }^{7}$ Anita Novinsky, embora faça esta ponderação, apresenta uma interpretação marcada por uma contradição metodológica. A autora diz que a Ilustração "refletiu-se palidamente em Portugal e no Brasil", não apresentando o mesmo radicalismo que caracterizou o pensamento ilustrado europeu. A veia mais rica da Ilustração portuguesa teria sido a crítica religiosa, feita pelos prisioneiros da Inquisição ou pelos libertinos que foram denunciados ao Santo Ofício. Os estrangeirados, ao contrário, seriam representantes de "uma ilustração acovardada e de compromissos", que não apresentava uma "proposta drástica e corajosa de mudanças estruturais do sistema“: eram porta-vozes de idéias conservadoras, se comparados aos filósofos e pensadores do Além-Pirineus. Ao adjetivar negativamente a Ilustração portuguesa, Anita desconsidera as especificidades das condições sociais, econômicas e políticas internas da Península Ibérica, a força das resistências internas às mudanças. Paradoxalmente, ao relacionar as idéias heterodoxas presentes em Coimbra no último quartel do século XVIII à "mentalidade subterrânea", forjada em séculos de repressão, claramente identifica elementos internos específicos da realidade portuguesa (NOVINSKY, Anita Waingort, Estudantes brasileiros 'afrancesados' da Universidade de Coimbra. a perseguição de Antônio de Morais Silva - 
Da mesma forma, pode-se dizer que o anti-despotismo e a consagração do direito dos povos de resistirem à tirania, pontos tão caros à Ilustração, encontraram em Portugal e na Espanha um substrato juspolítico e literário anterior - isto é, teorias corporativas e alguns movimentos políticos que apearam soberanos de poder.

A primeira manifestação ilustrada em Portugal veio dos estrangeirados, pessoas que, por um motivo ou por outro, circularam no Além-Pirineus, trazendo, ao retornarem, também idéias ou divulgando-as ainda do exterior ${ }^{8}$. Os estrangeirados contaram com aliados internos. Ao lado do inconformismo de estrangeirados como Dom Luís da Cunha, José da Cunha Brochado, os condes de Tarouca, Galveias, Ribeira Grande, o visconde de Vila Nova da Cerveira e Luís Antônio Verney, postaram-se homens como Teodoro de Almeida, o ministro Dom Rodrigo de Souza Coutinho e vários luso-brasileiros, dentre os quais destacam-se o dicionarista Antônio de Morais Silva, o médico Francisco de Mello Franco, o químico José Bonifácio de Andrada e Silva (que depois seria um grande estadista do Império do Brasil), o médico-químico Manuel Henriques de Paiva e o químico Vicente Seabra Telles ${ }^{9}$. Dos dois lados do Atlântico, assistiu-se a um movimento em prol da recuperação do império português, reforçando-se os laços de união entre a América e o Reino, com vistas "a um desenvolvimento integrado de um novo império, unificador da grande nação portuguesa", criticando-se a total subordinação dos interesses da colônia à metrópole ${ }^{10}$.

Os Ilustrados luso-brasileiros, em grande parte, irmanaram-se na crítica às instituições do Antigo Regime português, isoladas ou em seu conjunto, tais como o absolutismo arbitrário, os privilégios de casta, o fanatismo da inquisição, a preeminência dos jesuítas no ensino e o "atraso cultural" português ${ }^{11}$. Uns e outros procuraram situar Portugal "como o que de mais obsoleto havia no universo, como se toda a Europa já tivesse sido dominada pelos raios do Iluminismo, o que, na

1779-1806. In: COGGIOLA, Osvaldo [org.]. A revolução francesa e seu impacto na América Latina, op. cit., p. 357-358 e 365-7). As forças internas das instituições e dos agentes da conservação são, portanto, utilizadas apenas para explicar as reações heterodoxas dos libertinos, mas esquecidas na abordagem dos limites dos estrangeirados. Nesta tese, pelo contrário, procurar-se-á apreender a conservação e a renovação sempre tendo em vista a interferência das forças internas e das especificidades do mundo luso-brasileiro.

${ }^{8}$ NOVAIS, Fernando Antônio, op. cit., p. 219-220.

${ }^{9}$ Ibidem, p. 220-222.

${ }^{10}$ LYRA, Maria de Lourdes Viana, op. cit., p. 44.

${ }^{11}$ NOVAIS, Fernando Antônio, op. cit., loc. cit.. 
realidade, ainda não tinha ocorrido"12. Alguns enfrentaram fortíssimas resistências, que vieram a calar, amenizar ou amordaçar seu inconformismo; outros obtiveram sucesso no exterior, como José Bonifácio de Andrada e Silva e o médico Ribeiro Sanches. Esse último, nascido em 1699, foi um colaborador da Enciclopédia de Diderot e d'Alembert ${ }^{13}$, editada no raiar do reformismo português. Bonifácio, declarado seguidor de Voltaire - publicou versos que atacam o fanatismo e colocou como epígrafe do seu jornal "O Tamoyo" versos de Alzire: "Tu vois de ces tyrans la fureur despotique,/ ils pensent que pour eux le ciel fit l'Amerique"14 —, nos idos de 1800, descobriu quatro novos minerais, sendo que dois deles, o espodumênio e a petalita, vieram a ter grande importância histórica, e seu descobridor tornou-se o único brasileiro que de certa forma ligou-se à história da classificação periódica dos elementos químicos ${ }^{15}$.

Luís Antônio Verney, clérigo português radicado na Itália, autor de Verdadeiro Método de Estudar (1746), dentre outros livros, é um exemplo de estrangeirado que se empenhou para a superação da "letargia" presente na vida portuguesa sem contudo afrontar a religião católica e o papado; procurando despertar os portugueses "para tomar lugar na vida intelectual da Europa" e integrar "a novidade na tradição"16. VERNEY, uma das referências das reformas ilustradas adotadas pela Coroa a partir da ascensão ao trono de D. José I, atacou vários pilares da sociedade e da cultura portuguesa. Assim, condenou a identificação entre nobreza hereditária e virtude, considerando que nem vícios nem virtudes se transmitem pelo sangue $^{17}$. VERNEY, ademais, opôs-se com veemência aos métodos de ensino jesuíticos: como os demais reformistas, julgava-os obscurantistas, autoritários, livrescos, pedantes, pouco práticos; reprovava os castigos corporais e alguns livros de que se valiam os inacianos (pode-se citar, dentre eles, o Tratado de la Agudeça de

\footnotetext{
${ }^{12}$ RIBEIRO, Márcia Moisés, op. cit., p. 118. Este exagero dos Ilustrados portugueses, endossado sem críticas pela historiografia, talvez possuísse um sentido estratégico - ser um estímulo no combate contra os que resistiam às mudanças -, revelando, por isto mesmo, um empenho em acelerar a transformação do panorama cultural português.

${ }^{13}$ Ibidem, p. 116-117.

${ }^{14}$ ROUANET, Sérgio Paulo. Voltaire e a modernidade. Revista Tempo Brasileiro, Rio de Janeiro, 5 (24): 8-9, jul./dez. 1994.

${ }^{15}$ FILGUEIRAS, Carlos Alberto Lombardi. A química de José Bonifácio. Química Nova, São Paulo, 9 (4): 264, 1986.

${ }^{16}$ HAZARD, Paul. O pensamento europeu no século XVIII, op. cit., p. 90.

${ }^{17}$ VERNEY, Luís Antônio. Verdadeiro método de estudar. 3 ed. Porto: Domingos Barreira, [s.d.], p. 193-194 e 202.
} 
Baltazar Grácian e o Cursus Philosophicus de Soares Lusitano ${ }^{18}$. Era extremamente crítico em relação à medicina e ao seu ensino em Portugal, fazendo coro com aquele que mais se preocupou com esta questão, Ribeiro Sanches: atacava os escolásticos e os galênicos, ao mesmo tempo em que dizia que os médicos portugueses desconheciam a circulação do sangue e sua relação com o movimento do coração, ignorando até mesmo onde estavam as veias ${ }^{19}$.

Entretanto, embora fosse crítico da nobreza e do ensino jesuítico, VERNEY recomendava o uso das cartas do padre Antônio Vieira no ensino da gramática portuguesa; defendia apenas que os nobres tratassem os plebeus sem afetação e reconhecessem que ser nobre, possuir um título de nobreza, traz consigo a obrigação de possuir a virtude "e de exceder os plebeus" nessa matéria, não postulando em nenhum momento a abolição das distinções entre uns e outros ${ }^{20}$. Verney propôs a adoção de um novo método de estudar, dentro do qual se fizesse uso moderado do silogismo; não se apelasse a uma autoridade única, quer fosse esta Aristóteles ou outro pensador; se empregassem a observação e a experimentação, orientadas pela indução, para chegar ao conhecimento; houvesse estudo prioritário da língua portuguesa, sem contudo descuidar do latim; inexistisse vinculação do ensino da retórica ao latim, bem como emprego excessivo desta língua nos livros de ciências; se desenvolvesse o estudo do francês e do italiano, línguas para as quais as obras científicas em sua maioria encontravam-se traduzidas; se estabelecesse uma diferença entre o ensino destinado aos nobres (afinal, este deveria ser o diferencial deles) e àquele oferecido aos plebeus; e se contemplasse a educação de homens e mulheres, havendo no ensino oferecido a essas apenas alguns acréscimos (economia doméstica, prendas de salão e trabalho manual) ${ }^{21}$. VERNEY julgava que as mulheres tinham as mesmas capacidades intelectuais que os homens, colocando-se, portanto, do ponto de vista das relações de gênero, à frente de muitos de seus colegas; se era conservador do ponto de vista das relações entre nobreza e plebeus, era um revolucionário no que se referia à relação entre homens e mulheres ${ }^{22}$. Consoante com

\footnotetext{
${ }^{18}$ Ibidem, p. 66, 74-76, 140-141 e 174.

${ }^{19}$ RIBEIRO, Márcia Moisés, op. cit., p. 116-117.

${ }^{20}$ VERNEY, Luís Antônio, op. cit., p. 66 e 203-204.

${ }^{21}$ CARVALHO, Rômulo de, op. cit., p. 414-417 e 429-454; VERNEY, Luís Antônio, op. cit.; FERREIRA, Joaquim. Prefácio. In: VERNEY, Luís Antônio, op. cit., p. 29-53; e RODRIGUES, José Carlos. Idéias filosóficas e políticas em Minas Gerais no século XIX. Belo Horizonte: Itatiaia; São Paulo: Edusp, 1986, p. 35-45.

${ }^{22}$ VERNEY, Luís Antônio, op. cit., p. 215-228. É importante salientar que não se propunha um ensino
} 
a valorização da experimentação e da observação, o "barbadinho" considerava fundamental a leitura de Newton, Gassendi, Descartes, Galileu e dos divulgadores do primeiro ou do segundo (P. Malebranche, Bayle e Maignan, dentre eles) ${ }^{23}$.

\section{Reinado Josefino e Reformismo Ilustrado}

Com a morte de D. João V e a subida ao trono de D. José I e a ascensão de Sebastião de Carvalho e Mello ao ministério, o governo português passou a desenvolver uma série de reformas bafejadas pelas Luzes. O consulado pombalino sacudiu a sociedade lusa em todos os níveis, realizando um esforço para superar os problemas com os quais se defrontava Portugal ${ }^{24}$. Pombal empenhou-se em fortalecer o poder do Estado, em firmar a supremacia da Coroa face à nobreza e à igreja incluindo-se, aqui, os jesuítas - e em reformar a economia, com vistas a tirar Portugal da inferioridade em relação às potências européias ${ }^{25}$. Sua política, como mostra Francisco Calazans FALCON, centrava-se no ataque, feito com uma violência incomum, ao setor anti-absolutista da aristocracia nobiliária, ao setor antimonopolista da burguesa mercantil e ao setor hegemônico da aristocracia eclesiástica, todos eles os mais infensos às novas diretrizes ${ }^{26}$.

Nesse sentido, como afirma Fernando NOVAIS, promoveu reformas na política imperial, manufatureira e mercantil, favorecendo, através da interferência estatal, os setores sociais que pudessem impulsionar o comércio ultramarino e o desenvolvimento das manufaturas, fomentando não apenas a acumulação, mas também a retenção de capital em Portugal ${ }^{27}$. Pombal criou empresas manufatureiras, administradas diretamente pelo Estado, e apoiou os mercadores portugueses, contra os intermediários, os contrabandistas e os mercadores ingleses, constituindo a Companhia do Grão Pará e Maranhão e a Companhia do Comércio de Pernambuco e

totalmente igual a ambos os sexos, havendo mesmo uma idéia de que as mulheres não precisavam ter a mesma gama de conhecimentos que os homens. No ensino de história, assim, as mulheres não deviam "ler tudo o que se vai escrevendo na Academia Real sobre esta matéria: basta que se sirvam de um compêndio, ou leiam o de Faria, etc." (Ibidem, p. 222).

${ }^{23}$ Ibidem, p. 155-156.

24 BOTO, Carlota. Iluminismo e educação em Portugal: o legado do século XVIII. Revista da Faculdade de Educação/ Universidade de São Paulo, São Paulo 1, 1: 186-9, jan./ jun, 1996.

${ }^{25}$ NOVAIS, Fernando Antônio, op. cit., p. 203.

${ }^{26}$ FALCON, Francisco José Calazans, op. cit., p. 374-375.

${ }^{27}$ Esta assimilação dos efeitos do comércio ultramarino, cumpre salientar, era um problema dos mais complexos e de difícil resolução (NOVAIS, Fernando Antônio, op. cit., p. 199 e 223). 
Paraíba, que detinham o monopólio comercial, respectivamente, na região amazônica e no Nordeste brasileiro ${ }^{28}$. Favoreceu os grandes vinicultores na região do Douro, contra os pequenos, formando a Companhia Geral da Agricultura das Vinhas do Alto Douro $^{29}$. Procurou remodelar a nobreza. Primeiro, apoiando os grandes comerciantes e a nova nobreza - constituída por indivíduos ligados aos negócios, à burocracia, às letras - contra a velha nobreza - ligada à propriedade da terra e à agricultura, defensora da pureza de sangue e da linhagem, adepta dos velhos métodos de governo $^{30}$. Para tanto, permitiu à aristocracia o envolvimento em atividades comerciais sem que isto resultasse em envilecimento; deu igualdade aos comerciantes, que passaram a ser qualificados para cargos públicos; e enobreceu os que se envolvessem nas companhias privilegiadas de comércio $^{31}$. Suprimiu legalmente, em 1768, o puritanismo: algumas casas aristocráticas, desde 1663, estavam comprometidas em preservar a "pureza" de seu sangue, que acreditavam livre de qualquer "mancha" judaica, moura ou negra, contraindo matrimônios apenas entre $\mathrm{si}^{32}$. Em 1773, ademais, aboliu a distinção entre cristãos-velhos e cristãosnovos, pondo fim a uma secular discriminação. No rol das medidas tomadas por Sebastião de Carvalho e Melo incluem-se, ainda, a incorporação, à administração pública, de homens de negócios e latifundiários, de grupos locais, nos dois lados do Atlântico, e a subordinação, a partir de 1769, da inquisição ao poder régio, nomeando seu próprio irmão como inquisidor geral e ordenando que todos os bens confiscados pelo Santo Ofício passassem para o erário régio, criado oito anos antes, em $1761^{33}$.

O reformismo ilustrado abraçado por Pombal - e continuado nos reinados de Dona Maria I e na regência de seu filho, Dom João - logrou ser vanguarda no âmbito pedagógico. Assim, se a Ilustração Portuguesa foi importada, eclética, em função das

\footnotetext{
${ }^{28}$ MAXWELL, Kenneth, op. cit., p. 55, 59-60 e 88-89 e Idem, A devassa da devassa: a Inconfidência Mineira, Brasil - Portugal, 1750-1808. 3 ed. Rio de Janeiro: Paz e Terra, 1985, p. 96.

${ }^{29}$ Idem, Pombal: Paradox of the Enlightenment, op. cit., p. 62-63.

${ }^{30}$ Ibidem, p. 76-78 e 84.

${ }^{31}$ Ibidem, loc. cit..

32 Obrigou-se, até mesmo, a realização de matrimônios entre membros de famílias "puritanas" e não "puritanas" (FALCON, Francisco José Calazans, op. cit., p. 401).

${ }^{33}$ A política executada por Pombal no sentido de reformar a nobreza e de reforçar a subordinação desta ao poder régio foi levada ao paroxismo com a execução dos nobres supostamente implicados no atentado contra Dom José I, selando de forma irreconciliável a ruptura do governo com a nobreza tradicional (Ibidem, p. 377). Em Belém, em 1758, os marqueses de Távora, o duque de Aveiro e o conde de Atouguia, oriundos das casas nobres mais importantes do Reino (a primeira delas perdia em poder apenas para a família real), foram supliciados barbaramente em espetáculo público, fato que chocou as sensibilidades de intelectuais e de governantes europeus de então, acostumados apenas com a aplicação de punições deste gênero às pessoas de menor qualidade (MAXWELL, Kenneth. Pombal:
} 
próprias especificidades locais, empenhou-se em acompanhar o ritmo do que ocorria no exterior e, sobretudo, chegou mesmo "a referenciar posteriores projetos de educação pública" ${ }^{34}$. Pombal instituiu um sistema público de ensino antes mesmo da França, fundou o Colégio dos Nobres e reformou a Universidade de Coimbra, entre 1770 e 1772, imprimindo-lhe uma orientação que privilegiava as ciências naturais e a experimentação, procurando com isso criar uma nova elite cultural, mais aberta a um pensamento racional e empírico, e disseminar uma nova mentalidade na sociedade portuguesa, europeizando- $\mathrm{a}^{35}$.

A reforma da Universidade, pautando-se por destacar o ensino das ciências, envolveu a criação das faculdades de Medicina, Matemática e Filosofia (esta última, em substituição ao Colégio das Artes, incluía a Física Experimental, a Química e a História Natural). Os novos estatutos, de 1772, consagravam a observação e a experimentação no ensino das ciências. Para dar consecução a tal objetivo, foram construídas várias instalações e adquiridos materiais e instrumentos didáticos: "para a Medicina, o Hospital Escolar, o Teatro Anatômico e o Dispensário Farmacêutico; para a Matemática, o Observatório Astronômico; para a Filosofia, o Gabinete de História Natural, o Jardim Botânico, o Gabinete de Física Experimental (para onde foi transportado o riquíssimo conjunto de material didático que pertencera ao Colégio

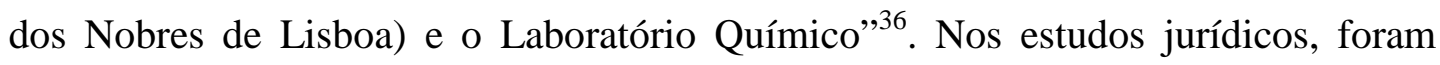
adotados os livros de Grotius, Pufendorf, Heinécio e Cujácio ${ }^{37}$. Ao mesmo tempo, foram demitidos professores e contratados novos, alguns deles estrangeiros e outros, trazidos do Colégio dos Nobres de Lisboa. Com as reformas pombalinas, as ciências e, de resto, a mentalidade científica, outrora sufocadas, ganharam alento.

Os jesuítas constituíam um sério obstáculo a essa série de desígnios pombalinos. Economicamente, o largo domínio temporal e material dos jesuítas no Reino e na América (especialmente nas missões guarani e amazônicas), isento do

\footnotetext{
Paradox of the Enlightenment, op. cit., p. 78-80, 83-84 e 87).

${ }^{34}$ BOTO, Carlota. Iluminismo e Educação em Portugal: o legado do século XVIII, op. cit., 186-189.

${ }^{35}$ CARVALHO, Rômulo de, op. cit., p. 429-354, 446-452 e 462-483; FERNANDES, Rogério. Os caminhos do $A B C$ : sociedade portuguesa e ensino de primeiras letras. Porto: Porto Editora, 1994, p. 69-114; DOMINGUES, Francisco Contente, op. cit., p. 118-120; NEVES, Guilherme Pereira das. Do império luso-brasileiro ao império do Brasil (1789-1822), op. cit., p: 77; e BOTO, Carlota, op. cit, 186-188. No propósito pombalino de criar uma nova elite, essa última autora identifica uma influência da perspectiva educacional de Voltaire e do ilustrado português Ribeiro Sanches, ambos temerosos em relação aos efeitos de uma educação universalizada (Ibidem, p. 180 e 185-186).

${ }^{36}$ CARVALHO, Rômulo de, op. cit., p. 466-480.

${ }^{37}$ FALCON, Francisco José Calazans, op. cit., p. 438.
} 
fisco, despertava cobiça e má vontade. A vinculação dos inacianos com comerciantes britânicos, em relação aos quais as missões do Paraguai constituíam fonte de enormes lucros, conduzia à idêntica rejeição. Do ponto de vista cultural, os jesuítas, ao mesmo tempo em que tinham forte presença na educação, tornavam-se vulneráveis às críticas feitas pelo Iluminismo e aos ciúmes que causavam em outros eclesiásticos, muitos deles seus declarados inimigos. No plano político, os inacianos punham entraves à ação da administração colonial e vieram a se desgastar profundamente diante da Coroa por causa de alguns episódios: primeiro, a guerra guaranítica; depois, a participação de membros da ordem em supostas ou verdadeiras conspirações contra as medidas de Pombal $^{38}$. Os jesuítas eram, além disso, os baluartes das teorias políticas corporativas, as quais colidiam com o absolutismo de D. José I. Pombal, em conformidade com a orientação regalista, reformista e absolutista que seguia, empenhou-se em fazer vingar, na teoria e na prática políticas, ora um absolutismo de cunho providencialista, que consagrava o princípio segundo o qual o poder real tinha uma origem divina direta, não se justificando uma tutela sobre o monarca quer de Roma, quer da sociedade ${ }^{39}$; ora um absolutismo de cunho contratualista, rompendo abruptamente, num e noutro caso, com a trajetória portuguesa política anterior e colocando Portugal em sintonia com a França e o centro da Europa, onde predominava largamente o providencialismo desde a segunda metade do século $\mathrm{XVII}^{40}$. As concepções corporativas de poder, seja em termos teóricos, seja em termos juspolíticos, representavam uma negação dessa orientação política seguida pelo ministro Sebastião José de Carvalho e Mello.

A reflexão teórica-política corporativa, embora não se chocasse frontalmente com a centralização do poder do Estado, não dava uma sustentação sólida ao

\footnotetext{
${ }^{38}$ MAXWELL, Kenneth. Pombal: paradox of the Enlightenment, op. cit., p. 55, 71-74 e 82-83.

${ }^{39}$ TORGAL, Luís Reis, op. cit., vol. 1, p. 6-7. Zília Osório de Castro sublinha a coerência existente entre a teoria política enunciada por Pombal e suas práticas (CASTRO, Zília Osório de. Poder Régio e os Direitos da Sociedade. O 'Absolutismo de compromisso' do reinado de D. Maria I. Ler História, Lisboa, 23: 11, 1992).

${ }^{40}$ TORGAL, Luís Reis, loc. cit. e XAVIER, Ângela Barreto, HESPANHA, Antônio Manuel, op. cit., p. 129, 135 e 137. Isto não quer dizer que, antes de Pombal, inexistissem em território lusitano autores que se aproximassem de teorias absolutistas providencialistas. Manuel Fernandes Vila Real, em Político Cristianíssimo (1641), embora não afirme explicitamente que o poder real vem diretamente de Deus, entende que este é o seu fundamento, chegando, em outra obra, o Anti-Caramuel, a defender que se respeitasse o mais possível a pessoa do rei (no caso, Filipe IV). Antônio Henrique Gomes, em Política Angélica (1647), advogava, em termos teóricos, a tese da origem divina do poder régio (TORGAL, Luís Reis, op. cit., vol. 2, p. 33). A influência do pensamento absolutista francês em Portugal no século XVII, porém, foi muito pequena (XAVIER, Ângela Barreto, HESPANHA, Antônio Manuel, op. cit., p. 135), motivo pelo qual se pode entender que a orientação pombalina
} 
absolutismo, impondo-lhe limites ${ }^{41}$, na medida em que atribuía uma origem "popular" para o poder e que postulava limitações ético-religiosas para o seu exercício. O rei ficava obrigado a curvar-se ao direito: obedecer às leis, fossem elas fundamentais ou ordinárias, e, ao mesmo tempo, respeitar os direitos particulares. Os tribunais palatinos, com isto, assumiam o papel de guardiões de justiça e dos direitos de cada um. A sociedade, além disso, era concebida como naturalmente ordenada, sendo irredutíveis os estatutos jurídico-institucionais dos "estados", das ordens, constituindo obrigação do governo temporal e do direito ratificar esta ordenação e, inversamente, sendo muito mal recebidas as inovações drásticas introduzidas nesta ordem pelo arbítrio régio ${ }^{42}$. Sendo os jesuítas os principais propagadores de tais teorias e opondo-se os mesmos ao desenvolvimento da economia e do comércio colonial de forma a fomentar a acumulação e a retenção de riquezas na metrópole, à definição das fronteiras das possessões portuguesas na América e à dinamização da cultura e da educação em Portugal sob o primado das Luzes, eles representavam, por conseguinte, a negação prática e teórica dos pilares da política do ministro de D. José I, motivo pelo qual foram perseguidos duramente ${ }^{43}$.

Quando a Coroa iniciava sua ofensiva regalista, reformista e anti-jesuítica, é importante lembrar, aconteceu um episódio dramático, o terremoto de Lisboa, em 1755, em torno do qual se travou uma luta entre, de um lado, Pombal e seus seguidores, partidários da Razão e do reforço do poder régio e, de outro, conservadores de todos os matizes, dentre eles alguns jesuítas, partidários de uma visão sacralizada de mundo. O terremoto de Lisboa desencadeou uma efervescência religiosa em Portugal e no exterior, sendo interpretado por populares e teólogos como castigo pelos pecados. Dentre os que propagaram visões deste gênero, destacaram-se o Patriarca de Lisboa e o padre Gabriel Malagrida, um dos mais

constituiu um fato novo.

${ }^{41}$ TORGAL, Luís Reis, op. cit., vol. 1, p. 66, 193 e 197-9. Jorge Borges de MACEDO radicaliza esta posição, pois considera que as "acusações que José Seabra da Silva lhes fazia, no seu longo panfleto [a Deducção Chronologica e Analitica], de que negavam o poder absoluto dos reis, eram perfeitamente pertinentes" (MACEDO, Jorge Borges de, op. cit., p. 77).

${ }^{42}$ XAVIER, Ângela Barreto, HESPANHA, Antônio Manuel, op. cit., p. 131-2.

43 Para Falcon, a oposição aos jesuítas era determinada pela orientação regalista do governo pombalino: ao atacar os jesuítas, Pombal tinha em mente, na verdade, redefinir o papel político da igreja, contestando sua hegemonia nas instâncias ideológicas do Estado e acompanhando a orientação individualista, secularizadora e individualista da Ilustração; o "combate antijesuítico foi a luta em prol da afirmação de uma autoridade real, civil, laica, sobre uma autoridade eclesiástica que viera até então mantendo e ampliando sua influência e controle, por intermédio de seus homens e de suas idéias, sobre a sociedade e o Estado" (FALCON, Francisco José Calazans, op. cit., p. 378-9 e 423-425). 
eminentes próceres jesuítas de então: eles atribuíram o terremoto, respectivamente, a "escândalos" e "desordens" encontrados no Reino e aos insultos verificados na Corte, que eles julgavam dever ser purificada; Malagrida não hesitou em desmentir os que explicavam o acontecido "a partir de causas exclusivamente naturais"44. Interpretações como estas eram inaceitáveis para os propósitos racionalistas e regalistas de Pombal, uma vez que expressavam uma visão de mundo dentro da qual se compreende que a vontade divina manifestar-se-ia em ocorrências terrestres cujo sentido seria preciso apreender - e, neste caso, esta "vontade divina", supostamente manifesta no terremoto, possuiria um sentido político claro, isto é, um questionamento do alcance e da eficiência da administração régia ${ }^{45}$. Obviamente, o perigo ao poder régio representado por tais posições alimentou ainda mais a fúria anti-jesuítica josefina.

Um nome importantíssimo da Ilustração portuguesa, Teodoro de Almeida, foi outra vítima do consulado Ilustrado pombalino. Sua trajetória espelha os limites do reformismo abraçado pela Coroa e, ao mesmo tempo, da própria Ilustração em Portugal. O famoso padre oratoriano dedicou-se a um projeto de difusão do saber entre os que não tinham estudos e, por isso, usou a língua vernácula em sua Recreação Filosófica ou diálogo sobre a filosofia natural para instrução de pessoas curiosas que não freqüentaram as aulas, obra enciclopédica em que procurava explicar os fenômenos naturais, passando pela física, biologia, astronomia e história da filosofia, ressaltando a origem divina dos mesmos fenômenos ${ }^{46}$. A obra citada marcava-se pelo ecletismo filosófico e pelo respeito à ortodoxia religiosa naquilo que era mais fundamental. Assim, por um lado, ao tratar dos céus e astros, Almeida não afrontou as perspectivas defendidas pela igreja, sendo cauteloso no tratamento do sistema coperniciano, assumindo-o como "hipótese"; por outro, punha em causa a idéia de uma autoridade acrítica e recorria, ao mesmo tempo, tanto a Newton quanto a Descartes e, até mesmo, Aristóteles. O ecletismo filosófico de Almeida, segundo Francisco Contente DOMINGUES, seria uma espécie de solução de compromisso entre as várias vertentes que se opunham ao formalismo da Escolástica e, além disso, uma forma de preservar a "causa última": Deus. A filosofia natural, na realidade,

\footnotetext{
${ }^{44}$ MIRANDA, Tiago Costa Pinto dos Reis, op. cit., p. 191.

${ }^{45}$ Ibidem, p. 192-193.

${ }^{46}$ DOMINGUES, Francisco Contente, op. cit., p. 47-49.
} 
seria um meio de se chegar ao Criador $^{47}$. Para Almeida, Deus criara o universo, cuidando de sua perfeição e dotando-o de leis de movimento que o fazem permanecer tal como foi delineado, leis estas mostradas pelo “'grande Newton (illustrado sem dúvida por Deos)"'; o Criador seria também responsável pelo universo moral que é o homem, dando-lhe leis para a vida em sociedade, cabendo ao cristão viver de acordo com elas, preferindo o bem comum ao seu próprio bem e subordinando-se à autoridade, a qual, entretanto, não poderia ser exorbitante. Por esta razão, Teodoro de Almeida opôs-se aos desígnios regalistas de Sebastião de Carvalho e Melo, marquês de Pombal, tendo sido perseguido e exilado ${ }^{48}$. Teodoro, enfim, conciliava Luzes e catolicismo, não os opondo como faziam ilustrados seus contemporâneos em outros países; seu esforço conciliatório, no entanto, desagradou à Coroa, na medida em que se recusava a aceitar a primazia desta sobre a igreja. Isso tudo revela a complexidade de interesses em jogo sob o Reformismo Ilustrado português; a dificuldade de se alcançar um equilíbrio entre eles; e, mais ainda, a estreiteza dos limites em que se moviam os pensadores.

Se a postura de Almeida não convergiu com o interesse pombalino de consolidar a autoridade régia e submeter a igreja à Coroa, outro oratoriano curvou-se ao regalismo: o padre Antônio Pereira de Figueiredo, deputado da Real Mesa Censória, um dos ideólogos de Pombal. Em 1769, FIGUEIREDO publicou Tentativa Teológica, obra em que defende a autoridade dos bispos para dispensar, em todos os casos, nas ocasiões de conflito entre o rei e o papa ${ }^{49}$. No "Proêmio" do livro, o autor, primeiro, apóia a ruptura com a Santa Sé determinada por D. José I em 1760:

"Nos principios de Agosto do anno de 1760 ordenou S. Magestade por seu Real Decreto, que nenhum dos seus Vassalos debaixo de graves penas tivesse com a Corte de Roma algum comércio, tanto no espiritual como no temporal. He este o modo ordinário com que a Magestade e Soberania dos Principes Catholicos (sem offensa da Religião

\footnotetext{
${ }^{47}$ Ibidem, p. 55-57, 61, 63 e 66-67.

${ }^{48}$ Ibidem, p. 91-92 e 156-158. Na América, a Real Mesa Censória puniu, com "dilatada, e incerta penalidade", o frei José de Santa Maria, religioso menor reformado da província da Conceição do Brasil, por haver defendido em 1773, em "Público", a "seguinte These = Jus eximit a Legibus Civilibus personas Ecclesiasticas tam quoadvim directivam quam coactivam, non vero quoadvim directivam indirectam" (isto é, as pessoas eclesiásticas estão livres da obediência às leis civis). Porém, como o prelado regular castigou o citado frei com severidade no ato mesmo em que apresentou sua proposição e como o último reconhecia "ser erronea, e inadmissivel semelhante doutrina”, D. José I ordenou sua absolvição, ficando o réu obrigado a escrever sua retratação ao seu superior provincial e remetê-la à Real Mesa Censória (IANTT, Real Mesa Censória, "Livro de Registro da Mesa Provisões", Livro 18).

${ }^{49}$ [FIGUEIREDO, Antônio Pereira]. Tentativa Teológica. Lisboa: 1769.
} 
ou Primado de S. Pedro) costuma despicar-se das injurias e desathençoens da Curia Romana"50.

Em seguida, FIGUEIREDO cita exemplos de reis que agiram à semelhança de D. José I e, então, explicita o propósito de sua obra:

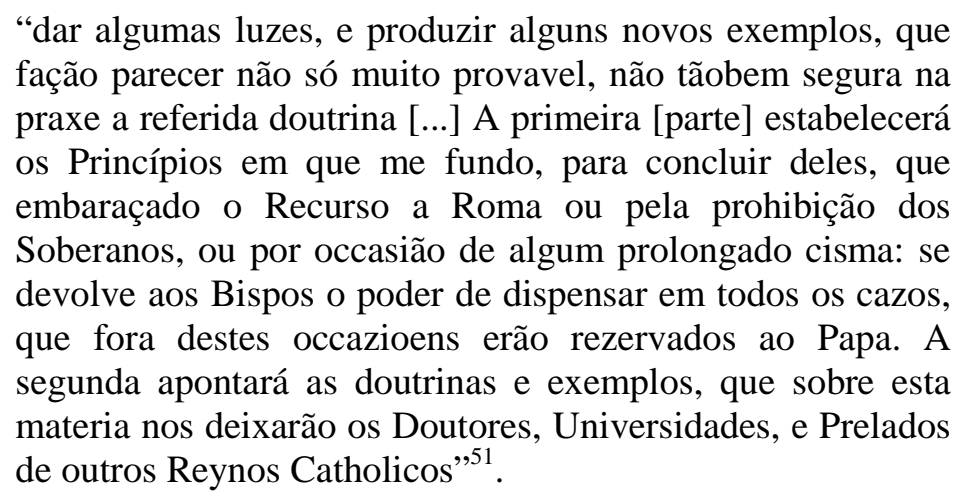

Ao construir um histórico dos poderes dos prelados, para comprovar que, nas ocasiões sublinhadas, ser-lhes-ia devolvido o poder de dispensar, o autor conta que Inocêncio III usou documentos apócrifos, forjados por Isidoro Mercador, para reservar a si a plenitude do poder eclesiástico, segundo a fórmula: só o papa "tem a Jurisdição imediatamente de Christo, e os Bispos só a recebem do Papa"52. Afirma, também, que Xisto V, persuadido desta posição, colocou no Índex a "Obra de Bellarmino [grande nome da Segunda Escolástica] de Romano Pontifice: porque nella se negava ao Papa o poder directo, e só lhe concedia o indirecto" ${ }^{, 53}$. E apela a são Bernardo, para quem:

"a jurisdição dos Bispos era tão imediatamente de Christo, como a do Papa: e [...] a plenitu do poder não a recebera o Papa para despojar os Bispos dos Direitos e funçoens proprias do seu caracter: mas sim para lhos conservar, sob pena de lhes fazer injuria, e de lhes ficar em restituição" ${ }^{54}$.

FIGUEIREDO conclui, assim, que:

"O fim porque os Bispos demittirão de si para a Sé Apostolica os poderes e faculdades de que estavão de posse: não podia ser outro, que a maior utilidade da Igreja Universal e de cada huma de suas Dioceses, que no Summo

\footnotetext{
${ }^{50}$ Ibidem, p. I.

${ }^{51}$ Ibidem, p. X-XI.

${ }^{52}$ Ibidem, p. 34-35.

${ }^{53}$ Ibidem, p. 35.

${ }^{54}$ Ibidem, p. 37.
} 
Pontifice tinhão hum prompto e sabio Provizor de todas as suas necessidades [...]. Embaraçado pelos Reys e Principes Soberanos o acesso e Recurso a Roma, não toca aos Bispos averiguar a justiça da causa; mas sim obedecer, e prover interinamente o que for necessario para bem espiritual dos subditos" $"$.

Apesar de defender a autoridade dos bispos, o direito desses dispensarem nas circunstâncias em que rei e papa estivessem atritados; embora anote que, nessas situações, caberia aos bispos obedecer aos soberanos, não entrando no mérito das causas destes; FIGUEIREDO, no entanto, mantém a primazia do papado no seio da igreja. No seu entendimento, o papa seria "por direito divino Primaz da Igreja", recebendo de Cristo imediatamente o governo e a administração "sobre a Igreja universal" ${ }^{56}$. Mostrando uma postura completamente oposta à seguida pelo também oratoriano Teodoro de Almeida, o padre Antônio Pereira de Figueiredo faz, assim, um esforço para legitimar as investidas regalistas de El-Rei, elabora uma tentativa de conciliá-las com os ensinamentos teológicos, no que não demonstra ser muito convincente, na medida em que fica patente a contradição entre as três idéias centrais que defende: a supremacia da autoridade régia no Reino, o direito dos prelados fazerem as dispensas quando os soberanos impedissem o contato com a Santa Sé e, ao mesmo tempo, a primazia do papado na instituição eclesiástica.

\section{Sob Dona Maria I e D. João}

O reinado mariano não significou uma ruptura radical com o consulado pombalino, nem em termos teóricos, nem em termos práticos, embora tenha constituído uma reação contra ele: em relação ao governo anterior, pautou-se, em linhas gerais, pela continuidade de princípios e nomes, pela inovação e pela reparação.

Por um lado, o absolutismo sobreviveu à "Viradeira", do mesmo modo que alguns homens como, por exemplo, o próprio filho de Pombal, que se manteve na presidência do senado da Câmara de Lisboa; Diogo Antônio Pina Manique, colaborador do governo anterior, que foi alçado à intendência geral de polícia em

\footnotetext{
${ }^{55}$ Ibidem, p. 189 e 195.
} 
1780; Martinho de Mello e Castro, ex-embaixador português em Londres e ministro do Ultramar, em cujo cargo foi mantido; e, por fim, José de Seabra da Silva, o “"segundo filho adotivo"” de Pombal, perseguido por ter conspirado contra ele, que foi reintegrado ${ }^{57}$.

Tanto no governo de Dona Maria I como no do Príncipe Regente, Dom João, ademais, continuou-se com o Reformismo Ilustrado, introduzindo-se, contudo, algumas alterações. Havia intelectuais ilustrados ocupando cargos no governo, à semelhança da governação anterior, mas muitos deles, significativamente, haviam se mantido distantes dos intuitos políticos de Pombal, embora, quanto aos desígnios culturais, demonstrassem grandes afinidades com ele. Em tal situação enquadrava-se, por exemplo, parcela significativa dos que tinham assento na Academia de Ciências, instituição patrocinada pelo governo ${ }^{58}$. Tais homens, por essa ambivalência, constituem um emblema da nova ordem pós-josefina: Ilustrados, porém antipombalinos. A política econômica reformista sofreu igualmente algumas alterações. Insistiu-se no combate ao contrabando e na defesa do exclusivismo comercial metropolitano nas colônias, mas se extinguiram os estancos e as companhias privilegiadas de comércio ${ }^{59}$. Continuou-se a perseguir o desenvolvimento manufatureiro do Reino, motivo por que se proibiram as manufaturas de tecidos no Brasil em $1785^{60}$. O Estado, no entanto, recuou da administração direta das empresas, alienando os estabelecimentos reais ${ }^{61}$; ao mesmo tempo, procurou-se aprimorar tecnicamente a produção tanto na metrópole como na colônia, incentivando-se a diversificação das atividades produtivas nesta última ${ }^{62}$. $\mathrm{Na}$ administração mariana, especificamente, parece ter-se verificado um certo titubeio quanto à visão imperial pombalina, em razão do que a ação governamental tornou-se prisioneira dos interesses e preconceitos da metrópole, excomungando-se num primeiro momento, por exemplo, a criação de uma fundição de ferro em Minas Gerais, proposta por Dom Rodrigo José de Menezes ${ }^{63}$. A instalação de fábricas de

\footnotetext{
${ }^{56}$ Ibidem, p. 6.

57 TAVARES, Adérito, PINTO, José dos Santos. Pina Manique: um homem entre duas épocas. Lisboa: Casa Pia de Lisboa, 1990, p. 13; CASTRO, Zília Osório de, op. cit., p. 12; MAXWELL, Kenneth. A devassa da devassa, op. cit., p. 93; e DOMINGUES, Francisco Contente, op. cit., p. 129.

${ }_{58}$ NOVAIS, Fernando Antônio, op. cit., p. 239 e DOMINGUES, Francisco Contente, op. cit., p. 106.

${ }^{59}$ NOVAIS, Fernando Antônio, op. cit., p. 239, 244-246 e 250.

${ }^{60}$ Ibidem, p. 268, 274 e 277.

${ }^{61}$ MAXWELL, Kenneth. A devassa da devassa, op. cit., p. 96.

${ }^{62}$ Ibidem, p. 257-259 e 281.

${ }^{63}$ MAXWELL, Kenneth. A devassa da devassa, op. cit., p. 98 e 119-120.
} 
ferros só seria aceita em 1795, sob a regência joanina, não sem considerar que "semelhante liberdade" poderia ocasionar um "desfalque" nos "reais direitos", motivo pelo qual elas ficavam obrigadas a arcar com uma "tarifa moderada“664. Movido pelo objetivo de industrializar o Reino, o Estado patrocinou pesquisas, abriu escolas e financiou publicações na área das ciências naturais para fomentar a produção de matérias-primas na América ${ }^{65}$.

D. João, em sua regência, teve à frente da Secretaria da Marinha e Ultramar, de 1795 a 1801, D. Rodrigo de Souza Coutinho (em 1801, este foi nomeado Presidente do Real Erário, cargo do qual foi demitido em 1803, retornando ao governo apenas em 1808). Ilustrado dos mais importantes de Portugal, apresentou várias propostas de mudança, dentro dos quadros do Antigo Regime, nem sempre concretizadas, mas que foram um grande estímulo para as elites luso-brasileiras. Do ponto de vista social, acreditava que a nobreza deveria distinguir-se pelas virtudes e méritos (à semelhança de Verney); no plano econômico, inspirava-se nas idéias liberais de Adam Smith, mantendo contudo a defesa de uma complementariedade mercantilista entre Reino e Ultramar; quanto à religião, entendia ser a religião um fundamento da vida social, devendo subordinar-se aos interesses do Estado; e, por fim, do ponto de vista político, propunha a constituição de um império lusobrasileiro, mantendo-se a unidade do mundo português e formando um grande Estado atlântico. Em consonância com este objetivo e, portanto, visando tornar a metrópole o pólo dinamizador das relações comerciais do império (não mais o centro dominador e monopolizador); inspirando-se nas mudanças propostas pelo abade Raynal e na concepção de império atlântico de Adam Smith, Dom Rodrigo apresentou um programa de reformas, provavelmente em 1798, à junta de ministros ${ }^{66}$ : reforma da máquina administrativa instituindo-se um sistema federativo, extinção dos monopólios, estímulo à atividade produtiva interdependente de todas as partes do império e diminuição da carga tributária ${ }^{67}$. Dom Rodrigo tomou medidas para dinamizar a agricultura e as manufaturas; apoiou à Tipografia do Arco do Cego; constituiu em torno de si um grupo de auxiliares formado por naturalistas e homens do porte de José Bonifácio, Azeredo Coutinho e Hipólito José da Costa, entre outros;

${ }^{64}$ Instruções de Luís Pinto de Souza Coutinho aos governadores das capitania do Brasil, 27/5/1795. Apud. NOVAIS, Fernando Antônio, op. cit., p. 284.

${ }^{65}$ DIAS, Maria Odila Leite Silva, op. cit., p. 113-116.

${ }^{66}$ LYRA, Maria de Lourdes Viana, op. cit., p. 66-70. 
estimulou a criação do Seminário de Olinda, no qual se enfatizariam a matemática e as ciências; e, em 1801, defendeu a transferência da capital do Império para o Brasil (aventada por D. Luís da Cunha, em 1738, e por Pombal, em 1762, tendo como antecedente mais distante a proposta de divisão do Império Português, apresentada pelo Padre Vieira em 1657). Dom Rodrigo, porém, viu-se bloqueado na maioria de suas iniciativas e, em 1803, foi alijado do cargo ${ }^{68}$.

Avaliadas as medidas econômicas do reinado mariano e da regência joanina e, ainda, os projetos e as realizações de D. Rodrigo de Souza Coutinho, pode-se examinar os dois últimos reinados reformistas ilustrados sob os pontos de vista educacional e político-cultural. Dona Maria priorizou o ensino de primeiras letras e, intencionalmente ou não, dificultou o acesso aos outros graus, reduzindo o número de aulas de nível médio e, com isto, criando obstáculos para o ingresso na Universidade $^{69}$. Sob o reinado mariano, durante a regência de Dom João, tomou-se uma importante iniciativa para modificar a prática médica: em 1794, publicou-se a Farmacopéia geral para o reino e domínios de Portugal, obra que versa sobre o preparo e a composição das fórmulas farmacêuticas no Reino e nas Colônias ${ }^{70}$.

Por outro lado, no reinado de Dona Maria I, adotaram-se medidas reparadoras em relação aos perseguidos e prejudicados pelo governo anterior, enquadrando-se nesses casos os jesuítas, os intelectuais ilustrados que não comungaram do regalismo pombalino (o oratoriano Teodoro de Almeida e o Bispo de Coimbra D. Manuel da Anunciação, por exemplo ${ }^{71}$ ) e, de resto, os encarcerados ou desterrados por motivos políticos, alvos de medidas conciliatórias por parte do novo governo. Isso, no entanto, não implicou a aprovação do retorno da Companhia de Jesus aos domínios portugueses $^{72}$. Fizeram-se alterações no âmbito da teoria de poder, passando-se de

${ }^{67}$ Ibidem, p. 80-81.

${ }^{68}$ NEVES, Guilherme Pereira das. Do império luso-brasileiro ao império do Brasil (1789-1822), op. cit., p. 79-84.

${ }^{69}$ CARVALHO, Rômulo de, op. cit., p. 489. Carlota Boto, a partir da importância concedida por Dona Maria I ao ensino primário, julga que sua perspectiva educacional aproximava-se da reflexão de Luís Antônio Verney e de Diderot, que consideravam importante multiplicar o acesso às primeiras letras (op. cit., p. 108 e 185-186).

${ }^{70}$ RIBEIRO, Márcia Moisés, op. cit., p. 129. A autora põe em dúvida a eficácia da obra na Colônia, na medida em que seus possíveis efeitos seriam amortecidos pela distância do continente americano e pelo analfabetismo que nele imperaria (Ibidem, p. 129-130).

${ }^{71}$ Dona Maria I recebeu o bispo, deu-lhe todas as satisfações e reparos e, ainda, mandou riscar a carta régia de 1768 que o depusera e o mandara prender (FALCON, Francisco José Calazans, op. cit., p. 428-9). Teodoro de Almeida permanecera por dez anos no estrangeiro, exilado, por suas divergências com Pombal (DOMINGUES, Francisco Contente, op. cit., p. 93).

72 BEIRÃO, Caetano. D. Maria I, 1777-1792: subsídios para a revisão da história do seu reinado. 4 
uma monarquia absoluta esclarecida para uma "monarquia temperada", que associava elementos das teorias corporativas e absolutistas providencialistas e, ainda, estava a meio caminho da monarquia constitucional. $O$ poder da rainha, segundo os parâmetros fixados em alguns documentos, tinha origem divina e hereditária; a legitimidade de seu acesso à Coroa, no entanto, não resultava apenas de Deus e da hereditariedade, mas também do consenso dos povos. Este meio termo aparece claramente nas palavras de Antônio Ribeiro dos Santos, para quem só “"a lisonja faz crer aos monarcas que eles têm o poder somente de Deus, e faz crer aos povos que somente o têm da mão do homem,",73.

Noutros documentos, no entanto, vê-se a sobrevivência do providencialismo pombalino. Em 1779, a Rainha encaminhou, através da Real Mesa Censória, uma provisão ao corregedor da comarca de Coimbra, ordenando-lhe que fizesse uma devassa com o intuito de identificar pessoas relacionadas à universidade que estivessem possuindo e lendo "Livros irregilionarios [sic]" que continham "maximas oppostas a estabilidade do Throno, a pureza da Fe, e a inteireza dos costumes" "74. A Rainha, no referido documento, toma esta iniciativa como sua obrigação enquanto monarca, tendo em vista que: "do supremo Poder que recebi immediatamente de Deos sobre os meus Vassalos, he inseparavel a estreitissima obrigação de os mantar [sic], e conservar na Religião Catholica, q. professão; devendo apartar delles tudo quanto a possão inficionar [sic]"75. O poder monárquico, "supremo", portanto, viria diretamente de Deus, o que demonstra a persistência de uma concepção providencialista de poder ao tempo de Dona Maria I.

A ebulição intelectual favorecida pelo reformismo, iniciado no reinado de Dom José I e continuado por Dona Maria I e pelo príncipe regente Dom João, teve limites. As antigas estruturas da universidade, primeiramente, continuaram as mesmas do período anterior; e, se com Pombal a universidade livrou-se da tutela dos jesuítas, permaneceu sob o jugo eclesiástico e religioso. O reitor das reformas, D. Francisco de Lemos, era clérigo, e, nos novos estatutos, registrava-se uma máxima

ed. Lisboa: Empresa Nacional de Publicidade, 1944, p. 262-3; CASTRO, Zília Osório de, op. cit., p. 12-13; e DOMINGUES, Francisco Contente, op. cit., p. 94-97.

${ }^{73}$ CASTRO, Zília Osório de, op. cit., p. 13-17.

${ }^{74}$ IANTT. Real Mesa Censória, "Livro de Registro da Mesa - Provisões", Livro 18, p. 160 e segs..

75 Ibidem, loc. cit.. Zília Osório de Castro não menciona a sobrevivência do providencialismo nas representações construídas pela monarquia portuguesa ao tempo de Dona Maria I. Não parece, no entanto, que Dona Maria I tenha se livrado de todo desta herança pombalina, como demonstra o documento citado. 
que consagrava a divisão entre os poderes da Igreja e do Estado e, ainda, o caráter divino de ambos, expressando o empenho pombalino de firmar o providencialismo: “"há dois Poderes pelos quais se rege e governa o mundo. Convém a saber: a Autoridade Sagrada da Igreja e o Poder Real: Que ambos precedem imediatamente de Deus" ${ }^{, 76}$. Com a ascensão de Dona Maria I, houve um retorno dos conservadores, cuja preeminência, contudo, foi ameaçada por reformas feitas em meados da década de 80 do século XVIII ${ }^{77}$. Essa universidade que se queria tirar do obscurantismo, além disso, foi vítima do mesmo controle e das mesmas violências que sufocavam a disseminação das idéias e do espírito crítico na sociedade portuguesa e brasileira de então: a inquisição, embora fragilizada, continuava a agir, perseguindo as Luzes que ultrapassavam os limites estipulados pela $\mathrm{Coroa}^{78}$. Se durante o período pombalino, como se viu, perseguiu-se Teodoro de Almeida, dentre outros intelectuais, alguns deles ilustrados, que se contrapunham as idéias defendidas pela Coroa, esta prática continuou sob o reinado mariano e sob a regência do príncipe D. João. Para tanto contribuíram a Real Mesa Censória (de cuja ação repressiva é exemplo a supracitada ordem de Dona Maria I, passada ao corregedor da comarca de Coimbra) e suas sucedâneas e, mesmo, a Intendência Geral de Polícia. Outros limites encontravam-se na própria estruturação da sociedade, que favorecia o conservadorismo.

Do quadro da Universidade de Coimbra reformada saíram intelectuais como os já citados José Bonifácio de Andrada e Silva, Antônio de Morais Silva, Francisco de Mello Franco, Vicente Seabra Telles e Manoel Joaquim Henriques de Paiva, todos eles luso-brasileiros. A biografia dos quatro últimos retrata os limites do reformismo ilustrado português: a preservação das estruturas repressivas por parte da Coroa; a timidez das idéias defendidas, algumas vezes oriunda da própria ação do absolutismo e, noutras ocasiões, definida pela estrutura social e pelos padrões de sociabilidade intelectual vigentes no mundo luso-brasileiro.

Antônio de Morais, nascido no Rio de Janeiro provavelmente em 1756, estudou gramática com um tio padre; Retórica sem mestre; filosofia nos Conventos de São Bento e Carmo no Rio de Janeiro; em Coimbra, cursou Geometria e bacharelou-se em Direito. Na universidade, ainda, estudou com empenho as línguas

\footnotetext{
${ }^{76}$ CARVALHO, Rômulo de, loc. cit..

${ }^{77}$ MARTINS, Wilson. História da inteligência brasileira, São Paulo: Cultrix: Edusp, 1977-78, vol. 1, p. 466.

${ }^{78}$ CARVALHO, Rômulo de, op. cit., p. 482-483.
} 
francesa, inglesa e italiana ${ }^{79}$. Tinha intenção de seguir a magistratura, mas o processo da inquisição veio a adiar seus planos. Como se verá no Capitulo 7, Morais defendeu, em conversas com amigos em Coimbra, proposições deístas e contrárias aos dogmas da igreja católica e, ainda, à inquisição portuguesa. Dois meses após o início do processo, foi ordenada sua prisão e, então, Morais fugiu para Londres. $\mathrm{Na}$ capital inglesa, contou com a proteção de Luís Pinto de Sousa Coutinho, ministro de Portugal na Inglaterra, depois visconde de Balsemão.

Em sua estadia de nove anos em Londres, organizou uma versão resumida do Dicionário de Bluteau, publicada em 1789; porém, nas edições subseqüentes, em 1813 e 1823 , a obra se enriquecera tanto, que se converteu num trabalho original ${ }^{80}$. Através da análise da obra e dos propósitos explicitados por seu autor, Wilson MARTINS conclui que Morais introduziu inovações, seja em relação ao dicionário de Bluteau, seja em relação às regras gramaticais, originalidade esta já presente na primeira edição e acentuada nas subseqüentes, passando pela ortografia, pelo número de verbetes, pelas fontes citadas e pelas áreas de saber abarcadas ${ }^{81}$. Segundo palavras do próprio Morais Silva, seu dicionário era melhor, mais completo e mais especificamente lexicológico do que o de Bluteau; teria como fontes os clássicos do idioma; compreenderia "os termos inovados nas artes, e ciências", os que vêm "nas Leis modernas", alguns deles tirados "da Dedução Cronológica, e outros papéis da Real Mesa Censória, e Ministeriais"; e estaria ainda enriquecido de "idéias filosóficas, e de noções relativas ao comércio, artes, manufaturas, à ciência política e econômica, e a um sem número de ramos de saber e erudição" ${ }^{\circledR 2}$. Antônio de Morais, portanto, introduziu inovações no léxico que acompanhavam as mudanças culturais e sócio-econômicas coevas.

Por volta de 1785, Morais SILVA regressou a Portugal. Neste mesmo ano, publicou em Lisboa a sua versão de História de Portugal, original inglês de uma sociedade de literatos ${ }^{83}$ obra em cujo prefácio o tradutor, por um lado, avisa ter conservado passagens originais críticas ao Santo Ofício e, por outro, defende

\footnotetext{
${ }^{79}$ IANTT, Inquisição de Lisboa, "Processo no 2015", p. 45.

${ }^{80}$ BAIÃO, António. Episódios dramáticos da inquisição portuguesa, 3 ed. Lisboa: Seara Nova, 1973, vol. 2, p. 131.

${ }^{81}$ MARTINS, Wilson. História da inteligência brasileira. São Paulo: Cultrix: Edusp, 1977-78, vol. 1, p. 516-518.

${ }^{82}$ Antônio de Morais Silva, apud. MARTINS, Wilson, op. cit., loc. cit..

${ }^{83}$ SILVA, Maria Beatriz Nizza da. "Silva, Antônio de Morais". In: Idem (coord.). Dicionário da história da colonização portuguesa no Brasil, Lisboa: Verbo, 1994, p. 762-763.
} 
amplamente este tribunal, dizendo que graças ao mesmo se conservou o Reino livre das heresias; que a inquisição se encontrava sujeita aos soberanos, ao contrário do que diziam seus adversários, ressalvando, no entanto, que havia casos nos quais os reis estavam submetidos aos pastores. Explica também que, depois do novo regimento que lhe fora dado por D. José I, os castigos aplicados aos réus tornaram-se brandos ${ }^{84}$. A fúria inquisitorial, de fato, diminuíra com o novo regimento - por isto mesmo, Morais atreveu-se a voltar a Portugal. Porém, foi sob a vigência do citado diploma legal, que Morais fez críticas severas à inquisição; fugiu, ao ser ameaçado de prisão; ao regressar, renegou suas palavras e, no prefácio citado, fez uma defesa previdente do tribunal. Aqui, portanto, começam a se entrever os limites do Reformismo Ilustrado: se a Coroa fez reformas culturais, econômicas e sociais, o pensamento não se tornou livre, motivo, como se verá a seguir, pelo qual muitos Ilustrados tiveram que abrandar o aspecto corrosivo de suas idéias.

O luso-brasileiro Vicente Seabra Teles foi um dos primeiros químicos fora da França a aceitar as idéias de Lavoisier, como o papel do oxigênio na combustão e na composição da água, e a adotar os novos termos desenvolvidos pelos autores franceses. Veio a fazê-lo ainda na década de 80 do século XVIII ${ }^{85}$. Ele, no entanto, apesar de ser brilhante como cientista, teve sua carreira travada na Universidade de Coimbra, nunca chegando ao posto de professor efetivo, nem tendo seu Elementos de química - o primeiro livro de química moderna escrito em língua portuguesa adotado como compêndio do curso de química ${ }^{86}$.

\footnotetext{
${ }^{84}$ No prefácio, Morais afirma: "trasladámos alguns lugares, em que os Authores desta obra maltratão o Regio Tribunal do Santo Officio da Inquisição, procedendo imprudentemente sem conhecimento da causa. Todos sabem hoje em dia a regularidade, com que naquelle recto Tribunal se procede, principalmente em virtude do novo Regimento, dado pelo Senhor Rei D. José; a brandura, com que castigão os réos, que já não se demorão nos carceres, senão o tempo necessario, para se lhes formar o processo; que em fim se lhes dá consentimento das culpas, para não allegarem esquecimento dellas [...]. Já, se nos lembrarmos, que por meio deste Tribunal se conservou o Reino illeso das heresias [...]. O que dizem contra a Inquisição sobre querer levantar o collo contra os Soberanos, he falso, e sem fundamento; e se alguma vez os quiz absolver de excommunhões, por inscursos em heresia, claro está, que seria isso sua obrigação, visto ser caso reservado áquelle Tribunal, e que a certos respeitos os Soberanos são tão sujeitos aos Pastores, e Ministros da Igreja, como os menores dos Fiéis. Aliás, quem não sabe, que os Ministros da Inquisição sempre estiverão á obediencia de seus legitimos Soberanos, e o quanto a bondade, e clemencia da nossa Augusta, e piissima Rainha tem influido na brandura, e humanidade, com que hojre se procede nas Inquisições deste Reino?" (SILVA, António de Moraes. História de Portugal composta em inglez por huma sociedade de litteratos, op. cit., vol. 1, p. IV-V).

${ }^{85}$ FILGUEIRAS, Carlos Alberto Lombardi. The mishaps of peripheral science: the life and work of Manoel Joaquim Henriques de Paiva, luso-brazilian chemist and physician of the late eighteenth century, Ambix, Cambridge, 2 (39): 82, july 1992.

${ }^{86}$ Ibidem, loc. cit. e Idem, Pioneiros da ciência no Brasil, Ciência Hoje, São Paulo, 8 (44):57, 1988.
} 
Manoel Henriques de Paiva, contemporâneo e desafeto de Seabra Telles, teve uma carreira ascendente ${ }^{87}$. Nascido em Castelo Branco, em 1752, com ascendência cristã-nova, migrou para o Brasil juntamente com sua família em 1769, tendo seu pai, Antônio Ribeiro de Paiva, assumido o posto de boticário do vice-rei, o Marquês de Lavradio. Manoel, então, tornou-se aprendiz do ofício de seu pai e de seu irmão, desenvolvendo o gosto pela farmácia e pela química, o que o levaria a seguir uma carreira científica. Após três anos de aprendizado como prático, em 1772, ingressou na Universidade de Coimbra, onde permaneceu até 1783. Foi aluno da primeira turma de medicina e química da universidade reformada. Em 1774, por indicação do professor italiano Domingos Vandelli, Manoel tornou-se demonstrador de química no Laboratório da Universidade e, um ano depois, professor substituto ${ }^{88}$. Entre 1777 e 1778, já graduado em física, estabeleceu-se em Lisboa, residindo no Rocio ${ }^{89}$. Competente físico e médico, primeiro propagandista da vacina em Portugal, era partidário das idéias de Stahl - que eram opostas às de Lavoisier, também conhecidas de Henriques desde 1789 -, vindo a incorporar-se à revolução química promovida pela escola francesa, mudando de posição, apenas em 1816.

Homem bem inserido socialmente, apadrinhado do intendente geral de polícia Pina Manique, Manuel publicou vários escritos ao longo de sua vida, nas áreas de química, medicina, farmácia e história natural, chegando à cifra de mais de cinqüenta publicações, incluindo-se trabalhos originais, traduções, textos em colaboração, comentários e relatos no Jornal Enciclopédico. Dentre seus escritos, destaca-se Elementos de Chimica e Farmacia, que veio à lume em 1789, obra que foi dedicada ao intendente geral de polícia Pina Manique, com quem o autor tinha boas relações, e que, segundo Carlos Alberto FILGUEIRAS, é quase uma tradução do livro Fundamenta Chimae, de Giovanni Scopoli ${ }^{90}$. Manteve-se no establishment de então,

\footnotetext{
${ }^{87}$ Sthal propunava que "quando uma coisa arde, seu peso deve diminuir porque a combustão implica a perda de um princípio que evola, o chamado princípio inflamável ou flogisto", ao invés de sustentar que a "combustão consiste na incorporação de uma substância ao combustível", o oxigênio FILGUEIRAS, Carlos Alberto Lombardi. The mishaps of peripheral science: the life and work of Manoel Joaquim Henriques de Paiva, luso-brazilian chemist and physician of the late eighteenth century, op. cit., p. 78; e RIZZINI, Carlos. O livro, o jornal e a tipografia no Brasil, 1500-1822: com um breve estudo geral sobre a informação. São Paulo: Imprensa Oficial do Estado, 1988, p. 271 (facsímile).

${ }^{88}$ FILGUEIRAS, Carlos Alberto Lombardi. The mishaps of peripheral science: the life and work of Manoel Joaquim Henriques de Paiva, luso-brazilian chemist and physician of the late ${ }^{89}$ Ibidem, p. 86. eighteenth century, op. cit., p. 75-90.

${ }^{90}$ Ibidem, p. 77-78 e 86 e IANTT, Inquisição de Lisboa, "Processo no 13369”, s/p.
} 
apesar de ter sido denunciado, como se verá no Capítulo 7, à inquisição de Coimbra por heresia e por ler livros proibidos ${ }^{91}$. Seu processo inquisitorial interrompe-se no sumário de culpas; não tendo prosseguimento, devido a seus contatos com Pina Manique, intendente geral de polícia ${ }^{92}$. Com isto, a carreira ascendente de Manuel prosseguiu, envolvendo, além de inúmeras publicações, a conquista de cargos, benesses e posições sociais. Até 1783, permaneceu vinculado à universidade e, já em 1786, a Gazeta de Lisboa anunciava que ele ministrava cursos livres de medicina, princípios físico-químicos da agricultura, história natural e química. ${ }^{93} \mathrm{Em} 1793$, tornou-se físico da câmara do príncipe regente; sendo indicado ainda como censor real e como cavaleiro da Ordem de Cristo. Em 1794, Pina Manique criou um curso de farmácia e química no Castelo de São Jorge, em Lisboa, sendo Manuel Henriques nomeado para a cadeira de Farmácia ${ }^{94}$. Em 1808, contudo, ele veio a cair em desgraça, pois sua simpatia pela revolução francesa transformou-o em suspeito de aliança com o inimigo, motivo pelo qual foi preso e ficou por anos privado de seu título de cavaleiro, suas honras e cargos, sendo condenado ao banimento para o Brasil, onde viveu até 1829. Em 1816, o rei Dom João VI restituiu-lhe os direitos e prerrogativas; em 1824, já cidadão brasileiro, foi nomeado pelo imperador dom Pedro I como professor de matéria médica e farmácia no Colégio Médico-Cirúrgico da Bahia ${ }^{95}$. Na trajetória de Henriques de Paiva, vêem-se, ao mesmo tempo, os seus méritos e seus limites enquanto intelectual ilustrado (a clarividência como médico e a simpatia pela Grande Revolução versus a recusa à revolução química, embora dela tivesse conhecimento); mais do que isso, contudo, mostra-se que a sorte do intelectual, do homem de Luzes, sob o Reformismo Ilustrado, era muito incerta, dependendo das oscilações das redes de sociabilidade e de influências definidas e condicionadas dentro de uma sociedade em que vigoravam privilégios e o absolutismo monárquico, isto é, dentro do Antigo Regime. Evidenciam-se, em suma, os limites das Luzes e do reformismo abraçado pelos monarcas em Portugal a partir da segunda metade do século XVIII.

O exame da trajetória de Francisco de Mello Franco, brilhante médico, cuja

\footnotetext{
${ }^{91}$ IANTT, Inquisição de Lisboa, "Processo no 13369", s/p.

${ }^{92}$ FILGUEIRAS, Carlos Alberto Lombardi. The mishaps of peripheral science: the life and work of Manoel Joaquim Henriques de Paiva, luso-brazilian chemist and physician of the late eighteenth century, op. cit., p. 77.

${ }^{93}$ Ibidem, p. 79.

${ }^{94}$ Ibidem, p. 82 e 86.
} 
fortuna não foi tão boa quanto a de Manuel Henriques, leva às mesmas conclusões. Denunciado junto com Antônio de Morais Silva e Manuel Henriques de Paiva à inquisição de Coimbra, passou quatro anos nos cárceres desta. Conseguiu formar-se ao sair da prisão, sendo obrigado pela inquisição a residir em Lisboa, onde permaneceu por trinta anos e tornou-se um renomado clínico ${ }^{96}$. Em 1792, integrou a junta médica que examinou D. Maria I, declarando-a insana. Em 1808, foi nomeado médico honorário da Real Câmara. Tornou-se, assim, um dos mais conceituados médicos em Portugal, competência esta que foi reconhecida por D. João VI que, em 1817, nomeou-o médico da princesa Maria Leopoldina, tendo Franco se integrado em Livorno à comitiva que a acompanhou ao Brasil. No Rio de Janeiro, cidade em que clinicou e se dedicou ao estudo das doenças que a afetavam, sua reputação como médico era elevada ${ }^{97}$. Os momentos finais de sua vida, no entanto, parecem demonstrar como a trajetória triunfante de um intelectual podia ser atingida pelas intrigas palacianas: Mello Franco foi proibido de entrar na Corte por ter sido Dom João VI convencido de que ele maquinara para destroná-lo. Ao mesmo tempo, ele foi atingido pela falência do banco em que depositara toda a sua fortuna, caindo na miséria $^{98}$.

A biografia de Melo Franco, se foi marcada pela conquista de postos e de reputação, pelo fim trágico, confirma sua inventividade como autor (e, por pressuposto, também leitor, aspecto a ser abordado no Capítulo 7), sendo por isto alvo de investidas da censura. Revela sua ousadia intelectual, sua filiação à Ilustração, bem como as contradições do Reformismo Ilustrado seguido pelo governo português. Mello Franco publicou alguns livros anos depois de ser processado pela inquisição. Seu Tratado da educação fysica dos meninos, para uso da nação portuguesa (1790) foi a primeira obra de puericultura editada por um brasileiro e revela um espírito autenticamente Ilustrado, que recorre à razão e à observação para construir seu saber, apreende a natureza como modelo de referência para definir seus critérios, regras e objetivos, questiona preconceitos presentes no sistema educativo tradicional e no senso comum (por exemplo, a amamentação das crianças pelas amas

\footnotetext{
${ }^{95}$ Ibidem, p. 86-87.

${ }^{96}$ SANTOS FILHO, Lycurgo Francisco de Melo Franco, In: SILVA, Maria Beatriz Nizza da (coord.), Dicionário da história da colonização portuguesa no Brasil, op. cit., p. 357.

${ }^{97}$ Ibidem, p. 357 e MARTINS, Wilson, op. cit., p. 522.

98 GRANDE Enciclopédia Portuguesa e Brasileira, Lisboa/ Rio de Janeiro: Editorial Enciclopédia Limitada, s/d, vol. 16, p. 834.
} 
de leite), relaciona as dimensões espiritual e física na formação do homem, critica a escolarização demasiado precoce e, expressando pressupostos empiristas, prioriza a educação sensorial $^{99}$. Ensaio sobre as febres (1829), segundo Wilson MARTINS, é um marco para a fundação de uma "medicina propriamente brasileira", enquanto Elementos de Hygiene (1820) revela o emprego da observação como método científico, em detrimento da especulação ou introspecção, e aponta a influência das doenças físicas, do clima, dos alimentos e das bebidas, da geografia, dos modos de vida, do sexo, do trabalho e de todos os corpos sobre o estado moral e propõe uma reforma global da educação física da mocidade, priorizando "as qualidades dos exercícios varonis", superando a indolência, a efeminação, a superstição e a credulidade $^{100}$.

A obra Medicina Theologica, ou supplica humilde, Feita a todos os Senhores Confessores, e Directores (1794), considerada por Afranio Peixoto como precursora dos escritos de Freud, esgotou-se uma semana depois de ter chegado às livrarias devido ao êxito junto ao público e à perseguição que lhe moveu o intendente geral de polícia Pina Manique - a edição desta obra, com autorização da Real Mesa Censória, causou tamanho rebuliço que foi apontada como uma das razões do fechamento deste tribunal ${ }^{101}$. Na obra, de fato, segundo Marina MASSIMI, propõese a substituição do confessor pelo médico, transformando-se a teologia moral em psicologia médica; valoriza-se, no entanto, a prática da confissão como instrumento terapêutico ou médico e esvazia-se seu caráter religioso. Rompe-se com a independência da alma em relação ao corpo, na medida em que se compreende ser impossível “'haver operação em huma alma que seja independente da modificação do corpo a que está unida", 102 e, por isso mesmo, entende-se que a origem dos pecados está em doenças particulares do corpo. Conclui-se disso que para ser um bom teólogo seria preciso aplicar-se ao estudo da medicina e, em especial, da neurologia ${ }^{103}$. A

\footnotetext{
99 MASSIMI, Marina. As idéias psicológicas de Francisco de Melo Franco, médico e iluminista brasileiro. Psicologia: teoria e pesquisa, Brasília, 7 (1): 84-86, 1991; e MORAES, Rubens Borba de. Bibliografia brasileira do período colonial. São Paulo: Instituto de Estudos Brasileiros/ Universidade de São Paulo 1969, p. 140. Rousseau também entendia que um "corpo fraco debilita a alma" (ROUSSEAU, J.-J. Emílio ou da educação, op. cit., p. 33).

${ }_{100}$ MASSIMI, Marina, op. cit., p. 88-89 e MARTINS, Wilson, op. cit., p. 522 e 464-469.

${ }^{101}$ MORAES, Rubens Borba de. Bibliografia brasileira do período colonial, op. cit., p. 140-142 e MARTINS, Wilson, op. cit., p. 522.

${ }^{102}$ Francisco de Melo Franco, apud. MASSIMI, Marina, op. cit., p. 87.

103 MASSIMI, Marina, op. cit., p. 86-87 e MORAES, Rubens Borba de. Bibliografia brasileira do período colonial, op. cit., p. 140-142.
} 
inversão da relação entre alma e corpo, o materialismo que parece estar subjacente a tal proposição, o questionamento da posição dos teólogos e a valorização do conhecimento médico-científico, em prejuízo da teologia, exprimem uma afinação com as Luzes e, mais do que isso, colidem com os ensinamentos da igreja e os interesses dos clérigos. Trata-se, portanto, de um livro cujas Luzes rompem o equilíbrio com as forças do Antigo Regime.

No Reino da Estupidez, publicado em 1818, Mello FRANCO reproduz as inquietações da atmosfera literária coimbrã de meados dos anos 1780, os efeitos da Ilustração e as contradições do Reformismo Ilustrado português. O livro, uma sátira poética à Universidade de Coimbra dos inícios da Viradeira, então restituída aos reacionários de outrora, circulou em manuscrito em 1785, após a saída de Mello Franco da prisão. Em sua composição ou circulação teria havido a colaboração de José Bonifácio de Andrada e Silva.

O Reino da Estupidez, de um lado, arrasa com toda uma tradição cultural letrada conservadora e, de outro, mostra-se claramente filiado à Ilustração, segredando leituras feitas e apropriadas e, ainda, redes de interesse e sociabilidade. No "Prólogo" do livro, fazem-se críticas aos clérigos e ao desrespeito perpetrado pelos canonistas coimbrãos em relação aos direitos que pertenceriam aos monarcas. Os clérigos "que por voto devem ser pobres, humildes, e castos, são os mais regalados, soberbos, e libidinosos, a quem custa muito cumprir os votos que fazem"; enquanto os canonistas "sahem daqui [Coimbra] com o cerebro entumecido com tanto Direito de Graciano, sem critica, sem methodo, engolindo, como alguns verdadeiros, immensos Cannones apocryphos, dando ao Papa a torto e a direito poderes, que lhe não competem por titulo nenhum e desbulhando os Reis dos que por Direito da Monarchia lhes são devidos" ${ }^{104}$. Se essas afirmações evocam a lembrança do regalismo josefino, a sombra do marquês de Pombal se torna bastante evidente no elogio que se faz às reformas feitas pelo mesmo na universidade, à introdução das ciências naturais, embora se frise que, na prática, as inovações se tornaram letra morta nas mão de grande parte dos professores, com o que reinava a Estupidez: "a Reforma trouxe á Universidade as Sciencias naturaes, que na verdade tiverão, e tem ainda alguns Mestres dignos de tal nome, mas que estes ficão submergidos pela materialidade dos Companheiros, que fazem a maior porção que para os distinguir he

${ }^{104}$ [FRANCO, Francisco de Mello]. Reino da estupidez, poema. Hambourg: 1820, p. IX-X. 
preciso ter vista bem perspicaz; tanto reina ainda aqui mesmo a Estupidez!"105. Passa-se, então, a narrar a história da deusa Estupidez:

"Que distante da Europa desterrada

$\mathrm{Na}$ Lusitania vem fundar seu Reino" $" 106$.

Escorraçada de toda a Europa culta, banida dos quatro cantos do mundo, a deusa Estupidez refugiou-se em Portugal, onde se uniu à "macilenta Inveja", à "vingadora Raiva", ao "duro Fanatismo", à Hipocrisia e à Superstição. Na passagem dessas deusas-irmãs por Lisboa, uma delas observou que a capital portuguesa sob Dona Maria I já não respirava os mesmos ares do reinado josefino, podendo, assim a Estupidez instalar seu reino em terras lusas:

““'Lisboa já não hé, torno a dizer-vos,

"A mesma, que ha dez annos se mostrava:

"He tudo devoção, tudo são terços

"Romarias, novenas, vias-sacras.

"Aqui he a nossa terra, aqui veremos

"A nossa cara Irman cobrar seu Reino""107.

Se nesse trecho percebe-se uma crítica à ignorância e à superstição na linha de Voltaire, logo após nota-se a valorização do saber e das ciências, bem como do desenvolvimento do comércio e das técnicas, ainda em chave tipicamente Ilustrada, lembrando a crítica de Raynal à dependência portuguesa em relação à Inglaterra. Assim, em meio à jornada, as deusas encontram um pai que lamenta a situação econômica e cultural de Portugal:

"He a pena maior, que me atormenta.

"Nomear Portuguez a qualquer homem,

"He fazer-lhe a maior descompustura,

"Que pode proferir a aguda lingua

“D'huma vil regateira enfurecida.

"He chamar-lhe sem duvida macaco,

"Sómente imitador de vãos caprichos

"Das estranhas Nações, não das virtudes.

"Sem rebuço, he chamar-lhe hum ignorante,

"Hum confirmado tollo, que não sabe

"Nem artes, nem sciencias, nem commercio.

"Miseravel Nação! Que fielmente

"Os thesouros franqueia aos Estrangeiros

"Por chitas, por fivellas, por volantes,

"E por outras imensas ninharias"”, 108 .

\footnotetext{
${ }^{105}$ Ibidem, p. XI.

${ }^{106}$ Ibidem, p. 2.

${ }^{107}$ Ibidem, p. 22.

${ }^{108}$ Ibidem, p. 24.
} 
A crítica aos clérigos, de moldes voltaireanos e de outros ilustrados franceses mais radicais, também se faz presente em o Reino da Estupidez. Os clérigos são acusados de serem indignos do nome de pastores:

"Santa Religião, tempos ditosos!

"Ou tu não es a mesma, ou teus Ministros

"De Pastores o nome não merecem"”, 109.

A partir da descrição de um "gordo Bispo", criticam-se o luxo e os costumes em que viviam os clérigos, a distância que seu modo de vida guardaria em relação aos tempos primitivos da igreja cristã:

““'[...]hum gordo Bispo,

"Que na Côrte se achava com licença.

"Vinha todo de seda, e do pescoço

"Huma cruz lhe pendia cravejada

"De lucidas saphiras; de brilhantes

"O majestoso annel cegava os olhos,

"E pouco menos as fivellas de oiro.

"O austero censor ficou pasmado

"A mirar o Prelado passeando.

"Depois, com vozes de azedume cheias,

"Para os outros se volta, assim dizendo

- "Oh costumes, oh tempos primitivos!

"Tempos, em que o Pastor só differia

"Do seu rebanho pelas sans virtudes,

"Pela vida exemplar, com que o guiava!

"Quem o santo Evangelho lê attento,

"Do supremo Pastor quem lê a vida,

"A presença de hum Bispo Petimétre

"Como pode levar á paciencia?","110.

A deusa Hipocrisia faz advertências ao Bispo, dando continuidade às críticas ao fausto e aos maus costumes clericais. Não lhe cobra a obediência às máximas do Evangelho, mas lhe recomenda a preservação das aparências:

"- He possivel, que durmas descansado,

Sem te lembrares do que diz o Povo,

"Do teu modo de vida, do teu fausto?

"Não digo que pratiques fielmente

"As maximas austeras do Evangelho:

"Para teres de santo o nome honroso,

"Não precisas de tanta austeridade.

"Embora te regales, te divirtas.

"Ainda mais se he possivel, do que d'antes,

${ }^{109}$ Ibidem, p. 26.

${ }^{110}$ Ibidem, p. 24-25. 
"Mas nisto deve haver certa medida.

"Sê embora hum velhaco, hum libertino,

"Hum lobo tragador do teu rebanho;

"Mas devem outras ser as apparencias;

"De outro modo, serás mal reputado [...]","111.

Finalmente a deusa Estupidez chega à Universidade de Coimbra, e o grande concílio de Lentes e Doutores reúne-se para discutir o que fazer, proferindo o lente de Teologia seu voto para que fosse restituída àquela divindade a dignidade que sempre gozou, por "direito divino e humano", naquela instituição universitária:

"O Reitor, e por hum, e outro lado

Os Lentes, e Doutores assentados [...],

E ao Lente Primaz de Theologia

Acena, que comece; logo feita

Ao congresso em geral submissa venia,

O seu voto profere nestes termos:

"Muitos Illustres, e sabios Academicos;

"Por direito Divino, e por Humano,

"Creio, que deve ser restituida

" $A$ ' grande Estupidez a dignidade

"Que nesta Academia gozou sempre.

"Bem sabeis, quão sagrados os direitos"",

Se a restituição da dignidade à Estupidez já indica a crítica à situação da universidade do Mondego e, mais ainda, ao anti-cientificismo e à desvalorização do saber que entendiam os Ilustrados portugueses virem de longa data no reino luso, esses alvos são explicitamente identificados ao se dar continuidade às palavras do lente de Teologia. Esse último, com efeito, considera desnecessário estudar, vendo nos estudos a origem de males de saúde; julga inúteis as ciências, na medida em que perturbam o divertimento e o sossego e não trazem qualquer retorno em termos materiais ou de honra:

\footnotetext{
““'Entrai pois, companheiros, em vós mesmos,

"Ponderai sem paixão, para que serve

"As pestanas queimar sobre os Autores,

"A estimavel saude arruinando?

"P'ra levar este tempo em bom socego,

"Divertir, e passar alegremente

"Acaso precisaes de mais sciencia?

"Se os dias desta breve, e curta vida

“Tivessemos c'os livros perturbado,

"Teriamos acaso mais prebendas,

"Mais dinheiro, mais honra, mais estima?

"De que podem servir estes estudos
}

\footnotetext{
111 Ibidem, p. 26-27.

112 Ibidem, p. 32-33.
} 
"Que mais da moda se cultivão hoje?","113

O lente, ainda, vê riscos de heresia na geometria, e chama a Inquisição - um dos alvos principais da Ilustração, fora e dentro de Portugal —; mostra dificuldades de reter os nomes das ciências naturais que então emergiam; qualifica-as como coisas de "estrangeiros"; reprova a dissecação de cadáveres, tomando-a como ofensiva ao espírito santo; e, por fim, zomba da observação da natureza como método para se chegar ao conhecimento na botânica e na história natural, convocando, então, todos a entronizar a "velha protetora" como "bons filhos", deixando-a em paz reinar:

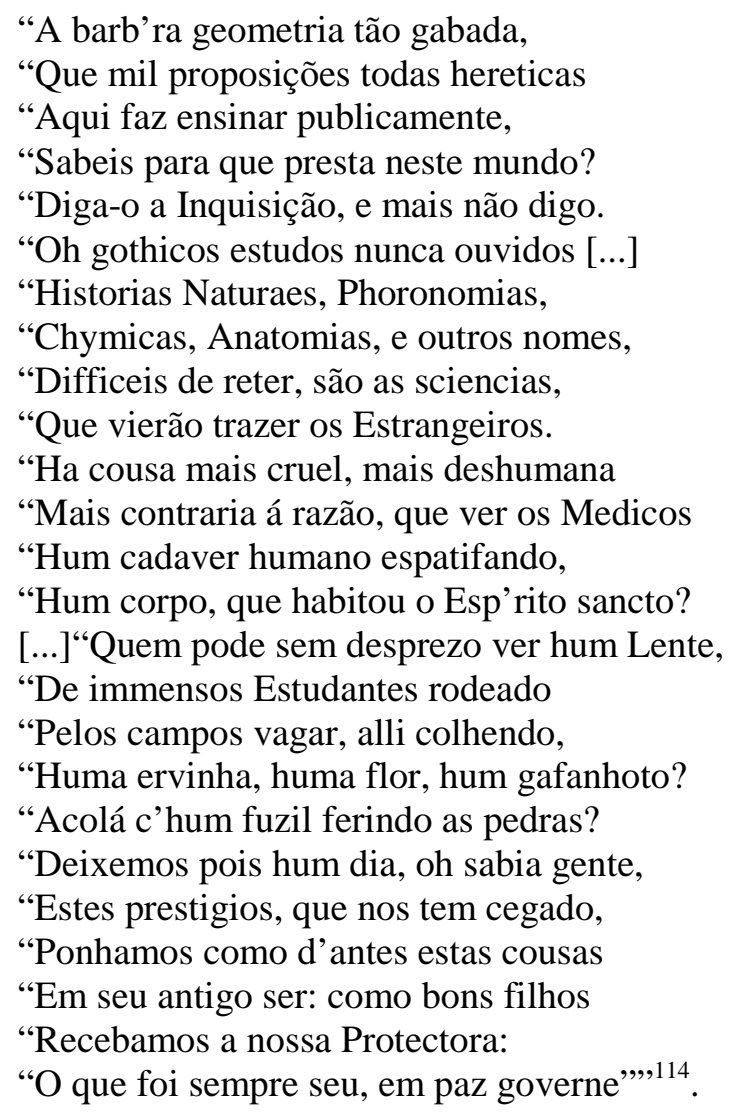

Pelo negativo, vê-se nessa passagem, portanto, uma ampla valorização do saber, uma defesa da importância das ciências naturais e da observação como métodos científicos; nota-se, ademais, a crítica à inquisição, à ignorância, à indolência, à acomodação às verdades pré-estabelecidas e à sua fonte, a Teologia, entendendo-as como predominantes na Universidade de Coimbra. Nada mais afinado com as Luzes!

\footnotetext{
113 Ibidem, p. 34.

${ }^{114}$ Ibidem, p. 35-36.
} 
Luzes, ainda, que exprimem relativa distância da conciliação predominante no Reformismo Ilustrado português, mostrando que também em Portugal o movimento Ilustrado marcou-se pela diversidade e comportou maiores ousadias.

Ao discurso do lente sucede ruidosa manifestação de aprovação de Frades e Becas; os estudantes também recebem a Estupidez com entusiasmo. Há, no entanto, uma ou outra oposição à divindade, como a de Tirceu, lente de Matemática, amante dos livros e contemplador da natureza, que traz à memória dos "sábios" presentes a lembrança da figura do marquês de Pombal ${ }^{115}$, mostrando que havia Luzes a brilhar na universidade, ainda que sufocadas sob o peso do obscurantismo. Mas o reitor, depois de um período de pausa, manda entronizar a Estupidez que, então, toma a universidade sob sua proteção, dizendo:

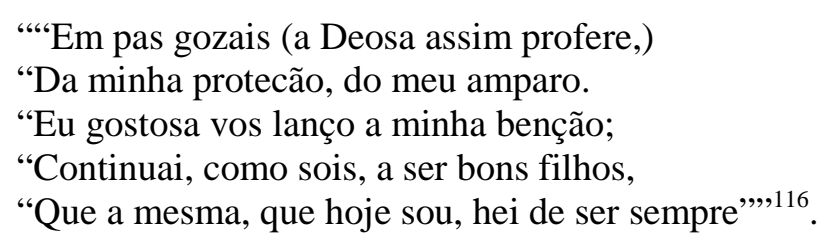

Toda essa aventura da Estupidez e a caracterização de seu domínio em Coimbra durante o reinado mariano, derrotando a mentalidade científica que lá ganhara espaço com Pombal, ecoam, como já se disse, máximas Ilustradas, revelando um autor bafejado de Luzes, e inquieto com as mazelas culturais de seu tempo! ${ }^{117}$. Não se deve esquecer, contudo, que sob dona Maria I, se houve algum retrocesso na instituição coimbrã, ele não foi absoluto (e a própria personagem Tirceu o demonstra) e, ainda, que nos postos de poder de todo o governo, houve uma alteração parcial de nomes e de grupos de intelectuais ilustrados, com sanções para aqueles estreitamente ligados ao marquês de Pombal. Assim, no Reino da Estupidez, além da explícita luta pelo império das Luzes e contra o domínio do obscurantismo, parece segredar-se uma disputa por nacos de poder dentro da estrutura do Antigo Regime, o que remete à complexidade de elementos e de interesses, às contradições, do Reformismo Ilustrado português. Todos as trajetórias de intelectuais ilustrados lusobrasileiros aqui examinadas, enfim, revelam a presença de idéias afinadas com a Ilustração em Portugal (incluindo-se aqui a revolução química de fins do século XVIII), mas, apontam, ao mesmo tempo, para os limites existentes na ordem política

\footnotetext{
115 Ibidem, p. 38-39

${ }^{116}$ Ibidem, p. 61-62.
} 
e social lusa para a proliferação das mesmas idéias, a constituição de grupos de poder pelos intelectuais ilustrados e a importância de se contar com os laços com pessoas politicamente influentes ou com o apoio de grupos, seja para o sucesso, seja para a mera sobrevivência, seja para a preservação da própria vida, seja, ainda, para a definição do próprio conteúdo das Luzes.

Se os limites do Reformismo Ilustrado até agora apontados valem para o Reino e para a América, é importante sublinhar as restrições que incidiram especificamente sobre a última. O propósito de fomentar o desenvolvimento cultural da colônia americana era levado até o ponto em que não representava uma ameaça à metrópole, em que não colidia com a manutenção dos laços de dependência colonial. Antes do período reformista, sob os reinados de Dom Pedro II e Dom João V, tendo em vista a necessidade de garantir a segurança de uma colônia que então prometia, com seu ouro e diamantes, ser fonte de imensas riquezas, o governo incentivou as atividades dos engenheiros militares, patrocinando construções e, em 1699, criando uma "aula" de "Fortificação", no Rio de Janeiro (o nome do curso sofreu alterações ao longo do século XVIII) ${ }^{118}$.

Essa subordinação do desenvolvimento cultural aos interesses sócioeconômicos e políticos do Estado português não sofreu abalos no período do Reformismo Ilustrado. No âmbito da educação universitária, preservou-se a dependência em relação à Universidade de Coimbra, considerada um aspecto nevrálgico para a sobrevivência do pacto colonial: se antes o governo impediu a criação de universidades no Brasil; se, até 1689, recusou-se a conceder todos os graus e privilégios universitários aos alunos dos colégios jesuíticos da colônia ${ }^{119}$; em 1768, rejeitou um pedido da câmara de Sabará para a criação de uma Aula de Cirurgia, alegando que tal medida relaxaria o vínculo da colônia em relação à metrópole. Segundo o procurador da Coroa, “"este vínculo não se devia relaxar e era princípio de relaxação a faculdade pública de uma Aula de Cirurgia",120. Com o

\footnotetext{
${ }^{117}$ FALCON, Francisco José Calazans, op. cit., p. 438.

${ }^{118}$ FILGUEIRAS, Carlos Alberto Lombardi. Origens da ciência no Brasil. Química Nova, 13 (3): 226, 1990.

${ }^{119}$ LEITE, Serafim. O curso de filosofia e tentativas para se criar a universidade do Brasil no século XVII, op. cit., p. 107-143; CASTELO-BRANCO, Fernando. Tentativa de criação de uma universidade no Brasil do século XVII. Anais da Academia Portuguesa de História, Lisboa, (21): 621631, 1972; e NEVES, Lúcia M. Bastos P. Universidade de Coimbra. In: SILVA, Maria Beatriz Nizza da (coord.). Dicionário da história da colonização portuguesa no Brasil, op. cit., p. 805-807.

${ }^{120}$ RAMOS, Donald. A 'Voz Popular' e a cultura popular no Brasil do século XVIII. In: SILVA, Maria Beatriz Nizza da (coord.). Cultura portuguesa na Terra de Santa Cruz. Lisboa: Editorial
} 
intuito de reforçar os elos entre a Colônia e o Reino, Pombal chegou até a incentivar a ida de brasileiros para Coimbra, concedendo bolsas de estudos para alunos pobres, e cuidou para amortecer o impacto do retorno dos estudantes à América, nomeandoos para cargos e missões públicas.

Grande parte das medidas culturais tomadas em relação à Colônia no período do Reformismo Ilustrado - mais precisamente, os estímulos à realização de estudos, à escritura de memórias sobre as potencialidades naturais da colônia e à constituição de academias científicas e literárias —, além disso, tinha sobretudo o sentido de assegurar e dinamizar a produção de matérias-primas em benefício de Portugal $^{121}$. Consoante com esta política pragmática e colonialista, a Coroa criou instituições educacionais que valorizavam os estudos práticos e científicos: a Real Academia de Artilharia, Fortificação e Desenho, em 1792, no Rio de Janeiro, e o Seminário de Olinda, em 1800, que, no parecer de Oliveira Lima, visava a formação de "gerações de párocos-exploradores, os quais a um tempo pastoreassem as almas e devassassem as riquezas vegetais e minerais de suas freguesias"122. No campo da medicina especificamente, permitiu a instalação em algumas localidades da Colônia apenas de cursos de arte cirúrgica, eminentemente práticos, em que se permitia aos alunos o acesso apenas a informações elementares ${ }^{123}$.

Este quadro se modificou em parte apenas em 1808, com a transferência da Corte para o Rio de Janeiro. O príncipe regente Dom João deu maior impulso à política de desenvolvimento de pesquisas científicas e de abertura de instituições de ensino na Colônia, então transformada em sede do Império português. Logo ao aportar na Bahia, fundou o Colégio Médico-Cirúrgico. Em seguida, já no Rio de Janeiro, instalou uma segunda escola de Medicina; abriu a Academia Real Militar, em substituição à “aula” instituída pelo conde de Resende; criou o Jardim Botânico;

\footnotetext{
Estampa, 1995, p. 143.

${ }^{121}$ DIAS, Maria Odila Leite Silva, op. cit., p. 113-148; FILGUEIRAS, Carlos Alberto Lombardi. João Manso Pereira, químico empírico do Brasil colonial. Química Nova, 16 (2): 155-160, 1993; e BOSCHI, Caio César. A universidade de Coimbra e a formação intelectual das elites mineiras coloniais. Estudos Históricos. Rio de Janeiro, 4 (7): 100-111, 1991.

${ }^{122}$ Citado por: AZEVEDO, Fernando de. A cultura brasileira: introdução ao estudo da cultura no Brasil. 6 ed. Rio de Janeiro: Editora UFRJ; Brasília: UnB, 1996, p. 549. Sobre o pensamento do Bispo Azeredo Coutinho, criador do Seminário de Olinda, veja: NEVES, Guilherme Pereira das. Pálidas e oblíquas luzes: J. J. da C. de Azeredo Coutinho 'A análise sobre a justiça do comércio do resgate dos escravos'. In: COLÓQUIO Internacional Colonização e escravidão. Realizado em Lisboa, em 1996 (datiloscrito) e ALVES, Gilberto Luiz. O pensamento burguês no seminário de Olinda (1800-1836). Ibitinga: Humanidades, 1993.

${ }^{123}$ RIBEIRO, Márcia Moisés, op. cit., p. 126-127.
} 
fundou o Laboratório de Química Aplicada, a Biblioteca Nacional, a Tipografia Régia; encorajou a abertura de tipografias particulares; e estimulou a vinda de dezenas de naturalistas estrangeiros à colônia americana ${ }^{124}$. Tais iniciativas educacionais e científicas, no entanto, sendo marcadas por seu caráter pragmático, escasso e circunstancial, não reverteram, na prática, a dependência, em termos da educação superior, da Universidade de Coimbra, nem levaram a um progresso científico expressivo. Assim, as Luzes, ao atingirem a América, por um lado, assentaram-se em redes de sociabilidade intelectual e de interesses, ora acomodandose, ora fustigando com maior intensidade alguns elementos do Antigo Regime e, por outro lado, no plano das iniciativas governamentais, viram-se subordinadas à manutenção da dependência cultural da Colônia em relação à metrópole, só ganhando maior impulso com a transferência da Corte para o Rio de Janeiro, permanecendo contudo mitigadas pelo pragmatismo e, sobretudo, pelos próprios horizontes e limites do absolutismo português.

${ }^{124}$ FILGUEIRAS, Carlos Alberto Lombardi. Origens da ciência no Brasil, op. cit., p. 222-229. 


\section{PARTE II:}

\section{Usos Prescritos e Interditados: a Censura}

Tem ultimamente chegado ao Meu Real conhecimento a narração dos horrorosos estragos que, neste século, mais que em todos os outros, tem causado a maior parte da Europa, o Espírito da Irreligião e da Falsa Filosofia [...] para atacar os Princípios mais sagrados da Religião, para invadir os mais sólidos fundamentos do Trono, $e$ para romper assim aqueles felicíssimos vínculos, com que mutuamente se sustentam, como aqueles que tão somente unem os Fiéis Cristãos à adorável pessoa de Jesus Cristo

(Edital da Real Mesa Censória de 24 de dezembro de 1770).

Sendo o Supremo Poder temporal um só único, indivíduo e o mesmo idêntico Poder em todos os Príncipes Soberanos, para Eles imediatamente emanados de Deus todo Poderoso, sem depender direta ou indiretamente de qualquer outro Poder deste Mundo para o Governo das Cousas Humanas e de tudo em que se interessa a Ordem Pública e bem do Estado Temporal [...], desde os princípios da Monarquia Portuguesa se observou o Direito e se estabeleceu o costume de não se publicarem Breves, Bulas ou quaisquer outros Rescriptos da Curia Romana [...] sem se precederem o prévio exame, Beneplácito Régio [...]

(SILVA, José de Seabra da. Deducção Chronologica e Analitica). 
Trono, Religião e Vassalos. A indissociabilidade destes elementos constituiu algo importantíssimo na censura literária na Época Colonial. A censura, no entanto, articulou esses elementos de modos diversos ao longo do período, apreendendo diferentemente as relações entre o poder temporal e o poder espiritual e entre soberano e vassalos. O marquês de Pombal, no reinado de D. José I, consoante ao despotismo esclarecido então em voga, procurou imprimir novo rumo a estas relações, cerceando as interferências da igreja e, ao mesmo tempo, impondo o Estado à sociedade. Sob Dona Maria I e durante a Regência de D. João, malgrado um certo recuo, essa orientação persistiu.

É objetivo desta segunda parte da tese, de um lado, focalizar as permanências dessa história, traçando um painel da ação do aparato censório português do século XVI até 1808, no que tange ao controle da circulação, da posse e da leitura de livros. De outro lado, quer-se examinar mais atentamente as singularidades que marcaram o período do Reformismo Ilustrado, mais precisamente o intervalo que se estende da criação da Real Mesa Censória, em 1768, até a transferência da Corte para o Rio de Janeiro, em 1808.

Inicialmente, no Capítulo 4, procurar-se-á inserir as reformas processadas no aparato censório a partir de 1768 no quadro mais amplo da política reformista iniciada com a ascensão de D. José I e de seu ministro Sebastião de Carvalho. Assim, serão identificados os órgãos que se encarregaram da censura no mundo lusobrasileiro antes de 1768, procurando-se observar as diretrizes que seguiram e avaliar o peso respectivo da igreja e do Estado na constituição dos mesmos. Neste mesmo capítulo, ainda, acompanhar-se-ão as transformações processadas no aparato censório de 1768 a 1808, os parâmetros que nortearam a ação dos mesmos e as principais obras que foram proibidas no período.

O Capítulo 5 dedicar-se-á à reconstituição das práticas dos órgãos censórios, mais precisamente no que concernia à fiscalização da posse e à circulação de livros, sendo, primeiro, apresentadas suas linhas gerais no período colonial; em seguida, examinadas as especificidades que as caracterizaram em dois momentos: antes e depois de 1768. O Capítulo 6 trata das licenças concedidas pelos órgãos censórios para a leitura de livros proibidos em Portugal e na América, buscando confrontar as normas que vigoravam sobre a concessão de licenças às práticas desenvolvidas pela censura, em suas mudanças ao longo do período do Reformismo Ilustrado. 


\section{Capítulo 4:}

\section{A Censura sob o Reformismo Ilustrado}

Na Europa do século XVIII, no bojo de um conjunto de reformas promovidas pelos governos, desenvolveu-se uma política de estatização da censura, que foi acompanhada pelo crescimento da preocupação com as obras de caráter político em detrimento das religiosas ${ }^{1}$.

Em Portugal, em 1768, criou-se a Real Mesa Censória, tribunal régio em cuja composição havia um mesmo número de leigos e de clérigos. A instalação deste órgão acompanhava a tendência geral de secularização da censura e fazia parte da política reformista, absolutista e regalista, teórica e prática, seguida pela Coroa portuguesa a partir do reinado de D. José I, expressando, deste modo, os interesses específicos do Reformismo Ilustrado Português.

Antes, porém, de examinar as inflexões produzidas com a estatização da censura, serão abordadas as linhas gerais da censura tríplice.

\section{Antecedentes: a Censura Tríplice (1517-1768)}

A censura no mundo luso-brasileiro, no período compreendido entre 1517 e 1768, esteve profundamente associada à Reforma Católica e à Contra-Reforma a propriamente dita. A Reforma Católica se estendeu do final da Idade Média até o século XVIII e teve como preocupação central aproximar a Igreja dos seus fiéis ${ }^{2}$. O povo cristão carecia de uma direção firme e de respostas para suas angústias em relação à salvação da alma, situação esta avivada num contexto de guerras e

\footnotetext{
${ }^{1} \mathrm{Na}$ Áustria, sob os cuidados de Gerhard van Swieten, estabeleceu-se uma comissão de censura de livros, medida que integrava um conjunto de reformas educacionais (Derek Beales. Apud. MAXEWLL, Kenneth. Pombal: Paradox of the Enlightenment, op. cit., p. 92).

${ }^{2}$ DELUMEAU, Jean. La Reforma. Barcelona: Editorial Labor, 1967, p. 13 e 26; MULLET, Michael. A Contra-Reforma. Lisboa: Gradiva, 1985, p. 8-12; e SOUZA, Laura de Mello e. O diabo e a Terra de Santa Cruz. São Paulo: Companhia das Letras, 1986, p. 89-92.
} 
calamidades e estimulada pelo aparecimento do livro impresso ${ }^{3}$. A preocupação de responder às angústias e à necessidade de orientação sentida pelos fiéis, colocandolhes as bases teológicas da religião, na realidade, está na origem da Reforma Católica e, mesmo, da Reforma Protestante. Embora tivessem pontos de conflito, ambos os movimentos fundavam-se nas mesmas motivações, tematizaram os mesmos problemas (a relação entre fé, obras e salvação; os sacramentos; a reeducação das massas; o sacerdócio; as relações entre Igreja e Estado etc.), ainda que de modo diferente, e usaram métodos similares (a caça às bruxas e a criação de escolas dominicais, por exemplo $)^{4}$.

A igreja católica tentou aproximar-se do seu rebanho através de uma série de medidas pelas quais promovia a aculturação do último e, ao mesmo tempo, reorganizava a si mesma e ao corpo clerical $^{5}$. Julgava-se que os fiéis estavam à deriva, e, de fato, as populações européias manifestavam, até mesmo no século XVIII, sob a máscara cristã, uma religiosidade e uma vivência eivadas de reminiscências pagãs e heterodoxas em relação ao cristianismo ${ }^{6}$; na América Portuguesa, havia um intenso sincretismo religioso - e moral - que refundia tradições pagãs, africanas, indígenas, católicas e judaicas, seus ritos e suas práticas mágicas $^{7}$. A remodelação da confissão, a realização de reformas sistemáticas nos bispados (disciplinando-os e inspecionando através das visitações episcopais, paróquia por paróquia), a fundação de colégios e universidades, a criação dos seminários integraram este conjunto de medidas reformistas ${ }^{8}$.

Algumas dessas medidas, contudo, possuíam um caráter também repressivo e, mais do que isto, expressavam uma outra orientação importante da Reforma Católica a partir da Reforma Protestante: o anti-protestantismo. Assim, nas deliberações do Concílio de Trento (1545-1563), marco da Contra-Reforma propriamente dita, vêemse posições antagônicas às defendidas pelos protestantes ${ }^{9}$ : o Concílio confirmou os sete sacramentos (batismo, crisma, matrimônio, penitência, ordenação, comunhão e

\footnotetext{
${ }^{3}$ DELUMEAU, Jean. La Reforma, op. cit., p. 6-12 e 21.

${ }^{4}$ Ibidem, p. 32-33, 65, 69 e 262-283 e MULLET, Michael, op. cit., p. 18 e 23.

${ }^{5}$ MULLET, Michael, op. cit., p. 48-49.

${ }^{6}$ Ibidem, p. 47-48; GUINZBURG, Carlo. Os andarilhos do bem: feitiçarias e cultos agrários nos séculos XVI e XVII. São Paulo: Companhia das Letras, 1988, p. 46-47; e Idem. O Queijo e os vermes: o cotidiano e as idéias de um moleiro. São Paulo: Companhia. das Letras, 1986, p. 69-70 e 216.

${ }^{7}$ SOUZA, Laura de Mello e. O diabo e a Terra de Santa Cruz, op. cit., p. 97- 98.

${ }^{8}$ MULLET, Michael, op. cit., p. 24 e 28-34.

${ }^{9}$ DELUMEAU, Jean. La Reforma, op. cit., p. 103.
} 
extrema-unção), o papel do homem na sua própria salvação (embora aceitasse como crucial a intervenção de Cristo na redenção da alma); exaltou a Virgem e os Santos; manteve a não aceitação da Bíblia e da missa em língua vulgar (os documentos litúrgicos, especialmente o Missal, deviam ser publicados apenas em latim); e, finalmente, recomendou a publicação de um Índex de livros proibidos ${ }^{10}$.

A publicação do Índex e a proibição do uso da Bíblia e dos documentos litúrgicos em língua vulgar não foram as únicas medidas do Concílio Tridentino que incidiram sobre o mundo dos livros. Trento determinou também que o Ordinário isto é, os Juízos Eclesiásticos existentes em cada diocese - autorizasse a publicação de obras de caráter sagrado apenas após um exame meticuloso; definiu punições aos indivíduos que imprimissem ou fizessem circular livros e manuscritos não autorizados; e fixou penalidades, semelhantes às aplicadas aos autores de tais escritos, para aqueles que os possuíssem ou lessem, exceto se o declarassem antecipadamente ${ }^{11}$. O controle das práticas de leitura, portanto, foi um dos elementos da ação da igreja católica da Contra-Reforma, integrando um movimento reformista e, ao mesmo tempo, de ataque às heterodoxias (aqui incluído o protestantismo).

As deliberações do Concílio de Trento foram prontamente aceitas, sem reticências, em Portugal e Espanha ${ }^{12}$. Nesses países, a ação do Santo Ofício da Inquisição e o esforço catequético da Companhia de Jesus, a mais importante ordem religiosa fundada no período da Contra-Reforma, ecoavam o espírito tridentino, além da obsessão anti-semita. Ambos visavam, de um lado, a aculturação do rebanho católico e, de outro, a repressão a tudo o que cheirasse à heresia, colocando, assim, os fiéis a par das conformidades estabelecidas pela Igreja ${ }^{13}$.

A censura, em Portugal, foi profundamente afetada pelo espírito da ContraReforma. Desde 1517, o Ordinário incumbiu-se da censura ${ }^{14}$. Muito cedo, porém, a atividade censória foi compartilhada com outros tribunais, não constituindo, portanto, monopólio do Ordinário: a Inquisição, a partir de 1536, a quem coube um papel importantíssimo, e o Desembargo do Paço, depois de $1576^{15}$. Esse sistema de

\footnotetext{
${ }^{10}$ Ibidem, p. 103-106 e MULLET, Michael, op. cit., p. 19 e 30.

${ }^{11}$ BASTOS, José Timóteo da Silva, op. cit, p. 19-20.

12 TORGAL, Luís Reis, op. cit., vol. 1, p. 110.

${ }^{13}$ MULLET, Michael, op. cit., p. 10 e 35-36; e VAINFAS, Ronaldo. Trópico dos pecados: moral, sexualidade e inquisição no Brasil. Rio de Janeiro: Campus, 1989, p. 7-32, 190-192 e 215-236. ${ }^{14}$ RIZZINI, Carlos, op. cit., p. 233.

${ }^{15}$ ALCALÁ, Angel. La censura inquisitorial de la literatura del Siglo de Oro en España y en Portugal: comparación de sus 'indices' y sus resultados. In: NOVINSKY, Anita, CARNEIRO, Maria
} 
tríplice censura perdurou até 1768. Os tribunais que cuidavam da censura eram independentes uns dos outros, possuindo cada qual suas regras e princípios; os documentos são bastante contraditórios sobre a articulação existente entre eles, indicando que os limites de atuação de cada um flutuaram no tempo ${ }^{16}$. Inicialmente, o Santo Ofício e o Ordinário defendiam a Igreja, enquanto o Desembargo do Paço, o poder civil ${ }^{17}$. Os clérigos tinham a primazia, pois eles eram os juízes da inquisição e do ordinário, controlando a concessão de duas das três licenças necessárias para que um livro fosse impresso. Concedia-se, além disso, prioridade ao combate à heresia, sem, contudo, relegar ao esquecimento as questões de caráter político, que foram mantidas em segundo plano ${ }^{18}$. Esta tendência, com o tempo, modificou-se.

A censura inquisitorial acompanhou a progressiva politização das edições portuguesas do século XVII, sobretudo das que se referiam à Restauração, e ampliou seus horizontes de preocupação para além dos limites da religião, examinando também os aspectos políticos. Com isso, houve problemas na articulação das atuações dos revedores inquisitoriais e da $\operatorname{Coroa}^{19}$. Muitas vezes, acrescente-se, heresia e contestações de ordem política se misturaram numa mesma obra, com o que a censura, primordialmente religiosa, assumiu um conteúdo político. Na obra do holandês e protestante jusnaturalista Hugo Grotius, por exemplo, defendia-se a idéia de que o papa não poderia, com a justificativa da dilatação da fé, conceder a Portugal o direito de dominar as Índias, seus mares e comércio: com base no direito natural e das gentes, o autor considerava legítimo a qualquer povo navegar pelos mares e comerciar com os indígenas. Esta obra foi praticamente toda proibida pelo Índex inquisitorial português de 1624 , sob o pretexto de que o autor era protestante e de que negava os direitos de Sua Santidade ${ }^{20}$.

Luiza Tucci (org.). Inquisição: ensaios sobre mentalidade, heresias e arte, Rio de Janeiro: Expressão e Cultura; São Paulo: Edusp, 1992, p. 429.

${ }^{16}$ MARQUILHAS, Rita. A faculdade das letras: leitura e escrita em Portugal no século XVII. Lisboa: Faculdade de Letras da Universidade de Lisboa, 1996, p. 170-171 (Tese de doutorado).

${ }^{17}$ MORAES, Rubens Borba de. Livros e bibliotecas no Brasil Colonial. São Paulo: Secretaria da Cultura, Ciência e Tecnologia do Estado de São Paulo, 1979, p. 51.

${ }^{18}$ BASTOS, José Timóteo da Silva, op. cit., p. 59-60.

${ }^{19}$ MARQUILHAS, Rita, op. cit., p. 171-172.

${ }^{20}$ TORGAL, Luís Reis, op. cit., vol. 1, p. 131. 
A censura, dividida entre o Desembargo do Paço, os Tribunais Eclesiásticos e a Inquisição, cada qual com dois examinadores, era bastante morosa na aprovação das obras. Ao exame faltavam unidade de critérios e regras claras e específicas, em virtude do que havia arbitrariedades ${ }^{21}$. Manuel Fernandes Vila Real, autor de Político Cristianíssimo, por exemplo, teve seu livro censurado pelo Santo Ofício devido apenas à sua condição de cristão-novo: um dos censores nenhum óbice encontrou para a publicação, mas os outros três procuraram dar uma interpretação particular, "própria", a afirmações completamente inócuas do autor, vindo a interditar a edição da obra ${ }^{22}$.

Até 1768, os Índices de Livros proibidos em Portugal, no caso das obras dogmáticas, freqüentemente foram cópias das proibições estabelecidas pela Sorbonne, Louvain, Roma e Espanha; em território luso chegou-se mesmo a promover reimpressões dos Índex tridentinos e romanos de 1551 (reimpresso em 1557), 1564 e 1597. Em Portugal, houve maior rigidez do que na Espanha em relação aos livros jocosos com clérigos e monarcas. E, ainda, foi-se mais radical do que em Roma quanto aos livros que continham traduções de textos bíblicos para o português $^{23}$. Até 1551, a Inquisição portuguesa proibiu praticamente apenas obras doutrinárias, deixando de lado as obras literárias ${ }^{24}$. O Índex Inquisitorial de 1551, o primeiro rol de livros proibidos elaborado pela inquisição portuguesa, inspirado no Índice de Louvain de 1550, interditou a leitura da Bíblia em português - a proibição da Bíblia em línguas vulgares, é bem verdade, generalizava-se no Ocidente, sendo, como já se mostrou, uma forma pela qual a igreja reagia contra o livre exame propugnado pelas Reformas Protestantes ${ }^{25}$. Além do "testamento de Christo em Lingoagem", pode-se destacar, dentre as obras julgadas defesas pelo mesmo Índex, sete Autos de Gil Vicente (cujo nome não é mencionado), e as "novelas de Joan bocatio" (o Boccacio, célebre escritor italiano, que teve em outra data também proibido o Decameron $)^{26}$.

O Índex de 1561 aferrolhou, dentre outros livros, as comédias de Jorge Ferreira de Vasconcelos: uma adaptação portuguesa de Celestina, do espanhol

\footnotetext{
${ }^{21}$ MARQUES, Maria Adelaide Salvador. A Real Mesa Censória e a cultura nacional. Coimbra: Universidade de Coimbra, [s/d]., p. 8 e 57 e MORAES, Rubens Borba de, op. cit., p. 51-52.

${ }^{22}$ TORGAL, Luís Reis, op. cit., vol. 1, p. 352 e 416.

${ }^{23}$ ALCALÁ, Angel, op. cit., p. 422-425.

${ }^{24}$ Ibidem, p. 426.

${ }^{25}$ Ibidem, loc. cit. e BASTOS, José Timóteo da Silva, op. cit., p. 44.
} 
Fernando Rojas, intitulada Eufrósina (1555), que apresentava, em relação à original, um maior número de situações eróticas, satíricas e a menção "expresa del origen judeoconverso de la protagonista, corrompida por su celestinesca Silvia de de Soussa"; e Ulisippo (sem data certa para a primeira edição), "estudio realista y satírico de las inmorales costumbres clandestinas de la burguesía lisboeta a través de las de uno de sus ciudadanos, Ullisippo, que por su significado etimológico cuenta por toda la ciudad" (mais tarde, foram permitidas as edições expurgadas de ambas, respectivamente, de 1616 e 1618$)^{27}$.

O rol de 1564 atingiu os "Tratados quer impressos, quer de mão de devoções, ou para milhor dizer, superstições que prometem a quem quer q'as fizer ou mander fazer q'alcançarem qualquer cousa que pedirem, ou escapará de todo perigo, ou cousas similhantes", que não parecem ser senão as denominadas "cartas de tocar" 28 . Pelo mesmo edital determinou-se também a proibição (ratificada em 1581) de Ropica Pnefma, obra escrita em 1531 por João de Barros, sob a influência de Erasmo, considerada uma manifestação do Renascimento português ${ }^{29}$. Nesse livro, cujo título helenista foi traduzido por seu autor como "Mercadería espiritual", Tempo, Vontade, Entendimento e Razão, personagens alegóricos, expressam um cetecismo maduro e falam sobre grandes problemas da vida humana, sendo a Razão apresentada como a vigia da ponte da Morte, "la que debe em todo caso examinar las falsas mercaderías y distinguirlas de las ortodoxas",30.

Em 1581, proibiram-se a Celestina, do espanhol Fernando de Rojas; a Diana, de Jorge de Montemayor, em "toas as partes"; em 1624, o novo Índice permitiu esta última $^{31}$. A Diana merece um comentário à parte, na medida em que, como se verá no Capítulo 7, foi obra das mais lidas na América Portuguesa na passagem do século XVI para o século XVII: redigida em castelhano pelo português Jorge Montemor ${ }^{32}$, tem como protagonista uma pastora, que procura reviver o idílio que mantivera com seu amante, o pastor Sireno, saindo em busca de lugares em que vivera e revisitando as velhas recordações. Segundo palavras de Sérgio Buarque de HOLANDA, esse livro é "declaradamente uma canção feminina, onde, tal como nas velhas canções de

\footnotetext{
${ }^{26}$ BASTOS, José Timóteo da Silva, op. cit., p. 42 e ALCALÁ, Angel, op. cit., p. 426 e 434.

${ }^{27}$ ALCALÁ, Angel, op. ci.t., p. 443.

${ }^{28}$ BASTOS, José Timóteo da Silva, op. cit., p. 42.

${ }^{29}$ Ibidem, loc. cit. e ALCALÁ, Angel, op. cit., p. 445.

${ }^{30}$ ALCALÁ, Angel, op. cit., loc. cit.

${ }^{31}$ Ibidem, p. 435 e 453.
} 
amigo, é natural que à mulher venha a caber a parte da vítima lamentosa, vítima, em verdade, da crueza e mobilidade dos homens" ${ }^{, 3}$.

Em 1584, a censura inquisitorial teve como vítima nada mais nada menos que Os Lusíadas, de Luís de Camões, obra que havia escapado em 1572 - nesta data, o revedor da inquisição apenas mandou que no livro se advertisse aos "Lectores que o Author pera encarecer dificuldade de nauegaçam \& entrada dos Portugueses na India usa de hua fição dos Deoses dos Gentios", com o fim de "ornar o estillo Poetico", não devendo, pois, os leitores confundir deuses falsos com verdadeiros ${ }^{34}$. Algumas passagens desse clássico da literatura portuguesa foram alteradas. Ao que parece, na mesma data, foram apreendidos o tratado De Justitia, de D. Jerônimo Osório, o Cícero português, e a edição feita por Galhardo de uma famosa obra sobre vidas de santos, o Flos Sanctorum ${ }^{35}$. Esta obra tornar-se-ia alvo de dúvidas por parte dos cristãos-novos no Reino, sendo, por isto, proibida em 1637 pela Inquisição ${ }^{36}$; em 1642, porém, foi autorizada a leitura da sua Segunda Parte por pessoas cristãs-velhas.

Em 1606, a inquisição portuguesa mandou que os livreiros entregassem o Don Quijote, comédias de Lope de Vega e obras de Petrarca. Em 1624, o Índex inquisitorial ordenou a alteração de vários trechos de Don Quijote, fazendo o mesmo com várias de suas Novelas ejemplares; o mesmo se deu com partes de algumas das obras de Lope de Vega; e "a satyra a Dom Luís de Góngora”, dentro da obra de Quevedo $^{37}$. Nesse mesmo Índex de 1624, o medo do protestantismo conduziu a Inquisição a proibir os livros em hebraico, alemão, flamengo e inglês, tidos mesmo os não arrolados no Índex - como perigosos, e a recomendar cautela com os franceses, fechando com isto as portas de Portugal para o contato com o AlémPirineus. O Índex de 1624 foi o último publicado em Portugal até as reformas pombalinas $^{38}$.

\footnotetext{
${ }^{32}$ HOLANDA, Sérgio Buarque de. Capítulos de literatura colonial, op. cit., p. 306.

${ }^{33}$ Ibidem, p. 306-311.

${ }^{34}$ BASTOS, José Timóteo da Silva, op. cit., p. 46. Sobre a proibição dos Lusíadas e o significado dela em termos da relação entre Estado e literatura em Portugal no século XVI, veja: LAJOLO, Marisa. Sociedade e literatura: parceria sedutora e problemática. In: ORLANDI, Eni Puccinelli (org.). Sociedade e linguagem. Campinas: Editora da Unicamp, 1997, p. 69-72.

${ }^{35}$ LAJOLO, Marisa, loc. cit.

${ }^{36}$ MARQUILHAS, Rita, op. cit., p. 193.

${ }^{37}$ ALCALÁ, Angel, op. cit., p. 432-433, 436 e 439.

${ }^{38}$ TORGAL, Luís Reis, op. cit., vol. 1, p. 113; XAVIER, Ângela Barreto, op. cit., p. 107; e ALCALÁ, Angel, op. cit., p. 433.
} 
A vigilância da inquisição sobre a impressão de livros fez-se presente também na Colônia, onde os prelos só foram liberados com a instalação da Corte portuguesa: em 1748, enviou-se ao comissário José de Souza Ribeiro, no Rio de Janeiro, carta em que se lhe ordenava "recolher todos os livros de Samuel Puffendorf e os remetesse a esta $\mathrm{Inq}^{\mathrm{m}}$ e q mandasse chamar o impressor ou impressores de q tiver noticia, e q os noteficasse por termo q assignaraõ pq naõ imprimaõ livros alguns, concluzões ou outros quaesquer papeis sem preceder expressa licença do Santo officio, e constando q depois de serem advertidos continuaraõ nesta introduzida e pernicioza novid ${ }^{\mathrm{e}} \mathrm{o}$ partecipasse a esta Meza $\mathrm{p}^{\mathrm{a}}$ se proceder contra elles" ${ }^{\text {39 }}$. Esta proibição, notável descoberta de Bruno Feitler, tem como alvo muito provavelmente a gráfica aberta por Antônio Isidoro da Fonseca em 1746, cujo fechamento foi ordenado pela Coroa em $1747^{40}$.

Além da censura propriamente dita, deve-se mencionar também o controle existente nos colégios jesuíticos em relação aos livros didáticos. Todos os "textos dos autores selecionados para os livros escolares eram inexoravelmente expurgados das palavras e passos que os pedagogos da Companhia de Jesus entendiam ser prejudiciais à formação moral e intelectual dos estudantes"41. Havia grande desconfiança em relação aos textos poéticos, sendo objeto de rigor principalmente os escritos em português ${ }^{42}$. Em 1583, a congregação provincial da Bahia propôs "que se desse alguma emenda aos livros de humanidades de Plauto, Terêncio, Horácio, Marcial e Ovídio" ${ }^{43}$. No ensino da filosofia e das ciências, o Ratio Studiorum, o plano pedagógico da companhia de Jesus, como se viu no Capítulo 1, consagrava um lugar especial a Aristóteles e a são Tomás. Os pontos do pensamento do primeiro ou os escritos de seus intérpretes, sempre que fossem desfavoráveis à ortodoxia da fé católica, eram proibidos ${ }^{44}$.

\footnotetext{
${ }^{39}$ IANTT, Inquisição de Lisboa, "Correspondência enviada - Registro", Livro 22, p. 405v-40. Agradeço a Bruno Feitler pelo repasse das preciosas informações colhidas nesse códice.

${ }^{40}$ RIZZINI, Carlos, op. cit., p. 310.

${ }^{41}$ CARVALHO, Rómulo de, op. cit., 1986, p. 339.

${ }^{42}$ Serafim Leite. Apud. ARAÚJO, Jorge de Souza. Perfil do leitor colonial. Rio de Janeiro: UFRJ, 1988, p. 46-47. (Tese de doutorado)

${ }^{43}$ Ibidem, loc. cit.

${ }^{44}$ Ratio Studiorum, apud. CARVALHO, Rómulo de, op. cit., p. 344-345.
} 


\section{Reformas do Aparato Censório (1768-1808)}

Pombal, em linhas gerais, como se observou anteriormente, desenvolveu uma ofensiva absolutista, regalista e reformista, atacando tudo o que ameaçava a preeminência do trono e que entendia ser obstáculo à modernização que almejava. A domesticação da inquisição, a subordinação da nobreza, as reformas econômicas, sociais e educacionais, o combate aos jesuítas e o ataque às teorias corporativas de poder foram episódios interligados desta ofensiva, assim como a criação da Real Mesa Censória. A existência desses alvos e o caráter interligado dos mesmos encontram-se por demais evidentes na documentação relativa ao novo tribunal censório.

Na lei de 5 de abril de 1768, que instituiu a Real Mesa - e também em muitos dos editais e leis expedidos pela mesma - são apresentados como objetivos a unificação do processo censório, o aumento de sua eficácia, sua subordinação direta à Coroa e, ao mesmo tempo, o prosseguimento da ofensiva contra os jesuítas, iniciada em 1759 com a expulsão da Companhia de Jesus ${ }^{45}$. A mencionada lei faz uso da obra Deducção Chronologica e Analítica, de José de Seabra da Silva(?) ${ }^{46}$, buscando com a mesma legitimar a reforma que se propunha para a censura. Na obra citada, conforme mostra o segundo texto em epígrafe nesta segunda parte da tese, ao mesmo tempo em que se afirma a origem imediatamente divina do poder régio, coloca-se sob a jurisdição dele a censura literária, renegando como indevida a ingerência romana e eclesiástica nesta matéria. Na lei de 5 de abril, não há menção à proveniência diretamente divina da realeza, mas são reproduzidos explicitamente trechos do livro de José de Seabra da Silva. Defende-se como "notório, inauferível e inabdicável Direito da Soberania Temporal" a censura dos livros, ainda quando estes fossem relativos a religiosos e à doutrina, situação em que pertenceriam também ao foro da igreja. Firma-se como direito e costume louvável das monarquias não

\footnotetext{
${ }^{45}$ MARQUES, Maria Adelaide Salvador, op. cit., p. 24-30 e 57; e MORAES, Rubens Borba de. Livros e bibliotecas no Brasil colonial, op. cit., p. 52.

${ }^{46}$ A autoria desta obra é motivo de discussão entre os historiadores. Alguns consideram que, ao menos em parte, sua composição foi feita pelo Marquês de Pombal. É certo, de qualquer modo, que ela possuía um caráter oficial e constituiu peça da propaganda do governo (MARQUES, Maria Adelaide Salvador, op. cit., p. 13-14 e MAXWELL, Kenneth. Pombal: Paradox of the Enlightenment, op. cit., p. 20), tendo inclusive sido distribuída com intuito propagandístico em várias partes do Reino (FALCON, Francisco José Calazans, op. cit., p. 380).
} 
permitir a publicação e a execução em seus domínios de "Bulas, Breves, ou Rescriptos, emanados da Curia de Roma", sem que antes os mesmos obtivessem o beneplácito régio. Ao mesmo tempo, lançam-se acusações contra os jesuítas, responsabilizando-os pela maquinação de um volumoso índice expurgatório de livros baseado nos Índex Romanos e sancionado pela inquisição, lesando com isto a Soberania Temporal; pela confusão na inspeção dos livros processada pelo desembargo do paço, inquisição e ordinário; pelo desterro "desta Monarquia" de "toda a boa e sãa Literatura", precipitando "todos os Vassalos de Portugal no inculpável, e necessário idiotismo". Na lei, ainda, registra-se como objetivo a superação das divisões e do enfraquecimento do sistema tríplice de censura vigente até então ${ }^{47}$. A lei, portanto, está eivada de regalismo e de uma preocupação em reforçar o poder da Coroa, tendo por correlato o anti-jesuitismo.

Como conseqüência do propósito regalista, absolutista e anti-corporativo que permeou a criação da Real Mesa Censória, incumbiu-se este tribunal da elaboração de um novo Índex Expurgatório $^{48}$, o qual, é preciso sublinhar, deixava de se confundir com o proposto pelo Papa, pois a introdução do Índex pontifício no Reino de Portugal e seus Domínios ficou condicionada à concessão do beneplácito real ${ }^{49}$. $\mathrm{O}$ empenho pombalino de afastar a ingerência da igreja na atividade censória foi de tal envergadura que, em abril de 1768, ordenou-se a prisão do bispo de Coimbra, D. Miguel da Anunciação, porque este, em uma carta pastoral, inseriu um índice de livros proibidos, assim considerados pelo prelado por conterem doutrinas perigosas para a fé e costumes (no índice estavam autores anti-católicos, tais como Voltaire e Rousseau, e pensadores regalistas) ${ }^{50}$.

Os jesuítas apareceram como alvos de ataque do consulado pombalino numa outra situação: como comparsas dos "puritanos". Nesta cumplicidade, bem como na perseguição que lhe foi movida, os livros se fizeram presentes. $\mathrm{O}$ "alvará de lei secretíssimo" de 1768, sancionado contra os puritanos, reproduz alguns topoi pombalinos referentes aos jesuítas: movidos pelo objetivo de arruinar o Reino com toda a segurança, os inacianos teriam proibido a introdução de "livros estrangeiros e

\footnotetext{
${ }^{47}$ Lei de 05 de abril de 1768. Apud. BASTOS, José Timóteo da Silva, op. cit., p. 69-70.

${ }^{48}$ MARQUES, Maria Adelaide Salvador, loc. cit.

${ }^{49}$ LEI de 02 de abril de 1768. In: COLEÇAM das leis, decretos, e alvarás que, compreende o feliz reinado D'El rey fidelíssimo D. José I, nosso senhor desde o annno de 1765 até 1770. Lisboa: Miguel Rodrigues, 1771.

${ }^{50}$ DOMINGUES, Francisco Contente, op. cit., p. 97.
} 
até de novas publicações da Europa", para que se não conhecesse o mal que eles faziam; o Padre Vieira, além disso, seria um impostor ${ }^{51}$. Os jesuítas, coroando o rol dos malefícios que causaram, teriam sido responsáveis pela introdução da seita dos puritanos entre a nobreza" ${ }^{\natural 2}$. O Alvará, por fim, manifestava uma preocupação com a existência de livros de genealogia que colocavam em dúvida a "pureza de sangue" de várias casas de primeira grandeza do Reino, famílias estas julgadas competentemente ‘limpas' pelos tribunais da Mesa de Consciência e Ordens e do Santo Ofício ${ }^{53}$. Por isto, estabeleceu que deveria "ser publicado um outro Alvará dando a conhecer os referidos livros de Genealogia e os que deles fazem reprovados usos" ${ }^{\text {"54 }}$. Embora J. Lúcio de Azevedo sugira que esta proposição de cunho censório não tenha sido cumprida $^{55}$ - talvez pela dificuldade política de concretizá-la face à correlação de forças entre a monarquia e a nobreza -, ela é congruente com as diretrizes gerais da política pombalina e demonstra como a censura literária afinava-se com essas.

A Real Mesa possuía uma outra notória preocupação, esta sim quase tão obsessiva como a referente aos inacianos: com os ventos mais radicais da Ilustração $^{56}$. As idéias de alguns pensadores da Ilustração punham em risco o delicado equilíbrio que o Reformismo Ilustrado português procurava manter entre a assimilação do pensamento crítico das Luzes e a contenção de seus possíveis efeitos: a contestação do absolutismo e do sistema colonial ${ }^{57}$. Por isso, mereceram o repúdio veemente do aparato censório luso, que publicou vários editais interditando a circulação e a leitura de escritos que os disseminavam ${ }^{58}$. Como a posição governamental diante das Luzes era ambivalente, assistiu-se, às vezes, a uma aparente contradição: a citação, em textos de leis e alvarás, de alguns autores e livros que condenara $^{59}$.

\footnotetext{
${ }^{51}$ CARNEIRO, Maria Luiza Tucci. Preconceito racial no Brasil Colônia: os cristãos-novos. São Paulo: Brasiliense, 1983, p. 178.

${ }^{52}$ Ibidem, loc. cit.

${ }^{53}$ Ibidem, p. 181.

${ }^{54}$ Ibidem, p. 182.

${ }^{55}$ Ibidem, p. 192.

${ }^{56}$ Francisco José Calazans Falcon, ao analisar o regimento do Santo Ofício ordenado em 1774, mostra que a Inquisição, após a reforma pombalina, também perseguia velhos e, ao mesmo tempo, novos demônios: de um lado, feiticeiros, sortílegos, adivinhadores, astrólogos, sigilistas e, de outro, os "jacobinos" (op. cit., p. 442).

${ }^{57}$ A posição de delicado equilíbrio face às Luzes por parte do reformismo ilustrado português é sublinhada em: NOVAIS, Fernando Antônio, op. cit., p. 224.

${ }_{58}^{5}$ IANTT. Real Mesa Censória, Editais, Caixa 1.

${ }^{59}$ Esta contradição é apontada por Francisco José Calazans Falcon (Ibidem, p. 445).
} 
Dona Maria I, em 1787, reformou a censura, criando um novo organismo em substituição à Real Mesa Censória: a Real Mesa da Comissão Geral para o exame e a censura dos livros. Justificou-se a iniciativa com a inoperância da Real Mesa Censória $^{60}$. Essa medida traduz o espírito do reinado de Dona Maria I: dar continuidade ao que lhe antecedeu e, ao mesmo tempo, fazer-lhe reparos em relação às medidas que não aprovava e alterar alguns rumos. Tal iniciativa não visava um rompimento com a política do governo anterior, mas implicou, é certo, um recuo, mais teórico do que prático, no ímpeto secularizador e regalista. $\mathrm{O}$ decreto de instituição da Real Mesa da Comissão Geral, de 21 de junho de 1787, subordinou implicitamente a Coroa ao Papado, invocando a bula Romanorum Pontificum, baixada pelo Papa Pio VI em 1780 e pela qual o Sumo Pontífice reclamava o direito da censura de livros, que the fora retirado por Pombal ${ }^{61}$. A Rainha reconheceu a autoridade pontifícia no assunto, ao mesmo tempo em que se proclamou autorizada pelo papa a criar o novo tribunal censório ${ }^{62}$. Determinou que o presidente do tribunal teria que ser necessariamente um clérigo ${ }^{63}$ e, além disso, restabeleceu a legitimidade da censura eclesiástica nas matérias religiosas, autorizando os bispos não a exercer o poder de permitir ou proibir que se imprimissem livros, mas apenas a "censurar, e declarar a doutrina", no que claramente havia uma nítida distância em relação às normas pombalinas, que não permitiam aos prelados gozar desta prerrogativa. Quando achassem "livros maos" circulando nos seus bispados, os prelados deveriam recorrer à Real Mesa da Comissão Geral ou à própria Coroa para que se tomassem as providências necessárias ${ }^{64}$. Simbolizando a continuidade subjacente à instituição do novo tribunal, foi nomeado como um dos seus deputados o padre Antônio Pereira de Figueiredo, oratoriano ilustrado, ex-deputado da Real Mesa Censória, autor de uma gramática que fora livro oficial sob Pombal e um dos teorizadores da práxis política do pombalismo ${ }^{65}$.

\footnotetext{
${ }^{60}$ MORAES, Rubem Borba de, op. cit., p. 54-55.

${ }^{61}$ CARREIRA, Laureano. O Teatro e a censura em Portugal na segunda metade do século XVIII. Lisboa: Imprensa Nacional/ Casa da Moeda, 1988, p. 79-80.

${ }^{62}$ Diz a Rainha pelo decreto que o Santo Padre Pio VI, "Presidente na Universal Igreja de Deos, delegou no Tribunal, e Ministros, que Eu nomear para intenderem sobre a permissão e prohibição dos Livros em Meus Reinos, e Domínios, aquella parte da sua Jurisdição necessária”. Decreto de 21 de junho de 1787. Apud. BASTOS, José Timóteo da Silva, op. cit., p. 132-133.

${ }^{63}$ MARTINS, Wilson, op. cit., vol. 1, p. 526.

${ }^{64}$ Decreto de 21 de junho de 1787. Apud. BASTOS, José Timóteo da Silva, op. cit., p. 134-135.

${ }^{65}$ MARQUES, Maria Adelaide Salvador, op. cit., p. 32 e CASTRO, Zília Osório de, op. cit., p. 12.
} 
A Rainha Dona Maria I restabeleceu a imprensa que fora suprimida por Pombal. Durante seu governo ocorreu a Revolução Francesa. Os ecos dos sucessos revolucionários chegavam a Portugal, colaborando para tanto as hesitações da Real Mesa da Comissão Geral para a censura de livros. Os sucessos revolucionários, as sublinhadas hesitações da censura e a insistente entrada de livros proibidos "libertinos", "sediciosos" e “irreligionários" em Portugal, inquietaram profundamente as esferas superiores do governo (a Intendência Geral de Polícia, o Desembargo do Paço e a própria Rainha, que passaram a se intrometer diretamente na atividade censória ${ }^{66}$. Com isso, ao contrário do que sugere a lei que instituiu a Real Mesa da Comissão Geral, verificou-se um recrudescimento do regalismo censório.

A Real Mesa da Comissão Geral recebeu severas críticas da Intendência Geral de Polícia, do Desembargo do Paço e da própria soberana. O ministro José de Seabra da Silva, em 03 de dezembro de 1789, enviou queixas ao presidente do tribunal. Acusava-o de excessivo cuidado com as obras que se pretendiam imprimir no Reino e, inversamente, de tolerância com escritos vindos do estrangeiro, motivo pelo qual teriam se espalhado em Portugal uma multidão de livros "escandalosos", "libertinos" e "sediciosos",67. Lembrava que a mesa fora encarregada de elaborar um novo índice de livros proibidos, mas que não chegou a fazê-lo. O ministro, por fim, ameaçou o presidente com a substituição da mesa caso não fossem tomadas medidas mais severas ${ }^{68}$. A Rainha, por sua vez, reprovou a publicação do livro Pastor Fido, de Guarini, traduzida por Tomé Joaquim Gonzaga, primo de Tomás Antônio Gonzaga, bem como a edição da Restauração da Disciplina, do padre Francisco Álvares Vitório e das poesias do abade de Jazente; mandou, ainda, cancelar a reimpressão do livro Analyse de Profissão de Fé do Santo Padre Pio IV. ${ }^{69}$ A mesa obedeceu prontamente às ordens régias ${ }^{70}$.

Com os progressos da Revolução Francesa e com a impotência da Real Mesa da Comissão para exercer a censura com o rigor desejado, as medidas repressivas das esferas superiores do governo em relação à entrada de livros sediciosos se

\footnotetext{
${ }^{66}$ BASTOS, José Timóteo da Silva, op. cit., p. 143-144.

${ }^{67}$ Ibidem, p. 141-2 e RIZZINI, Carlos, op. cit., p. 263.

${ }^{68}$ BASTOS, José Timóteo da Silva, op. cit, p. 142.

${ }^{69}$ Ibidem, p. 143-4.

${ }^{70}$ BEIRÃO, Caetano, op. cit., p. 389-390.
} 
intensificaram $^{71}$. Nessa investida, a Coroa não hesitou em multiplicar os controles, recorrendo a esquemas existentes no passado. Assim, em 1791, a Coroa reconheceu, pela primeira vez desde 1768, a autoridade do Santo Ofício em matéria da censura literária, autorizando o bispo inquisidor-geral a proceder contra os que comprassem, vendessem, lessem ou possuíssem "livros perniciosos" à "Santa Fé,"72. Em 1794, as críticas à "liberalidade" do tribunal tornaram-se mais ferozes diante do que se julgou ser mais uma negligência sua: a Real Mesa da Comissão dera licença para a publicação do livro Medicina Teológica, obra cuja doutrina foi considerada "perigosa e heterodoxa" por Pina Manique, o Intendente Geral de Polícia, e que provocou uma enorme efervescência nos círculos intelectuais e literários. Manique desvelou-se em apreender os exemplares da obra e moveu obstinada busca no sentido de identificar seu autor, sem contudo obter sucesso - Francisco de Mello Franco, médico mineiro ilustrado, autor do livro, permaneceu oculto no anonimato até $1862^{73}$.

Em 17 de dezembro de 1794, a Coroa extinguiu a Real Mesa da Comissão Geral para exame e censura de livros e, ao mesmo tempo, restabeleceu o sistema da tríplice censura, apresentando como justificativa, primeiramente, a ineficácia da censura unificada e, em segundo lugar, "a extraordinaria, e temivel Revolução Literaria, e Doutrinal", que então atentava contra "as opiniões estabelecidas", propagando novos princípios Políticos, Filosóficos, Teológicos, e Jurídicos, em perigo "da Religião, dos Impérios e das Sociedades"74. Retornando-se ao sistema dos três poderes, Inquisição, Ordinário e Desembargo do Paço voltaram a se ocupar da censura literária, devendo esta ser iniciada "ou pelo Ordinario, ou pelo Santo Officio da Inquisição, sem que entre hum, e outro se consider[ass]e, ou question[ass]e precedencia"; depois deles, então, agiria o Desembargo do Paço ${ }^{75}$. Com isso, houve, de um lado, um recuo na secularização da censura e, de outro, uma continuidade do predomínio laico, na medida em que o Desembargo do Paço desempenhava um papel central (e final) no processo censório. Se antes de 1768, ele ocupara um lugar de destaque; se ao tempo da Real Mesa da Comissão Geral, passara a interferir indiretamente na atividade censória; a partir de 1794, sua influência cresceu, mesmo porque a Inquisição, então submissa à monarquia, se encontrava com o poder político

\footnotetext{
${ }^{71}$ Ibidem, loc. cit.

${ }^{72}$ CARREIRA, Laureano, op. cit., p. 89-90.

${ }^{73}$ MORAES, Rubens Borba de. Bibliografia brasileira do período colonial, op. cit., p. 142-143.

${ }^{74}$ CARTA de Lei de 17 de dezembro de 1794. In: COLLEÇÃO de Leis. [s.1.], [s.d.], vol. 7, p. 89.
} 
enfraquecido. No caso da América Portuguesa especificamente, com a transferência da família real, em 1808, criou-se a mesa do Desembargo do Paço no Rio de Janeiro, a qual veio a disputar com a Junta Diretora da Imprensa Régia, recém-instalada, a jurisdição sobre a censura, saindo-se vitoriosa, ganhando o controle sobre a impressão, o comércio e a circulação de $\operatorname{livros}^{76}$.

Com a reinstalação deste sistema, estabeleceu-se que seriam usadas as regras do regimento da Real Mesa Censória, de 05 de abril de 1768, para a revisão e censura dos livros ${ }^{77}$, distribuindo-se as funções extra-censórias, desempenhadas sucessivamente pela Real Mesa e pela Real Mesa da Comissão Geral, para outros $\operatorname{organismos}^{78}$. Aos 30 de julho de 1795, fixaram-se, através de um alvará, normas para a articulação dos três órgãos que se voltavam para a censura, reafirmando-se a obediência àquelas regras da Real Mesa Censória, “accomodadas ás novas Providencias" e, ao mesmo tempo, evidenciando um recuo no ímpeto secularizador ${ }^{79}$. Primeiramente, definiu-se que à igreja pertencia o "Direito da Censura Doutrinal sobre as Materias da Religião", enquanto à monarquia cabiam "Dous Direitos Essenciaes, inseparaveis da Soberania, quais são o da Censura Doutrinal nas Matérias Civis do Estado, e o da Permissão, ou Prohibição externa dos Livros, e Papeis, ou já estampados, ou que hajão de se estampar": com isto, estabelecia-se que a igreja podia fazer o exame dos livros religiosos, mas era o Estado quem avaliava os livros sobre assuntos laicos e, ademais, quem podia baixar a proibição ou não de todos os livros, fossem eles civis ou religiosos. A Coroa, portanto, mantinha-se sobreposta à instituição eclesiástica ${ }^{80}$.

Em segundo lugar, determinou-se que os três tribunais possuíam esferas distintas de atuação, devendo cada qual conter-se "dentro dos limites de sua

\footnotetext{
${ }^{75}$ Ibidem, p. 89v-90.

${ }^{76}$ NEVES, Lúcia Maria Bastos P., BESSONE, Tânia Bessone. O Medo dos 'abomináveis princípios franceses': a censura dos livros nos inícios do século XIX no Brasil. Acervo, Rio de Janeiro, 4 (1): 113-119, jan./ jun. 1989).

${ }^{77}$ CARTA de Lei de 17 de dezembro de 1794, op. cit., p. 89v.

${ }^{78}$ CARREIRA, Laureano, op. cit., p. 92. A censura literária tornava-se praticamente a única - e esvaziada - atribuição que restou à Inquisição em Portugal, até 1821, e no Brasil, até 1810 - JOBIM, Leopoldo Collor. O Santo Ofício da inquisição no Brasil Setecentista: estudo de uma denúncia. Estudos Ibero-Americanos, Porto Alegre, 13 (2): 197, dez. 1987. No Brasil, a Inquisição funcionou até 1810, quando o Príncipe Regente, em Tratado assinado com a Inglaterra, eliminou-a de suas possessões americanas (AVELLAR, Hélio de Alcântara. História administrativa do Brasil; a administração pombalina. 2 ed., Brasília: Fundação Centro de Formação do Servidor Público/ Universidade de Brasília, 1983, p. 149).

${ }^{79}$ ALVARÁ de 30 de julho de 1795. In: COLLEÇÃO de Leis, op. cit.,vol. 7, p. 129.

${ }^{80}$ Ibidem, loc. cit.
} 
competencia, sem que" um se intrometesse no que fosse "proprio, e privativo" dos outros $^{81}$. Ao Ordinário da diocese em que os livros fossem impressos autorizava-se censurar "tão sómente as Doutrinas que acharem directa, ou indirectamente contrarias aos Dogmas de nossa Santa Fé, e á Moral Christã, ou opppostas à Disciplina geralmente recebida, e praticada em toda a Igreja, ou na Igreja Nacional"; a Inquisição, sendo um tribunal encarregado de zelar pela pureza doutrinal e, consequentemente, cabendo-lhe reprimir as heresias, poderia censurar apenas os "erros, contra cujos Authores, ou Sectarios tiver Direito de proceder, na conformidade de seu novo Regimento de 1774"; e, por fim, o Desembargo do Paço se reservaria a examinar e a censurar as doutrinas que corrompessem "os costumes públicos da Nação", as leis e direitos da Coroa, e que perturbassem "a tranquillidade geral do Estado, e particularmente" dos vassalos ${ }^{82}$.

Os tribunais, no entanto, poderiam colaborar uns com os outros, "depois de haverem satisfeito á sua Censura competente", enviando observações não atinentes às suas respectivas esferas para o conhecimento das demais, se assim julgassem conveniente. Além disso, tal como ocorreu ao se instituir a Real Comissão Geral, o Patriarca e os ordinários de Portugal e seus domínios ficaram autorizados a examinar, censurar e condenar todos e quaisquer livros no que tocasse à religião, ainda que corressem com as revisões e licenças exigidas, podendo avisar e admoestar "por suas Instrucções Pastoraes a todos os seus Diocesanos" e, também, devendo notificar a Secretaria de Estado para que se proibissem, corrigissem ou expurgassem os livros em questão ${ }^{83}$.

Na história da censura em Portugal e seus domínios, em suma, de 1517 a 1808, nota-se uma inflexão em 1768, quando foi criada a Real Mesa Censória, marco de um esforço secularizador, tendo por correlato uma série de medidas de cunho reformista, regalista e Ilustrado. A tendência secularizadora, embora amenizada em 1787 com a instalação da Real Mesa da Comissão Geral para a censura de livros e, mais ainda, com a reinstalação da censura tríplice em 1794, não sucumbiu. A conjuntura revolucionária levou as esferas superiores do governo a se inquietarem progressivamente com a censura, desenvolvendo uma crítica insistente às vacilações da Real Mesa da Comissão Geral, interferindo diretamente na ação desta e acionando

\footnotetext{
${ }^{81}$ Ibidem, loc. cit.

${ }^{82}$ Ibidem, p. 129-129v.
} 
outros órgãos na repressão à circulação de livros proibidos. Assim, o retorno do sistema da tríplice censura a partir de 1794, não significou um retrocesso: o Desembargo do Paço, na prática, dava a última palavra sobre a atividade censória, embora ouvisse o Ordinário e a Inquisição em matéria religiosa. Após 1768, a ambivalência dos governos de D. José I, Dona Maria I e do Príncipe D. João, ao mesmo tempo reformistas e defensores do Antigo Regime, propondo-se a equilibrar uma e outra posturas, repercutiu de alguma forma na ação de censura: se houve da parte dela uma maior clareza no que toca ao combate aos opositores do Reformismo Ilustrado, como os jesuítas, existiu, de outro lado, em algumas circunstâncias, uma certa fragilidade e, até mesmo simpatia, em relação aos que criticavam as instituições do Antigo Regime. Daí ter-se verificado, por muitas vezes ao final do século XVIII, a interferência direta do Desembargo do Paço e da Intendência Geral de Polícia e, até mesmo da Rainha, na censura literária.

\section{Parâmetros de Censura e Obras Proibidas}

Sob D. José I e, em menor grau, no reinado mariano, como se viu anteriormente, procurou-se enraizar uma teoria e uma prática absolutista providencialista. Essa disposição, em termos da ação do aparato censório, levou a um combate às teorias corporativas de poder, que advogavam a soberania popular, e a seus principais defensores, os jesuítas. Conduziu, igualmente, a uma ofensiva contra os milenarismos e as vertentes radicais da Ilustração.

Todos esses alvos evidenciam-se nos critérios gerais para a proibição de obras fixados pelo aparato censório: primeiro, em 1768, quando do estabelecimento da Real Mesa Censória e, depois, em 1795, no reinado mariano, quando o príncipe regente D. João sancionou um alvará determinando critérios comuns para que o Desembargo do Paço, o Ordinário e a Inquisição censurassem os livros.

Nos diferentes editais e leis promulgados pelos órgãos censórios fica perceptível também que as teorias corporativas de poder, os milenarismos e as idéias Ilustradas radicais eram os principais objetos da repressão. Evidencia-se, ademais, a preocupação com o reforço do poder do Estado.

\footnotetext{
${ }^{83}$ Ibidem, p. 130 e 136.
} 
No regimento da Real Mesa Censória, de 1768, fixaram-se quinze condições que tornavam as obras passíveis de proibição ${ }^{84}$. Entrariam no Índex do referido tribunal, as obras: 1 - de autoria de ateus, que combatessem "nossa Santa Religião"; 2 - de autores protestantes contrários a fé católica; e 3 - que negassem a obediência ao Papa ${ }^{85}$. Os escritos dos protestantes, como se pode observar, e dos ilustrados mais radicais, como se deduz, enquadravam-se perfeitamente em uma ou mais dessas condições, ou mesmo em todas. A estas condições seguiam-se outras, que permitiam a proibição dos escritos milenaristas e/ ou jesuíticos, a saber (acompanhando a sequiência numérica existente no regimento supracitado): 4- ensinar feitiçaria, quiromancia, magia e astrologia; e 5- apoiar a superstição ou o fanatismo por detrás de um aparente zelo religioso. Dois outros critérios tornavam suprimíveis alguns "livros filosóficos": 6 - conter obscenidades que corrompessem os costumes e a moral do país; e 7 - ser infamatórios e trazer sátiras, que atacassem diretamente as pessoas, ultrapassando os limites da decência ${ }^{86}$.

Seguia-se, ainda, uma condição cujos endereços certeiros eram, de um lado, Maquiavel e seus seguidores e, de outro, Rousseau e, possivelmente, outros ilustrados críticos do despotismo e, mesmo, numa leitura enviesada, os teóricos da Segunda Escolástica e alguns historiadores da Restauração Portuguesa que defendiam o direito de resistência à tirania: 8 - defender que o soberano tudo pode contra o bem comum do vassalo ou que, ao contrário, tudo concedem ao povo, fomentando o "sistema maquiavélico", ou, em contraposição, a "seita dos monarcômacos" $" 87$. Defensores do protestantismo, heréticos em geral e parte significativa dos ilustrados poderiam estar compreendidos na condição 9: utilizar a Bíblia em sentido diverso do empregado pela Igreja. O fantasma jesuítico e papista, gerado pelo regalismo dos governos reformistas ilustrados lusos, está por trás da condições 10 e 11: 10 - misturar, sem discernimento, os Artigos Dogmáticos da Fé com pontos que fossem de mera Disciplina (deviam ser proibidos inteira ou parcialmente, exceto quando apenas apresentassem as diversas doutrinas, escolas e interesses de países); e 11 - os que impugnassem os Direitos, Leis, Costumes, privilégios, concordatas etc. da Coroa e dos Vassalos. Os Ilustrados, mais uma vez,

\footnotetext{
${ }^{84}$ MARQUES, Maria Adelaide Salvador, op. cit., p. 47.

${ }^{85}$ Ibidem, loc. cit.

${ }^{86}$ Sobre tais condições, veja: Ibidem, p. 48.

${ }^{87}$ Ibidem, loc. cit.
} 
compareciam, agora claramente nomeados, na condição 14: ser de autoria dos "Pervertidos Filósofos destes últimos tempos". A condição 15 proibia todos os livros publicados anonimamente na Holanda e Suíça que versassem sobre a separação entre o Sacerdócio e o Império. Os jesuítas e seu método probabilista são mencionados numa condição e, com certeza, presumidos noutra, respectivamente: 16 - ser de autoria de jesuítas, fundamentando-se suas conclusões na "autoridade extrínseca da razão particular" e 17- ser livro para as Escolas Menores contrário ao sistema estabelecido pelas Instruções e Alvará de 28 de junho de $1759^{88}$. A censura ao probabilismo jesuítico, é importante salientar, possuía também conotações políticas. Em Portugal, Almada de Mendonça, ministro português à Época Pombalina, fez uma alusão - ainda que implícita - à possibilidade dos jesuítas aplicarem o probabilismo na política: disse temer as reações dos inacianos à ofensiva da Coroa, pois eles podiam considerar legítimas as mais severas reações, dentre elas "matar quem os persegu[iss]e"", princípio este que, segundo ele, seria consagrado por autores como Gaspar Hurtado e Valério Regnauld, dentre outros ${ }^{89}$. Na Espanha, não se aventou meramente a possibilidade de uso político do probabilismo pelos jesuítas, indo-se mais além: uma das razões alegadas para sua expulsão em 1767 foi o emprego do probabilismo para aconselhar o descumprimento das leis do Estado Absolutista ${ }^{90}$.

No regimento da Real Mesa Censória, também determinavam-se cláusulas que eram exceções nas proibições, aberturas nas mesmas: a condição de número 12 , que permitia a teólogos a leitura de livros "heréticos e ímpios" e a de número 13, que liberava os livros dos autores "Tolerados por efeito da paz de Munster e Osnaburg": Grotius, Puffendorf, Bynkershoeck, Barbeircac, Vitriario, Thomazio, Wolfio e Cocceio $^{91}$.

A partir dessas condições, é possível concluir que se concedia um peso expressivo aos livros contra a religião (sete condições, da $1^{\mathrm{a}}$ à $5^{\mathrm{a}}$, a $9^{\mathrm{a}}$ e a $10^{\mathrm{a}}$ ) e à política (seis, a $8^{\mathrm{a}}$ e da $10^{\mathrm{a}}$ à $14^{\mathrm{a}}$ ) e, inversamente, pouca importância aos que afrontassem a moral (duas, a $6^{\mathrm{a}}$ e a $7^{\mathrm{a}}$ ) e a cultura (três, $5^{\mathrm{a}}, 6^{\mathrm{a}}$ e $\left.15^{\mathrm{a}}\right)^{92}$. Além disso, pode-se identificar quais eram os adversários mais visados pelo aparato censório: os

\footnotetext{
${ }^{88}$ Ibidem, p. 150.

${ }^{89}$ Como se vê, Almada alude não apenas ao probabilismo, mas também ao direito de resistência à tirania, defendido por teólogos da Segunda Escolástica, muitos deles jesuítas. Veja sobre o assunto: MIRANDA, Tiago Costa Pinto dos Reis, op. cit., p. 254-255.

${ }^{90}$ MORSE, Richard M., op. cit., p. 53.

${ }^{91}$ MARQUES, Maria Adelaide Salvador, op. cit., p. 47-50.
} 
jesuítas, agraciados em 7 condições (números 4, 5, 8, 10, 11, 16 e 17); os Ilustrados mais radicais, em igual proporção, em 7 condições $(1,3,6,7,8,9$ e 14); os protestantes, em 3 condições (2, 3 e 9) e, por fim, os maquiavélicos, inclusos em apenas uma das condições.

No alvará sancionado pelo Príncipe Regente, em 30 de julho de 1795, em nome de Dona Maria I, regulando os critérios pelos quais a Inquisição, o Ordinário e o Desembargo do Paço deveriam censurar os livros, como já se esclareceu anteriormente, diz-se que as condições fixadas no regimento da Real Mesa Censória de 1768 são "acomodadas" "93. De fato, comparando os critérios definidos em 1795 com aquelas condições, observam-se muitas similitudes; como indicativo da “acomodação", no entanto, nota-se um grau de minúcia maior e, sobretudo, uma preocupação mais nítida contra os "estragos" da Ilustração, que então davam sinais de força expressando-se em movimentos políticos. Os Ilustrados podiam ser enquadrados em 20 das 25 condições (I a XII; XVI; XVIII a XX; XXII a XXV); enquanto que os jesuítas; os mais próximos deles neste ranking, chegavam a 7 condições (XIII a XVI; XIX-XX e XXII).

As condições de número I, II, III, IV, V, VI e VII certamente atingiam as obras de alguns Ilustrados, particularmente Voltaire, Diderot, Holbach e Rousseau, e, em menor grau, escritos de outros filósofos; e, ainda, uma ou outra condição poderia incidir sobre escritos de judeus e de muçulmanos; são elas: I -sustentar o "Atheismo, o Politheismo, o Fatalismo, Espinosismo, o Materialismo e outros erros opostos às verdades demonstradas na Theologia Natural”; II - propor "o Deísmo, combatendo a necessidade, e existência da Revelação Divina"; ter "por verdadeiras revelações o Paganismo, e o Mahometismo"; ou considerar “obrigatória a religião de Moysés”; III -inculcar "a liberdade de crença"; IV -atacar "os sólidos princípios em que assentão a Religião Christã; combatendo ou a Divindade da Escritura, e da Tradição; ou a Infallibilidade da Igreja Universal, ou a Authoridade Legítima do Pontífice Romano, e dos mais Bispos nas Decisões a respeito da Revelação"; V - impugnar "algum dos Mystérios da Religião Christã", ou contrariar "alguns dos Artigos, e Dogmas de nossa Fé”, consagrados desde os inícios do cristianismo, ou definidos nos concílios,

\footnotetext{
92 Ibidem, p. 50-51.

${ }^{93}$ ALVARÁ de 17 de dezembro de 1795. In: COLLEÇÃO de Leis, op. cit., vol. 7, p. 137.
} 
ou aprovados pela igreja ${ }^{94}$; VI -defender "como verdades da Fé Divina, Opiniões meramente humanas"; e VII - admitir "como verdadeiro, o Contraditório Systema do Indifferentismo particular, querendo formar de todas as Seitas entre si opostas na Doutrinas Dogmática uma igreja monstruosa com o nome de Christã",95.

Notoriamente contra os Ilustrados mais ousados era a condição VIII, que, em sua primeira parte, também atingia os autores adeptos do galicanismo ${ }^{96}$; ela mandava proibir os escritos que pervertessem "a Natureza e Constituição do Governo Eclesiástico, e a Ordem da Jierarquia estabelecida por Jesu Cristo", quer unindo nos príncipes seculares o poder temporal e o religioso (caso de Rousseau, como se viu), quer suprimindo as diferenças entre os fiéis e os ministros da igreja e, entre estes e os bispos e o Papa $^{97}$. Atingiam igualmente obras de alguns Ilustrados, assim como livros que contivessem teses do protestantismo, as condições: IX - difundir erros “contra a Authoridade Legislativa da Igreja e suas Leis em particular, ou contra o Poder Espiritual das chaves que Jesus Cristo lhe" deu, usando-o (a igreja) nas leis canônicas e na concessão de indulgências; $\mathrm{X}$ - propor doutrinas que estimulassem a divisão entre os cristãos, "incitando por elas uma Igreja contra a outra" ou levando os fiéis a desobedecerem seus pastores e prelados; e XI - combater "Pontos da Disciplina Ecclesiástica" universalmente aceitos pelo catolicismo ${ }^{98}$. A condição XII também respingava sobre próceres da Ilustração, embora atingisse pensadores que os antecederam no tempo: introduzir os paradoxos do "Pyrrorismo Moral, e as erradas Máximas da vã Filosofia dos Incrédulos", contrariando o direito natural e os "Princípios da Moral Revelada"99.

Se até aqui os Ilustrados quase se monopolizaram como alvos, sendo contemplados em 12 condições, a partir da condição XIII começam a aparecer os jesuítas $^{100}$. Com efeito, as condições XIII, XIV e XV apresentam uma terminologia usada recorrentemente contra os inacianos pela governação pombalina e muito presente nas determinações do regimento da Real Mesa Censória: XIII - fomentar "a

\footnotetext{
${ }^{94}$ Ibidem, p. 137.

${ }^{95}$ Ibidem, p. 137v.

${ }^{96} \mathrm{O}$ galicanismo era uma forma de anti-romanismo, assentando-se no princípio da superioridade real em matéria, direta ou indiretamente, temporal, ou no princípio segundo o qual as igrejas nacionais eram superiores administrativa e teologicamente face ao papado (TORGAL, Luís Reis, op. cit., vol. I, p. 255).

97 ALVARÁ de 17 de dezembro de 1795. In: COLLEÇÃO de Leis, op. cit., vol. 7, p. 137v.

${ }^{98}$ Ibidem, loc. cit.

${ }^{99}$ Ibidem, p. 138.

${ }^{100}$ Ibidem, loc. cit.
} 
Superstição e o Fanatismo", causando males à igreja e ao Estado e fazendo da "Religião instrumento feroz de perseguição, e crueldade"; XIV - difundir "falsas Revelações, e Milagres", a "Astrologia Judiciária"101 e "outra qualquer espécie de Artes Divinatórias, condenadas pelas Leis Eclesiásticas e Civis"; e XV - recorrer "unicamente ao Probabilismo, e às arbitrárias Opiniões dos Authores Escolásticos", ensinando "huma Moral relaxada e escandalosa, que corrompe os costumes e ilude as Consciências" $" 102$.

Alguns Ilustrados (Voltaire, dentre eles), os protestantes e, até mesmo os jesuítas (tal como os concebiam as autoridades de então) parecem ser pegos pela condição XVI: abusar “das Sagradas Escrituras, ou seja dando ás suas palavras hum sentido alheio do que lhes dá a Igreja, ou seja profanando-as com applicações indecentes". Alguns inacianos estavam subsumidos na condição XVII, mais especificamente os adeptos do quietismo e do molinosismo: estabelecer erros baseando-se na "má intelligencia da verdadeira Theologia Mystica" e nos "desvarios dos Quietistas, e Visionarios". O quietismo era uma "doutrina que associava a perfeição cristã ao chamado amor de Deus, ao sossego da alma e à anulação da vontade em favor da contemplação"103; para Miguel de Molinos - jesuíta espanhol do século XVII que, depois de gozar de prestígio em Roma, foi proscrito pela igreja como heresiarca -, à defesa do amor a Deus, conjugava-se o não oferecimento de resistência aos pecados da carne, cometidos por tentação demoníaca ${ }^{104}$.

Os autores em cujas obras houvesse obscenidades, no que se incluíam algumas obras classificadas como "filosóficas", ficavam proibidos pela condição

\footnotetext{
${ }^{101}$ A astrologia judiciária compreendia quatro disciplinas: "previsões gerais, que se atinham às predições dos acontecimentos celestes (eclipses, conjunções de planetas, questões metereológicas)", voltando-se, portanto, para objetos de estudo da astronomia; as "natividades, estudo das condições celestes na data do nascimento das pessoas, permitindo a elaboração de horóscopos"; as "eleiçães, ou determinação dos dias e momentos favoráveis para certas decisões; e as questões horárias", ao que parece, infuenciadas pelos astrônomos árabes e que permitiam ao astrólogo dar conta de qualquer questão, desde que tivesse em mãos o "momento exato em que a situação acontecera" (HERMANN, Jaqueline, op. cit., p. 211-212).

${ }_{102}$ ALVARÁ de 17 de dezembro de 1795. In: COLLEÇÃO de Leis, op. cit., vol. 7, loc. cit.

${ }^{103}$ MORA, Adelina Sarrión. Sexualidad y confesión: la solicitación ante el tribunal del santo oficio (siglos XVI-XIX). Madrid: Alianza Editorial, 1994, p. 205-207 e VAINFAS, Ronaldo. Trópico dos pecados. Rio de Janeiro: Campus, 1989, p. 202.

${ }^{104}$ A bula Coelistis Pastor (1687), de Inocêncio XI, "condenava Molinos e os seus discípulos que reclamavam que ocasionalmente o diabo violentava os corpos humanos de tal forma que mesmo os corpos dos místicos mais pios se tornavam suas vítimas passivas e que poderiam cometer actos pecaminosos (em particular ter relações sexuais) sem que o estado de contemplação abençoada fosse interrompido" (Leszek Kochakowicz. Diabo, In: ENCICLOPÉDIA Einaudi - vol. 12, Mythos/logos, Sagrado/Profano. Lisboa: Imprensa Nacional/ Casa da Moeda, 1987, p. 262).
} 
XVIII: conter "discursos licenciosos em Prosa, ou Verso, que affrontão o pejo, e a modestia, desbaratão os costumes, e pervertem a Educação religiosa da Mocidade"105. Os Ilustrados de um modo mais geral e também os "monarcômacos" defensores de teorias corporativas de poder, dentre eles os jesuítas, ficavam compreendidos nas condições seguintes: XIX - atacar "a Constituição, e fórma do Governo do Estado, a Soberania, e Independencia do Throno, os Privilegios, Liberdades, Acordos, e outros Direitos da Real Coroa, e dos Vassalos della, as Ordenações, e Leis do Reino, e os Costumes públicos, e authorizados da Nação" ${ }^{106}$; e XX - adotar as idéias da "Seita dos Monarcomacos"107.

Os seguidores de Maquiavel eram contemplados na condição XXI: inculcar “os detestáveis erros de Machiavelo", tudo permitindo "aos que mandão", "ainda que seja contra o Bem Commum", ultrapassando os "justos limites da legitima Obediencia dos Subditos, ordenada pelos Direitos Divino, Natural, e Positivo" ${ }^{\text {"108. }}$ Essa retórica guarda proximidade com a presente nas teorias corporativas de poder, ao mesmo tempo em que converge com a oposição dos Ilustrados ao maquiavelismo; no regimento da Real Mesa Censória, embora a mesma condição também se apresente, isso não se dá nos mesmos termos. A proximidade maior com a retórica mencionada, no entanto, não implicou renúncia ao propósito regalista que marcava a Real Mesa Censória; na condição XXII, este propósito está claro, implicando certamente a censura a obras papistas, de jesuítas ou de outros defensores de teorias corporativas de poder e, eventualmente, de algum Ilustrado: confundir "os Sagrados, e Independentes Direitos" do "Sacerdocio, e do Imperio", ao tomar por assunto a concórdia entre eles. Os Ilustrados, além disso, certamente se tornavam alvos certeiros das condições XXIII, XXIV e XXV (esta última enredando, além deles, os satíricos em geral): XXIII - ensinar "Doutrinas, que se oppõem á sã Moral Politica, e se encaminhão a perverter os Costumes, e Obrigações Civis dos Cidadãos, e a Prática das Virtudes Sociaes, e Patrioticas, e a introduzir no Estado Principios funestos ou á sua Segurança, ou á sua Tranquilidade, ou á sua geral Economia”; XXIV - fazer "Censuras, e Invectivas, que se dirigem a fazer o Governo Publico ou odioso, ou desprezível aos Póvos”, abalando os laços que os unem “a seus Principes, e aos

\footnotetext{
105 ALVARÁ de 17 de dezembro de 1795. In: COLLEÇÃO de Leis, op. cit., vol. 7, p. 138.

${ }^{106}$ Ibidem, p. 138-138v.

${ }^{107}$ Ibidem, p. 138v.

${ }^{108}$ Ibidem, loc. cit.
} 
Mandatarios, e Delegados de Seu Supremo Poder"; e XXV - encerrar "discursos declamatorio, e satyricos", difamando "pessoas ou públicas, ou particulares"109.

Os principais autores que tiveram seus livros proibidos, após a criação da Real Mesa Censória, foram escritores, teólogos ou religiosos considerados vinculados, de algum modo, aos jesuítas, alguns deles defensores de teorias corporativas de poder ou partidários de concepções milenaristas. A Deducção Chronologica e Analitica, obra de referência da censura, principalmente na Época Pombalina, é permeada pelo anti-jesuitismo. Nela, a Companhia de Jesus é apresentada como "huma monarquia concentrada no Governo dispótico", "huma sociedade leonina, e formada para destruir toda a União Christã, e todas as outras sociedades Religiosas, e Civis”; uma adversária da Restauração Portuguesa de 1640; os inacianos são responsabilizados pela expulsão "de todos os homens doutos", pela supressão de "todos os livros de boa instrução", pelas "revoluções dos dous Reynados próximos precedentes" ao de Dom José I. A Deducção atribui-lhes a difusão das profecias do "Çapateiro Santo Simão Gomes" aplicando-as a diversas pessoas; a Dom João IV: na "Colleção de imposturas intitulada = Jardim Ameno"; na crônica feita por Balthazar Telles; em Monarquia Luzitana, Imperio de Christo; e em trovas que se assegurava serem da autoria do padre Antonio Vieira, intituladas Profecias de Gonsalianes Bandarra, Çapateiro de Correa, natural da Villa de Trancoso. Adjetiva-se a influência de Vieira como funesta, compreendendo-a como fator de corrupção do príncipe Teodósio "até o ponto de lhe fazer crer, que pela Astronomia, e Astrologia, podia adivinhar" ${ }^{\text {"110 }}$. Além disso, associam-se os inacianos à decadência do comércio, da navegação e do poderio militar português e, ainda, ao desequilíbrio das relações entre Estado e Igreja ${ }^{111}$. Essa oposição aos jesuítas foi continuamente reiterada nos editais censórios, nos quais a Deducção muitas vezes apareceu como referência explícita. O cipoal de adjetivações e de informações antijesuíticas que pululam nesses editais, como já foi dito - em certos casos, inteiramente refutáveis ${ }^{112}$ - recobre o interesse governamental de reforçar o absolutismo e realizar

\footnotetext{
${ }^{109}$ Ibidem, loc. cit.

${ }^{110}$ SILVA, José de Seabra da, op. cit., vol. 1, p. 189-192, 197-198; 205 e 216-217.

${ }^{111}$ BASTOS, José Timóteo da Silva, op. cit., p. 63.

${ }^{112}$ É inteiramente falso, por exemplo, que os jesuítas se colocaram contra a Restauração Portuguesa, como lembra José Timóteo da Silva Bastos (op. cit., p. 64). É questionável, ainda, tomá-los como maquinadores da ignorância e do fanatismo em Portugal, como se mostrou anteriormente.
} 
reformas modernizantes em Portugal, interesse em função do qual os jesuítas se tornaram, ao mesmo tempo, obstáculos e bodes expiatórios.

A criação da Real Mesa Censória, como se viu, fazia parte de uma ampla estratégia regalista da Coroa portuguesa, sendo um dos primeiros alvos os Índex romanos, que não seriam válidos em Portugal sem a chancela régia. O regalismo inerente à criação do novo tribunal manifesta-se claramente na lei de 04 de dezembro de 1769, pela qual se proibiram várias obras que respeitavam as Bulas intituladas da Cea do Senhor. Tais Bulas, assim como os Índices Expurgatórios romanos, introduziam "Maximas tão contrarias ao Direito Divino, Natural, e das Gentes, como á Independência Temporal da" Coroa, necessária "para conservar entre o Sacerdocio, e o Imperio aquella consonante harmonia, sem a qual nem hum, nem outro podem subsistir sem hum continuado milagre”. Se as Bulas e os Índices referidos haviam sido proibidos na lei de 02 de abril de 1768, isso não fora explicitado em relação a diferentes livros, então em circulação em Portugal, os quais continham as mesmas “identicas Maximas conteúdas nas sobreditas Bullas”. O edital de 04 de dezembro de 1769, então, vinha a fazê-lo, proibindo obras dos seguintes autores: Nicolai Eymerici; Francisci Pegnae; Paulum Grillandum; Ambrosium de Vignate; Thomae Delbene; Caeseris Carenae; Francisci Pegnae; Ludovici de Paramo; Jacobi Simancas; Ludovici Carrerii; Francisci Bordoni; Antonii de Souza; Sebastiani Salelles; Joannis Baptistae Nerii; Francisci de Torre-Blanca. O citado edital proibia também Litterae Apostolicae diversorum Romanorum Pontificum pro Officio Sanctissimae Inquisitionis Romae in Aedibus Populi Romani ${ }^{113}$.

A preocupação com a defesa dos direitos régios esteve por detrás do edital de 03 de junho de 1776, que proibia "novos Catecismos da Doutrina Christã manuscriptos, e espalhados sem as licenças necessárias”. Esses Catecismos, além de terem sido "ditctados pelo espirito da soberba, desobediencia, novidade, e ignorancia em Matherais Theologicas"; de serem "escriptos com um futilissimo, inutil, e confuso Methodo de Ensinar a Doutrina Catholica"; de conterem proposições novas, "e por isso perigosas, e inductivas de erros"; entravam em choque com "alguns dos

\footnotetext{
${ }^{113}$ LEI de 04 de dezembro de 1769. In: COLLEÇÃO de Leis, op. cit., vol. 2, p. 314 . O mesmo espírito regalista presidiu a proibição de uma notícia sobre o jubileu de Clemente XIV (EDITAL 22 de abril de 1774. In: COLLEÇÃO de Leis, op. cit., vol. 4, s/p.)
} 
Pontos Dogmaticos; mas tambem a legitima obediencia, que se deve aos Prelados da Igreja, e aos Soberanos"114.

O primeiro edital publicado pela mesa, datado de 10 de junho de 1768, proibiu algumas obras que apresentavam profecias milenaristas atribuídas aos sapateiros Gonçalo Annes Bandarra e Simão Gomes, indicando como seus verdadeiros autores o padre Antônio Vieira e os "seus sócios" da Companhia de Jesus ${ }^{115}$. Tais obras eram: Ecco das Vozes Saudozas, publicada em Lisboa no ano de 1757, na oficina de Francisco Luiz Ameno, com licenças obtidas graças à conivência dos censores, livro que continha a Carta Apologética escrita por el Padre Antonio Vieira de la Companhia de Jesus al Padre Jacome Iquaça; Vida do çapateiro Santo Simão Gomes, editada em 1759, na oficina de José Felipe; Balatus Ovium (1640), de Pantaleão Rodrigues Pacheco; e Vox Tuturis Portugalliae Gemens (1649), de Nicolau Monteiro. Tais obras seriam "falsas temerarias sediciozas e infames", não podendo "nenhuma pessoa de qualquer estado, ou condição", retê-las, devendo antes entregar os exemplares que possuíssem à secretaria da Real Mesa Censória ${ }^{116}$.

Segundo o referido edital, Vieira profanara diferentes "lugares da Sagrada Escriptura / como sempre foi seu costume/ para sustentar as taes pertendidas prophecias de Bandarra por elle maquinadas como se as verdades eternas dos Textos sagrados pudessem ter alguma combinação com as imposturas da malicia humana"; Vieira fora condenado pela Inquisição em 1667 pela "impostura das referidas profecias"; ele e os jesuítas antedatavam livros e ocultavam sua participação na escritura de alguns textos, tudo isto para iludir as pessoas da veracidade das ditas predições, para as "persuadirem antigas". Diziam, assim, que estas últimas haviam sido compostas ao tempo de D. João III, “quando na verdade tinhão sido maquinadas depois da Aclamação do Senhor Dom João o IV"117.

O mesmo cunho anti-milenarista e anti-jesuítico encontra-se no edital de 9 de dezembro de 1774, pelo qual se proibiram três livros de Manoel Bocarro Francez, autor mencionado no Capítulo 1: Anacephaleoses da Monarquia Lusitana, publicado em 1624; Luz pequena Lunar, e Estellifera da Monarquia Lusitana, editado em Roma em 1625; e Status Astrologicus Anacephaleosis prima Monarchice

\footnotetext{
${ }^{114}$ EDITAL de 03 de junho de 1776. In: COLLEÇÃO de Leis, op. cit., vol. 5, s/p.

${ }^{115}$ IANTT, Real Mesa Censória, Caixa 1, Edital de 10 de junho de 1768, p. 1, 2

${ }^{116}$ Ibidem, p. 1, 2 e 3-3v.

${ }^{117}$ Ibidem, p 1-3.
} 
Lusitance, impresso em Hamburgo no ano de $1626^{118}$. Tais livros eram "hum daquelles muitos maliciosos, e perniciosos Estratagemas" usados pela "extincta Sociedade Jesuitica", cujos resultados seriam "os mais ruinosos a huma Sociedade Illuminada, Civil, e Christã", tendo por principal assunto

\begin{abstract}
"o mostrar, e persuadir: Que o Princípio, e Fim das Monarquias, e Imperios do Mundo estam pendentes do Curso, e Movimento dos Astros; e que por Cálculos Astrologicos se provava que no Seculo passado [isto é, o XVII] havia de acabar o Imperio Otomano; em cujo lugar se levantaria outro novo Imperio em Portugal; declarando, qual dos Soberanos desta Monarquia havia de ser o primeiro Imperador do novo Lusitano Imperio; cujo Chefe havia também dominar em [sic] todos os Póvos sujeitos ao Imperador dos Turcos"119.
\end{abstract}

Além de refutar as profecias segundo as quais Portugal constituiria o Quinto Império e de renegar a interferência dos astros no curso da história, o edital reprovava outros elementos presentes nas mencionadas obras e os efeitos provocados pelas mesmas: a crença na "Pedra Filosofal" e na possibilidade da "Alchimia, ou Arte de converter huns em outros Metaes"; a sedução dos soberanos, ministros e vassalos com o "estrondoso Eco de huma tão inesperada, e espantosa novidade" (o Quinto Império); o desassossego dos povos; a introdução em Portugal do Index Expurgatorio Romano Jesuitico; e a utilização da idéia de Quinto Império para a satisfação dos interesses particulares dos jesuítas ${ }^{120}$.

O edital faz uma refutação mais ampla das idéias e escritos milenaristas. Depois de arrolar escritos de outros autores - o Jardim Ameno e mais Esperanças de Portugal; Quinto Império do Mundo, do padre Antônio Vieira - cujos fins seriam os mesmos das obras proibidas supracitadas, acusa-os todos de acumularem "famosas, e falsas Profecias, Revelações, Vaticinios, e Prognosticos, attribuidos a varios Santos, Servos de Deos, Varões Illustres, Astrologos eminentissimos, Sibilas, e até a Homens Pagãos; preparando anticipadamente os animos para acreditarem as ditas Profecias, e Revelações", imputando-as a "Santo Isidoro, a S. Methodio, a S. Cyrillo Eremita, a João Carrião, e á Sibilla Erythrea”. Segundo essas profecias, primeiro, D. Sebastião seria o Encuberto; e, num momento ulterior, após a morte de

\footnotetext{
${ }^{118}$ IANTT, Real Mesa Censória, Caixa 1, Edital da 9 de dezembro de 1774.

${ }^{119}$ Ibidem.
} 
D. João IV, as mesmas postulavam que este último monarca ressuscitaria para chefiar o Quinto Império do Mundo. Tais profecias, prossegue o edital em sua condenação, tornavam os homens "Estupidos, Enthusiastas, Supersticiosos, e Fanaticos", acostumando-os a pensar "em Futuros contingentes, quando não há Meio algum para se conhecerem, a esperar cousas vans, e extraordinarias; e a investigar pelo natural Curso, e Movimento dos Astros futuros acontecimentos, que dependem do Livre Arbitrio"121. Tudo isso constituiria a "base da Ignorancia, da Insipiencia, da Superstição, e do Fanatismo"; afastaria os "Homens das uteis, e proveitossas applicações Fysicas"; impossibilitaria que se fizessem "reflexões sérias, e maduras sobre as Cousas Moraes"122. O edital de 9 de dezembro de 1774, enfim, peça condenatória dos milenarismos e dos jesuítas, sintetiza a história desses elementos na cultura portuguesa e, ao mesmo tempo, expressa uma concepção Ilustrada acerca da relação do homem com a história e com os mistérios divinos: a história constitui-se terreno de livre arbítrio, sendo impossível prevê-la, seja apelando para as profecias, seja conjugando tal apelo à observação dos astros; os homens devem, assim, de um lado, voltar-se para as "applicações Fysicas", para as ciências, e, de outro, desenvolver reflexões "sérias e maduras sobre as Cousas Moraes", a fé e a relação com o Criador. Insinua-se, assim, a cisão que resultará do amplo processo de transformações que então principiavam, a cisão entre o mundo moral-religioso e o mundo histórico-físico, aludida no Capítulo 2: o edital censório em tela afigura-se, portanto, como expressão do Reformismo Ilustrado Português e segreda as decorrências históricas futuras do seu desenrolar e de outras transformações.

Não apenas os escritos milenaristas dos jesuítas e dos seus supostos aliados foram vítimas da censura. O Edital de 12 de dezembro de 1771 condenou todo o "Systema" dos Jesuítas, cuja base era a "perniciosa Ethica de Aristoteles, fonte de todas as agressões moraes" que perpetravam; "Moral corrompida, e relaxada" que causava danos ao "verdadeiro Christianismo", as "consciencias dos Fieis", ao "socego publico, e do mesmo Throno Real" ${ }^{23}$. Ao enumerar os "erros" e "pecados" constituivos dessa Moral Jesuítica assentada no "Scepticismo Aristotelico", o edital reiterava várias das já citadas condições que tornavam os livros proibidos,

\footnotetext{
${ }^{120}$ Ibidem.

${ }^{121}$ Ibidem.

${ }^{122}$ Ibidem.

${ }^{123}$ IANTT, Real Mesa Censória, Caixa 1, Edital da 12 de dezembro de 1771, p. 1-2.
} 
acrescentando-lhes alguns crimes contra a vida, a propriedade, a fé católica e, até mesmo, contra a realeza: o "Probabilismo, a Simonia real, e confidencial, a Blasfemia, o Sacrilegio, a Magia, a Astrologia judiciaria, a Irreligião, a Idolatria, a Impudicia, a Obscenidade, o Perjurio, a Injustiça, o Furto, o Homicidio, o Regicidio, o Parricidio, o Suicidio, a Relaxação do Sigilio Sacramental" ${ }^{124}$. No edital, portanto, a realeza era colocada como vítima das idéias jesuíticas pelo fato destas supostamente consagrarem o regicídio.

O edital de 12 de dezembro de 1771, ainda, compreendia que as "perversas Doutrinas" dos jesuítas encontravam-se "espalhadas e vagas" pelas numerosas obras e, ao mesmo tempo, se achavam "unidas" entre os mesmos inacianos, "constituindo entre elles hum todo individuo", devido ao "Systema de uniformidade" que os regia, deixando-os todos submetidos ao "seu despótico Geral"" fugissem de tudo que era "pecado', “abominação" e "prevaricação contra seus Reys, e contra a sua Patria", mantendo a "lealdade aos seus Soberanos" e aos ministros deste, primeiramente, determinava que se entregassem certas obras à Real Mesa; em segundo lugar, proibia várias outras; e por fim, mandava que alguns títulos não corressem "sem que no principio dos Tomos" fosse afixada uma "Nota das Doutrinas censuradas", a qual seria estampada na Tipografia Régia ${ }^{126}$.

Dentre as principais obras cujos exemplares deveriam ser entregues ao tribunal, estavam: o tratado de Rege, \& Regis Institutione, de João Mariana; a Crise Theologica, de Carlos Antônio Casnedi; o Tyrannicidio, de Diogo Keller; a Apologia da Moral da sua Sociedade, de Honorato Fabri; as Obras, de João Adão; os Afforismos, de Manoel de Sá ${ }^{127}$. Já entre livros que foram proibidos, podem-se citar: o tratado de Justitia, \& Jure, de Luís de Molina; a Theologia Moral, de Paulo Layman; a Theologia Moral Universal, de Paulo Gabriel Antonio; a Theologia Tripartita, de Ricardo Arsdekin; as Obras, de Thomaz Sanches; as Obras, de Vicente Filliucio; as Obras Moraes, de Fernando de Castro Palao; o Catecismo Theologico, de Francisco Pomey; Damnate Theses, de Domingos Viva; o Manual Theologico, de Francisco Perrin; e as Instituições Moraes, de João Azor ${ }^{128}$. Como obras nas quais se deveria afixar uma nota de censura, é possível destacar: as Disputas e o tratado de

\footnotetext{
124 Ibidem, p. 2.

125 Ibidem, p. 3.

${ }^{126}$ Ibidem, p. 3-5.

127 Ibidem, p. 3.
} 
Potest. Sum. Pontif., ambas de Roberto Bellarmino; os Opusculos Theologicos, Afforism, de Martinho Becano; e os Commentarios aos quatro Profetas Maiores, de Cornelio A Lapide ${ }^{129}$.

Dentre os vários autores censurados citados acima, observam-se três grandes nomes da Segunda Escolástica (Molina, Bellarmino e Mariana), além de João Azor, defensores das teorias corporativas de poder e, por conseguinte, da origem popular do poder régio, "monarcômacos"; a presença deles no edital censório em questão converge com a orientação política imprimida pela Coroa portuguesa a partir de consulado pombalino. Além dos "monarcômacos", podem-se identificar autores tributários do probabilismo, doutrina casuística cujos efeitos políticos pareciam causar temor à Coroa portuguesa a partir de Pombal: Paul Laymann, para quem "cada um pode agir conforme a opinião que homens doutos defendem como provável e segura na prática", e Castro Palao, segundo o qual, quando "“agimos segundo uma opinião provável agimos de acordo com a mais provável""130. Ao mesmo tempo, vêse no rol dos censurados também o nome do rigorista, anti-probabilista, Paul Gabriel Antoine $^{131}$.

A Sentença de 24 de julho de 1769 tinha como alvo indireto os inacianos e apresentava elementos espirituais e temporais como motivos da perseguição que se movia contra os mesmos, deixando entrever os ditames políticos da ação censória. Ela condenava os adeptos da seita do sigilismo, chamados Jacobeus ou Beatos, por permitir o relaxamento do sigilo sacramental, "seguindo as pestilênciaes doutrinas dos pertendidos Jezuitas, e de outros homens”. Tal condenação implicou a proibição de obras dos seguintes autores: Adam Fanuero, Alonço Rodrigues, Amadeo Guimeneo ("nome supposto do Jezuita Matheus Moya”), Antonio Dianna, Carlos Renato Biluart, Claudio La Croix, Estevão Fagundes, Francisco Soares Granatense, Francisco Soares Lusitano, Gabriel Vasques, João Marin, João Mõz do Prado, Leandro do Santíssimo Sacramento, Leonardo Lersio, Thomas Hurtado, Thomas Tamburino ${ }^{132}$. Levou a interdição igualmente de "Todos os Livros e papeis dos Jacobeos em defença de sua infame pratica", de "Todos os livros que seguem e defendem os costumes dos Armênios" e de "Todos os que defendem as Proposições

\footnotetext{
${ }^{128}$ Ibidem, p. 4-5.

${ }^{129}$ Ibidem, p. 6.

${ }^{130}$ DELUMEAU, Jean. A confissão e o perdão, op. cit., p. 106.

${ }^{131}$ Ibidem, p. 114 e CHIARAMONTE, José Carlos, op. cit., p. 29.
} 
dos Iluminados" "133. Tais autores e livros defendiam "que podia haver cazos, nos quaes a Relaxação do sigillo Sacramental, se pudesse fazer justa, e necessaria”, constituindo em torno desta pressuposição "uma seita" que dela se servia para satisfazer interesses temporais, econômicos e políticos, ou às "suas vinganças" 134 . A sentença referida mandava riscar e abolir as proposições similares que viessem a ser encontradas em outros livros.

Condenação espiritual de um jesuíta, permeada por interesses políticos e por uma visão racional de mundo que se esforçava por libertar Portugal do império da sacralidade, aparece no edital que 30 de abril de 1772, que proibia e mandava queimar a obra Juizo sobre a verdadeira causa do Terremoto, que padeceo a Corte de Lisboa..., do padre Gabriel Malagrida ${ }^{135}$. Segundo o edital citado, essa obra fora concebida segundo "hum espirito infame, fanatico, malicioso, temerário e heretico", cujo objetivo era "propagar o sedicioso, e perniciossimo Fanatismo", similar ao difundido pelos inacianos à época de El-Rei Dom Sebastião. Segundo o edital em questão, Malagrida concebeu o terremoto que destruiu Lisboa em 1755 como um castigo de Deus, quando na realidade era "hum dos effeitos das causas naturaes, e naturalmente reguladas; cuja ordem, e modo de obrar não está Deos obrigado como Author Natural, e Causa Universal, e Primeira a impedir, suspender, nem embaraçar"; além disso, o jesuíta queria persuadir os "fiéis Vassalos" a recorrer aos "Exercícios" da companhia como uma espécie de penitência, encobrindo com isto os interesses "temporaes, e perversos" dessa ${ }^{136}$. ser encontradas em outros livros. Dois anos depois, a Real Mesa Censória, através do edital datado de 28 de abril, proibiu uma Carta que Dom Clemente José Colaço Leitão, bispo de Cochim, escreveu de Coulão a Dom Salvador dos Reis, arcebispo de Cranganor, ambos jesuítas, em defesa do padre Gabriel Malagrida e em ataque à sua condenação e martírio pela Inquisição portuguesa; à semelhança do ocorrido com o escrito de Malagrida, aplicou-se a esta carta a pena de fogo, proibindo-se, ainda, que qualquer pessoa, de qualquer estado, a possuísse $^{137}$.

Outro flanco utilizado para atacar os jesuítas foi o molinosismo. O edital de

\footnotetext{
${ }^{132}$ SENTENÇA de 24 de julho de 1769. In: COLLEÇÃO de Leis, op. cit., vol. 3, p. 265-268.

${ }^{133}$ Ibidem, loc. cit.

${ }^{134}$ Ibidem, loc. cit.

${ }^{135}$ IANTT, Real Mesa Censória, Caixa 1, Edital de 30 de abril de 1772.

${ }^{136}$ Ibidem.

${ }^{137}$ IANTT, Real Mesa Censória, Caixa 1, Edital de 28 de abril de 1774.
} 
06 de abril de 1769 proibiu várias obras - dentre elas, Máximas Espirituais, do Frei Affonso dos Prazeres, publicada em Lisboa pela primeira vez em 1737 e, pela segunda, com acréscimo, em 1740 - que assimilavam "o perniciosíssimo erro das violências diabólicas nos atos externos da sensualidade para com esta falta de doutrina se abrir caminho largo, e franco às paixões, e excessos da lascívia, passando-se [?] as maiores surpresas dela debaixo do pretexto de se imputarem a coações do demônio as culpas da fragilidade, e malícia dos que caíam em tão graves pecados" $" 138$.

No edital de 10 de junho de 1768, apresentam-se alguns elementos centrais das condenações de cunho religioso que se fizeram às obras dos jesuítas, embora o edital, ao que parece, não se refira às mesmas em particular. $\mathrm{O}$ edital censurou as obras Vida de Santa Maria Magdalena, composta em italiano por D. Antonio Júlio Brognole Sale - e suas versões, em português, do frei Antonio Lopes Cabral (1695) e do padre frei Antonio de Assumpção, religioso dominicano (1747) - pelo fato de que tal livro, na verdade, seria "uma novela das mais licenciosas, organizada de afetos indecentes, pensamentos pueris, jogos de espírito, metáforas, alegorias e ficções só próprias de séculos de barbaridade e ignorância; e de outras muitas coisas inteiramente alheias de majestade, e pureza do cristianismo", contendo opiniões desprezadas pelos "Sábios da primeira ordem, e críticos católicos mais verdadeiros na antigüidade Eclesiástica". No mesmo edital expõe-se o ideal de uma piedade "verdadeira e sólida": ser dirigida "pelas luzes da razão e da verdade"139.

Razão e verdade eram elementos norteadores da devoção, da piedade cristã, preconizada pela censura sob o Reformismo Ilustrado. Tais elementos aparecem claramente no edital de 10 de junho de 1771, pelo qual foram proibidos livros em sua totalidade, provavelmente, de autoria dos inacianos: Desengano dos Peccadores (1765), de Alexandre Perier; Vida da Veneravel Rosa Maria Serio de Santo Antonio (1749), do padre José Gentil; Vida do Veneravel Padre Belchior de Pontes (1752), do padre Manoel da Fonseca; Escola de Desengano em fórma de Cartas (1768), de João Batista Salazar; e Manipulus Spicarurm Monachii \& Genuae, sem autor especificado; Cartas Directivas, do Padre Sinfronio Ferrás; e Escola de Desengano em forma de Cartas, de João Baptista Salazar. Alegou-se, no mencionado edital de

\footnotetext{
${ }^{138}$ IANTT, Real Mesa Censória, Livro 9, Edital da Real Mesa Censória de 06 de abril de 1769, p. 50$51 \mathrm{v}$.
} 
1771, que tais livros continham "respectivamente doutrinas erroneas, tendentes a inspirar o temor puramente servil, e a contaminar alguns artigos da Fé, com interpretações sofisticas; nelles por outra parte se manifesta corrompida a piedade com relações apócryfas, falsos exemplos, sucessos extraordinarios, meras illusões, affectos indecentes, e ditames perigosos, tão alheios do Espirito da Igreja e da Verdadeira Mystica, como incompativeis com uma solida, saudavel, e bem regulada devocao". Essas proibições, assim, se evidenciam mais uma vez o anti-jesuitismo pombalino, expressam também o interesse Ilustrado de imprimir maior racionalidade à devoção religiosa ${ }^{140}$.

A obra Desengano dos Pecadores mereceu, além disso, um edital proibitivo à parte, pois sua proibição dava-se "não só pelos erros Theológicos [...] mas igualmente pelas ridiculas Estampas, de que foi estofado" ${ }^{\prime 141}$. As estampas, no geral, foram motivo de vigilância da censura. Segundo o supracitado edital de 10 de junho de 1771, tal vigilância seria uma "pratica universal de toda a Europa, onde aos Tribunaes competentes para o exame dos Livros" competiria "também o conhecimento, exame, e approvação das Estampas", estivessem elas "incorporadas nas Obras dos Authores, ou" corressem "em folhas simplesmente volantes". Em Portugal, de acordo com a Lei de 05 de abril de 1768, era proibido “introduzir, imprimir, ou vender [...] Estampa alguma incorporada em Livros, ou solta em folhas volantes, sem que para a publicação delles" precedessem "as aprovações, e licenças desta Mesa" ${ }^{142}$. E, de fato, há documentos que mostram que se tentou colocar essa determinação em prática: aos 17 de agosto de 1775, o Marquês de Pombal remeteu ao Bispo de Beja cópia de ordem da Secretaria de Estado dos Negócios do Reino, encaminhada ao Administrador Geral da Alfândega de Lisboa, "com o Assumpto da Remessa, que de todas as Estampas, Colleçoens dellas, se deve fazer da mesma Alfandega para a Real Meza Censoria, assim de serem por Ella examinados na forma declarada na sobredita ordem"143.

\footnotetext{
${ }^{139}$ Ibidem.

${ }^{140}$ IANTT, Real Mesa Censória, Edital de 10 de junho de 1771, Caixa 1. É importante observar que em outros editais censórios não esmiuçados aqui aparece o mesmo princípio para a proibição de obras religiosas. Veja: IANTT, Real Mesa Censória, Edital de 12 de junho de 1770 e Edital de 22 de dezembro de 1768.

${ }^{141}$ EDITAL de 22 de maio de 1771. In: COLLEÇÃO de Leis, op. cit., vol. 4, s/p.

142 Ibidem.

${ }^{143}$ IANTT, Real Mesa Censória, Decretos e avisos recebidos pela mesa, Caixa 188.
} 
Alvos de ataque também se tornaram a maior parte dos livros sobre a Restauração de 1640, nos quais se apelava às teorias corporativas de poder para legitimar a rebelião portuguesa contra o domínio espanhol. Antes mesmo da criação da Real Mesa Censória, em 1767, uma junta de lentes e desembargadores, a requerimento do procurador da Coroa, condenou o livro de Francisco Velasco de Gouvea, declarando-o " "obra informe, absurda, ignorante e apócrifa"”144 . Em 1789, a Real Mesa da Comissão Geral para a censura de livros aprovou parecer do revedor frei João Batista de São Caetano, condenando a obra referida: como estaria dito na Deducção Chronologica, ela "contem propozições absurdas, como são as que se transcrevem no §619 da mesma Deducção - q’ o poder dos Reys está nos povos: q' suposto estes o transfirão nos Reys como lhe verifica substancialm.te o podem reassumir, e depor os Reys, e q' os Papas também em algumas ocasiões podem fazer o mesmo" $" 145$.

A obra Histoire des Révolutions de Portugal, do abade Vertot, também mereceu a atenção da censura. Não foi proibida a sua circulação, mas, em 1807 portanto, muitos anos depois da reforma pombalina da censura -, José Joaquim da Cunha de Azeredo COUTINHO, então bispo de Elvas, pronunciou-se sobre uma tradução da obra para o português. Seu intento parecia ser proibir a publicação da obra, mas, como seu ofício, de acordo com suas próprias palavras, não lhe permitiria fazê-lo, o bispo, no parecer, sugeriu a realização de modificações na tradução portuguesa. Embora não seja possível dizer se o parecer foi aprovado, nem se o mesmo fora feito para o Ordinário de Elvas ou para o Desembargo do Paço, pode-se notar nele uma convergência com as preocupações evidenciadas na censura desde 1768. Depois de afirmar que a tradução fora mal feita, não sabendo o tradutor nem "francês nem português", Azeredo disse persuadir-se a ordenar que determinados trechos fossem "riscados ou corrigidos em razão da sua doutr"."146. No campo doutrinário, chamaram sua atenção pontos referentes à monarquia lusitana: a Restauração Portuguesa de 1640 e a relação entre, de um lado, o governante e, de outro, a Inquisição e a justiça. Quanto à Restauração, o Bispo queria suprimir a caracterização do movimento como sedicioso, fixando-se no direito de Dom João IV

\footnotetext{
${ }^{144}$ BASTOS, José Timóteo da Silva, op. cit., p. 95.

${ }^{145}$ Parecer do revedor Fr. João Baptista de S. Caetano. Apud. BASTOS, José Timóteo da Silva, op. cit., loc. cit.

${ }^{146}$ BNL. Seção de Reservados, [Exame e crítica da historia das Revoluções de Portugal do abade
} 
ao trono português. Azeredo escreveu, num texto riscado, que Vertot, na página 68, afirmaria:

"Em fim appareceo o dia, aonde o successo hia a decidir se o Duque de Bragança merecia o titulo de Rei e de libertador da Patria, ou o nome de rebellado, e de inim $^{\circ}$. do Estado".

No entendimento de Azeredo,

"Vertot escreveo este periodo com pouca reflexão, porq. a justiça da causa do Snr. Rei D. João IV não podia depender do bom ou mao successo da sua aclamção; e por conseg ${ }^{\text {te }}$. ainda q. a empresa [?] se malograsse não mereceria jamais o nome de rebellado. Julgo por tanto q. esta expressão se deve modificar como offensiva dos $\operatorname{dir}^{\text {tos }}$. da Sereniss ${ }^{\text {a }}$. casa de Bragg ${ }^{\text {ca }}$. q. parece pôr em duvida; o q. se pode fazer muito facil ${ }^{\text {mte }}$., escrevendo conseguiria em lugar de merecia" ${ }^{, 147}$.

$\mathrm{Na}$ realidade, o que se vê é o Bispo empenhar-se em apagar o aspecto sedicioso da Restauração e de seu protagonista, reduzindo-a à luta por uma "causa" de "justiça", pelos direitos da "casa de Brag şa .", em função do que não caberia jamais afirmar-se que D. João IV "merecia" o título de rei ou de rebelado, dependendo do sucesso ou do fracasso do movimento: por merecimento, ele já o teria; tratava-se apenas de uma luta para consegui-lo.

No parecer de Azeredo, nota-se uma interpretação oficial (ou oficiosa) em relação à Inquisição: esta não poderia ter desnudado seu caráter de instrumento político nas mãos do rei ${ }^{148}$. Segundo o então bispo de Elvas, Vertot afirma que o rei de Portugal "serve-se utilm" ${ }^{\text {te }}$. do formidavel Tribunal da Inquisição como de mais iguais instrum ${ }^{\text {to }}$. da politica". Isso, segundo o parecer do Bispo: "Deve riscar-se por q. alem de conter huma proposição sebre q. alem de sobre uso feliz, he injuriosa ao throno, e ao Tribunal da Inquisição" ${ }^{149}$. O uso político da Inquisição pelo Rei, portanto, constituiria uma injúria a uma e a outro. Não se poderia igualmente aceitar que os oficiais da Inquisição fossem, ainda que em sua minoria, adjetivados como "scelerados", nem que seria admissível que "a maior parte dos Juizes sabem sempre

Vertot, e de alegação jurídica de José Joaquim da Cunha de Azeredo Coutinho], Caixa nº 217, Mss 16.

${ }^{147}$ Ibidem (os grifos constam do próprio documento).

148 Ibidem.

${ }^{149}$ Ibidem (os riscos constam do próprio documento). 
acommodar a vont. d'aquelles q. governão"150 . O Bispo, para impedi-lo, ordenou que se riscassem tais trechos. Nas entrelinhas do parecer de Azeredo Coutinho, enfim, vê-se que não poderia ser publicado nada que pudesse conduzir à idéia de que seria legítimo a um povo rebelar-se, de que isto ocorrera na aclamação de D. João IV, de que a Inquisição e a Justiça serviam aos interesses políticos dos governantes: em outros termos, era preciso negar a tradição juspolítica corporativa-escolástica e, ao mesmo tempo, ocultar a mecânica do poder régio português.

A censura sob o Reformismo Ilustrado português, embora bafejada de Luzes, embora tomasse essas como referência para proibir obras religiosas e/ou jesuíticas, não poupou boa parte dos textos da Ilustração e mesmo de pensadores políticos modernos anteriores ao século XVIII. Logo em 23 de fevereiro de 1769, a Real Mesa Censória proibiu Sur la destrution de Jezuites de France, "impreço sem nome [do autor]", mas cujo autoria é atribuída a d'Alembert ${ }^{151}$, sob o pretexto de que, apesar de ser crítico em relação aos inacianos, em algumas passagens, acabaria por fazer uma apologia dos mesmos ${ }^{152}$.

Em 1769, aos 12 de dezembro, um outro edital proscrevia várias obras por seus ataques à Inquisição portuguesa ${ }^{153}$. Dentre elas figurava o Dictionnaire Historique, \& Critique de Pedro Bayle, deísta francês, havendo ainda menção a autores hoje praticamente desconhecidos: Reginaldo Gonsalves Montano, Filipe de Limborch, Gilberto Burneto, Josue Rousseau, Jacob Basnage e Jacob Usserio ${ }^{154}$.

\footnotetext{
${ }^{150}$ Ibidem.

${ }^{151}$ HAZARD, Paul. O pensamento europeu no século XVIII, op. cit., p. 106.

${ }^{152}$ IANTT, Real Mesa Censória, Edital de 23 de fevereiro de 1769, Caixa 1.

${ }^{153}$ IANTT, Real Mesa Censória, Edital de 12 de dezembro de 1769, Caixa 1

${ }^{154}$ Ibidem.
} 
Nesse edital expõe-se uma visão sobre o papel da Inquisição e a relação entre religião natural e religião revelada, contrapondo-se aos críticos da Inquisição e às idéias defendidas por filósofos deístas, materialistas e ateístas da Ilustração. Qualifica-se a religião como o "objecto mais importante ao Genero Humano", da qual dependeriam a "Bemaventurança Temporal, e Eterna; a prosperidade da Igreja; a segurança do Imperio; e geralmente todo o bem da união, e sociedade Christãa, e civil". Fundamento do Estado, da Igreja, da Sociedade cristã e civil, não era bastante — no que se vê uma refutação dos deísmos — "a Religião Natural para a completa satisfação desta importantissima divida" com o Criador, sendo necessária, de modo absoluto e indispensável, a "Religião revelada para podermos pensar, e sentir dignamente de Deos". Caberia, assim, crer em "todos os mysterios revelados", devendo as leis temporais e espirituais conservar os "Dogmas da Fé" e as "Regras da Moral Evangélica". O "Santo Officio da Inquisição" seria, dentre "todos os estabelecimentos humanos", o que mais tinha contribuído para a conservação da fé cristã. Após apresentar um breve histórico da instalação do tribunal em Portugal, enaltecendo sua atuação, e, ainda, depois de afirmar que faltava conhecimento desta sua colaboração e do "verdadeiro estado da Inquisição deste Reino", o edital menciona "huma multidão de Escritores, aliás doutos, bem intencionados, e beneméritos da Igreja" e outros, "homens malignos", que denegriram o "sobredito Tribunal util, e necessario, com calumnias atrozes". Por fim, refuta todas as acusações que se faziam contra a Inquisição: que a mesma ofendia a autoridade real, usurpava o direito dos bispos, estabelecia e propagava máximas ultramontanas, era cruel e sanguinária e só se interessava pelos bens confiscados dos réus ${ }^{155}$.

O mais importante edital que se voltou contra os Ilustrados e os pensadores políticos modernos, no entanto, é o de 24 de setembro de 1770. Seus alvos são o deísmo, o materialismo e o ateísmo; da mesma forma que ocorre no edital de 12 de dezembro de 1769, nele se esboça uma visão sobre a religião, o indivíduo, a sociedade e o império. Afirma-se a primazia absoluta do cristianismo, única religião que, "pela excelência de sua Doutrina, e sublimes preceitos de sua moral", pode dirigir o coração do homem, iluminar o seu espírito, regular os seus ofícios e pôr "o mais forte freio às suas paixões"; única religião que faria com que o homem conhecesse "a influência da razão natural", sujeitasse "as suas fracas luzes às

${ }^{155}$ Ibidem. 
superiores verdades de Revelação Divina, comunicadas pela escritura, e pela Tradição". A religião conduziria o homem "à prática de todas as virtudes, e ao mais perfeito exercício das suas obrigações”, e o faria cônscio da obrigação que devia a Deus e ao próximo. Aqui, portanto, primeiro, está implícita a necessidade de se aliar religião natural e religião revelada; em segundo lugar, concebe-se o cristianismo como a verdadeira e única religião; e, além disso, entende-se que um de seus papéis consistiria em nortear a conduta individual e social do homem, sujeitando-se à razão natural, refreando suas paixões, fazendo-o agradecer a Deus e amar ao próximo. À religião caberia também outro papel: "Estabelece[r] a boa ordem, e o Poder do Governo Político: firma[r] a autoridade e proteção nos Soberanos: Assegura[r] a sujeição e obediência nos vassalos", sendo o temor do juízo final um elemento que conteria o homem. Portanto, a religião instituiria a autoridade nos reis e a obediência nos vassalos, seria o fundamento da sociedade política ${ }^{156}$.

Por essas razões, segundo o mesmo edital, a Coroa vinha combater os estragos que a "irreligião" estava a provocar "na maior parte da Europa", ferindo os "Principios mais sagrados da mesma Religião, para invadir os mais solidos fundamentos do Throno" e para romper os vínculos que uniam os fiéis a Cristo. Para tanto, o edital proibia inúmeras obras escritas por homens que se auto-denominavam Espíritos Fortes, Filósofos, podendo-se destacar dentre eles Ilustrados radicais e mesmo outros, que defendiam a fé cristã. Dentre as obras e autores arrolados no edital censório em tela, é possível citar: Mémoires secrètes de la république des lettres, Lettres Cabalistiques, Lettres Chinoises e Lettres Juives, obras de autoria do Marquês d'Argens; Dictionnaire Historique, \& Critique e Oeuvres diverses, de Pierre Bayle; Histoire du Peuple de Dieu, Défense de la seconde partie de l'Histoire du Peuple de Dieu e Nouvelle défense de l'Histoire du Peuple de Dieu, escritas pelo jesuíta Joseph Isaac Berruyer; L'Antiquité dévoilée par ses usages e Recherches sur l'origine $d u$ Despotisme Oriental, de Nicolas Antoine Boulanger, um dos colaboradores da Enciclopédia; A Discourse of the grounds, \& reasons of the Christian Religion e The Discourse of freethinking, occasioned by the rise and growth of a sect called freethinkers, dentre outras obras de Anthony Collins; Elementa Philosophica de Cive e Leviathan, ambas de Thomas Hobbes; Lettre sur

${ }^{156}$ IANTT, Real Mesa Censória, Edital de 24 de setembro de 1770, Caixa 1, p.1-2. 
les Aveugles, à l'usage de ceux, qui voyent ${ }^{157}$, de Diderot (cujo autoria não é mencionada no edital, mas que se sabe chegou a ser preso devido ao caráter blasfemo desta obra ${ }^{158}$ ); os Contes, \& Nouvelles, de La Fontaine; The Grumbling hive, or Knaves turned Honest, do Barão de Mandeville; L'Histoire naturelle de l'Ame, de J. O. de la Mettrie; e Refutation des erreurs de B. Spinoza, do M. Fénélon, arcebispo de Cambraia. O edital tornava defesos escritos de autoria de Jean-Jacques Rousseau: Émile, ou de l'Education; Lettres écrites de la Montagne; Julie, ou la Nouvelle Heloïse e Du Contrat Social, ou Principes du Droit Politique. Interditava, do mesmo modo, Le Sopha, Conte Moral, de Claude Prosper J. de Crébillon Fils; Tractatus Theologico-Politicus, dentre outras obras de Spinoza; The rights of the Christian Church afferted e Christianity as old as the Creation, ambas de Matheus Tindal; e Christianity not Mysterious, de J. Toland. Proibia também várias obras de François Marie Arouet Voltaire: Lettres Philosophiques; Essai sur l'Histoire Générale; Précis de l'Ecclésiastique; Mélanges de Littérature, d'Histoire, \& de Philosophie; Religion Naturelle; Poème sur le désastre de Lisbonne; La Loi Naturelle; Epître à Uranie, Candide, ou l'Optimisme; La Pucelle d'Orléans; Dictionnaire Philosophique Portatif; La Philosophie de l'Histoire; La Princesse de Babylone; dentre outras obras. O mesmo edital censurava escritos sem autoria mencionada e incluídos entre as obras filosóficas estudadas por Robert Darnton, tais como ${ }^{159}$ : L'Evangile de la raison e De l'Esprit e o Nouveau Dictionnaire Historique portatif, par une Societé des Gens de Lettres, impresso em Amsterdã em 1769. Mandava, ainda, queimar na praça do Comércio, em Lisboa: Analyse de Bayle; Dictionnaire Philosophique; Lettres Turques; Oeuvres Philosophiques de La Mettrie; e, por fim, Recueil Nécessaire e Recherches sur l'Origine du Despotisme Oriental ${ }^{160}$.

Alguns filósofos da Ilustração ou cujas idéias foram essenciais para a mesma escaparam à sanha proibitiva do referido edital de 24 de setembro de 1770, mas tiveram suas obras proibidas e incluídas num catálogo organizado pela Real Mesa Censória, podendo-se citar os nomes de: d'Alembert, Bielfeld (que podia ser lido apenas por aqueles que tivessem licença, segundo edital de 03 de fevereiro de 1769), Brissot, Buffon, Cesare Beccaria, Condorcet, Condillac, Holbach, John Locke,

\footnotetext{
${ }^{157}$ Ibidem, p. 2-3.

${ }^{158}$ VIGUERIE, Jean de. Histoire et dictionnaire du temps des Lumières, op. cit., p. 906.

${ }^{159}$ DARNTON, Robert. Edição e sedição: o universo da literatura clandestina no século XVIII. Trad. Myriam Campello. São Paulo: Companhia das Letras, 1992, p. 69 e 19.
} 
Mably, Marmontel, Mirabeau, Montesquieu, Rétif de la Bretonne e Thomas Paine ${ }^{161}$; historiadores como William Robertson e Gibbon; e, ainda, cientistas como Carnot, Pinel e Tissot ${ }^{162}$. Além desses, foi vítima da censura Cláudio Adrião Elvecio (Claude Adrien Helvétius); sua obra Le Vrai Sens d'un système de la Nature foi interditada pelo edital de 05 de dezembro de 1775, no qual, além de se ver uma digressão sobre os homens de "espiritos fortes" em termos muito próximos aos encontrados no edital de 24 de setembro de 1770, justifica-se a proibição da obra pelo fato de conter "na maior parte dos seus Capitulos Proposições hereticas, ímpias, escandalosas, oppostas ao Culto devido a Deos, e a seus ineffaveis attributos; contrárias aos Direitos" da Coroa, ao "socego, e tranquilidade publica" dos "Povos; persuadindo, além do Materialismo, e Atheismo, o Suicidio, e outras horriveis impiedades, e blasfemias"163. A Henriade de Voltaire foi suprimida, mas Tomás Aquino de Belo Freitas traduziu-a e publicou-a em 1796 (ou 1789?), tradução esta também objeto de censura, numa demonstração de contradição dos órgãos censórios ${ }^{164}$.

Proibida também foi uma obra Ilustrada que teve grande impacto, em particular na América Portuguesa: a Histoire Philosophique et Politique des Établissements et du commerce des européens dans les deux Indes, de Thomas François Raynal Guillaume. Censurada na França, colocada no Índex, julgada ímpia, blasfematória, acusada de incitar os povos a se revoltarem contra seus soberanos e a caírem na subversão ${ }^{165}$, esta obra teve, de 1770 a 1780 , dezessete edições e, no período compreendido entre 1781 e 1787 , outras dezessete ${ }^{166}$. Caiu nas malhas do edital de 11 de outubro de 1773, por espalhar "libertinagens", apartando os "espiritos fracos, e á mocidade inadvertida" da "crença verdadeiramente Christã, e Orthodoxa, e fazelos sectarios da erronea, impia, e reprovada Filosofia", insinuando-se seu autor um "escandaloso Monarcomaco" ao "atacar as Leis mais Santas", "desacreditar as Nações mais polidas", "denegrir os Ministerios mais illuminados" e "infamar os

\footnotetext{
${ }^{160}$ IANTT, Real Mesa Censória, Edital de 24 de setembro de 1770, Caixa 1, p. 3-7.

${ }^{161}$ CATALOGO dos livros defesos neste Reino, desde o dia da Criação da Real Mesa Cençoria athé ao prezente, op. cit., p. 118-206.

162 Ibidem, p. 380-380v.

${ }^{163}$ EDITAL de 05 de dezembro de 1775. In: COLLEÇÃO de Leys, op. cit., vol. 5, s/p.

${ }^{164}$ CATALOGO dos livros defesos neste Reino, desde o dia da Criação da Real Mesa Cençoria athé ao prezente, op. cit., p. e MORAES, Rubens Borba de. Livros e bibliotecas no Brasil colonial, op. cit., p. 57. As datas de publicação da obra em questão em português, apresentadas nessas duas fontes, não conferem, daí haver dúvida se foi em 1789 ou 1796.

${ }^{165}$ HAZARD, Paul. O pensamento europeu no século XVIII, op. cit., p. 96.

${ }^{166}$ LEITE, Paulo Gomes. A propagação do Iluminismo em Minas Gerais. Revista Minas Gerais, Belo
} 
estabelecimentos mais prudentes, e interessantes". Defesa da fé, das prerrogativas e direitos régios, da inquisição e do colonialismo - é isto que se pode ler ou inferir dessa argumentação. Todavia, tal argumentação se estende, apresentando novos elementos que remetem ao interesse de preservação da religião cristã, condenando-se as seguintes idéias supostamente presentes na obra: a compreensão das leis, que instituíram o cristianismo e proibiram o paganismo, como absurdas; a admissão da poligamia pela religião cristã; o questionamento dos mistérios e ritos da igreja e a qualificação do estado religioso como supersticioso ${ }^{167}$.

Pensadores e escritores do porte de Maquiavel, Montaigne, Espinoza, Jean Bodin, John Milton, Puffendorf (que deveria ser tolerado, mas acabou entrando para o rol de autores defesos), Rabelais e Thomas Morus também foram vítimas da censura portuguesa, tendo suas obras proibidas ${ }^{168}$. Clássicos como Anacreonte, Catulo e Ovídio eram proibidos, embora tivessem seus versos traduzidos e publicados pelos poetas árcades luso-brasileiros ${ }^{169}$. O Promptuario de Teologia Moral de Francisco Larraga, certamente um dos mais presentes manuais de teologia moral nas bibliotecas luso-brasileiras, teve sua edição espanhola de 1729 proibida $^{170}$. Ao mesmo tempo, a censura relacionou-se às reformas educacionais de 1759 e 1772 , principalmente após 1771, quando as atribuições da Diretoria Geral de Ensino passaram para a Real Mesa Censória, criada três anos antes ${ }^{171}$. Com as reformas, proibiram-se muitos dos livros usados pelos inacianos, ao mesmo tempo em que se preservou, de algum modo, a prática empregada pelos últimos de expurgar trechos de textos de autores antigos selecionados. Foi proibida a Gramática Latina de Manoel Álvares, bem como as obras de seus comentadores: Antônio Franco, João Nunes Freire, José Soares e Madureira ${ }^{172}$. Em idêntica situação ficou a "mais concorrida obra de estudos lingüísticos no século XVIII brasileiro"173, a Prosódia, de Bento Pereira, pois se considerava que, com seu uso, os estudantes correriam o perigo "de

\footnotetext{
Horizonte, 2 (13): 25, jan. 1989.

${ }^{167}$ IANTT, Real Mesa Censória, Edital de 17 de outubro de 1773, Caixa 1.

${ }^{168}$ CATALOGO dos livros defesos neste Reino, desde o dia da Criação da Real Mesa Cençoria athé ao prezente, op. cit., p. 118-206.

${ }^{169}$ MORAES, Rubens Borba de. Livros e bibliotecas no Brasil colonial, op. cit., p. 57.

${ }^{170}$ CATALOGO dos livros defesos neste Reino, desde o dia da Criação da Real Mesa Cençoria athé ao prezente, op. cit., p. 118-206.

${ }^{171}$ CARVALHO, Rómulo de, op. cit., p. 453.

${ }^{172}$ Alvará régio de 28 de junho de 1759. Apud. ANDRADE, António Alberto Banha de. A reforma pombalina nos estudos secundários do Brasil. São Paulo: Saraiva, Edusp, 1978, p. 161.

${ }^{173}$ ARAÚJO, Jorge de Souza, op. cit., p. 90.
} 
se lhes imprimir logo nos primeiros anos a multidão de palavras bárbaras, de que está cheia"174. Não se consideravam confiáveis as obras dos "Escritores antigos", em razão do que se prescrevia o uso da coleção feita por Chompré em Paris, em 1752, "para uso da Mocidade Christãa"175.

O Alvará de 30 de setembro de 1770 tomou algumas medidas relacionando livros e educação, em consonância com a política pombalina, de inspiração verneyniana, de dar prioridade ao ensino da língua e da gramática portuguesa, e, ainda, com o entendimento explícito de que "a correção das línguas Nacionais" era "um dos objetos mais atendíveis para a cultura dos Povos civilizados, por dependerem dela a clareza, a energia, e a majestade, com que devem estabelecer as Leis, e persuadir a verdade da Religião, e fazer úteis, e agradáveis os Escritos" ${ }^{\text {"176 }}$. Primeiramente, o Alvará ordenou aos mestres de língua latina que, ao receberem seus alunos, os instruíssem previamente, por seis meses, na língua portuguesa, usando a Gramatica Portugueza, composta por Antônio José dos Reis Lobato. Em segundo lugar, o Alvará determinou a abolição de uso de processos litigiosos e sentenças judiciais no ensino de primeiras letras, substituindo-os pelo "Catecismo pequeno do Bispo de Montpellier Carlos Joaquim Colbert, mandado traduzir pelo Arcebispo de Évora para instrucção dos seus diocesanos, para que por elle vam tambem aprendendo os Princípios da Religião" ${ }^{177}$, obra que se tornou relativamente freqüente nas bibliotecas da América portuguesa.

Um último aspecto a ser observado em relação aos parâmetros da censura portuguesa sob o Reformismo Ilustrado refere-se à sua posição diante dos sucessos revolucionários na França. Considerando-se que os jornais de então estavam submetidos à censura, pode-se, através deles, analisar se o posicionamento desta se manteve o mesmo ao longo do processo revolucionário que conturbou a França. A princípio, a Gazeta de Lisboa e o Jornal Encyclopedico dedicado à Rainha $N$. Senhora deixaram vazar notícias sobre a Revolução, "todas elas favoráveis aos agitadores que atacavam a ordem antiga e às idéias novas": opiniões generosas sobre o duque de Orléans, em 1787 e em 1789; críticas à “"cega"” adesão dos militares à Coroa, no que toca à repressão a distúrbios em Bordéus e Toulouse, em 1788;

\footnotetext{
${ }^{174}$ Alvará régio de 28 de junho de 1759, op. cit., p. 171.

175 Ibidem, p. 169.

${ }^{176}$ ALVARÁ de 30 de setembro de 1770. In: COLLEÇÃO de Leis, op. cit., vol. 3, s/p.

${ }^{177}$ Ibidem.
} 
referências às " "traças"” da Nobreza contra o terceiro estado, na reunião de Estados Gerais, em 1789; elogio à representação igual às das outras ordens obtida pelo terceiro estado, no mesmo ano; apologia à Constituição; defesa dos “"direitos do homem"”; e a narração pormenorizada dos sucessos posteriores da grande revolução, da tomada da Bastilha até agosto de $1789^{178}$. A partir desta data, deixou-se de fazer menção a tais acontecimentos e à França, país que só reapareceu no noticiário em dezembro, com uma notícia sobre uma reunião da Academia francesa. As notícias políticas só retornariam em julho de 90 , mas com tom cauteloso ${ }^{179}$.

Nos anos de 1792 e 1793, a Gazeta de Lisboa deu notícia de alguns feitos revolucionários, mas sempre resguardando a visão pró-Luís XVI e, ainda, revelando uma preocupação de qualificar como exógeno à gente portuguesa o que se julgava nocivo nos acontecimentos franceses. Assim, aos 15 de Fevereiro de 1793, o jornal lisboeta, depois de comentar eventos militares que se passaram na França, informava que "S. M. em demonstração de sentimento pela infeliz morte do Rei de França, Luiz XVI, se encerrou por dois dias, que principiárão a 8 do corrente, e tomou luto por hum mês, 15 dias rigoroso [sic], e 15 alliviado, e o mesmo ordenou que se observasse na Corte. Pelo mesmo motivo se mandárão fechar os Theatros por 2 dias" ${ }^{180}$. Uma semana depois, o jornal abria espaço para o testamento do rei de França, datado de 25 de dezembro de 1792. No testamento, Luís XVI faz recomendações ao delfim e, ao final delas, percebe-se claramente uma defesa das prerrogativas do absolutismo: "não [se] póde fazer felizes os seus povos senão reinando segundo as Leis; mas ao mesmo tempo [...] hum Rei não pode fazellas respeitar, nem fazer o bem que deseja, sem ter a authoridade necessaria: aliás, estando sujeito nas suas operaçoes, e não inspirando respeito, he mais prejudicial do que util"181 . Aos 12 de Março de 1793, a Gazeta busca, implicitamente, afugentar os riscos que a Revolução na França representava para a monarquia portuguesa, reafirmando a fidelidade dos vassalos desta, assim noticiando: a "conjuntura actual tem dado a conhecer que nos animos dos Portuguezes existe ainda a mesma lealdade para com os seus Soberanos, e o mesmo zelo pela gloria da Nação, que em tantas

\footnotetext{
${ }^{178}$ BEIRÃO, Caetano, op. cit., p. 370-380.

${ }^{179}$ CASTRO, Zília Osório de, loc. cit.

${ }^{180}$ IANTT, Real Mesa Censória, Gazeta de Lisboa, Caixa 468, No 1-53, 1793.

${ }^{181}$ Ibidem.
} 
outras occasiões se fizerão admirar em todas as partes do mundo, ornando a nossa Historia com os mais brilhantes factos" ${ }^{\prime 182}$.

A simpatia inicial manifestada pelos mencionados jornais portugueses diante da Revolução Francesa e o temor suscitado a partir do recrudescimento do movimento revolucionário mostram que o posicionamento da censura alterou-se ao longo do tempo: a princípio, a censura liberou os jornais, endossando suas simpatias em relação à Revolução Francesa; depois, veio a cerceá-los e a promover, ao mesmo tempo, uma defesa do absolutismo e de Luís XVI e uma apologia da fidelidade dos portugueses à monarquia. $\mathrm{O}$ endosso inicial da censura à Revolução expressa a delicadeza do equilíbrio em que se encontrava o Reformismo Ilustrado português no período mariano e, ao mesmo tempo, sugere que a ação da Real Mesa da Comissão Geral da censura foi palco de vacilações.

$\mathrm{E}$, de fato, tais vacilações se revelaram uma realidade recorrente: em vários momentos, a Real Mesa da Comissão Geral não apenas autorizou a publicação ou a entrada de livros que afrontavam o absolutismo, como chegou a corroborar as idéias dos mesmos. A obra Processo verbal da Assembléia dos Notáveis que houve em Versalhes no anno de 1787, impressa em Paris em 1788, por exemplo, foi permitida pelo censor José Bernardo Gama e Ataíde, que considerava que as falas nela contidas “"se dirigem ao melhoramento da monarquia"," ${ }^{83}$. O censor que examinou o livro Recherches sur les Etats Unis, em quatro volumes, embora o considerasse um "veneno" por ser "sedicioso", autorizou sua leitura aos que tivessem licença do tribunal, fazendo em seu parecer uma defesa do "governo democrático" e do direito de todos os homens à liberdade ${ }^{184}$. No seu entendimento, era reprovável o sucedido na França, mas o "'Sistema de governo Popular parece sempre plausível, $\mathrm{m}^{\text {to }}$. mais mostrando-se nestes Livros já praticado: E não he menos apetecível pelo que toca à Religião, pondo por princípio universal, q' todos os homens nacem livres, igualm. $^{\text {te, }, 185}$.

A atividade censória portuguesa, a partir de Pombal, em linhas gerais, portanto, tinha como alvos, de um lado, os filósofos bafejados pelas Luzes e, de outro, o "fanatismo", a "ignorância" e a licenciosidade, isto é, uma vida sem decoro,

\footnotetext{
182 Ibidem.

${ }^{183}$ BASTOS, José Timóteo Silva, op. cit., p. 138-9.

${ }^{184}$ Ibidem, loc. cit.

${ }^{185}$ Ibidem, p. 140.
} 
desonesta, solta, personificada nos jesuítas, partidários de idéias milenaristas, molinosistas e de teorias corporativas de poder. A censura propugnava as "luzes da razão e da verdade", fundadas em "católicos verdadeiros"; esforçava-se por conciliar a "Razão", os interesses do catolicismo e do Estado - no que se incluía a oposição aos jesuítas. Movendo-se num equilíbrio tênue, a censura portuguesa chegou ora a perder de vista os interesses da monarquia, ora exorbitou-os ao ponto de colocar as Luzes que eram sua referência na penumbra da interdição, oscilando entre concessões excessivas e severidade demasiada. Essa oscilação, como se verá nos Capítulos 5 e 6, fez-se presente na fiscalização da circulação e da posse de livros, bem como na concessão de licenças para a leitura de obras defesas. Em relação a essas últimas, ao final do período, sob a Real Comissão Geral, como se verá adiante, a balança pendeu para as Luzes. 


\section{Capítulo 5: \\ O Controle e a Difusão da Circulação e da Posse de Livros}

No mundo luso-brasileiro, de 1517 a 1808, a fiscalização desenvolvida pelos órgãos censórios sobre a circulação, posse e leitura de livros proibidos e, de resto, a atividade censória em geral (no que se inclui o controle sobre a impressão), apresentaram alguns traços comuns, permanentes, malgrado as modificações processadas. Ao mesmo tempo, as alterações verificadas no aparato censório determinaram certas peculiaridades na ação fiscalizatória.

Por essas razões, primeiramente, serão apresentadas as linhas gerais do funcionamento da censura, em particular da fiscalização da posse, circulação e leitura e, em seguida, as singularidades do período da tríplice censura, de 1517 a 1768.

Depois, será focalizada a etapa subseqüente, que se estende de 1768 a 1808, iniciando-se com a criação da Real Mesa Censória, período em que a censura foi exercida sob a égide do Reformismo Ilustrado ${ }^{1}$.

Foge aos propósitos desta tese analisar detidamente as interferências da censura sobre a produção e a impressão dos livros, que serão abordadas apenas marginalmente.

\section{Linhas Gerais}

O desenvolvimento da atividade censória em Portugal e seus domínios nunca logrou conter nem a publicação, nem a entrada, nem a posse, nem a leitura de livros proibidos. Isto não quer dizer que os órgãos censórios não tenham colocado

\footnotetext{
${ }^{1}$ A partir de 1768, como se observou anteriormente, a censura coube, sucessivamente, à Real Mesa Censória (1768-1787), à Real Mesa da Comissão Geral para a censura de livros (1787-1794) e à Inquisição, Ordinário e Desembargo do Paço (1794 -1820). Todavia, apesar dessa diversidade, houve uma certa uniformidade de procedimentos. $\mathrm{O}$ regimento utilizado para a censura permaneceu o mesmo desde 1768, isto é, era o da Real Mesa Censória. A lei de 17 de julho de 1795, que regulou o funcionamento da censura tríplice, além disso, não introduziu modificações radicais em relação ao que se aplicava anteriormente (desde 1768), exceto pelo seu maior rigor (CARREIRA, Laureano, op. cit., p. 92-93). Essa situação e o fato da documentação encontrar-se reunida num único fundo (o da Real Mesa Censória) justificam a abordagem conjunta da censura no intervalo 1768-1808.
} 
obstáculos à impressão, ao comércio, à posse e à leitura. Interditar os descaminhos do livro foi sempre uma preocupação, em alguns momentos mais intensa, noutros menos. O problema é que contra este propósito pesaram alguns limites. Primeiro, o contraste entre o dinamismo editorial e mercantil dos profissionais do livro e a lentidão de uma máquina burocrática incumbida de várias tarefas: emitir, preventivamente, licenças ou recusas de impressão; publicar "índices da 'biblioteca' defesa, éditos sobre a condenação de obras individuais a serem cotejados com os títulos detectados em circulação"; fornecer autorizações particulares de leitura, permitindo a algumas pessoas a posse e a leitura de livros proibidos; e, por fim, exercer a repressão judicial, perseguindo toda a desobediência às normas de impressão, venda e leitura de livros ${ }^{2}$. Previnir, interditar e reprimir, atuando no circuito que vai da produção do livro até sua leitura, eram tarefas demasiadamente hercúleas para uma máquina burocrática lenta, para a qual faltavam critérios únicos, uniformidade na ação repressiva, articulação entre os vários órgãos ou esferas de fiscalização, problema este que se agravava nos domínios coloniais.

No que concernia especificamente à circulação, posse e leitura de livros proibidos, a fiscalização encontrava outros óbices. Havia, primeiramente, uma espécie de "estamentalização-corporativização" do uso do livro: a posse e a leitura de livros, além de serem um privilégio no sentido econômico, algo acessível no geral apenas aos mais abastados, eram também, no caso dos livros proibidos, um privilégio legal, de categoria profissional ou nível cultural, ou até mesmo, de cunho estritamente estamental. Algumas pessoas podiam ler determinados livros e autores, que, inversamente, eram proibidos para a maioria da população. Esse privilégio, por seu turno, acabava por redundar na permissão para que os próprios livreiros comercializassem junto aos privilegiados algumas obras proibidas. Essas aberturas dadas pela "estamentalização-corporativização" da posse e da leitura do livro, portanto, facilitavam a circulação dos livros proibidos, que, com freqüência, atingiam aqueles a quem a lei vedava possuí-los e lê-los. Há que considerar, por fim, outros dois fatores. Na Europa Ocidental no século XVIII, as interdições governamentais produziam um efeito diverso daquele que almejavam, pois acabavam por estimular

\footnotetext{
${ }^{2}$ MARQUILHAS, Rita. op. cit., p. 174-175. Apesar da autora citada deter-se na análise do aparato censório especificamente no século XVII, concentrando-se na Inquisição, suas colocações são válidas também para o período posterior e, com certeza, podem ser estendidas para a América Portuguesa.
} 
os leitores a procurarem os livros proibidos ${ }^{3}$, não escapando esse fato à consciência dos censores portugueses: em 1776, a Real Mesa Censória interditou as Memórias Turcas, mas não se arriscou a fazê-lo por edital “"porque nascendo da proibição o apetite' receava 'que, querendo-se evitar a lição de semelhante obra, servisse o edital de desafiar a curiosidade para ver o que ela contém",4. Ao mesmo tempo, em resposta e estimulando essa receptividade do livro defeso, estruturou-se toda uma rede clandestina de impressão, comércio, leitura e, mesmo, reprodução em manuscrito das obras proibidas ${ }^{5}$. Com isto, como observou Rita Marquilhas, há uma "uma céptica distância entre o que ficou determinado nas compilações de normas", e o que concretamente "se verificou em matéria de erradicação dos textos" heterodoxos ${ }^{6}$. No contexto colonial, essas dificuldades parecem ter se agravado e, ainda, variado conforme o espaço e época: Rubens Borba de Moraes observou, na América Portuguesa, uma "falta de uniformidade no cumprimento das injunções da censura", havendo "severidade em certas capitanias em determinadas épocas" e "nenhuma fiscalização em outras partes do país", atribuindo essa diversidade de situações à "autonomia dos capitães-generais e às circunstâncias de momento"”.

\section{Censura Tríplice e Fiscalização}

A lentidão e a falta de uniformidade na ação censória eram evidentes no tempo em que a censura ficou sob o encargo da Inquisição, do Desembargo do Paço e do Juízo Eclesiástico. Existiram falhas, além disso, que advinham do caráter seletivo, de natureza "estamental-corporativa" ou profissional, das proibições estipuladas pela Inquisição: havia "juízos explicitamente formulados sobre a escala sociocultural” dos leitores, estabelecendo-se uma distinção entre "“gente ignorante' ('vulgar', 'comum', 'que menos entende', 'carecida de letras') e os notórios pelo nível de cultura". Aos "ignorantes", facilmente sugestionáveis, gente a ser educada,

\footnotetext{
${ }^{3}$ HAZARD, Paul. O pensamento europeu no século XVIII, op. cit., p. 96-98. Isto parecia acontecer também no século anterior. O livro de Hugo Grotius, proibido pelo Índex de 1624, circulou em Portugal sob a forma de manuscritos (TORGAL, Luís Reis, op. cit., vol. 1, p. 298).

${ }^{4}$ BASTOS, José Timóteo da Silva, op. cit., p. 110.

${ }^{5}$ DARNTON, Robert. Edição e sedição: o universo da literatura clandestina no século XVIII, op. cit., p. 37-126.

${ }^{6}$ MARQUILHAS, Rita, loc. cit.. A autora faz esta observação referindo-se especificamente à Inquisição, mas, com certeza, sua conclusão pode ser estendida aos outros órgãos que atuaram na censura literária.

${ }^{7}$ MORAES, Rubens Borba de. Livros e bibliotecas no Brasil Colonial, op. cit., p. 59.
} 
deveria ser cerceado o acesso a determinados livros. Enquanto à elite intelectual constituída pelos "letrados conhecidos" e pelos religiosos em geral, grupo ao qual se integravam os próprios censores, acabava-se por conceder não só a licença para possuir e ler livros proibidos, como também, a partir do Índex de 1624, a permissão para que desempenhassem uma forma de autocensura, expurgando seus próprios textos. Em uma palavra, a "identidade de cada leitor determinava o grau de confiança que o Santo Ofício nele poderia depositar",

O tribunal do Santo Ofício foi peça fundamental durante a vigência do sistema de tríplice censura, de 1517 a 1768. Nesse período, o Conselho Geral do Santo Ofício podia ordenar a inspeção de bibliotecas públicas e particulares e, ainda, de navios ancorados nos portos ${ }^{9}$. Após 1768 , durante a fase da censura única, a interferência da Inquisição no que se relacionava à posse e à leitura de livros proibidos foi mantida, na medida em que ambas, posse e leitura, muitas vezes coincidiam com a implicação em heresia, crime da jurisdição inquisitorial. Assim, a Inquisição imiscuiu-se no controle da posse e da leitura de livros mesmo depois de 1768: até 1787, sujeitando-se à primazia da Real Mesa Censória e, de 1787 a 1794, de sua sucedânea, a Real Mesa da Comissão Geral para a censura de livros. A partir de 1791, a Inquisição retomou o direito de censurar obras no que tocasse à pureza da fé, mantendo-se com as mesmas prerrogativas sobre leitura e posse de livros proibidos; depois de 1794, em relação a esse último aspecto, a inquisição passou a subordinar-se ao Desembargo do Paço. Assim, ao se tratar da participação da Inquisição na repressão à posse e à leitura de livros proibidos durante a vigência do sistema da tríplice censura, eventualmente serão desrespeitados os limites cronológicos 1536-1768, mencionando-se ações desenvolvidas quer no período de censura unificada, entre 1768 e 1794, quer quando se retornou ao sistema tríplice, sob a tutela do Desembargo do Paço, entre 1794 e 1808.

\footnotetext{
${ }^{8}$ MARQUILHAS, Rita, p. 191-197.

${ }^{9}$ BASTOS, José Timóteo da Silva, op. cit., p. 41.
} 
A Inquisição empregava revedores para visitar as livrarias. Havia também os visitadores das naus, encarregados de apreender livros nas embarcações. A Inquisição, além disso, contava com comissários e familiares, agentes espalhados por todos os domínios d'El-Rei, que, dentre outras coisas, fiscalizavam a posse e a leitura de livros proibidos e publicavam editais contendo róis desses últimos. Outro apoio importante para a ação inquisitorial foram alguns padres da Companhia de Jesus, provavelmente também investidos da função de comissários ou familiares da Inquisição, caso em que se enquadravam, segundo informação de Bruno Feitler, os reitores dos colégios, designados "comissários eleitos" (provisórios).

No Brasil, foram localizados 33 qualificadores e apenas um visitador de naus, no Maranhão do início do século XVII ${ }^{10}$. Na correspondência inquisitorial, há informações mais substanciais sobre o funcionamento da censura na Colônia. Evidencia-se, primeiro, o envio à América Portuguesa de editais de livros proibidos pela Inquisição. Em 1696, mandaram-se 22 editais de livros proibidos de Antônio da Fonseca, para serem publicados na cidade da Bahia e demais partes que se achassem necessário. Com o mesmo intuito, foram encaminhados ao padre Felipe Coelho, da Companhia de Jesus em Pernambuco, mais seis editais dos sobreditos livros, a serem publicados naquela capitania, "adentrando a Paraíba". O mesmo número de editais foi enviado para o Rio de Janeiro. Em 1722 e 1725, foram remetidos, respectivamente, a Pernambuco e a São Paulo "das Minas", editais de livros proibidos, em ambos os casos aos cuidados do reitor dos colégios ${ }^{11}$. Além da publicação de editais censórios, a correspondência inquisitorial mostra que o controle sobre livros e leitura assumia outros contornos: em 1711, mandou-se que se examinassem no Rio de Janeiro as bibliotecas das pessoas que falecessem, apreendendo-se os livros proibidos que possivelmente viessem a ser encontrados ${ }^{12}$. E, em janeiro de 1750, ordenou-se ao comissário da Bahia, que investigasse as bibliotecas de letrados, com o objetivo de encontrar livros proibidos ${ }^{13}$. Em suma, a Inquisição mandava publicar editais de livros proibidos e investigar bibliotecas de

\footnotetext{
${ }^{10}$ SIQUEIRA, Sônia. A Inquisição portuguesa e a sociedade colonial. São Paulo: Ática, 1978, p. 170172.

${ }^{11}$ IANTT, Inquisição de Lisboa, Correspondência enviada - Registro, Livros 20 e 21. Agradeço a Bruno Feitler pelo repasse das informações colhidas nos seguintes códices da Inquisição de Lisboa: livros 20, 21, 22, 220, 283 e 284.

${ }^{12}$ IANTT, Inquisição de Lisboa, Correspondência enviada - Registro, Livro 20.

${ }^{13}$ IANTT, Inquisição de Lisboa, Correspondência enviada - Registro, Livro 22, fol. 429.
} 
falecidos e de letrados. Não é possível, no entanto, avaliar a freqüência e a amplitude dessas medidas e, muito menos, os seus resultados.

É certo que os comissários colaboravam com regularidade na vigilância sobre os livros e a leitura. Em 1722, o comissário do Santo Ofício na vila de Nossa Senhora da Candelária de Itu, encaminhava à Lisboa duas denúncias: uma primeira, feita por Domingos Fernandes Porto, a partir do famigerado "ouvir dizer", contra Jacome de Brito e seus familiares e, uma segunda, do capitão João Paes Rodrigues, contra Diogo Mendes Torres. Jacome e família estariam implicados em "huas acçoens judaicas", enquanto Diogo Mendes "tinha hum livro que tratava de acçoens judaica" ${ }^{\text {"14 }}$. Mesmo no período em que a censura literária ficou sob a jurisdição da Real Mesa e, depois, da Real Mesa da Comissão Geral para censura, entre 1768 e 1794, os comissários continuaram a enviar à Inquisição denúncias sobre a posse de livros proibidos, uma vez que esses apareciam associados à heresia. Assim, o frei José Barreto Coutinho, comissário do Santo Ofício no Rio de Janeiro, em 1778, escrevia à Inquisição de Lisboa que ouvira “dizer" pelo padre mestre frei Tomé da Madre de Deus, do Convento do Carmo, que o doutor Tomé Joaquim Gonzaga, "faltava pouco $\mathrm{p}^{\mathrm{a}}$. erege; e q. conservava Livros prohibidos, que dizia ele ter faculdade para os poder ler e ter"15. Da mesma forma agiu o doutor Nicolau Gomes Xavier, comissário em Minas, na passagem do século XVIII para o século XIX: em 1781, por exemplo, mandava uma denúncia feita por Manoel Rodrigues Cordeiro, aprendiz de Gramática em Santa Luzia, contra Miguel Eugenio, subdiácono ou diácono, por reproduzir uma interpretação heterodoxa do Novo Testamento, ouvida de teólogos no Rio de Janeiro, segundo a qual não seria necessário o batismo para a salvação no caso dos que não tivessem culpa pessoal ${ }^{16}$.

Até mesmo quando se encontravam em trânsito, os comissários mostravam-se zelosos de suas atribuições, enviando delações à Lisboa, como fez, do Rio de Janeiro, em 1778, o comissário Felix Josef de Aquino, contra o sargento-mor Manoel Antônio Machado, morador da Vila de Pernáqua (Paranágua), por ler livros proibidos

\footnotetext{
${ }^{14}$ IANTT, Inquisição de Lisboa, Cadernos do Promotor no 91, Livro 284, fol. 544. Sobre a relação entre cristãos-novos, livros e práticas de leitura na América Portuguesa, há indicações instigantes em: FEITLER, Bruno. Les nouveaux-chretiéns dans la Capitainerie du Paraíba au XVIII ${ }^{\mathrm{e}}$ siècle. Cahiers du Brésil Contemporain, Paris, (32): 89-106, 1997.

${ }^{15}$ IANTT, Inquisição de Lisboa, Cadernos do Promotor no 130 (1750-1790), Livro 319.

${ }^{16}$ Ibidem.
} 
e, a partir deles, levantar dúvidas sobre preceitos da fé cristã ${ }^{17}$. Os comissários serviam em alguns casos, além disso, como intermediários de confissões, como fez Francisco de Almeida Branco, em Sergipe, na povoação da Estância, termo de Vila Real da Praia: em 1779, ele remeteu à Inquisição a auto-delação feita por Antônio Bernardo da Rocha, que lera em Lisboa um livro proibido francês que continha heresias e falara sobre seu conteúdo às pessoas "rústicas" da mencionada povoação sergipana $^{18}$. Os comissários, finalmente, nem sempre se limitavam a repassar as denúncias recebidas, na medida em que teciam considerações sobre o fundamento das últimas e, ainda, sobre os obstáculos que uma apuração das mesmas poderia encontrar $^{19}$. Isto foi feito, em 1801, da cidade de São Paulo, pelo comissário Paulo de Souza Rocha, a respeito de uma denúncia de José Álvares Dantas, vigário da matriz da Vila de Taubaté, contra Bento Álvares de Lacerda e Castro, cadete do regimento de voluntários e suposto parente do general da capitania, por dizer blasfêmias e heresias, duvidando das "Sagradas escrituras, $p^{r}$. serem escritas $p^{r}$. homens" ${ }^{20}$. Em correspondência ao Santo Ofício, o comissário informou que sua "avançada idade", suas "quotidianas moléstias" e a distância entre Taubaté e São Paulo impediam uma averiguação pessoal; a inexistência na capital paulista de outro comissário e o fato do vigário não o poder ser, já que era, no caso, o denunciante, dificultavam também a apuração da denúncia ${ }^{21}$. Alertou, ainda, serem necessárias providências para a segurança e uma ordem expressa do Príncipe Regente, pois o denunciado se achava "debaxo do comando, e governo desta Capitania". Ao mesmo tempo, pelas informações que tinha tomado, concluíra que o denunciado não era parente do

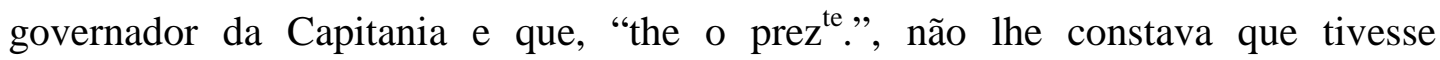
pronunciado as "taes blasfemias" 22 .

Os exemplos citados mostram que o apoio dos comissários e familiares ao tribunal da Inquisição era sustentado na colaboração oferecida pela própria população, através de denúncias e confissões. As gentes funcionavam como elementos fiscalizadores da circulação, posse e leitura de livros proibidos, encaminhando denúncias aos tribunais - no caso do Brasil, ao de Lisboa. Duarte

\footnotetext{
${ }^{17}$ Ibidem

${ }^{18}$ Ibidem.

${ }^{19}$ Ibidem.

${ }^{20}$ IANTT, Inquisição de Lisboa, Caderno do Promotor nº 134 (1797-1802), Livro 322.

${ }^{21}$ Ibidem.

${ }^{22}$ Ibidem.
} 
Guterres, em 1639, denunciou ao Santo Ofício que nove anos antes, numa sinagoga em Amsterdã, encontrou um cristão-novo, Manoel Dias Soeiro, que depois soube ser o rabino Menassé ben Israel, que lhe noticiara ter "mandado dois caixois de liuros que tinha composto a espanha hú caixaõ e ao brazil outro e que o liuro se intitula reconciliacoens de la sagrada escritura", dos quais o próprio denunciante conservava um exemplar, que iria entregar à mesa ${ }^{23}$. No início do século XVIII, o padre secular Manoel Américo da Costa, em Olinda, denunciou o capitão Cosme da Silveira por indagar-lhe, numa discussão sobre o "que conta o livro de Fernão Mendes Pinto", “qual ley he mais verdadeyra", a dos judeus ou a dos cristãos ${ }^{24}$.

Joäo Luís Sayão, cônego da Sé de Mariana, foi um exímio denunciante da Inquisição. Dizendo-se ser "fundado unicamente na obediência ao Santo Officio", levava sua vigilância e zelo compulsivos pela ortodoxia ao extremo de vasculhar as estantes de bibliotecas alheias, avisando aos seus proprietários sobre a existência de livros proibidos, às vezes insistentemente, sem, contudo, causar-lhes temor, permanecendo os livros no mesmo lugar. Suas denúncias foram feitas após a extinção da Real Mesa da Comissão Geral para a censura de livros, quando do retorno ao sistema de censura tríplice. Em 1795, Sayão enviou uma denúncia contra o Visconde de Barbacena, governador das Minas à época da Inconfidência, e vários membros da igreja, como o padre Inácio José Ferreira de Souza, por possuírem livros proibidos $^{25}$. Em 1801, Sayão voltou suas baterias contra Manuel da Cunha Pacheco, pároco da Vila de S. Bento do Tamanduá, bispado de Mariana, por este ter lido a obra Código da Humanidade ou outra do mesmo gênero, enviada a um homem que morava no Rio de Janeiro. Salientou, porém, que Manuel da Cunha era um "homem orthodoxo", que o mesmo denunciara ao Santo Ofício quem possuía a citada obra e, ainda, que a lera "por cauza de algum, ou alguns tratados, e allegou o das uzuras"26.

Os visitadores dos Santo Ofício enviados especialmente às partes do Brasil coletaram também denúncias a respeito de livros proibidos ${ }^{27}$. Heitor Furtado de

${ }^{23}$ IANTT, Inquisição de Lisboa, Cadernos do Promotor no 19, Livro 220, fol. 20-21.

${ }^{24}$ IANTT, Inquisição de Lisboa, Cadernos do Promotor no 90, Livro 283, fol. 51.

${ }^{25}$ Denúncias que a Esta Inquisição enviou o Comissário Frei Feliz de Santa Thereza Nascentes... apud. JOBIM, Leopoldo Collor. O Santo Ofício da Inquisição no Brasil Setecentista: estudo de uma denúncia. Revista de Estudos Ibero-Americanos, Porto Alegre, 13 (2): 201-208, dez. 1987.

${ }^{26}$ IANTT, Inquisição de Lisboa, Cadernos do Promotor no 134, Livro 322, 1797-1802. Há outras denúncias feitas pelo mesmo, como a enviada em 1802 contra um relojoeiro de nome Custódio (IANTT, Inquisição de Lisboa, Maços Novos, Mç 27, $\mathrm{n}^{\circ}$ 28).

${ }^{27}$ Outras referências a esta preocupação são indicadas por: SIQUEIRA, Sônia A., op. cit., p. 228; In: MELlO, José A. Gonsalves de (org.). Primeira visitação do Santo Ofício às partes do Brasil: 
Mendonça, em sua visitação à Bahia e ao Recôncavo (1591-92) e a Pernambuco (1594-1595), e D. Marcos Teixeira, em visita à Bahia, entre 1618 e 1620, interrogaram confessantes a respeito da posse e leitura de livros proibidos. A Inquisição perseguia, além dos judaizantes, os mouros, os que defendiam idéias protestantes e aqueles que punham em dúvida os dogmas e leis da igreja de Roma, duvidando da Virgindade de Maria, dizendo que não havia pecado na fornicação, negando a existência do Purgatório, vivendo em bigamia e questionando os sacramentos $^{28}$. Na primeira visitação à Bahia, nas interrogações relacionadas a livros proibidos, insinuaram-se os fantasmas luterano e mouro (este, em apenas um caso). Perguntou-se sobre o contato com luteranos e sobre a leitura de livros de autoria desses a alguns confessantes, como: Bartolomeu Garcez, cristão-novo, alfaiate, que confessou ter dito que " "por clérigos e frades se há de perder o mundo"”; Manuel Antônio, torneiro, cristão-novo, que confessou ter afirmado anos antes "que melhor estado é o de bom casado que as outras ordens dos religiosos"; e Francisco Pires, cristão-velho, que anos antes sustentara ser o estado dos casados "melhor que os outros estados dos religiosos, pois Deus o fizera"29. Já a Miguel de Roxas Moralles, catelhano, cristão-velho, lavrador, foi perguntado "se algum tempo andou e comunicou entre mouros ou luteranos, e se tem livros deles" ${ }^{\prime 30}$. Ele confessou ter discutido com Antônio Castanheira sobre os castelhanos e os portugueses: o último desdenhara dos castelhanos e lhe dissera que " antes mouro que castelhano", ao que ele retrucou " "antes mouro que português"”. O visitador interessou-se também por identificar pessoas que possuíssem Bíblias, principalmente em linguagem, mas também em latim ${ }^{31}$. Em Pernambuco e na Paraíba, o primeiro visitador do Santo Ofício demonstrou idêntica preocupação com a influência dos "hereges", interrogando a muitos confessantes sobre a manutenção de contatos com luteranos ou outros "hereges" e seus livros; em caso afirmativo, situação esta em que estiveram os tripulantes de uma frota capturada por luteranos franceses, em fins de 1594, o

confissões de Pernambuco. Recife: Universidade Federal de Pernambuco, 1970, p. 25-37; e SILVA, Maria Beatriz Nizza da. Sociedade, instituições e cultura. In: JOHNSON, Harold, Idem (coord.). Nova história da expansão Portuguesa: o império brasileiro: 1500-1620. Lisboa: Editorial Estampa, 1992, p. 541-542.

${ }^{28}$ VAINFAS, Ronaldo. Introdução. In: VAINFAS, Ronaldo (org.) Confissões da Bahia: Santo Ofício da Inquisição de Lisboa. São Paulo: Companhia das Letras, 1997, p. 9-10.

${ }^{29}$ Confissões da Bahia: Santo Ofício da Inquisição de Lisboa, op. cit., p. 176-7, 280-281 e 344-345.

${ }^{30}$ Ibidem, p. 187-189.

${ }^{31}$ SILVA, Maria Beatriz Nizza da. Sociedade, instituições e cultura, op. cit., p. 541. 
inquisidor esmiuçou os detalhes dos contatos e o envolvimento dos confessantes, que, via de regra, contavam que os luteranos faziam suas salvas, "lendo por livros, desbarretados, sem cruz nem imagem alguma"32.

O segundo visitador na Bahia, Marcos Texeira, manifestou o mesmo receio. Interrogou pormenorizadamente o cristão-novo Fernão Mendes, em 1618, sobre o livro intitulado Belial, que o mesmo confessara ler, indagando, dentre outras coisas, se o referido livro "tinha licença do Santo Officio" e se "tinha alguãs preposições ou cousas contra a nossa sancta fee catholica, ou algûas preposições ou cousas mal soantes, e cõntra o que tem e ensina a sancta madre Igreja de Roma" ou opiniões que fossem "cousas de herejes" 33 . Perguntou ao cristão-velho Pero Ferreira, no mesmo ano, defensor da proposição segundo a qual o "estado dos bõns casados era tão bom como o dos Religiosos", se "andara por terras de suspeita, ou tratara co gente de suspeita na fee ou lera por algû livro defeso que tivesse o dito erro ou outros semelhantes"; interrogação similar foi feita também a Pero de Goncalves Silva, cristão-novo, que falara mal da excomunhão ${ }^{34}$. É bom ressaltar, no entanto, que todas essas situações não obscurecem o fato - muito pelo contrário, vêm a demonstrá-lo - de que o controle sobre o livro era um, dentre outros tantos alvos, da ação inquisitorial, e, ainda, que isto certamente contribuiu para gerar falhas no sistema de fiscalização.

Aspecto nebuloso sobre a fiscalização da posse, leitura e circulação de livros no Brasil refere-se à atuação dos tribunais eclesiásticos. O segundo visitador do Santo Ofício Marcos Teixeira, ao interrogar o já citado confessante Fernão Mendes sobre a leitura de Belial, perguntou-lhe se "tanto que soube, que o [livro] era [defeso] o levou ao Ordinario, ou ao Comissario do $S^{\text {to }}$. Offo . como tinha de obrigação" 35 , do que se pode deduzir, primeiro, que os leitores deviam entregar livros proibidos aos tribunais eclesiásticos e, em segundo lugar, que esses últimos atuavam na censura literária também na Colônia, já nos inícios do século XVII. O exercício dessa fiscalização por parte do Ordinário na América Portuguesa encontra-se, não apenas sugerido, mas determinado, é bem verdade, pelas Constituições Primeiras do

\footnotetext{
${ }^{32}$ MELLO, José Antônio Gonsalves de, op. cit., p. 64-66, 69-74, 78 e 88-89.

${ }^{33}$ SEGUNDA visitação do Santo Ofício às partes do Brasil pelo inquisidor e visitador o licenciado Marcos Teixeira. Livro das Confissões e Ratificações da Bahia - 1618-1620. (Introd. Eduardo d’Oliveira França e Sônia A.Siqueira). Anais do Museu Paulista, São Paulo (17): 123-547, 1963.

${ }^{34}$ Ibidem, p. 405-406 e 423-424.

${ }^{35}$ Ibidem, p. 358.
} 
Arcebispado da Bahia, datadas do início do século XVIII e que regeram todos os bispados da Colônia a partir de então.

As Constituições proibiam ouvir e proceder a leitura de livros julgados “defesos pelos catálogos do Sumo Pontífice e da Inquisição do Reino, ou” ainda, proibidos pelas autoridades diocesanas. Determinavam aos vigários gerais dos bispados que chamassem os mestres ou os capitães dos navios, inquirindo-os sobre os livros possivelmente lidos na viagem, ou que viessem embarcados, remetidos a alguém. Nenhum livro da alfândega poderia ser entregue aos seus donos sem antes serem examinados pelo vigário geral. Aqueles que vendessem ou tivessem livros “de causas sagradas sem nome de autor, não sendo primeiro revistos e aprovados pelo ordinário", incorreriam em pena de excomunhão maior e pagariam 100 cruzados, ocorrendo o mesmo aos que comunicassem, lessem ou divulgassem livros não impressos, manuscritos ${ }^{36}$. Não há indicações, contudo, que evidenciem a aplicação dessas determinações. Na documentação do juízo eclesiástico de Mariana, por exemplo, inexiste qualquer menção à repressão, à posse, à leitura e, muito menos, ao comércio de livros proibidos ${ }^{37}$.

\section{Fiscalização e Difusão de Livros sob o Reformismo Ilustrado}

Com a criação da Real Mesa Censória, concentraram-se num único tribunal amplos poderes para fiscalizar todas as obras existentes em Portugal e seus domínios. Esta concentração foi mantida com a substituição desse tribunal pela Real Mesa da Comissão Geral para a censura de livros, cujos procedimentos não diferiram dos de sua antecessora. Marcavam-na também as arbitrariedades, a ineficácia e a falta de critério. A reinstalação do sistema de tríplice censura (Inquisição, Ordinário e Desembargo do Paço), como já foi sublinhado, não alterou fundamentalmente a rotina da censura, pois esta ficou em grande parte sob o controle do Desembargo do Paço. Isto vale para a fiscalização da posse, da leitura e da circulação de livros, matérias sobre as quais o Desembargo parecia dar a palavra final, conforme sugerem as palavras registradas na licença concedida em Lisboa a João Ferreira da Câmara,

\footnotetext{
${ }^{36}$ VIDE, Dom Sebastião Monteiro da. Constituições primeiras do arcebispado da Bahia (1707). Coimbra: 1720 , vol. 1, p. 8.

${ }^{37}$ PIRES, Maria do Carmo. Juízes e infratores: o tribunal eclesiástico do bispado de Mariana (17481800). Franca: Faculdade de História, Direito e Serviço Social da Unesp, 1997 (Dissertação de
} 
procedente da América, aos 12 de dezembro de 1799: “Achão-se juntas as Aprovações do Santo Officio, e Ordinario; e a vista de tudo V. A. determinará o q. for do seu Real Agrado a Respeito da entrega dos ditos Livros" ${ }^{38}$. Dois dias depois, anotou-se a ordem final, passada pelo Desembargo: "Entregue-se" 39 . Face a essa situação, é possível apreender em bloco o período iniciado em 1768.

\subsection{Alfândegas e Entrada de Livros}

Por determinação da Real Mesa Censória, os juízes das alfândegas ficaram obrigados a remeter todos livros que nelas se achassem para a casa da revisão ${ }^{40}$. $\mathrm{O}$ viajante Carl Rugers sublinhou que, caso algum nacional ou estrangeiro caísse " "na asneira de declarar na alfândega os livros que mandou vir", era de temer que tivesse que esperar por eles muito tempo "e até, talvez, de ficar sem alguns"”,41. Isso não escapava à consciência de outros contemporâneos, em particular dos peritos em matéria de livro, como o mercador Pedro José Reis, em Lisboa. Este, depois de vender a obra De l'autorité du roy touchant l'aage [sic] nécessaire à la profession solonnelle des religieux, de Roland Le Vayer Boutigny, ao já citado cônego João Luiz Sayão, de Mariana, não queria que o mesmo, quando o referido sacerdote retornava da Corte para as Minas, a "“pusesse no catálogo de livros que se haviam de apresentar à Real Mesa da Comissão Geral para se haver de dar a licença necessária de poder embarcar-se, dando com isto a entender que se não deixava passar", ${ }^{\text {, }}$. De fato, os que colaboravam com a censura, declarando e listando na alfândega os livros que levavam consigo em seus deslocamentos ou que remetiam a outrem, facilitavam a ação da fiscalização, correndo o risco de ficar sem alguns deles. Isso valeu tanto para os que aportavam na América, quanto para os que desembarcavam no Reino.

Muitos dos que retornavam da América ao Reino trazendo livros ou que os recebiam deste continente eram pegos de surpresa, não tendo à mão quer uma lista

mestrado).

\footnotetext{
${ }^{38}$ IANTT, Real Mesa Censória, Caixa 144.

${ }^{39}$ Ibidem.

${ }^{40}$ IANTT, Real Mesa Censória, Caixa 1, Ordem de 10 de junho de 1768.

${ }^{41}$ Carl Rugers. apud. GUEDES, Fernando. O livro e a leitura em Portugal: subsídios para a sua história (séculos XVIII e XIX). Lisboa: Verbo, 1987, p. 79.

${ }^{42}$ HIGGS, David. Linguagem perigosa e a defesa da Religião no Brasil da segunda metade do século XVIII. In: SILVA, Maria Beatriz Nizza da (coord.). Cultura portuguesa na Terra de Santa Cruz, op. cit., p. 166.
} 
em que constassem os dados dos seus livros, quer uma licença do aparato censório. Esse último não se furtava a reter a bagagem e a examiná-la, com o que, então, os proprietários ficavam obrigados a listar seus livros e a pedir licença para reavê-los. Os pilotos, comandantes, cirurgiões e capelães que integravam a tripulação dos navios foram surpreendidos com certa frequiência com a apreensão dos seus livros. Uma vez que os ofícios que exerciam os tornavam cônscios da presença da fiscalização, pode-se supor, de um lado, que os referidos proprietários de livros contavam poder enganá-la, escondendo os livros - e, por isso mesmo, não portavam rol ou pedido de licença - e, de outro, que agiam desse modo porque a fiscalização era irregular e passível de burla. Para alguns proprietários a surpresa era tamanha que sequer haviam cuidado de preservar a lembrança dos livros que possuíam ou que traziam emprestados. Tal esquecimento vitimou, por exemplo, João Antonio Lontro, piloto do Navio Seilão, que chegava à Lisboa em 1803, oriundo do Rio de Janeiro; em seu pedido de licença, feito após a apreensão dos livros na alfândega, registrou os seguintes termos: "Lembrança dos libros [sic] de Uzo q. se achão na Alfandega [...] que me não Lembrão os Titullos $\mathrm{p}^{\mathrm{r}}$. serem emprestados que todos se achão atados em hum Lenço branco e são Honze volumes $p^{r}$. todos"43.

Em outras situações, no entanto, a memória funcionou. Tomás Gonçalves, capitão do navio Mercúrio, chegando à Corte vindo da Bahia em 1805, viu seus livros serem apreendidos na alfândega: "no desembarque do seu fato lhe fizerão recolher à Alfandega os Livros", motivo pelo qual ele nomeou como seu bastante procurador o Fr. João de S. Bernardo, para que pudesse "receber do Tribunal do Dezembargo do paço vinte e hum livro [sic] empreços" que possuía, sobre os quais havia um "mapa" que anexava ${ }^{44}$.

Surpreendidos ou não, muitos proprietários de livros, quando chegavam ou saíam de Portugal sem ou com licença, acabaram por tê-los interceptados para exame. Na alfândega de Lisboa, por exemplo, isto ocorreu, em 1771, com Francisco Herculano Raposo e Santos, mestre do Bergantim Venturoso, procedente de Pernambuco, que trazia livros "entre o seu fato de uso" 45 . Nas mesmas alfândegas foram retidos e examinados, ainda, os livros de Diogo Miguel Faria, ouvidor de Goiás, em 1788; de João Luís de Souza Sayão, o cônego de Mariana já mencionado

\footnotetext{
${ }^{43}$ IANTT, Real Mesa Censória, caixa 149.

${ }^{44}$ Ibidem.
} 
como delator do Santo Ofício, nos anos de 1790 e 1792; e o também citado Manoel Joaquim Henriques de Paiva, médico e químico, em 1790 e $1792^{46}$. Nem figuras ilustres livraram-se dos embaraços da alfândega de Lisboa. Nela se retiveram os livros do arcebispo soteropolitano, liberados em 28 de julho de $1780^{47}$. Outras vítimas bem situadas foram: o desembargador João Fernandes de Oliveira, intendente dos Diamantes, que vinha do Rio de Janeiro com "hum caixão de livros de Seu uso"; e Joaquim José Sabino, bacharel, ex-secretário do governo do Maranhão, que chegava em 1800 com "hum dos caixotes da sua livraria" 48 .

Já na alfândega do Porto, se "recolherão" os livros de Joaquim de Oliveira Freire, piloto, procedente de Pernambuco, em 1772; se "tirarão" outros tantos de Manoel Pereira Álvares, chegado do Brasil, em 1776; se retiveram "três livros de cirurgia" de Francisco José da Silva, cirurgião de navio, procedente do Rio de Janeiro, em 1779 (ao que tudo indica, ele escapara incólume da fiscalização da alfândega de Lisboa, por onde passara antes); se recolheram os livros de uso de Luís Antônio Roberto de Sá Garção, auditor do segundo regimento do Porto, transferido do Rio de Janeiro, onde ocupara a mesma posição, em 1779; se fez a "aprehenção" dos livros de José Correa Lisboa, mestre piloto da corveta Nossa Senhora da Conceição e Santo Antônio, vindo também da capital carioca, em 1779; e "não deixarão levar os livros que trazia" o doutor João Mendes Ribeiro de Vasconcelos, oriundo do Rio de Janeiro, quando estava "tirando [...] a sua movilia",49 Em 1771, o desembargador Antônio de Matos Silva chegou ao Porto, vindo do Rio de Janeiro, trazendo sua biblioteca, não tendo qualquer problema com a alfândega; porém, em 1777, instalado provavelmente em Lisboa, já de posse de "Molina et justitia et jure", obra defesa, de autoria de um dos grandes expoentes da Segunda Escolástca, como se viu no Capítulo 1, mandou seus livros virem do Porto. A alfândega despachou seus livros, à exceção da obra proibida supracitada, do reputado defensor do direito de resistência à tirania. Só conseguiu reavê-la após apresentar um pedido de licença à Real Mesa Censória para possuí-la ${ }^{50}$.

\footnotetext{
${ }^{45}$ Ibidem.

${ }^{46}$ IANTT, Real Mesa Censória, Livros 15, p. 12 e 154-154v e Livro 16, p. 58, 68 e 170.

${ }^{47}$ IANTT, Real Mesa Censória, Livro 18, p. 198.

${ }^{48}$ IANTT, Real Mesa Censória, Caixa 149.

${ }^{49}$ Ibidem.

${ }^{50}$ IANTT, Real Mesa Censória, Caixa 113.
} 
Os advogados e aqueles que exerciam cargos de magistratura na Colônia, que por razão do ofício sabiam identificar mais facilmente que livros eram proibidos, chegavam a se antecipar à mesa, declarando não possuir obras defesas. Faustino da Costa Valente, em 1795, ex-desembargador no Pará, escreveu à mesa que: "Este Catalogo [da biblioteca] não contem livro algum que pela parte que compete a este Tribunal mereça ter por sua Doutrina Reprovado, ou expurgado". No despacho do tribunal, reiterou-se o parecer do desembargador: "os $\mathrm{L}^{\mathrm{os}}$. mencionados neste Catalogo não contêm Doutrinas perigozas, ou reprovadas"51. Do mesmo Pará chegou, em 1807, o ouvidor Jose de Mattos Pereira Godinho, que também declarara ao Desembargo do Paço não possuir livros "probidos pellas Leys" ${ }^{\text {"52 }}$. Os bacharéis Manoel Dias da Costa e Bernardo Dias da Costa, pai e filho, procedentes do Rio de Janeiro e chegados ao Porto em 1769, afirmavam que no "caixão de Livros" trazido por eles era certo "de não terem nenhums conteudos na $\mathrm{Sn}^{\mathrm{a} .}$ da Real Meza Censoria dada em 24 de Julho" 53 .

Os órgãos censórios implicavam-se com a imprecisão das listas encaminhadas pelos que desejavam embarcar livros. Em 1795, Pedro José Reis tentava enviar livros de Lisboa para a Paraíba, mas não obteve licença do Desembargo do Paço, que exigiu dele a apresentação de uma "Relação exacta" dos livros que desejava mandar, "com individuação de todo o titulo de cada hum dos Livros, dos nomes dos seus Aucteres [sic], do tempo e do lugar da Impreção"54. De Manoel José da Costa, certamente um mercador, cobrou-se a apresentação da "Relação dos papeis prezos" (isto é, dos impressos interceptados na alfândega), que o mesmo desejava enviar do Porto para o Brasil e que, de modo genérico, arrolara como "um sorti ${ }^{\text {mto }}$. de Estampas de folha, meia folha, e quarto, todas de Santos, varios Treslados, Taboadas [...] tudo isto impreço há já $\mathrm{m}^{\text {tos }}$. annos com licença" ${ }^{\text {"55 }}$. Em 1769, um ano após a instalação da Real Mesa Censória, Boaventura Maciel Aranha, recebeu da cidade da Bahia "hum Caixote de livros, que he[ra] resto dos que tinha mandado para aquella Cidade", todos eles de sua autoria, "vinte de folio, que constão [sic] de vidas de Santos Portugueses; quatro com os titulos de cuidados da vida, e descuidos da morte em

\footnotetext{
${ }^{51}$ IANTT, Real Mesa Censória, Caixa 149.

${ }^{52}$ Ibidem.

${ }^{53}$ Ibidem.

${ }^{54}$ IANTT, Real Mesa Censória, Caixa 163.

${ }^{55}$ IANTT, Real Mesa Censória, Caixa 151.
} 
quarto; e outro em $8^{\circ}$ com o titulo de Aflição, e Amor de Maria Santissima" ${ }^{\text {"56 }}$. Como os livros não tinham sido objeto de exame da mesa - afinal, ela ainda inexistia para censurá-lo quando de sua impressão -, era necessário fazê-lo. Não se tratando de uma mera situação de fiscalização de posse de livros, foi ordenado ao referido autor que apresentasse os mesmos livros "de que faz[ia] menção [...] p p . lhe deferir"

Na Colônia, os livros eram retidos por não terem licença do tribunal censório para entrarem. Isso ocorreu, por exemplo, com o padre frei José de Santa Ana, missionário apostólico no Real Seminário da Bahia. Ele remeteu livros a Salvador pelo navio Nossa Senhora da Boa Viagem e Santo Antônio, tendo para tanto retirado a respectiva licença. Mas o capitão da embarcação perdeu-a e, por isso, os livros ficaram retidos na alfândega da Bahia. Em 20 de julho de 1775, a Real Mesa Censória ordenou ao juiz da alfândega que fossem entregues os livros ao missionário $^{58}$. O juiz da alfândega da Bahia procedeu de forma similar com Antônio Ferreira Andrade, que viu seus exemplares da Oração Acadêmica do Pe. Maciel serem retidos por falta de licença e, depois, liberados por provisão em 11 de junho de 1776. O mesmo sucedeu com João Amado da Costa, que obteve provisão liberando seus livros em 11 de maio de 1781. Em 1776, Domingos de Bastos Vianna remetera livros com a devida licença para a mesma cidade, mas "porque sucedeo perderse a dita licença", nas alfândegas soteropolitanas se duvidava "dar Despacho aos referidos sem que apareç[esse] a ordem respectiva" ${ }^{, 59}$.

Alguns indivíduos cujos livros foram apreendidos nas alfândegas tiveram-nos parcialmente retidos após o exame dos órgãos censórios. Uns, quando partiam de Portugal para a América; outros, quando chegavam no Reino procedentes do Novo Mundo. Nos idos de 1795, o cônego José Vieira de Lemos e Sampaio dirigia-se de volta à sua terra, a Bahia, carregando livros em sua bagagem, livros estes listados num rol: um deles ficou retido pela censura, Juz Ecclesiasticum, Protestantium ${ }^{60}$. Embaraço similar vitimou o padre secular Manoel de Santiago, que em 1799 pretendia ir ao Rio de Janeiro e, depois, voltar à Lisboa, "com os livros de seu uso": a mesa liberou seus livros, à exceção de Mystica Cidade de Deos, de Maria d'

\footnotetext{
${ }^{56}$ IANTT, Real Mesa Censória, Caixa 149.

${ }^{57}$ Ibidem.

${ }^{58}$ IANTT, Real Mesa Censória, Caixa 157 e Livro 18, p. 7.

${ }^{59}$ IANTT, Real Mesa Censória, Caixa 157 e Livro 18, p. 43, 95 e 215.

${ }^{60}$ IANTT, Real Mesa Censória, Caixa 157.
} 
Agreda, que foi confiscado ${ }^{61}$. Antônio Máximo de Brito, que se dirigia também ao Rio em 1775, foi obrigado a entregar três dos livros que registrou na lista que encaminhou à mesa: Arte de Furtar e L'Home conduit par La razion e Barrone ${ }^{62}$. Do padre Manoel de Araújo, bacharel em cânones, natural do Rio de Janeiro, que retornava à sua cidade natal em 1796, exigiu-se que esclarecesse quais eram, dentre seus livros, "as Obras de Formei, o tempo e o lugar de sua impreção"63. O cirurgião Luís Sá de Gouvea obteve licença para conduzir consigo para o Rio de Janeiro os "livros da sua proficão", ficando excluídos "alguns Espirituais", assim denominados imprecisamente pelos revisores ${ }^{64}$. A casa livreira francesa Viúva Bertrand \& Filhos, em 1795, foi intimada a apresentar à "Meza a obra intitulada Almeyda Restauração de Portugal", que estava a enviar para o Brasil ${ }^{65}$.

Dentre os procedentes da América desembarcados no Reino, houve também quem ficasse com os livros retidos após o exame. Antônio da Costa Agra, procedente da Bahia e chegado ao Porto em 1769, recebeu todos os seus livros, "exceptuando-se a obra de Lacroix, que" teve de remeter à "Meza". O mesmo sucedeu a José de Castro Pereira de Aguiar, no Porto, em 1775, que recebia da Bahia os livros que herdara do seu tio, o reverendo doutor Simão de Castro Passos: nas alfândegas detiveram-se "o Soares Luizitano e as Crizes Theologicas de Casnedi" da Costa Ataide, governador e capitão general do Estado do Grão-Pará, em 1770, viu serem retidos em Lisboa, dentre os livros que tinha "p. seu uso", "quatro volumes Erudition Completa de Bielfeld" — obra que continha críticas à Inquisição portuguesa e à situação dos cristãos novos, como se viu no Capítulo 2 -, motivo pelo qual encaminhou um pedido de licença para a Real Mesa Censória ${ }^{67}$.

${ }^{61}$ IANTT, Real Mesa Censória, Caixa 153.

${ }^{62}$ Ibidem.

${ }^{63}$ Ibidem. No rol de livros que havia entregue, Araújo registrou a seguinte declaração, com outra tinta: "Declaro q. as obras de Formey q. tenho, são os principios de Direito Natural rezumido de Vol. f em 8 - 3 vol. - 1758: E o Philosopho Paycos e chretian. In- 12 - 6 vol. 1752".

${ }^{64}$ Ibidem.

${ }^{65}$ IANTT, Real Mesa Censória, Caixa 151.

${ }^{66}$ Ibidem.

${ }^{67}$ IANTT, Real Mesa Censória, Livro 13. 
Há casos em que é difícil identificar para onde iam e de onde vinham alguns livros retidos e, mais ainda, saber qual era o destino dos seus proprietários: o médico e inconfidente baiano Cipriano José Barata de Almeida, em 1790, que teve retida a Henriade, de Voltaire, e o padre Agostinho de Faria, da Bahia, em 1788, que viu seus livros serem liberados, à exceção do "Larraga" (isto é, o Promptuario de Theologia Moral de Francisco Larraga ${ }^{68}$. Nesses casos, é possível assegurar apenas que se tratava de gente com passagem pela América e que se encontrava momentaneamente no Reino.

A fiscalização nas alfândegas pecava ora pelos excessos, ora pelas concessões, ora pela falta de coerência. Excesso de rigor foi aplicado a Bernardo João de Almeyda, cuja licença para remeter determinadas obras para o Rio de Janeiro, em 1795, foi condicionada ao cumprimento de uma formalidade burocrática: os revisores comunicaram-lhe que "Concede[ria]m a Licença assinado o catalogo" de obras $^{69}$. A incoerência das alfândegas era tamanha que um mesmo livro, em tempos muito próximos, podia entrar pelas mãos de uma pessoa e ficar retido quando outra tentava passá-lo ${ }^{70}$. Assim, José Ferreira Cidade, provavelmente a serviço de um mercador de livros, em 1785, conseguiu receber da alfândega obras proibidas como: Les Incas, de Marmontel, proibida em 1771; Lettres Persanes, de Montesquieu, suprimida na mesma data; Oeuvres de J. J. Rousseau, proibida em data que não é possível precisar; Oeuvres de Voltaire, censuradas parcialmente em 1770; L'Histoire Ecclesiastique de Mosheim, cuja leitura foi autorizada a portadores de licença em 1779; e Histoire philosophique et politique des deux Indes, do abade Raynal ${ }^{71}$, suprimida em 1773, e uma versão resumida e modificada da mesma ${ }^{72}$, Révolution de l'Amérique. A mesma sorte não teve João Batista Reycend, livreiro estabelecido em Lisboa, três anos depois. A alfândega reteve, de uma única remessa, as já citadas Lettres Persannes, de Montesquieu; as Oeuvres, de Voltaire; e a Histoire

\footnotetext{
${ }^{68}$ IANTT, Real Mesa Censória, Livro 15, p. 10 e 168.

${ }^{69}$ IANTT, Real Mesa Censória, Caixa 153.

${ }^{70}$ Sobre o comércio livreiro entre Portugal e Brasil, veja especialmente: NEVES, Lúcia Maria Bastos P. das. Comércio de livros e censura de idéias no Brasil, Ler História, Lisboa, (23) : 61-78, 1993 e CAIEIRO, Francisco da Gama. Livros e livreiros franceses em Lisboa, nos fins do setecentos e no primeiro quartel do século XIX, Boletim Bibliográfico da Universidade de Coimbra, Coimbra (35): 139-168, p. 1980, especialmente as páginas 159 e 165.

${ }^{71}$ IANTT, Real Mesa Censória, Caixa 169 e CATALOGO dos livros defesos neste Reino, desde o dia da Criação da Real Mesa Cençoria athé ao prezente, op. cit.., p. 155-157, 175, 188-189 e 202-204.

72 FIGUEIREDO, Luciano Raposo de Almeida, MUNTEAL FILHO, Osvaldo. Prefácio. In: RAYNAL, Guillaume - Thomas François. A revolução da América, op. cit., p. 2. Obra proibida pelo
} 
philosophique, do abade Raynal; e mais outros livros defesos: as Liaisons dangereuses, obra suprimida em 1780; o Traité des délits et des Peines, de Beccaria, cuja leitura foi permitida aos portadores de licença em 1788; Puccelle d'Orléans, de Voltaire, suprimida em 1770; Esprit de Raynal (seria, na realidade, de autoria de Helvétius, proibida em 1770?); Oeuvres de Nicolas L'Englet du Fresnoy, proibidas na classe das obscenas (sem data); e livros não nomeados de Helvetius. A alfândega, entretanto, liberou, dessa mesma remessa, Oeuvres de Mr. Le Sage (na realidade, Alain René Lesage), dentre as quais poderia estar a defesa Le Diable boîteux ${ }^{73}$. No mesmo ano de 1788, a alfândega reteve, de uma remessa de livros de propriedade de Pedro José Reis, livreiro com loja no Chiado em Lisboa ${ }^{74}$, as obras História de Carlos V, de William Robertson, e Elementa Philosophica de Cive, de Thomas Hobbes $^{75}$. Se Pedro Reis não conseguiu passar um livro de Robertson, a casa de livros Borel \& Borel, anos antes, em 1783, recebera obras proibidas do mesmo autor e também de autoria de Marmontel, sem ter problemas na alfândega ${ }^{76}$. Belisário, obra de Marmontel proibida pela Real Mesa Censória, destinada a João José da Beux, por seu turno, fora apreendida pela censura, nos idos de $1784^{77}$. Essas contradições da censura na alfândega, ora retendo, ora liberando os mesmos livros, poderiam ser atribuídas à ausência ou à existência de licença para possuir livros proibidos - isto é, os que possuíam licença conseguiam liberar as obras, enquanto os que não as tinham ficavam com as obras retidas. Tal hipótese, porém, não se sustenta, pois não há menção a licenças nos documentos relativos aos casos citados e, além disso, se houvesse a diferenciação indicada, o livreiro J. B. Reycend conseguiria passar todos os seus livros proibidos e não apenas um deles. Um argumento a mais contra aquela hipótese encontra-se nos próprios códices de registro

edital de 11 de outubro de 1773.

${ }^{73}$ IANTT, Real Mesa Censória, Livro 15, p. 39-45; CATALGO dos livros defesos neste Reino, desde o dia da Criação da Real Mesa Cençoria athé ao prezente, op. cit.., p. 127, 148, 156, 162-163 e 202204 e VIGUERIE, Jean de, op. cit., p. 1113.

${ }^{74}$ IANTT, Real Mesa Censória, Gazeta de Lisboa, de 07 de julho de 1787, Caixa 469.

${ }^{75}$ IANTT, Real Mesa Censória, Livro 15, p. 38v. Obra proibida pelo edital de 24 de setembro de 1770.

${ }^{76}$ IANTT, Real Mesa Censória, Caixa 169.

${ }^{77}$ Ibidem. É preciso esclarecer que as obras de Marmontel foram proibidas em datas diferentes e que isto não contradiz as conclusões expostas. Além de Les Incas ou la Destruction du Péru (como já se viu, proibido em 1771), Belisário foi suprimido no "tempo da Real Mesa cençória", sem que o Catálogo explicite a data (informa apenas que uma tradução da obra corria livremente nos idos de 1814); e, por fim, os Contos Morais e os Novos Contos tiveram sua leitura autorizada para os portadores de licença em 1802, não sendo possível assegurar que estivessem liberados totalmente antes desta data. 
e saída de livros da casa de revisão: houve contínuas liberações de obras proibidas aos livreiros, sob a condição de que eles não as vendessem ${ }^{78} . \mathrm{O}$ resultado desse quadro, enfim, foi uma redução da eficácia da fiscalização nas alfândegas.

A incoerência da fiscalização censória nas alfândegas evidencia-se concretamente em relação a duas remessas de um livro de Locke: uma para a Bahia, a pedido dos Bertrand, família de livreiros, e outra para o Brasil, sem especificação de local, a pedido do padre Francisco José de Gouvea e Albuquerque ${ }^{79}$. Foi negada licença para que a Viúva Bertrand exportasse o referido livro para a Bahia, em 16 de novembro de 1795, mas o padre Francisco José de Gouvea Sá e Albuquerque, em 23 de julho de 1796, obteve um despacho favorável.

A secretaria da Corte, em 06 de agosto de 1796, suspendeu a decisão, confrontando-a com aquela tomada em relação à Viúva Bertrand. Nessa ocasião, solicitou-se a Sua Majestade que determinasse a liberação do livro ou a entrega dos exemplares do mesmo pelos seus proprietários para que fossem suprimidos, tendo a secretaria da Corte recomendado essa última possibilidade. Foi-se, no entanto, mais além, explicitando-se claramente a falta de coerência, pois, na justificativa para a interdição da remessa do livro de Locke, ponderou-se que "sua Leitura" não faria "menos danno na Corte do q. nos Domínios ultramarinos" $" 80$ - ou seja, se na Corte o dito livro não entrava, por que isso seria permitido no Brasil? As próprias altas esferas do Estado, portanto, percebiam a incoerência das alfândegas e clamavam pelo uso de um critério único na liberação e retenção de obras.

A vigilância nas alfândegas, além de incoerente, era bastante vulnerável. Os livros proibidos continuaram entrando em Portugal, sendo a documentação inquisitorial, os registros policiais e os testemunhos de estrangeiros da época eloqüentes a esse respeito ${ }^{81}$. Os diplomatas portugueses usavam os fundos falsos de suas malas para introduzir livros defesos, lidos muitas vezes quando aqueles estavam no exterior ${ }^{82}$. O contrabando, segundo o viajante Carl Ruders, “"era a maneira mais usual e menos embaraçosa empregada pelos particulares"” para possuir as obras defesas, bastando, caso houvesse interesse por algum livro estrangeiro, contactar

\footnotetext{
${ }^{78}$ IANTT, Real Mesa Censória, Livros no 15 e 16.

${ }^{79}$ IANTT, Real Mesa Censória, Caixas 151 e 157.

${ }^{80}$ Ibidem.

${ }^{81}$ LISBOA, João Luís. Ciência e política: ler nos finais do Antigo Regime. Lisboa: INIC/ Centro de História da Cultura da Universidade Nova de Lisboa, 1991, p. 31.

${ }^{82}$ XAVIER, Ângela Barreto, op. cit., p. 108.
} 
algum marinheiro, que se encarregaria de "“o trazer e de o fazer chegar ao seu destino" "83. O mesmo se dava na América, onde os autos das devassas das Inconfidências de Minas, Rio e Bahia, do segundo quartel do século XVIII, bem como os documentos enviados ao Santo Ofício, atestam a presença de livros proibidos, certamente resultante em grande parte do contrabando. Os autos das devassas, ademais, registram a própria prática do contrabando e as práticas de leitura que lhe eram imediatamente subseqüentes. O padre Francisco Agostinho Gomes, um dos implicados na Inconfidência Baiana, obtinha jornais e livros através de capitães e pilotos que passavam pela Bahia; Francisco Muniz Barreto trouxera de Portugal em sua bagagem, conforme declaração dele próprio feita em 1799, escritos como "As Ruínas", de Volney, e "Aviso de S. Petesburgo"; e, além disso, ao que parece, uma nau francesa despejara livros que teriam influenciado os ânimos dos conjurados soteropolitanos ${ }^{84}$.

No Rio de Janeiro, o professor régio, poeta e "conjurado" Manoel Inácio da Silva Alvarenga contou que conseguira uns exemplares de Mercúrios - ao que parece, uma gazeta francesa de circulação proibida nos domínios de El-Rei - graças aos préstimos de "um inglês que passara" pela cidade, não sabendo informar se o mesmo era militar ou paisano ${ }^{85}$. O bacharel Mariano Pereira da Fonseca, também acusado de Inconfidência, "em ocasiões que chegavam navios da Europa", em "algumas vezes na botica de José Luís, que ficava[va] defronte da capela do Carmo", nos idos de 1794, "trazia o correio da Europa e aí o lia, mostrando grande satisfação com os progressos que os franceses faziam" em sua revolução, seguindo-se disto algumas discussões ${ }^{86}$. Tal comportamento de Mariano, é importante dizer, não parecia ser algo muito infrequiente.

Todos esses proprietários de livros empregaram seus ardis para furtar-se ou para ludibriar a fiscalização, embora não seja possível precisar exatamente como o fizeram. Lúcia Bastos P. das Neves sugere que, para ludibriar a censura nas alfândegas e, por conseguinte, contrabandear os livros, os leitores escondiam-nos ou

\footnotetext{
${ }^{83}$ Carl Israel Ruders. Apud. GUEDES, Fernando, op. cit, p. 79-80.

${ }^{84}$ TAVARES, Luís Henrique Dias. História da sedição intentada na Bahia ("A Conspiração dos Alfaiates"). São Paulo: Pioneira; Brasília: MEC/ INL, 1975, p. 85-7.

${ }^{85}$ AUTOS de Devassa - Prisão dos Letrados do Rio de Janeiro (1794). Niterói: Arquivo Público do Estado do Rio de Janeiro; Rio de Janeiro: UERJ, 1994, p. 151.

${ }^{86}$ Ibidem, p. 75-76.
} 
faziam-nos desaparecer ${ }^{87}$. Num único registro nos documentos, aparece um proprietário infrator que, de certa forma, sumiu com seus livros e que, por esse motivo, caiu nas malhas do Desembargo do Paço. Em junho de 1807, o padre Leonardo Correa da Silva, capelão do Bergantim Sacramento, desembarcou em Lisboa, procedente de Pernambuco, com um baú de livros e entregou uma listagem incompleta dos títulos e/ou autores dos livros, declarando não serem eles "dos proibidos" e solicitando ao tribunal a liberação dos mesmos. Os livros ficaram retidos na alfândega e, em 20 de junho, foi passada uma portaria para conduzi-los para a casa de revisão do Desembargo do Paço. O padre, então, deveria pagar pelo transporte dos livros a uma companhia de homens que ficava a serviço da alfândega. Mas recusou-se a fazê-lo, dizendo que deveria pagar à companhia "quem a mandava trabalhar, pois que elle tinha um moço do seu conhecimento para fazer a quela [sic] condução" ${ }^{\text {88 }}$. O contínuo José Veríssimo Serrão, a quem foram ditas estas palavras, depois de ouvi-las, ordenou aos carregadores que pegassem logo no baú, pois seriam pagos na casa ou armazém da revisão. Os moços falaram-lhe para abrir a porta do armazém e, enquanto ele o fazia, conduziram o baú diretamente para a casa do padre Leonardo, a mando deste. Cinco dias depois, o contínuo, sentindo-se ofendido e enganado, encaminhou uma representação denunciando a falcatrua ao Desembargo do Paço, levantando a suspeita de que a fiscalização fora por terra, pois o padre já se tinha assenhoreado dos livros ${ }^{89}$.

O tribunal, no dia 26 de junho, diante do sucedido, ordenou ao corregedor do bairro da Alfama que fizesse uma diligência na casa do padre Leonardo, apreendendo todos os livros que nela se achassem, enviando-os ao armazém da revisão ${ }^{90}$. Ordenou, igualmente, a prisão dos moços da companhia envolvidos no extravio dos livros; nenhuma medida, entretanto, foi tomada contra o padre, mesmo tendo ele sido acusado pelos carregadores de ser o mentor de toda a trama. Aos 03 de agosto, o tribunal soltou os carregadores da prisão e, aos 18 do mesmo mês, entregou os livros ao padre, depois que o mesmo complementou o rol de obras encaminhado inicialmente ${ }^{91}$.

\footnotetext{
${ }^{87}$ NEVES, Lúcia Maria Bastos P. das. Comércio de livros e censura de idéias no Brasil, op. cit., p. 68.

${ }^{88}$ IANTT, Real Mesa Censória, Caixa 149.

${ }^{89}$ Ibidem

90 Ibidem.

${ }^{91}$ Ibidem.
} 
Vê-se, neste caso singular, que havia possibilidades de burlar a fiscalização e que, para tanto, contribuíram, de um lado, a inabilidade dos agentes censórios e, de outro, a argúcia do proprietário. Nota-se, ainda, que, mesmo tendo ocorrido a burla, seu mentor não recebeu qualquer sanção, nem foi interrogado, sendo punidos apenas aqueles que foram os executores, isto é, os homens da companhia de transporte. Todo o quadro indica que o padre agiu de má fé: entregou uma listagem incompleta dos seus livros, ludibriou e cerceou a censura, com a cumplicidade dos carregadores, impediu que seus livros fossem fiscalizados e, ainda, pode-se suspeitar que, já em sua casa, ocultou ou se livrou de livros proibidos. O delito, além disso, só foi registrado porque o contínuo se sentiu ofendido em suas atribuições. Trata-se, portanto, de uma situação de repressão a infratores das regras da censura em que se exprime a mesma lógica pela qual o Estado regulava a relação dos leitores com os livros, impondo-lhes limites em conformidade com a desigualdade de direitos inerente a uma sociedade de tipo estamental. Assim, se ter e ler livros eram possibilidades que variavam conforme o estado e a profissão dos indivíduos segregando-se o vulgo do acesso aos livros proibidos, como se mostrará no Capítulo 6 -, esta mesma lógica, quando aplicada à repressão aos descaminhos do livro, implicava um maior rigor com aquela mesma gente tida como desqualificada e, inversamente, condescendia com os que eram considerados aptos para ler e possuir livros proibidos.

A façanha do padre Leonardo; o olhar vesgo da censura ao punir os cúmplices deste eclesiástico, as cobranças de licença para a entrada e saída de livros; a surpresa de muitos indivíduos com esta ação (com a qual deviam estar familiarizados pela rotina de seus ofícios); as incoerências na retenção e liberação de alguns livros proibidos; e a persistente presença desses são bastante reveladores sobre a situação da censura nos domínios de Portugal. Sugerem, por um lado, que a existência de livros proibidos devia-se em grande parte ao contrabando, mas não apenas a ele e, por outro lado, mostram, sem dúvida alguma, que, primeiramente, havia físcalização nas alfândegas; em segundo lugar, que não era impossível aos proprietários burlá-la, caso usassem de argúcia e encontrassem uma colaboração voluntária ou involuntária dos funcionários; e, por fim, que as autoridades superiores do aparato censório atuavam seguindo uma seletividade "estamental-corporativa" ao punir os infratores. Aos olhos de hoje, esses contrastes soam como mera falta de critério, denotam 
fragilidade do aparato censório. Todavia, eles representam muito mais do que isto: são reveladores da estratificação que perpassava a relação entre sociedade e livros, estratificação esta em que a censura se encontrava imersa.

Essa mesma estratificação "estamental-corporativa", que perpassava à relação entre livro e sociedade, evidente na repressão diferenciada aos envolvidos no desvio dos livros do padre Leonardo, é importante acrescentar, manifestou-se com muita clareza numa outra situação repressiva, não relacionada propriamente à entrada de livros pelas alfândegas, mas à posse e leitura ilegal de livros proibidos em Coimbra, em junho de $1779^{92}$. Nessa data, como já se mencionou no Capítulo 3, a Rainha ordenou ao corregedor da comarca de Coimbra que realizasse uma devassa para punir o "gravissimo dano" de possuir e ler obras proibidas ou que haviam entrado no Reino sem as devidas licenças, enfim, "Livros irreligionarios", com "maximas oppostas a estabilidade do Throno, a pureza da Fe, e a inteireza dos costumes". Para tanto, na ordem expedida, anexou-se um rol com títulos e autores, em sua quase exclusividade coincidentes com os condenados no edital da Real Mesa Censória de 24 de setembro de 1770, já analisado no Capítulo 4. Ao corregedor foi recomendado inquirir "sujeitos de conhecida probidade, e impondo-lhes a mais estreita obrigação de segredo"; dar buscas "nas proprias Casas" dos implicados, depois de ver "acabada a mesma Devassa", e também nas "loges de Estrangeiros Mercadores de Livros". Todavia, nas instruções complementares, deixou-se claro que a repressão deveria ser seletiva, pois o corregedor, primeiro, não poderia dar buscas nas "Bibliothecas do commum dos Collegios" e nas bibliotecas "particulares daquelles sugeitos q. forem do $\mathrm{S}^{\text {to }}$. Officio"; nem lhe seria permitido, ademais, prender os Lentes da Universidade, os opositores às cadeiras da mesma e as "Pessoas constituidas em Dignidade". Todas as demais deveriam ser presas "na Cadeia dessa Cidade sendo Seculares, e sendo Regulares" ficariam sob a jurisdição de seus respectivos $\operatorname{prelados}^{93}$.

Retornando às alfândegas, fica claro que as autoridades tinham consciência da sua vulnerabilidade. Diogo Antônio Pina Manique, o Intendente Geral de Polícia, considerava que pela via aduaneira, de Lisboa ou Setúbal, entravam no Reino as obras defesas, “a maior parte dos livros ímpios e sediciosos que aparecem no

\footnotetext{
${ }_{92}^{9}$ IANTT, Real Mesa Censória, Livro 18, p. 160 e segs.

${ }^{93}$ Ibidem, p. 160-160v.
} 
público de mão em mão",94. Manique deu várias batidas na alfândega de Lisboa, tendo encontrado numa ocasião uma caixa contendo livros de Raynal, Voltaire (dentre eles, a Pucelle D'Orléans) e D'Bricot ${ }^{95}$. O mesmo intendente chegou a confiscar livros remetidos ao ministro da Suécia e a abrir subrepticiamente, nos idos de 1791, uma caixa de livros chegada do exterior para o duque de Lafões, parente da Rainha Dona Maria I, e para o cavaleiro Lebzelten, funcionário do governo austríaco em Lisboa, vindo a encontrar livros proibidos $^{96}$.

Certamente sob o impacto da Revolução Francesa, em 1792, a Coroa dirigiu uma provisão a todos os juízes das alfândegas, dentre eles os de São Paulo, Santos, Rio de Janeiro, Bahia, Pernambuco, Pará, Maranhão, Paraíba e Santa Catarina, para que tomassem "hum par. $\mathrm{cu}^{\text {do }}$. q. de bordo dos Navios tanto Nacionais como Estrangeiros se não extraião Livros alguns, e ao mesmo tempo se não entreguem às partes sem q. estas vos mostrem Prov ${ }^{\mathrm{am}}$. da [...] Real Meza da Comam G ${ }^{\mathrm{al}}$. q. assim ord $^{\mathrm{e}}$, e q. esta seja acompanhada de um catalogo assinado pelo Secret ${ }^{\mathrm{ro}} . " 97$.

É provável que também os vice-reis tenham participado da fiscalização sobre a entrada de livros nas alfândegas. O vice-rei Conde de Resende, segundo Paulo Gomes LEITE, mandou realizar uma busca no navio Conceição, no Rio de Janeiro, em 1799, não para encontrar livros proibidos, mas cartas escritas pelo prisioneiro Francisco Álvaro da Silva Freire, cadete contra quem recaía a suspeição de ser jacobino. No navio, mais precisamente no beliche de Vicente Guedes, um moçambicano amigo do acusado, foram encontrados 25 livros, alguns deles proibidos. Desses livros proibidos, alguns foram confiscados: Lettres Cabalistiques; Lettres Chinoises; o Émile e Discours sur l'Origine et les Fondements de l'inégalité parmi les Hommes, de Rousseau; e duas obras de Helvetius. Dois livros escritos em inglês foram também apreendidos pelo simples fato desta língua ser desconhecida

\footnotetext{
${ }^{94}$ RIZZINI, Carlos, op. cit., p. 264.

${ }^{95}$ TAVARES, Luís Henrique Dias, op. cit., p. 87.

96 Teófilo Braga. Apud. DOMINGUES, Francisco Contente, op. cit., p. 129. Ao que parece, houve um caso anterior de retenção na alfândega de livros pertencentes ao duque de Lafões, pois, em maio de 1777, o Visconde de Villa Nova da Cerveira ordenou que "na Alfandega da Cidade de Lisboa se entreg[ass]em ao Procurador do Duque de Lafoens os livros de seu uzo logo que forem conduzidos para a dita Alfandega". Em 1791, Dona Maria I ordenou a devolução pela Real Mesa da Comissão Geral de todos os livros pertencentes ao ministro do imperador austríaco, que nela se achavam "demorados por motivo de serem proibidos". De fato, estavam na caixa obras de Voltaire, Rousseau e Raynal (IANTT, Real Mesa Censória, Decretos e avisos recebidos pela mesa, Caixa 188).

${ }^{97}$ IANTT, Real Mesa Censória, Livro 18, p. 396.
} 
pelo realizador da operação, Dr. João de Figueiredo ${ }^{98}$. Ao mesmo tempo, algumas obras proibidas passaram ilesas (escritos de Marmontel, Voltaire ${ }^{99}$ e Condillac). Essa operação - de racionalidade bastante contraditória ou, no mínimo, questionável indica que obras defesas possivelmente eram apreendidas em ações governamentais que tinham outros objetivos que não confiscar livros.

Pina Manique reforçou seu esmero em reprimir a entrada de livros do exterior, dificultando a entrada de estrangeiros, vigiando os que se encontravam no Reino e, ainda, perseguindo os maçons e os lusos que se suspeitavam estarem espalhando idéias contrárias à ordem estabelecida. $\mathrm{O}$ recrudescimento subseqüente da severidade da mesa; a maior vigilância por parte da Intendência Geral de Polícia e a colaboração da Inquisição e dos prelados — a primeira, ameaçando excomungar os fiéis que comprassem, vendessem ou possuíssem livros ou escritos "hereges", "ímpios", "libertinos; os últimos, colaborando com o poder civil, intensificando o ensino da doutrina e, ainda, exortando os diocesanos à fidelidade ao rei ${ }^{100}$ — não modificaram substancialmente a situação de ineficiência. Livros proibidos continuaram a entrar, seja no Reino, seja na América.

\subsection{Autoridades Coloniais e Posse de Livros}

Todas as entidades e pessoas que imprimissem, vendessem ou possuíssem livros ficaram obrigadas, segundo o Edital de 10 de julho de 1769, a enviar à Real Mesa Censória uma lista ou catálogo de todos os seus livros ${ }^{101}$. Rubens Borba de Moraes afirma desconhecer a existência de qualquer documento que mostre se o edital foi ou não cumprido na Colônia ${ }^{102}$. Na documentação da Real Mesa Censória, até hoje foi localizado um único caso em que se vê, ao mesmo tempo, o cumprimento dessas determinações do Edital por um leitor da América Portuguesa e a realização da censura pela mesa. O padre Marcelino Lopes, advogado na cidade da Bahia, encaminhou seus livros ao tribunal da Relação da Bahia, para que fossem revisados. Temendo que os livros fossem destruídos pelo cupim, devido ao tempo que já se

\footnotetext{
${ }^{98}$ LEITE, Paulo Gomes. A maçonaria, o Iluminismo e a Inconfidência Mineira, op. cit., p. 18-23.

${ }^{99}$ No caso, a obra Théâtre, de Voltaire, a qual era permitida. Porém, algumas edições dela continham escritos do mesmo autor que eram proibidos (CATALOGO dos livros defesos neste Reino, desde o dia da Criação da Real Mesa Cençoria athé ao prezente, op. cit., p. 202).

${ }^{100}$ BEIRÃO, Caetano, op. cit., p. 390.

${ }^{101}$ IANTT, Real Mesa Censória, Caixa 1, Edital de 10 de julho de 1769.
} 
passava desde que os entregara, pediu à Real Mesa que ordenasse a revisão dos mesmos, anexando para tanto um rol (que não consta da documentação). A Real Mesa passou, então, provisão ao desembargador chanceler da relação da Bahia para entregar todos os livros de que tratava o "Rol incluzo - excepto o Larraga. Meza 23 de Dez ${ }^{\text {ro }}$. de $1773{ }^{\prime 103}$. Os já citados bacharéis Manoel Dias da Costa e Bernardo Dias da Costa, em 1769, recém-chegados ao Porto vindos do Rio, não fizeram na Colônia o rol solicitado pela lei, mas manifestaram preocupação em relação a isto, alertando o tribunal que não puderam "satisfazer aos requezitos ordenados no Edital e Ley de 10 de Julho deste presente anno [de 1769] por haverem ausentes e falta da entrega dos ditos livros", que estavam retidos na alfândega ${ }^{104}$.

D. Francisco Manuel da Ressurreição, bispo de São Paulo, em 1776, queixouse ao Marquês de Pombal sobre o não recebimento dos editais da Real Mesa Censória e sobre a inexistência de alguém que os executasse ${ }^{105}$. É certo, contudo, que os editais chegavam, ao menos para alguns, como os bispos de Mariana, os ouvidores de comarca, os governadores e os juízes das câmaras. Em Minas Gerais, por exemplo, em 1771, as autoridades de Vila Rica remetiam ao juiz da cidade de Mariana um "maço de Edittaes da Real Meza Sensória”, para que o mesmo os fizesse publicar e executar, assinando um recibo de sua entrega ${ }^{106}$. O vereador e juiz de fora da Vila de Sabará encaminhou correspondência aos arraiais e termos da mesma vila ordenando que, em obediência às determinações da Real Mesa Censória, se denunciassem as pessoas que retivessem livros do padre Antônio Vieira considerados sediciosos pelo mesmo tribunal e, ainda, que se queimassem as tais obras ${ }^{107}$. Os editais do aparato censório sancionados a partir de meados da década de 1770, além disso, mencionam explicitamente a participação dos capitães generais e governadores das possessões coloniais na atividade censória.

\footnotetext{
102 MORAIS, Rubens Borba de, op. cit., p. 53.

${ }^{103}$ IANTT, Real Mesa Censória, Caixa 157.

${ }^{104}$ IANTT, Real Mesa Censória, Caixa 149.

${ }^{105}$ MORAES, Rubens Borba de. Livros e bibliotecas no Brasil Colonial, op. cit., p. 58.

106 APM, Câmara Municipal de Mariana, Livro 22, p. 53. A existência de coleções encadernadas de editais e ordens da mesa, originalmente avulsos, na atual Biblioteca do Palácio Episcopal de Mariana, sugere que os bispos recebiam esses textos legais.

${ }_{107}$ APM, Câmara Municipal de Sabará, Livro 25, p. 49 (sou grato à Cláudia Chaves pela indicação deste códice).
} 
Os ouvidores procuraram cumprir as determinações dos editais: alguns magistrados da América informaram aos tribunais censórios sobre a divulgação daqueles e remeteram, aos órgãos superiores do governo colonial ou a Lisboa, os livros proibidos que lhes foram entregues ${ }^{108}$. Havia na Colônia, portanto, não apenas uma fiscalização da entrada de livros proibidos, mas também da sua posse. Do Maranhão, o ouvidor Bruno Antônio de Cardoso Munhoz, em 1770, comunicava à Real Mesa Censória a publicação dos editais que proibiam os livros Madalena pecadora, amante e penitente e a Pastoral do Bispo de Coimbra, informando também que ninguém lhe entregara nenhum dos mencionados livros ${ }^{109}$. Notificação de teor semelhante foi feita pelos ouvidores das comarcas de Paranaguá e Rio de Janeiro, no mesmo ano ${ }^{110}$. Em 1772, o ouvidor da comarca do Pará, comunicou não só a publicação do edital de 12 de dezembro de 1771, como também a apreensão de livros mencionados no mesmo: "quatro caixotes de livros e dous Mulinas [sic, isto é, Luís de Molina] de Just et jure avulsos", entregues por diferentes pessoas ${ }^{111}$. Bem sucedido também foi o ouvidor José Ribeiro Guimarães de Ataíde, da comarca da Vila de Nossa Senhora da Vitória: em 1773, notificou o tribunal sobre a publicação do Edital de 12 de dezembro de 1771 e o recebimento de cinco livros compreendidos no mesmo "a saber = dois dos Afforismos de Mel. de Sa, e tres das obras Moraes de Fernando de Castro Palao"112. O mesmo ouvidor contou que José Cardoso Pereira, irmão e testamenteiro do padre Antônio Teixeira, falecido em Paranaguá, herdara deste vários livros, dentre eles oito volumes de obras que eram proibidas, os quais foram entregues à ouvidoria e remetidos ao governo da Bahia ${ }^{113}$. Nessas notificações de entrega de livros apresentadas pelos ouvidores, vê-se a presença de obras de Luís de Molina, teórico da Segunda Escolástica, e de Fernando de Castro Palao, ambos proibidos pelo edital da Real Mesa Censória de 12 de dezembro de 1771, voltado contra as influências, supostas ou reais, dos jesuítas, especialmente as concepções corporativas de poder e o probabilismo. Como se verá no Capítulo 6, os autores proibidos pelo mencionado edital — atestando a força e o prestígio que tais autores tinham diante dos leitores e justificando os temores da censura - apareciam

\footnotetext{
${ }^{108}$ A documentação é muito descontínua. Isso deixa dúvidas sobre sua constância, ou então, indica que muitos registros dela se perderam.

${ }^{109}$ IANTT, Real Mesa Censória, Caixa 185.

${ }^{110}$ Ibidem.

${ }^{111}$ Ibidem.

${ }^{112}$ Ibidem.
} 
freqüentemente nas bibliotecas dos requerentes que solicitavam licença aos tribunais censórios para ler livros proibidos que eles próprios discriminavam.

Os ouvidores, assim como todos os ministros e os demais oficiais de justiça e fazenda, receberam provisões para deixarem transitar obras: isso sucedeu, em 15 de fevereiro de 1777, em relação aos livros que Bernardo Miguel de Souza queria remeter do Porto para "Goiases" e, em 7 de outubro de 1776, em relação aos livros que Francisco Lamy enviava do Porto para a cidade da Bahia ${ }^{114}$. Essas provisões que liberavam a circulação de determinados livros, as queixas do bispo de São Paulo, as parcas informações dos ouvidores sobre a divulgação dos editais censórios e o recebimento eventual dos livros neles mencionados; e, no caso do ouvidor de Vitória, a identificação e entrega de livros proibidos pelo testamenteiro, em síntese, mostram, por um lado, que a fiscalização da posse de livros proibidos ocorria na Colônia, com a colaboração dos ouvidores e demais oficiais de justiça e fazenda e, por outro lado, que o funcionamento da censura era inconstante e relativamente frágil, dependente em grande parte da boa vontade dos proprietários e leitores de livros. Sem a boa vontade desses, não seria possível nem identificar quem possuía livros proibidos, nem muito menos apreendê-los.

As proibições de livros instituídas pelas reformas educacionais, bem como as sugestões de obras didáticas, repercutiram no Reino e na América Portuguesa. Em Portugal, os encarregados das reformas não deixaram de cuidar da apreensão de livros proibidos ${ }^{115}$. Na América, no Estado do Grão-Pará e Maranhão, o governador Manoel Bernardo de Mello e Castro, que ascendeu ao poder em 1759 - antes, portanto, da criação da Real Mesa Censória - exigiu o uso de livros que consagrassem o moderno método de escrever, ler e contar, e a nova gramática ${ }^{116}$. Na Bahia, o desembargador Thomas Roby procurou coibir, dentro do possível, o emprego dos livros condenados pelas reformas do ensino e, inversamente, tentou difundir a adoção das obras consagradas por estas últimas ${ }^{117}$. Como a Arte de gramática latina, do padre Antônio Félix Mendes e a Arte de gramática latina, do Padre Antônio Pereira - ambas recomendadas e editadas para o ensino em Portugal

\footnotetext{
${ }^{113}$ Ibidem.

${ }^{114}$ IANTT, Real Mesa Censória, Livro no 18, p. 60 e 82.

${ }^{115}$ FALCON, Francisco José Calazans, op. cit., p. 434.

${ }^{116}$ ARAÚJO, Jorge de Souza, op. cit., p. 84.

${ }^{117}$ ANDRADE, António Alberto Banha de, op. cit., p. 29-30.
} 
durante as reformas pombalinas e presentes no Brasil já em $1759^{118}$ - não chegavam a 400 exemplares, “"o primeiro tomo da Selecta não excedia o número de 200 e os Diccionarios [eram] muito poucos"”, Roby circunscreveu sua adoção à cidade da Bahia e à vila de Cachoeira ${ }^{119}$. Nos outros lugares da capitania, permitiu que permanecesse o antigo método “"enquanto não chegavam os livros necessários"” para o novo ${ }^{120}$. Ao mesmo tempo, o desembargador interditou a Prosódia, de Bento Pereira, condicionando a proibição, no entanto, à chegada dos Dicionários do novo sistema, cuja vinda pediu com urgência ${ }^{121}$. Faltaram os novos livros também em Pernambuco $^{122}$ e, ao que parece, esse problema foi freqüente na América Portuguesa em geral, ao menos durante alguns anos. A falta de livros e a resistência de alguns mestres formados no método jesuítico ajudaram a emperrar a consecução das reformas do ensino e contribuíram para a sobrevivência do emprego dos velhos $\operatorname{livros}^{123}$.

Em Minas Gerais, em 1799, a Coroa instituiu a inspeção das escolas ${ }^{124}$, para a qual os governadores deveriam nomear anualmente lentes reputados para, dentre outras atribuições, visitar as escolas e avaliar o trabalho dos mestres, o "Methodo que seguem nas Lições, e explicações dos Authores, da Escolha dos Livros por onde" ensinavam $^{125}$. Embora não se possa dizer se esta determinação foi cumprida, nem esclarecer o modo como o foi, ela e as demais iniciativas apontadas anteriormente evidenciam que a censura fez-se presente no ensino e chamou a atenção dos órgãos estatais que se incumbiram do mesmo.

Noutras ocasiões, a censura ou o controle da circulação e posse de livros ligou-se ao confisco do bens da Companhia de Jesus, dentre os quais se incluíam livros. No Espírito Santo, por determinação da Real Mesa Censória, o ouvidor da comarca de Vitória recebeu os livros da biblioteca do colégio de São Tiago,

\footnotetext{
${ }^{118}$ Ibidem, loc. cit.

${ }^{119}$ Ibidem, loc. cit.

${ }^{120}$ Ibidem, loc. cit.

${ }^{121}$ Ibidem, loc. cit.

122 Ibidem, p. 59 e 80.

${ }^{123}$ Ibidem, p. 115.

${ }^{124}$ Carta régia a Bernardo José de Lorena, de 19 de agosto de 1799. Apud. CARVALHO, Feu de. Instrução pública: primeiras aulas e escolas de Minas Gerais. Revista do Arquivo Público Mineiro, Belo Horizonte, 24 (1): 352, 1933.

${ }^{125}$ Ofício do Conselho Ultramarino a Bernardo José de Lorena. Apud. CARVALHO, Feu de, op. cit., p. 355 .
} 
pertencente aos inacianos ${ }^{126}$. Em 1772, o capitão Manoel Pinto Ribeiro, depositário dos bens do colégio e tesoureiro geral do seqüestro que se fez dos mesmos, informou à ouvidoria que, nas bibliotecas do colégio e do convento de São Francisco, se achava "hum tomo em oitavo que se intitula Aforismos Confesanorum", de Manoel de Sá, livro este proibido pelo edital da Real Mesa Censória de 12 de dezembro de 1771, então recentemente publicado e afixado na Vila. Em função disso, o capitão entregou os dois exemplares do livro à justiça, isto é, ao ouvidor, o qual os guardou "debaixo de chave no Cartório"127.

$\mathrm{Na}$ Bahia, verificou-se tão somente um controle do Estado sobre os livros pertencentes à Companhia de Jesus, não propriamente uma ofensiva da censura. $\mathrm{Na}$ mesma cidade, o já citado desembargador Tomás Roby envolveu-se no seqüestro dos livros da biblioteca dos jesuítas do colégio, não se tendo notícia sobre o confisco de livros defesos que porventura veio a encontrar ${ }^{128}$. Na Amazônia, além de controle sobre o espólio jesuítico, houve também censura. Assim, em 1760, o governador Manuel Bernardo de Mello e Castro propôs que os livros dos jesuítas fossem reunidos para se formar uma biblioteca no Pará, sendo as duplicatas enviadas a Lisboa, já que a população não tinha condições financeiras de comprá-las ${ }^{129}$. Não se sabe qual foi exatamente a decisão tomada pela Coroa, mas em 1770 o próprio marquês de Pombal comunicou à Real Mesa Censória que "vinte e quatro Caixoens de Livros [...] chegaram da Cidade de Belém do Grão Pará", ordenando "que com os mesmos Livros se executem as suas Reaes Ordens", ou seja, que eles fossem objeto de exame ${ }^{130}$.

A Coroa ordenou a entrega à censura dos livros proibidos porventura existentes nas bibliotecas conventuais, tendo o marquês de Pombal mandado à Real Mesa Censória, em 30 de maio de 1774, cópia de um aviso circular "que se expedio aos Prelados Mayores das Ordens Regulares existentes nestes Reynos, e seus Dominios, em consequencia do qual" deviam ser entregues "na secretaria desta Real Meza Censoria todos os Livros, que contra as Prohibiçoens da mesma Meza se conserva[sse]m nas Bibliotecas dos Conventos das suas respectivas Ordens, e

\footnotetext{
${ }^{126}$ J. T. de Oliveira. Apud. ARAÚJO, Jorge de Souza, op. cit., p. 82.

${ }^{127}$ IANTT, Real Mesa Censória, Editais, Ofícios, Caixa 185.

${ }^{128}$ ARAÚJO, Jorge de Souza, op. cit., p. 95.

${ }^{129}$ Ibidem, loc. cit.

${ }^{130}$ IANTT, Real Mesa Censória, Decretos e avisos recebidos pela mesa, Caixa 188.
} 
extrahir Certidoens das Referidas entregues"131. Não se localizou, contudo, qualquer notícia da aplicação dessa medida na América, havendo apenas menção à entrega de livros pertencentes a bibliotecas situadas em Portugal: a Real Casa das Necessidades, em maio de 1778, enviou à Real Mesa as obras defesas em conformidade com as proibições baixadas pelos editais de 1768 “em diante". Ao Colégio de Évora determinou-se, em agosto de 1779, e reforçou-se, em setembro de 1779, a entrega de "todos os Livros impressos, e manuscriptos, e as Prozodias incompletas na sua impressão, pertencentes ao Collegio de Evora, que foi dos Padres denominados da extincta Companhia de Jezus" ${ }^{\text {132 }}$. Não se deve, contudo, pensar que a política de apreensão dos livros proibidos encontrados nas livrarias dos mosteiros e casas religiosas foi implacável e absoluta. Como se verá no Capítulo 6, muitas delas foram beneficiadas com licenças para possuir livros defesos.

Nas medidas adotadas pelo Estado em relação aos livros didáticos, fica patente que além de se proibir, tinha-se em mente um interesse também propagandístico, embora esse ocupasse um lugar secundário face ao objetivo primeiro de reprimir as idéias julgadas perigosas ${ }^{133}$. À semelhança do que acontecia com os livros didáticos que propugnavam novos métodos, úteis para a concretização e a difusão das reformas pedagógicas, algumas obras prestavam-se à defesa do absolutismo e ao combate às influências da Revolução Francesa e, ainda, à dinamização das atividades agrícolas na Colônia. O governador da capitania de Minas Gerais, D. Bernardo José de Lorena, em 1799, dirigiu ao juiz da câmara da cidade de Mariana, alguns exemplares de uma obra sobre a Revolução Francesa, que havia sido traduzida em Londres para o português e na qual "energicamente se manifestão os abominaveis principios vistos" do então governo da França. A Coroa, visando "perpetuar o sucego, de felicidades dos seus vassalos" e deixando-lhes "notorio, e constante, que são odiozos, tão orrendos" os "Crimes, que tem Caracterizado a atroz Revolução Franceza, e manchado aquela Nação que athe os mesmos Americanos detestão, e aborrecem com indignação a pessima Doutrina, e as máximas mais depravadas ainda daquele feroz, e perfido Governo", mandara um grande número de exemplares da obra citada ao governo capitania, que, por sua vez,

\footnotetext{
${ }^{131}$ Ibidem.

132 Ibidem.

${ }^{133}$ Sobre o predomínio desse ideal repressivo na ação do Estado, veja: NEVES, Lúcia Maria Bastos P. das. Comércio de livros e censura de idéias no Brasil, op. cit., p. 73.
} 
os remetia ao juiz de Mariana para "os fazer publicos" o quanto fosse "possivel no seu Termo" 134 .

D. Rodrigo de Souza Coutinho, embaixador de Dona Maria I e ministro do príncipe D. João, enviou sistematicamente o Fazendeiro do Brasil, do frei José Mariano da Conceição Veloso - uma série de traduções e tratados sobre a cana de açúcar, o algodão, as bebidas "alimentosas", as especiarias da Índia e as novas técnicas agrárias, reunidos em onze volumes e publicados com o patrocínio da Coroa, com o intuito de dinamizar a produção de matérias-primas para a industrialização de Portugal - para distribuição entre os lavradores da América Portuguesa $^{135}$. Em Minas Gerais, por exemplo, os ouvidores das comarcas foram incumbidos de vender os volumes aos interessados; em 1800, o governador da Capitania recebeu uma caixa contendo vários exemplares de livros, em sua maioria obras que incentivavam as produções agrícolas comerciais, dentre elas Cultura e Opulência do Brasil, de Antonil, e Arvore Asucareira, Fazend ${ }^{\text {ros }}$ Caffé, Cultura das Batatas e Fazend ${ }^{\text {ro }}$ Asucar ${ }^{136}$. No mesmo caixote havia títulos que pareciam ser de outra natureza, como Historias da América (seria a de Rocha Pitta?) e Caligrafia. Ao governador de Goiás, no mesmo ano, foram remetidos livros com perfil similar aos daqueles enviados ao capitão general de Minas: $2^{o s}$ de Bergman, Fazend ${ }^{\text {ro }}$ de Anil, Manoal Mineralogico e Elegias $C^{o}$ Cardozo $^{137}$.

Examinando a ação dos órgãos censórios portugueses, especialmente durante o período do Reformismo Ilustrado, entre 1768 e 1808, no circuito América-Reino, de um lado, constata-se que se verificou uma atuação do governo e dos tribunais nos campos da difusão e do controle da circulação e da posse de livros.

Se houve incoerências nas ações, se essas se pautaram ora pelo excesso do rigor ora pela frouxidão, não se pode negar, contudo, que os órgãos censórios tiveram em vista reprimir os livros que propugnassem idéias milenaristas (como

\footnotetext{
${ }^{134}$ APM, Câmara Municipal de Mariana, Livro 22, p. 176.

135 DIAS, Maria Odila Leite Silva, op. cit., p. 120. Segundo Rubens Borba de Moraes, dessa obra foram publicados apenas dez volumes, embora ela tivesse certamente muito mais; sua história, além disso, foi um tanto triste: por falta de interesse das autoridades coloniais, ela acabou ficando encalhada nas secretarias de governo, e os bichos acabaram por devorar tudo, tendo as sobras sido vendidas ainda no Império como papel velho para fogueteiros (BIBLIOGRAFIA Brasileira do Período Colonial, op. cit., p. 395).

${ }^{136}$ MENESES, José Newton Coelho. O continente rústico: abastecimento alimentar na Comarca do Serro Frio (1750-1810). Belo Horizonte: FAFICH-UFMG, 1997, p. 111-112. (Dissertação de Mestrado).

${ }^{137}$ Ibidem, loc. cit.
} 
ocorreu com as obras de Vieira, que se ordenou fossem queimadas, em Minas Gerais), teorias corporativas de poder (como ocorreu com o livro Luís de Molina), ou mesmo, que fossem simplesmente de autoria de pessoas julgadas subordinadas aos jesuítas (a exemplo de Castro Palao), ou ainda, que conduziam a uma devoção marcada pela superstição e pelo fanatismo (como Agreda, por exemplo).

A intervenção da Coroa e dos tribunais censórios, ademais, também não poupou os filósofos da Ilustração (Voltaire, Raynal, Bielfeld, Marmontel etc.) ou aqueles que, mesmo não sendo propriamente Ilustrados, deixaram-lhes um considerável legado (Locke, por exemplo). Uns e outros, como se viu nos Capítulos 3 e 4, aos olhos da Coroa, ameaçavam seus propósitos reformistas e regalistas. Ao mesmo tempo, as agências governamentais, procuraram difundir livros e idéias convenientes ao absolutismo e, por conseguinte, contrários à onda revolucionária; que se adequassem às reformas educacionais então implementadas (a Gramática de Antônio Pereira, por exemplo); e que pudessem dinamizar as atividades econômicas na América (o Fazendeiro do Brasil, dentre eles).

Se a existência de tais alvos é inegável, bem como sua vinculação com as diretrizes gerais das governações Reformistas Ilustradas portuguesas, é irrefutável a fragilidade do aparato estatal para concretizá-las. Os tribunais censórios, em parte devido à própria ambigüidade - definida pelo tênue equilíbrio entre reformar e conservar, marca registrada do Reformismo Ilustrado português, como ensina Fernando Novais - de seus parâmetros, que embora fossem Ilustrados, eram hostis à boa parte das idéias trazidas pelas Luzes; em parte devido às implicações que o caráter estamental da sociedade trazia para a posse e leitura de livros, que eram perpassadas pela idéia de privilégio (é sempre bom lembrar a trapaça montada pelo padre Leonardo, bem como a punição torta aplicada pela censura e, ainda, as ordens da Rainha para a repressão seletiva dos leitores "irreligionários" em Coimbra em 1779); devido, ainda, aos descompassos e as contradições da burocracia estatal (citem-se, as retenções e liberações de uma mesma obra ou o envio à Colônia de livros que jamais chegaram aos seus destinatários ideais) — enfim, devido à interação desses fatores, os tribunais não lograram êxito na sua atuação. As altas esferas do governo, por isso mesmo, não só cobraram maior agilidade, como passaram a interferir diretamente sobre as áreas jurisdicionadas aos tribunais censórios, sendo um emblema disso a atuação de Pina Manique. 
O Estado desenvolveu retenções, apreensões e buscas de livros, através dos próprios tribunais censórios, da Intendência Geral de Polícia, dos governadores e ouvidores do Ultramar. Nada disso impediu que livros proibidos circulassem, fossem possuídos - e lidos! Para os leitores, a própria obrigatoriedade de submeter seus livros à fiscalização dos órgãos censórios, fosse para possuí-los, fosse para se locomoverem com os mesmos, ora não foi reconhecida enquanto tal, ora foi deliberada e argutamente afrontada. E, nesse ponto, residia um dos nós da ação fiscalizatória: sem a boa vontade dos leitores, a censura, em parte significativa, ficava comprometida. Dessa outra faceta da história da censura, recuperaram-se aqui alguns fragmentos: ao mesmo tempo em que se deu vez às iniciativas repressivas ou de propaganda da Coroa, vislumbraram-se resistências, ardis, desobediências, protagonizadas pelos leitores.

Houve, entretanto, um campo específico, limitado, dentro do qual muitos leitores se curvaram à fúria estatal: a obtenção de licenças para a leitura de livros proibidos. Sobre esse tema, que será o assunto do próximo capítulo, ficam, então, algumas interrogações: quais foram as regras e as diretrizes seguidas pelos órgãos censórios na concessão das referidas licenças? Em que medida a prática respeitou as normas e foi fiel às diretrizes mais amplas fixadas pela Coroa? A ambigüidade que cercava a relação da Coroa e, de resto, da própria censura, face às Luzes também se evidenciou na concessão de licenças para a leitura de obras defesas? A seletividade estamental-profissional, a noção de privilégio, cujas influências se pôde detectar ao examinar a circulação e a posse de livros em geral, também afetou o campo em questão? A política de concessão de licenças foi a mesma durante todo o período, de 1768 a 1808? Todas essas interrogações serão abordadas a seguir, no Capítulo 6. 


\section{Capítulo 6:}

\section{As Licenças para Posse e Leitura de Livros Proibidos}

\section{Regras de concessão}

A Real Mesa Censória, a Real Mesa da Comissão Geral para a censura de livros e o Desembargo do Paço, tal como fazia antes a Inquisição, autorizaram algumas pessoas e instituições a possuírem livros proibidos.

A concessão de licença para leitura e posse de livros proibidos era regulada com precisão pelo regimento da Real Mesa Censória, de 18 de maio de 1768, que também estabelecia normas para revalidação das licenças passadas pelo Santo Ofício, dos breves e das concessões pontifícias ${ }^{1}$. Nas inspeções dessas licenças anteriormente passadas e na concessão de licenças novas, a Real Mesa Censória deveria agir com "muita cautela e moderação; informando-se primeiro das qualidades das Pessoas, que" as pedissem; e facultando-as "somente às Doutas, e prudentes, em que ce[ssa]sse moralmente todo o receyo de perigo". Os breves e comissões pontifícias, concedidos aos prelados ou inquisidores depois da vigência do regimento, além disso, só teriam valor após serem examinados pela mesa ${ }^{2}$.

Com a volta da censura tríplice a partir de 1794, a concessão de licenças, do ponto de vista legal, não se alterou profundamente. O mesmo alvará que em 1795 fixou regras para a proibição de livros, também baixou determinações sobre a concessão de licenças para leitura e posse de obras defesas, tomando-a como uma prática necessária para o bem da religião e do Estado. As licenças deveriam ser concedidas apenas a "alguns Varões Doutos, Pios, e Prudentes", para que os mesmos pudessem ficar "mais plenamente inteirados" das razões e fundamentos dos livros proibidos, estando, assim, em condições de "refutar as Doutrinas, e Erros" neles existentes, ou então, "delles tirar algum proveito"3 . Ao Desembargo do Paço caberia conceder licenças "quanto á classe dos Livros contra o Estado", independentemente

\footnotetext{
${ }^{1}$ IANTT, Real Mesa Censória, Caixa 1, Regimento da Real Mesa Censória, p. 9.

${ }^{2}$ Ibidem, loc. cit.
} 
do parecer do Ordinário e da Inquisição. Porém, quanto à "classe dos Livros contra a Religião", não as poderia conceder jamais, sem que primeiro os requerentes the apresentassem "Licença expressa por escrito, assim do seu Bispo Diocesano, ou do Bispo vizinho, se forem de Territorio Nullus Dioecesis, como da Inquisição do Santo Officio, a cujo districto" pertencessem, autorizando a "lição dos ditos Livros" 4.

Em documentos posteriores a 1795, encontram-se referências não muito precisas à parte desse trâmite prescrito pela lei: em 1805, o Desembargo do Paço exigiu dos clérigos regulares e teólogos D. João do C. de Maria e D. Antônio de Maria Santíssimo que juntassem as "licenças das outras autoridades" e, em 1817, o próprio requerente, o cônego Joaquim Pedro da Costa Marial, reitor da catedral de Faro, no Algarve, manifestou consciência da necessidade de ter licença do seu Ordinário e do Desembargo do Paço. Registrou, assim, que para "ler e reter Livros prohibidos por quaesquer Indices expurgatorios", em "Conformidade da Lei de 30 de junho de 1795", devia “appresentar licença não só de seu ordinário, mas também deste Tribunal [do Desembargo do Paço]",

Após o retorno à censura tríplice, além disso, manteve-se o mesmo procedimento usado pela Real Mesa Censória e pela Real Mesa da Comissão Geral, em relação às licenças concedidas pelo papado. Essas últimas deveriam ser apresentadas na Secretaria de Estado dos Negócios do Reino, juntamente com informações dos Bispos a que estivessem sujeitos os requerentes, para que se lhes desse o "Real Beneplacito, e lhes manda[sse] deferir pela Meza como fo[sse] bem".

Segundo a regra duodécima do regimento da Real Mesa Censória, a "Universidade, as Livrarias das Comunidades, e aquelles Mestres Theologos, que por serem os Lentes actuais, necessitam de terem, e lerem os sobreditos livros [Heréticos e ímpios] para os impugnarem", poderiam beneficiar-se com licenças para ler e possuir livros proibidos ${ }^{7}$.

Um assento da mesa datado de 1770 enrijeceu a prática de concessão de licenças, determinando que essas não fossem passadas de forma absoluta, "ainda a pessoas de literatura", mas “"coarctada a certo tempo e a certos livros, para salvar todo o perigo e prejuízo que da lição deles”” pudesse resultar “"à doutrina da Igreja e

\footnotetext{
${ }^{3}$ ALVARÁ de 30 de julho de 1795. In: COLLEÇÃO de Leis, op. cit., vol. 7, p. 135v.

${ }^{4}$ Ibidem, loc. cit.

${ }^{5}$ IANTT, Real Mesa Censória, Requerimentos, Caixa 113 (negrito meu).

${ }^{6}$ ALVARÁ de 30 de julho de 1795. In: COLLEÇÃO de Leis, op. cit., vol. 7, loc. cit.
} 
aos direitos da Monarquia",8. Dessa forma, a alguns seria autorizada a leitura de livros “"da competência temporal da Mesa"”, mas não da espiritual e, a outros, da “"competência espiritual”", mas não da temporal ${ }^{9}$. Muito excepcionalmente, segundo o citado regimento, seria permitido a livreiros, mercadores de livros e impressores possuir livros defesos ${ }^{10}$. A duração das licenças também foi objeto de preocupação do alvará que regulou o funcionamento da censura tríplice, datado de 1795: ele determinava que as licenças poderiam ser concedidas "todas por certo tempo" e, ao que parece, só em casos excepcionais seriam passadas "para sempre"11.

\section{Limites e possibilidades da documentação}

Através dos requerimentos encaminhados pelos leitores que desejavam alcançar autorização para ler livros proibidos, dos despachos anotados pelas autoridades nos mesmos requerimentos e das provisões através das quais os tribunais censórios outorgavam as licenças, é possível ver como as normas supracitadas foram aplicadas na prática. Os requerimentos eram formalmente dirigidos a El-Rei e endereçados aos tribunais censórios, que poderiam obviamente atendê-los ou não. Nas provisões, os tribunais definiam o tipo de licença expedida, variável de acordo com o perfil profissional e social dos beneficiários, autorizando, dessa forma, a posse e/ou a leitura de diferentes gêneros de livros proibidos. As provisões encontram-se transcritas em livros; as permissões e proibições estabelecidas pelas mesmas, além disso, vêm registradas ocasionalmente em despachos dados nos próprios requerimentos enviados pelos leitores que desejavam ser agraciados com licenças para posse e leitura de livros defesos.

Os órgãos censórios usualmente aplicavam os números 1, 2 e 3 (e quase nunca 4 e 5) para identificar e classificar os tipos de licenças, ou então, deixavam essa numeração de lado quando se tratava de licenças concedidas a livreiros, ou que permitiam a posse e leitura de livros determinados, ou ainda, que liberavam apenas o

\footnotetext{
${ }^{7}$ IANTT, Real Mesa Censória, Caixa 1, Regimento da Real Mesa Censória, loc. cit.

${ }^{8}$ Apud. CARREIRA, Laureano, op. cit., p. 60-61.

${ }^{9}$ Ibidem, loc. cit.

${ }^{10}$ MARQUES, Maria Adelaide Salvador, op. cit., p. 47.

${ }^{11}$ A dúvida existe porque o artigo está redigido de forma extremamente confusa, como se vê a seguir: "quanto as Pessoas a quem as der, não tiverem mostrado pelo bom uso das que houverem conseguido, que não ha perigo, mas que ao contrário haverá utilidade em se lhes concederem para sempre" (ALVARÁ de 30 de julho de 1795. In: COLLEÇÃO de Leis, op. cit., vol. 7, loc. cit.).
} 
uso de obras relativas às áreas profissionais específicas de cada um dos requerentes. Há, todavia, inúmeras exceções a essa regra geral. Assim, nos despachos dados em 1770 e 1772 a todos os requerimentos, não só de leitores e situações que se enquadravam nas categorias supracitadas (isto é, livreiros ou uso de obras específicas e profissionais), não se registraram os números relativos a cada um dos tipos de licença-provisão, vendo-se em alguns casos apenas a expressão "Provisão na forma do costume", e sendo anotadas as permissões e proibições que atingiam a cada requerente como leitor. Já nos despachos feitos nas solicitações do período compreendido entre 1773 e 1825, dá-se o oposto: registram-se os números-tipos das licenças, mas não as proibições e permissões deles decorrentes para os leitores. Nos despachos inexistem anotações de licenças de $n^{\circ} 4$, tipo que aparece uma única vez nos livros de registro de provisões. Nestas, por sua vez, não aparece nenhuma licença de $n^{\circ} 5^{12}$.

Conforme mostra o Gráfico I, os requerimentos (268) e, por conseguinte, os despachos, embora abranjam o período que vai de 1770 a 1825, são quase totalmente omissos em relação aos anos de 1770 e 1771 (existem apenas 3 referentes a esses anos), e, ademais, estão concentrados em termos numéricos no intervalo compreendido entre 1772 e 1777 , atingindo o ápice em $1772^{13}$. Se para os anos de 1770 e 1771, há poucos requerimentos, como se vê no Gráfico I (respectivamente, 2 e 1), nos livros em que se encontram trasladadas as provisões, porém, registra-se um expressivo número de licenças, perfazendo, respectivamente, as cifras de 16 e 23 concessões. Dentre essas últimas, havia 17 licenças que nada mais são do que o resultado do exame de breves concedidos por Sua Santidade, em tempos anteriores à Real Mesa Censória ${ }^{14}$.

\footnotetext{
${ }^{12}$ IANTT, Real Mesa Censória, Requerimentos, Caixas 112 e 113, e Provisões, Livros 2, 13 e 14.

${ }^{13}$ IANTT, Real Mesa Censória, Requerimentos, Caixas 112 e 113.

${ }^{14}$ IANTT, Real Mesa Censória, Provisões, Livros 2 e 13.
} 


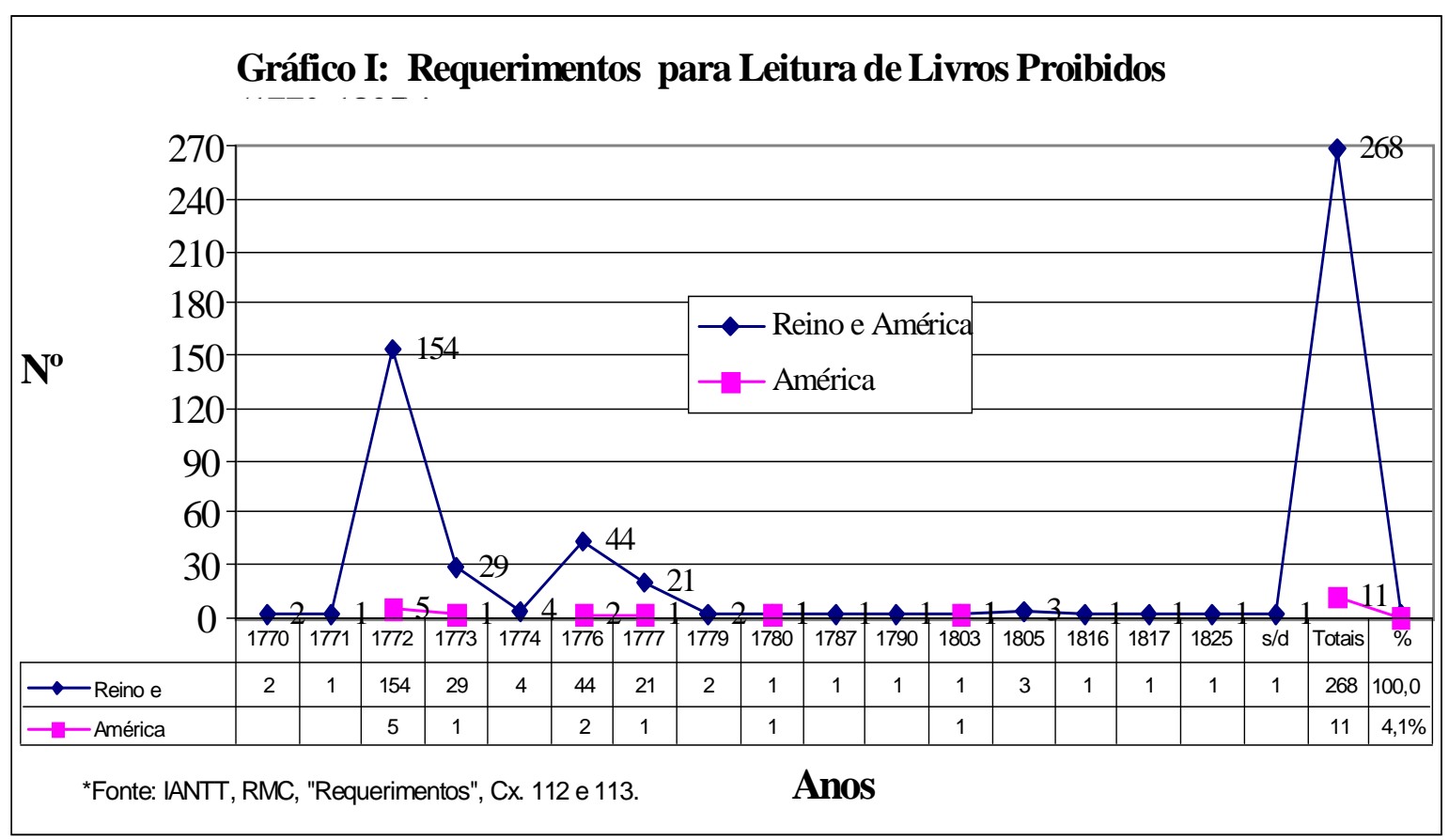

As diferenças numéricas entre requerimentos e provisões, assim, indicam que alguns documentos devem ter se extraviado. As altas cifras das provisões, por seu turno, em particular de licenças originadas de breves papais, mostram a procura de acomodação dos leitores às novas leis, submetendo os breves ao exame da Real Mesa Censória. No Gráfico I, observa-se também que 252 requerimentos foram feitos de 1772 a 1777, o que corresponde a 94,02\% do total (268). Esses elementos todos sugerem que, logo após a criação da Real Mesa Censória em 1768, no período que se estende de 1770 a 1777, houve uma grande remessa de requerimentos por parte dos leitores, que acorreram ao novo tribunal seja para legalizar o anseio e a prática de ler livros proibidos, seja pelo fato de que, já possuindo licença concedida pela Inquisição e pelo papado, desejavam adaptar-se às novas normas, que tornavam necessária a chancela régia e, mais do que isso, que faziam da expedição de licença uma prerrogativa do Estado ${ }^{15}$. Tal conclusão, sublinhe-se, só pôde ser feita com base no uso simultâneo das duas séries documentais em questão: requerimentos-despachos e provisões de licença.

O quadro que emerge dos requerimentos datados de 1772 a 1774, no entanto, pouco difere daquele que se pode formar a partir do exame das provisões trasladadas nos livros da Real Mesa Censória no mesmo período, observando-se, em linhas

\footnotetext{
${ }^{15}$ IANTT, Real Mesa Censória, Requerimentos, Caixas 112 e 113.
} 
gerais, uma repetição de nomes e datas, motivo pelo qual não se quantificou os dados contidos nos livros de provisões correspondentes, opção esta reforçada pelo péssimo estado de conservação de um deles e pela pouca legibilidade de outro ${ }^{16}$. Já em relação aos anos de 1775, 1776 e 1777, como se pode constatar confrontando os Gráficos I e II, evidencia-se a alternância de ligeiras e pronunciadas diferenças numéricas entre requerimentos e provisões: enquanto os primeiros somam respectivamente 0,44 e 21, as últimas totalizam, na mesma ordem, 39, 51 e 24 licenças ${ }^{17}$. Prosseguindo no cotejo das duas séries através dos gráficos supracitados, notam-se similitudes no intervalo 1780-1789, em que há poucos requerimentos e nenhuma provisão de licença. Como explicar a modéstia desses últimos números? Requerimentos e/ ou livro de provisões teriam se perdido? Não é possível responder a essas dúvidas, que ficam, portanto, merecendo investigações futuras. Em relação ao período que se estende de 1790 a 1794, observam-se disparidades numéricas: enquanto não há registro de requerimentos feitos entre 1790 e 1802, as provisões de licença chegam à cifra de 171 , de 1790 a 1794 (Gráfico II) ${ }^{18}$. Pode-se, portanto, afirmar que houve o desaparecimento de requerimentos e que, à falta do exame do livro de provisões, pouco se saberia sobre as licenças para a leitura de livros proibidos entre 1790 e 1794 . Haveria alguma correlação entre a grande demanda dos leitores por autorização para ler livros proibidos e os eventos revolucionários que atingiam a França? Ou seria essa demanda reflexo um pouco tardio da efetiva atuação Real Mesa da Comissão Geral para a censura de livros, que veio a substituir a Real Mesa Censória em 1787, e do conseqüente temor gerado entre os leitores? Não há elementos que possam tornar essas interrogações algo mais que especulações.

\footnotetext{
${ }^{16}$ IANTT, Real Mesa Censória, Requerimentos, Caixa 113 e Provisões, Livros 2 e 13. O livro 2 possui problemas de conservação, enquanto que o livro 13, em alguns trechos, apresenta uma letra esmaecida pela corrosão e grafia das mais difíceis de decifrar.

${ }^{17}$ IANTT, Real Mesa Censória, Requerimentos, Caixas 113 e Provisões, Livro 14. Seria possível explicar um número menor de provisões em relação ao de requerimentos — afinal, nem todos os requerimentos eram deferidos — mas isto não se aplicaria a esta situação, já que nela se verifica o oposto (há um número maior de provisões).

${ }^{18}$ IANTT, Real Mesa Censória, Requerimentos, Caixa 113 e Provisões, Livro 14.
} 


\section{Gráfico II - Provisões de Licenças (1775-1794)*}

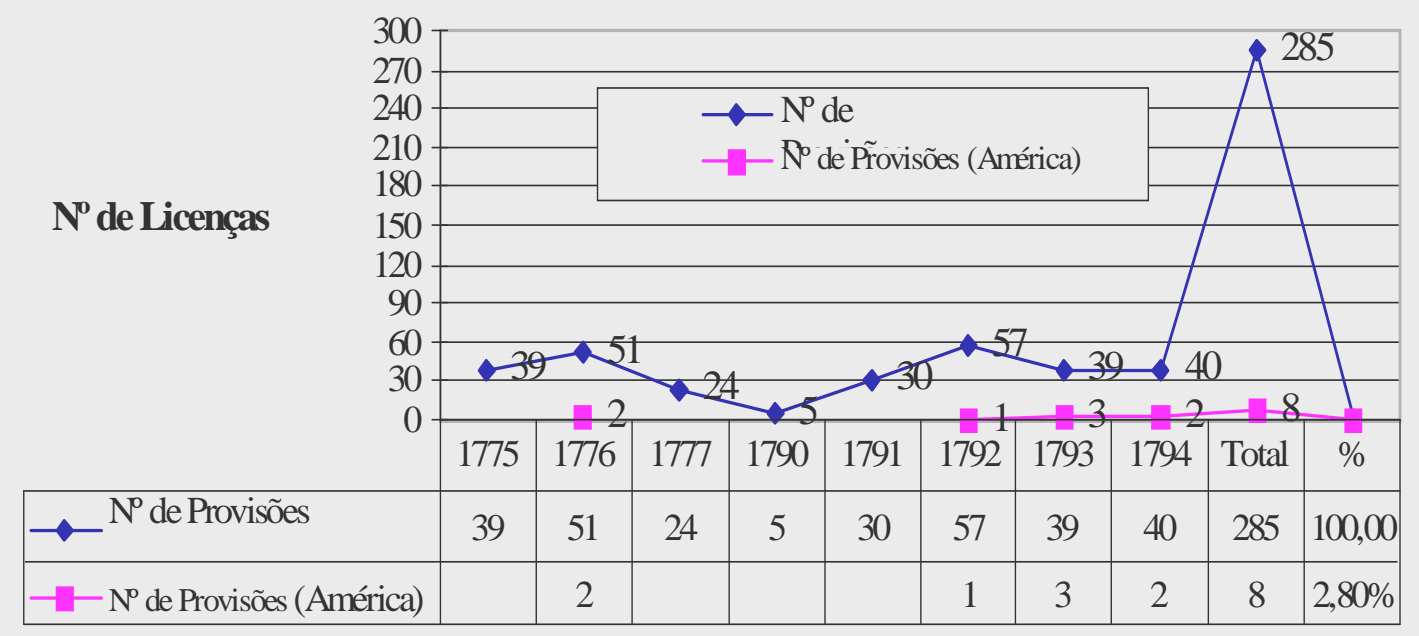

Anos

*Fonte: IANTT, RMC, "Provisões", Lv. 14

Em relação aos anos posteriores a 1794, observa-se a mesma situação identificada nos anos 1780-1789. Há cifras baixas, que pouco se elevam acima de 1; apenas em 1805 chega-se a 3 licenças, como mostra o Gráfico $\mathbf{I}^{\mathbf{1 9}}$. O decréscimo coincide com o retorno à censura tríplice, com a instalação daquele complexo trâmite judicial para a obtenção das licenças e com o enrijecimento das normas: como se viu, o Desembargo do Paço tinha jurisdição exclusiva sobre a licença de leitura de obras contra o Estado, mas precisava do aval do Ordinário e da Inquisição para os casos de obras religiosas proibidas. É possível que a documentação relativa à concessão de licenças depois de 1794 tenha sido alocada em fundo diverso das passadas no período anterior, ou ainda que tenha sido perdida seja na Inquisição, seja nos Juízos Eclesiásticos; esse número pequeno talvez se deva, ainda, a uma maior rigidez na concessão de licenças. Se essas hipóteses confirmarem-se (o que exige também pesquisas futuras), ter-se-á mais um elemento a comprovar a relação entre a documentação e as vicissitudes da censura a partir de 1768.

Apesar de serem descontínuos no tempo, inúmeros, lacunares e em alguns casos ilegíveis, requerimentos e provisões são extremamente ricos. Os primeiros, na medida em que contêm justificativas feitas pelos requerentes com o objetivo de obter

\footnotetext{
${ }^{19}$ Ibidem.
} 
licenças para ler livros proibidos, permitem examinar a relação estabelecida pelo leitor com os livros defesos, do seu ponto de vista e/ou para agradar o tribunal. Os requerimentos, ainda, bem como as provisões, ao delimitarem o conteúdo do privilégio legal que alguns leitores tinham em relação à leitura e à posse de livros proibidos, fornecem elementos para compreender como o Estado modulava a concessão de licenças, como aplicava na prática as normas fixadas. A documentação, enfim, permite sobretudo apreender as tensões estabelecidas entre Estado e sociedade em torno da leitura de livros defesos, as resistências que a última movia às iniciativas do primeiro, bem como confirmar, no campo específico da relação entre leitores e livros censurados, as linhas e os impasses de âmbito mais geral da política Reformista Ilustrada adotada pela Coroa portuguesa.

Uma conclusão pode ser estabelecida sobre as licenças para a leitura e posse de livros proibidos antes mesmo de se esquadrinhá-las: as licenças eram, de um lado, uma mercê da Coroa, e, de outro, um direito inerente à condição social ou categoria profissional dos que as solicitavam, não escapando tal princípio à consciência e à pena de alguns dos que as requeriam. Esse sentido duplo, inerente ao mecanismo das licenças, ao mesmo tempo mercês e privilégios, pode ser entrevisto em dois requerimentos encaminhados pelo marquês de Penalva: em 1770, ele pediu licença para ler livros proibidos, mas conseguiu autorização apenas para ter e ler o Dictionnaire Historique \& Critique de Pierre Bayle; em 1771, descontente com permissão tão limitada e alegando ter outras obras proibidas, veio apresentar nova solicitação, não tendo sido, no entanto, atendido. Penalva, portanto, não se resignou à primeira negativa da Real Mesa Censória, insistindo em obter dela uma concessão mais ampla, a qual, na realidade, viria apenas legalizar uma situação que já era fato — aliás, reconhecido pelo próprio Penalva. Essa situação mostra, por um lado, que a licença para leitura de livros proibidos era assumida como um direito pelo nobre português em questão; um direito, insista-se, experimentado antes mesmo de ser legalizado. Por outro lado, demonstra que o tribunal, provavelmente em consonância com a diretriz pombalina de sobrepor a Coroa à sociedade, disciplinando em particular a nobreza, não cedeu à insistência de Penalva. Privilégios estamentais e ímpeto absolutista, assim, parecem travar um embate. Esse conflito, entretanto, não foi levado ao seu limite extremo, na medida em que inexiste notícia de que o tribunal tenha apreendido os livros do marquês, o que sugere que os privilégios deste último, 
de fato, sobreviveram, à revelia do cumprimento das normas ${ }^{20}$.

Para aproveitar a riqueza e driblar as discrepâncias e os problemas verificados nas duas fontes documentais em questão (requerimentos e livros de provisões de licenças), optou-se pelo uso simultâneo e complementar de ambas, preenchendo-se as lacunas de uma documentação com as informações de outra e vice-versa, evitando-se ao máximo a quantificação de informações duplicadas. Assim, para realizar a quantificação, tomou-se um primeiro conjunto de documentos, constituído por todos despachos anotados nos requerimentos encaminhados pelos leitores ${ }^{21} \mathrm{e}$, ainda, pelas provisões registradas nos livros referentes aos anos de 1770 e $1771^{22}$, compreendendo, no todo, o período que vai de 1770 a 1825 . Isto permitiu cobrir o desaparecimento de requerimentos datados de 1770 e 1771. Um segundo conjunto de documentos foi definido pelas provisões de licenças passadas de 1775 até 1794, intervalo em que há discrepâncias, maiores ou menores, entre as licenças anotadas nos livros de provisões e aquelas registradas nos requerimentos ${ }^{23}$.

\section{Práticas de concessão}

Somando-se os requerimentos remetidos entre 1772 e 1825 às transcrições de licenças feitas em 1770-1771 nos livros dos tribunais censórios, chega-se a uma cifra total de 311 pedidos para a leitura e posse de livros proibidos, no período que se estende de 1769 a $1825^{24}$. Como se vê no Gráfico III, 307 documentos - doravante serão denominados requerimentos, apesar de incluírem também as provisões dos anos 1770-1771 — datam do período compreendido entre 1769 e 1808, sendo as aprovações muito superiores em número às escusas: a Real Mesa Censória e os tribunais que lhe sucederam contemplaram com licenças 298 requerimentos (97\%) e com escusas apenas 9 (2,93\%). Incluiu-se entre essas um requerimento que não recebeu despacho, por se supor que tenha sido recusado ${ }^{25}$.

\footnotetext{
${ }^{20}$ IANTT, Real Mesa Censória, Provisões, Livro 13, p. 11v e 22v-23.

${ }^{21}$ IANTT, Real Mesa Censória, Requerimentos, Caixas 112 e 113.

${ }^{22}$ IANTT, Real Mesa Censória, Provisões, Livros 2 e 13.

${ }^{23}$ IANTT, Real Mesa Censória, Provisões, Livro 14.

${ }^{24}$ IANTT, Real Mesa Censória, Provisões, Livros 2 e 13 e Requerimentos, Caixas 112 e 113.

${ }^{25}$ Ibidem.
} 


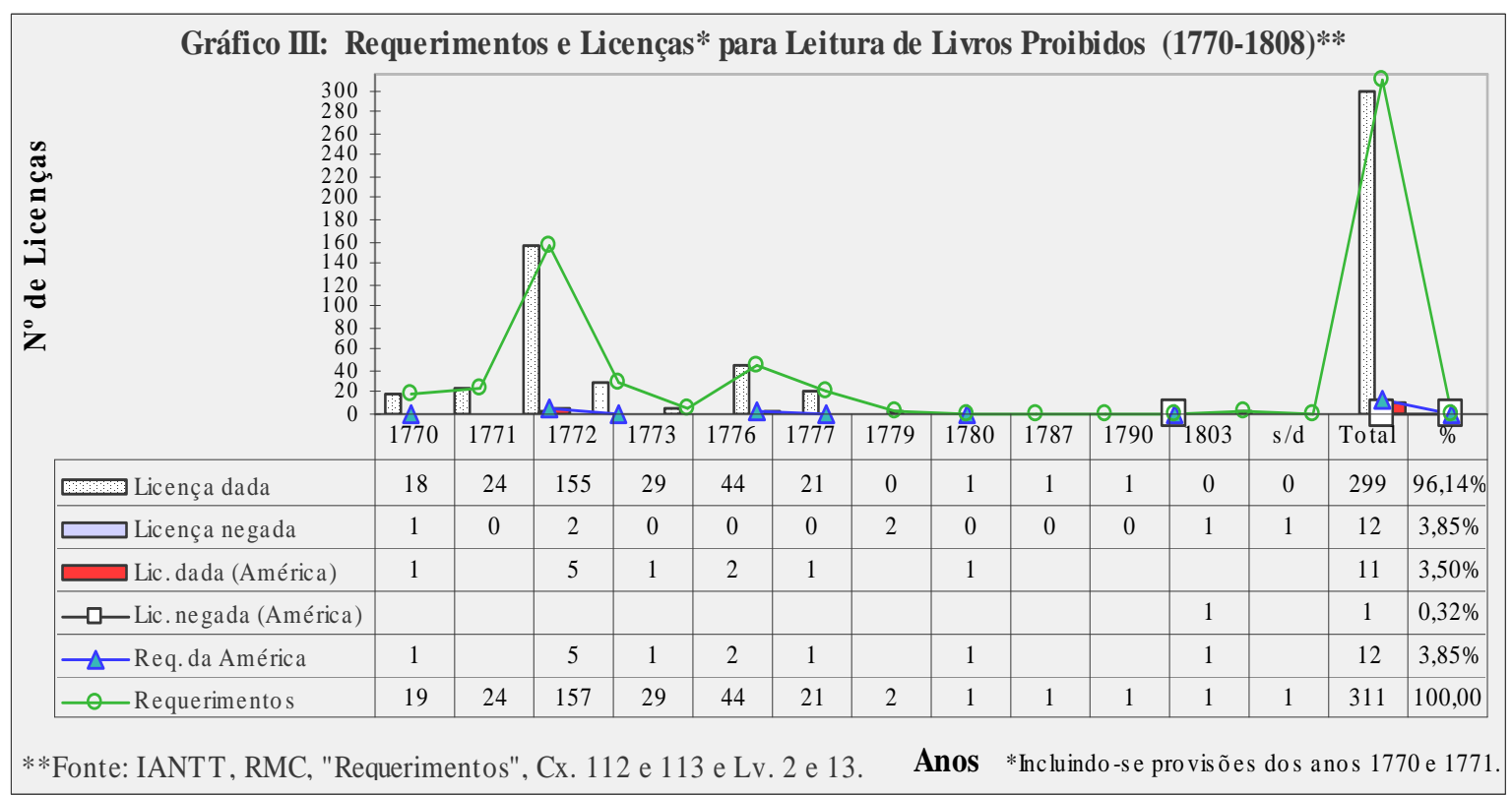

Dos requerimentos, 12 (3,85\% do total) referiam-se a pessoas que residiam ou que haviam passado pela América Portuguesa, tendo 11 deles (3,58\% do total e $91,66 \%$ dos requerimentos remetidos por pessoas com passagem pelas possessões portuguesas na América) sido contemplados com licença e 1 (0,32\% do total), escusado $^{26}$.

Retornando ao Gráfico II, pode-se constatar que foram passadas 285 provisões de licença para a leitura de livros proibidos entre 1775 e 1794, sendo 8 $(2,8 \%)$ delas passadas a indivíduos que então residiam ou que haviam habitado tempos antes a América Portuguesa ${ }^{27}$. Todos os requerentes e beneficiados com licenças - isso não foi representado nos Gráfico II e III - eram "varões", ou seja, em consonância com a exigência da legislação, implícita em 1768 e explícita em 1795 , nenhuma mulher solicitou ou foi contemplada com licença para leitura e posse de livros proibidos ${ }^{28}$.

As licenças, como se indicou anteriormente, muitas vezes recebiam números para sua classificação - 1, 2, 3 e, muito raramente, 4 e 5. Além disso, as licenças permitiam aos seus beneficiários uma liberdade diferenciada em relação aos livros defesos. Assim, definiam suspensões ou, pelo contrário, determinavam a obrigatoriedade da observância das proibições fixadas em alguns editais censórios; autorizavam a leitura de obras profissionais ou de livros explicitamente nomeados

\footnotetext{
${ }^{26}$ Ibidem. Algumas pessoas encaminharam mais de um requerimento, à mesma época ou em datas diferentes. Optou-se aqui por contabilizar a todos.

${ }^{27}$ IANTT, Real Mesa Censória, Provisões, Livro 14.

${ }^{28}$ IANTT, Real Mesa Censória, Requerimentos, Caixas 112 e 113 e Provisões, Livros 2, 13 e 14.
} 
pelos censores e requerentes; e liberavam ou desautorizavam o acesso a obras de cunho religioso. Aberturas e inflexibilidades dos órgãos censórios na concessão de licenças para leitura de livros proibidos guardaram relações com o perfil sócioprofissional dos beneficiários e também com a conjuntura histórica ${ }^{29}$.

Para apreender a lógica que presidia a combinação desses elementos, primeiramente, focalizar-se-ão as participações respectivas de clérigos e leigos entre os beneficiários de licenças e a distribuição dos tipos-números entre esses leitores. Depois, será analisado o que foi suspenso e o que, pelo contrário, se manteve interditado, nas licenças passadas para a leitura e posse de livros proibidos, observando-se como as proibições de leitura suspensas e mantidas associavam-se aos tipos-números das licenças. Em seguida, far-se-á uma correlação entre perfil sócioprofissional dos leitores, tipos de licenças concedidas e proibições mantidas e suspensas, realizando-se, ao mesmo tempo, uma radiografia das licenças concedidas aos que habitavam ou que haviam passado pela América.

\subsection{Clérigos, leigos e tipos de licenças}

Conforme mostra o Gráfico IV, os clérigos preponderavam sobre os leigos entre os requerentes contemplados com licenças para ler livros proibidos, passadas pelos tribunais censórios entre 1770 e 1808 , e entre os que foram beneficiados com provisões nos anos de 1770 e 1771 , somando 171 ocorrências $(57,38 \%$ dos requerimentos). $\mathrm{Na}$ imensa maioria dos requerimentos e provisões não consta $\mathrm{o}$ número-tipo da licença: há 102 incidências dessa situação, o que corresponde a $60,22 \%$ dos documentos (dentre elas, para não se deixar o gráfico muito carregado de dados pouco significativos, foi incluída uma única licença de tipo 5). Em segundo lugar, vêm as licenças de tipo 2, que perfazem um total de 43 (25,14\%). Muito atrás estão as licenças de tipo $3(5 ; 9,94 \%)$ e de tipo $1(1 ; 4,67 \%)$.

\footnotetext{
${ }^{29}$ Ibidem.
} 


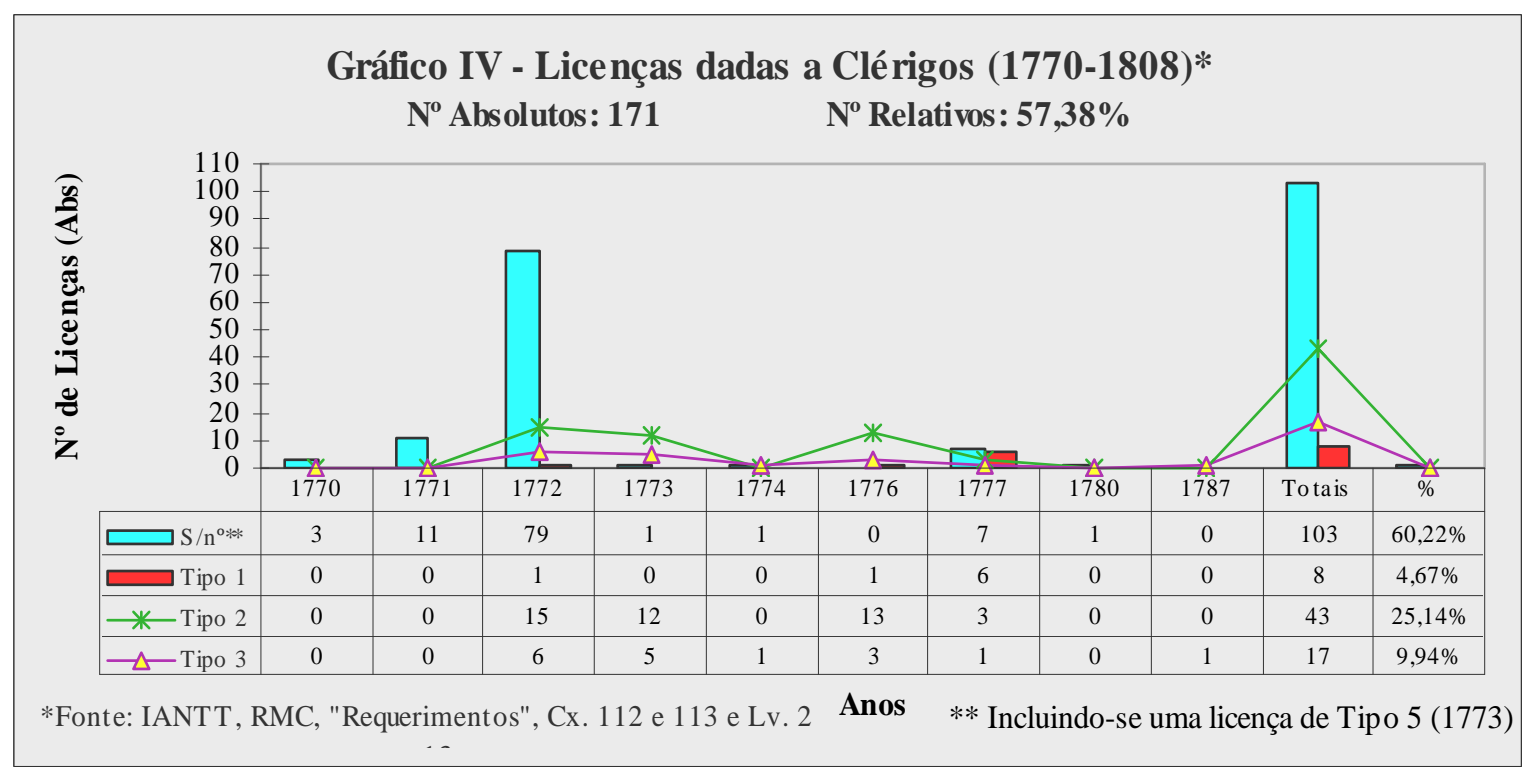

Entre os requerentes contemplados com licenças para ler livros proibidos passadas pelos tribunais censórios entre 1770 e 1808 ou beneficiados com provisões nos anos de 1770 e 1771, conforme mostra o Gráfico V, os leigos eram menos numerosos que os clérigos somando $127(42,61 \%)^{30}$.

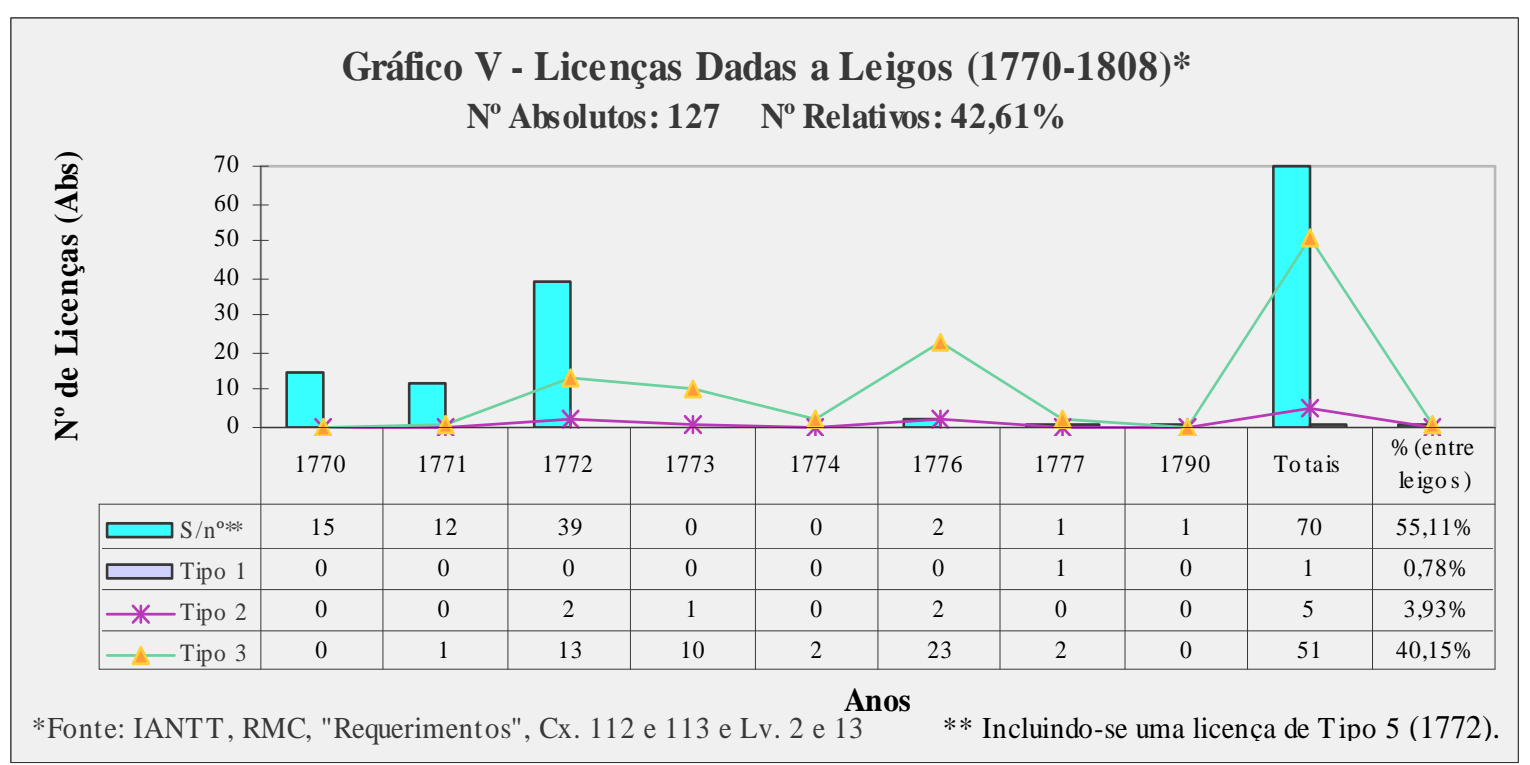

Como ocorreu com os clérigos, na imensa maioria dos requerimentos de leigos, não se registraram os números-tipos das provisões passadas: isso ocorreu em 70 delas $(55,11 \%$; dentre elas, para não se deixar o gráfico sobrecarregado de

\footnotetext{
${ }^{30}$ IANTT, Real Mesa Censória, Requerimentos, Caixas 112 e 113 e Provisões, Livros 2 e 13.
} 
informações numericamente insignificantes, foi incluída uma única licença de tipo $5)^{31}$. Diferentemente dos clérigos, no entanto, a segunda posição coube às licenças de tipo 3, que atingiam cifra igual a $51(40,15 \%)$, seguindo-se as licenças de tipo 2 (5; $3,93 \%)$ e tipo $1(1 ; 0,78 \%)^{32}$. Essas diferenças entre clérigos e leigos no que se refere à distribuição dos tipos-números de licenças, como se verá a seguir, corresponderam a maiores restrições para os leigos em relação aos livros proibidos.

Os dados colhidos nas provisões passadas entre 1775 e 1794 confirmam, em linhas gerais, a participação diferenciada de clérigos e leigos entre os beneficiários de licenças, verificada nos despachos dados nos requerimentos entre 1770 e 1808. Conforme mostra o Gráfico VI, os clérigos correspondiam a mais da metade dos beneficiários com provisões de licença para leitura de livros proibidos entre 1775 e 1794: de um total de 285 beneficiários, eles somavam $149(52,28 \%)^{33}$.

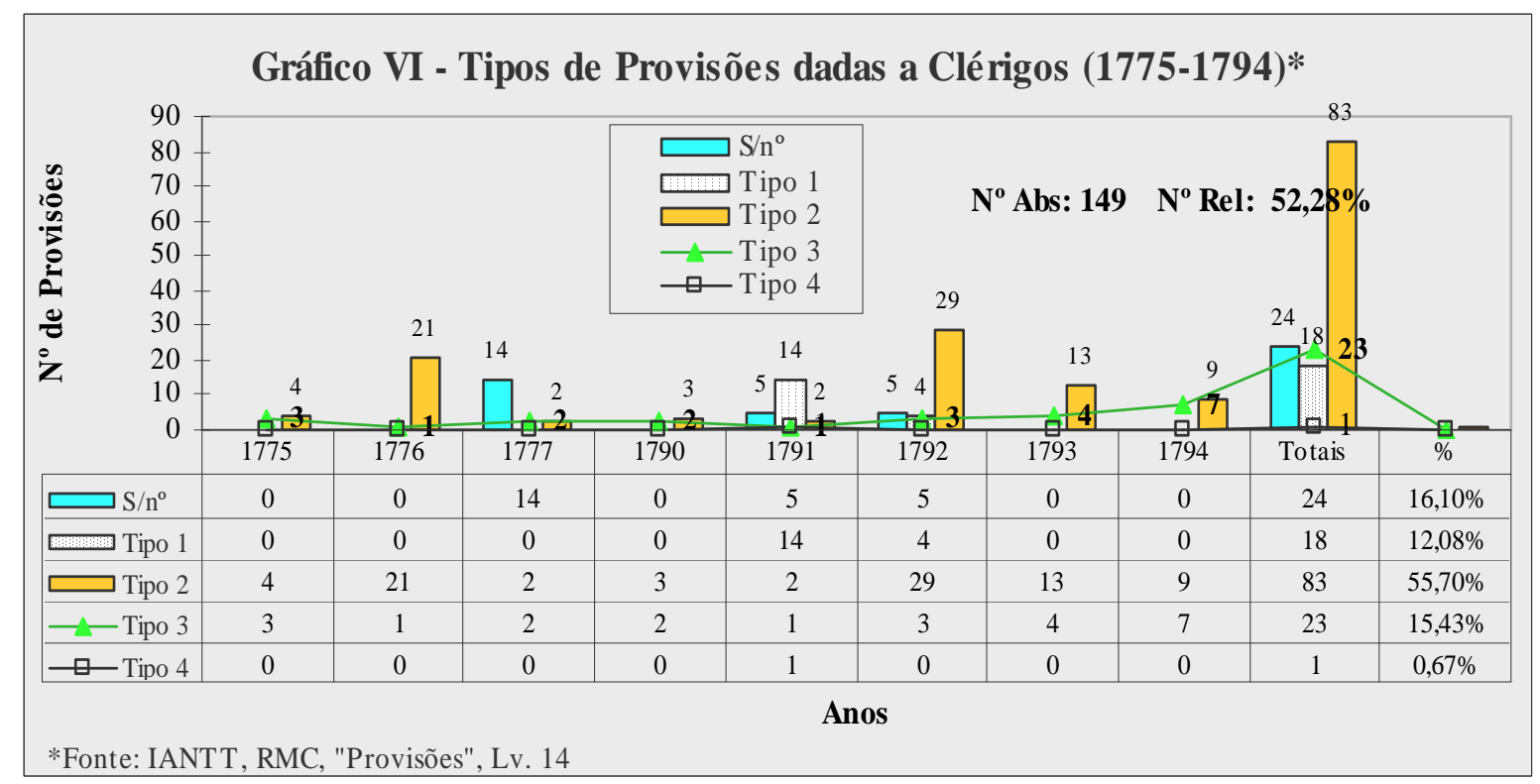

Entre os clérigos que tiveram provisões registradas, a participação das licenças sem número-tipo, no entanto, não é a maior: se há 24 (16,10\%) licenças sem número, são 83 as licenças de número 2 (55,70\%); 23, as de número 3 (15,4\%); 18, as de número $1(12,08 \%)$ e apenas 1 , com número $4(0,67 \%)$. Portanto, comparandose as provisões com os despachos dados nos requerimentos remetidos por clérigos, a grande diferença está no menor número de provisões sem número e na existência de

\footnotetext{
${ }^{31}$ Ibidem.

${ }^{32}$ Ibidem

${ }^{33}$ IANTT, Real Mesa Censória, Provisões, Livro 14.
} 
licenças de tipo 4, enquanto no mais, permanece a mesma seqüência de tipos: em termos numéricos, preponderam, de forma decrescente, as provisões de tipo 2, 3 e $1^{34}$.

Não foi possível saber seguramente se os beneficiários de 64 provisões eram clérigos ou leigos, embora provavelmente pertencessem a essa última categoria. Já nas $72(25,26 \%)$ restantes, fica clara a condição de leigo dos beneficiários. Conforme mostra o Gráfico VII, do mesmo modo que ocorre entre os clérigos que obtiveram provisões entre 1775 e 1794, a participação das licenças sem número entre os beneficiários leigos $(11 ; 15,27 \%)$, não é preponderante em termos numéricos ${ }^{35}$. Essa é, portanto, uma diferença comum das provisões de 1775-1794 em relação às licenças dadas nos despachos registrados nos requerimentos encaminhados por clérigos e leigos entre 1770 e $1808^{36}$.

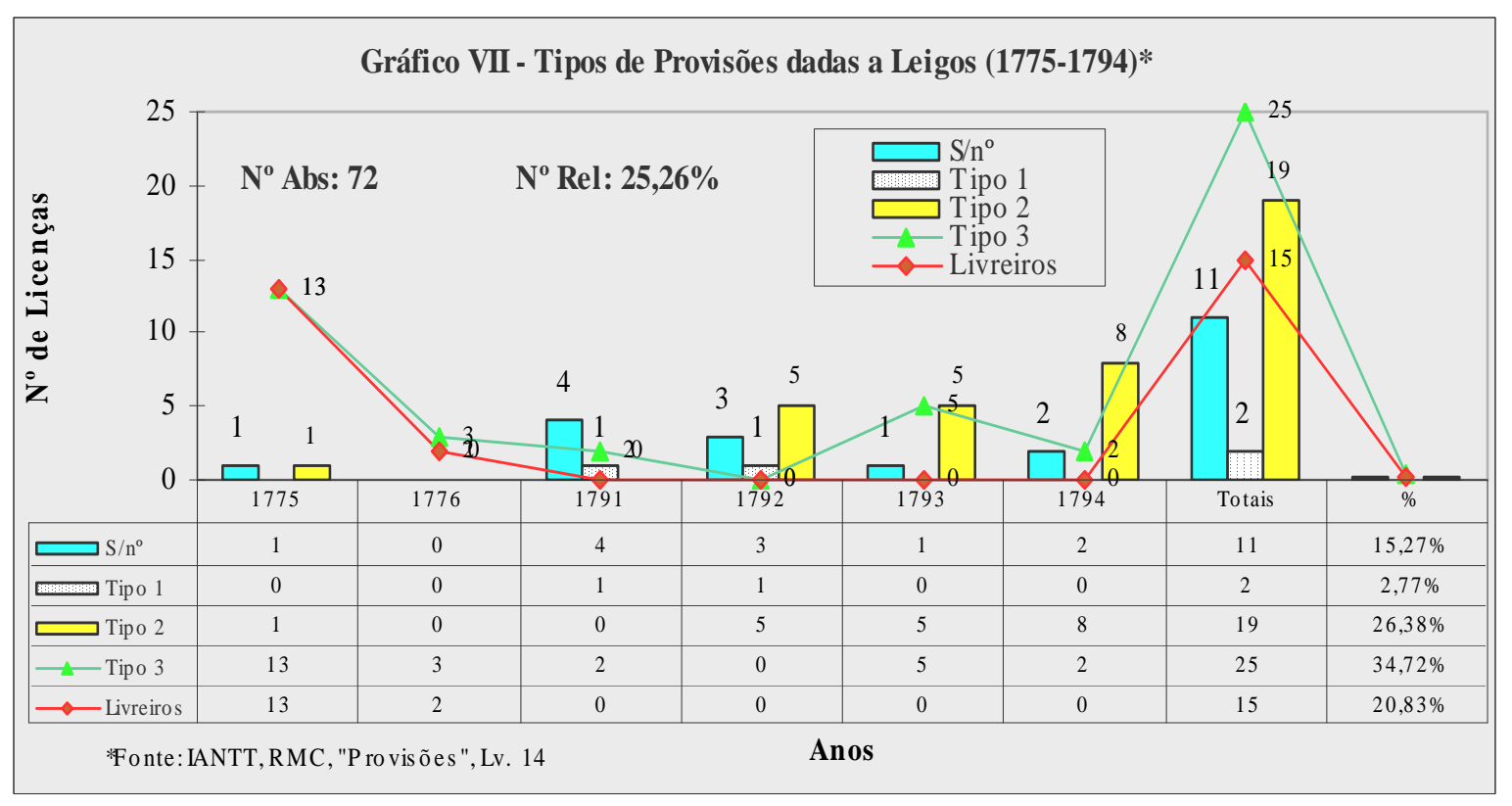

As provisões passadas a leigos também diferem das licenças anotadas nos despachos dados nos requerimentos em relação a dois outros aspectos: primeiramente, há um grande número de livreiros beneficiados $(15 ; 20,83 \%)$; e, em segundo lugar, entre 1790 e 1794, as licenças de tipo 2 passam à dianteira das licenças de tipo 3, correspondendo, respectivamente, a 18 e 9 provisões. A

\footnotetext{
${ }^{34}$ Ibidem.

${ }^{35}$ Ibidem.

${ }^{36}$ Ibidem.
} 
semelhança entre o conjunto das provisões concedidas a leigos, de 1775 a 1794, e as licenças anotadas nos despachos, entre 1770 e 1808, reside na participação numérica decrescente entre os tipos 3, 2 e 1 . No conjunto das provisões, esses tipos somam, respectivamente, $24(34,72 \%), 19(26,38 \%)$ e $2(2,79 \%)$. Deve-se salientar que o fato de existirem 64 provisões para as quais não foi possível discernir se tinham por beneficiários leigos ou clérigos não compromete a confiabilidade das conclusões acima. Isto porque há grandes probabilidades delas terem beneficiado a leigos e, assim sendo, os números das licenças de tipos 3, 2 e 1 passadas aos mesmos subiriam para 65, 39 e 3, mantendo-se, portanto, a mesma ordem decrescente sublinhada entre as provisões passadas seguramente a leigos. De igual maneira, a preponderância numérica das provisões de tipo 2 sobre as de tipo 3 entre os leigos, no período compreendido entre 1790 e 1794, também não seria afetada: as licenças de tipo 2 totalizariam 34, enquanto as de tipo 3 ficariam reduzidas a $17^{37}$.

\subsection{Tipos de licenças e proibições mantidas e suspensas}

Os tipos-números de licenças correspondem, cada qual, a um conjunto de proibições mantidas e suspensas com certa regularidade. Essa correspondência regular verificou-se nos despachos dados nos requerimentos e nas provisões. Examinando-se as proibições salvaguardadas pelas licenças, percebe-se que continuaram a vigorar, isolada ou conjuntamente, os editais e leis seguintes: de 10 de junho de 1768, que proibia obras milenaristas; de 24 de julho de 1769, que interditava os livros da seita dos jacobeus, adepta do sigilismo e, por isso, do relaxamento do sigilo sacramental; de 04 de dezembro do mesmo ano, que se voltava contra os escritos que respeitavam a Bula da Cea; e de 24 de setembro de 1770, que punha na ilegalidade as obras dos "pervertidos filósofos", em sua maioria textos da Ilustração, conforme se viu no Capítulo 4. A preservação da validade desses editais indica que eles eram considerados os mais fundamentais pela censura, e, doravante, assim serão denominados neste capítulo. Em um único caso, foram mantidas as proibições dos editais de 11 de outubro de 1773, que penalizava a obra Histoire Philosophique et Politique, do abade Raynal, e de 05 de dezembro de 1775, que tinha por vítima o livro Le vrai Sens du Système de la Nature, de Claudio Adrião Helvécio.

\footnotetext{
${ }^{37}$ Ibidem.
} 
À vigência, isolada ou conjunta, dos editais referidos — os dois últimos, como se salientou, são uma exceção, uma vez que foram preservados uma única vez -, as licenças aliavam, conforme o perfil do leitor, a manutenção das proibições referentes a obras religiosas e, ainda, a interdição ou não do Dicionário de Pierre Bayle, livro proibido pelos editais de 12 de dezembro de 1769 e de 24 de setembro de 1770 .

Outras licenças, por fim, autorizavam apenas a leitura de algumas obras específicas, explicitamente nomeadas pelos requerentes, em sua maioria proibidas pelo edital de 12 de dezembro de 1771, edital este que se opunha à influência jesuítica e, dentro dessa, às concepções corporativas de poder da Segunda Escolástica e ao probabilismo, como se viu no Capítulo 4; ou então, o citado Dicionário de Bayle; ou, ainda, numa quantidade infinitamente menor de casos, textos de autoria dos filósofos da Ilustração. Todas essas proibições resguardadas, pode-se concluir, afinavam-se com o Reformismo Ilustrado que inspirava a Coroa portuguesa desde a ascensão de D. José I ao trono, na medida em que defendiam o regalismo, atacavam os jesuítas (aqui se incluindo as concepções corporativas de poder, os milenarismos, o probabilismo e o anti-cientificismo) e condenavam as idéias mais radicais da Ilustração, dentre elas o anti-colonialismo, o materialismo, o ateísmo e o deísmo.

A articulação, nas licenças para leitura de livros proibidos, da suspensão e preservação das proibições, além de diferenciar-se conforme a categoria do leitorbeneficiário, sofreu também alterações no tempo, ou seja, a correspondência entre tipos de licença e manutenção e suspensão de proibições modificou-se ao longo dos anos. Podem-se detectar dois momentos distintos: o primeiro, logo nos inícios da atuação da Real Mesa Censória, nos anos 1770, e um segundo, nos anos 90, quando a Real Mesa da Comissão Geral cuidava da censura. Os anos 1770 são cobertos pelos despachos dados nos requerimentos enviados pelos leitores para obtenção de licença para ler livros proibidos e pelas provisões; o segundo período, dos anos 1790, é coberto quase que exclusivamente pelas últimas ${ }^{38}$.

Nos despachos, principalmente nos anos 1770-1772, como já se disse, constam menções à vigência e à suspensão de proibições, mas não os números classificatórios; nos despachos dados em datas posteriores, raramente aquelas informações aparecem, havendo apenas a atribuição por parte dos censores dos

${ }^{38}$ IANTT, Real Mesa Censória, Requerimentos, Caixa 112 e Provisões, Livro 14 
números de classificação. Nas provisões passadas nos anos que vão de 1775 a 1794, constam números classificatórios, permissões e proibições. A modificação mais evidente, como se verá a seguir, atingiu as licenças de Tipo 2. Nos anos 1790, houve nessas licenças um aumento das aberturas fixadas, restando pouquíssimas interdições ${ }^{39}$.

No Gráfico VIII, relativo às proibições mantidas e às interdições suspensas nos despachos dados nos requerimentos que visavam a obtenção de licença para leitura de livros proibidos, entre 1770 e 1808, vê-se que 171 das 268 licenças não contêm número classificatório. Nem todas elas, porém, trazem informações sobre as proibições. Apenas 162 as possuem (para chegar a este número, basta subtrair de 171 os 9 despachos incompletos ou que se referem a licenças passadas a livreiros, sem proibições registradas). Dessas 162 licenças, 158 (97,53\% do total de licenças com informações completas e não dadas a livreiros) foram concedidas entre 1770 e 1772, no auge do consulado pombalino ${ }^{40}$.

Como mostra a soma dos valores das colunas e linhas verdes do Gráfico VIII, a primeira combinação mais freqüente atingiu 49 licenças $(30,24 \%$ das que contêm dados sobre proibições e liberações) ${ }^{41}$. Tal combinação preservava as interdições fixadas pelos editais de 10 de junho de 1768, de 24 de julho de 1769 e de 04 de julho desse mesmo ano - os quais, como se sabe, estavam imbuídos de propósitos regalistas e anti-jesuíticos, sendo anti-corporativos, anti-milenaristas e contrários ao que se julgava anti-cientificista nas idéias dos inacianos -, mas liberava as obras proibidas de cunho religioso e, ainda, de autoria dos "filósofos" condenados pelo edital de 24 de setembro de $1770^{42}$.

\footnotetext{
${ }^{39}$ Ibidem.

${ }^{40}$ IANTT, Real Mesa Censória, Requerimentos, Caixas 112 e 113 e Provisões, Livros 2 e 13.

41 Ibidem.

${ }^{42}$ Ibidem.
} 
Gráfico VIII - Proibições fixadas em Editais e de Obras Mantidas (M) e Suspensas (S) nas Provisões (1770-71) e Licenças (1772-90)

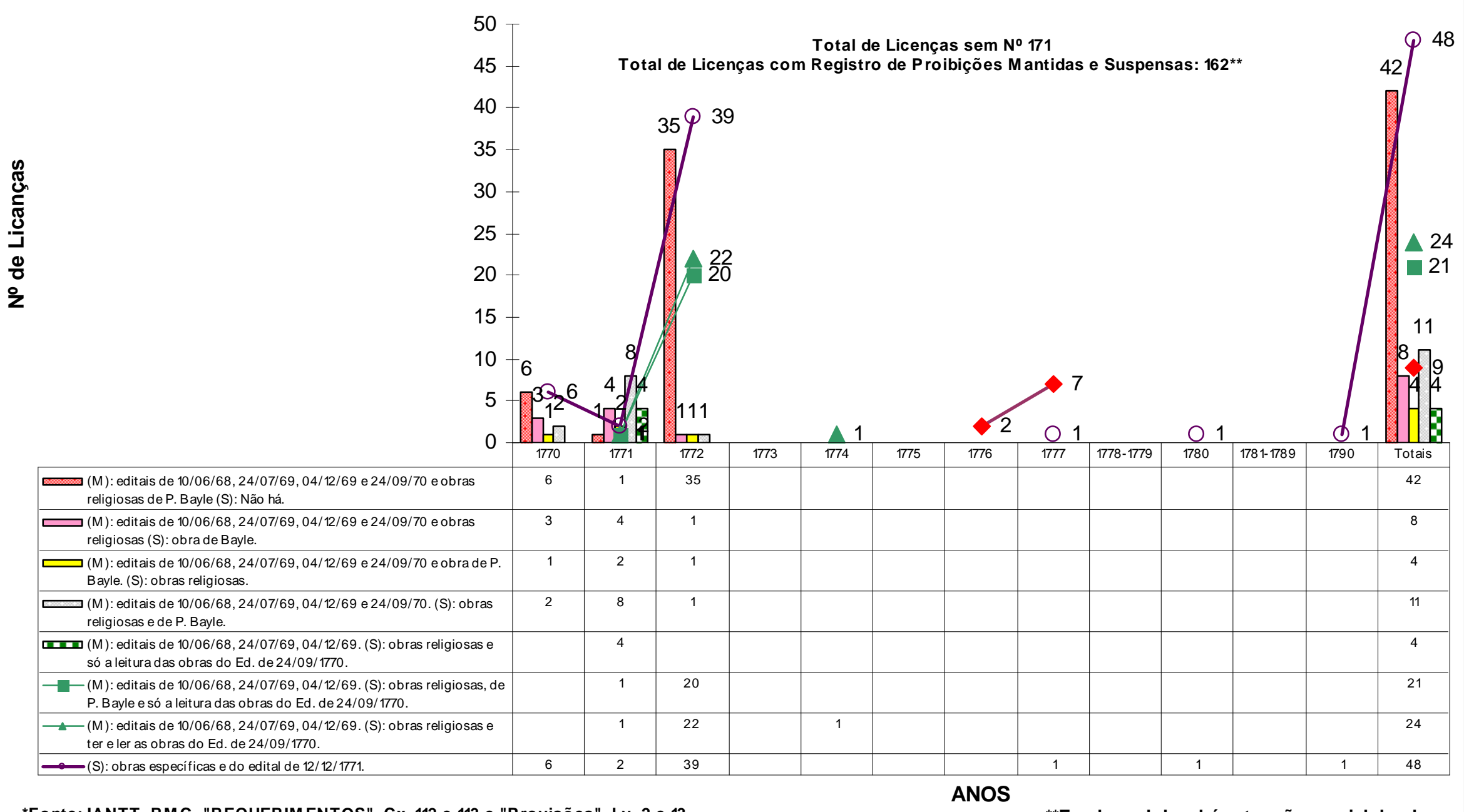

*Fonte: IANTT, RMC, "REQUERIM ENTOS", Cx. 112 e 113 e "Provisões", Lv. 2 e 13.

**Em duas delas, há retenção parcial de obras 
A flexibilização das proibições nessas licenças, embora tivesse um ponto comum no que tocava aos livros proibidos religiosos, em relação aos "filósofos" mostrava-se bem nuançada: 4 (2,46\%) licenças autorizavam apenas a leitura - e não a posse — das obras desses últimos; $21(12,96 \%)$ permitiam a posse da obra de Pierre Bayle e apenas a leitura das demais condenadas pelo edital de 24 de setembro de 1770; e, por fim, as restantes $25(15,43 \%)$, tornavam lícitas a posse e a leitura de todas as obras do supracitado edital ${ }^{43}$. Em relação aos "filósofos", portanto, havia uma gradação nas concessões, que acompanhava a diferenciação de perfil dos beneficiários, prática perfeitamente lógica quando se tem em consideração que se tratava de uma sociedade estamental, em que as leis variavam conforme a posição social dos indivíduos ${ }^{44}$.

Se o mecanismo de concessão de licenças, em si, já demonstra a vinculação entre livros e privilégios, as nuances da censura no que se refere à liberação dos livros dos "filósofos" vêm apenas confirmar o mesmo vínculo. Essa combinação tinha como beneficiários majoritários os clérigos e encontrava-se na quase totalidade das licenças de Tipo 2, as quais, como já se viu, correspondiam a 25,14\% das licenças passadas aos padres ${ }^{45}$.

Em 48 licenças $(29,62 \%$ das licenças em que há menções a proibições suspensas e mantidas), conforme o Gráfico VIII, proibia-se tudo o que não fosse a leitura de obras específicas. Salvaguardava-se, portanto, a vigência de todas as proibições, inclusive daquelas baixadas pelos editais de 10 de junho de 1768, 24 de julho de 1769, 04 de dezembro de 1769 e 24 de setembro de 1770. Permitiam-se, em 5 licenças (3,08\%), só o Dicionário de Bayle; em 33 licenças (20,37\%), determinadas obras proibidas pelo edital de 12 de dezembro de 1771 (apenas uma autorizou a leitura de todos os livros proscritos neste edital); e em 11 (6,79\%), outras obras, dentre elas algumas de autoria de filósofos Ilustrados. As licenças em questão eram, portanto, autorizações dadas para a leitura de obras especificadas pelos leitores e nomeadas pelos censores, muitas delas trazendo concepções corporativas de poder e idéias probabilistas $(20,37 \%$ é uma cifra bastante elevada e mostra a força dessas idéias entre os intelectuais portugueses e "brasileiros") e, em número muito menor, idéias dos filósofos ilustrados. Quantificando-se a freqüência com que esses livros e

\footnotetext{
${ }^{43}$ Ibidem.

${ }^{44}$ Ibidem.
} 
autores apareceram nas licenças sem número, constata-se que, em primeiro lugar, estavam as Obras, de Thomas Sanches (são citadas em 12 das 33 licenças em que se liberam obras específicas condenadas pelo edital de 12 de dezembro de 1771) ${ }^{46}$. Depois, vinham todas as obras proibidas na $2^{\mathrm{a}}$ classe do referido edital (9 licenças); de Justitia et Jure, de Luís de Molina, teólogo da Segunda Escolástica (8 licenças); e, em 6 licenças cada uma, Obras Moraes de Fernando de Castro Palao, Theologia Moral Universal de Paul Gabriel Antoine, Damanatae Theses de Domingos Viva; seguindo-se em menor número as obras de João de Cardenas, Paulo Layman, João Reuter, Ricardo Arsdekim, Vicente Filliucio e João Azor. Saindo do universo de autores e títulos condenados no edital de 1771, vê-se a presença, em duas licenças, de Christiano Thomasio. As obras seguintes aparecem nos registros, cada qual uma única vez: Code de I'Humanité ou la Législation Universelle, Naturelle et Politique, par une Société de Gens de Lettres, em 13 volumes, revisto por Mr. Felice, cujos primeiros volumes foram autorizados pela censura e os demais permitidos aos que tivessem licença ${ }^{47}$; História Ecclesiástica, de Massein, ou melhor Institutiones Historicae Ecclesiasticae, do Barão Jean Laurent de Moshein, liberada para os que tivessem licença, segundo o edital de 22 de outubro de $1779^{48}$; e a Erudition Completa, de Bielfeld ${ }^{49}$.

Comparando-se essas licenças sem número com aquelas que receberam uma classificação numérica, percebe-se que elas tinham características iguais às de duas licenças de tipo 5, passadas em 1772 e em 1773, respectivamente a um leigo e a um clérigo: o advogado Manuel Joaquim de Figueiredo, contemplado com licença para ler a obra de Thomas Sanches, proibida na $2^{\mathrm{a}}$ classe do edital de 12 de dezembro de 1771; e o padre João Gonsalves Pereira, autorizado a ler os livros de "João Azdr [= Azor], Luis de Molina, Paulo Layman, Paulo Gabriel Ant ${ }^{\circ}$., Ricardo Ars dekim [Sic], Thomas Sanches", enquadradas nos supracitados edital e classe ${ }^{50}$.

Logo em seguida, em terceiro lugar, como consta no Gráfico VIII, vinha, em 42 licenças $(25,92 \%)$, a mais absoluta das manutenções de proibições. Nessa

\footnotetext{
${ }^{45}$ Ibidem.

${ }^{46}$ Ibidem.

${ }^{47}$ CATALOGO dos livros defesos neste Reino, desde o dia da Criação da Real Mesa Cençoria athé ao prezente, op. cit., p. 150.

${ }^{48}$ Ibidem, p. 175 e IANTT, Real Mesa Censória, Requerimentos, Caixas 112 e 113 e Provisões, Livros 2 e 13.

${ }^{49}$ IANTT, Real Mesa Censória, Provisões, Livro 13.

${ }^{50}$ IANTT, Real Mesa Censória, Requerimentos, Caixas 113.
} 
combinação, preservavam-se a vigência dos editais de 10 de junho de 1768, de 24 de julho de 1769, de 04 de dezembro de 1769 e de 24 de setembro de 1770; e a proibição de obras religiosas e do Dicionário de Pierre Bayle. Não se suspendia a vigência de nenhum desses editais proibitivos, nem a interdição das obras religiosas censuradas. Sob o Reformismo Ilustrado português, portanto, em mais de 1/4 das licenças concedidas, não se tergiversava no que se referia aos editais censórios e proibições fundamentais. Tal combinação fazia-se presente em grande parte das licenças de tipo 3, não sendo, no entanto, a única combinação presente nas mesmas. As licenças de tipo 3, como se mostrou anteriormente, foram as mais concedidas aos leigos $(40,15 \% \text { dos leigos beneficiários as receberam })^{51}$.

As três combinações de proibições mencionadas compreendiam 139 licenças, o que corresponde a $85,8 \%$ dos requerimentos em que há informações completas sobre o teor das liberações. O rigor dessas combinações é variável, indo da autorização da leitura de obras específicas à manutenção de todas as proibições, fossem aquelas fixadas pelos editais fundamentais, fossem as relativas às obras religiosas, passando pela suspensão da interdição das obras religiosas proibidas e dos "filósofos" condenados pelo edital de 24 de setembro de 1770. Essa última combinação, como se viu, era feita de modo diferenciado, liberando-se ora apenas a posse da obra de Pierre Bayle e a leitura das demais proscritas pelo mesmo edital de 24 de setembro de 1770, ora a leitura de todas elas, ora a leitura e também a posse das mesmas.

As combinações de proibições e liberações que se seguiam às supracitadas, conforme mostra o Gráfico VIII, eram bem menos expressivas do ponto de vista numérico; nelas se vê uma frouxidão limitada. Assim, em quarto lugar, vinham as licenças em que se preservava a validade dos quatro editais fundamentais (11 licenças; 6,79\%). Tais licenças, suspendiam as proibições referentes às obras religiosas e de Pierre Bayle. Como será mostrado ao se examinarem as provisões, essa combinação de proibições mantidas e suspensas preponderava nas licenças passadas aos livreiros e fazia-se presente em algumas poucas licenças classificadas como de tipo 2. Na quinta posição, estavam as licenças que, além da vigência dos citados editais, mantinham as proibições referentes a obras religiosas $(8 ; 4,93 \%)$, abrindo concessão apenas quanto ao Dictionnaire de Pierre Bayle. Mais à frente, ao

${ }^{51}$ IANTT, Real Mesa Censória, Requerimentos, Caixas 112 e 113 e Provisões, Livros 2 e 13. 
se analisarem as provisões, ficará claro que essa combinação aparecia em algumas licenças de tipo 3 e, em quantidade ínfima de casos, em licenças de tipo 1 e nas passadas a livreiros. Por fim, estavam as licenças que ordenavam a obediência aos editais fundamentais e proibiam a obra de Bayle $(4 ; 2,46 \%)$, flexibilizando-se apenas em relação às obras religiosas proibidas. Tal combinação, como se verá a seguir no exame das provisões, esteve presente também em algumas licenças de tipo $3^{52}$.

Entre 1775 e 1794, registraram-se 285 provisões. Como consta no Gráfico IX, 114 dessas provisões foram passadas entre 1775 e 1777, sendo que apenas duas delas foram transcritas de forma incompleta (o que dá um total de 112 licenças copiadas na íntegra; em números relativos, 39,29\% do total). Em tais provisões - a segunda série documental em exame, como se disse anteriormente - identificam-se os editais e as obras cujas proibições foram salvaguardadas e, inversamente, suspensas. Nos anos 1775-1777, as combinações entre proibições mantidas e suspensas nas provisões transcritas nos livros dos tribunais censórios guardaram grande similitude com o que se observou nos despachos dados nos requerimentos que, em sua maioria, como se evidenciou, foram enviados nos anos 1770-1774 ${ }^{53}$. Observando-se o Gráfico IX e somando-se as colunas com diferentes tons de cor-derosa, constata-se que, em 49 licenças $(43,75 \%$ das provisões transcritas integralmente no período), salvaguardaram-se as proibições dos quatro editais e leis fundamentais (de 10 de junho de 1768, 24 de julho de 1769, 04 de dezembro do mesmo ano e 24 de setembro de 1779) e aquelas referentes às obras religiosas.

\footnotetext{
${ }^{52}$ Ibidem.

${ }^{53}$ IANTT, Real Mesa Censória, Provisões, Livro 14.
} 
Gráfico IX: Proibições em Editais e de Obras Mantidas (M) e Suspensas (S) nas Provisões (1775 - 1777)*

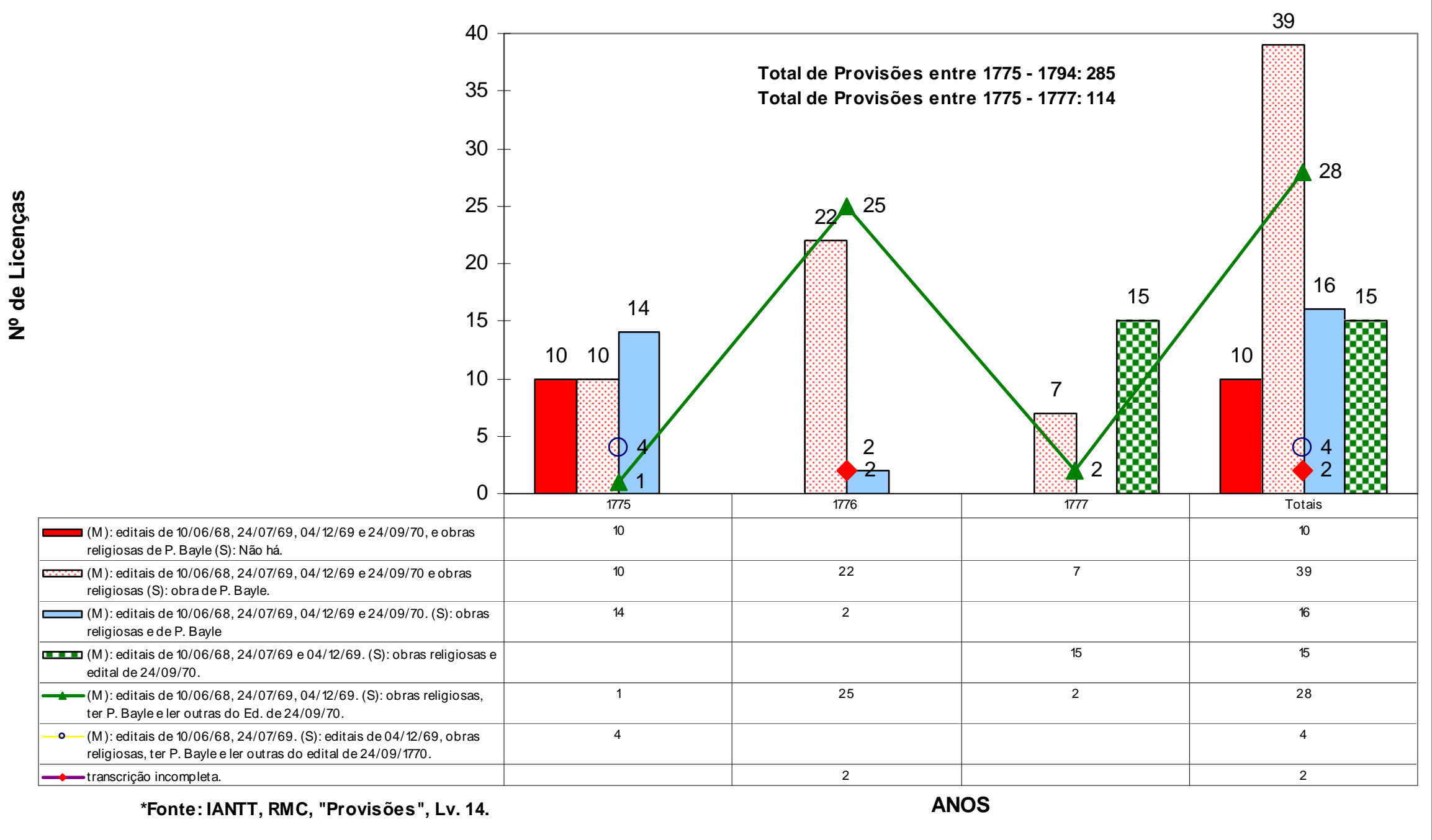


Em 39 dessas licenças (34,82\% das provisões copiadas na íntegra), suspendeu-se a proibição do Dictionnaire de Pierre Bayle, enquanto o inverso sucedeu com as $10(8,92 \%)$ restantes. Essas 10 licenças, portanto, preservavam a vigência de todos os editais e leis, das proibições relativas às obras religiosas e de Pierre Bayle. Essa combinação, em suas duas variações, compreendeu a quase totalidade das licenças de tipo 3 (47 das 49 licenças deste tipo), fazendo-se presente também em outras duas licenças: uma passada a um livreiro e, ainda, outra, sem classificação. Entre 1775 e 1777, as licenças de tipo 3 beneficiaram provavelmente, em sua imensa maioria, os leigos: das 49 licenças, em 22 foi possível identificar se os beneficiários eram leigos ou clérigos e, dentre essas, os leigos somavam 16 e os clérigos, $6^{54}$.

A segunda combinação mais freqüente entre 1775 e 1777, dada pela soma das colunas e linhas verdes do Gráfico IX, presente em 43 licenças (38,39\%), preservava as proibições definidas em apenas três dos quatro editais fundamentais (de 10 de junho de 1768, 24 de julho de 1769 e 04 de dezembro de 1769). Ao mesmo tempo, em todas essas licenças, liberavam-se as obras religiosas proibidas. Em 15 (13,39\%) dessas licenças, além disso, o mesmo se dava com as obras proscritas pelo edital de 24 de setembro de 1770 , enquanto que as outras 28 (25\%) permitiam a posse do Dictionnaire de Bayle e apenas a leitura (excluía-se, portanto, a posse) dos demais livros condenados pelo já citado edital de 24 de setembro de 1770. Essa segunda combinação, em suas duas variações, correspondeu a quase todas as licenças de tipo 2 (28 em 32) e que não receberam classificação-n ${ }^{\circ}$ dos censores (15 dentre 16). Entre 1775 e 1777, os clérigos praticamente monopolizaram as licenças de tipo 2: das 32 que foram passadas, eles ficaram com $27^{55}$.

Em terceiro lugar, em termos numéricos, no período compreendido entre 1775 e 1777, vinham as licenças que mantinham em vigor os 4 editais fundamentais, mas suspendiam a vigência das proibições concernentes às obras religiosas e, ainda, ao livro de Pierre Bayle. Essa combinação fez-se presente em 16 (14,28\%) licenças no período considerado e correspondeu, em sua totalidade, às autorizações passadas a livreiros. Em último lugar ficaram as licenças que mantinham em vigência os editais de 10 de julho de 1768 e 24 de julho de 1769, suspendendo a validade dos editais de

\footnotetext{
${ }^{54}$ Ibidem.

${ }^{55}$ Ibidem.
} 
04 de dezembro de 1769 e das proibições referentes às obras de religião, permitindo, em relação ao edital de 24 de setembro de 1770, ter o livro de Pierre Bayle e ler os demais. Essa combinação fez-se presente em 4 licenças, todas elas de número-tipo $2^{56}$.

Entre 1776 e 1789, não se registraram provisões, que só reapareceram em 1790, prosseguindo até 1794. As combinações observadas entre proibições resguardadas e suspensas, entre 1790 e 1794, revelam sensíveis diferenças em relação ao período precedente, conforme mostra o Gráfico $\mathbf{X}^{\mathbf{5 7}}$. Entre 1790 e 1794, passaram-se 171 provisões, o que corresponde a 60\% das provisões passadas de 1775 até 1794. Dessas 171 provisões, 15 (8,77\% das provisões passadas de 1790 a 1794) foram copiadas de forma incompleta. Com isso, o número das provisões transcritas na íntegra no período reduz-se a 156. Das 156 provisões trasladadas integralmente, $15(9,61 \%)$ se referiam a obras profissionais $(9 ; 5,76 \%)$ ou específicas $(6 ; 3,84 \%)$

\footnotetext{
${ }^{56}$ Ibidem.

${ }^{57}$ Ibidem.
} 


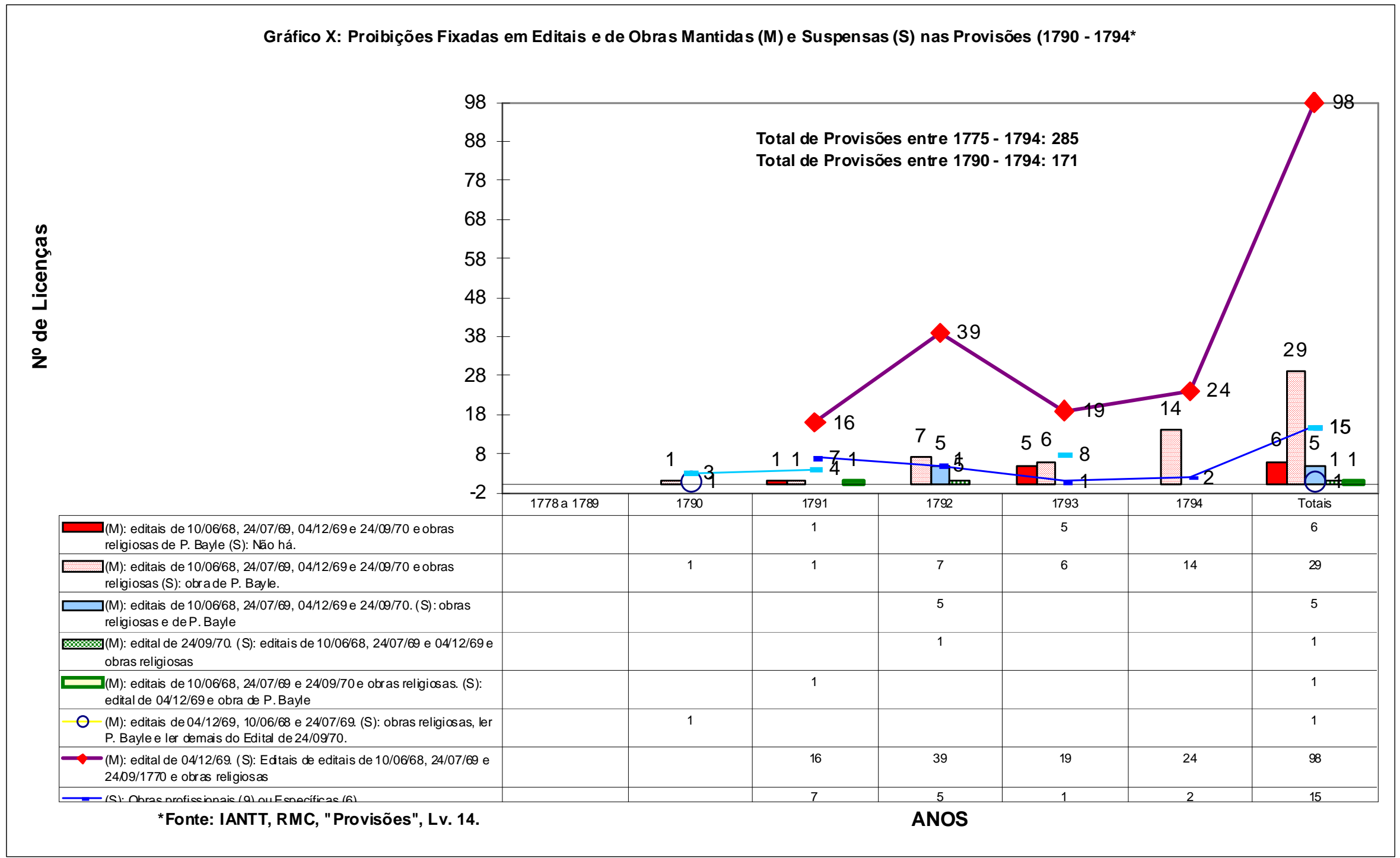


Em $98(62,82 \%)$ das 156 provisões para as quais é possível identificar as proibições mantidas e suspensas, manteve-se a vigência apenas do edital de 04 de dezembro de 1769, suspendendo-se todas as demais interdições ${ }^{58}$. Essa combinação atingiu a quase totalidade das licenças de tipos 2 (75 em 90) e 1 (20 em 21) concedidas no período, fazendo-se presente, ainda, em algumas licenças sem número classificatório. Seus beneficiários foram em sua maioria clérigos: eles ficaram com 53 das 90 provisões de licença de tipo 2 e, ainda, com 18 das 21 de tipo $1^{59}$.

Dessas 98 licenças, 58 (37,17\% das provisões transcritas na íntegra) traziam a seguinte observação, em acréscimo à validade do edital supracitado: "e isto enqto. Eu [a Rainha] não houver por bem relaxar a sua proibição" ${ }^{60}$. Essa observação e a preservação isolada do edital de 04 de dezembro de 1769 representam um relaxamento sem par na concessão de licença para leitura de livros proibidos pela Real Mesa da Comissão Geral para a censura de livros, quando comparada à sua antecessora, a Real Mesa Censória. Isso vai ao encontro das acusações de ineficácia feitas contra o tribunal por José de Seabra Silva, citadas no Capítulo 4, e, ao mesmo tempo, talvez explique por que outras esferas do aparelho de Estado, como a Intendência Geral de Polícia, tomaram iniciativas nesse período no campo da circulação de livros proibidos. Ficam, ademais, algumas interrogações: seria a "relaxação" um indício de que os ventos liberalizantes da Ilustração e da Revolução Francesa contaminaram a ação da Real Mesa da Comissão Geral, no que se referia à concessão de licença para leitura de livros proibidos? Aquele equilíbrio instável, sobre o qual se moveu o Reformismo Ilustrado português, rompera-se, em termos das licenças para a leitura de livros proibidos, a favor da Ilustração? Para responder a essas perguntas com mais segurança, é preciso examinar se essas licenças "relaxadas" tiveram rivais no período em questão e, ainda, traçar o perfil dos beneficiados pelas diferentes combinações de licenças nesse último período, de 1790 a 1794, e nos dois períodos anteriores: 1770-1774 e 1775-1777.

De 1790 a 1794, a combinação apresentada acima, de proibições mantidas e suspensas, não foi a única, embora tenha sido majoritária ${ }^{61}$. Em segundo lugar,

\footnotetext{
${ }^{58}$ Ibidem.

${ }^{59}$ Ibidem.

${ }^{60}$ Ibidem.

${ }^{61}$ Ibidem.
} 
vinham as licenças em que se mantinham todas as proibições fixadas nos editais e referentes às obras religiosas, chegando à cifra de 35 (22,43\%); 29 (18,58\%) delas liberavam o Dictionnaire de Pierre Bayle. Tal combinação, em suas duas variações, correspondeu a maior parte das licenças de tipo 3 (33 em 39) e, ainda, a uma licença de tipo 1 (que perfaziam um total de 21) e a uma, sem classificação (que somavam 20). Não é possível avaliar com segurança as proporções de clérigos e leigos beneficiados quer com a combinação em exame, quer com as licenças de tipo 3. Primeiro, porque há muitos beneficiários em relação aos quais foi impossível identificar se eram clérigos ou leigos. Além disso, porque o número de clérigos com licenças de tipo 3 é igual a 17, cifra que é menos do que a metade da totalidade das licenças de tipo 3 (39) e, inversamente, pouco mais do que a metade das licenças desse tipo em que há a combinação em exame de proibições mantidas e suspensas $(33)^{62}$.

Logo atrás da segunda combinação, estavam as licenças que permitiam unicamente a leitura de obras profissionais (9) e específicas (6), totalizando esses casos 15 licenças, conforme mostra o Gráfico X. Dentre as licenças para obras profissionais, 5 fixavam a validade do edital de 04 de dezembro de 1769 - esse número não foi contabilizado no Gráfico $\mathbf{X}$, deixando-se as licenças profissionais à parte no que se refere à combinação das proibições mantidas e suspensas -, enquanto outras duas determinavam a vigência dos quatro editais fundamentais. As fórmulas dessas licenças permitiam as seguintes aberturas nas proibições: ter e ler "todos os livros prohibidos q. tratem da sua profissão"; para "todos os relativos à sua faculdade"; "pertencentes tão somente à sua faculdade"; "ter e ler livros pertencentes à Faculdade de Leis". Quatro (4) das obras específicas cuja liberação foi solicitada e autorizada tinham como autores teólogos, juristas, historiadores eclesiásticos e canonistas, alguns deles enquadrados no edital de 12 de dezembro de 1771, mas nenhum, ao que parece, defensor de concepções corporativas de poder. As duas outras licenças restantes autorizavam os já citados Code de l'humanité, do professor Felice e as Instituições Políticas de Bielfeld ${ }^{63}$.

Pode-se concluir, portanto, que, no período de 1790 a 1794, a Real Mesa da Comissão Geral para a censura de livros, no que dizia respeito à concessão de

\footnotetext{
${ }^{62}$ Ibidem.

${ }^{63}$ Ibidem.
} 
licenças para leitura de livros proibidos, foi do quase absoluto relaxamento ao extremo rigor; oscilou entre, de um lado, a autorização de todos os livros, exceto os que haviam sido condenados pelo edital de 04 de dezembro de 1769 (o de cunho mais regalista); e, de outro, a manutenção das proibições relativas a obras religiosas e fixadas em todos os editais fundamentais. As licenças de cunho profissional, previstas e defendidas pela legislação em 1770, foram uma peculiaridade do período e parecem marcar-se pela mesma oscilação. Numericamente, além disso, o relaxamento preponderava, abandonando-se em grande parte algumas marcas do período pombalino: o anti-jesuitismo e o ataque frontal às idéias dos ilustrados que ameaçavam o Antigo Regime. Isso já parece sinalizar que o equilíbrio instável que marcava o Reformismo Ilustrado Português rompia-se; que as perspectivas liberalizantes da Ilustração e da Revolução seduziam os próprios juízes da Real Mesa da Comissão Geral para a censura de livros.

\subsection{Regalias, origem e perfil dos beneficiários em sua variação no tempo}

Uma avaliação mais precisa da abertura verificada na concessão das licenças para a leitura de livros proibidos nos anos 1790, especialmente de 1792 a 1794, requer que se descreva com mais precisão o perfil dos seu maiores beneficiários e suas respectivas regalias. Para tanto, primeiro, analisar-se-ão as variações na participação de cada tipo (1, 2, 3, 4 e 5) de licença de 1770 a 1794; em seguida, será traçado o perfil dos seus beneficiários, em suas mudanças, identificando-se as proibições suspensas e resguardadas e destacando-se os que tinham residência ou passagem pela América.

Entre 1770 e 1794, a participação dos tipos de licenças 1, 2, 3, 4 e 5 acompanhou a tendência à flexibilização das proibições observada nos últimos anos do período. Foi-se de uma maior participação das licenças de tipo 3, mais rígidas, no início do período, para uma preponderância das licenças de tipo 2, mais liberais, a partir de $1792^{64}$. Na primeira série documental, a dos despachos dados nos requerimentos, como já se disse, há um grande número de licenças sem número-tipo nos anos de 1770-1772. No Gráfico XI, se forem desconsideradas essas licenças sem classificação, vê-se que as licenças de tipo 3 mantiveram-se na preponderância até

${ }^{64}$ IANTT, Real Mesa Censória, Requerimentos, Caixas 112 e 113 e Provisões, Livros 2, 13 e 14. 
1776: elas eram 19 em 1772 e 26 em 1776, enquanto as de tipo 2, nas mesmas datas, somavam respectivamente 17 e $15^{65}$.

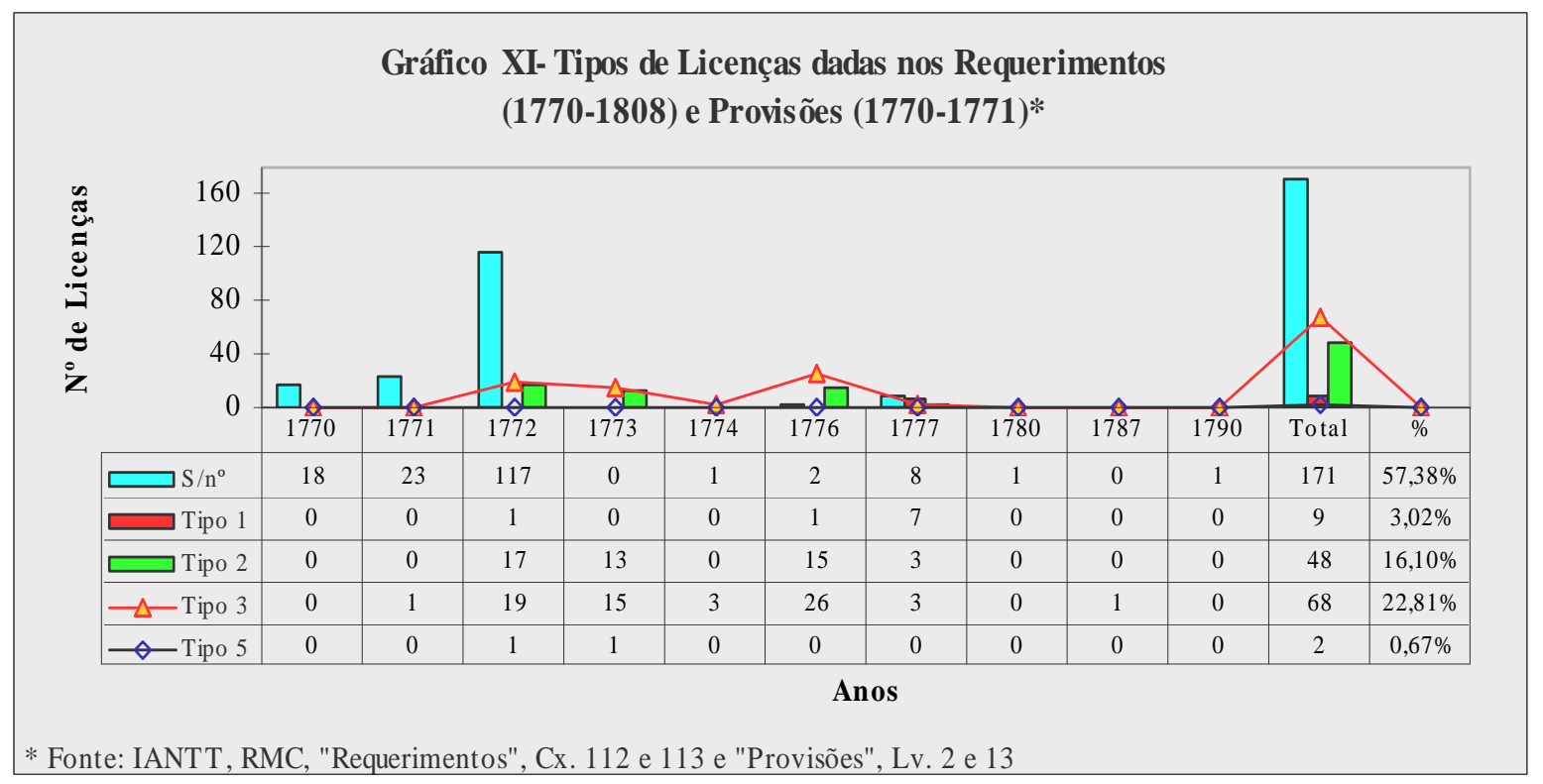

Em 1777, as licenças de tipo 3 igualaram-se em quantidade às licenças de tipo 2, cada qual chegando a um total de 3 . Mas ambas tiveram à frente as licenças de tipo 1 (7), as quais, como já se viu, tendiam a ser mais liberais do que as de tipo 3 (infelizmente, para os anos em questão, fica difícil assegurá-lo, na medida em que, nos despachos, inexistem menções a proibições suspensas e mantidas).

Nos anos seguintes, como já se observou, essa série documental está comprometida, fazendo-se necessário apelar para a segunda série documental, a das provisões. Na série das licenças-despachos como um todo, de 1770 até 1808, o primeiro lugar entre as licenças com número classificatório coube às de tipo 3 (68; $22,81 \%)$, vindo em seguida as de tipo $2(48 ; 16,10 \%)$ e, muito atrás, as de tipos 1 (9; $3,02 \%)$ e $5(2 ; 0,67 \%)^{66}$.

Como se observa no Gráfico XII, em 1775, as provisões de tipo 3 preponderaram sobre as de tipo 2 (somavam, respectivamente, 18 e 5). Em 1776, essa relação se equilibrou, pois as licenças de tipo 3 totalizavam 24, enquanto as de tipo 2 chegavam a 25. Em 1777, voltou-se a favorecer as licenças de tipo 3: elas atingiam a cifra de 7 , tendo as de tipo 2 chegado a apenas $2^{67}$. Em 1791, predominaram as licenças de tipo 1, enquanto de 1792 até 1794 as licenças de tipo 2

\footnotetext{
${ }^{65}$ IANTT, Real Mesa Censória, Requerimentos, Caixas 112 e 113 e Provisões, Livros 2 e 13.

${ }^{66}$ Ibidem.
} 
passaram a ocupar o primeiro lugar, com os seguintes números: 37,24 e 24, contra 6, 0 e 0 das licenças de tipo $3^{68}$.

Na série documental como um todo, de 1775 a 1794, o primeiro lugar dentre as licenças com número classificatório coube às de tipo 2 (122; 42,80\%), vindo em seguida as de tipo $3(88 ; 30,87 \%)$, tipo $1(21 ; 7,36 \%)$ e tipo $4(1,0,35 \%)$. Os livreiros somaram 17 beneficiários $(5,96 \%)^{69}$. Essa primazia numérica das licenças de tipo 2 no conjunto da série é mais um elemento que confirma a supracitada tendência liberalizante da censura na concessão de livros proibidos.

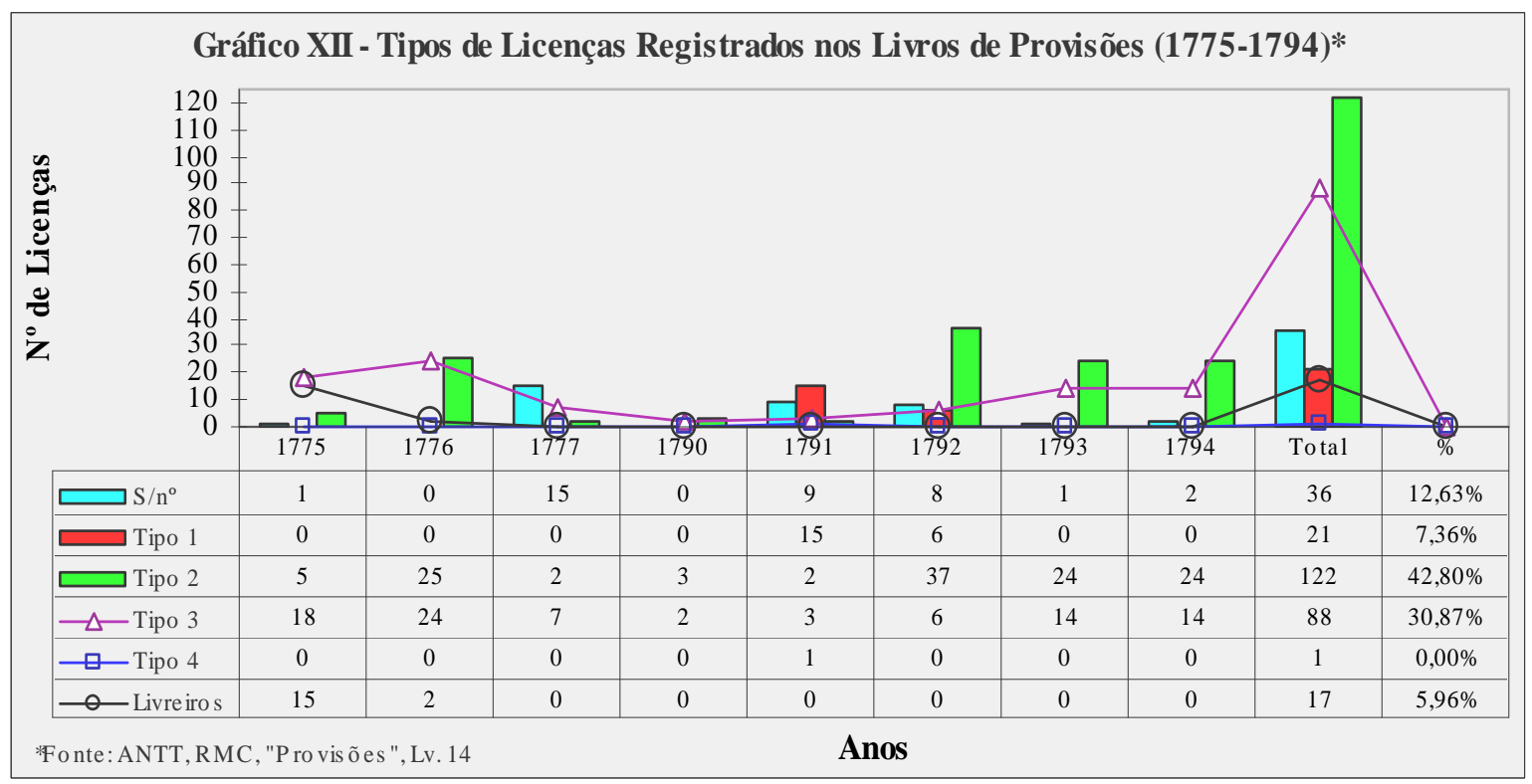

Quem eram os beneficiários típicos das licenças de tipo 1, 2 e 3 e que proibições foram preservadas e suspensas em cada um desses casos? Já se observou que as licenças de tipo 2 favoreciam, em sua maioria, a clérigos, e as de tipo 3, a leigos; igualmente se observou que as licenças de tipo 2 e 1 garantiam mais liberdades aos leitores que as licenças de tipo 3, sendo essas aberturas ampliadas nos anos $1792-94^{70}$. O quadro, no entanto, como se verá a seguir, era mais complexo.

A regra duodécima do regimento da Real Mesa Censória, já mencionada anteriormente, ao definir àqueles a quem se poderia dar a mercê de ler livros proibidos, mencionava inicialmente dois grupos de beneficiários: "Universidades" e

\footnotetext{
${ }^{67}$ IANTT, Real Mesa Censória, Provisões, Livro 14.

${ }^{68}$.Ibidem.

${ }^{69}$ Ibidem.

70 Ibidem.
} 
"Livrarias das Comunidades"71. As licenças de tipo ou número 1 correspondiam, em linhas gerais, a essa primeira categoria fixada na lei. Não se encontrou nenhuma licença de tipo 1 que tenha beneficiado explicitamente alguma instituição ou pessoa da América Portuguesa; no máximo, a Colônia talvez estivesse incluída sob a denominação "Portugal e seus domínios", utilizada em um ou outro caso de ordem clerical beneficiada.

Examinando-se, primeiramente, os requerimentos encaminhados pelos interessados em obter licença para ler livros proibidos entre 1770 e 1808 e os despachos neles registrados, constata-se que as licenças de tipo 1 foram concedidas a instituições escolares e monásticas e/ou a seus membros coletiva ou individualmente. Nos 9 despachos em que o número 1 foi registrado, os beneficiários foram bibliotecas de instituições escolares ou monásticas, ou ainda, diocesanas ${ }^{72}$. Entre 1772 e 1777, assim, foram beneficiadas com licenças de tipo 1, graças a requerimentos de reitores, priores, provinciais ou procuradores da mitra, as livrarias dos seguintes colégios, congregações, mosteiros ou dioceses: o Colégio de S. Pedro e S. Paulo da Nação Inglesa; o Colégio dos Padres Irlandeses da Ordem de S. Domingos; os mosteiros de S. Bernardo em Alcobaça e Coimbra; e os mosteiros das províncias de S. Maria de Arrábida, de São Francisco dos Algarves e de São Francisco de Portugal e da Congregação dos Agostinhos Descalços de Portugal e Seus Dominios; e, por fim, a mitra de Beja ${ }^{73}$.

Embora os despachos dados nos requerimentos, na maioria das vezes, não permitam correlacionar tipos de licença e proibições mantidas e suspensas, como já se advertiu neste capítulo, é possível identificar características comuns às licenças sem número anotadas nos despachos referidos, que beneficiaram bibliotecas de instituições monásticas, de escolas ou de indivíduos ligados às mesmas. Em 28 licenças que tiveram beneficiários enquadrados nessa categoria, percebe-se que 22 mantiveram em vigor apenas três dos quatro editais fundamentais (10/06/1768; 24/07/1769 e 04/12/1769), suspendendo a vigência do edital de 24 de setembro de 1770 e as proibições relativas a obras de religião. Permitiram-se, nesses casos, a leitura e a posse das obras dos "pervertidos filósofos" da Ilustração ${ }^{74}$. Tais proibições

\footnotetext{
${ }^{71}$ IANTT, Real Mesa Censória, Caixa 1, Regimento da Real Mesa Censória, loc. cit.

${ }^{72}$ IANTT, Real Mesa Censória, Requerimentos, Caixa 113.

${ }^{73}$ Ibidem.

${ }^{74}$ IANTT, Real Mesa Censória, Requerimentos, Caixa 112.
} 
e permissões foram anotadas pela Real Mesa Censória, em 1774, por exemplo, no despacho dado ao requerimento encaminhado pelo abade frei João do Pilar, do Mosteiro de São Bento da Saúde, em Lisboa, em cuja livraria havia escritos dos “monarcômacos" Molina e Bellarmino, livros de teólogos proibidos pelo edital de 12 de dezembro de 1771 e "obras filosóficas" - Lettres Chinoises e Lettres cabalistiques, ambas do Marquês de Argens - e Lettres Provinciales e L'Espion, arroladas de forma truncada, provavelmente também dois livros "filosóficos"75. Pode-se dizer que prevaleceu uma determinada orientação censória (e política) na concessão de licenças de tipo 1, nos anos 1770: privilegiou-se o ataque aos milenarismos, um dos elementos da "velha ordem" estigmatizada pelos governos Reformistas Ilustrados de Portugal, havendo menor rigor em relação às teorias corporativas de poder, às idéias radicais da Ilustração e às obras religiosas em geral ${ }^{76}$. A abertura concedida pela censura quanto a essas últimas, é importante frisar, beneficiando às bibliotecas de escolas, universidades e comunidades, convergia com o que estipulava o regimento da Real Mesa Censória ${ }^{77}$, mas, ao mesmo tempo, colidia com ordens expedidas pelo próprio marquês de Pombal, citadas no Capítulo 5, no sentido de que se entregassem à Real Mesa Censória os livros proibidos existentes nas livrarias dos colégios e mosteiros ${ }^{78}$. Essa lógica foi levada a extremos em alguns casos, como, por exemplo, o de Manuel Tavares Coutinho da Silva: em 1772, ele conseguiu licença ampla para a livraria do Colégio dos Militares da Universidade de Coimbra (permitiu-se a leitura de obras religiosas e as proibidas pelo edital de 24/09/1770), mas, para sua livraria pessoal, as restrições retiradas em relação àquela livraria foram mantidas ${ }^{79}$.

O perfil dos beneficiários de licenças de tipo 1, registradas nos livros de provisões em 1791 e 1792, pouco difere daquele encontrado nos despachos dados nos requerimentos nos anos 1770. No geral, as provisões de licenças de tipo 1 foram passadas para membros de ordens religiosas ou a padres seculares e a leigos que se encontravam envolvidos em atividades docentes ${ }^{80}$. No entanto, concederam-se licenças de tipo 1 a um leque mais amplo de beneficiários, fora do âmbito das ordens

\footnotetext{
${ }^{75}$ IANTT, Real Mesa Censória, Requerimentos, Caixa 113.

${ }^{76}$ IANTT, Real Mesa Censória, Requerimentos, Caixas 112 e 113.

${ }^{77}$ MARQUES, Maria Adelaide Salvador, op. cit., p. 49.

${ }^{78}$ IANTT, Real Mesa Censória, Decretos e avisos recebidos pela mesa, Caixa 188.

${ }^{79}$ IANTT, Real Mesa Censória, Requerimentos, Caixa 113.

${ }^{80}$ IANTT, Real Mesa Censória, Provisões, Livro 14.
} 
religiosas e/ou de escolas, como religiosos seculares e leigos com formação em cânones ou teologia e/ ou que ocupavam postos importantes na hierarquia eclesiástica e na magistratura civil. Nas provisões de licenças de tipo 1, todas elas passadas em 1791 e 1792, assim, foram beneficiados 21 indivíduos, 18 deles clérigos e apenas 2 leigos (uma das provisões foi copiada de forma incompleta, motivo pelo qual não foi possível identificar a ocupação do beneficiário). Dos 18 clérigos, 10 tinham nível superior em Teologia ou Cânones, 4 deles dedicando-se à docência; 10 clérigos eram regulares e 8, seculares. Entre os clérigos, além disso, 2 ocupavam postos importantes nas suas dioceses e um era um abade. Dos 2 leigos, ambos com formação superior, um dedicava-se ao ensino de Filosofia e outro era um magistrado $^{81}$. O frei Joaquim de Santa Ana Carvalho é um exemplo de clérigo regular contemplado pela Real Mesa da Comissão Geral sobre o exame e censura de livros com "Prov" ${ }^{\mathrm{am}} \cdot \mathrm{p}^{\mathrm{a}}$. Ler $\mathrm{L}^{\text {os }}$. Prohibidos [...] $\mathrm{N}^{\mathrm{o}}$. $1^{\mathrm{o}}$ ", passada em $1791^{82}$. As proibições preservadas e suspensas nas provisões de tipo 1, todas elas passadas em 1791 e 1792, como se esclareceu anteriormente, marcaram-se por uma extrema liberalidade, mantendo válido apenas o edital de 04 de dezembro de 1769 (isto aconteceu em 20 das 21 licenças deste tipo que foram concedidas). Assim, nos anos 1791 e 1792, as licenças de tipo 1 não só deram continuidade ao maior relaxamento das proibições observado nas licenças desse mesmo tipo datadas dos anos 1770, como também ampliaram-no ${ }^{83}$.

A regra duodécima do regimento da Real Mesa Censória definia uma segunda categoria de beneficiários de licenças, que vinha logo após as Universidades e Livrarias de Comunidades: os "Mestres Teólogos" que fossem "Lentes", que precisassem conhecer os livros ímpios e heréticos para refutá-los.

Os despachos anotados entre 1772 e 1777 nos requerimentos para leitura de livros proibidos, grosso modo, sugerem que se seguiu a citada regra do regimento da Real Mesa Censória. Nesses documentos vê-se que as licenças de tipo 2 foram predominantemente concedidas a teólogos ou a clérigos que se dedicavam à vida monástica, ou ao ensino, pessoas, enfim, para as quais as questões teológicas eram uma matéria essencial de preocupação, fosse para a propagação, fosse para a depuração da fé cristã. Os leigos beneficiados com licenças de tipo 2, uma minoria,

\footnotetext{
${ }^{81}$ Ibidem.

${ }^{82}$ Ibidem, p. 94-95.
} 
possuíam, em sua maior parte, formação superior, atuando na docência e no aparato judicial e repressivo. Assim, das 48 pessoas que receberam licenças de tipo 2, 43 pertenciam ao estado clerical e 5, eram leigas. Dos 43 clérigos, 24 eram regulares e 36 tinham formação de nível superior, 32 dos quais em teologia. Dentre esses teólogos, por sua vez, 15 dedicavam-se também à docência e 3 tinham formação em leis. Além dos teólogos, havia 2 professores e 1 requerente formado em leis e cânones. Dos 5 leigos contemplados com licenças de tipo 2, 3 tinham formação de nível superior: o desembargador Manuel Gonçalves de Miranda, Intendente Geral de Polícia; D. Paulo Hodar, professor de Línguas Orientais na Universidade de Coimbra; e, por fim, o desembargador Francisco Xavier do Vale ${ }^{84}$.

Há despachos, como se viu, nos quais não se anotou o número-tipo da licença concedida. Confrontando-se as proibições resguardadas e suspensas nesses despachos com o conteúdo das licenças registradas nos livros de provisões, no entanto, é possível presumir os números-tipos, sendo isso válido para as licenças de tipo 2. A comparação entre despachos dados em requerimentos assinados por uma mesma pessoa e enviados em datas diferentes corrobora também a inferência de tipos. Assim, por exemplo, em 1772, José da Estrela obteve duas licenças, respectivamente em abril e julho, cada qual merecendo despachos diferentes, cujos conteúdos, no entanto, são idênticos conforme a tipologia: em abril, permitiu-se ao mesmo ler obras religiosas, obras proibidas em 24 de setembro de 1770 e possuir Bayle; e, em julho, anotou-se unicamente "No. 2" ${ }^{\text {"85 }}$. Considerando-se que a tendência das licenças de tipo 2 foi manter apenas três dos quatro editais fundamentais (10/06/1768, 24/07/1769 e 04/12/1769), suspendendo-se as proibições relativas a obras religiosas e a validade, parcial ou total, do edital de 24 de setembro de 1770, chega-se a 27 licenças presumivelmente de tipo $2^{86}$. Todas elas foram passadas a clérigos, dos quais 20 eram teólogos (9 destes também professores), 3 dedicavam-se ao magistério, 1 era bispo e 1 possuía o título de doutor e era ministro da cúria do patriarcado de Lisboa (faltam dados para os dois requerentes restantes). Nas licenças supostamente de número 2 , portanto, confirma-se a obediência à regra duodécima do regimento da Real Mesa Censória, na medida em que os beneficiários

\footnotetext{
${ }^{83}$ Ibidem.

${ }^{84}$ IANTT, Real Mesa Censória, Requerimentos, Caixa 113 e Provisões, Livros 2 e 13.

${ }^{85}$ IANTT, Real Mesa Censória, Requerimentos, Caixa 112.

${ }^{86}$ Ibidem.
} 
são, em sua totalidade clérigos, em sua maioria teólogos e/ou docentes ou, ainda, membros da alta hierarquia eclesiástica ${ }^{87}$.

O perfil dos beneficiários de provisões de tipo 2 é mais complexo, aproximando-se e distanciando-se daquele verificado nos despachos de licenças anotados nos requerimentos. Considerando-se as provisões em seu conjunto, de 1775 a 1794, vê-se que os clérigos preponderavam entre os beneficiários de licenças de tipo 2: eles somavam 83, enquanto os leigos e os que não se pôde classificar com segurança nessa categoria (embora haja grande probabilidade de se enquadrarem na mesma) chegavam a 54. Dos 83 clérigos, 63 eram regulares e 20 seculares, sendo que 38 possuíam formação de nível superior, 30 dos quais em teologia; 18 clérigos eram também professores. Dos clérigos sem formação universitária declarada, 6 ocupavam postos importantes na hierarquia eclesiástica. Dos 39 leigos ou beneficiários cujo estado não se conseguiu identificar, 32 possuíam instrução universitária ou equivalente, sendo 25 deles em leis, 12 dos quais sendo também professores (havia outros 2 professores que atuavam em área diferente de leis e cânones e apenas 1 teólogo).

Esses dados mostram que as provisões de tipo 2 não obedeceram fielmente à regra duodécima da Real Mesa Censória, na medida em que beneficiaram muitos leigos, em grande parte sem vínculos com o ensino; o número de leigos, além disso, é proporcionalmente muito maior do que aquele verificado nas licenças de tipo 2 anotadas nos despachos. Esse maior número de leigos por si só revela uma maior abertura dos tribunais censórios. Pode-se, no entanto, precisar essa abertura no tempo, percebendo-se com isso uma coincidência cronológica entre o maior número de leigos beneficiados com licenças de tipo 2 e o relaxamento dos tribunais censórios em relação às proibições resguardadas: se esse relaxamento ocorreu nos anos 1790 , 34 dos 39 leigos e indivíduos sem estado identificado, beneficiados com licenças de tipo 2, obtiveram-nas entre 1790 e 1794 . Em outros termos: a esmagadora maioria dos não-clérigos beneficiados com licenças de tipo 2 alcançaram essa mercê no mesmo momento em que a Real Comissão Geral para a censura de livros abrandava as proibições mantidas nas licenças do tipo citado, restringindo-as àquelas fixadas no edital de 04 de dezembro de 1769. Conclui-se, portanto, que o perfil dos beneficiados com provisões de licenças de tipo 2 aproxima-se em parte daquele encontrado entre

${ }^{87}$ Ibidem. 
os requerentes apenas nos anos 1770: em grande parte, os contemplados com licenças desse tipo eram clérigos com formação superior em teologia, ou que eram regulares e/ou que exerciam atividades relacionadas ao ensino; ou então, leigos que dedicavam-se à docência. De 1790 a 1794, porém, a Real Comissão Geral para a censura de livros concedeu licenças de tipo 2 com mais liberalidade, atingindo um número proporcionalmente maior de não-clérigos, sem envolvimento com questões teológicas ou com o ensino.

Houve indivíduos naturais ou residentes na América portuguesa, ou ainda, que tiveram passagem por esse "continente", incluídos entre os beneficiários de licenças de tipo 2. Seus nomes não aparecem nos requerimentos, mas apenas no livro de provisões. Somam, no total, 4, sendo todos eles teólogos ou homens da alta hierarquia eclesiástica colonial: o cônego João Luiz de Souza Sayão, então tesoureiro-mór da Sé de Minas Gerais, bacharel em Cânones - famigerado e exímio delator do Santo Ofício, como se mostrou no Capítulo 5 - , que obteve em 1792 licença pelo tempo de dez anos; o frei José Capistrano de S. Bento, religioso da província da Conceição do Rio de Janeiro e nela lente de Teologia, cuja licença, também por dez anos, foi passada em 1793; no mesmo ano e cidade, com idêntica duração, o frei Raimundo de Penafort da Anunciação, professor de Teologia no Convento de Santo Antônio, que um ano antes havia descrito a leitura da sentença pronunciada contra os Inconfidentes Mineiros, bem como a execução do alferes Joaquim José da Silva Xavier; e, em 1794, Manoel de Almeida Maciel, deão da Sé metropolitana da Bahia e provisor do mesmo arcebispado ${ }^{88}$.

As licenças de número 3 contemplaram uma categoria mais heterogênea de indivíduos, não incluídos na regra duodécima do regimento da Real Mesa Censória, mas certamente considerados "doutos" e "prudentes", como se prescrevia em outra parte do mesmo documento legal. Como será mostrado a seguir, seus beneficiários eram em sua maioria leigos com formação de nível superior, principalmente em leis, mas não só; os clérigos eram uma minoria e, no geral, também tinham instrução superior, majoritariamente em leis e cânones, e, raramente, em teologia.

Nos requerimentos enviados pelos leitores que ambicionavam o direito legal de ler livros proibidos, há 68 despachos em que se vê a concessão de licenças de tipo 3. Os beneficiários dessas licenças eram, em sua maioria, leigos (51; o que

${ }^{88}$ IANTT, Real Mesa Censória, Livro 14, p. 130, 139 e 163. 
corresponde a 3/4 dos requerentes que obtiveram licenças desse tipo), cabendo aos clérigos uma posição minoritária (17; o que corresponde a 1/4 dos que alcançaram licenças de tipo 3). Dos 51 leigos beneficiados com licenças de tipo 3, 41 possuíam instrução de nível superior, 33 deles em Leis e Cânones, sendo que 17 ocupavam cargos na magistratura. Dois requerentes leigos de nível superior exerciam a medicina e outros 2, envolviam-se no ensino. Havia, ainda, 2 requerentes que ocuparam postos de governadores no ultramar, 12 nobres (6 deles com nível superior). Já entre os 17 clérigos, 14 possuíam instrução superior, 12 deles em cânones. Dos formados em Cânones, 1 era também teólogo, 5 ocupavam cargos na magistratura e outros 5 encontravam-se em altos postos na hierarquia eclesiástica. Dos clérigos sem instrução superior declarada, 2 ocupavam altos postos na hierarquia $^{89}$.

A partir do conteúdo das provisões de número 3 pode-se inferir que muitas licenças anotadas nos requerimentos sem referência numérica eram do tipo 3. Como se viu, as provisões de tipo 3 salvaguardaram as proibições dos quatro editais e leis fundamentais (de 10 de junho de 1768, 24 de julho de 1769, 04 de dezembro do mesmo ano e 24 de setembro de 1770) e aquelas referentes às obras religiosas, ora suspendendo, ora mantendo a interdição à obra de Pierre Bayle. Usando-se tais proibições mantidas e suspensas como critério para classificação das licenças sem número passadas nos despachos, chega-se a um total de 50 licenças de tipo 3: 40 delas concedidas a leigos e 10 a clérigos. Dos 40 leigos, 30 tinham instrução de nível superior, sendo que 26 deles em leis, 15 dos quais ocupando cargos na magistratura e 2 sendo docentes. Entre os leigos sem instrução superior declarada, havia 3 estudantes, 1 nobre e 1 conselheiro do Conselho Ultramarino. Dos 10 clérigos, 8 tinham nível superior de instrução e os outros 2 encontravam-se em altos postos da hierarquia eclesiástica. Dentre os 8 clérigos que tiveram instrução superior, 7 obtiveram formação em leis e cânones, sendo que 5 deles exerciam funções de magistrados ${ }^{90}$.

As provisões de licença de tipo 3, por seu turno, contemplaram 88 indivíduos, entre 1775 e 1794, 23 deles pertencentes ao estado clerical e 65 leigos ou com grande probabilidade de sê-lo, embora seja impossível afirmá-lo de forma categórica. Dos

\footnotetext{
${ }^{89}$ IANTT, Real Mesa Censória, Requerimentos, Caixa 113 e Livros 2 e 3.

${ }^{90}$ IANTT, Real Mesa Censória, Requerimentos, Caixa 112.
} 
23 clérigos, 12 eram regulares, 8 tinham formação superior, 4 deles em leis e cânones e 2 em teologia; 4 desses clérigos eram também professores. Dois clérigos sem formação universitária declarada ocupavam cargos de relevo na hierarquia eclesiástica. Dentre os 65 classificados como leigos, 38 tinham formação universitária ou equivalente, 19 deles seguramente em leis e outros 17 intitulados apenas "bacharéis". Um dos leigos fora governador no Ultramar e 5 deles eram professores (3, na área de leis). Nos despachos em que se vê anotado o número 3, naqueles que se presume uma licença desse tipo e, ainda, nas provisões de licenças do mesmo tipo, observa-se a permanência de um mesmo perfil de beneficiários: em sua maioria leigos, mas também clérigos, em parcela significativa, com formação superior em leis e, em menor número, em outras áreas; alguns deles ocupando postos importantes na magistratura ou na hierarquia civil e eclesiástica; indivíduos, ainda, para os quais as questões teológicas não eram fundamentais.

Na América Portuguesa, Luiz J. de Carvalho e Melo, desembargador da Relação do Rio de Janeiro, foi um dos beneficiários de provisão de licença de tipo 3, que lhe foi passada em 1794 e pela qual mantinham-se as proibições estipuladas pelos editais e sentenças de 10 de junho de 1768, 24 de julho de 1769, 04 de dezembro do mesmo ano e 24 de setembro de 1770; ficando-lhe autorizada a leitura do Dicionário de Bayle e de livros proibidos que não tratassem de religião ${ }^{91}$. Outros habitantes da Colônia que receberam provisões para leitura de livros proibidos de tipo 3, todas elas com duração de dez anos, foram: em 1772, Miguel Carlos Caldeira de Pina, desembargador da Casa de Suplicação da Bahia; no mesmo ano, Thomé Gomes Gonzaga Neves, advogado na cidade do Rio de Janeiro ${ }^{92}$; em 1773, Miguel Serrão de Reis, chanceler da Relação da Cidade da Baía ${ }^{93}$; em 1776, o padre Antônio Caetano de Almeida, bacharel em Cânones pela nova Universidade de Coimbra, então, vigário da igreja de Nossa Senhora do Pilar de São João d'El Rei; em 1793, Domingos Miz. Caldas, professor de Gramática Latina no Pará; e, em 1794, João da Cunha Soto Maior, fiscal dos diamantes do Serro Frio ${ }^{94}$.

Nos requerimentos examinados, é possível identificar, dentre os beneficiários de licença de tipo 3 que nasceram ou passaram, ou então, que moravam na América

\footnotetext{
${ }^{91}$ IANTT, Real Mesa Censória, Provisões, Livro 14, p. 164.

${ }^{92}$ IANTT, Real Mesa Censória, Provisões, Livro 13, p. 37v-38v e 116-117.

${ }^{93}$ IANTT, Real Mesa Censória, Provisões, Livro 13, p. 125-126.

${ }^{94}$ IANTT, Real Mesa Censória, Provisões, Livro 14, p. 143-144 e 160.
} 
Portuguesa quando solicitaram a mercê do tribunal censório, alguns dos nomes supracitados, encontrados nos livros de provisões: Tomé Gomes Gonzaga Neves e Miguel Serrão de Vis e Antônio Caetano de Almeida, em 1772 ${ }^{95}$. Todavia, outros nomes não são repetidos, a saber: em 1773, o desembargador Costa Matoso, magistrado com passagem por Minas Gerais, onde foi ferrenho adversário de D. Frei Manuel da Cruz, primeiro prelado marianense (na realidade, como se verá adiante, tratava-se de um pedido de inspeção de licença pontifícia, anteriormente passada à inquisição); em 1776, D. Luís Antônio de Souza Botelho Mourão, o Morgado de Mateus, que fora governador e capitão general de São Paulo ${ }^{96}$; e Alexandre da Silva Pedrosa Guimarães, em 1772, natural da Bahia, formado em Cânones e ministro apostólico do Tribunal da Legacia ${ }^{97}$. Todos esses homens, como se pode observar, tinham alguns traços comuns entre si e com o padrão de beneficiário de licenças de tipo 3: ou estavam na magistratura, ou haviam ocupado postos importantes na administração colonial, e/ou possuíam uma formação universitária, implícita ou explícita, em leis e cânones, ou, ainda, exerciam o magistério, não sendo demasiado estreitas suas relações com a teologia.

As provisões de tipo 4 e 5, como já se mostrou, foram concedidas a um número insignificante de pessoas, não cabendo esmiuçar o perfil dos que delas se beneficiaram. As licenças dadas para obras específicas já foram discutidas anteriormente, ao se examinarem as proibições mantidas e suspensas. Cabe aqui, portanto, apenas indicar aqueles que eram naturais da América ou que nela habitaram e que foram contemplados com licenças para obras específicas. O Dr. Pedro Joze Augusto Flávio de Faria, no Brasil, deão do Rio de Janeiro, possuía, em 1780, a História Ecclesiástica, de Massein (Institutiones Historicae Ecclesiasticae, do Barão Jean Laurent de Moshein, obra proibida, mas liberada para os que tivessem licença, pelo edital de 22 de outubro de 1779) ${ }^{98}$. Além dele, três outros requerentes que residiam ou tiveram alguma passagem pela América Portuguesa alcançaram licença para ler obras específicas, todos eles possuidores de obras proibidas pelo edital de 12 de dezembro de 1771: em 1772, Roque Roiz de Carvalho, padre secular, filósofo, teólogo, formado em Cânones, confessor e pregador aprovado em Lisboa e no Rio de

\footnotetext{
95 IANTT, Real Mesa Censória, Requerimentos, Caixa 112.

${ }^{96}$ IANTT, Real Mesa Censória, Requerimentos, Caixa 113.

${ }^{97}$ IANTT, Real Mesa Censória, Requerimentos, Caixa 112.

${ }^{98}$ IANTT, Real Mesa Censória, Requerimentos, Caixa 113.
} 
Janeiro, que tinha livros de Vicente Filliucio, João Azor, Paulo Layman e Ricardo Arsdekin; em 1772, Luiz Borges Agripino, arcipreste da Sé do Grão-Pará, aposentado, assistente em Lisboa, em cujas mãos estavam as Obras de Domingos Viva e as Instituições Moraes de João Azor ${ }^{99}$; e, por fim, em 1777, o desembargador Antônio de Matos Silva, citado anteriormente no Capítulo 5 por ter seu Tratado de Justitia, \& Jure, de Luís de Molina, apreendido na alfândega ${ }^{100}$.

Do conjunto dos requerimentos examinados, dois foram encaminhados ao tribunal censório por mercadores, obtendo licença. Francisco Clamopin Durand, conhecido mercador de livros do Porto, enviou dois requerimentos, ambos datados de 1776. No segundo requerimento, explicou que encaminhara o primeiro pedido por sugestão do Juiz de Fora, "p". poder vender" os livros defesos, como se tinha “concedido aos mais livreiros", não tendo obtido resposta. O segundo requerimento obteve despacho, sendo Durand autorizado a "vender $\mathrm{L}^{\mathrm{os}}$. prohibidos $\mathrm{p}^{\mathrm{o}} \cdot \mathrm{t}^{\mathrm{po}}$. de tres años", em 1776. No mesmo ano, o mercador de livros Miguel Francisco também foi autorizado a vender livros proibidos pelo tempo de três anos ${ }^{101}$. Vê-se, portanto, que não houve interdições nas licenças anotadas em requerimentos passados aos livreiros.

Como já se observou anteriormente, as provisões de licenças concedidas aos livreiros, entre 1775 e 1794, não eram muito liberais, estando, via de regra, a meio caminho das licenças de tipos 2 e 3: nelas se manteve a vigência dos editais fundamentais, autorizando-se, a posse da obra de Pierre Bayle e, com exceção de um único caso, também de obras religiosas proibidas. Todas essas provisões foram passadas entre 1775 e 1776, beneficiando livreiros famosos na capital portuguesa, dentre os quais: Francisco Mallen, João José Bertrand, Francisco Rolland, João Pedro Aillaud, João Batista Reycend, Francisco Durand, Camillo De'Beux, Jorge Rey e Francisco Gonçalves e Filhos ${ }^{102}$.

Sabe-se que os livreiros envolveram-se no comércio ilegal de livros proibidos, vendendo-os a pessoas desprovidas de licenças para terem-nos e leremnos. Em certas ocasiões, porém, cobraram a licença de seus clientes antes de venderem-lhes livros defesos. Em 1776, o fidalgo, mestre de campo e familiar do Santo Ofício Rodrigo de Souza da Silva Aleiforado, deixava explícita a existência

\footnotetext{
${ }^{99}$ IANTT, Real Mesa Censória, Requerimentos, Caixa 112 e Provisões, Livro 13, p. 120.

${ }^{100}$ IANTT, Real Mesa Censória, Requerimentos, Caixa 113.

${ }^{101}$ Ibidem.

${ }^{102}$ IANTT, Real Mesa Censória, Provisões, Livro 14, p. 16-56.
} 
dessa cobrança: em requerimento em que solicitava licença à Real Mesa para possuir e ler livros proibidos, destacava que, com isso, "os Livreiros a q ${ }^{\mathrm{m}}$. a mesma Licença lhe for aprezentada tenhão a liberdade de lhe vender ${ }^{\mathrm{e}} \sim$ as referidas obras que forem uteis a instrução" dele ${ }^{103}$. Quatro anos depois, o citado Dr. Pedro Joze Augusto Flávio de Faria, deão do Rio de Janeiro, enfrentou concretamente a necessidade de ser portador de licença para conseguir comprar legalmente Institutiones Historicae Ecclesiasticae, do Barão Jean Laurent Moshein. Então de passagem por Lisboa, comprara a referida obra "q se acha[va] retida na Real Meza Censoria", acrescentando que a obra fora adquirida do seu dono, o "Monsieur Borel, e Comp a mercador de Livros nesta corte". Como a não podia obter sem que fosse conferida a “dita grasa para a poder tirar da mencionada Meza", requeria, então, que se lhe desse licença, no que obteve sucesso ${ }^{104}$. Não é possível saber se a obra mencionada fora apreendida pela mesa antes ou depois da compra pelo deão do Rio de Janeiro, mas de qualquer forma o exemplo citado revela que a compra de um livro proibido junto a livreiros nem sempre se fazia à margem da lei, requerendo, pelo contrário, licença do tribunal censório.

Um único habitante da América Portuguesa teve seu pedido de licença negado pelo Desembargo do Paço: Daniel Eduardo Roiz Grijó, “Advogado publico nos auditor ${ }^{\text {os }}$ da Com $^{\text {ca }}$. de Pernambuco"105. Esse requerente conseguira arrancar, anos antes, uma provisão de Dom João, então Príncipe Regente, autorizando-o a advogar - isto era necessário por ele não ser formado em leis - por tempo de três anos nos auditórios de Pernambuco. Insatisfeito, Daniel Eduardo, em 1803, pediu para advogar sem qualquer limitação de tempo, em qualquer auditório do Brasil, acrescentando, ainda, a solicitação de licença para leitura de livros proibidos. Justificava sua iniciativa pela necessidade de aumentar sua instrução - topos muito comum nos requerimentos, como se verá no capítulo 7 - e por ser seu propósito dar " $m$ or. realce" para a Religião e "mais fundamental ${ }^{\text {me }}$. sustentar os $\mathrm{Dir}^{\mathrm{tos}}$. da Regia authori $^{\text {de }}$, a cada passo atacada pelas continuas uzurpacçõens e operçõens [sic] do sempre avido clero, praticado ordinariam ${ }^{\mathrm{e}}$. com notorio vexame dos fieis vassalos de V. A. R., moradores naquelas Colonias, q . a não serem os da classes q . o sup ${ }^{\mathrm{e}}$. exercita, q . lhes obstão aos seus violentos impulços pelos recurços, q . sempre

\footnotetext{
${ }^{103}$ IANTT, Real Mesa Censória, Requerimentos, Caixa 113.

${ }^{104}$ Ibidem.
} 


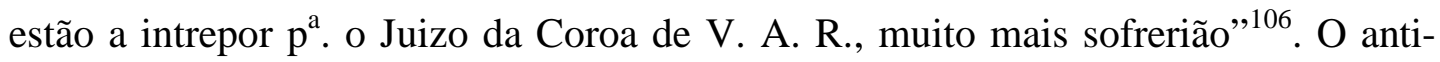
clericalismo, as juras de fidelidade ao Trono e à religião, e a condenação contra o "vexame" a que estariam submetidos os vassalos, defendidos com loquacidade por Daniel, não sensibilizaram os juízes do Desembargo do Paço, quanto mais que o requerente era apenas um advogado prático. Pôs-se no requerimento, então, um breve despacho: "Escusado",107.

Findado o prazo de validade das licenças, havia que solicitar sua renovação. Em 1776, por exemplo, o padre José Francisco de Mendonça, monsenhor da Santa Igreja Patriarcal (isto é, do patriarcado de Lisboa), informava à Real Mesa que ele tinha livros proibidos e licença e, como essa havia acabado, ele não podia "continuar a lelos sem nova faculdade" do tribunal. Por isto, ele encaminhou seu pedido de nova licença, no que foi atendido, sendo-lhe passada licença de número 2. ${ }^{108}$. Em 1777, ninguém menos que o frei Francisco Xavier de Lemos, o reitor reformista da Universidade de Coimbra no período pombalino, alegava que "a mesma graça se acha[va] finda e porq . ainda assist[ia] ao Sup $^{\text {te }}$. a mesma necessid ${ }^{\text {de }}$. de Ler, e ter os $\mathrm{d}^{\mathrm{os}}$. Livros", pedia nova licença ao tribunal, que, em resposta, assentiu, concedendolhe uma licença de número 2, por um prazo de dez anos ${ }^{109}$. Num caso extremo de obediência à mesa e de valorização da posse de licença, D. Manoel Jozé Lobo da Silveira, brigadeiro dos exércitos e coronel do regimento da segunda armada, em 1776, informou ter conseguido anteriormente "Licença para Ler, e reter os Livros prohibidos", mas porque a dita licença se perdeu, ele passava a necessitar de "outra semelhante para se instruir, e habilitar melhor para servir" à Coroa por "meio da Lição" dos livros mencionados, recebendo, então, uma licença de número $3{ }^{110}$.

A validação das licenças concedidas anteriormente pela Inquisição motivou a preocupação do sistema censório criado em 1768. A prática de solicitar licença para leitura de livros proibidos ao papado era comum em Portugal. No século XVII, por exemplo, importantes figuras do cenário político português, como D. Vicente Nogueira, o Marquês de Nizza, Cristóvão Soares de Abreu e D. Pedro Mendonça de São Payo, tentaram obter de Sua Santidade autorização para ler livros defesos. D.

\footnotetext{
${ }^{105}$ Ibidem.

${ }^{106}$ Ibidem.

${ }^{107}$ Ibidem.

${ }^{108}$ Ibidem.

${ }^{109}$ Ibidem.

${ }^{110}$ Ibidem.
} 
Vasco Luís da Gama, conde da Vidigueira e, depois marquês de Nizza, com certeza foi coroado de êxito no seu intento, tendo que se contentar, no entanto, com uma autorização restrita a alguns livros ${ }^{111}$.

No século XVIII, essa prática teve continuidade e, com a implantação da censura estatal unificada e em razão de suas exigências, muitos leitores procuraram validar as licenças papais, havendo, como já se disse, 17 casos desse tipo nos dois primeiros anos de funcionamento da Real Mesa Censória ${ }^{112}$. Em 1757, por exemplo, o fidalgo Francisco Bernardo Holbeche, ouvidor de Barcelos, obtivera licença de Sua Santidade, mandada então à Inquisição portuguesa, para ler livros proibidos, excluindo-se unicamente as "obras de Machiavello, e Adonis de Marino"; em 1772, o mesmo Francisco, exercendo o cargo de ouvidor de Barcelos, enviou à Real Mesa o sobredito breve, em conformidade com as exigências do regimento desse tribunal censório, obtendo licença de tipo $3^{113}$. À mesma exigência curvou-se, em 1773, com um certo atraso, uma autoridade de nível mais elevado, o ex-governador de Angola, D. Francisco Innocencio de Souza Coutinho. Nos idos de 1751, obteve do papa Benedito XIV autorização para "legere ac retinere libros prohibitos agentes de Philosophia Mathesi Puello, Jure Pacis ac Belli, Hist ${ }^{\mathrm{a}}$. Ecclezia, et prof ${ }^{\mathrm{a}}$. Ire libros Politicos, Gram ${ }^{\text {cos }}$., Poeticos, et Rhetoricos., Exceptis - ter superstitiosa continentibus, et operibus Nicolas Macchiavelli, Adonides Marini, caterisque de obscenis, et contra Religne ex. professo agentibus In quoru"114. Ao saber que a Real Mesa exigia que se lhe enviassem as licenças para ler livros proibidos obtidas do Papado, Inocêncio, então governador de Angola, “ordenou à sua Familia a mandasse entregar, esta a não achou, nem conheceu confundida com outros muitos papeis"; então, em 1773, tendo-a encontrado, ele próprio a enviou à Real Mesa, que lhe passou uma licença de tipo 3, permitindo-lhe, no entanto, a leitura do Dicionário de Bayle $^{115}$. Em 1773, o já citado desembargador Costa Matoso, que atuou em Minas Gerais, pedia que a Real Mesa lhe desse licença para ler livros defesos, "como the fo[ra] ja dada por Breve Pontificio" ${ }^{\prime 16}$.

Examinando-se o funcionamento da censura portuguesa no período do

\footnotetext{
${ }^{111}$ TORGAL, Luís Reis, op. cit., vol. 1, p. 132 e 205.

112 IANTT, Real Mesa Censória, Requerimentos, Caixa 112 e Provisões, Livro 2 e 13.

${ }^{113}$ IANTT, Real Mesa Censória, Requerimentos, Caixa 112.

${ }^{114}$ IANTT, Real Mesa Censória, Requerimentos, Caixa 113.

115 Ibidem.

${ }^{116}$ Ibidem.
} 
Reformismo Ilustrado, no que se referia à fixação de interdições, à fiscalização da circulação e da posse de livros, e à concessão de licenças para a leitura de livros proibidos, em resumo, nota-se uma coerência com a política desenvolvida num âmbito mais geral pela Coroa. Sob a influência das Luzes, o governo lusitano, a partir de 1750, como se viu no Capítulo 3, empreendeu um enorme esforço no sentido de firmar o poder régio em relação à igreja e à sociedade, em particular à nobreza; de promover reformas sócio-econômicas para fomentar a acumulação e a retenção de capital em Portugal, desenvolvendo as manufaturas, o comércio ultramarino e as atividades produtivas na Colônia; e de dinamizar as atividades científico-culturais e educativas, estimulando as ciências e instituindo um dos primeiros sistemas de educação pública da Europa. Tudo isso dentro dos quadros do Antigo Regime. Visando alcançar esses objetivos, movendo-se por uma mistura de reformismo, regalismo, absolutismo e pragmatismo, a Coroa, por um lado, atacou de maneira feroz os jesuítas, mistos de bodes expiatórios e de obstáculos, a nobreza tradicional e alguns elementos que deitavam raízes na cultura lusitana, destacandose, dentre esses, as teorias corporativas de poder (e, em correlação com elas, algumas interpretações históricas da Restauração Portuguesa de 1640), os milenarismos e o anti-cientificismo. Ao mesmo tempo, as governações que se sucederam desde 1750 procuraram conter, com ímpeto variado, de modo oscilante, com titubeios e ambigüidades, em função mesmo de sua perspectiva Ilustrada, a onda revolucionária que tinha como epicentro a França. A ação do aparato censório desenvolveu-se segundo esses parâmetros, buscando atingir esses alvos fixados pelas diretrizes governamentais de âmbito mais amplo: nos quadros do Antigo Regime, sob a influência das Luzes, reprimiram-se a circulação e a posse de livros que contivessem concepções corporativas de poder ou que as referendassem na interpretação de episódios da história portuguesa; tentou-se extirpar os milenarismos e o anticientificismo que grassavam na cultura portuguesa; e não se pouparam esforços, ainda, para impedir a entrada das idéias trazidas pelas Luzes que afrontassem o absolutismo, a religião cristã, a Inquisição e o colonialismo.

Os resultados dos esforços dos órgãos censórios, no que se referia à circulação e à propriedade de livros em geral, não foram coroados de êxito, como se explicou no Capítulo 5. Colaborou para o fracasso a ambigüidade da própria situação governamental sob o Reformismo Ilustrado, em que se aliavam Luzes e 
Antigo Regime, reformas e repressão. Contribuíram para o mesmo resultado, ademais, o enraizamento, nas práticas de censura e dos leitores em geral, de uma relação com o livro e com a leitura marcada pela idéia de privilégio; a desarticulação, o descompasso, a fragilidade e as contradições estabelecidas entre os vários órgãos da burocracia estatal; e a má vontade dos leitores, que não se curvavam aos ditames régios.

A prática de concessão de licenças para a leitura de livros proibidos mostrou grande afinidade com as diretrizes governamentais e com os parâmetros fixados pelos órgãos censórios citados anteriormente. Embora implicassem a suspensão da vigência de proibições no âmbito das leituras, as licenças não o faziam de forma absoluta, preservando, isolada ou conjuntamente, a vigência de algumas proibições: às relativas a obras religiosas e as fixadas nos editais censórios de 10 de junho de 1768, 24 de julho de 1769, 04 de dezembro de 1769 e 24 de setembro de 1770. Tais editais tinham em mira a eliminação da interferência da igreja em negócios julgados seculares, a extirpação de toda uma herança cultural atribuída aos jesuítas (isto é, os milenarismos, o anti-cientificismo, o sigilismo, as teorias corporativas de poder e suas derivações) e a contenção dos efeitos "irreligionários" e revolucionários das Luzes.

Dando-se a partir da solicitação dos próprios leitores, a concessão de licenças para a leitura de obras defesas constitui uma dimensão particular para se avaliar a orientação dos órgãos censórios, para confrontar normas e práticas, na medida em que implicava a abertura, à censura, dos interesses e do mundo literário em que estavam imersos os leitores, oferecendo-lhe, desse modo, condições "laboratoriais" de experimentação. A concessão de licenças para a leitura de livros proibidos pelos órgãos censórios, entretanto, sofreu as mesmas injunções que afetaram o controle da circulação e da posse de livros em geral. O perfil dos requerentes-beneficiários de licenças remetia a uma amostra reduzida do conjunto dos leitores: tratava-se de um segmento elitizado, sobretudo do ponto de vista intelectual, constituído em grande parte por clérigos e, em menor proporção, por leigos; ambos, clérigos e leigos, em sua imensa maioria, com formação de nível superior em Leis e Cânones ou Teologia, envolvidos em atividades monásticas e/ou de ensino, e/ou exercendo cargos de alguma importância no aparato judicial-administrativo; entre os beneficiários de licenças, encontravam-se também as bibliotecas das instituições monásticas e 
escolares em que se encastelavam os mesmos leitores. Esse perfil exprime a injunção de um elemento interveniente no controle censório da circulação e da posse de livros em geral: posse e leitura de livros proibidos estiveram permeados por privilégios de cunho estamental e profissional. Isso, é importante ressaltar, valia tanto para a perspectiva dos leitores, quanto da censura: se a censura limitava a concessão de licenças a pessoas com o perfil discriminado, só se candidatavam à obtenção das mesmas, com raras exceções, pessoas que se julgavam enquadrar-se nas exigências. A interferência de uma seletividade estamental, dada como pré-requisito legal e reconhecida e aceita pelos leitores que se apresentavam para receber licenças, fez-se presente igualmente, além disso, na modulação feita pela censura dos tipos de licenças e das regalias dadas aos leitores, isto é, dos editais e interdições cuja validade seria mantida ou, pelo contrário, suspensa. Às diferentes espécies de leitores, ofereceram-se distintos tipos de licenças e manteve-se ou suspendeu-se, de forma diversa, a vigência das proibições fundamentais sublinhadas acima: os beneficiados com as maiores aberturas foram, assim, as instituições monásticas e de ensino e os clérigos com formação em teologia que desenvolviam atividades de educativas ou que viviam em mosteiros.

Essa orientação seletiva, contudo, não sobreviveu imóvel ao efeito das transformações históricas que se processavam no último quartel do século XVIII. A prática de concessão de licenças, especialmente nos anos 1790-1794, últimos tempos de funcionamento da Real Mesa da Comissão Geral para a censura, por um lado, contemplou um expressivo número de leigos com licenças outrora reservadas a indivíduos que exercessem atividades ligadas à teologia e ao ensino e, por outro lado, suspendeu, para grande parte dos beneficiários de licenças, as proibições até então resguardadas, preservando a vigência apenas do edital de 04 de dezembro de 1769, deixando entrever-se, ademais, a possibilidade de também eliminá-la. Abandonaramse, assim, em meados dos anos 1790, nas concessões de licença para a leitura de livros proibidos, em grande parte, o anti-jesuitismo, o anti-milenarismo, a oposição às teorias corporativas de poder e aos ventos radicais das Luzes, sobrevivendo apenas o regalismo - era esse o espírito que presidia o edital cuja vigência foi mantida, de 04 de dezembro de 1769. A censura, ao final do período mariano e no início da regência de D. João, numa conjuntura de crise do Antigo Regime, portanto, afrouxou as comportas na concessão de licenças: flexibilizou as proibições e dilatou o leque dos 
beneficiários de maiores liberdades. As razões que estão por trás dessa transformação, no entanto, não estão claras. Teria a Revolução contaminado os censores, acentuando a ambigüidade que permeava as diretrizes e a ação estatal desde o início do período do Reformismo Ilustrado? Ou seria apenas um sintoma da decantada fragilidade da Real Mesa da Comissão Geral para a censura de livros? O mais provável é que esses dois fatores tenham se aliado. De qualquer forma, isso veio a contribuir, com certeza, para que, no seio das elites, as Luzes se difundissem e, ao mesmo tempo, para que se preservassem elementos da herança atribuída aos jesuítas. E, no universo dos leitores que solicitaram licenças, as teorias corporativas de poder e o probabilismo eram elementos bastante vivos, tendo muitos dos mesmos manifestado o desejo de ler e possuir os livros que os divulgavam. 


\section{PARTE III:}

\section{Usos do Livro pelos Leitores:}

\section{Leitura e Ordem Religiosa e Política}

Aparece uma nuvem no meio daquela Bahia, lança uma manga ao mar, vai sorvendo por oculto segredo da natureza grande quantidade de água, e depois que está bem cheia, depois que está bem carregada, dá-lhe o vento, e vai chover daqui a trinta, daqui a cincoenta léguas. Pois, nuvem ingrata, nuvem injusta, se na Bahia tomaste essa água, se na Bahia te encheste, porque não choves também na Bahia? [...] Tais como isto são muitas vezes os ministros que vêm ao Brasil, e é fortuna geral as partes ultramarinas. Partem de Portugal estas nuvens [... e em chegando, verbi gratia, a esta Bahia, não fazem mais que chupar, adquirir, ajuntar, encher-se (por meios ocultos, mais sabidos), e ao cabo de três ou quatro anos, em vez de fertilizarem a nossa terra com água que era nossa, abrem as asas do vento, e vão chover a Lisboa, esperdiçar a Madrid. Por isso nada lhe luz ao Brasil, por mais que dê, nada lhe monta, e nada lhe aproveita, por mais que faça, por mais que desfaça

(Padre Antônio Vieira, Sermões, Bahia, 1640).

era pena, que uns países tão ricos como estes [isto é, as Capitanias da América Portuguesa] estivessem reduzidos à maior miséria, só porque a Europa, como esponja, lhe estivesse chupando toda a substância, e os exmos. Generais de três em três anos traziam uma quadrilha, a que chamavam criados, que depois de comerem a honra, a fazenda, e os ofícios, que deviam ser dos habitantes, se iam rindo deles para Portugal

(Alferes Joaquim José da Silva Xavier, ADIM, Minas Gerais, 1789). 
Esta terceira parte da tese consagra-se inteiramente aos usos dos livros atribuídos pelos leitores. Embora sejam priorizados os usos dos livros ao tempo do Reformismo Ilustrado português, não se perderão de vista seus antecedentes, nos séculos XVI, XVII e na primeira metade do século XVIII, na medida em que os mesmos ajudam a compreender as inflexões produzidas na vida cultural portuguesa com a ascensão de D. José I e de seu ministro Sebastião de Carvalho e Mello.

No Capítulo 7, far-se-á uma abordagem mais geral e panorâmica dos usos do livro na Colônia. Primeiro, avaliando em que medida as mudanças ocasionadas pelo Reformismo Ilustrado afetaram as relações com o saber e os livros, tanto do ponto de vista da Coroa e de seus agentes, dos intelectuais ligados à ordem, quanto da sociedade num âmbito mais geral. Em seguida, buscar-se-á apreender quais usos eram dados aos livros pelos leitores: usos gerais, inferidos a partir da circulação livreira e da distribuição da posse de livros e da tônica da composição das bibliotecas; usos explícitos, ainda sob um prisma mais geral, declarados pelos próprios leitores; e, ao final, restringindo-se o campo de visão às leituras heterodoxas, as apropriações dos textos feitas pelos leitores, leituras inventivas, leituras em grande parte heréticas.

No Capítulo 8, serão analisadas as relações entre os Inconfidentes de Minas Gerais e os livros, sob o Reformismo Ilustrado Português, examinando-se o peso respectivo que tiveram, de um lado, a Segunda Escolástica, os Milenarismos, a Restauração Portuguesa e, de outro, as Luzes e a Revolução Norte-Americana, sobre as práticas de leitura e a Sedição Mineira. 


\section{Capítulo 7:}

\section{Dos Usos em Geral à Inventividade e à Heresia}

\section{Do Medo ao Prestígio do Saber}

A relação do Estado Português com o saber e com o livro, dos inícios do século XVI até 1750, marcava-se por temores e senões, motivando controles, interdições e concessões. Se esta tendência foi amenizada no período do Reformismo Ilustrado, entre 1750 e 1822, dando lugar não apenas a uma valorização do conhecimento, mas também ao uso de sua difusão para combater as idéias e livros julgados nocivos, nunca se perdeu de vista a necessidade de estabelecer interdições, como se evidenciou nos Capítulos 4, 5 e 6.

Educar, a partir das reformas pombalinas, como se viu no Capítulo 3, tornouse uma missão assumida, ao menos em teoria, pelo Estado; um Estado que incorporou, talvez mais no discurso do que na prática, a máxima segundo a qual a ciência constitui instrumento da riqueza das nações, patrocinando, inclusive, a publicação de livros e expedições científicas. Ao mesmo tempo, as autoridades demonstraram preocupação especial com determinadas obras: as escritas pelos filósofos Ilustrados e as "maquinadas" pelos jesuítas, aqui cabendo um amplo espectro literário, como se mostrou na segunda parte desta tese. Tais obras, assim, transformaram-se em alvos de inúmeros editais censórios e, ainda, de busca e retenção nas alfândegas e, até mesmo, nas bibliotecas particulares. O Estado Português sob o Reformismo Ilustrado, dessa forma, cultivou um zelo pelo controle da circulação, da posse e da leitura de livros, guiando-se, como se evidenciou nos Capítulos 5 e 6, por uma seletividade de cunho estamental-profissional e nem sempre primando pela coerência ou pela eficácia.

Deslocando-se do Estado para a sociedade, observam-se, do século XVI ao XVII, a força do medo em relação aos livros e, durante o século XVIII, a progressiva substituição desse temor por uma valorização. Nos séculos XVI e XVII, em 
discursos de autores e intelectuais representantes da cultura erudita e oficial, pode-se verificar uma compreensão de que o livro e o saber representariam um perigo para a ordem constituída. Parte dos representantes da cultura erudita e oficial manifestou temor quanto à possibilidade do conhecimento tornar-se porta para a perda do bom juízo, para o questionamento da ordem moral, religiosa e política vigente. A idéia de que o conhecimento punha a perder o juízo, ironizada por Miguel de Cervantes em seu D. Quixote - D. Quixote, "del poco dormir y del mucho ler se le secó el celebro, de manera que vino a perder el juicio"1 -, encontrou na América Portuguesa defensores ilustres.

No século XVI, o jesuíta Manuel da NÓBREGA acreditava que a catequese dos brasis seria melhor sucedida do que a de outros gentios, na medida em que era mais simples converter um ignorante do que um "malicioso e soberbo", do que "um filósofo, que todo se funda em sutilezas da razão”. Isso porque as cousas mais essenciais da fé cristã "não se podem provar por razão demonstrativa, antes muitas são sobre toda razão humana"2. Portanto, a falta de conhecimento auxiliava a catequese e, pelo negativo, a "malícia" e a "soberba" apresentavam-se como ameaças. No século XVII, o já citado padre Antônio Vieira, conforme se esclareceu no Capítulo 1, compreendia que o desejo de saber havia matado Eva e muitos dos jesuítas; que a "universidade das almas", isto é, a salvação, era mais importante do que as universidades; em razão desses pressupostos, Vieira contrapôs livro-saber à salvação-ação, concedendo primazia ao último binômio. No mesmo século, viu-se também o peregrino da América, Nuno Marques Pereira, advogar posição semelhante. Segundo Marisa LAJOLO e Regina ZILBERMAN, para Nuno, melhor seria "ser caritativo, do que ler que é bom sê-lo" e, ainda, no entender do mesmo, haveria alguns livros que "ensina[ria]m a falar para pecar"3. Os livros para Nuno, portanto, seriam, ao mesmo tempo, perigosos e inferiores à ação, proposições estas convergentes com as defendidas por Vieira. O poeta Antônio Mendes Bordalo é outro que mostra a persistência de uma visão depreciativa a respeito do conhecimento e do livro no século XVIII, voltando-se, no entanto, contra ela: o protagonista de sua obra é um homem dividido entre o que aprendeu nos livros e a

\footnotetext{
${ }^{1}$ Miguel de Cervantes. Apud. MARQUILHAS, Rita, op. cit., p. 195.

${ }^{2}$ NÓBREGA, Manuel da. Diálogo sobre a Conversão do Gentio. In: LEITE, Serafim. Cartas dos primeiros Jesuítas do Brasil, op. cit., vol. 2, p. 338-339.

${ }^{3}$ LAJOLO, Marisa, ZILBERMAN, Regina. A leitura rarefeita: livro e literatura no Brasil. São Paulo:
} 
falta de reconhecimento por parte de seus conterrâneos; essa situação faz com que a personagem decida por liquidar sua biblioteca, tida como fonte de seus males, sendo demovido disso pela voz do narrador, que lhe apresenta uma solução, ela própria encontrada nos livros ${ }^{4}$.

Se no século XVIII sobrevivia o desprestígio do conhecimento, a difusão do princípio contrário entre as autoridades e intelectuais da ordem tornou-se incontestável e disseminou-se na sociedade. A valorização do saber e dos livros permeia o Reino da Estupidez, de Francisco de Mello Franco, defensor de Pombal e crítico de Dona Maria I, como se mostrou no Capítulo 3. Além disso, o supracitado Bordalo em sua obra, procurou superar a imagem do livro como fonte de um saber que traz malefícios, projetando nele a solução para esses últimos. Esses exemplos parecem expressar a difusão do prestígio do livro e do saber na sociedade, ou mais precisamente, nas camadas proprietárias. Antes mesmo das reformas educacionais pombalinas, "a população branca, sobretudo a pertencente aos segmentos superiores da sociedade, vinha dando alguma educação aos jovens, obtida principalmente nos centros urbanos, longe dos pais": : a instrução, além de inscrever-se numa civilidade das aparências, constituindo um apanágio dos privilegiados que ostentavam as insígnias obtidas, abria portas para a conquista de cargos para aqueles que podiam e almejavam ascender, sendo, portanto, um elemento de reforço do status ou de sua melhoria e, ainda, de sua ostentação ${ }^{6}$.

No século XVIII, a valorização da escola na Colônia cresceu, particularmente em Minas Gerais, certamente sob o impacto do florescimento de uma civilização de moldes mais urbanos. Embora seja difícil avaliar o apreço pela instrução escolar na Colônia, é possível alinhavar algumas impressões sobre a região Sudeste, a partir de meados do século XVIII. Nas elites, entre os proprietários de terras e lavras e os grandes comerciantes, assistiu-se a um maior devotamento à instrução. Mesmo dentro de tão estreito espectro social, a acreditar-se na observação do viajante Auguste SAINT-HILAIRE, entretanto, esse apreço distribuiu-se de modo irregular. Muitos dos comerciantes europeus estabelecidos no Brasil eram rústicos, não sabiam

\footnotetext{
Brasiliense, 1991, p. 61.

${ }^{4}$ Ibidem, p. 74-75.

5 Ibidem, p. 31.

${ }^{6}$ Nos colégios jesuíticos, prestigiavam-se às cerimônias de outorga dos graus acadêmicos, nas quais se usavam as insígnias correspondentes; os alunos, em fins do século XVII, exibiam-nas em outras ocasiões, igualmente públicas, mas não oficiais.
} 
sequer ler e escrever; tendo começado do nada, ao se tornarem ricos, conservavam-se no mesmo estado. No início do século XIX, os cafeicultores do vale do Paraíba fluminense possuíam perfil similar: nada gastavam com a educação dos filhos. Em Minas Gerais, no período de maior opulência do ouro, os proprietários fizeram, muitas vezes, sacrifícios para educar os filhos: enviavam-nos à Universidade de Coimbra, a fim de capacitá-los a ocupar altos cargos e, quando não tinham posses suficientes, matriculavam-nos no Seminário de Mariana ${ }^{7}$. Além do desejo de garantir um futuro melhor para os filhos, esses pais moviam-se por preconceitos: temiam que eles não herdassem "os estímulos da honra”, mas os costumes dos negros, mulatos e gentios $^{8}$.

Se ao longo do período colonial observou-se uma mudança de postura da parte do Estado e da sociedade em relação ao saber e aos livros, verificando-se uma tendência crescente de valorização de ambos, superando em parte os temores onipresentes nos momentos iniciais da colonização, ficam algumas interrogações sobre a situação dos usos dos livros pelos leitores. Que usos esses últimos atribuíam aos livros na Colônia? Houve alguma modificação nesses usos durante a Época do Reformismo Ilustrado, acompanhando os progressos da valorização do saber? Neste capítulo, procurar-se-á responder a essas perguntas. Assim, primeiramente, serão abordados os usos implícitos, aqueles inferidos a partir dos gêneros, da distribuição da posse e da circulação das obras. Para tanto far-se-á um exame da distribuição da posse de livros e da tônica da composição das bibliotecas, do século XVI aos inícios do século XIX, detalhando-se a situação de duas localidades específicas, num tempo mais limitado: Rio de Janeiro e Mariana, do Setecentos até a Independência. Num segundo momento, serão focalizadas as utilidades mais concretas e efetivas que lhes foram dadas pelos leitores, os usos explícitos: o ponto de partida será a recuperação das concepções de uso construídas pelos próprios leitores em correspondências, obras literárias e, fundamentalmente, em requerimentos enviados, da América e do Reino, aos tribunais censórios portugueses, entre 1768 e 1808; depois, analisar-se-ão as apropriações inventivas que os leitores fizeram dos textos, ao longo de todo o

\footnotetext{
${ }^{7}$ SAINT-HILAIRE, Auguste. Segunda viagem do Rio de Janeiro a Minas Gerais e São Paulo, 1822. Trad. Vivaldi Moreira. Belo Horizonte: Itatiaia; São Paulo: Edusp, 1974, p. 43, 80 e 103.

${ }^{8}$ CARRATO, José Ferreira. Igreja, Iluminismo e escolas mineiras coloniais. São Paulo: Companhia Editora Nacional: Edusp, 1968, p. 101-104.
} 
período colonial, destacando-se em particular as leituras heréticas, recolhidas de modos diversos pela Inquisição portuguesa.

Nessa última etapa, é preciso advertir, não há a pretensão de resgatar genuínas manifestações dos leitores reinóis e coloniais. Primeiro, porque a própria documentação é fragmentária, descontínua no espaço e no tempo e, ainda, concentrase em grande parte na segunda metade do século XVIII (o recuo para tempos distantes da Época das Luzes constitui apenas uma estratégia para identificar os traços específicos do Setecentos e dos inícios do século XIX). Na parte referente às concepções de uso dos leitores, ademais, a expectativa limita-se apenas a apreender os usos plausíveis dos livros. Isto porque as concepções citadas foram extraídas em grande parte de requerimentos encaminhados aos tribunais censórios pelos proprietários de livros, contendo portanto justificativas para seus intentos de ler, transportar ou possuir determinados livros, em alguns casos, proibidos, num período determinado, isto é, de 1768 a 1808. Como justificativas que foram, contêm aquilo que os leitores sabiam que agradaria aos tribunais censórios; seu conteúdo foi pensado pelos mesmos com vista ao atendimento das solicitações que realizavam, embora expressem, em muitos momentos, sentimentos e posições extremamente pessoais dos requerentes. Como justificativas feitas entre 1768 e 1808, além disso, com segurança servem para pensar nos usos plausíveis nesse exato período e possíveis antes dele.

Já a abordagem das práticas de leitura tem como propósito aproximar-se de um campo delimitado das apropriações dos textos feitas pelos leitores: aquelas referentes às leituras ilícitas, particularmente as heréticas. Este limite é um imperativo da própria documentação utilizada, marcadamente inquisitorial: na medida em que essa última constitui, sobretudo, o repositório de leituras que ultrapassaram a barreira da legalidade e se aproximaram perigosamente da heresia, ela abre espaço principalmente para as práticas ilícitas, mais precisamente para as leituras que se engastam em proposições heréticas. O objetivo, assim, é tratar das apropriações inventivas dos livros, em especial as de caráter herético, principalmente durante o período do Reformismo Ilustrado. Portanto, da primeira à última parte deste capítulo, dos usos implícitos aos usos explícitos, afunila-se a perspectiva: das leituras em geral passa-se para o particular das leituras inventivas. Afunila-se a 
perspectiva, reduz-se o campo dos usos e, ao mesmo tempo, ilumina-se o potencial subversivo dos livros, dos leitores e das leituras.

\section{Posse e composição das bibliotecas na América: usos implícitos dos livros}

Na América Portuguesa, os leitores atribuíam aos livros, subentendendo-se aqui toda a sorte de impressos, múltiplas utilidades. Enquanto objetos de leitura, os impressos eram fontes de conhecimento, de deleite, meios de acesso ao sagrado e elementos de ornamentação. Os livros, ademais, afiguraram-se como fatores de poder, contribuindo para que seus leitores questionassem ou, inversamente, para que viessem a reforçar a ordem estabelecida, fosse ela política, sexual, religiosa ou econômica, nos âmbitos privado e público. Para os leitores, os livros, assim, inscreviam-se em relações de saber, poder e prazer, sendo importantes nas vidas privada e pública, definindo redes de sociabilidade. Nesses usos é possível antever similitudes com o que se observa na realidade contemporânea, mas ao contrário do que se pode imaginar à primeira vista, eles não eram então universais. Depois de Gutemberg, os usos apontados para os livros generalizavam-se, é verdade, mas nas sociedades Ocidentais; não valiam nem para a Coréia, nem para a China, onde os produtos dos prelos eram reservados ao uso exclusivo da administração do soberano 9 .

\subsection{Séculos XVI e XVII}

Na América Portuguesa no século XVI, havia poucos livros, conforme sugerem os poucos e dispersos testemunhos que restaram sobre o assunto. O número de proprietários de livros era extremamente pequeno e, ainda, cada um deles tinha uma quantia muito reduzida de volumes, em grande parte referentes à religião e, também, à literatura, destacando-se em cada um desses campos, respectivamente, o Flos Sanctorum e A Diana, obra luso-castelhana de projeção européia de autoria do poeta Jorge de Montemor ${ }^{10}$. A exceção nesse quadro de penúria livresca talvez tenha

\footnotetext{
${ }^{9}$ CHARTIER, Roger. Introdução: a cultura do objeto impresso. In: CHARTIER, Roger (coord.). As utilizações do objecto impresso. Algés [Portugal]: Difel, 1998, p. 9-10.

${ }^{10}$ MORAES, Rubens Borba de. Livros e bibliotecas no Brasil Colonial. São Paulo: Secretaria da Cultura, Ciência e Tecnologia do Estado de São Paulo, 1973, p. 23; ARAÚJO, Jorge de Souza. O
} 
sido a França Antártida, onde havia livros de inspiração calvinista: segundo relatos dos jesuítas Manoel da NÓBREGA e José de ANCHIETA, ao esmagarem a efêmera colônia francesa, os portugueses encontraram um missal com imagens roídas e uma multidão de livros calvinistas; na mesma colônia, conforme Pero de Vila Nova, que nela viveu por algum tempo, vindo a estabelecer-se depois na Bahia, usavam-se livros para ensinar a "seita luterana" e realizar as cerimônias religiosas ${ }^{11}$. Contudo, o maior proprietário de livros, no século XVI, não foi nem português, nem francês, mas, como sublinha Luiz MOTT, provavelmente o italiano Rafael Olivi, estabelecido em Ilhéus, dono de 27 volumes $^{12}$.

No século XVII, a situação da posse de livros praticamente não se modificou em relação ao século anterior. O historiador Alcântara MACHADO debruçou-se sobre cerca de 450 inventários, feitos em São Paulo entre 1578 e 1700, encontrando livros em 15. Somando os livros relacionados nesses 15 inventários, chegou-se a um total de 55 títulos. Em sua maior parte, eram obras devocionais, dentre elas: Horas de rezar em linguagem, Floro Cristiano e Imagem da Vida Cristã, de Frei Heitor Pinto. Em termos de literatura profana, havia títulos como: Crônica do Grão Capitão, de Gonçalo de Córdova, e Novelas, de Miguel de Cervantes. A única obra jurídica encontrada foi Ordenações do Reino. Como didáticos, relacionavam-se, dentre outros, Tratado Prático de Aritmética, e Prosódia, obra de Bento Pereira ${ }^{13}$. Além disso, na América Portuguesa em geral, alguns cristãos-novos recorriam a livros para expressar secretamente a fé judaica, sendo exemplos o Alvará dos Macabeus, livro sagrado que conta a história dos sete varões deste nome ${ }^{14}$, e Reconciliaçoens de la

perfil do leitor Colonial. Artes e Literatura, Revista de Cultura Vozes, Petrópolis, (4): 448-450, jul./ago. 1989; VAINFAS, Ronaldo (org.). Confissões da Bahia: Santo Ofício da Inquisição de Lisboa. São Paulo: Companhia das Letras, 1997, p. 97-101 e 206-207; e VAINFAS, Ronaldo. Sodomia, mulheres e Inquisição: notas sobre sexualidade e homossexualismo feminino no Brasil Colônia, p. 13 (mimeograf.). Sobre Jorge de Montemor e A Diana, veja: HOLANDA, Sérgio Buarque de. Capítulos de literatura Colonial. São Paulo: Brasiliense, 1991, p. 306-311, e FRANCO, Márcia Maria de Arruda. A correspondência entre Sá de Miranda e Jorge de Montemor. Caligrama, Belo Horizonte, 3: 129-146, novembro/ 1998.

${ }^{11}$ ANCHIETA, José de. Cartas, informações, fragmentos históricos e sermões. Belo Horizonte: Itatiaia; São Paulo: Edusp, 1988, p. 170; NÓBREGA, Manuel da. Cartas do Brasil: cartas jesuíticas I: 1549-1560. Rio de Janeiro: Imprensa Nacional, 1886, p. 174; e VAINFAS, Ronaldo (org.). Confissões da Bahia: Santo Ofício da Inquisição de Lisboa, op. cit., p. 191-194.

${ }^{12}$ MOTT, Luiz. A Inquisição em Ilhéus. Revista FESPI, Ilhéus, (10): 74-75, jul./ dez. 88/89.

${ }^{13}$ MACHADO, Alcântara. Vida e morte do Bandeirante. Belo Horizonte: Itatiaia; São Paulo: Edusp, 1980, p. 103-104.

${ }^{14}$ VAINFAS, Ronaldo. Introdução. In: Idem (org.). Confissões da Bahia: Santo Ofício da Inquisição de Lisboa, op. cit., p. 53. 
sagrada escritura, do rabino Menassé ben Israel, enviada à América portuguesa no século XVII ${ }^{15}$.

A modéstia das bibliotecas familiares e individuais do período encontrava o contraponto nos colégios jesuíticos: um inventário feito sobre os livros da biblioteca do colégio da Bahia, em 1694, registra a quantia de 3000 volumes; no Rio de Janeiro, no início do XVIII, no espaço da biblioteca, estima-se, poderiam caber 5000 livros; no Pará, em 1718, um total de 1263 volumes ${ }^{16}$. As informações referentes às bibliotecas nos séculos XVI e XVII sugerem que os livros então em circulação eram principalmente literários ou de cunho religioso e que os maiores acervos bibliográficos atendiam à rotina das atividades dos colégios jesuíticos. Os livros, portanto, constituíam fontes de conhecimento e de acesso ao sagrado. Se isso não representou apenas uso de livros ortodoxos — como se pôde inferir a partir da posse, na Guanabara, de livros calvinistas e, de modo mais disperso e subterrâneo, de textos judaicos - não significou tampouco, como se verá adiante, que os escritos ortodoxos foram usados segundo a perspectiva recomendada pela Igreja e pelo Estado.

\subsection{Do Século das Luzes à Independência}

A partir do século XVIII, assistiu-se a uma mudança tanto na posse de livros como na composição das bibliotecas. Primeiro, tem-se a impressão de que a propriedade de livros, ainda que escassa, tornou-se mais disseminada que nos séculos anteriores. Além disso, em algumas livrarias, em particular nas pertencentes a pessoas que tiveram acesso a uma educação mais esmerada, abriu-se espaço para as ciências e os saberes profanos, percebendo-se nos títulos e autores ecos da Ilustração. Mesmo assim, é importante frisar, as obras devocionais e, de resto, religiosas, no conjunto, continuaram a predominar.

O exame dos inventários no Rio de Janeiro e de Minas Gerais sugere que a propriedade de livros foi favorecida pela constituição de uma civilização urbana, com um expressivo setor de serviços e um aumento do nível educacional. No Rio de Janeiro, outro estímulo foi a elevação da cidade à condição de capital, desde 1763, do

\footnotetext{
${ }^{15}$ IANTT, Inquisição de Lisboa, Cadernos do Promotor, no 19, Livro 220, p. 20-21 (agradeço a Bruno Feitler pela gentileza de fornecer esta informação).

${ }^{16}$ GROVER, Mark L.. The book and the Conquest: Jesuit libraries in Colonial Brazil. Libraries and Culture, Austin, 28 (3): 271-273, 1993.
} 
Vice-Reino do Brasil e, de 1808 até 1821, de todo o Império Português, com o que aumentou o número de pessoas envolvidas no setor de serviços e com formação superior, para as quais a leitura era uma exigência do próprio exercício profissional. Tanto no Rio de Janeiro quanto em Minas Gerais, continuaram a ser poucos os proprietários de livros, representando parcela insignificante da população livre. A distribuição da posse de livros diferenciava-se conforme a categoria profissional e a posição social dos inventariados. A posse de livros concentrava-se entre os detentores da propriedade de terras e escravos, marcadamente entre aqueles que a conjugavam à dedicação à carreira sacerdotal, ao direito, à cirurgia e à farmácia, ou ainda, ao comércio, à navegação, aos estudos, às atividades militares e ao exercício de cargos públicos.

Em 61 inventários cariocas, todos de leigos, examinados no Arquivo Nacional, foram localizados 9 proprietários de livros, isto é, $14,75 \%{ }^{17}$. A amostragem, que compreende o período 1751-1822, privilegia o último quartel do século XVIII, exclui os clérigos e, além desses limites, é bastante acanhada em termos numéricos, motivo pelo qual os dados colhidos devem ser interpretados com reservas, ou melhor, como indicativos de tendências a serem comprovadas, como se fará a seguir, através do confronto com fontes de outros lugares e de outros tipos. $\mathrm{Na}$ Tabela I, pode-se observar que a participação dos proprietários de livros entre os inventariados no primeiro quartel do Oitocentos $(5,88 \%)$ é bastante inferior à registrada nos últimos 25 anos do século precedente (19,04\%). Dos 9 inventariados mencionados que possuíam livros, todos eles leigos (os padres não foram incluídos na investigação, como já se salientou), 3 eram proprietários de terras, casas e escravos; 2 possuíam casas e escravos e encontravam-se envolvidos, se não na extração, ao menos no comércio de pedras e metais preciosos; 3 inventariados aliavam, à posse de bens imóveis e / ou móveis, ou o título de doutor, ou a condição de licenciado em cirurgia ou de boticário; e, finalmente, um último, dedicava-se indiretamente ao comércio livreiro ${ }^{18}$.

\footnotetext{
${ }^{17}$ Arquivo Nacional (AN). Inventários (1751-1822). O universo de inventários existentes é demasiado amplo, chegando a milhares. Por problemas de organização do próprio arquivo, a seleção dos inventários foi aleatória, embora tenham-se priorizados os anos terminados em 0 e 5.

${ }^{18} \mathrm{AN}$. Inventários (ano, $\mathrm{n}^{\circ}$ do processo, caixa, maço e/ou galeria): 1796, 9215, 7162, 478; 1781, 9024, 1135,$5158 ; 795,9335,5149, \mathrm{~A} ; 1791,456,8904,2295 ; 1786,2438, \mathrm{~A} / 2298 ; 1783,22,3629, \mathrm{~A}$; 1801, 8853, -, 462; 1794, 9263, 5915, A; e 1795, 9113, 7159, 475.
} 


\begin{tabular}{|c|c|c|c|}
\hline \multicolumn{4}{|c|}{ Tabela I: Posse de Livros no Rio de Janeiro (1751-1822) } \\
\hline Anos & $\begin{array}{c}\mathbf{N}^{\mathbf{0}} \\
\text { Inventários }\end{array}$ & $\begin{array}{c}\mathbf{N}^{\mathbf{0}} \text { de Proprietários de livros } \\
\text { (Absolutos) }\end{array}$ & $\begin{array}{c}\mathbf{N}^{\mathbf{0}} \text { de Proprietários de } \\
\text { livros (Relativos) }\end{array}$ \\
\hline $1751-1775$ & 2 & 0 & $19,04 \%$ \\
\hline $1776-1800$ & 42 & 8 & $5,88 \%$ \\
\hline $1801-1822$ & 17 & 1 & $14,75 \%$ \\
\hline TOTAL & 61 & 9 & \\
\hline
\end{tabular}

Fonte: Arquivo Nacional, "Inventários”, 1751-1822.

O decréscimo da posse de livros verificado nos inícios do século XIX entre os inventariados do Rio de Janeiro, em teoria, invalidaria a associação feita inicialmente entre a difusão da propriedade de livros e o alegado aumento da expressão do setor de serviços e dos indivíduos com formação universitária, a partir da instalação da Corte em 1808. A participação diferenciada, no interior da amostragem, dos indivíduos com esse perfil nos dois períodos definidos - o último quartel do século XVIII e o primeiro do XIX -, no entanto, parece explicar isto: se no primeiro período, há, entre os inventariados, três indivíduos ou com formação universitária ou ligados ao setor de serviços (um doutor-advogado, um licenciado e uma sogra de um livreiro), no segundo, há apenas um (um boticário). Todos eles, saliente-se, eram proprietários de livros. A explicação, assim, está na própria limitação da amostragem dos inventários.

As cifras referentes à distribuição da posse de livros no Rio de Janeiro diferem pouco das encontradas para Diamantina e Mariana, em Minas Gerais. Num total de 66 inventários de Diamantina, Júnia FURTADO localizou livros em 14 $(20 \%)^{19}$. Nesses inventários, os padres e os funcionários graduados da Real Extração rivalizavam quanto à posse de livros: três padres e três funcionários possuíam livros, correspondendo cada um desses dois grupos a $20 \%$ dos proprietários de livros ${ }^{20}$. Em Mariana, foram examinados todos os inventários de leigos e clérigos existentes no cartório do segundo ofício, referentes ao período que se estende de 1714 a 1822 , chegando-se a um total de 911 documentos. Classificando-se os inventariados em 9 categorias - clérigos, advogados, boticários, cirurgiões, mercadores, licenciados (sem que se pudesse identificar suas áreas de atuação), militares de ordenança ou de tropa paga, proprietários de bens imóveis (terras agrícolas e/ou casas e/ou terras minerais) sem patente ou ofício, e, por fim, inventariados sem ofício, patentes ou

\footnotetext{
${ }^{19}$ FURTADO, Júnia. O livro da capa verde: o regimento diamantino de 1771 e a vida no distrito diamantino no período da Real Extração. São Paulo: Anna Blume, 1996, p. 54-55.
} 
bens imóveis - constatou-se que o perfil dos proprietários de livros de Mariana muito se aproxima do observado em Diamantina e no Rio de Janeiro (ressalvando-se, nesta última cidade, os clérigos), confirmando-se em parte a hipótese lançada por Sílvio Gabriel DINIZ, segundo a qual eram os burocratas do governo da Capitania, os ouvidores das comarcas, os advogados ou bacharéis e os clérigos que constituíam as elites culturais ${ }^{21}$.

Conforme mostra a Tabela 2, dentre os inventariados (911), os proprietários de biblioteca eram $76(8,34 \%)$, dos quais 71 (93,42\% dos inventariados com livros) eram brancos e livres; 1 , mulato e livre; 1, negro e forro; e os 3 restantes não tinham cor e condição especificadas. As mulheres somavam 9 (11,84\%), enquanto os homens chegavam a $67(89,15 \%)$. Os clérigos formavam a categoria, em termos numéricos, mais expressiva dentre os proprietários de livros. De um total de 37 clérigos inventariados, 22 possuíam livros, o que corresponde a 59,45\% do número de padres, $28,94 \%$ do conjunto de inventariados com livros e $2,41 \%$ da soma dos inventariados no período considerado. Logo em seguida, vinham os proprietários de bens de raiz sem ofício ou patentes e, depois, os detentores de patentes militares, perfazendo as seguintes cifras, respectivamente: 21 (3,79\% da categoria, 27,63\% dos possuidores de livro e 2,30\% dos inventariados) e 17 (13,38\% da categoria, 22,36\% dos donos de livros e 1,86\% dos inventariados). Na terceira e quarta colocações, estavam os boticários e os inventariados que não tinham nem bens de raiz, nem patentes, nem ofícios, respectivamente com os seguintes números: 6 (75\% da categoria, $7,89 \%$ dos proprietários de livros e $0,65 \%$ dos inventariados) e 4 (2,25\% do grupo, 5,36\% dos proprietários de livros e 0,43\% dos inventariados).

\footnotetext{
${ }^{20}$ Ibidem, loc. cit.

${ }^{21}$ DINIZ, Sílvio Gabriel. Biblioteca setecentista nas Minas Gerais, Revista do Instituto Histórico e Geográfico de Minas Gerais, Belo Horizonte, (6): 334, 1959.
} 


\begin{tabular}{|c|c|c|c|c|c|c|}
\hline \multicolumn{7}{|c|}{ Tabela II - Posse de Livros em Mariana (1714-1822) } \\
\hline \multirow[b]{2}{*}{ Categoria/ Ofício } & \multicolumn{2}{|c|}{\begin{tabular}{|c|}
$\mathbf{N}^{\mathbf{0}} \mathrm{de}$ \\
Inventariado \\
$\mathrm{S}$
\end{tabular}} & \multicolumn{4}{|c|}{$\mathrm{N}^{\circ}$ de Inventariados com Livros } \\
\hline & Abs & $\%$ & Abs & $\begin{array}{c}\mathbf{\%} \\
\text { (Categoria } \\
\text { ) }\end{array}$ & $\begin{array}{c}\% \\
\text { (prop. de } \\
\text { livros) }\end{array}$ & $\begin{array}{c}\% \\
\text { (Total) }\end{array}$ \\
\hline Clérigos* & 37 & $4,06 \%$ & 22 & $59,45 \%$ & $28,94 \%$ & 2,41 \\
\hline Advogados & 3 & $0,32 \%$ & 3 & $100 \%$ & 3,94 & 0,32 \\
\hline Boticários** & 8 & $0,87 \%$ & 6 & $75 \%$ & $7,89 \%$ & $0,65 \%$ \\
\hline Cirurgiões*** & 1 & $0,10 \%$ & 1 & $100 \%$ & $1,31 \%$ & $0,10 \%$ \\
\hline Mercadores & 2 & $0,21 \%$ & 1 & $50 \%$ & $1,31 \%$ & $0,10 \%$ \\
\hline Licenciados (sem especificação) & 3 & $0,32 \%$ & 1 & $33,33 \%$ & $1,31 \%$ & $0,10 \%$ \\
\hline $\begin{array}{l}\text { Militares de Ordenanças e de } \\
\text { Tropa Paga }\end{array}$ & 127 & $\begin{array}{c}13,94 \\
\%\end{array}$ & 17 & $13,38 \%$ & $22,36 \%$ & $1,86 \%$ \\
\hline $\begin{array}{l}\text { Proprietário de bens imóveis, } \\
\text { sem ofício ou patente }\end{array}$ & 553 & $60,7 \%$ & 21 & $3,79 \%$ & $27,63 \%$ & $2,30 \%$ \\
\hline $\begin{array}{l}\text { Sem ofício, patentes ou bens } \\
\text { imóveis }\end{array}$ & 177 & $\begin{array}{c}19,42 \\
\%\end{array}$ & 4 & $2,25 \%$ & $5,, 26 \%$ & $0,43 \%$ \\
\hline SUBTOTAIS & 911 & 100 & 76 & - & $99,92 \%$ & $9,59 \%$ \\
\hline
\end{tabular}

Fonte: Arquivo da Casa Setecentista de Mariana, $2^{\circ}$ Ofício, Inventários, 1714-1822.

Depois, encontravam-se os advogados, os cirurgiões, os mercadores e os licenciados, cada uma dessas categorias respectivamente com as seguintes cifras: 3 (100\% da categoria, 3,94\% dos possuidores de livros e 0,32\% dos inventariados), 1 (100\% da categoria, $1,31 \%$ dos donos de livros e $0,10 \%$ dos inventariados), 1 (50\% da categoria, $1,31 \%$ dos possuidores de livros, e $0,10 \%$ dos inventariados) e 1 ( $33 \%$ da categoria, $1,31 \%$ dos proprietários de livros e $0,10 \%$ dos inventariados $)^{22}$.

${ }^{22}$ Arquivo da Casa Setecentista de Mariana (ACSM), $2^{\circ}$ Ofício, Inventários (Ano, Códice, Auto): $1802,20,529 ; 1795,21,544 ; 1759,21,553 ; 1800,23,589 ; 1812,24,610 ; 1814,25,628 ; 1810,33$, $777 ; 1789,34,801 ; 1816,35,823 ; 1786,77,1663 ; 1809,88,1906 ; 1782,50,1141 ; 1821,117,2357$; $1819,46,1034 ; 1814,44,991 ; 1815,101,2142 ; 1774,129,2602 ; 1811,84,1814 ; 1805,81,1736$; $1807,97,2076 ; 1813,123,2478 ; 1822,117,2356 ; 1774,83,1774 ; 1788,87,1871 ; 1806,86,1847$; $1819,83,1776 ; 1811,136,2761 ; 1798,51,1162 ; 1803,76,1648 ; 1765,67,1474 ; 1819,60,1351$; 
Se os indivíduos que possuíam imóveis, sem ofício definido, se aqueles que detinham patentes militares e, por fim, se os inventariados que não tinham nem essas nem aqueles, despontavam à frente de advogados, cirurgiões e boticários dentre os possuidores de livro, é importante lembrar como se dava a distribuição dos que tinham bibliotecas dentro de cada categoria. Nessa comparação, fica evidente que advogados, cirurgiões, boticários e licenciados, juntamente com os clérigos, passavam à frente dos demais, na medida em que entre $33 \%$ e $100 \%$ dos membros de cada uma dessas categoria se enquadravam na condição de dono de livros. Isso leva à suposição de que para essas categorias o livro era um elemento essencial no exercício profissional. A composição das bibliotecas de Mariana, no geral, confirma esta hipótese, na medida em que, como se verá a seguir, os livros guardavam laços estreitos com os ofícios dos inventariados que os possuíam, isto é, a maior parte dos livros que compunham um número expressivo de bibliotecas referiam-se às áreas de atuação profissional dos inventariados. O exame mais apurado da composição de bibliotecas identificadas na documentação censória, também a ser feito adiante, converge para a mesma conclusão. Fica, portanto, destacado - e, de certo modo, antecipado - um uso importante do livro no período colonial: como fonte de saberes relativos ao exercício profissional.

Outros aspectos que merecem ser apontados na descrição do perfil dos proprietários de livros de Mariana dizem respeito à escravaria que esses possuíam, ao valor total dos seus bens e, ainda, à relação entre as categorias de ofício e a posse de bens de raiz. Todos os cirurgiões, mercadores e boticários que tinham livros, também eram detentores de bens de raiz, enquanto o mesmo acontecia entre $19(86,3 \%)$ dos 22 clérigos e 12 (70,58\%) dos 17 militares. Enquanto os monte-mores (isto é, a soma do valor dos bens, descontadas as dívidas) máximo, médio e mínimo do conjunto dos inventariados correspondiam à $64: 144 \$ 544,00,2: 649 \$ 152,35$ e 0 (zero); entre os proprietários de livros, atingiam, respectivamente, 64:144\$544,00, 6.310\$686,24 e $71 \$ 778,00$, demonstrando que, na média, os donos de bibliotecas eram mais

$1771,69,1517 ; 1814,56,1283 ; 1795,61,1363 ; 1786,54,1230 ; 1762,57,1284 ; 1822,95,2033$; $1783,74,1615 ; 1822,72,1565 ; 1796,66,1456 ; 1770,66,1457 ; 1819,72,1566 ; 1815,54,1220$; $1789,92,1978 ; 1753,85,1826 ; 1730,78,1674 ; 1805,78,1681 ; 1743,116,2327 ; 1738,91,1959$; $1787,46,1027 ; 1799,95,2033 ; 1756,41,941 ; 1811,87,1878 ; 1818,59,1344 ; 1811,45,1009 ; 1722$, 45,$1012 ; 1790,101,2143 ; 1817,32,767 ; 1813,116,2332 ; 1807,84,1810 ; 1807,134,2708 ; 1803$, 53,$1202 ; 1817,50,1134 ; 1822,50,1133 ; 1782,59,1332 ; 1821,127,2556 ; 1817,32,770 ; 1814,49$, $1128 ; 1801,95,2030 ; 1816,120,2421 ; 1819,70,1534 ; 1819,79,1690 ; 1777,46,1045 ; 1806,86$, $1852 ; 1812,49,1109 ; 1770,140,2815$. 
aquinhoados do que os demais inventariados. Os números máximo, médio e mínimo de escravos reforçam a mesma conclusão: entre os inventariados, têm-se, respectivamente 193, 10,16 e 0 (zero) escravos; já entre os que possuíam livros, vêem-se 146, 20,63 e 0 (zero) escravos. Se o número máximo de escravos entre os inventariados era maior do que aquele verificado entre os que detinham bibliotecas, na média os últimos possuíam mais escravos. Desses números, enfim, conclui-se que o típico proprietário de bibliotecas em Mariana somava a posse de bens de raiz à dedicação ao sacerdócio, às atividades militares, à botica, à advocacia, ao comércio e à cirurgia; do que se supõe ser o livro usado, em grande parte, como fonte de conhecimento para o exercício profissional. O predomínio de proprietários de livros com esse perfil elitizado, todavia, não excluiu totalmente a possibilidade de indivíduos situados em posição inferior da escala social terem acesso à propriedade de bibliotecas. Como se viu, dois inventariados eram "homens de cor"; ambos não dispunham de bens de raiz: um deles era mulato, tendo um patrimônio líquido de $656 \$ 208,50$ e apenas um escravo (números bem inferiores à média apresentada pelos proprietários de livros); e o outro era negro forro, detendo um patrimônio de $1.137 \$ 875,00$ e 5 escravos (números também abaixo da média encontrada entre os que possuíam livros). Esse último inventariado era alfabetizado (ou melhor, capaz de assinar o próprio nome) e, dentre seus bens, havia pratarias, louças e jóias ${ }^{23}$.

No Gráfico XIII, é possível acompanhar a evolução da posse de livros entre os inventariados de Mariana, entre 1714 e 1822. Observando-se as linhas correspondentes aos inventariados e, em paralelo, aos proprietários de livros e aos inventariados cujos ofícios, via de regra, se associam com livros (clérigos, advogados, cirurgiões, boticários, licenciados e mercadores), constata-se uma elevação comum dos números, quando se vai do início ao fim do período. Os ritmos desse crescimento, no entanto, foram desiguais. A proporção de proprietários de livros no número total de inventariados variou ao longo do período: no primeiro subperíodo (1714-1730), era de 8,33\%; no segundo (1732 a 1745), 5,12\%; no terceiro (1746 a 1760), 6,12\%; no quarto (1761-1775), 10,14\%; no quinto (1776 a 1790), 6,43\%; no sexto (1791 a 1805), 5,76\%; e, por fim, no último (1805 a 1822), $11 \%$. Até 1775 , portanto, oscilou-se entre $5,12 \%$ e $8,33 \%$, caindo-se logo em seguida para cifras em torno de 6\%. Entre 1806 e 1822, porém, a participação dos donos de

${ }^{23}$ ACSM, $2^{\circ}$ Ofício, Inventários (códices, autos e anos): 87, 1888, 1788; e 123, 1813, 2478. 
bibliotecas entre os inventariados aumentou, atingindo o nível mais elevado durante o período examinado $11 \%$.

No Gráfico XIII, comparando-se a linha referente aos inventários com livros à relativa aos inventariados cujos ofícios envolvem contato mais estreito com impressos, vê-se que o crescimento da participação dos donos de biblioteca a partir de 1805 tem uma explicação: acompanha o aumento da proporção dos indivíduos que se dedicavam aos ofícios supracitados no conjunto dos inventariados; eles eram 8 entre 1776 e 1790 (4,67\%), pulando para 31 (8,75\%) no último subperíodo. O ritmo de crescimento similar observado nas linhas referentes aos inventariados proprietários de livros e aos inventariados clérigos, boticários, cirurgiões, licenciados e mercadores, dessa forma, é mais um elemento que mostra a intimidade dessas categorias com os livros. Além disso, sugere que para as mesmas os livros tinham uma utilidade profissional, como se pretende comprovar adiante.

Embora a elevação do número de proprietários de bibliotecas em Mariana, entre 1714 e 1822, seja oposta à tendência de decréscimo observada no Rio de Janeiro, entre 1750 e 1822, pode-se compreender essa diferenciação à luz da presença distinta, entre os inventariados das duas cidades, nos subperíodos em questão, dos indivíduos ligados ao sacerdócio, botica, cirurgia, advocacia e comércio: entre os inventariados de Mariana, essa presença aumentou, ocorrendo o inverso no Rio de Janeiro. As porcentagens de proprietários de livros obtidas para Rio de Janeiro, Diamantina e Mariana, respectivamente, $14,5 \%, 20 \%$ e 8,34\%, como se vê, são bastante diferentes entre si, sendo mais baixa a da Leal Cidade, justamente a localidade em relação a qual se consultou um maior número de inventários. As mesmas porcentagens, ademais, encontram-se muito distantes — o que está dentro das expectativas - das apresentadas pela França setecentista: 33\% dos inventariados, nas cidades do oeste francês, e 22,6\%, em Paris, no anos 1750, possuíam livros ${ }^{24}$.

\footnotetext{
${ }^{24}$ CHARTIER, Roger. Lectures et lecteurs dans la France d'Ancien Régime, op.cit., p. 167-168.
} 


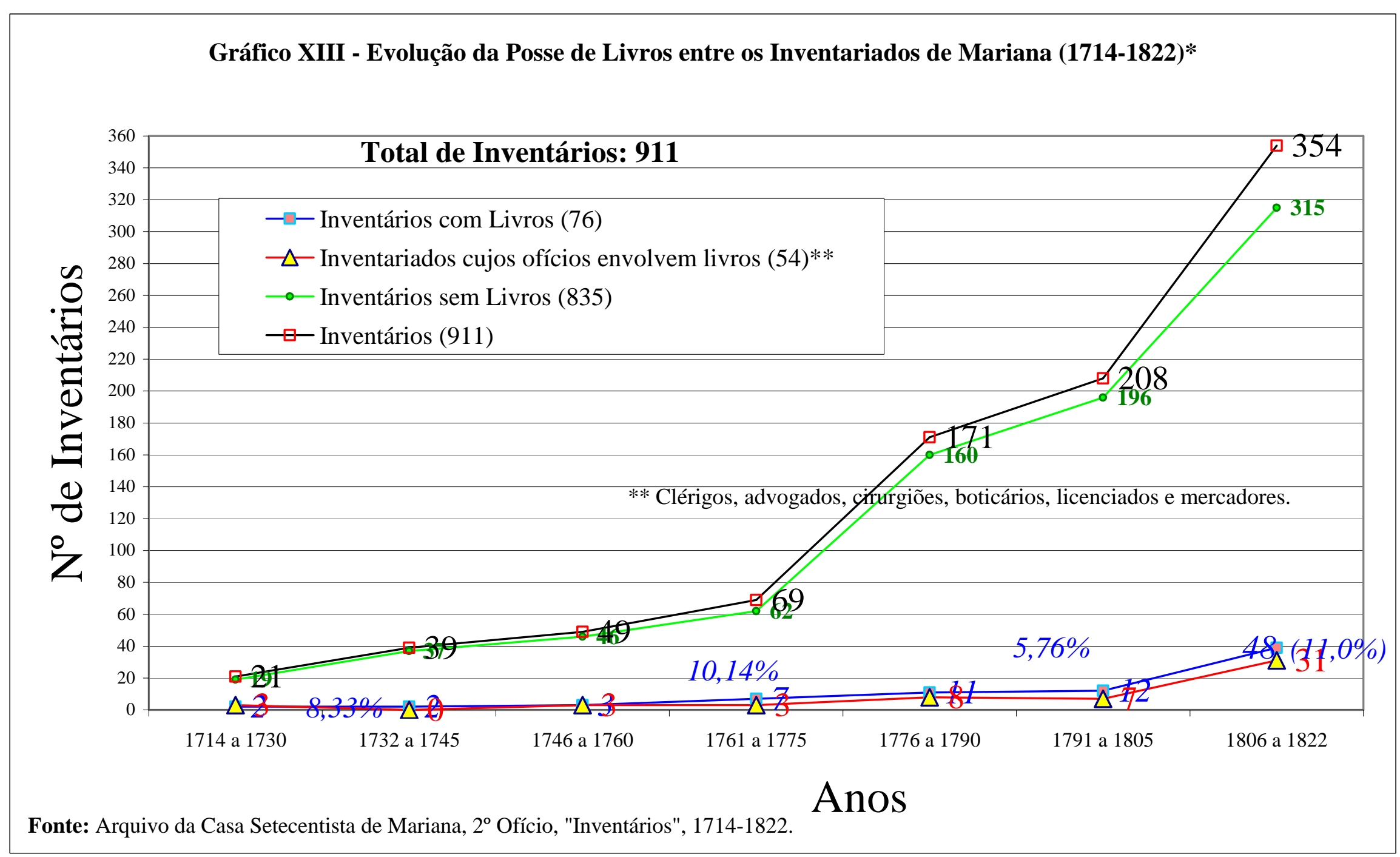


Em outros tipos de documentação, como a inquisitorial e censória, o perfil de proprietário de livro típico apresenta-se bastante similar ao dos inventariados do Rio de Janeiro e Mariana. Dentre 53 indivíduos que saíram de portos da América Portuguesa (Bahia, Rio de Janeiro, Pernambuco, Pará e Maranhão) em direção a Portugal levando consigo suas bibliotecas, ou então, que tiveram as mesmas mandadas para a metrópole, ou ainda, que mandaram livros para o Reino como objeto de transações comerciais, entre 1769 e 1820, registrando dados sobre essas remessas em listas enviadas aos órgãos censórios: 13 estavam vinculados ao comércio livreiro; 10 eram advogados; 8, clérigos; 6, cirurgiões-médicos; 6, navegadores; 2 , estudantes; 2 , pertenciam à nobreza; 1 , boticário; 1 , alto funcionário da burocracia estatal; e, por fim, 4 não declararam ou forneceram pistas mais consistentes sobre sua ocupação ou sua posição social ${ }^{25}$. Descontando-se os livreiros e seus agentes, portanto, os advogados, os clérigos e os médicos destacavam-se, do ponto de vista numérico, na documentação censória em questão, entre os proprietários de livros, reiterando o perfil de proprietário típico de livro elaborado a partir dos inventários de Mariana. A grande diferença reside na presença dos navegadores, que, obviamente, não poderiam aparecer no coração de Minas Gerais.

Esses últimos números, colhidos na documentação censória, é importante advertir, não devem ser tomados como expressão exata da distribuição da posse de livros na Colônia. Eles permitem observar a difusão da propriedade de livros entre os grupos profissionais e as ordens que mais se deslocavam do Reino para a Colônia e vice-versa ou que faziam da relação entre os dois lados do Atlântico o seu ofício: os mercadores de livros e seus agentes, que desenvolviam suas transações entre o Reino e América; os advogados que haviam saído de Portugal para ocupar cargos na magistratura na Colônia e que retornavam à metrópole; os estudantes que iam complementar seus estudos em Coimbra e que voltavam à sua "pátria" formados; os nobres que vinham cá para exercer funções administrativas e militares; os navegadores e médicos-cirurgiões das embarcações, cuja vida marcava-se essencialmente pela rotina das viagens; e, ainda, os padres que iam e vinham seja para desenvolver o ministério pastoral, seja para o exercício de funções na administração eclesiástica.

${ }^{25}$ IANTT, Real Mesa Censória, caixas 144 e 149. 
Dos 130 cristãos-novos cujos bens foram confiscados pela Inquisição no século XVIII, conforme rol feito por Anita NOVINSKY, 15 possuíam livros $(11,5 \%)$, dentre os quais 6 eram advogados; 1 , mercador; 5 , médicos; 1 , tendeiro; e 2, proprietários de terras, plantadores de cana. Esses indivíduos, em sua maioria, eram naturais e/ou moradores do Rio de Janeiro, Bahia e, num único caso, Minas Gerais ${ }^{26}$. Essa distribuição da posse de livros, exceto pela ausência compreensível dos clérigos entre os proprietários — os estatutos de "pureza de sangue", embora nem sempre tenham sido respeitados, vedavam o acesso dos que tivessem ascendência judaica ao sacerdócio $^{27}$ - converge com a encontrada nos inventários de Mariana e do Rio de Janeiro e na documentação censória referente a portos do Sudeste, Norte e Nordeste da Colônia. Enfim, a partir desses três tipos de fontes, referentes a localidades distintas da América, pode-se concluir que, dentre os proprietários de livros na Colônia, destacavam-se os advogados, clérigos, médicos, boticários, navegadores e militares, além, é claro, dos mercadores de livros. Esse perfil típico de proprietário de livros, sublinhe-se mais uma vez, conduz à hipótese de que os livros possuíam, aos olhos dos leitores, um uso de natureza profissional, subsidiando-os com conhecimentos necessários para o exercício dos ofícios aos quais se dedicavam.

A composição das bibliotecas supracitadas de Mariana e daquelas enviadas da América para Portugal, todas elas datadas dos século XVIII e do primeiro quartel do século XIX, conduz também à conclusão de que os livros eram, em grande parte, fontes de conhecimento necessários para o exercício profissional, embora servissem, à semelhança do que se verificava freqüentemente nos séculos XVI e XVII, para a vivência da fé e para o desenvolvimento de estudos escolares. Idêntica conclusão é produzida pelos dados referentes ao comércio livreiro - nesta tese, far-se-á menção superficial ao comércio de livros da América para Portugal e também às transações de sentido inverso, isto é, da metrópole para a Colônia, neste caso, porém, restringindo o enfoque aos impressos de baixo valor econômico.

Um dos primeiros aspectos referentes à composição das bibliotecas que salta aos olhos refere-se ao número de livros e volumes das mesmas. Em Mariana, nas 76

\footnotetext{
${ }^{26}$ NOVINSKY, Anita. Inquisição: inventários de bens confiscados a cristãos-novos: fontes para a história de Portugal e do Brasil. Lisboa: Imprensa Nacional/ Casa da Moeda; Rio de Janeiro: Camões, [1976].

${ }^{27}$ VILLALTA, Luiz Carlos. A "torpeza diversificada dos vícios": celibato, concubinato e casamento no mundo dos letrados de Minas Gerais (1748-1801). São Paulo: FFLCH-USP, 1993 (Dissertação de mestrado), p. 61-114.
} 
bibliotecas encontradas em 911 inventários do cartório do $2^{\circ}$ ofício feitos entre 1714 e 1822, contabilizam-se 1253 obras, algumas delas repetindo-se com maior ou menor freqüência entre um inventariado e outro, perfazendo um total de 2031 volumes. $\mathrm{Na}$ composição das bibliotecas marianenses havia, assim, um número médio de 16,48 obras e 26,72 volumes. Os números mínimo e máximo de livros por livraria eram bastante diferentes. A maior biblioteca pertencia ao doutor José Pereira Ribeiro, advogado citado nos autos de devassa da Inconfidência Mineira como possuidor da Histoire philosophique et politique des etablissements et du commerce des européens dans les deux Indes, do abade Raynal: contava com 211 títulos e 476 volumes ${ }^{28}$. Na segunda colocação estava a biblioteca do padre Manuel da Cunha Osório, professor do colégio do Sumidouro, termo de Mariana, que reunia 125 títulos. Na terceira posição, ficava a biblioteca do coronel João Batista de Figueiredo Leitão (73 títulos e 125 volumes); logo em seguida, empatadas, com 64 títulos cada uma, encontravamse as bibliotecas do padre Francisco Soares Bernardes (130 volumes) e do advogado Jacinto de Figueiredo Vieira de Andrade (162 volumes $)^{29}$. Esses números estão bastante distantes dos apurados em outras duas bibliotecas mineiras coloniais: a do bispo de Mariana D. Frei Domingos da Encarnação Pontével, falecido em Ouro Preto em 1793, que contava com 412 títulos e 1056 volumes, e a do cônego Luís Vieira da Silva, Inconfidente Mineiro, que abrigava 279 títulos e 612 volumes ${ }^{30}$.

As 11 menores bibliotecas reuniam apenas um único título cada uma. Em 5 delas, missais; e, nas restantes, cada um dos seguintes livros: Cartilha de Metal, um jogo de Breviários", Sermoens (sem especificação de autor), uma obra do médico português João Curvo de Semmedo, um livro de Alves de Faria intitulado Martinho Cedendo e um "Livro em branco com colchetes preto e capa de veludo" ${ }^{\text {. }}$. Nesse último caso, tudo indica que não se está sequer diante de uma biblioteca de obra única, na medida em que o livro em questão parece ser apenas um borrão e não um

\footnotetext{
${ }^{28}$ Sobre a biblioteca do Dr. José Pereira Ribeiro e de outros advogados nas Minas Gerais do século XVIII, veja: ANTUNES, Álvaro de Araújo. Resquícios de leitura nas práticas advocatórias setecentistas em Minas Gerais. In: CONGRESSO DE HISTÓRIA DA LEITURA E DO LIVRO NO BRASIL, I, 1998, Campinas (inédito).

${ }^{29}$ ACSM. $2^{\circ}$ Ofício, Inventários (1714-1822).

${ }^{30}$ VILLALTA, Luiz Carlos. Os clérigos e os livros nas Minas Gerais da segunda metade do século XVIII. Acervo: revista do Arquivo Nacional. Rio de Janeiro, 8 (1-2): 43, jan./dez. 1995.

31 ACSM, $2^{\circ}$ Ofício, Inventários (Ano, Códice, Auto): 1819, 60, 1351; 1805, 78, 1681; 1796, 66, 1456 ; 1815, 54, 1220; 1730, 78, 1674; 1787, 46, 1027; 1802, 20, 529; 1799, 95, 2033; 1790, 101, 2143; 1817, 32, 770; e 1819, 79, 1690.
} 
impresso; como não é possível garanti-lo, manteve-se a inclusão do registro entre as livrarias.

Deve-se salientar que os registros sobre livros feitos nos inventários de Mariana (o que não é uma particularidade local, como se sabe) não contêm, às vezes, informações minimamente precisas sobre os livros, o que cria obstáculos à investigação histórica. Em 4 inventários, assim, não se discriminam os livros possuídos pelos inventariados, usando-se as seguintes expressões genéricas: "hua Livraria com Estante, Escrivaninha e mais pertences [de] advocacia" (o significativo aqui, em termos de usos do livro, é a associação entre uma profissão, a advocacia, e a posse de livros, incluídos dentre outros "pertences" característicos daquela); "huma livraria com sua estante"; "vários Livros velhos" e "vários Livros e Breviários"32. Em 16 inventários, ainda, omitem-se ora os nomes dos autores, ora os títulos, quase sempre anotados de forma truncada, ora a quantidade de volumes, o que traz dificuldades para a quantificação ${ }^{33}$. Em função desses problemas verificados nas fontes, a identificação, classificação e quantificação dos dados referentes aos autores e títulos presentes nas bibliotecas não são exatas, apresentando algumas lacunas.

Nas bibliotecas de Mariana, os livros religiosos preponderavam, correspondendo a 503 livros e 904 volumes, respectivamente, em números relativos, $40,1 \%$ e $44,5 \%$ dos totais. Os livros, além disso, em grande parte tinham relação com as áreas de atuação profissional dos seus respectivos donos. Classificaram-se como profissionais os livros de religião (teologia, cânones, dicionários eclesiásticos, história sagrada e história eclesiástica, liturgia e devoção) para os padres; os livros de medicina, farmácia e química para boticários, médicos e cirurgiões; as obras de leis e cânones para advogados; os textos de medicina, farmácia, artes militares e história militar para militares; e, por fim, os livros religiosos e didáticos para padresprofessores. Com base nessa classificação, identificam-se 583 obras profissionais inventariadas, perfazendo um total de 954 volumes, o que equivale, em números relativos, respectivamente, a 46,5\% e 46,97\%. Das 72 bibliotecas para as quais se tem uma discriminação minimamente precisa de títulos e/ou autores, 29 apresentam

\footnotetext{
${ }^{32}$ ACSM, $2^{\circ}$ Ofício, Inventários (Ano, Códice, Auto): 1789, 92, 1978; 1816, 35, 823; 1811, 87, 1878; e 1813, 116, 2332.

33 ACSM, $2^{\circ}$ Ofício, Inventários (Ano, Códice, Auto): 1805, 81, 1736; 1813, 123, 2478; 1813, 123 , $2478 ; 1788,87,1871 ; 1819,83,1776 ; 1811,136,2761 ; 1803,76,1648 ; 1762,57,1284 ; 1783,74$, $1615 ; 1822,72,1565 ; 1753,85,1753 ; 1819,46,1034 ; 1795,21,544 ; 1817,32,770 ; 1814,49,1128$; e $1816,120,2421$.
} 
entre 50 e $100 \%$ de obras profissionais e 4 possuem cerca de $1 / 3$ de livros classificáveis na mesma categoria. Somando-se essas cifras, chega-se a 33 inventários, o que corresponde a 43,4\% dentre todos nos quais se anotam livros e a $45,8 \%$ daqueles em que o registro contém alguma precisão ${ }^{34}$. Os livros religiosos, por seu turno, além de onipresentes em 20 das 22 bibliotecas clericais ${ }^{35}$, nas quais constituíam entre $60 \%$ e $100 \%$ dos títulos, predominavam em 15 bibliotecas nãoclericais, variando de 2/3 à totalidade dos títulos nelas encontrados, os quais, é bem verdade, eram muito reduzidos: dentre as bibliotecas não-clericais em que predominavam livros religiosos, a maior tinha 39 títulos, enquanto a menor possuía apenas $1^{36}$. Tais dados, portanto, confirmam a hipótese segundo a qual os livros eram, principalmente, usados para o exercício profissional ou como instrumento de vivência de fé.

As ciências exatas e naturais - matemática, química, botânica, física, medicina, farmácia e agronomia - contavam com 106 obras e 119 volumes (respectivamente, $8,45 \%$ e $5,85 \%$ ), cifras bem mais modestas, mas, de qualquer forma, nada desprezíveis. Havia 72 livros para os quais se pode vislumbrar um papel didático, escolar ou religioso, totalizando 76 volumes (respectivamente, 5,74\% e $3,74 \%$ ). Menores ainda eram os números referentes às obras de autores Ilustrados, que chegavam a 37, com 88 volumes, o que, em números relativos, corresponde a 2,95\% e 4,33\%. Esses 37 livros de autores Ilustrados, ainda, distribuíam-se de modo muito concentrado nas bibliotecas marianenses analisadas: 26 deles pertenciam ao Dr. José Pereira Ribeiro; 4 ao padre-mestre Osório e os outros encontravam-se espalhados por mais de 6 bibliotecas, variando de 1 a 2 títulos em cada uma delas.

Avaliando-se os tipos de livro, autores e títulos mais freqüentes, primeiramente, nota-se a participação numérica sem par dos breviários, que chegam a 63, o que equivale a $5 \%$ do total de livros (é preciso lembrar que, em alguns inventários, não se especificou a quantidade de breviários, como se mencionou anteriormente, falando-se apenas em "breviários", o que sugere que a cifra obtida é bem menor do que a encontrada na realidade). Em seguida, vinham os Missais (22;

\footnotetext{
${ }^{34}$ ACSM. $2^{\circ}$ Ofício, Inventários (1714-1822).

${ }^{35}$ Nas duas bibliotecas restantes, pertencentes a André Vaz de Almeida, clérigo secular, e a Manuel Joaquim da Cunha Osório, padre e professor do colégio do Sumidouro, os livros religiosos compreendiam respectivamente 6 e 47 títulos, equivalendo a quase a metade dos encontrados em uma e a 1/3, da outra (ACSM, $2^{\circ}$ Ofício, Inventários: 1812, 49, 1109 e 1770, 140, 2815).

${ }^{36}$ ACSM. $2^{\circ}$ Ofício, Inventários (1714-1822).
} 
1,75\%); diferentes versões, livros e comentários da Bíblia (21; 1,67\%); e, ainda, diversos Livros de Horas (14; 1,14\%).

Entre os autores e/ ou títulos mais freqüentes, figuravam, em primeiro lugar, os Livros de Santa Bárbara, totalizando 34 exemplares (2,71\%), número pouco menor do que o das obras Ilustradas, atingindo o valor monetário irrisório de \$170 (cento e setenta réis). Todos esses Livros de Santa Bárbara estavam concentrados nas mãos de um único proprietário, um mercador, cujos bens foram inventariados em 1789. Como se verá adiante, tais livros foram os mais enviados para a América a partir de 1768, e o fato dos mesmos figurarem em um único inventário, não aparecendo nos demais, explica-se pelo seu baixo valor: sendo pouco valiosos, não eram dignos de figurar isoladamente nos diversos róis de bens inventariados (no inventário marianense, os citados livros aparecem porque em função de sua quantidade acabam por alcançar uma cifra economicamente digna de alguma relevância) ${ }^{37}$.

Em segundo lugar, muito distante do ponto de vista numérico, mas com distribuição não monopolizada, estava o Promptuario de Theologia Moral, de Francisco Larraga, obra que teve uma de suas edições, a de 1729, proibida pela censura portuguesa e que, como se viu, por mais de uma vez foi interceptada nas alfândegas luso-brasileiras. Bem próximo de Larraga, aparecendo 9 vezes, em 7 inventários distintos, correspondendo a $0,71 \%$ dos livros, encontravam-se Horácio, sendo algumas das obras arroladas certamente de uso nos cursos de gramática latina (Horácio Comentado, Horácio Comentario Literal, Odes, Poesias e ad usum Delphini), e Virgílio, também com obras de cunho didático (os títulos dos livros ora não aparecem, ora surgem truncados, encontrando-se nos registros apenas: Latino $e$ Francês, Público e Comentário Literal). Vinham logo atrás as Constituições Primeiras do Arcebispado da Bahia, de Dom Sebastião Monteiro da Vide e Concílio Tridentino - deve-se advertir que não é possível assegurar que este título correspondia a uma única obra —, ambas aparecendo 8 vezes, compreendendo $0,63 \%$ do total de obras.

\footnotetext{
${ }^{37}$ Os nomes de autores e os títulos das obras que se seguem foram confrontados com as informações da Bibliotheca Lusitana, de Diogo Barbosa Machado (op. cit.) e com um levantamento feito dos autores e títulos das obras publicadas antes de 1822, existentes na Biblioteca do Palácio Episcopal de Mariana.
} 
Na posição seguinte, totalizando 7 aparições ( $0,55 \%$ das obras), estavam: Conducta de Confessores no Tribunal da Penitência, obra vertida do francês em vernáculo; Ovídio, com Comentario de..., Comento de..., ad usum Delphini, Tristes e Metamorfoses, obras provavelmente de uso didático, que se distribuíam em 5 inventários; o médico português João Curvo de Semmedo, com Polianthea medicina; e Observações, livros presentes em 7 inventários. As Seletas Latinas — pode-se supor que eram de diferentes edições, na medida em que às vezes são classificadas como "nova" ou "velha" - figuram 6 vezes $(0,47 \%)$, em inventários diferentes. Com 6 menções, aparece também D. Francisco da Fonseca Henriquez Mirandella, médico português, sem que os títulos de suas obras tenham sido transcritos sempre, exceto os seguintes: Medicina e Âncora Medicinal.

A obra Luz verdadeira, e recopilado exame de toda a Cirurgia, de Antônio Ferreira, comparece em 5 registros $(0,39 \%$ das obras $)$, mesma cifra alcançada pela Prosódia de Bento Pereira, obra didática proibida para uso nas escolas a partir das reformas pombalinas (portanto, tal obra, apesar da censura, não desapareceu das bibliotecas). Na mesma posição que a última, com 5 aparições $(0,39 \%)$, mas em livros diferentes, encontram-se dois "filósofos" da Ilustração, um português e um francês: Luís Antônio Verney, com três títulos (Verdadeiro Método de Estudar; Apparatus ad Philosophiam et Theologiam ad usum Lusitanorum adolescentium; e De Re Methaphysica ad usum Lusitanorum adolescentium) e Voltaire, com quatro títulos (La Henriade; Le Siècle de Louis XIV; Histoire de Charles XII; e, talvez, La Loi Naturelle ${ }^{38}$ ). As obras de Voltaire eram monopolizadas pelos proprietários das duas maiores bibliotecas: o Dr. José Pereira Ribeiro, que possuía todos os títulos supracitados, e o padre-mestre Manuel Osório, que detinha provavelmente apenas a Histoire de Charles XII ${ }^{39}$.

Com 4 aparições, encontram-se: a Pharmacopea Tubalence, de Manoel Coelho Rodrigues; as Ordenações do Reino; Pároco Instruído; o Caderno de Santos Novos; Mocidade enganada e desenganada, do padre Manuel Conciencia; Septem Linguarum Calepinus Hoc est Lexicon Latinum, de Facciolato; distintas "obras" do papa Benedito XIV (Bullarium, Constituiçoens, Instituiçoens Eccleziasticas e outra sem título); a Theologia, de Francisco Genetto; livros diferentes de Hugonis de

\footnotetext{
${ }^{38}$ No inventário consta o nome do autor e o título Principios de Direito Natural (ACSM, Inventários, $1798,51,1162)$.
} 
Sancto Charo sobre a Bíblia; títulos diversos e anotados de forma truncada, todos eles de medicina, do médico português Duarte Madeira Arraes; e um autor (?) chamado Felis Potestas, cuja única obra discriminada é Theologia. O jurista português Antônio de Souza Macedo faz-se presente com segurança em 4 registros e, talvez, noutro, em que figura apenas o nome "Macedo", seguido de "Obras"; nos resgistros citados, mencionam-se os seguintes títulos: Flores de Espanha Excelencias de Portugal en que brevementes se trata lo mejor de sus Historias...; Ulyssipo. Poema Heroico; e Eva e Ave Maria triumphante Theatro de erudição e Filosofia Christã̃ em que se reprezentão os dous estados do mundo cahido em Eva e levantado em Ave. O matemático, professor e pesquisador francês Étienne Bézout (1730-1783), cuja teoria geral da eliminação entre um número qualquer de equações subsiste até nossos dias ${ }^{40}$, também se faz presente 5 vezes, com obras como: Geometria, Elementos de Trigonometria e Elementos de Aritmética. Dos autores que aparecem três vezes, podem ser destacados os nomes do padre Antônio Vieira, com Sermões, em duas bibliotecas e, com "toda a obra", numa outra livraria; Jacobo Besombes, com Theologia Moral; François de Salignac de la Mothe-Fénélon, com As Aventuras de Telêmaco; e Maria d'Agreda, com Mística Cidade de Deus, obra proibida. Podem-se citar, ainda, os seguintes autores, de presença numérica pequena, mas relevantes: por se referirem à América portuguesa, Sebastião da Rocha Pitta e Santa Rita Durão, em 1 inventário, e Luís Ferreira Gomes, autor de Erário Mineral, em 2; por terem sido condenados pela censura devido às suas supostas ligações com os jesuítas, o probabilista Fernando de Castro Palao e o anti-probabilista Paul Gabriel Antoine, ambos em 2 inventários; por ser partidário de teorias corporativas de poder, o conde da Ericeira, com História do Portugal Restaurado, obra presente na biblioteca de Ana Joaquina de São Boaventura; e, por ser das mais enviadas para o Rio de Janeiro, como se verá adiante, Histoire de Gil Blas de Santillane, de Alain René Lesage, presente em 2 inventários. A História do Portugal Restaurado, como se verá no Capítulo 8, talvez tenha sido emprestada aos Inconfidentes, da mesma forma que se supõe ter acontecido com a Histoire philosophique et politique des etablissements et du commerce des européens dans les deux Indes, do abade Raynal, que teria sido possuída pelo Dr. Pereira Ribeiro, embora não esteja no seu inventário.

\footnotetext{
${ }^{39}$ A dúvida deve-se ao fato de no inventário constar o seguinte registro: "Estoria de Carlos []oze".

${ }^{40}$ VIGUERIE, Jean de, op. cit., p. 762.
} 
Da Ilustração, além das obras de Verney, Bézout e Voltaire já citadas, encontravam-se nas bibliotecas de Mariana: d'Alembert, com Mélanges de literature; o padre Teodoro de Almeida, com Recreação Filosófica e Feliz Independente; o Barão de Bielfeld, com Instituições Políticas; Condilac, com Obra Elementar; o Mr. De Felice, com Leçons de Logique; Bento Feijó, com Theatro Critico Universal; o oratoriano Antônio Pereira de Figueiredo com Pequeno resumo de figuras de sintaxe latina; Antonio Genovesi, com Logica e Methaphisica; Gessner, com título ilegível; Simon-Nicolas Linguet, com Obras; Carl von Linné, com Philosophia Botanice; Mably, com Direito Público e obras diversas não discriminadas; Montesquieu, com Obras; Manuel Joaquim Henriques de Paiva, ou então, Vicente Seabra Telles, com Elementos de Química; E. A. Pluquet et alli, com Dicionário das heresias; William Robertson, com Histoire de l'Amerique; Antônio Ribeiro Sanches, com Tratado da conservação da saúde dos povos; José de Seabra da Silva, com sua Dedução cronológica e analítica; e Domingos Vandeli, com Dicionário.

Nas bibliotecas de Mariana em análise, havia 49 obras e 126 volumes sobre os quais pesava alguma forma censura. No geral, no entanto, não se tratava de livros que ensejaram uma censura absoluta, ou melhor, segundo os termos usados então, "suprimidos". Sobre o manual de teologia moral de Francisco Larraga recaía apenas a interdição de uma edição (a de 1729, em espanhol), ainda que se possa suspeitar que não só essa edição tenha sido objeto das retenções feitas nas alfândegas, citadas no Capítulo 5; a Prosódia tinha seu uso proibido, tudo indica, apenas para fins didático-escolares; Puffendorf e Grotius, de acordo com o regimento da Real Mesa Censória, deveriam ser tolerados, mas contraditoriamente entraram para o rol de livros defesos feito pelos tribunais censórios; Bielfeld, conforme determinação do edital de 03 de fevereiro de 1769, podia ser lido pelos que tivessem licença; a Histoire de l'Amérique de William Robertson foi, em data indefinida, proibida e, depois, em 22 de março de 1801, liberada para os que tivessem licença; as obras do padre Antônio Vieira estavam num inventário de 1756, portanto, anterior às proibições, que vieram a se dar só a partir da criação da Real Mesa Censória, em 1768; em situação similar estava Mélanges de Literature, de Alembert, ao que parece proibida apenas em 1802, data posterior àquela em que foi inventariada (1798), e, ainda, o Código, talvez de Frederico II, liberado aos que tivessem licença em 1800, mas inventariado em 1798. Assim, sobravam como motivo de proibição severa 
apenas: a Mística Cidade de Deus, de Maria d'Agreda; a Pratica de Jaime Corella (suprimida em 7 de julho de 1770); o probabilista Fernando de Castro Palao, proibido pelo edital de 12 de dezembro de 1771; e as obras de Mably e Voltaire, possuídas pelo coimbrão Dr. José Pereira Ribeiro e, no caso do último autor, também pelo padre-mestre Osório. O maior refinamento intelectual e a sede de saber, assim, pareciam levar os proprietários mais intelectualizados de livros a não respeitarem as interdições, usando livros condenados pela censura.

Os números referentes a títulos de obras e nomes de autores mais freqüentes nas bibliotecas de Mariana convergem muito parcialmente com aqueles verificados por Márcia ABREU entre os livros remetidos de Lisboa para o Rio de Janeiro, arrolados em listas submetidas aos tribunais censórios portugueses entre $1768 \mathrm{e}$ $1822^{41}$. Segundo ABREU, as obras de Belas Letras mais enviadas para o Rio de Janeiro foram: Les Aventures de Télemaque, de Fénélon; Selecta Latini, de Pierre Chompré; Histoire de Gil Blas de Santillane; de Alain René Lesage; História do Imperador Carlos Magno, e dos doze pares de França; Les Mille et Une Nuits, de Antoine Galland; Obras poeticas de M. M. de B. du Bocage; Lances da Ventura, acasos da desgraça e heroísmos da virtude, de D. Felix Moreno de Monroy e Ros; o Feliz independente do mundo e da fortuna, do padre Teodoro de Almeida; Caroline, de Isabelle de Montoliru; e The Complaint or Nights Thoughts on Life, Death, and Immortality, de Edward Young. Desses nomes todos, como se viu anteriormente, apenas as Seletas e As Aventuras de Telêmaco encontravam-se em Mariana em números dignos de nota, não sendo porém dos mais altos, enquanto Histoire de Gil Blas de Santillane e Feliz Independente apareciam, respectivamente, em 2 e 1 inventários.

Na composição das bibliotecas de Mariana, no entanto, vislumbram-se alguns ecos das remessas de impressos de baixo valor econômico que se destinavam a Colônia, com origem no Reino. Na passagem do século XVIII para o XIX, remeteram-se para a Colônia Kalendarios para o uzo do Officio Divino, "folhinhas de reza e anno p ${ }^{\text {ro }}$ o de 1801" e "escriptos de confição": no primeiro caso, para vários locais; no segundo, para São Paulo, Mariana e Rio de Janeiro; e, no terceiro, apenas para essa última cidade ${ }^{42}$. Outros impressos enviados foram as "estampas e

\footnotetext{
${ }^{41}$ ABREU, Márcia. Leituras Coloniais (1768-1822), op. cit., s.p.

${ }^{42}$ IANTT, Real Mesa Censória, Caixa 153.
} 
Novenas do Coração de Jezus", cujo destino foi a cidade da Bahia em 1799, e as "folhinhas da ordem", mandadas também para a urbe soteropolitana, pelo procurador da ordem do Carmo, em $1796^{43}$. As religiosas de santa Bárbara do Rio de Janeiro, nos idos de 1800, recebiam "os Livros de Igr ${ }^{\mathrm{a}}$. $\mathrm{p}^{\mathrm{a}}$. seo uso e outros mais pedidos por ellas $\mathrm{p}^{\mathrm{a}}$. seo capelão" ${ }^{\text {"4 }}$. Nenhum desses impressos religiosos superou, em termos de quantidade em circulação, os Livros de $S^{t a}$. Barbara, escritos de devoção remetidos aos milhares para todos os cantos da América Portuguesa, o que certamente os tornou os mais presentes nas nossas residências ${ }^{45}$. Como se viu, tais livros se achavam em Mariana em grande número, embora concentrados nas mãos de um único proprietário; significativamente, as "folhinhas de reza e anno p ${ }^{\text {ro }}$ o de 1801" ou de outros anos, embora explicitamente remetidas à Leal Cidade, não figuram nos inventários: seu baixo valor econômico e a circunscrição de seu uso a um tempo limitado certamente as tornavam desprezíveis aos olhos dos inventariantes.

A ampla circulação desses impressos de baixo valor econômico, que auxiliavam os fiéis a praticarem suas devoções religiosas, a assistirem aos ofícios sagrados e a se prepararem para o sacramento da penitência, e a grande presença dos livros religiosos nas bibliotecas de Mariana, entre 1714 e 1822, apontam para uma utilidade importante dada aos livros pelos leitores no período colonial, presente desde o século XVI e que avançou pela Época das Luzes: alguns livros e outros tantos impressos permitiam o acesso dos leitores às verdades sagradas e auxiliavam nas cerimônias, nos ritos religiosos e, pode-se supor, nas práticas de devoção privada.

A composição das bibliotecas marianenses pode ser confrontada com as bibliotecas e os livros que foram mandados da América para Portugal, submetidos ao crivo da censura portuguesa, entre 1769 e 1820. As similitudes são grandes quando os termos de comparação são tamanho e freqüência de obras profissionais e religiosas. Dos 53 indivíduos que remeteram livros de Pernambuco, Rio de Janeiro, Pará, Bahia e Maranhão para diferentes localidades do Reino, 40 eram propriamente donos de bibliotecas, enquanto os 13 demais dedicavam-se ao comércio de livros. Analisando-se exclusivamente as listas de livros, correspondentes a bibliotecas, com entrada em Portugal oriundos do Brasil, percebe-se que os maiores proprietários de

\footnotetext{
${ }^{43}$ IANTT, Real Mesa Censória, Caixa 157.

${ }^{44}$ IANTT, Real mesa Censória, Caixa 153.
} 
livros eram dois indivíduos com formação em leis: Francisco José de Miranda, desembargador no Porto, que em 1807 levava 322 títulos e 650 volumes; e Antônio da Costa Agra, advogado, cuja biblioteca, em 1769, compunha-se por 164 títulos e 305 volumes. A biblioteca que ocupava a terceira posição, em termos de número de títulos e volumes, pertencia a um clérigo: Manoel José de Almeida, canonista pela Universidade de Coimbra, que em 1799, detinha a posse de 149 títulos e 429 volumes. Já a menor biblioteca, com um título apenas, pertencia a Mathias Jozé Ferreira de Abreu, que exercia o cargo de contador geral em 1805.

As bibliotecas dos dez advogados identificados compreendiam de 14 a 322 títulos, chegando a uma média de 74,8 livros por acervo e, em nove casos, compondo-se principalmente de obras jurídicas. Os oito clérigos detentores de livros reuniam de 4 a 149 títulos, perfazendo uma média de 36,2 títulos por biblioteca. Esses eclesiásticos possuíam obras em sua maioria referentes à religião, com exceção de Manoel Álvares Leal, cuja biblioteca contava com 58 títulos $^{46}$ : embora tivesse cerca de 15 títulos de ciências sacras, as demais áreas somadas alcançavam uma cifra superior: literatura e gramática (10), história profana (11), dicionários (4), ciências (6), direito-filosofia (1), filosofia (2) e geografia (2), o que dava um total de 35 livros não referentes diretamente a assuntos religiosos (não foi possível classificar 7 títulos). As bibliotecas dos cirurgiões-médicos, em número de 6 , apresentavam dimensões bem menores que as pertencentes aos advogados e eclesiásticos, compreendendo de um a 32 títulos. Em todas elas, preponderavam as obras de medicina e farmácia, que em três casos eram secundadas ou por livros devocionais, ou de ciências, história e belas letras. Rivalizando com os médicos, estavam os navegadores, que somavam também 6 e que tinham de 5 a 47 títulos (15,8 em média), sendo somente um deles exceção à regra de possuir um maior número de livros de cunho profissional: enquanto 5 navegadores tinham livros de aritmética, astronomia, navegação, história marítima, um capitão de navio possuía títulos preponderantemente de história e belas letras. Complementavam a lista, ainda, dois nobres, com 33 e 28 títulos cada, um deles com expressivo número de obras militares e ambos com livros de ciências, história e belas letras; dois estudantes, um com 14 e outro com 40 títulos, em sua maioria de belas letras e/ou didáticos; e o já citado

\footnotetext{
${ }^{45}$ Ibidem.

${ }^{46}$ Um deles repetia-se: o livro As Aventuras de Telêmaco, de Fénélon, foi registrado duas vezes (numa
} 
contador do erário régio, possuidor de uma única obra intitulada Sciencia de Governo $^{47}$. Esses dados numéricos, portanto, permitem concluir que as bibliotecas levadas da América para o Reino, entre 1769 e 1814, em sua maioria, à semelhança do que ocorria com grande parte das bibliotecas de Mariana, tinham uma composição determinada pelas carreiras profissionais de seus proprietários, do que se pode depreender que os livros serviam aos leitores, em grande parte, como fonte de conhecimentos necessários para o exercício profissional.

A quantificação dos tipos de obras, dos títulos e dos autores enviados para a metrópole, registrados em listas submetidas à censura, permite detectar coincidências parciais com os autores, títulos e tipos de livros arrolados nos inventários de Mariana. A amplitude geográfica, profissional e temporal das listas submetidas à censura permite ter uma visão mais geral sobre a composição das bibliotecas na Colônia, uma vez que se originam, como já se disse, de diferentes portos da América portuguesa, indo do Sudeste ao Norte. Mas, é importante ressaltar, a freqüência com que aparecem os autores e títulos nessas listas está longe de ser representativa do conjunto dos livros que fizeram o percurso inverso, saindo de Portugal para os diversos portos da América, também arrolados para o exame dos tribunais censórios, e que serão objeto de estudo no futuro.

Na quantificação dos autores, títulos e tipos de obras remetidas da América para o Reino, incluíram-se também os impressos e livros enviados por livreiros, ou seja, não se limitou o universo de análise às bibliotecas propriamente ditas, abrangendo-se o conjunto dos livros em circulação da Colônia rumo a Portugal. Feita essa observação, pode-se afirmar que a mais alta cifra alcançada pertence ao Regim $^{\text {to }}$. de mil, e oito centos, e dezaceis, $p^{a}$. os Boticarios do Reyno de Portugal e Algarves, do qual se enviaram 800 exemplares do Rio de Janeiro para Lisboa, a pedido do boticário de Sua Majestade, em 1817. Em seguida, vem a Pratica Criminal do Foro Militar, remetida da Bahia por Manoel Jozé da Cruz, em 1816: 300 exemplares. Os impressos em questão, pode-se inferir, tinham certamente um uso determinado: servir para o exercício profissional, seja regulando as atividades de botica, seja instruindo em questões jurídico-militares. Em terceiro lugar, está um impresso cujo título é dos mais surpreendentes, não tendo sido possível identificar a 
natureza do seu conteúdo: Folhetos do Homem, e Aranha, enviado em 1805, também da capital soteropolitana, em número de 50. Na quarta posição se encontra um livro intitulado Catecismo doutrinal, do qual foram encaminhados 38 exemplares, em 1796, por Joze Aniçeto Rapozo, de Pernambuco. Da mesma pessoa e local, partiram também os livros que ocupavam o lugar seguinte: as Comédias de Terêncio e os Comentários das Comédias de Terêncio, que, somados, atingiam a cifra de 30 exemplares.

Se até aqui vêem-se impressos e livros encaminhados com maior freqüência por livreiros, as próximas colocações já trazem números referentes a livreiros e, ao mesmo tempo, a proprietários de bibliotecas, de diferentes locais e datas. Assim, o $6^{\circ}$ lugar é ocupado pelas Ordenações, seus repertórios, algumas vezes seguidas de comentários, dos quais saíram da América 20 exemplares. Na sétima posição, comparece a Bíblia, aqui se incluindo as concordâncias, livros isolados e, ainda, comentários da mesma: chegou-se a um total de 18 exemplares.

Bem mais atrás, estão os juristas portugueses Matheus Homem Leitão, autor da obra De Jure Lusitano in tres Tractatus, com 13 menções, e Gabriel Pereira de Castro, com 12 referências somadas dos seguintes livros: Tractatus de manu regia; Ulissea, ou Lisboa edificada. Poema Heróico; Prática Lusitana omnibus utroque foro versantibus, \& necessaria ${ }^{48}$.

Com 11 citações, encontram-se Decisiones e outra obra cujo título não foi discriminado, de autoria de Melchior Phebo; Manuel Mendes de Castro, com obras distintas, sendo, ao que parece, a mais presente Pratica Lusitana omnibus utroque foro versantibus \& necessaria; e Gabriel Álvares Valasco Castelhano (não se conseguiu identificar os títulos dos livros) $)^{49}$.

Silvestre Gomes de Moraes alcança a marca de 10 citações, com Executoribus Instrumentarum, \& sententiarum e outros livros. Com 9 referências, está a obra As Aventuras de Têlemaco, de Fénélon, em diferentes edições, em

\footnotetext{
${ }^{48}$ Os nomes de autores e os títulos das obras que se seguem foram confrontados com as informações da Biliotheca Lusitana, de Diogo Barbosa Machado (op. cit.) e com um levantamento feito dos autores e títulos das obras publicadas antes de 1822, existentes na Biblioteca do Palácio Episcopal de Mariana.

${ }^{49}$ Em 12 registros apareceram o sobrenome "Barbosa", nem sempre com referências aos títulos das obras, que freqüentemente registraram-se truncados. Da forma como se encontram grafados os títulos, eles podem ser tanto de Manuel Barbosa, quanto de Agostinho Barbosa, reputado canonista português (TORGAL, Luís Reis, op. cit., vol 1, p 111). Pedro Barbosa Homem, jurista português defensor de concepções corporativas de poder (Ibidem, vol. 2, p. 23), constitui outra possibilidade, embora mais remota. Por este motivo, preferiu-se não mencionar a supracitada cifra.
} 
português, espanhol, inglês e francês, identificada por Márcia Abreu entre as mais enviadas ao Rio de Janeiro e com presença numericamente digna de nota entre os inventários de Mariana.

Oito livros de autoria de Antônio de Sousa Macedo, também muito presente na Leal Cidade, registram-se nas remessas de livros em questão: 5 exemplares de Decisiones Supremi Senatus Justitiae Lusitania, et Supreme Concilii Fisci; e os outros 3, de Flores de Espana, Excelencias de Portugal en que brevementes se trata lo mejor de sus Historias; Ulyssipo, Poema Heroico; e Eva e Ave Maria triumphante Theatro de erudição e Filosofia Christaã. Na mesma posição, com 8 referências, encontram-se outros três juristas portugueses: Manuel Álvares Pegas, com suas obras Tractabus de Ordinibus Militaribus; Resolutiones Forenses e um livro cujo título não foi possível identificar; Antônio Vanguerve Cabral, com Pratica Judicial (em 4 registros, o título da obra não foi mencionado); e Manuel Gonçalves da Silva, com os livros ad Commentaria ad Ordinationes Regni Portugalliae.

Étienne Bézout, matemático dos mais presentes nas bibliotecas de Mariana, obtém 7 referências, com obras distintas sobre matemática, álgebra e geometria. Com a mesma cifra, ficam Francisco Pinheiro (de Censu \& Emphyteusi e Tractatus de Testamentis) e Miguel Reynoso (Practicae in quibus multa, quae in controversiam forensibus judiciis e títulos não discriminados). Com 6 citações, vêm Miguel Cabedo de Vasconcelos, célebre jurisconsulto português, com Decisiones (não foi possível localizar o título completo da obra); o orador romano Cícero (com De Oficiis; Epístolas; Obrigações e Orações); Alexandre Gomes Caetano (com várias obras, dentre elas, a mais freqüente, Manual Practico Judicial, Civil e Criminal); e Facciolato, com Septem Linguarum Calepinus Hoc est Lexicon Latinum (esse livro, com presença numericamente respeitável também nas bibliotecas de Mariana).

Cinco menções é a marca obtida por Bento Cardoso Osório, com Praxis de Patronatu Regio, et Seculari; Manoel Lopes Ferreira, com Pratica Criminal expendida na forma da Praxe, observada neste nosso Reyno de Portugal; Heinécio, teórico jusnaturalista; Diogo Camacho Guerreiro de Aroim, com De munere Judicis Orphanorum opus in quinque Tractabus divisum quorum primus est de Inventario..., Opusculum de Privilegiis Familiarum Sancte Inquisitionis omnium Judicum..., Tractatus de Recusationibus, e Escola Moral Politica Christãa e Juridica. 
Provavelmente Voltaire se encontra também nessa posição, pois, além de aparecerem sua La Henriade e Le Siècle de Louis XIV, mencionam-se outros três títulos sem autoria discriminada (Histoire de Louis XIV, Vida de Carlos XII e Carlos XII, rei da Suécia), que talvez sejam do grande filósofo deísta francês. Voltaire é, assim, outro ponto de coincidência entre as bibliotecas de Mariana e as bibliotecas enviadas da América para o Reino (é preciso frisar que tal presença era circunscrita, em Mariana, estando concentrada nas mãos de dois proprietários de livros). Por fim, com 4 menções, se seguiam os seguintes autores: Vinio; Menochio; os poetas portugueses Luís de Camões e Bocage; o clássico Virgílio (muito freqüente nas bibliotecas marianenses); o também beletrista inglês Milton (com Paradis Perdu); os juristas Gregorio Martins Caminha, Antônio de Paiva e Pona e Antônio da Gama; o canonista-jurista Sanches (não é possível saber se o prenome desse autor era Thomas ou Ludovico) e o papa Benedito XIV. Francisco Larraga, autor dos mais presentes nas bibliotecas de Mariana, só apareceu duas vezes entre os livros enviados da América a Portugal.

Saindo dos títulos e autores mais freqüentes, deve-se destacar, ainda, escritores ligados aos jesuítas, alguns deles probabilistas e defensores de teorias corporativas de poder, como Luís de Molina, Casnedi, Claudio La Croix, Paul Laymann; autores luso-brasileiros como Basílio da Gama e Dom Sebastião Monteiro da Vide; historiadores que focalizaram a Restauração Portuguesa, tais como o abade Vertot e o Mr. La Clède (que trata do assunto de passagem); do matemático clássico Euclides Megarense; do maior expoente da literatura inglesa William Shakespeare; e do milenarista Antônio Vieira (Eco das Vozes Saudosas, obra condenada pela censura a partir de Pombal, como se observou no Capítulo 4).

Como em Mariana, entre os livros remetidos da América a Portugal, havia alguns de autoria dos "filósofos" da Ilustração: Teodoro de Almeida, Buffon, Condilac, Francisco de Mello Franco, Edward Gibbon, Antonio Genovesi (o Genuensi), De Felice, Antônio de Morais Silva, Mably, Alexander Pope, William Robertson, Rousseau, José de Seabara da Silva, Jonatham Swift, Luís Antônio Verney e do pai do liberalismo econômico Adam Smith. Nas mesmas remessas, achavam-se também livros de renomados cientistas, como Carnot, Cabanis, Isaac Newton e Pinel, além do supracitado Bézout; e dos jusnaturalistas Grotius e Puffendorf. Os livros dos "filósofos" e dos cientistas, em grande parte, pertenciam ao 
nobre e militar D. João de Souza Coutinho, que partia de volta ao Reino em 1816. Esse fato merece ser destacado, pois, em Mariana, sucedia o mesmo: livros com o perfil similar encontravam-se concentrados nas bibliotecas do Dr. José Pereira Ribeiro e do padre-mestre Osório. Essa mesma concentração já foi observada, em outro estudo, ao se compararem bibliotecas de 10 clérigos "mineiros" da segunda metade do século XVIII, dentre eles dois bispos, D. Frei Manuel da Cruz e D. Frei Domingos da Encarnação Pontével, e três Inconfidentes: o cônego Luís Vieira da Silva, o padre Carlos Correia de Toledo e o padre Manuel Rodrigues da Costa. Enquanto os clérigos que se envolveram na Conjuração de Minas Gerais e o bispo Dom Frei Domingos da Encarnação Pontével, ex-professor de teologia, apresentavam bibliotecas nas quais se observavam interesses literários que ultrapassavam as exigências imediatas da vida pastoral, demostrando curiosidade em relação às obras da Ilustração (destacando-se, nesse aspecto, o cônego Luís Vieira da Silva), a questões propriamente teológicas e, ainda, a matérias de ciências exatas e naturais, com os demais clérigos ocorria o inverso, havendo um vínculo estreito (no duplo sentido do termo) entre suas bibliotecas e as necessidades corriqueiras do sacerdócio $^{50}$. Enfim, quer-se dizer que as Luzes e as ciências (não se pensando aqui nos casos em que essas tinham um uso profissional imediato), rastreadas a partir da composição das bibliotecas e da distribuição das mesmas entre os grupos sociais, atingiam e seduziam um pequeno grupo no interior do conjunto dos letrados: uma elite, dentro das elites. Entre essas elites fundamentalmente, ao que parece, os livros tinham usos que iam além das fronteiras profissionais ou da vivência religiosa imediata, expressando uma curiosidade ampla em relação ao homem, ao mundo natural, ao Estado e à própria divindade.

Tomando-se o período colonial como um todo, em suma, conclui-se que as bibliotecas não se fizeram muito presentes na sociedade, embora sua distribuição, ao que pareça, tenha crescido a partir do século XVIII entre a população livre. No século XVIII e nos inícios do XIX, o tamanho das bibliotecas, tanto de Mariana quanto daquelas levadas da América para o Reino, era diverso, não sendo determinado pela riqueza, mas pelo grau de refinamento intelectual e de escolaridade dos proprietários. Via de regra, advogados e padres e, em menor escala, cirurgiões e

\footnotetext{
${ }^{50}$ VILLALTA, Luiz Carlos. Os clérigos e os livros nas Minas Gerais da segunda metade do século XVIII, op. cit., p. 28-29.
} 
boticários, possuíam as maiores bibliotecas. Havia, ainda, uma relação estreita entre, de um lado, a composição das livrarias e, de outro, a condição social e os ofícios dos seus proprietários. Aqueles que se dedicavam a ofícios, na maioria das vezes, possuíam livros relacionados às suas carreiras, enquanto entre os demais, imperavam obras devocionais e, em menor escala, de medicina, história, belas letras e ciências exatas e naturais. As remessas de livros e de bibliotecas da América para Portugal, entre 1769 e 1820, somadas às livrarias de Mariana e comparadas às bibliotecas encontradas nos séculos anteriores, mostram uma maior presença dos livros profissionais e um crescimento de interesse pelas ciências físicas e naturais. Ao contrário das bibliotecas de Mariana, os autores e livros mais freqüentes nas remessas destinadas a Portugal, no entanto, tratavam de leis, sendo os assuntos religiosos menos onipresentes, embora a ligação das leis aos cânones envolvesse sua abordagem em boa parte das obras jurídicas. Os usos relativos ao sagrado, convém sublinhar, ocupavam ainda um lugar de destaque, como revela a circulação de impressos de baixo valor, majoritariamente religiosos. Pelo volume desse comércio, pressupõe-se que os impressos citados tiveram uma ampla divulgação, podendo-se, em função disso, tomá-los como bons indicadores sobre usos costumeiramente atribuídos aos "livros".

Alguns autores muito freqüentes na sede da áurea diocese e nas listas de livros mandados ao Rio de Janeiro estudadas por Márcia Abreu, além disso, aparecem entre as obras enviadas da Colônia para Portugal, podendo-se destacar: Bézout, Fénélon e Antônio de Souza Macedo. Nas bibliotecas de Mariana e nos livros encaminhados da América ao Reino, observam-se igualmente a ampliação do leque de escritores de belas letras e a existência de teólogos ligados à Segunda Escolástica, de escritos do padre Antônio Vieira, muitos deles proibidos pela censura portuguesa, e de obras que abordam, especifica ou marginalmente, a Restauração Portuguesa de 1640, de autoria de Ericeira, Vertot e La Clède. Todos esses elementos permitem deduzir que os livros subsidiavam com suas informações o exercício de profissões, constituíam meios de acesso às "verdades sagradas" e também eram objeto de deleite, de recreio.

Sob esse último aspecto é essencial pensar nas relações entre, de um lado, as Luzes e as ciências e, de outro, as bibliotecas e a origem sócio-profissional dos seus proprietários: desconsiderando as obras científicas de uso profissional, percebe-se 
que Luzes e Ciências ecoavam nas bibliotecas coloniais da segunda metade do século XVIII até 1822, mas, via de regra, disseminavam-se nos segmentos mais elitizados dos proprietários de livros, entre as "elites das elites". Essa marca social, embora não tenha sido absoluta, apesar de não impedir que as Luzes chegassem a segmentos hierarquicamente inferiores da população, traz subsídios importantes para fazer inferências sobre os usos implícitos dos livros: se é certo que esses últimos operaram, como se pôde depreender dos inventários e listas de livros submetidas aos tribunais censórios, como fonte de saberes necessários para o exercício profissionais e úteis para a vivência imediata da religiosidade, eles serviam também para indagações mais profundas e menos estreitas sobre o homem, a natureza, o Estado e a religião, ultrapassando as restrições legais, isto é, os senões da censura. No limite, assim, alguns livros poderiam ser apropriados para questionamentos da ordem. Os usos implícitos que se pode inferir da distribuição da posse dos livros no seio da sociedade colonial, enfim, remetem ao exercício de profissões, à relação com o sagrado e ao entretenimento e, ainda, segredam uma possibilidade: a subversão religiosa e política, tão temida pelas autoridades.

Uma análise mais detalhada dos inventários — o que foge aos objetivos desta tese - permitiria conjecturar que os livros, enquanto objeto, eram signos de status, de poder, na medida em que sua posse acompanhava-se com relativa frequiência de outros elementos materiais então passíveis de ostentação: louças, jóias e pratarias ${ }^{51}$. Outros tipos de documentos parecem confluir para a mesma idéia. Nos seqüestros dos bens dos Inconfidentes de Minas Gerais, chama a atenção a minúcia com que a aparência e os aspectos materiais de alguns livros (em particular o formato) são descritos, revelando a importância que tinham então não só para o ato de ler mas também para o aparecer: por exemplo, em meio à descrição de "três livros de meias folhas, quatro de quarto e oito pequenos, que estavam cosidos dentro de um saco de

\footnotetext{
${ }^{51}$ Há na arqueologia uma discussão sobre o emprego de vestígios de louça (faiança e porcelana) como indicadores de status econômico e nível de renda. Hoje a tendência dos estudos é refutar esta utilização, na medida em que escavações feitas em sítios referentes a grupos sócio-econômicos hierarquicamente distintos mostram que os mesmos se apresentam homogêneos no que se refere às louças. Salienta-se, no entanto, que por isso mesmo, as louças apresentam uma dimensão ostentatória: representavam um gasto excepcional, feito às custas de privações e com um objetivo claramente de exibição (BAUGHER, Sherene, VENABLES, Robert W.. Ceramics as indicators of status and class in eighteenth-century New York. In: WOOD, S. M. Spencer. Consumer choice in historical archaeology. New York: Plenum Press, 1987, p. 31-53 e 59). Assim, se não são seguras como único índice de status e renda, são relevantes do ponto de vista da identificação do desejo dos indivíduos ostentarem uma posição social que não tinham.
} 
aniagem" "52 , pertencentes a Cláudio Manuel da Costa, há a menção a "umas Horas Latinas, com suas chapinhas de prata" ${ }^{, 33}$ (itálicos meus). Na documentação da Real Mesa Censória, igualmente os livros populares tinham seus aspectos materiais cuidadosamente descritos, o que reforça a tese de que sua aparência possuía importância ${ }^{54}$. Essas informações confluem para a hipótese de que posse e leitura de livros estiveram recortadas pela civilidade das aparências - código de maneiras convenientes aos grandes, que longe de caracterizar o indivíduo inteiramente, dissimulava ou travestia a realidade íntima do sentimento, estabelecendo uma tensão entre o parecer e o ser, conferindo mais importância ao visível ${ }^{55}$. Por enquanto, no entanto, fique-se na reafirmação daqueles usos inferidos da distribuição da posse de livros e da composição das bibliotecas coloniais - livros como fonte de conhecimento (em grande parte, ligado ao exercício de ofícios), de acesso ao sagrado e de entretenimento e, potencialmente, de subversão - deixando-se suas possíveis utilidades como ornamento e símbolo material de status para uma abordagem mais à frente.

\section{Utilidades dos livros, no dizer dos leitores luso-brasileiros}

Os livros, como já se salientou, prestavam-se a usos ligados ao sagrado ou, pelo contrário, extremamente mundanos, alguns deles com uma conotação coletiva e, talvez, pública, e outros, pelo contrário, se não propriamente privada, ao menos íntima. A intensa contigüidade que alguns leitores estabeleceram com seus livros pode ser medida nas entrelinhas de um pedido feito por José Álvares Branco Muniz Barreto, doutor e desembargador, que em 1796 dizia, em requerimento encaminhado

\footnotetext{
52 AUTOS de devassa da Inconfidência Mineira. 2 ed. Brasília: Câmara dos Deputados; Belo Horizonte: Imprensa Oficial de Minas Gerais, 1980, vol. 6, p. 101. Aniagem é um pano grosseiro sem acabamento, de juta ou de outra fibra vegetal análoga, usada para confecção de fardos.

${ }^{53}$ Ibidem, loc. cit.

${ }^{54}$ IANTT, Real Mesa Censória, Caixa 153.

55 Nas palavras de Philippe Ariès, "o indivíduo não era como era, e sim como parecia, ou melhor como conseguia parecer", podendo haver um completo desacordo entre o público e o privado, o íntimo (ARIĚS, Philippe. Por uma história da vida privada, In: ARIÈS, Philippe, CHARTIER, Roger. História da vida privada: da Renascença ao século das Luzes. Trad. Hildegard Feist, São Paulo: Companhia das Letras, 1991, p. 9. Veja: CHARTIER, Roger. Lectures et lecteurs dans la France D'Ancien Régime, op. cit., p. 58-70; REYEL, Jacques. Os usos de civilidade. In: ARIÈS, Philippe, CHARTIER, Roger (org.), op. cit., p. 186-94; e RAMOS, Donald. A 'Voz Popular' e a cultura popular no Brasil do século XVIII, op. cit., p. 139. A dimensão ostentatória ocupada pelos livros evidencia-se no uso de estantes que simulam ter livros, mas não os têm, móveis esses existentes em museus referentes ao período colonial.
} 
ao Desembargo do Paço, embarcar de Lisboa "para a Bahia com sua mulher, e filhos, e mais familia em o Navio Viriato, e pertende levar os livros" que arrolava numa lista: portanto, os livros somavam-se à mulher, filhos, família, e, juntamente com esses três elementos, encerravam o universo da existência particular do desembargador, aos olhos dele próprio ${ }^{56}$.

No universo privado, o livro tinha também aquele papel apresentado como hipótese anteriormente: operava como ornamento. Testemunhos diferentes das listagens de livros enviadas à censura, dos inventários e dos seqüestros de bens dos Inconfidentes, fornecem outros indícios que reiteram aquele sublinhado papel. Porque haviam "de estar na estante juntos", funcionando como enfeites, Manuel Ribeiro dos Santos, um livreiro das Minas de meados dos Setecentos, exigia que seus fornecedores lhe enviassem os livros "com títulos dourados nas costas", "os mais

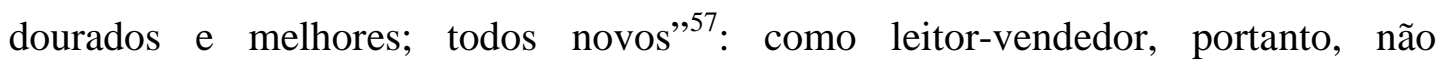
descuidava dos aspectos materiais do livro e das possibilidades de usá-lo como ornamento. Para Tomás Antônio GONZAGA, a aparência do livro de algum modo poderia assumir relevância aos olhos do leitor, construindo nesse uma certa idéia favorável do conteúdo daquele:
"o gesto, mais o traje, nas pessoas
faz o mesmo que fazem os letreiros
nas frentes enfeitadas dos livrinhos,
que dão do que eles tratam boa idéia" ${ }^{38}$.

Além de explicitamente serem assimilados como co-participantes da existência íntima e de serem enfeites, os livros foram claramente reconhecidos pelos leitores como fontes de conhecimento. Joaquim Bernardino de Sena Ribeiro, bacharel que se deslocava de Lisboa para o Rio de Janeiro em 1799, por exemplo, dizia se achar "prompto a seguir viagem", carregando consigo livros "para os seus Estudos" $"$. Entre os requerimentos encaminhados do Reino e da Colônia aos tribunais censórios para obtenção de licença para ler livros proibidos, entre 1768 e 1808, o objetivo de "melhor se instruir" era uma das justificativas mais

\footnotetext{
${ }^{56}$ IANTT, Real Mesa Censória, Caixa 157.

${ }^{57}$ DINIZ, Sílvio Gabriel. Um livreiro em Vila Rica no meado do século XVIII. Kriterion. Belo Horizonte, (47/48): 180-198, jan./jun. 1959.

${ }^{58}$ GONZAGA, Tomás Antônio. Cartas chilenas. In: PROENÇA FILHO, Domício (org.) A poesia dos Inconfidentes: poesia completa de Cláudio Manuel da Costa, Tomás Antônio Gonzaga e Alvarenga Peixoto. Rio de Janeiro: Nova Aguilar, 1996, p. 911.

${ }^{59}$ IANTT, Real Mesa Censória, Caixa 153.
} 
freqüentemente apresentadas. As fórmulas usadas pelos requerentes para expressar o intento de usar os livros enquanto fontes de conhecimento foram as mais diversas. Não se resumiram ao lacônico "melhor se instruir", destacando-se em seu conteúdo as seguintes utilidades derivadas: para "exercício de sua ocupação", "faculdade", "ministério", "estudos"; para "conhecer melhor os erros e combatê-los"; "para conhecer as doutrinas de que se deve apartar"; para melhor procedimento em casos, situações, dúvidas; porque "está escrevendo livros"; "para maior inteligência dos autores" ou "estudos"; "para bem servir a Vossa Majestade"; para se instruir "só nas doutrinas que não forem reprovadas" (ou o contrário); "para averiguação das doutrinas"; e para "maior construção da vida literária"60. Como se vê, o anseio por mais conhecimento subsidiava tanto o exercício de atividades profissionais e acadêmicas, quanto propósitos explícitos de cunho político e doutrinário, que iam da familiaridade ou do afastamento de idéias defesas até a subserviência à realeza. A última fórmula, no entanto, em que se alia o uso do livro como fonte de saber ao desejo de acessar a "vida literária", talvez oculte uma outra utilidade: a inserção em redes de sociabilidades nas quais o livro era a base.

Dos requerimentos encaminhados por leitores residentes na América ou que tiveram passagem por esse continente, podem ser retirados alguns exemplos de justificativas e, por conseguinte, de usos postulados para os livros proibidos por seus leitores. O já citado padre Antônio Caetano de Almeida, bacharel em Cânones, vigário em São João d'El Rey, em 1776, dizia querer ler livros proibidos “para a sua melhor, e mais facil instrucção, e para mais proporcionadamente poder empregar-se em algumas funçoens do seo sagrado ministerio". Nessa justificativa, como se vê, associam-se livro, conhecimento e ofício, algo já apontado nos padrões identificados nos requerimentos. De modo mais sucinto, mas levando à mesma posição, em 1780, o Dr. Pedro Joze Augusto Flávio de Faria, também graduado em Cânones e deão do Rio de Janeiro, explicou "q p a a sua maior instrucção desejava ler, e concervar" uma obra "q se acha[va] retida na Real Meza Censoria". Mencionando unicamente o desejo de melhor instrução, em 1773, Costa Matoso, ex-desembargador em Minas Gerais, pediu licença para ler livros defesos, aduzindo, contudo, que obtivera anteriormente licença que "lhe foi ja dada por Breve Pontificio", datado de 1758 e

\footnotetext{
${ }^{60}$ IANTT, Real Mesa Censória, Requerimentos, Caixas 112 e 113.
} 
passado ao Santo Ofício ${ }^{61}$.

Os usos do livro como fonte de conhecimentos necessários para o exercício de ofícios aparecem em outros documentos que não os pedidos de licença para leitura de livros proibidos. A estreiteza desses laços, já inferida na análise da distribuição da posse de livros e da composição das bibliotecas na Colônia, foi continuamente reiterada. Antônio Ferreira França, bacharel em filosofia, matemática e medicina pela Universidade de Coimbra e professor régio de geometria, em 1799 se dirigia para a Bahia e dizia levar "em sua companhia" livros "para seu uzo, e de seos discipulos"62. Francisco de Veras Nascentes, estudante que se mudava do Rio de Janeiro para Lisboa, em 1808, carregava consigo "huns livros, que erão do uzo das aulas, que frequentava" ${ }^{\prime 63}$. Francisco Herculano Rapozo e Santos, que aportava em 1807 em Lisboa, procedente de Pernambuco, mestre do Bergantim Venturoso, declarava que "entre o seu fato de uzo trouce huns livros de Navegação"64. Francisco José da Silva, cirurgião, chegando ao Porto, vindo do Rio de Janeiro em 1779, carregava "entre a sua movilia [...] três livros de cirurgia", os quais eram do seu "uso [...] p $\mathrm{p}^{\mathrm{a}}$. exercer a sua arte" ${ }^{\text {}}$. Outro que atribuiu aos livros essa mesma utilidade foi José Caetano de Lima, que da América se deslocava para o Porto, em 1779, exercendo no navio santo Antônio o ofício de cirurgião: ele declarou que trazia consigo "entre os mais fatto $[\ldots]$ os livros [...] da profição",66 .

Houve, na América, quem tentou dar um colorido político — subserviente e bajulador - à justificativa apresentada para a obtenção de licença para ler livros proibidos: o já mencionado Daniel Grijó, advogado público e sem diploma, em Pernambuco, em 1803. Como se viu no Capítulo 6, não foi convincente em seu propósito de obter licença "não só $\mathrm{p}^{\mathrm{r}}$. sua $\mathrm{p}^{\mathrm{er}}$. instrucção, utilid" do publico, como $\mathrm{p}^{\mathrm{a}}$. $\mathrm{m}^{\text {or }}$. e mais fundamentalm ${ }^{\mathrm{e}}$. sustentar os $\operatorname{Dir}^{\text {tos }}$. da Regia authorid ${ }^{\mathrm{e} "}$, quanto mais que ele teceu seguidas considerações que maculavam a reputação do clero pernambucano e se apresentou como defensor do povo, que estaria sendo vexado pelos sacerdotes ${ }^{67}$. Nessa justificativa - e talvez isto não tenha passado desapercebido pela censura insinua-se aquela possibilidade de uso destacada na análise da composição das

${ }^{61}$ IANTT, Real Mesa Censória, Requerimentos, Caixa 113.

${ }^{62}$ IANTT, Real Mesa Censória, Caixa 157.

${ }^{63}$ IANTT, Real Mesa Censória, Caixa 149.

${ }^{64}$ Ibidem.

${ }^{65}$ Ibidem.

${ }^{66}$ IANTT, Real Mesa Censória, Caixa 144. 
bibliotecas: o livro como fonte de conhecimentos para a subversão da ordem. Grijó não o diz, pelo contrário, propõe-se a defender os direitos régios: mas sua loquacidade em dizer-se próximo ao povo e refratário aos clérigos sugere que o objetivo contrário era uma grande possibilidade dentro de suas expectativas.

Se o uso dos livros postulado por Grijó, associando conhecimento e poder, não sensibilizou os censores, é importante dizer que a mesma associação era comum, sem a ambigüidade do rábula pernambucano, encontrando-se em outras fontes que não os requerimentos. Para as autoridades governamentais, inclusive as do universo colonial, a relação com os livros, não apenas como fonte de saber e de acesso ao sagrado, mas também como objeto de divertimento, esteve marcada pela sua utilidade para o exercício do poder. Os livros eram compreendidos como essenciais para um bom governo, sendo esta máxima registrada na literatura. Nas Cartas Chilenas, de Tomás Antônio GONZAGA, obra literária em que se satiriza Luís da Cunha Menezes, governador da Capitania de Minas Gerais, sob a figura da personagem Fanfarrão Minésio, estabelecem-se alguns traços que caracterizariam o bom governante ${ }^{68}$. O governante ideal deveria ler "doutos livros" e tratar com "sábios", afirmando a personagem Critilo:

"Amigo Doroteu, quem rege os povos deve ler, de contínuo, os doutos livros, e deve só tratar com sábios homens" $" 69$.

A necessidade de possuir bibliotecas e de ler livros para o exercício do governo pode ser inferida no negativo da imagem de Fanfarrão Minésio, protótipo de tirano. Fanfarrão decidia sobre os mais variados casos, "de moral, ou de direito", ou medicina:

"sem botar (que ainda é mais) abaixo um livro, da sua sempre virgem livraria" ${ }^{\text {"70 }}$.

Os livros esclareciam os dirigentes sobre a arte de bem governar, municiavam-nos contra os adversários, informando-os sobre as idéias que precisavam combater, podendo ser úteis inclusive para se defenderem em atos praticados no exercício de funções de governo. O conde de Assumar, que governou

\footnotetext{
${ }^{67}$ IANTT, Real Mesa Censória, Requerimentos, Caixa 113.

${ }^{68}$ A historiografia tem colocado obstáculos à identificação automática entre Luís da Cunha Menezes e Fanfarrão Minésio, entre Vila Rica e Santiago; veja a este respeito: FURTADO, Joaci Pereira. Uma república de leitores: história e memória na recepção das "Cartas Chilenas" (1845-1989). São Paulo : Hucitec, 1997, p. 75 e segs.

${ }^{69}$ GONZAGA, Tomás Antônio. Cartas chilenas, op. cit., p. 825.
} 
as Minas nos primeiros anos da década de 1720, por exemplo, apelou aos livros quando se viu processado por Pascoal da Silva e ameaçado de excomunhão. Assumar escreveu ao bispo do Rio pedindo-lhe conselhos. Esse o mandou consultar homens doutos. Na dúvida sobre se recorria aos doutos vivos ou aos mortos, e ciente de que os letrados das Minas não estariam do seu lado, recorreu aos livros, lendo, como assinala Laura de Mello e SOUZA, obras de Hipócrates, Platão, Ulpiano, Cassiodoro, Tertuliano, Salviano, São Jerônimo, São João Crisóstomo, Santo Agostinho e São Gregório ${ }^{71}$.

Utilidade similar foi conferida aos livros por Gomes Freire de ANDRADE, outro célebre governador e figura de primeira grandeza da administração portuguesa na América. Ao passar o poder a seu irmão, José Antônio Freire de Andrade, deixoulhe uma instrução, na qual discorria sobre sua experiência de governo e recomendava a leitura de obras. Aconselhou seu irmão e sucessor a consultar, na pequena biblioteca existente no palácio dos governadores, em Vila Rica, "Cristiano Política de Imperadores Católicos, e outros" autores, pois "tudo o que eles referem são bases sólidas para os acertos". Recomendou, ainda, ao irmão, que, à noite, se dedicasse à leitura de "livros históricos ou militares", depois de receber as pessoas importantes que o procurassem,"72.

Os livros, para os governantes, contudo, não apenas continham ensinamentos: além disso (e, por isso mesmo), divertiam-nos, como sucedeu com o governador Martinho de Mendonça de Pina e de Proença, que, em Vila Rica em 1736, pedia a Gomes Freire de Andrade que lhe mandasse "as memórias de Carvines adeceonadas' ou as 'obras de Mr. Rollim', ou 'alguma couza de viagens da América', 'principalmente o Pe. Terillet, e do Pe. Labat as Ilhas da América', porquanto tinha já algum tempo livre para se "devirtir na Lição",73.

Não apenas os governantes divertiam-se, contudo, com os livros. Em alguns requerimentos enviados aos tribunais censórios para transportar livros da América para o Reino e vice-versa, ao lado da idéia do livro enquanto fonte de conhecimento,

\footnotetext{
${ }^{70}$ Ibidem, p. 811.

${ }^{71}$ SOUZA, Laura de Mello e. Estudo crítico. In: Discurso histórico e político sobre a sublevação que nas Minas houve no ano de 1720. Belo Horizonte: Fundação João Pinheiro; Centro de Estudos Históricos e Culturais, 1995, p. 40-41.

72 ANDRADE, Gomes Freire de. Instrução e norma. In: LOPES, Eliane Marta Teixeira. Colonizadorcolonizado: uma relação educativa no movimento da história. Belo Horizonte: UFMG, 1985, p. 252-4.

${ }^{73}$ DINIZ, Sílvio Gabriel. Biblioteca setecentista nas Minas Gerais, op. cit., p. 334-335.
} 
aparece a associação com "recreio"; noutras, àquela se aliaram a "diversão", o "entretenimento" e a "curiosidade". O padre Francisco de S. Barbara, nos idos de 1778, fora ao Rio de Janeiro assistir "no serviço da Terra Santa" e, depois, "se trasnportou $\mathrm{p}^{\mathrm{a}}$. este Reyno [de Portugal] Remetendo a Roupa do seu uzo pa ${ }^{\mathrm{a}}$. a Cidade do Porto, e entre esta os Livros que const[avam] da Lista [de livros] junta", havia uns que eram "para seu recreyo espiritual" "T4 Thomaz Gonçalves, capitão do navio Mercurio, em viagem da Bahia à Lisboa, nos idos de 1805, carregava os livros "necessarios para a Sua navegação como tambem outros de historia, e divertim ${ }^{\text {tos }}$. em que entret[inha] o tempo nas suas navegaçoens". José Correa, mestre piloto da corveta Nossa Senhora da Conceição e Santo Antônio e Almas, em 1779, no percurso do Rio de Janeiro ao Porto, levava entre seus pertences alguns livros que em sua maior parte eram "de seu serviço Nautico sem os quaes não" podia "ser completo no seu emprego", havendo, ainda, outros, de "que a sua curiocidade se empregava"75.

Nos requerimentos para a leitura de livros proibidos, às fórmulas que associam livro e "melhor instrução", somam-se outras de natureza bem distinta. Ao invés de se concentrarem na serventia do livro para os leitores, fazem o percurso inverso, centrando-se na reputação dos últimos para, em seguida, afirmar o direito e a capacidade dos mesmos de ler livros proibidos: os requerentes teriam capacidade e nível de instrução que os autorizariam a lê-los, ou a saber discernir "verdades" de “erros". Assim, o desembargador Antônio de Matos Silva, em 1777, afirmava que, entre os seus livros "q. lhe vierão do Porto no Hiate com a invocação do S. ${ }^{r}$ do Bom fim, se acharão os [de Luís de] Molina de justitia et jure a q. se lhe não deu desp ${ }^{\circ}$. por serem prohibidos, e por q. [tinha...] capacide . e talento para. a lição [...] delles distinguindo as doutrinas $\mathrm{p}^{\mathrm{a}}$. não se aproveitar das q. podem ser offensivas à Religião, e as Soberanias desta Coroa, e dir ${ }^{\text {to }}$. do Reyno.”, pedia licença para conservá-los. Se nesta justificativa a "capacidade" e o "talento" do leitor-requerente são colocados a serviço da religião e do rei, no requerimento apresentado pelo Morgado de Mateus, ex-governador de São Paulo, aqueles atributos mostram-se claramente mais centrados na própria reputação do requerente. Ele alegou ser "verçado na lingua franceza e Ingleza, e Latina"; ter, "alem dos continuados estudos a q . se applicou, a Instrucção de ter governado honze Annos a Capitania de São

\footnotetext{
${ }^{74}$ IANTT, Real Mesa Censória, Caixa 149 (itálicos meus).

${ }^{75}$ Ibidem.
} 
Paullo", e saber que o "Regio Tribunal" havia "dado Licença a outros Sugeitos p poderem Ler Livros porividos [sic]"; e "não desemerece[r] pellas Suas applicaçoes e Estudos a mesma graça"76.

Subjacente à alegação está a idéia de que as leituras devem variar conforme a "capacidade", os "serviços" e os "direitos" dos indivíduos, definidos por suas origens sócio-profissionais, algo que era reconhecido pelos próprios censores inquisitoriais e que se achava enraizado entre os leitores, como se evidenciou no Capítulo 6. Nas entrelinhas escapa, portanto, a vinculação entre leitura e privilégio existente nas sociedades do Antigo Regime; emerge, sobretudo, o uso do livro enquanto signo de status, de posição social, como objeto cujo acesso estava permeado pelos privilégios, dos quais a própria concessão de licenças para leitura de livros proibidos era um exemplo. Os usos dos livros, segundo os próprios leitores, em resumo, confirmam as inferências feitas na análise dos inventários. Os livros, primeiramente, inscreviam-se numa sociedade regida pela idéia de privilégio e pela glorificação das aparências: a posse dos mesmos era, no caso dos livros proibidos, assumida explicitamente por alguns leitores como um direito por merecimento (e não propriamente por nascimento); os livros, em geral, eram um símbolo de poder e, por isto mesmo, operavam como ornamento. Os livros, além disso, serviam enquanto fonte de saber: eles forneciam conhecimentos necessários para o exercício de ofícios, para a realização de estudos escolares, para a vivência imediata das crenças religiosas e para a depuração e defesa da fé. Sendo fontes de conhecimento, os livros engastavam-se em relações e estratégias de poder, oferecendo subsídios para aqueles que dominavam e, como sugere uma leitura das entrelinhas das afirmações feitas pelo advogado pernambucano Daniel Grijó, também para aqueles que, pelo contrário, almejavam subverter a ordem. Nesse ponto, encontra-se a abertura, portanto, para a heresia e para a sedição. A potencialidade subversiva do livro foi claramente explicitada por Nuno de Freitas, um estudante coimbrão, de fins do século XVIII, o qual, como se verá a seguir, foi preso pela Inquisição sob a acusação de heresia, junto com outros alunos, dentre eles Antônio de Morais Silva e Francisco de Mello Franco. Antônio de Morais emprestara-lhe o Emílio, de Rousseau, e, segundo Nuno, da leitura do livro ele passou à heresia, pondo em dúvida as verdades reveladas da religião católica:

\footnotetext{
${ }^{76}$ IANTT, Real Mesa Censória, Requerimentos, Caixa 113.
} 
"que elle Reo [isto é, Nuno] nunca tinha visto, e Leo, seguindose desta lição dúvidas, como duvidou athe se vir aprezentar nesta Meza [a mesa da Inquisição de Coimbra] da Revelação, e dos Castigos eternos, chegando no sobredito tempo quazi a termo de asentar que era certa a doutrina do dito Autor, falsa a Escriptura Sagrada, a tradição e todos os Dogmas da Religião Catholica Romana, e não duvida o viria a fazer senão fora prezo por este [sic] Inquisição" $"$.

\section{Leituras Inventivas e Heresia}

A heresia implica, via de regra, uma leitura, uma audição ou uma apropriação inventiva de textos e símbolos considerados sagrados. Na América Portuguesa, do século XVI até o final da Época Colonial, e também no Reino, em fins do século XVIII, essa relação entre leitura e heresia comumente se verificou. Assim, a heresia teve, como um de seus passaportes, a inventividade dos leitores no contato com os textos sagrados. Antes de passar à abordagem das relações entre leituras e heresias na América, dos séculos XVI e XVII e, depois, do século das Luzes e dos inícios do Oitocentos, cumpre precisar o que se está entendendo por inventividade. Inventividade é a criatividade e a liberdade que o leitor exercita diante dos livros e, de resto, face aos agentes que estão por trás de sua produção ou que interferem em sua circulação e posse. Essa liberdade é desenvolvida de diferentes formas pelos leitores: possuindo obras proibidas; fazendo dessas últimas um elemento importante para afrontar os princípios defendidos pela censura e pelos poderes constituídos; criticando os próprios textos, duvidando de suas afirmações e subvertendo o seu sentido; e, por fim, apropriando-se das idéias contactadas na leitura para criticar a própria realidade imediata em que se vive. A inventividade, nessas quatro acepções, no mundo luso-brasileiro, muitas vezes, quando não conduziu à heresia, ao menos reforçou-a, sendo de qualquer modo um seu correlato.

\subsection{Antecedentes Quinhentistas e Seiscentistas na América}

Na América Portuguesa, do século XVI ao XVIII e, no Reino, principalmente ao final do Setecentos, houve leitores que caíram nas garras da justiça eclesiástica ou da Inquisição e que se pautaram pelo desenvolvimento de leituras inventivas. De

\footnotetext{
${ }^{77}$ IANTT. Inquisição de Lisboa, Processo no 2015.
} 
algum modo, tais leitores foram acusados ou confessaram delitos que remetiam a livros contactados e a leituras realizadas. Embora muitas vezes não seja possível assegurar a veracidade das acusações e confissões, seja dos condenados, seja dos demais, nas fontes inquisitoriais vê-se uma riqueza de dados para a história das práticas de leitura. Mesmo se as informações encontradas não forem rigorosamente verdadeiras, elas indicam possibilidades de leitura e de apropriação dos livros existentes no passado. Ou seja, os implicados podem não ter feito as leituras ou mesmo não ter-se apropriado dos livros tal como consta das denúncias e das confissões, mas leituras e apropriações foram realizadas por alguém e, mais do que isso, circularam socialmente no período considerado. Assim, os exemplos a seguir, direta ou indiretamente, dão uma idéia de quão inventivos foram alguns leitores coloniais e reinóis.

O ponto de partida pode ser uma leitura inventiva das mais freqüentes, de meados do século XVI aos inícios do século XVII, e que não tinha nenhum conteúdo herético. Trata-se das leituras que tinham por base A Diana, obra redigida em castelhano pelo português Jorge Montemor ${ }^{78}$, proibida pela Inquisição portuguesa no século XVI, como se mostrou no Capítulo 4. Tendo como protagonista uma pastora, ex-amante de Sireno, cujo abandono a leva a sair em busca dos lugares onde vivera seu idílio com o fito de revirer as velhas recordações, tal obra é, segundo palavras de Sérgio Buarque, "declaradamente uma canção feminina, onde, tal como nas velhas canções de amigo, é natural que à mulher venha a caber a parte da vítima lamentosa, vítima, em verdade, da crueza e mobilidade dos homens"79.

Em fins do século XVI e início do Seiscentos, o livro em questão era objeto de uma leitura intensiva, isto é, seus leitores o leram por repetidas vezes. Leram-no, ainda, mesmo sabendo ser ele defeso. Em Pernambuco, Bartolomeu Fragoso, licenciado em Artes, era um aficcionado pelo livro ${ }^{80}$; Bento Teixeira, o autor da Prosopopéia, ao que parece também o lia, a acreditar-se numa denúncia feita ao Santo Ofício ${ }^{81}$. Na Bahia, Domingos Gomes Pimenta, morador em Passé, manteve-se possuindo-o e lendo-o, por muitas vezes, sem embargo de algumas pessoas lhe

\footnotetext{
${ }^{78}$ HOLANDA, Sérgio Buarque de. Capítulos de literatura Colonial, op. cit., p. 306.

${ }^{79}$ Ibidem, p. 306-311.

${ }^{80}$ SILVA, Maria Beatriz Nizza da. Sociedade, instituições e cultura. In: JOHNSON, Harold, SILVA, Maria Beatriz Nizza da (coord.). Nova história da expansão portuguesa: o império brasileiro: 15001620. Lisboa: Editorial Estampa, 1992, p. 541-542.

${ }^{81}$ HOLANDA, Sérgio Buarque de. Capítulos de literatura Colonial, op. cit., p. 28.
} 
dizerem "que o dito livro era defeso" "e ele ter para si que o era" 82 . Também na Bahia, em Matoim, Nuno Fernandes confessou o mesmo delito — e idêntica consciência: sabendo "ele que o livro chamado Diana era defeso, ele contudo leu por ele muitas vezes, não lhe lembra quantas". Nuno, além disso, confessou ler outras obras proibidas: "Ovídio de Mefamorgis [as Metamorfoses, de Ovídio] em linguagem, não sabendo ser defeso", o mesmo se dando com Eufrozina, comédia de Jorge Ferreira de Vasconcelos, publicada em 1555 e depois proibida pela Inquisição ${ }^{83}$.

Displicência em relação à proibição também se verificou da parte de Bartolomeu Fragoso, licenciado em Artes, igualmente na Bahia: numa ocasião, quando estava "lendo ele por uma Diana, de Monte Mayor, lhe disseram que era proibido aquele livro e, sem embargo disso, ele o acabou de ler depois de ouvir que era proibido"; interrogado pelo inquisidor, contou que "já o rompeu, e assim como ia lendo o ia rompendo" ${ }^{\prime 4}$. Mesma reticência em relação à proibição inquisitorial verificou-se da parte de Bento da Costa, cristão-novo, na Bahia, em 1618: fora avisado por algumas pessoas, dentre elas um barqueiro, de que o livro Diana era obra proibida, mas mesmo assim "o lera por espaço de dous meses no fim dos quais the levara de casa Christovão Veiera [sic] escrivão dos aggravos da Relação da Bahia" Paula de Siqueira, também na Bahia, mais de duas décadas antes, foi outra leitora intensiva e inventiva da Diana. Em torno desse livro, construiu uma rede de sociabilidades fundada na oralidade: lendo-o com prazer, por inúmeras vezes, chegou a decorá-lo e a usá-lo para contar às amigas histórias de pastores, ninfas e amores. Atrevidamente, Paula afirmou, diante do Santo Ofício, não ver razão para se proibir

\footnotetext{
${ }^{82}$ VAINFAS, Ronaldo (org.). Confissões da Bahia: Santo Ofício da Inquisição de Lisboa, op. cit., p. 206-7.

${ }^{83}$ Ibidem, p. 300. Informou que, desses três livros, "somente tinha o dito Ovídio", o que parece indicar que os demais ou eram emprestados, ou foram passados a outrem após a leitura.

${ }^{84}$ Ibidem, p. 97-9. Bartolomeu, ao que tudo indica, era bastante ousado para os padrões da época, pois colocava suas vontades, seu conhecimento e sua sede de saber acima das proibições e da própria fé em Cristo. Numa discussão com seu mestre de artes "acerca de uma conta da circunferência e diâmetro da Terra, dizendo ele", Bartolomeu, "que a dita conta feita por ele conforme certas opiniões que ele seguia estava certa", ouviu de seu mestre que ele "errava na dita conta, com palavras de escândalo" (Ibidem, loc. cit.). Em resposta ao mestre, então, "à porta dos estudos”, proferiu as seguintes palavras: “Tão certo estou nestas contas que, dado caso que cá viesse Cristo e me dissesse não ser assim, cuido não daria crédito a mo dizer'، (Ibidem, loc. cit.). Segundo Ronaldo Vainfas, Bartolomeu foi processado e condenado pelo visitador do Santo Ofício a sair em público e fazer abjuração de leve suspeita na fé após ouvir sentença na igreja, sendo degredado para todo o sempre da Bahia.

${ }^{85}$ SEGUNDA visitação do Santo Ofício às partes do Brasil pelo inquisidor e visitador o licenciado Marcos Teixeira. Livro das Confissões e Ratificações da Bahia - 1618-1620, op. cit., p. 372-373.
} 
o livro citado, acrescentando "que tinha muito gosto de lê-lo" e que, por sua vontade, "sempre o leria não fosse sabê-lo 'quase todo de cor","86.

Paula de Siqueira, no entanto, não se resumiu apenas a essa leitura heterodoxa. Uma velha feiticeira chamada Boca Torta "lhe deu uma carta que chamam de tocar" ${ }^{\circledR 7}$, um tipo de escrito que conferia poderes mágicos a quem os possuísse, proibido pela censura portuguesa no século XVI, como se mostrou no Capítulo 4. Para que a carta fizesse efeito, a referida feiticeira teria dito à confessante ser necessário "que fosse a três padres que lhe dissessem três evangelhos, e a dita velha depois lha tornou dizendo-lhe que já tinham dito três evangelhos na cabeça sobre a dita carta" ${ }^{\natural 8}$. Paula alegou não ter lido, nem usado a carta de tocar, acrescentando ainda que a tinha queimado havia "mais de sete ou oito anos" $"$. Além de possuir e ler livros proibidos, Paula de Siqueira, portanto, deteve uma carta de tocar, escrito nada ortodoxo, que alegou não ter usado, proibido pela censura inquisitorial em 1564. E o uso dela, feito ou não por Paula-e, com certeza, realizado por outras pessoas no período colonial, como Adrião Pereira, em Belém, em 1763, em pleno Século das Luzes ${ }^{90}$ —, implicava uma considerável inventividade no trato com a Escritura Sagrada, conforme apontam as palavras atribuídas à Boca Torta, na medida que requeria a leitura de três evangelhos. Aqui, portanto, inventividade é sinônimo de violação das normas censórias e daquelas fixadas pela igreja católica em relação aos usos da Bíblia, que não deveria ser elemento de magia.

Se Paula negou ter usado a Bíblia de forma tão pouco ortodoxa, o mesmo não pôde fazer nos idos de 1675, um mulato recém-chegado à Lisboa, vindo de Pernambuco. Ele foi denunciado à Inquisição por possuir alguns papéis: uma oração de S. Cipriano em português; duas cartas de tocar com o Evangelho de S. João, em latim, e outras palavras da Sagrada Escritura e, ainda, um papel em que se ensinava a usar as referidas cartas de tocar. Nesse último papel, propunha-se uma utilização

\footnotetext{
${ }^{86}$ VAINFAS, Ronaldo. Sodomia, mulheres e Inquisição: notas sobre sexualidade e homossexualismo feminino no Brasil Colônia, p. 13 (mimeograf.).

${ }^{87}$ VAINFAS, Ronaldo (org.). Confissões da Bahia: santo ofício da Inquisição de Lisboa, op. cit., p. $110-1$.

${ }^{88}$ Ibidem, loc. cit.

${ }^{89}$ Ibidem, loc. cit.

${ }^{90}$ LIVRO da visitação do Santo Ofício da Inquisição ao Estado do Grão-Pará: 1763-1769. Petrópolis: Vozes, 1978, p. 130. Sobre o assunto, veja também: SOUZA, Laura de Mello e. O diabo e a Terra de Santa Cruz, op. cit., p. 228-230.
} 
bastante heterodoxa da oração e do Evangelho citados, começando-se com os seguintes termos:

"Jesus Cristo emtrou, vençeo escarnesseo e teve quoanto quis asim tenha eu de fulano óu fulana tudo quoanto eu quizer. Asim como o iferno erguerão e abaixaram e tirarão os santos padres que lá estavão, assim venssa eu esta creatura e tudo quoanto eu desejar" ${ }^{\prime 1}$.

Em seguida, estabelecia-se o dever de mandar rezar três missas em cima desses papéis, colocando-os debaixo da pedra de ara e, por fim, ler três evangelhos de São João. Vê-se, aqui, um leitor inventivo que subvertia a utilidade prescrita pela Igreja aos textos e símbolos sagrados, associando-os à magia, imergindo-os na leitura oral.

As práticas mágicas envolvendo o uso de livros e objetos sagrados, ao que tudo indica, não eram incomuns no período colonial. Em 1618, na Bahia, Maria de Penhosa, cristã-velha, confessou ao visitador da Inquisição D. Marcos Teixeira que meses antes havia feito "huas sortes cõ hum Livro das horas de Nossa Senhora e co hua chave por lho pedir Barbara Gudinha", sua vizinha, "para descobrir hum furto", esclarecendo que aprendera a tirar as mesmas sortes com amigas suas ${ }^{92}$. Com fito idêntico, nas mesma cidade e data, Antônio da Costa, também cristão-velho, fora a casa de Ana Coelha, a qual, a seu pedido,

"fizera diante elle a feitiçaria q. chamão das Horas de Nossa Senhora q he[ra] do modo seguinte. Tomou hu Livro das Horas de Nossa Senhora, e abridoo [sic] lhe meteu hua chave de cadeado no meyo ficando a maior parte da chave de fora, e fechando as horas cõ as brochas pos hu dedo na chave e cõ o dedo de hu menino seu filho posto tambem na chave de modo q ficava o Livro no ar e nomeando" ${ }^{\text {"93 }}$.

A Escritura Sagrada, de fato, não escapava à sanha inventiva dos leitores. Alguns, desobedeciam a proibição de lê-la em língua vernácula. Em Pernambuco, Filipe Cavalcanti, senhor de engenho florentino, e João Nunes, mercador cristãonovo, foram denunciados por este delito; além disso, uma mulher solicitava ao

\footnotetext{
${ }^{91}$ MARQUILHAS, Rita, op. cit., p. 87.

92 SEGUNDA visitação do Santo Ofício às partes do Brasil pelo inquisidor e visitador o licenciado Marcos Teixeira. Livro das Confissões e Ratificações da Bahia - 1618-1620, op. cit., p. 449.

${ }^{93}$ Ibidem, p. 447. O mesmo Antônio da Costa cultivava certo apreço pela magia, tendo copiado um livro de quiromancia que lhe havia sido emprestado por Brás Sarmento, cristão-velho, obra em que havia "cousas curiosas", nas quais ele "não tinha fee". O confessante alegava não saber que o dito livro era defeso (op. cit., p. 448).
} 
mestre-escola Bento Pereira, já mencionado anteriormente, "para lhe declarar a Bíblia de latim em linguagem" (isto é, em português), conjugando a desobediência à norma com tradução e leitura oral ${ }^{94}$. O mesmo Bento Pereira, em depoimento à Inquisição, revelava erudição, discorrendo sobre livros pouco ortodoxos, ainda que para combatê-los: mostrou desenvoltura em relação ao Talmude e aos talmudistas, classificando-os, juntamente com os cabalistas, como os piores inimigos da fé cristã ${ }^{95}$. Para tanto, apoiou-se no Simbolo de la Fé, do frei Luís de Granada, e no De Gloria et Nobilitae Civile et Cristiana, do bispo Jerônimo Osório. Não é possível assegurar que essa ortodoxia era dissimulação; sabe-se, no entanto, que ele discutiu sobre a Criação com o presidente do mosteiro onde habitou, depois de ter matado a própria mulher: "defendeu a tese herética de que Adão, ainda que não pecasse, nem por isso deixaria de morrer"; falou, ainda, que, como Deus criara o homem à sua imagem, não iria aplicar-lhe mais castigo no além túmulo do que os tormentos da consciência, tese esta que parecia negar a existência do Inferno ${ }^{96}$. Já Manoel Homem de Carvalho, cristão-novo, em Salvador, em 1620, lera, segundo sua própria confissão, uma Bíblia "impresa e traduzida em ligua [sic] Castelhana”, aconselhado por determinadas pessoas que queriam que ele passasse para a "Ley de Moisés"97. Logo, se não retomou suas crenças judaicas, ao menos desobedeceu às ordens censórias que interditavam a leitura da Bíblia em linguagem. Risco de tangenciar o judaísmo, ao que parece, também correu João de Araújo, holandês, cristão-novo, na mesma cidade, um ano antes: achara em um escritório "dous livros impressos encadernados em purgaminho [sic], hum em Lingoa Castelhana, outra [sic] em Portugues, hum cõ todo o Psalterio de David, e outro cõ os Psalmos penitenciaes e outras orações tudo traduzido", tendo entregue os livros ao saber que os mesmos eram proibidos ${ }^{98}$.

Havia quem colocasse num mesmo plano a Escritura Sagrada e os escritos profanos mais mundanos, como Manuel Barroso, cristão-velho, na Paraíba, em 1595. Ele confessou ao visitador do Santo Ofício ter debatido com Cosmo Borges sobre contas que tinha com ele, "lançadas no seu livro" (do confessante). Colerizado, disse

\footnotetext{
${ }^{94}$ SILVA, Maria Beatriz Nizza da. Sociedade, instituições e cultura, op. cit., p. 541-542.

${ }^{95}$ HOLANDA, Sérgio Buarque de. Capítulos de Literatura Colonial, op. cit., p. 28.

${ }^{96}$ Ibidem, loc. cit.

${ }^{97}$ SEGUNDA visitação do Santo Ofício às partes do Brasil pelo inquisidor e visitador o licenciado Marcos Teixeira. Livro das Confissões e Ratificações da Bahia - 1618-1620, op. cit., p. 507.

${ }^{98}$ Ibidem, p. 435-436.
} 
"que assim como os evangelistas falavam verdade nos evangelhos, assim ele confessante falava verdade nas adições do seu livro que tinha nele assentadas" 99 . Em outras circunstâncias, cristãos-novos e cristãos-velhos duvidaram da veracidade do Evangelho de São João, considerando-o mentiroso. Roque Garcia confessou que, alguns nos antes de 1591, em Sergipe, discutira com o capitão Tomé da Rocha sobre uma menção que uns negros fizeram a mortes feitas pelos gentios. O capitão disseralhe, então, "que os negros mentiram", ao que o confessante respondeu "que tanto cria no que diziam aqueles negros como nos Evangelhos de são João"; alegou o confessante, porém, que "disse aquelas palavras parvamente"100. Maria Varella, cristã-velha, em 1592, moradora no Recôncavo Baiano, contou ao inquisidor que, fazia dez ou doze meses, falara que "cria tanto à sua negra como o Evangelho de são João"101. Andresa Rodrigues, cristã-velha, também no Recôncavo, em 1592, confessou que dissera dois anos antes que sua negra Felipa "tanta verdade falava [...] como o Evangelho de são João"102. A isto o visitador indagou-lhe se sabia "que a verdade do Evangelho é infalível, em que nunca pode haver engano, e que a sua negra, ainda em caso que" falasse a verdade, poderia enganar-se. Em resposta, Andressa mostrou-se contrita, dizendo que acreditava na "certeza infalível do Evangelho, mas que, com agastamento, sem considerar, disse a dita blasfêmia" ${ }^{\prime 103}$.

No Nordeste, no final do século XVI, encontravam-se ainda outros leitores inventivos: alguns por possuírem e lerem livros proibidos, outros por fazerem de livros ortodoxos motivo de pilhéria ou de discordância. Diogo de Couto, vigário da vara em Pernambuco, lia livros interditados por Roma ou pelo Santo Ofício, como a Ropica Pnefma, de João de Barros, estimulando outras pessoas a fazê-lo ${ }^{104}$. Heitor Antunes, mercador, morador de Matoim, Bahia, possuía um “Alvará dos Macabeus”,

\footnotetext{
${ }^{99}$ MELLO, José Antônio Gonsalves de. Confissões de Pernambuco (1594-1595): primeira visitação do Santo Ofício às partes do Brasil, op. cit., p. 129.

${ }^{100}$ VAINFAS, Ronaldo (org.). Confissões da Bahia: Santo Ofício da Inquisição de Lisboa, op. cit., p. 91.

${ }^{101}$ Ibidem, p. 311.

102 Ibidem, p. 323.

103 Ibidem, loc. cit. Em determinadas circunstâncias, as dúvidas sobre a Escritura Sagrada eram lançadas como um artifício retórico, de conversação. João Poré Montafaux, por exemplo, flamengo estabelecido em Salvador nos idos de 1618, encolerizado com a incredulidade de um soldado, pôs em xeque a própria palavra de Deus, dizendo-lhe que a seguir suas idéias (do militar), "se não creria as maravilhas de Deus e de seus sanctos que estavão escritas" (SEGUNDA visitação do Santo Ofício às partes do Brasil pelo inquisidor e visitador o licenciado Marcos Teixeira. Livro das Confissões e Ratificações da Bahia - 1618-1620, op. cit., p. 457).

${ }^{104}$ MELLO, Evaldo Cabral de. O nome e o sangue: uma fraude genealógica no Pernambuco Colonial.
} São Paulo: Companhia das Letras, 1989, p. 180. 
segundo Ronaldo VAINFAS, “um dos livros sagrados dos judeus que conta a história dos sete varões deste nome" ${ }^{\text {105 }}$. Fernão Gomes, na Bahia, cristão-novo, fez de um livro motivo para apresentar uma proposição heterodoxa: "em casa de Besuarte de Andrade, levando-lhe ele uma obra, vindo a falar sobre ela”, Fernão disse “"eu sou alfaiate que não furto e neste caso não devo nada a nenhum homem, nem mulher, nem à minha alma, nem a Deus" "106. O florentino Rafael Olivi, em Ilhéus, em 1574, lera o Flos Sanctorum, livro que conta as vidas dos santos e de Jesus Cristo, e, ainda, o Cântico dos Cânticos, do Antigo Testamento. Acusaram-no de dizer que a:

"religião fora inventada para sujeitar as gentes, por que com as armas nem com o Império nunca acabaram de sujeitar; que os portugueses faziam tanta honra a Nossa Senhora e a tratavam e veneravam tanto as imagens da Madre de Deus, que parecia que faziam tanta honra a ela como a seu filho e que isso não lhe parecia bem" 107 .

Pesaram-lhe, além disso, outras acusações: fazer a apologia dos turcos, dizendo, talvez referindo-se à poligamia, que eles estavam certos; criticar abertamente o papa, os cardeais, o presépio; e profanar a ermida de sua fazenda, permitindo que negros tivessem nela "ajuntamento com as negras"108. Olivi, além disso, seria cético em relação a certos milagres relatados no Flos Sanctorum: as chagas e a levitação de São Francisco e o milagre de São Silvestre na conversão do imperador Constantino, considerada por ele "“arte mágica",109. Comentando o livro Cântico dos Cânticos, por fim, teria afirmado que "a dileta de Salomão era sua puta", apropriando-se, assim, da Escritura Sagrada de um modo nada ortodoxo ${ }^{110}$. Ao invés de aceitar as histórias que lia, portanto, Olivi, parecia mostrar-se inventivo, criticando e fazendo irreverências sobre os conteúdos das obras ${ }^{111}$. E, tal como Paula de Siqueira, mergulhou na oralidade, alardeando suas dúvidas.

O Flos Sanctorum, como se viu no Capítulo 4, foi proibido em 1637 pela Inquisição; em 1642, os cristãos-velhos receberam autorização para ler sua Segunda Parte. Essa mesma parte, contudo, era proibida à época da instalação da Real Mesa

\footnotetext{
${ }^{105}$ VAINFAS, Ronaldo (org.). Confissões da Bahia: Santo Ofício da Inquisição de Lisboa, op. cit., p. 53.

${ }^{106}$ Ibidem, p. 55-56.

${ }^{107}$ MOTT, Luiz Mott, A Inquisição em Ilhéus, Revista FESPI, Ilhéus, (10): 74, jul./ dez. 88/89.

${ }^{108}$ Ibidem, p. 74-75.

${ }^{109}$ Ibidem, loc. cit..

110 Ibidem, loc. cit.

${ }^{111}$ Olivi foi preso pela justiça eclesiástica e mantido incomunicável, sendo os documentos acusatórios enviados à Inquisição de Lisboa, a qual, contudo, considerou as denúncias contraditórias, insuficientes para a prisão, ordenando que o mesmo fosse despachado na Bahia (Ibidem, p. 75). É possível,
} 
Censória, uma vez que em 1768 foi necessário ao padre Antunes Leitão pedir licença para lê-la ${ }^{112}$. Na América portuguesa ao final do Quinhentos, ao que tudo indica, verificava-se ao menos uma postura inventiva em relação ao referido livro. Álvaro Sanches, cristão-novo, na Bahia, em 1591, confessou ao visitador da Inquisição de Lisboa, Heitor Furtado de Mendonça, que, dezoito anos antes, em Passé, "tomou um Flos sanctorum e com um alfinete picou uma figura que estava debuxada [palavra galega cujo significado é desenhada] no dito Flos sanctorum de Nossa Senhora e lhe picou a coroa e parte da cabeça de Nossa Senhora, e picava a dita imagem para a tirar em debuxo e lhe ser de molde para por ele tirar outros debuxos semelhantes, e isto fez com esta intenção boa, sem ter intenção ruim, nem pensamento dela" 113 . Sanches, talvez, não pusesse em xeque as histórias do livro citado, quem sabe sequer desrespeitasse a imagem de Nossa Senhora, mas, de algum modo, ele conferia ao livro uma utilidade outra, apropriando-se dele de uma forma muito original, ao retirar partes de uma ilustração de Maria e transformá-las em moldes.

A inventividade dos leitores em relação às imagens não se limitou ao picar. Em Pernambuco, nos idos de 1593, uma gravura italiana que Luís Mendes de Thoar, um empregado doméstico, pregara em sua cama, suscitou uma leitura bastante inventiva por parte deste. A partir da observação da cena retratada na gravura, em que se viam o Pai, o Filho e o Espírito Santo a coroar Nossa Senhora, Luís Mendes concluía que o Espírito Santo deveria ser a segunda pessoa, e o Filho a terceira, com o que não concordava um outro empregado doméstico, que, fiel à ortodoxia, considerava o inverso. Nessa leitura intensiva vê-se, assim, o peso do concreto na lógica do pensamento popular; toma-se a representação pela coisa representada ${ }^{114}$; representa-se, lê-se e pensa-se sobre conceitos abstratos a partir de elementos concretos — isto é, a ordem da pessoas da Trindade é definida a partir de uma gravura.

Na França Antártida, colônia francesa que abrigava — não sem tensões — calvinistas e católicos, como se apontou anteriormente, circularam livros calvinistas. A posse de tais livros, nesse fugaz enclave francês na América Portuguesa, não

\footnotetext{
portanto, que a inventividade da leitura não fosse dele, mas sim de seus acusadores.

${ }^{112}$ IANTT, Real Mesa Censória, Livro, p. 34-34v.

${ }^{113}$ VAINFAS, Ronaldo (org.). Confissões da Bahia: santo ofício da Inquisição de Lisboa, op. cit., p. 101.

${ }^{114}$ SOUZA, Laura de Mello e. Inferno Atlântico: demonologia e colonização (séculos XV e XVII), op. cit., p. 49-50.
} 
constitui propriamente uma manifestação de inventividade, dado que não se vivia aí sob as normas lusitanas. Mas a existência de tais obras "heréticas", em espaço tão contíguo às terras de El-rei, logo repercutiu nessas últimas, suscitando usos inventivos. Pero da Vila Nova e Jean Cointa, ex-colonos da França Antártida, fugiram para o lado português, levando consigo, livros "hereges" ou, ao menos as apropriações que fizeram das idéias que encontraram nesses. Pero da Vila Nova e sua família, todos católicos, estabeleceram-se na colônia francesa em 1557. Pero, então com cerca de 19 anos, freqüentou por alguns dias, ao que parece à força, às aulas ministradas pelos reformados, tomando contato com as doutrinas e livros que os "luteranos" divulgavam. Nessas aulas, assim, ele "ouvia aos mesmos luteranos ler e ensinar a seita luterana e cerimônias dela" ${ }^{, 15}$.

Onze meses depois de chegar ao Rio, Pero fugiu para o território português. Em fins do século XVI, encontrava-se estabelecido na Bahia, onde contara para algumas pessoas os "erros luteranos" aprendidos na juventude, o que se chocava com os ditames da igreja católica, que, em plena Contra-Reforma, se esmerava por conter a difusão do protestantismo. Quando da visitação do inquisidor Heitor Furtado de Mendonça, Pero apresentou-se à mesa do tribunal, relatando seu contato com livros protestantes e confessando sua imprudência - ou, nos termos que aqui se apresentam, sua inventividade — de comentar os referidos "erros", alegando que nunca deixara de ser católico.

Jean de Cointa, ou João de Bolés, aportou no Rio de Janeiro em 1557. Na então colônia francesa, ensinou "as artes liberais, grego e hebraico, e era mui versado na Sagrada Escritura"116 e na língua espanhola ${ }^{117}$, chegando a "dar lições públicas", principiando pelo Evangelho de São João ${ }^{118}$. De algum modo, imiscuiu-se nas disputas teológicas travadas entre calvinistas e católicos, sendo considerado um papista pelos primeiros (segundo Jean de LÉRY, embora ele tivesse abjurado publicamente o papismo, renunciado à transubstanciação e à consubstanciação, dizia ““este é o meu corpo, este é meu sangue', e tais palavras só podiam significar que ali

\footnotetext{
${ }^{115}$ VAINFAS, Ronaldo (org.). Confissões da Bahia: Santo Ofício da Inquisição de Lisboa, op. cit., p, p. 191-4. O confessante foi processado pelo visitador, sendo sentenciado a abjurar de leve e não contar a ninguém como eram os "costumes luteranos".

116 ANCHIETA, José de. Cartas, informações, fragmentos históricos e sermões. Belo Horizonte: Itatiaia; São Paulo: Edusp, 1988, p. 167.

117 SILVA, Maria Beatriz Nizza da. Sociedade, instituições e cultura, op. cit., p. 513-516.

${ }^{118}$ LÉRY, Jean de. Viagem à terra do Brasil. Trad. Sérgio Milliet. Belo Horizonte: Itatiaia; São Paulo: Edusp, 1980, p. 98.
} 
se encontravam o corpo e o sangue de Jesus Cristo") ${ }^{119}$. Quando os franceses preparavam-se para atacar a Capitania de São Vicente, resolveu abandonar seus compatriotas, traindo-os, passando para o lado dos portugueses, motivo pelo qual deve ter angariado simpatias entre esses últimos. Em São Vicente e Piratininga, não perdeu oportunidade para exibir sua cultura e expressar suas posições, granjeando popularidade por sua facilidade de conversação. Suas posições sobre a religião e a igreja, no entanto, não eram muito conformes ao estabelecido pela igreja católica. Ele costumava ler "em seu cartapácio" um "trecho que tresladara de um livro de Lutero", obra proibida. Quando questionado sobre isto, Bolés respondeu "que na sua terra era lícito ler todos os livros" $"$. Dizia, dentre outras coisas, que o Papa era "hum homem como nós" (isto é, um homem comum) e que tinha em Roma "putarias de homens, por que pagam dinheiros" ${ }^{\prime 21}$. Assim, logo entrou em atrito com os jesuítas, que o viam como um rival perigoso. O inaciano Luís da Grã, em 1560, acusou-o de possuir "livros [...] cheios de heresia" e de cativar a muitos com sua "peçonha luterana", vindo, então, a denunciá-lo ao ouvidor eclesiástico de Santos, o qual absolveu-o. No entanto, quando Bolés viajava para o Reino, tendo a nau em que se encontrava parado na Bahia, foi preso por ordem do bispo. Novas testemunhas foram ouvidas, dentre elas o governador Mem de Sá, que atestou a importância de sua participação para a conquista do Rio de Janeiro aos franceses. O processo foi encaminhado à Inquisição de Lisboa, da qual Bolés se livrou apenas em $1564^{122}$.

A autoridade papal era outra vítima da inventividade dos leitores. Às vezes, tratava-se apenas de zombaria, de galhofa, sem maiores questionamentos. Assim, André Lopes Ilhoa, cristão-novo, em Salvador, nos idos de 1618, conversava com o padre Antônio Neto e outras duas pessoas sobre a Bula da Composição, sobre a qual havia muitas dúvidas, sendo trazido então o "Regim ${ }^{\text {to }}$., e tomando o [...] na mão dissera, ora averiguemos estas palavras não sendo tensão delle [...] dizer as ditas palavras em desprezo da Bulla, senão pellas duvidas e desbarates q. se tratavão"123.

\footnotetext{
${ }^{119}$ Ibidem, p. 94.

${ }^{120}$ SILVA, Maria Beatriz Nizza da. Sociedade, instituições e cultura, op. cit., loc. cit.

${ }^{121}$ LEITE, Serafim, Cartas dos primeiros Jesuítas do Brasil, São Paulo: Comissão do IV Centenário, 1954, vol. 3, p. 179. Essa imagem negativa de Roma era bastante disseminada. O capitão donatário Pero do Campo Tourinho apresentava, à mesma época, idéias similares sobre a Cidade Eterna. Gil Vicente escrevia: "Ó Roma sempre vi lá/ Que matas pecados cá/ e leixas viver os teus.../ Assolves a todo o mundo / e não te lembras de ti/ nem vés que te vas ao fundo" (apud. José Timóteo da Silva Bastos, op. cit., p. 17).

${ }^{122}$ SILVA, Maria Beatriz Nizza da. Sociedade, instituições e cultura, op. cit., loc. cit.

${ }^{123}$ SEGUNDA visitação do Santo Ofício às partes do Brasil pelo inquisidor e visitador o licenciado
} 
Quando interrogado pelo inquisidor se punha em dúvida a autoridade papal — o que "era heresia" - , André respondeu "que sentira sempre, e sentia bem das ditas Bullas, e nuca [sic] duvidarado [sic] poder do Sumo Pontifice"124.

Nos séculos XVI e XVII, na América Portuguesa, em suma, existiram indivíduos que demonstravam inventividade enquanto leitores, desrespeitando as proibições da censura portuguesa, usando textos considerados sagrados pela Igreja em artes mágicas e, até mesmo, pondo em dúvida as verdades que os mesmos traziam. Essa inventividade, muitas vezes, assim, levou-os a blasfemarem, a zombarem e a questionarem documentos eclesiásticos, livros de devoção e passagens da Escritura Sagrada (com destaque para os Evangelhos de são João), chegando alguns, a partir disso, a resgatar seu credo judaico e, outros, a pôr em dúvida os dogmas, os mistérios da fé católica e a autoridade pontifícia, Assim, algumas leituras, num tempo de Reforma e Contra-Reforma, abriram caminho ou corroboraram heresias.

\subsection{Luzes e proposições heréticas e iconoclastas no mundo luso-brasileiro}

A correlação entre leitura e incursões pela magia, pela fé judaica e pela heresia manteve-se no século XVIII. Alguns incorriam em heresias quase que inocentemente, como Ambrósio Nunes, na Paraíba dos idos de 1742, onde, em viagem com um seu parente, "puchando por um livro que trazia principiou nele a ler os Martírios da Paixão de Cristo Senhor Nosso e disse a ele confitente que visse a quem queria adorar e conhecer por Deus que era um homem que fora preso e asautado [sic]" ${ }^{\prime 125}$. Se nessa humanização de Jesus Cristo não parece haver nenhum indício de incredulidade ou de desvio para o judaísmo, houve casos em que tais possibilidades ficaram bem evidentes. Em 1732, Simão Rodrigues Luís Nunes e Luís de Valença liam por alguns livros

\footnotetext{
Marcos Teixeira. Livro das Confissões e Ratificações da Bahia - 1618-1620, op. cit., p. 401.

${ }^{124}$ Ibidem, p. 402.

125 IANTT, Inquisição de Lisboa, Processo 3754 (devo a Bruno Feitler todas as informações sobre processos inquisitoriais em que se associavam judaísmo e leitura). Alguns leitores apenas comentavam episódios do Velho Testamento, sem maiores implicações quer para a fé judaica, quer para a fé católica. Em 1732, Diogo Lopes assistira a uma conversa de Ambrósio Nunes sobre Sansão, na qual se dissera que esse último "tinha sido mui valente e tinha derrubado um templo e no mesmo tempo"; Diogo esclareceu que "ouvia as ditas práticas, mas não sabia a que elas encaminhavam" (IANTT, Inquisição de Lisboa, Processo no 8032).
} 
"que declaravam a forma dos preceitos da dita lei [de Moisés], recomendando estes também as pessoas que se achavam presentes que os ditos jejuns se haviam de oferecer a Deus dos Céus, escarnecendo de Cristo Senhor Nosso, injuriando a sua lei e louvando e encarecendo a de Moisés como única para a salvação das almas, e não passaram mais" ${ }^{126}$.

Esses dois últimos leitores, portanto, não apenas usavam os livros para professar sua fé no judaísmo, como também desacreditavam o cristianismo. Outros, no entanto, iam do Velho Testamento à profissão de fé no judaísmo, parando nesse ponto, como Luís da Fonseca que, "em abono a Lei de Moisés", disse "que Moises andara quarenta anos pelo deserto e outras coisas mais"127. Em 1734, também na Paraíba, Fernando Henriques afirmou que a Lei de Moisés "era boa e verdadeira para a salvação das almas e tirando por um caderno de papel principiou a ler", afirmando "que eram os salmos de David", que era preciso "rezar por observância da dita lei"128. Alguns leitores, à semelhança do que fez Fernando Henriques, copiavam trechos e orações em papéis, usando-os em suas práticas religiosas judaicas. O Capitão Teodózio de Lemos Duarte, familiar do Santo Ofício, numa inquirição feita na Paraïba, em 1733, no engenho de Poxim, veio a "achar muitas orações, manuscritas, bolsinhas e um livro entitulado Pasion del hombre Dios, o qual [...] era dos Livros proibidos",

O percurso inverso, no entanto, do judaísmo ao catolicismo através dos livros, parece ter sido experimentado por outros leitores: em 1729, por exemplo, Diogo Nunes Thomas, homem velho de 83 anos, morador na Paraíba, confessava ter largado a Lei de Moisés, "alumiado pelo Espírito Santo por conhecer que ia errado e por ler um livro entitulado diferença entre o temporal e o eterno", convertendo-se, então, à lei de Cristo $^{130}$. O mesmo se deu com Simão Rodrigues Fonseca, embora se possa suspeitar que sua conversão fosse uma mera dissimulação para escapar da condenação pelo Santo Ofício. Em 1736, ele confessava que recebera de "seu pai em um papel sete salmos traduzidos em Português para ele confitente tomar de cor"; tendo vivido na Leis de Moisés até ser preso pela Inquisição, no colégio "dos Padres

\footnotetext{
${ }^{126}$ IANTT, Inquisição de Lisboa, Processo $\mathrm{n}^{\circ} 12$.

${ }^{127}$ IANTT, Inquisição de Lisboa, Processo no 8032.

${ }^{128}$ IANTT, Inquisição de Lisboa, Processo no 436.

${ }^{129}$ IANTT, Inquisição de Lisboa, Processo no 9397.

${ }^{130}$ IANTT, Inquisição de Lisboa, Processo no 196.
} 
da Companhia da Cidade de Olinda", deixou-se abraçar a "Lei de Cristo Senhor Nosso, porque lendo alguns livros espirituais como são = Diferença entre o Temporal e Eterno $=$ e Oriente conquistado a Jesus Cristo = e Palavras de Deus dezatada [?] e outros mais, conheceu que ia errado" ${ }^{\prime 131}$.

Os cristãos-novos não agiram como leitores inventivos apenas no Nordeste. Em Minas, também nos inícios do século XVIII, há indícios de que se comportavam da mesma forma. Em Ouro Preto, nos idos de 1722, várias pessoas reuniam-se com Diogo Henrique para ouvi-lo ler o livro Eva e Ave, de Antônio de Souza de Macedo - autor que, como se verificou neste Capítulo, era dos mais presentes nas bibliotecas de Mariana - , e falar sobre as vidas dos santos, ao que tudo indica colocando-as em dúvida ${ }^{132}$. No mesmo ano, chegava em Lisboa, proveniente de Minas Gerais, onde passara boa parte de sua juventude, Pedro Rates Henequim. Na história desse homem, observa-se a presença de outra correlação entre heresias e leituras, que, se passava pelo judaísmo, tinha como ponto central a fé cristã, associando as obras do padre Antônio Vieira à defesa de proposições milenaristas e, por conseguinte, mostrando que o milenarismo profético do nosso mais célebre orador católico fez-se presente no universo colonial ${ }^{133}$. Henequim, nascido em Lisboa em 1680, filho ilegítimo de Francisco Henequim, alto funcionário da embaixada das Províncias Unidas em Lisboa, uma família nobre, recebeu, do lado paterno, influência da religião dos huguenotes e, do lado materno, a instrução católica $^{134}$. Ao aportar em Lisboa, Henequim trazia consigo propósitos políticoreligiosos claramente milenaristas: queria convencer o infante D. Manuel, irmão de D. João V, a estabelecer-se na América Meridional e a tornar-se seu Imperador, entendendo que ele havia de ser o fundador do Quinto Império do Mundo, de que falava "a Escritura". Essa proposta, um crime de lesa-majestade, segundo Adriana ROMEIRO, parece ter seduzido o infante e, se concretizada, arrancaria de El-rei a “"melhor parte dos [seus] domínios"”. Para Henequim, no entanto, tal proposição custou a vida, não por configurar um crime de lesa-majestade, mas por ser herética: ele foi condenado à morte em 1744, quando então beirava os 60 anos ${ }^{135}$.

\footnotetext{
${ }^{131}$ IANTT, Inquisição de Lisboa, Processo no 2919.

${ }^{132}$ IANTT. Inquisição de Lisboa, Processo no 7487.

${ }^{133}$ GOMES, Plínio Freire, op. cit., p. 124 e ROMEIRO, Adriana, op. cit., p. 12.

${ }^{134}$ ROMEIRO, Adriana, op. cit., p. 44 e 95.

135 Ibidem, p. 26-47. Não se sabe ao certo em que medida Henequim logrou sucesso em conquistar adeptos à sua causa política, havendo indícios de que, por alguma motivação, não se quis dar
} 
Em 1732, Simão de Oliveira e Souza, mestre de latim, com quem Henequim vivia no beco do Jasmim, em Lisboa, denunciou-o à Inquisição, denúncia esta desconsiderada por se levar em conta o histórico desabonador daquele que a fazia. Segundo a denúncia, Henequim defendera, dentre outras proposições heréticas, as seguintes idéias: a Virgem concebera através do Espírito Santo; haveria a possibilidade de salvação dos condenados ao Inferno; e Deus teria uma natureza corpórea, que seria a matéria cristalina de que eram feitos os anjos. Afirmava, além disso, "que os sentidos das Sagradas Escrituras somente a ele lhos tinha Deus revelado",136.

Henequim, ademais, de algum modo, colocava em dúvida o mau procedimento dos judeus, reproduzindo alguns topoi milenaristas, aqui abordados no Capítulo 1, dizendo que “"brevemente, e antes de dois anos se renovará o Mundo, e no seu governo havera unus Pastor et unum Ovile, e que as dez Tribos [de Israel] se verão congregadas pois estas andam espalhados por toda a América, e assim renascidas as suas primeiras memórias"”. Essas proposições eram indissociáveis dos livros possuídos por Henequim: ele, aliás, nunca se separava de "um pequeno baú, o qual não permitia a ninguém abrir, e onde guardava uma_Bíblia - 'pela qual esta[va] lendo continuamente' - e 'vários papéis', dos quais dizia querer 'fazer uma obra na qual manifest[ass]e o verdadeiro sentido das Escrituras, e o quanto os Expositores, e Santos Padres trataram, e escreveram deles às cegas","137.

Em 1741, Henequim foi novamente denunciado à Inquisição por defender proposições contrárias aos ensinamentos da igreja e, ainda, por recorrer à "“cabala proibida na interpretação das Sagradas Escrituras",138. Preso pela Inquisição, confirmou acreditar-se eleito por Deus para desvendar as muitas maravilhas “"por ninguém sabidas, nem descobertas, e ocultas nas Divinas Letras""139. Expôs suas idéias ao inquisidor em verdadeiras conferências, em tom professoral, arrolando argumentos e conceitos, discorrendo sobre as "sutilezas e astúcias da teologia, ancorando as proposições-chaves, perfeitamente delimitadas, nas provas retiradas da Bíblia”. Apelou com insistência para passagens bíblicas, citadas na versão latina e,

consecução à apuração e, por conseguinte, à punição da parte política de seu delito. Assim, ele foi julgado e condenado por heresia, ficando seu caso restrito à jurisdição inquisitorial.

${ }^{136}$ Ibidem, p. 35.

${ }^{137}$ Ibidem, p. 31-33.

${ }^{138}$ Ibidem, p. 37.

${ }^{139}$ Ibidem, p. 38. 
em alguns casos, ousou "mesmo corrigir a Vulgata de são Jerônimo, descobrindo novos sentidos nos termos hebraicos originais" ${ }^{\prime 40}$.

Se algumas das proposições já apontadas lembram as idéias do padre Vieira, Henequim, por vezes, fez uma transcrição quase literal do pensamento desse último. Ambos tinham uma mesma percepção sobre a elucidação do texto bíblico: Henequim dizia também ter achado o lugar do Paraíso, “‘às primeiras enxadadas"”. Henequim, como Vieira, além disso, acreditava ser importante o método da interpretação das escrituras, defendendo a tese de que o comentador deveria ultrapassar os limites da exegese tradicional, recorrendo a modalidades de interpretação pouco comuns. Os dois milenaristas, ademais, reconheciam os quatro princípios de interpretação das Escrituras estabelecidos por são Boaventura no século XII (literal, moral, alegórico e analógico), juntando-lhes o "sentido histórico"; buscando nas variantes do texto bíblico, nas suas antigas versões, explicações para o mistério oculto em cada letra. Ambos, ainda, entendiam que os Santos Padres não sabiam tudo simplesmente porque não podiam saber tudo. Por fim, as realidades americanas conduziram-nos a uma reflexão profunda sobre as implicações teológicas do desconhecimento do Novo Mundo por parte dos expositores e comentadores das Escrituras, motivo pelo qual buscavam "inscrever este universo novo naquilo que julgavam ser a fonte de toda a verdade e, ao mesmo tempo, estabelecer as bases de uma crítica da exegese tradicional, de modo a filtrar o Verbo através do conhecimento daquelas realidades"141 O uso da cabala, no entanto, os separava: Henequim o defendia, Vieira, jamais ${ }^{142}$.

Henequim dizia que que a língua portuguesa era a língua da corte celeste ${ }^{143} \mathrm{e}$ que o "Paraíso Terreal está no meio do Brasil em umas serranias"”; falava que “"havia no Brasil uma árvore, a qual dava uns frutos como maçãs, e como figos, e que esta era a árvore do Paraíso"”; postulava que “"Adão fora criado no Brasil, e dele se passara a pé enxuto para Jerusalém'; acreditava também que os quatro rios do

\footnotetext{
${ }^{140}$ Ibidem, p. 38.

${ }^{141}$ Ibidem, p. 80-84.

142 Ibidem, p. 83.

${ }^{143}$ Esta proposição lembra $O$ livro dos cem capítulos e dos quarenta estatutos, escrito milenarista redigido em alemão por um anômimo, entre 1498 e 1510, ignorado até o final do século passado (DELUMEAU, Jean. Mil anos de felicidade: uma história do paraíso, op. cit., p.111) Nesse livro, o amor à terra natal inscrevia-se numa posição chauvinista, dentro da qual se concebia que, no futuro reino da paz, a língua seria o alemão, em substituição ao latim; o alemão, além disso, seria a 'língua que falava Adão [...] Na arca de Noé não havia outra língua senão a de Adão, isto é, o alemão, que Jafé trouxe para as margens do Reno"” (Ibidem, p. 113).
} 
Paraíso chamavam-se Säo Francisco, das Amazonas e outros'“; e punha fé que “"Deus tinha criado o mundo no Brasil"” etc. ${ }^{144}$.

Segundo ROMEIRO, é possível que Henequim tenha lançado os fundamentos de sua teoria milenarista ainda nas Minas Gerais, incluindo-se a proposta de que D. Manuel fundasse o Quinto Império, isto porque os feitos bélicos do príncipe espalharam-se pela América através da Gazeta de Lisboa ${ }^{145}$. Henequim, ademais, não foi o único indivíduo com passagem por Minas Gerais a defender proposições milenaristas. Em 1720, dois anos antes do regresso de Henequim ao Reino, chegava a Lisboa um padre baiano, com o intuito de anunciar ao rei D. João V a iminência do fim dos tempos e revelar a sua condição de profeta e messias, sendo também preso pela Inquisição e queimado. Ambos, é importante frisar, "haviam sido marcados pelas idéias do padre Vieira; demonstravam uma atitude francamente filossemita, expressa pelo esforço de compatibilizar o cristianismo e o judaísmo; valorizavam a estada ou o nascimento no Brasil como um fator decisivo no processo de revelação religiosa; e finalmente, tanto um quanto outro haviam estado nas Minas na década de $1710^{, 146}$.

Henequim logo meteu-se em outra conspiração, intentada em julho de 1740, junto ao cônsul espanhol Jorge de Macazaga, propunha a conquista das minas do Serro Frio pela Espanha; o cônsul citado, porém, após averiguar as informações prestadas, considerou o projeto sem fundamento, julgando-o uma "impostura"147. Se a história de Pedro Rates Henequim, juntando leitura, heresia e conspiração, sugere a circulação das idéias milenaristas do padre Antônio Vieira em Minas Gerais, na primeira vintena do século XVIII, mostra também que, nessa apropriação do legado vieirista, houve, primeiramente, uma inventividade de Henequim enquanto leitor e, em decorrência disso, uma subversão do sentido original existente nos textos lidos: não há nos escritos de Vieira, como se viu no Capítulo 1, qualquer intuito de fazer da América Portuguesa e da afronta aos direitos de El-Rei os fundamentos do Quinto Império, nem seguir de projetar nessas terras a imagem do Éden. Quinto Império, Portugal e El-Rei são, destaque-se, no pensamento de Vieira, indissociáveis. A inventividade protagonizada por Pedro Rates Henequim na leitura dos textos de

\footnotetext{
${ }^{144}$ ROMEIRO, Adriana, op. cit., p. 31.

${ }^{145}$ Ibidem, p. 74 e p. 96

146 Ibidem, p. 15-17.

${ }^{147}$ Ibidem, p. 28-29.
} 
Vieira, como se verá no Capítulo 8, encontrou não propriamente seguidores, mas leitores à altura, igualmente inventivos e subversivos, entre os Inconfidentes Mineiros: laicizando a visão edênica da América, apropriando-se das críticas do padre Antônio Vieira à administração colonial, inspirando-se na Restauração Portuguesa de 1640, sonhando (ao menos alguns) com a vinda de um príncipe português para chefiar um império terrestre na América e, ainda, embalados pela Ilustração e pela história da Independência das Treze Colônias inglesas, os Inconfidentes conjuraram contra o domínio português em Minas Gerais. $\mathrm{O}$ exame dessa amalgamação, no entanto, ficará para o próximo capítulo, reservando-se a este a análise da imbricação das leituras, com as Luzes e as proposições iconoclastas e heréticas dos séculos XVI e XVII.

A Ilustração, de fato, a partir de meados do século XVIII, motivou freqüentemente leituras inventivas, algumas delas com conteúdo claramente heréticos. Na capital francesa, a "filosofia" espraiou-se pelas ruas, sem que ninguém ou nenhuma barreira lograsse conter este movimento. Segundo Paul HAZARD, a “filosofia está nos clubes e nas assembléias, nos cafés, ao redor das mesas de chá", “sob as árvores do Palácio Real ou nos jardins de Luxemburgo". A polícia ouve seus murmúrios, segue seus passos, mas revela-se incapaz de sufocar o seu furor. Frases contra a religião, pronunciadas até mesmo por padres, ecoam pela cidade ${ }^{148}$. Em Lisboa, próximo ao último quartel do século XVIII, movimento similar ocorria; do continente europeu, ele se propagava para a América Portuguesa; nada conseguia conter sua vaga. Com efeito, as devassas das Inconfidências de Minas, Rio de Janeiro e Bahia retratam os efeitos subversivos da Ilustração entre leitores, às vezes sobremaneira inventivos. Além disso, várias denúncias sobre leitores, livros e leituras heterodoxas foram encaminhadas no período ao Santo Ofício. Embora não seja possível avaliar em que medida tais denúncias tinham ou não veracidade, como já se salientou, pode-se tomá-las como outros indícios da repercussão dos livros e das leituras proibidas na sociedade luso-brasileira.

As idéias Ilustradas muitas vezes misturavam-se àquelas proposições heréticas e blasfêmias evidenciadas como correlatos de muitas das leituras inventivas abordadas anteriormente, algumas delas de origem judaica ou cristã-nova. A apologia dos livros Ilustrados proibidos e suas idéias; a leitura de obras heterodoxas;

${ }^{148}$ Paul Hazard. O Pensamento Europeu no Século XVIII, op. cit., p. 94. 
as dúvidas sobre os dogmas da Igreja, a Inquisição, as censuras eclesiásticas; e a defesa de proposições contrárias à fé católica, estiveram freqüentemente unidas nos domínios portugueses na segunda metade do século XVIII. Anita NOVINSKY, como se viu no Capítulo 3, considera que as posturas críticas face à religião não foram obra da Ilustração, mas sim de uma "descristianização interior", de uma mentalidade clandestina, subterrânea, desenvolvida por "uma camada da sociedade", ao longo e em resistência a séculos de repressão, mormente a inquisitorial. Nessa "mentalidade" encontrar-se-iam subsumidos "uma postura iconoclasta contra os santos, contra o confessionário, contra o culto e as cerimônias, que eram ridicularizados e atacados juntamente com toda Igreja militante"149. A Ilustração só teria alimentado esta mentalidade ${ }^{150}$. De fato, muitas vezes fica difícil discernir com clareza os respectivos pesos da Ilustração e das proposições heréticas e iconoclastas que vicejavam no mundo luso-brasileiro desde o século XVI, aqui analisadas em suas manifestações na América, na definição das idéias heterodoxas expostas pelos leitores de fins do século XVIII. A dificuldade de discernir um e outros elementos, Ilustração e proposições heréticas e iconoclastas, advém mesmo do fato das últimas terem-se propagado oralmente no mundo luso-brasileiro ao longo de mais de dois séculos.

No entanto, há circunstâncias em que se reconhecem nitidamente as origens das proposições feitas pelos leitores. Dessa forma, primeiramente, urge considerar, ao mesmo tempo, os efeitos e o impacto das idéias Ilustradas e a interferência daquelas proposições, identificando, sempre que possível, como elementos desses níveis culturais distintos foram apropriados e reunidos. Em segundo lugar, é preciso entender que os pontos de confluência da Ilustração com o substrato cultural oral preexistente talvez seja um dos fatores explicativos para a receptividade que as Idéias Ilustradas tiveram, para a ânsia com que os livros proibidos que as continham foram procurados: os leitores identificavam nas obras verdades com os quais de antemão tinham afinidade e, por isto, mesmo as procuravam. Por fim, as proposições constituem um elemento importante, dentre outros presentes no respectivo contexto histórico, para compreender a própria inventividade com que os leitores liam os

\footnotetext{
${ }^{149}$ NOVINSKY, Anita Waingort. Estudantes brasileiros 'afrancesados' da Universidade de Coimbra. a perseguição de Antônio de Morais Silva - 1779-1806. In: COGGIOLA, Osvaldo (org.). A Revolução Francesa e seu impacto na América Latina, op. cit., p. 365 e 367-368.

${ }^{150}$ Ibidem, loc. cit..
} 
livros, Ilustrados ou não: nelas está, sem dúvida alguma, uma das chaves para compreender a criatividade com que se atribuíram sentidos aos textos.

Um exemplo de como Ilustração e proposições heréticas anteriores se misturaram nas idéias expressas pelos leitores encontra-se na denúncia feita pelo padre Francisco de Souza Raposos. Numa jornada de Coimbra à Lisboa, em 1799, o sacerdote ouviu Jerônimo Dier — judeu expatriado do Reino trinta anos antes pelo Santo Ofício e residente na capital portuguesa com salvo-conduto - propugnar a licitude e a naturalidade de toda espécie de luxúria, dizer-se seguidor de Voltaire, afirmar que Jesus Cristo era um filósofo de mentiras, falar que o único milagre divino fora criar tudo e, ainda, zombar da prática cristã de representar Deus em pinturas $^{151}$. Dier, portanto, ao mesmo tempo em que se dizia inspirado em um filósofo, expunha idéias consagradas tanto em escritos Ilustrados como em algumas das proposições heréticas e blasfêmias aqui destacadas anteriormente. $\mathrm{O}$ descrédito em relação aos milagres e a zombaria em relação à representação de Deus em pinturas lembram, por exemplo, as proposições defendidas por Rafael Olivi e aqui apontadas, em Ilhéus de meados do século XVI.

Em Lisboa, em 1798, Pedro Dias Pereira Chaves parecia juntar as proposições heréticas iconoclastas às obras de Voltaire e Rousseau, ao modo de analisar a realidade exercitado por estes e a um raciocínio calcado na primazia da Razão, no uso da observação e na leitura crítica das Escrituras Sagradas: as proposições vinham, assim, a instalar-se sob as Luzes. Com efeito, Chaves costumava levar consigo "alguns tomos" de obras dos autores mencionados e, "lendo em portugues os erros que elles avansavão", tentava convencer Maria Vicencia do Carmo, “dizendo-lhe que não havia eternidade, porque nós não eramos mais que hum animal, ou huma planta acabando tudo com a nossa morte, e que por isso era falso haver premio ou castigo eterno [...] não havia inferno, nem Diabos porque estes só erão, os que nos atormentavão neste mundo". Ele não duvidava da existência de Deus, mas sim de Cristo, com base nos escritos dos apóstolos; questionava a existência dos santos; e, ainda, defendia o amor aos semelhante como sinal de boa vida $^{152}$. Todas essas idéias, além de evocarem pontos defendidos por Voltaire, lembram aquelas defendidas pelo ateísta Alberto Radicati de Passerano, o qual, como

${ }^{151}$ IANTT, Inquisição de Lisboa, Cadernos do Promotor no 134 (1797-1802), Livro 322, s/p.

${ }^{152}$ IANTT, Inquisição de Lisboa, Cadernos do Promotor no 133 (1792-1800), Livro 321, s/p 
se mostrou no Capítulo 2, duvidava da existência do inferno, considerava que não haveria justiça humana e divina, e via na morte um meio através do qual a natureza dava origem a outros seres.

Idéias que apontavam também para a interpenetração da Ilustração com as proposições heréticas enraizadas do mundo luso-brasileiro foram proferidas pelo padre José Pedro, por volta de 1798, morador no Saldanha, em Lisboa: ele foi denunciado por colocar em dúvida a infalibilidade papal e a existência de uma só igreja, dizendo que lia livros proibidos, que tinha licença para tanto e que "porque eles ditos livros proibidos declaravam muitas verdades é que eram proibidos" ${ }^{\text {153. Tal }}$ afirmação permite supor que o interesse do padre José Pedro pelos livros proibidos residiria no fato de seus conteúdos apontarem para verdades preexistentes, elementos esses anteriores aos livros, pertencentes às proposições (daí a associação estabelecida por ele entre "verdades" e proibição).

Muitos outros indivíduos, contudo, parecem ter-se embriagado com a Ilustração sem que seja possível, devido em parte às lacunas das fontes, detectar confluências com elementos das proposições heréticas presentes no mundo lusobrasileiro desde o século XVI. Noutros casos, devido também às omissões da documentação, a influência Ilustrada pode ser presumida, mas não assegurada. De qualquer forma, as Luzes foram adentrando pelo Reino, favorecidas ou não pelas proposições heréticas e iconoclastas, interpenetrando-se ou não com essas através da leitura, oral e silenciosa, e das "disputas" que se travavam em torno dos livros, freqüentes até mesmo nas embarcações que chegavam das várias partes do Império português. Pode-se, por exemplo, aventar a hipótese de que a Ilustração influenciou Raimundo José Colaço e os filhos de Manoel Gonçalves Ramos, todos naturais do Brasil e residentes em Lisboa, a transformarem o escritório do último em "aula", na qual se debatiam, em 1801, as "proposições mais horrendas contra a Fé e Dogma Católico". Ao mesmo tempo, ao verificar o conteúdo das mesmas proposições, logo vêm à lembrança as palavras de alguns dos leitores que viveram na América nos séculos XVI e XVII. Ecoando máximas da Ilustração e, sobretudo, reiterando proposições seculares, eles negavam os preceitos da abstinência de carne nos dias santos, duvidavam da canonização dos santos, desprezavam a excomunhão e as

${ }^{153}$ IANTT, Inquisição de Lisboa, Cadernos do Promotor no 134 (1797-1802), Livro 322, s/p. 
censuras eclesiásticas e asseveravam que o Santo Ofício não teria grande longevidade ${ }^{154}$.

Exemplo de situação na qual aparecem apenas os livros ilustrados, mas não as proposições, quiçá instigadoras do interesse pelos citados livros, encontra-se na denúncia feita contra o padre Frei João Cabral. Monge de Cister, conventual e colegial em Coimbra, assistente na Vila dos Pios, prelazia de Tomar. Nos idos de 1799, o padre frei circulava com um folheto pequeno intitulado Voz da Razão, em que havia a exposição de pontos contrários e dúvidas sobre a fé cristã, sem os defender abertamente. Tal folheto foi lido em voz alta por João Leonardo Chaves quando sua irmã passava por perto, tendo esta ficado muito aflita com o que escutara $^{155}$. A partir dessas informações, pode-se qualificar o padre frei apenas como tributário - ou propagandista involuntário - exclusivamente da Ilustração: não há nelas o menor vestígio daquelas proposições heréticas de origens mais remotas, observadas na América portuguesa desde o Quinhentos. O mesmo se dá em relação a Gertrudes Rasa - mulher casada, que, no Recolhimento de Nossa Senhora da Encarnação, provavelmente em Lisboa, lia livros franceses e os recomendava a uma amiga $^{156}$ —; a um assistente na casa do marquês de Marialva — que se mostrava seguidor da "doutrina de Voltaire" alta, em uma loja, também em Lisboa, um livro francês que falava contra a religião, iniciando uma disputa a partir de então sobre a imortalidade da alma ${ }^{158}$ - e, ainda, Manoel José Vaz Leitão — doutor em leis, ele mostrava um exemplar manuscrito do "Cathecismo Francês", oferecendo-o a um amigo, junto à botica de Sebastião, na vila de Covilhã, em $1801^{159}$. A influência de Voltaire — autor Ilustrado mais presente nas bibliotecas de Mariana e nas remessas de livro feitas da América a Portugal, como se viu — verificava-se, é bem verdade, na própria família real: D. José, filho de Dona Maria I, príncipe do Brasil, segundo Caetano BEIRÃO, além de discípulo de Fénélon, seria um príncipe filósofo, caso único em Portugal, dedicando-se provavelmente à leitura de Rousseau, dos enciclopedistas e de Voltaire; sem dúvida alguma era um "inimigo dos frades e do dogmatismo católico, apesar de ir à missa

\footnotetext{
${ }^{154}$ Ibidem, s/p.

155 Ibidem, s/p.

${ }^{156}$ Ibidem, s/p.

${ }^{157}$ IANTT, Inquisição de Lisboa, Cadernos do Promotor no 130 (1778-1790), Livro 318, p. 22.

${ }^{158}$ IANTT, Inquisição de Lisboa, Cadernos do Promotor no 134 (1797-1802), Livro 322, s/p.

${ }^{159}$ Ibidem, s/p.
} 
todos os dias", tendo seu confessor declarado que "melífluos palradores afrancesados, italianados, voltaireanos, enciclopedistas têm envenenado todas as sãs doutrinas", fazendo, com isso, alusões a D. José e à sua esposa, Dona Maria Francisca Benedita ${ }^{160}$.

Em Coimbra, cidade universitária, no último quartel do século XVIII, esse panorama talvez tenha se radicalizado: os questionamentos à ordem religiosa e moral eram mais substantivos e, ao mesmo tempo, mais prisioneiros da Ilustração, menos vinculados às proposições heréticas e iconoclastas e às blasfêmicas cuja presença se detectou na América Portuguesa desde o século XVI. As reformas pombalinas, cujas Luzes são festejadas no Reino da Estupidez, como se mostrou no Capítulo 3, foram certamente um estímulo a essas heterodoxias.

Dentre esses coimbrãos heterodoxos, encontram-se figuras que se destacaram posteriormente no mundo cultural luso-brasileiro, como se mostrou no Capítulo 3: Antônio de Morais Silva, Francisco de Mello Franco e Manuel Joaquim Henriques de Paiva ${ }^{161}$. Eles e outros alunos ou recém-egressos da universidade — podem-se citar, dentre eles, o brasileiro Antônio Pereira de Caldas; João Laureano Nunes Leger, Franciso José de Almeida, José Maria da Fonseca, Vicente Júlio Fernandes, Nuno de Freitas e Antônio Caetano de Freitas, nascidos no Portugal continental ou Insular - ousavam ler oralmente livros "filosóficos", emprestá-los, expor e discutir seus conteúdos, travando "disputas" e imergindo numa boêmia literária, muitas vezes companheira da contestação aos dogmas de religião católica, tangenciando a heresia. Faziam-no não apenas às escondidas, nas dependências da universidade, mas também em suas casas e pelas ruas de Coimbra ${ }^{162}$. Para tanto, de um lado, contribuiu a leitura de livros ilustrados - acompanhada muito secundariamente, ao que parece, daquelas proposições seculares aqui abordadas - e, de outro, pesou a inventividade desses homens enquanto leitores.

A influência dos livros Ilustrados nos questionamentos feitos por tais indivíduos foi reconhecida por eles próprios. Antônio de Morais, depois de saber que fora denunciado à Inquisição de Coimbra, ponderou com seu colega Vicente Júlio

\footnotetext{
${ }^{160}$ BEIRÃO, Caetano, op.cit., p. 361-363.

${ }^{161}$ Os papéis de maior destaque no Brasil foram justamente exercidos pelos egressos da universidade reformada, muito mais do que por aqueles que se formaram anteriormente (NEVES, Lúcia M. P. Bastos. Universidade de Coimbra, In: SILVA, Maria Beatriz Nizza da (coord.). Dicionário da história da colonização portuguesa no Brasil, op. cit., p. 806-807).

${ }^{162}$ IANTT, Inquisição de Lisboa, Cadernos do Promotor no 130 (1750-1790), Liv. 319, p. 65-78 e
} 
Fernandes sobre "o grande perigo em que estavão" de ter "tirado de Ler livros", aconselhando-o "que os não Lesse, pois elle Lendo-os ficara em duvida por quem [SIC] os escrivia não sabia o que dezia, e que o milhor era hir vivendo ao som das agoas que ao dipois ninguem sabia o que se passava"163 — portanto, os livros seriam a origem das dúvidas e, assim sendo, conviria não lê-los e deixar as coisas como estavam. Ao confessar-se à Inquisição de Lisboa, Antônio de Morais deixou mais evidente o lugar especial ocupado pelos livros no que toca aos seus "erros": afirmou que "a Liçam dos Livros que tem declarado fora quem pervertera a ele Reo em os erros que fazem a materia de sua comfissão". Acrescentou a isso a sua própria inventividade - "cahira nesta mizeria por efeito de sua fragil natureza" — e algo que talvez remeta às proposições heréticas seculares luso-brasileiras — disse "que munto [sic] concorrera o mao exemplo, e trato familiar com pessoas pervertidas" ${ }^{\text {"164 }}$. Antonio Caetano de Freitas atribuiu a um livro existente na livraria da Universidade a responsabilidade por suas idéias: no livro "se descreviam as crueldades do Tribunal do Santo Officio" e, por isso, Antônio Caetano persuadiu-se "que tudo isto assim era, como se dizia no dito Livro, e assim o Referio em caza aos seus companheiros"165. Nuno de Freitas, como se destacou anteriormente, atribuiu seus erros à leitura do Emílio, de Rousseau, que lhe fora emprestado por Antônio de Morais Silva. Em todos esses casos, enfim, emerge aquela utilidade dos livros inferida da composição das bibliotecas e observada nas entrelinhas das concepções de uso apresentadas em requerimentos encaminhados à censura pelos leitores: os livros podiam constituir também fonte de um saber dotado de potencial subversivo ${ }^{166}$.

É certo que, por detrás das palavras dos supracitados leitores, palavras que atribuem aos livros um papel importante nas heterodoxias, oculta-se em parte o desejo dos réus de aliviar a responsabilidade que eles próprios tiveram na formulação das proposições. Essa responsabilidade-inventividade do leitor foi explicitada pelo estudante Antônio da Silva Lisboa: Antônio de Morais emprestara-lhe a "obra grande de Genuense em sinco volumes", de cuja "Lição e argumentos, que vio no dito Autor contra as verdades da Religião Christãa não obstante a confutação [sic] delles, que tambem trás, entrou a duvidar das mesmas verdades, parecendolhe, que ellas talvez o

Processo $\mathrm{n}^{\circ} 2015$.

${ }^{163}$ IANTT, Inquisição de Lisboa, Processo no 2015, p. 4-4v.

${ }^{164}$ Ibidem, p. 47v.

${ }^{165}$ Ibidem, p. 10. 
não serião, pois erão combatidas por tantos homens grandes"167. Entre o ortodoxo Genuense e outros "tantos homens grandes", como se viu, o leitor Antônio da Silva Lisboa optou pelos últimos, abraçando da argumentação do primeiro os argumentos contra a fé católica, deixando de lado os favoráveis que lá encontrou - uma demonstração de que era um leitor inventivo e de que talvez tivesse algumas preferências prévias. Tais demonstrações de inventividade e de existência de posições prévias não diminuem a importância dos escritos, que, de alguma forma, constituíam referência e fonte para as idéias desses jovens. Ademais, a perseguição que os órgãos repressivos moveram aos livros proibidos e o teor das idéias apresentadas pelos leitores tornam inegável a influência das obras.

Esses jovens universitários caíram nas garras da Inquisição por obra de Francisco Cândido Chaves, também estudante, a quem Antônio de Morais Silva e outros amigos acolheram quando enfrentava dificuldades. Em 17 de maio de 1779, ele compareceu à Inquisição de Coimbra, denunciando seus companheiros, principalmente Antônio de Morais, como defensores de proposições heréticas e dos filósofos Ilustrados. O delator retornou ao tribunal com novas denúncias, por mais duas vezes. Após a denúncia, iniciou-se a apuração dos fatos, sendo chamado para depor o estudante João Laureano Nunes Leger. João Laureano, seguindo conselho de Francisco de Mello Franco, então estudante de medicina e residente em Coimbra, violou o sigilo do depoimento, comunicando o que sucedera na mesa do Santo Ofício aos seus companheiros. Os estudantes, com base nisso, procuraram ajustar entre si os discursos que apresentariam à Inquisição ${ }^{168}$. Segundo o delator, em várias ocasiões e lugares, os estudantes discutiram temas religiosos a partir de autores Ilustrados, cujos livros eram permutados, destacando-se os de Rousseau, a quem chamavam "profundíssimo filósofo"169.

Ao longo dos processos movidos contra os acusados, de fato, vêem-se relatadas permutas e o comércio informal dos seguintes livros: Emílios de Rousseau, o mais concorrido de todos, objeto de tradução e circulação em manuscrito; Cartas do Marquês de Argent; Sistema da Natureza, do Barão de Holbach, atribuído erroneamente a Mirabeau; Cartas Persas, de Montesquieu; Cartas Cabalísticas, do

\footnotetext{
${ }^{166}$ Ibidem, p. $25 \mathrm{v}$.

${ }^{167}$ Ibidem, p. $28 \mathrm{v}$.

${ }^{168}$ BAIÃO, Antônio, op. cit., vol. 2, p. 113-126.

169 IANTT, Inquisição de Lisboa, Processo $n^{\circ}$ 2015, passim; Processo $n^{\circ}$ 1557, s/p; e BAIÃO,
} 
Marquês de Argent; Donzela de Orleans, de Voltaire; Instituições Políticas, de Bielfeld; Contrato Social, de Rousseau; "obra grande", de Genuense (Antonio Genovesi). Locke é também outro autor mencionado ${ }^{170}$.

Nas discussões, conforme as denúncias, os coimbrãos em foco teriam abraçado as seguintes proposições:

"era fabula tudo o que se dizia do inferno e dos seus castigos, sendo Deus tão benigno; não havia purgatorio; a alma era mortal porque, estando no corpo havia de ocupar logar, e ocupando logar era corporea e por conseguinte mortal; negavam factos da Escritura, dizendo que em parte é necessaria a sua doutrina sómente para conter os homens na sociedade, em muitas partes é fabulosa e noutras contem factos pecaminosos e menos licitos; os preceitos do jejum e da abstinência de carne nos dias prohibidos eram quimeras; as missas eram uma historia para ganhar dinheiro; negam a validade das indulgencias, escarnecem d'elas, da sua virtude e da autoridade pontificia; por ocasião de pregar o padre mestre Durão ouvio-lhe dizer que ele tinha errado em querer provar a pureza de N. Senhora pela razão natural, quando, para ela se provar, só pela Escritura Sagrada, que eles negavam; falavam contra os frades e o estado eclesiastico" ${ }^{\prime 171}$.

Além disso, esses jovens comeram carne - ou assistiram a outros comerem - em dias proibidos; cozinharam-na no laboratório da universidade e em casa de Manoel Joaquim Henriques de Paiva, então demonstrador de química ${ }^{172}$.

João Laureano Nunes Leger, ao confessar em 1780, contra-atacou Francisco Cândido, acusando-o, dentre outras coisas, de rasgar em sua presença "hum livro de horaçõins e devoçoins dizendo q aquilo não servia de nada”. Nessa sua confissão, no entanto, implicou seus colegas em crimes. Segundo ele, o estudante Francisco José de Almeida "dezia, e seguia q a fornicação simples não hera pecado" (proposição de longa data presente na América, como mostra Ronaldo VAINFAS $^{173}$ ); lia livros proibidos, transcrevera uns papéis, juntamente com Lourenço Justiniano, de "hum livro prohibido"; dizia que a "Escriptura Sagrada tinha padecido de $\mathrm{m}^{\text {tas }}$. vesoins, e $\mathrm{q} \sim$ por isto estaria viciada e que os theologos he $\mathrm{q} \sim$

Antônio, op. cit., vol. 2, p. 114.

${ }^{170}$ IANTT, Inquisição de Lisboa, Processo $\mathrm{n}^{\circ}$ 2015, passim e Processo $\mathrm{n}^{\circ}$ 1557, s/p.

${ }^{171}$ Inquisição de Coimbra. Processo no 8094. apud. BAIÃO, Antônio, op. cit., vol. 2, p. 114.

${ }^{172}$ IANTT, Inquisição de Lisboa, Processo no $13369, \mathrm{~s} / \mathrm{p}$.

${ }^{173}$ VAINFAS, Ronaldo. Trópico dos pecados, op. cit., p. 59-76. 
fazião escura, q ella por si hera clara, q qualquer hera capas de a intender" ${ }^{174}$.

O livro proibido que fora traduzido parcialmente era uma obra de Rousseau, talvez o Émile; o conteúdo da obra explicitado pelo confessante, como se pode observar a seguir, de qualquer forma, remete à tolerância e à religião civil preconizadas pelo filósofo suíço:

\begin{abstract}
"na [referida obra] se excluía a Religião Revelada, e se asentava que só havia a Ley Natural, e que cada hum estava obrigado a seguir a Religião do seu Paiz; porque em tanta diversidade de Religiõens, ignorandose qual dellas fosse a verdadeira, devia cada hum exteriormente acomodar-se com a dominante do Paiz, em que vivesse, seguindo sempre o que lhe ditasse a Leiz [sic] de Sua Razão interiormente, e que observando também o que lhe ensinarão seus Pais, ainda que ella não fosse a verdadeira não peccava em seguir pelo fazer por ignorancia, concluindo de tudo, que era justo o tolerantismo, e indiferentismo e $\sim$ materia de Religião" ${ }^{, 175}$.
\end{abstract}

Antônio de Morais Silva sobressai no processo. Francisco Cândido fez denúncias específicas sobre ele. Após ver "uma gata com dores de parto", Morais Silva, segundo o delator, teria dito: "Eis ahi o pecado original de Adão, tudo são efeitos naturais e não ha tal pecado" ${ }^{176}$. Morais teria também pronunciado palavras contra o Santo Ofício, dizendo que este: "era um tribunal estabelecido sem autoridade pois, com bulas falsas, viera a Portugal um italiano, Savedra, e o instituíra, com auxílio dos padres da companhia; era o Santo Ofício contrário à Escritura Sagrada pois Cristo mandava que ninguém fosse obrigado a crer na sua lei com violência e o Santo Ofício obrava mal em obrigar por força a seguir a religião que melhor se ajustasse à sua razão. Só, por política, compreendia pois a Inquisição: para evitar diferenças de crenças no mesmo país"177.

Morais Silva, portanto, primeiramente, urdia uma análise do Gênesis, confrontando-o com dados colhidos na observação imediata (o parto da gata), destruindo com isto a tese do Pecado Original. Em segundo lugar, usava informações históricas para criticar a Inquisição, de um modo que a dessacralizava e condenava. Além disso, considerava que a religião devia ajustar-se à razão e não poderia conduzir à intolerância. Essa visão crítica, pode-se supor, baseava-se numa releitura

\footnotetext{
${ }^{174}$ IANTT, Inquisição de Lisboa, Processo no $1557, \mathrm{~s} / \mathrm{p}$.

${ }^{175}$ Ibidem.

${ }^{176}$ IANTT, Inquisição de Coimbra, Processo nº 8094, apud. BAIÃO, Antônio, op. cit., loc cit.

${ }^{177}$ Ibidem., p. 117.
} 
da Bíblia — afinal Morais afirmou que "Cristo mandava que ninguém fosse obrigado a crer na sua lei com violência" —, atribuindo-lhe um sentido diverso daquele desejado pelas autoridades. Porém, não é a leitura da Bíblia a origem mais provável dessas idéias defendidas por Morais Silva, na medida em que elas guardam grandes similitudes com o que afirmam Rousseau e, especial, Voltaire, no Dicionário Filosófico, e, ainda, a obra Universal History from the earliest account of time, to the present, que seria traduzida para o português pelo próprio Antônio de Morais Silva, anos depois, em 1788. Conforme se mostrou no Capítulo 2, a tópica da tolerância era um consenso entre os Ilustrados e, além disso, na obra supracitada de Voltaire, de um lado, narra-se o estabelecimento da Inquisição, reputando-o à ação de Saavedra e seus documentos falsos e, de outro lado, existe um convite à tolerância religiosa e uma denúncia das violências feitas pelo Santo Ofício e, de resto, pela igreja, em nome de Cristo. Já em Universal History from the earliest account of time, to the present, obra também editada em francês, conta-se a instalação da Inquisição em solo lusitano, centrando-se igualmente na figura de Sávedra e sua bula falsa. João Laureano Nunes Leger afirma que um "author frances" fora usado para se fazer proposições contra o Santo Ofício e, embora o mesmo estudante classifique Locke como francês, pode-se concluir que Voltaire foi a fonte de inspiração mais provável das idéias em discussão, pronunciadas pelo grande dicionarista luso-brasileiro ${ }^{178}$.

A inventividade do leitor Antônio de Morais certamente não se contentava com desafios que se limitassem apenas à leitura de obras proibidas e à defesa de idéias heterodoxas colhidas nos livros, ou mesmo, à conjugação dessas idéias aos dados obtidos na observação. Passava pela atribuição aos livros de sentidos diversos daqueles estabelecidos por seus autores ou pelas autoridades eclesiásticas e civis. Envolvia a manipulação do fato de que a um texto podem ser atribuídos vários sentidos: Morais parecia jogar com essa polissemia a seu favor, conforme as circunstâncias. Assim, nos interrogatórios, procurou escapar das acusações fazendo confissões diminutas e amenizando suas afirmações; para tanto utilizou dos livros que lera para tentar enganar os inquisidores, diminuindo o conteúdo explosivo de suas idéias. Para legitimar ou justificar suas proposições, ora mencionou livros ortodoxos ou tolerados, ora apelou para o fato de serem as questões teológicas matérias obrigatórias da filosofia, em cujo estudo ele se aplicara. Assim, por

${ }^{178}$ ANTT, Inquisição de Coimbra, Processo no 1557. 
exemplo, primeiramente, confessou ter disputado sobre pontos da teologia, tais como "o comércio da alma com o corpo", "sua natureza, espiritualidade, liberdade, immortalidade, da existencia de Deos e Religião Natural, necessidade da Revelação" ${ }^{\prime 179}$. Depois, alegou ter apresentado sobre tais pontos os argumentos favoráveis e os contrários, dizendo ter extraído esses últimos das "obras de Genuensis, Abadi Clarqui, Pedro Daniel Depini, Bregier, nas suas admiráveis refutações do Deismo, e matrialysmo [sic]" ${ }^{\text {180 }}$, obras e autores esses defensores, de algum modo, da ortodoxia ${ }^{181}$.

Dois meses após o início do processo, foi ordenada a prisão de Antônio de Morais e, então, ele fugiu para Londres, voltando a Portugal apenas em 1785. Em seu retorno, Morais fez uma ampla confissão à Inquisição de Lisboa, dizendo-se arrependido de seus erros e classificando as idéias que defendera como coisa do passado. Afirmou, então, que, entre 1777 e 1779, quando estudava em Coimbra,

"principiou a Ler alguns Livros anticatholicos, e entre eles o Emilio de Rossau [sic], e vendo nele a confissão de Fé, na qual protesta o author ser sectario da religião natural, como unica, verdadeira, e suficiente para a felicidade do homem, ele aprezentado se sentio de tal sorte tocado, e movido destas erradas, e preversas maximas, que se convenceo destes erros e pessimas doutrinas, que abraçou, e seguio [...] em consequencia de abraçar tão erradas maximas, negou a existencia da revelação asim do novo, como do antigo testamento, tendo por fabulozos estes Livros sagrados, e tudo quanto eles nos revelam, cingindose tam somente ao que alcança o entendimento pela força natural, e da graça: a reparação do homem feita por Jesus Christo, e que este seja Deos, e homem juntamente; e enfim os prodigos, e milagres obrados a favor do homem em todos os estados, particularmente em a Ley da graça, reputando por invenção huma. a jerarchia ecleziastica, a authoridade, e poder do seo vigario, e dos Bispos sucessores dos apóstolos" $"$.

\footnotetext{
${ }^{179}$ IANTT, Inquisição de Coimbra, Processo nº 8094. apud. BAIÃO, Antônio, op. cit., vol. 2, p. 123. ${ }^{180}$ Ibidem, loc. cit.

181 "Bregier" era certamente Nicolas Sylvestre Bergier, padre e teólogo francês, consagrado ao combate da incredulidade, autor de vasta obra, dentre elas Déisme réfuté par lui-même (VIGUERIE, Jean de, op. cit., p. 754). "Abadi Clarqui”, com certeza Samuel Clarke, um teólogo e predicador da Inglaterra, na passagem do Seiscentos para o Setecentos, usava o ceticismo filosófico para defender a religião revelada, apoiando-a com todos seus recursos lógicos e derivando-a de princípios universais, ganhando por tais procedimentos a admiração de Voltaire (HAZARD, Paul. La crise de la conscience européenne (1680-1715), op. cit., p. 238-239 e CASSIRER, Ernst. Filosofía de la Ilustración, op. cit., p. 201-202). Sobre Pedro Daniel, não se localizou nenhuma informação.

${ }^{182}$ IANTT, Inquisição de Lisboa, Processo no 2015, p. 39-39v.
} 
Confessou que "se lembrava haver falado, e disputado em diversas ocazioens, e com diferentes pessoas", estudantes da mesma universidade, amigos, "e alguns deles, companheiros, muito frequentemente em materias de religiam". Tais estudantes "comunicavão huns a outros os Livros Ereticos, que cada hum tinha; e fazendo menção dos argomentos contrarios aos dogmas da catholica romana, os quais ele apresentado aprovava, reduzindo toda a religiam aos ditames da rezam, desprezando as verdades reveladas pelo lume da fé, e tendo os dogmas, e perceitos mais saudaveis, e sagrados por fiçoens, e imposturas"183.

Movera-o nesses debates, por muitas vezes, a vaidade, a presunção, o desejo de ser singular e

\begin{abstract}
"mostrar superioridade de conhecimentos adquiridos com os seos estudos, que não dava credito aos milagres, que se inculcão ao Povo nos demonstrativos deles postos nas Igrejas, nem os julgava verdadeiros: e se lembra ter dito em similhantes ocazioens, que a Theologia Escolastica estava chea de questoens inuteis, e vans [...] que seguia não guardava os perceitos ecclesiasticos, deixando de ouvir missa nos dias em que era obrigado ouvila, comendo carne nos dias em que a Igreja prohibe o uzo dela, satisfazendo ao perceito da comfissam, e comunham só por comprimento do Mundo, e com este mesmo fim" ${ }^{184}$.
\end{abstract}

Sobre a graça de Deus, dissera "que era hum bixo muito grande, com huma Mitra muito alta na cabeça, e que só Santo Agostinho podia com ela, dito com rizo todos aplaudiram" ${ }^{185}$. Disse também que, nos interrogatórios feitos antes de sua fuga, mentira ao Santo Ofício e que, quando saía do tribunal, injuriava-o, chamando-lhe “boqueirão do Inferno, barbaro, cruel, caza de petas [isto é, mentiras], e sofismas, e quantos nomes injuriosos lhe sugiria a sua imaginaçam" ${ }^{\text {186 }}$. Confirmou, além disso, com outras palavras, a denúncia de Francisco Cândido no que toca à sua apreciação sobre o parto de uma gata, do qual concluíra "que se o padecer dores as mulheres em os partos fose castigo de Deos pelo peccado de Eva, os irracionaes as não teriam, querendo dar a entender ser falço o socedido a respeito de Eva, que de todo o modo

\footnotetext{
${ }^{183}$ Ibidem, loc. cit.

${ }^{184}$ Ibidem, loc. cit.

185 Ibidem, p. 41.

${ }^{186}$ Ibidem, p. 40v.
} 
as mulheres sempre pareriam com dores" ${ }^{\prime 187}$. Pôs em dúvida, portanto, os ensinamentos do Gênesis.

Em sua defesa, alegou, primeiro, que fugira para a Inglaterra "não por querer viver em Liberdade, sim porque lhe foi mais comodo possivel". E, ainda, que não precisaria confessar à Inquisição, podendo ir diretamente à Cidade Eterna fazer sua apresentação, mas optou por apresentar-se, confessando "suas culpas sinceramente, e sogeitar-se a todo o castigo que ela [a Inquisição] for servida darlhe", acrescentando que fizera uma confissão verdadeira com um missionário apostólico em Londres, com poder para absolver todo crime de heresia ${ }^{188}$. Fora doutrinado por esse missionário em Londres, tendo lido "boas doutrinas" nos livros "do Abade Condilac, e das Cartas do Arcebispo de Fenelon, e emquanto rezidio naquela Cidade, viveo sempre na religiam Catholica Romana, e com a graça de Deos nela espera perseverar ate a morte" ${ }^{\prime 189}$. Nesse ponto é possível notar em que medida os efeitos dos livros foram manobrados pelo astuto leitor em sua confissão à Inquisição, no sentido de ofuscar sua inventividade, sua responsabilidade na apropriação das idéias que encontrara nos escritos: se antes Morais Silva afirmara que nos livros, em particular o de Rousseau, encontrava-se a origem dos seus "erros", aqui, da mesma forma, seus “acertos" são imputados também a livros, os de Condilac e Fénélon. Enfim, se os livros foram de fato importantes, não se pode cair nos artifícios que o leitor criou para minimizar sua responsabilidade: o leitor teve um papel considerável na adesão e exposição de proposições heterodoxas. Essa responsabilidade do leitor é visível na própria esperteza com que ele utilizou e citou os livros.

\footnotetext{
${ }^{187}$ Ibidem, p. 41v. Nessa naturalização das dores do parto - e, por conseguinte, nesse afastamento dos ensinamentos da Bíblia - e no apelo à observação de um fato de impacto para comprovar sua tese, é possível que Morais tenha sido influenciado por Rousseau e, ao mesmo tempo, tenha revelado, mais uma vez sua criatividade, sua inventividade enquanto leitor. Rousseau, como se evidenciou no Capítulo 2, tinha na idéia cristã de Queda um de seus alvos. No Emílio, o grande filósofo suíço naturaliza as dores do parto e apela à experiência ao apresentar a forma por ele julgada ideal para responder à pergunta "Como se fazem as crianças?", feita por muitas dessas. A resposta ideal teria sido dada por uma mulher muito modesta, mãe de um garoto que tinha recentemente expelido pela urina "uma pedrinha que lhe rasgara a uretra: - "Meu filho, responde a mãe sem hesitar, as mulheres as mijam com dores que às vezes lhe custam a vida. Riam os loucos e escandalizem-se os tolos, mas que os sábios procurem saber se alguma vez encontrarão uma resposta judiciosa e que alcance melhor os seus fins" (ROUSSEAU, J.-J., Emílio ou da educação, op. cit., p. 282). Morais teria sido inventivo, assim, primeiro, por questionar uma verdade da religião revelada, do Gênesis; e, em segundo lugar, por absorver com certa liberdade a tese central da passagem citada do Emílio, a estrutura de argumentação nele empregada e também o questionamento de Rousseau à Queda, construindo a partir desses pilares uma forma de demonstrar a seus companheiros a falsidade da noção de Pecado Original. ${ }^{188}$ Ibidem, p. 42-42v.

${ }^{189}$ Ibidem, p. 42v.
} 
Em 27 de julho de 1785, Morais foi sentenciado a penas espirituais. Entrou, depois disso, na carreira da magistratura, como desembargador da Relação da Bahia, porém, por atritos com o chanceler, renunciou ao cargo e instalou-se em Pernambuco, tornando-se senhor de engenho e recebendo a patente de capitão-mor do Recife e coronel de milícias de Moribeca ${ }^{190}$. Em maio de 1806, no entanto, Joaquim Marques de Azevedo, comissário do Santo Ofício em Pernambuco, enviou à Inquisição de Lisboa duas denúncias contra Morais Silva, feitas por Francisco da Costa Cordeiro e Manoel do Carmo Inojoza. O primeiro acusou-o de viver "escandalosamente", "falto de religião e pouco católico", não ouvindo missa, comendo carne em dias de jejum e levando sua mulher, filhos e escravos a agirem da mesma forma. Antônio de Morais, além disso, obrigava os escravos a trabalhar em dias de preceito. Seus filhos, por fim, teriam arrastado pelo campo uma imagem do Menino Jesus. Em setembro do mesmo ano, a Inquisição ordenou ao comissário que realizasse diligências, as quais vieram a confirmar a denúncia. $\mathrm{O}$ processo, no entanto, foi arquivado: como afirma Antônio BAIÃO, a "Inquisição já não podia mais morder" ${ }^{\prime 191}$. No ano de 1817 , já sexagenário, Morais Silva assistiu à revolução republicana de Pernambuco, tendo sido nomeado pelos revolucionários, sem o consultarem, ministro do governo provisório, o que recusou, considerando o movimento uma "“borracheira e atrevimento grande que havia de causar muita lágrima"192. Em 1822, seu conservadorismo político outra vez veio à tona, pois ele manifestou seu desacordo com a Independência do Brasil ${ }^{193}$. Assim, embora leitor de Rousseau, dele selecionou apenas as concepções acerca da religião, não passando sequer longe da idéia de "vontade geral"194.

\footnotetext{
${ }^{190}$ NOVINSKY, Anita Waingort. Estudantes Brasileiros "Afrancesados" da Universidade de Coimbra. A Perseguição de Antônio de Morais Silva (1779-1806), op. cit., p. 363.

${ }^{191}$ BAIÃO, Antônio, op. cit.., vol. 2, p. 127-130.

${ }^{192}$ SILVA, Maria Beatriz Nizza da. Silva, MORAIS, Antônio de. In: Idem (coord.). Dicionário da história da colonização portuguesa no Brasil, op. cit., p. 763 e MARTINS, Wilson, op. cit., p. 516.

${ }^{193}$ MARTINS, Wilson, op. cit., loc. cit.

${ }^{194}$ Em Pernambuco, em 1798, bem antes portanto de 1822, a noção de que os Estados deviam ter como base de sua constituição a vontade geral dos povos mostrava-se enraizada, como demonstra o conteúdo de uma representação que a Câmara Iguaçu e mais quatro vilas circunvizinhas enviaram ao governo sobre a arrematação das carnes frescas; no citado documento, assim, afirma-se: “"os contratos que tocam ao bem dos povos não podem ser estipulados validamente senão com cada uma das respectivas câmaras, que representam os mesmos povos, porque seria contra a justiça natural obrigados a estar por uma convenção em que não consentiram pelos seus representantes"”. A identificação da influência de Rousseau nessa representação não escapou à perspicácia do bispo Azeredo Coutinho, motivando comentários seus em carta a D. Rodrigo de Souza Coutinho (Carta a Rodrigo de Souza Coutinho de 24 setembro de 1801. Apud. NEVES, Guilherme Pereira das. Pálidas e oblíquas Luzes: J. J. Da C. De Azeredo Coutinho e a Análise sobre a justiça do comércio do resgate
} 
Antônio Morais, em suma, é um exemplo acabado de leitor inventivo e Ilustrado. Primeiramente, por ter enfrentado as interdições do aparato censório português, possuindo livros proibidos e aderindo às proposições que neles encontrou, principalmente em Voltaire, em Rousseau e na obra Universal History from the earliest account of time, to the present: a defesa da religião natural; o ataque à Inquisição; a negação da revelação do Novo e do Antigo Testamento, considerandoos mentirosos, zombando da graça divina e duvidando do Pecado Original, da Virgindade de Maria, da divindade de Jesus e dos milagres, duvidando da imortalidade da alma, do Purgatório, da necessidade dos jejuns; a consideração da hierarquia eclesiástica como invenção e dos dogmas como imposturas. Inventivo, em segundo lugar, por ter utilizado os conhecimentos adquiridos em leituras ortodoxas, fossem os próprios evangelhos, fossem os escritos dos defensores da religião revelada, num sentido oposto ao fixado nos próprios textos ou pela Igreja, procedimento esse evidente no episódio do parto da gata e na crítica à Inquisição e na justificativa que deu para suas posições quando das primeiras inquirições. Inventivo, também, por ter ultrapassado os próprios escritos heterodoxos que lera, aplicando o método de análise da realidade por eles proposto, baseado na observação e na crítica histórica, a outras situações. Na história de Antônio de Morais Silva, enfim, emerge a figura de um leitor inventivo e concretiza-se aquele uso dos livros, destacado anteriormente como possibilidade e temido pela autoridades desde o início da colonização: o livro enquanto fonte de informações que conduzem ou reiteram expectativas de subversão da ordem. Por conta dessa inscrição dos usos do livro em relações e em estratégias de poder, Morais teve, num momento, que fugir para Londres e, posteriormente, que abdicar aparentemente de suas convicções, renegando suas idéias, fingindo-se reconciliado com o catolicismo, tudo isso para escapar das malhas da repressão da Inquisição, já em ocaso, mas não extinta. A biografia de Morais mostra, ainda, a frágil situação dos intelectuais portugueses sob o Reformismo Ilustrado: além da necessidade de acomodação do discurso, esses homens tiveram que contar com fortes apoios políticos, sem os quais até mesmo sua sobrevivência poderia ficar comprometida. Movendo-se em meio ao equilíbrio

dos escravos'. In: COLÓQUIO INTERNACIONAL “COLONIZAÇÃO E ESCRAVIDÃO”. Realizado em Lisboa, em 1996 (datiloscrito)). Portanto, as idéias políticas de Rousseau não foram abraçadas por Morais por serem desconhecidas, mas porque não se adaptavam às suas convicções políticas conservadoras. 
instável e aos limites do Reformismo Ilustrado português, Morais foi um leitor e agente histórico subversivo, mas apenas em termos religiosos, não demonstrando a menor crítica fosse ao absolutismo, fosse ao colonialismo. Na política, ele se manteve um conservador, distanciando-se justamente do filósofo a quem, junto com seus amigos coimbrãos, qualificava como "profundíssimo filósofo".

Manuel Joaquim Henriques de Paiva, outro luso-brasileiro envolvido na boêmia literário-herética coimbra, escapou praticamente ileso da Inquisição, apesar de recaírem sobre suas costas denúncias respeitáveis: além de comer e cozinhar carne em dias de preceito, em sua casa e no laboratório da universidade, emprestara ou comprara o Emílio, de Rousseau, para Antônio de Morais e Antônio Caetano de Freitas, e lera "venenosos livros", a partir dos quais punha em dúvida a imortalidade da alma e dizia que "a abstinência de carne era invenção dos homens" "195. Seu processo inquisitorial interrompe-se no sumário de culpas; não tendo prosseguimento, devido a seus contatos com Pina Manique, Intendente Geral de Polícia ${ }^{196}$.

Francisco de Mello Franco, então estudante de Medicina, esteve também implicado nas discussões e delitos protagonizados por Antônio de Morais Silva. Não foi possível localizar seu processo inquisitorial no Instituto dos Arquivos Nacionais da Torre do Tombo, mas, nos processos de Antônio de Morais e de outros implicados, constam algumas informações sobre sua participação. O estudante João Laureano, logo que foi chamado à mesa da Inquisição de Coimbra, aconselhou-se com Francisco de Mello Franco, tendo este lhe falado para avisar aos demais, no que foi obedecido, bem como em ajustar os depoimentos. Mello Franco meteu-se na rede de circulação de "dous ou mais tomos das Cartas do Marquez de Argent". Antônio de Morais, às vésperas de fugir, deixou-lhe livros para vender, sendo do seu produto retirado um tanto para cobrir um empréstimo que fizera ao mesmo Morais e outra quantia para um filho deste ${ }^{197}$. Por volta de 1777, emprestara de Antônio da Silva Lisboa "hum tomo da obra de Russó [sic], que segundo a sua lembrança era o Terceiro no qual leo alguma couza”. Fez essa menção aos inquisidores anos depois por ser a dita obra então proibida e alegou não lembrar se ela continha “doutrinas

\footnotetext{
195 IANTT, Inquisição de Lisboa, Processo no 13369”, s/p.

${ }^{196}$ FILGUEIRAS, Carlos Alberto L. The mishaps of peripheral science: the life and work of Manoel Joaquim Henriques de Paiva, Luso-Brazilian chemist and physician of the late Eighteenth Century", op. cit., p. 77.
} 
erroneas"198. Foi sentenciado por crime de heresia - “"herege, naturalista e dogmático" ${ }^{\prime 199}$ — e ouviu sua sentença em auto de fé de 26 de agosto de $1781^{200}$. Pode-se afirmar, portanto, com base nessas poucas informações, que Francisco de Mello Franco foi um leitor inventivo: leu e trocou livros proibidos e participou de algum modo das discussões que se fizeram em torno desses. Por sua inventividade, passou quatro anos nos cárceres da Inquisição ${ }^{201}$.

As Luzes não limitaram o raio de sua influência ao Reino, chegando também à América Portuguesa. Em Minas Gerais, em Pernambuco, no Paraná, na Bahia, no Maranhão, em São Paulo, em Sergipe e no Rio de Janeiro, liam-se e debatiam-se obras que contestavam os dogmas do catolicismo e as normas eclesiásticas, pondo-se em dúvida passagens da Bíblia e, fundamentalmente, a noção de uma autoridade inquestionável. Em alguns casos a inventividade dos leitores resumiu-se ao questionamento das verdades estabelecidas pela Igreja; noutros, foi-se além dos próprios textos. Alguns leitores certamente eram tributários da Ilustração, ora associando-a visivelmente às proposições heréticas e iconoclastas que vicejavam na Colônia desde os inícios do século XVI; ora não explicitando qualquer laço com essas.

Em alguns casos, fica impossível esmiuçar o conteúdo das apropriações feitas pelos leitores, avaliar o quanto eles se aproximaram dos textos e/ou daquelas proposições heréticas e iconoclastas presentes na Colônia desde o Quinhentos. Impossibilidade de avaliar o conteúdo da apropriação é o que se verifica em relação a Hilário da Silva Porto, escrivão de órfãos em Vila Rica, em 1782: sabe-se apenas que ele duvidava do conteúdo de uma obra que lia, sem que seja possível identificar qualquer outra influência: elogiava a "lei dos libertinos" e duvidava de doutrinas religiosas ortodoxas de um livro que Tomás Gomes de Sá estava lendo ${ }^{202}$. Pode-se dizer, assim, que sua inventividade resumia-se a pôr em dúvida uma idéia religiosa ortodoxa. Já em relação a João Coelho de Sá, tesoureiro do Real Erário, em Pernambuco, nos idos de 1795, é possível detectar uma situação diferente, igualmente lacunar, mas marcada também pela inventividade da leitura: ele lia livro

\footnotetext{
${ }^{197}$ IANTT, Inquisição de Lisboa, Processo no 2015 , p. 3v-5v.

${ }^{198}$ Ibidem, p. 17.

${ }^{199}$ MARTINS, Wilson, op. cit., p. 465.

${ }^{200}$ IANTT, Inquisição de Lisboa, Processo no 2015, p. 16-16v.

201 SANTOS FILHO, Lycurgo Francisco de Melo Franco. In: SILVA, Maria Beatriz Nizza da (coord.). Dicionário da história da colonização portuguesa no Brasil, op. cit., p. 357.
} 
ortodoxos que combatiam as idéias de Rousseau; entretanto, dedicava-se a expor essas últimas em "conversas literárias", ao invés de defender a ortodoxia, motivo pelo qual temia ser denunciado ao Santo Ofício ${ }^{203}$. Portanto, sua leitura de um livro ortodoxo foi inventiva na medida em que selecionou, para exposição em público, apenas o que era heterodoxo. Em Aracaju, Sergipe, em 1779, Antônio Bernardo denunciava a si mesmo por contar na vila de Lagarte o que havia lido, em Lisboa, num livro francês proibido, o Système de la Nature, do Barão de Holbach: se aqui não é possível avaliar o conteúdo das falas de Bernardo, pode-se precisar ao menos a origem Ilustrada delas, atestada por ele próprio ${ }^{204}$.

Na Vila de Paranaguá, então jurisdicionada a São Paulo, hoje Paraná, em 1778, o sargento-mor Manoel Antônio Machado duvidava do céu, do inferno e da imortalidade da alma, recorrendo a livros proibidos para corroborar suas afirmações. Fica visível nas proposições de Machado a existência de similitude com elementos colhidos na Ilustração, através dos aludidos livros proibidos: a rejeição à imortalidade da alma, como se mostrou no Capítulo 2, era defendida por muitos pensadores Ilustrados. Percebem-se, também, pontos de convergência com idéias heréticas presentes na Colônia desde o século XVI, bastando evocar aqui as dúvidas de Bento Pereira, em Pernambuco, nos idos de 1590, sobre a existência do Inferno ${ }^{205}$. Logo, pode-se supor que se amalgamaram, nas idéias expostas por Manoel Machado, as Luzes e as proposições heréticas de grande longevidade na Colônia. Em Minas Gerais, mais precisamente, em Santa Luzia, em 1781, o subdiácono Miguel Eugênio, provavelmente debaixo da influência da recusa Ilustrada à idéia de uma autoridade inquestionável e do empenho de muito de seus autores no sentido de submeter a Escritura Sagrada à crítica, lia os Evangelhos de uma forma dissonante da proposta pela igreja católica e duvidava do batismo. Ele divergiu de Manoel Roiz sobre a necessidade do batismo para a salvação, dizendo que Cristo "não disse neste Texto [isto é, os Evangelhos] que se perdiam os que não fossem batizados"206.

Questionamento dos ensinamentos da Igreja era o que fazia Joaquim José de Souza, em Cairu, na Bahia, em 1793, reportando-se explicitamente a um texto Ilustrado: o livro Instituições Políticas, provavelmente de Biefeld, em francês, cujas

\footnotetext{
${ }^{202}$ IANTT, Inquisição de Lisboa, Cadernos do Promotor, Livro 319.

${ }^{203}$ IANTT, Inquisição de Lisboa, Cadernos do Promotor, Livro 321.

${ }^{204}$ IANTT, Inquisição de Lisboa, Cadernos do Promotor, Livro 320.

${ }^{205}$ IANTT, Inquisição de Lisboa, Cadernos do Promotor, Livro 319.
} 
proposições sobre os cristãos-novos e a Inquisição foram examinadas no Capítulo 2. Joaquim José afirmava, segundo se denunciava a partir do livro referido, que o Purgatório era "invenção dos homens para por este meio perceberem emolumento os eclesiásticos", que a confissão auricular era reprovável, que as excomunhões constituíam uma mentira, ocorrendo o mesmo com a canonização dos $\operatorname{Santos}^{207}$. Já um outro habitante da Bahia na mesma época, mais precisamente de Salvador, duvidava que a fornicação simples fosse pecado mortal, pois, para ele, as palavras da Bíblia proibiam apenas o adultério $^{208}$. Se a defesa da fornicação simples enraizava-se na moralidade das gentes da América Portuguesa, sendo consagrada pela moralidade popular desde os princípios da colonização, vê-se que o soteropolitano em questão procura reforçá-la a partir de uma leitura crítica da Bíblia, o que pode ter nexos com o sublinhada dedicação de alguns Ilustrados ao questionamento da Escritura Sagrada.

Imbuído certamente da resistência à idéia de autoridade, o desembargador Tomé Joaquim Gonzaga - primo do poeta e conjurado Tomás Antônio Gonzaga, tradutor de Pastor Fiel, de Guarini, obra censurada pela Real Comissão Geral para a Censura de livros em $1789^{209}$ — encontrando-se no Rio de Janeiro nos idos de 1778, conservava em seu poder livros proibidos, dizendo ter "faculdade para os poder ler e ter" e defendia algumas proposições temerárias, dentre as quais aquela segundo a qual não haveria Inferno, proposição essa que, se pode ser Ilustrada, tinha antecedentes mais longínquos no tempo, no mundo luso-brasileiro ${ }^{210}$.

Fusão de proposições heréticas seculares e de idéias e práticas trazidas pelas Luzes é o que se vê numa denúncia feita na Vila de Taubaté, São Paulo, em 1801, contra Bento Álvares de Lacerda, adventício do Rio de Janeiro, parente ou protegido do então governador da Capitania. Diante de padres e de um médico ele defendeu idéias que lembram algumas proposições defendidas ou por Rafael Olivi, ou imputadas a Jean Cointá, em meados do século XVI, ou ainda consagradas nos escritos dos Ilustrados que seguiam princípios materialistas: ele disse que "q . não havia certeza da existencia de Jezus Christo na Eucharistia", negou "a immortalide da alma” e escarneceu "das Sagradas imagens, dezendo, q . pedaços de páos velhos, herão aquelles, sigarrando diante dellas, no mesmo Templo, na occazião da

\footnotetext{
${ }^{206}$ Ibidem.

${ }^{207}$ IANTT, Inquisição de Lisboa, Cadernos do Promotor, Livro 320.

${ }^{208}$ Ibidem.

${ }^{209}$ MORAES, Rubens Borba de. Bibliografia brasileira do Período Colonial, op. cit., p. 179-180.
} 
Missa"211. Apresentou, igualmente, uma proposição herética presente entre os estudantes coimbrãos luso-brasileiros citados anteriormente e, ainda, de grande longevidade na Colônia, sendo objeto de cuidadosa investigação realizada por Luís MOTT: a idéia segundo a qual Maria, mãe de Jesus, não seria virgem ${ }^{212}$. O herege de Taubaté, assim, afirmou que "a Bem Aventurada, Virgem Maria N. Senhora podia ser puta, antes do Parto, e no Parto" ${ }^{, 213}$. Da mesma forma que os Quinhentistas, Bento Álvares “não acreditava, no q . mandava crer a $S^{\text {ta }}$. Igreja, e Sagradas escrituras", fazendo, porém, uma referência que não se encontrou entre aqueles: ele duvidava das “Sagradas escrituras, $p^{r}$. serem escritas $p^{r}$. homens". Nesse ponto, parece insinuar-se uma perspectiva particular, talvez estranha aos homens do século XVI e possível entre aqueles que viviam sob as Luzes: a compreensão da Bíblia como invenção humana e como algo que, segundo Voltaire, conforme se observou no Capítulo 2, só trouxera infelicidade. Bento Álvares duvidava, além disso, da própria bondade do Criador, dizendo que ele " hera máo, pr. ter creado, aquelles, q . se havião de perder, e q não acreditava nelle, $\mathrm{p}^{\mathrm{r}}$. q. não via com os seos olhos". Nas entrelinhas dessa proposição, percebe-se uma visão materialista da realidade - afinal, os homens se perdem, inexistindo, portanto, salvação e vida pós-morte e, ainda, só se poderia crer em Deus se ele fosse captado pela visão - , constituindo-se, portanto, como um outro elemento que parece ser particular dos Ilustrados, mesmo assim exclusivamente daqueles "filósofos" que eram materialistas e ateístas. Por fim, Álvares dizia que "não acreditava no baptismo, q . tinha recebido, $p^{r}$. q . não tinha conhecim $^{\text {to }}$. disso, e q. estava na sua vont ${ }^{\mathrm{e}}$. o baptizarse, outra vez" e que "q . o comer carne, nos dias de jejum, não hera pecado": se essa última proposição evoca as práticas alimentares dos coimbrãos Antônio de Morais Silva, a primeira, coloca Bento Álvares na mesma posição que o supracitado subdiácono mineiro Miguel Eugênio; ambas, porém, não mostram ser algo específico do Século das Luzes. O herege de Taubaté, enfim, parece amalgamar as Luzes a toda uma herança de proposições heréticas, seculares.

\footnotetext{
${ }^{210}$ IANTT, Inquisição de Lisboa, Cadernos do Promotor, Livro 319.

${ }^{211}$ IANTT, Inquisição de Lisboa, Cadernos do Promotor, Livro 322.

212 MOTT, Luiz. O sexo proibido: gays, virgens e escravos nas garras da Inquisição. Campinas: Papirus, 1989. Essa proposição não foi abordada anteriormente por não se ter localizado nenhuma referência em que apareça tendo como suportes explícitos livros e leituras.

${ }^{213}$ Ibidem.
} 
Em torno dos livros e das heresias aconteceu de alguns leitores construírem proposições políticas, algumas heterodoxas e outras, ao menos, curiosas. No Maranhão, o sargento-mor Aires Carneiro, em 1779, diante do seu pároco "reproduzia passagens duvidosas de livros proibidos", questionava o ofício divino de "lições da Sagrada Escritura", as vidas dos santos e os Salmos de Davi. Manifestava também desprezo pelo Santo Ofício, descrença em relação à autoridade papal e à divindade de Cristo, tendo fé apenas num Deus criador do mundo e na lei natural, estando provavelmente influenciado pelas proposições deístas, anti-inquisitoriais e anti-católicas de Voltaire ${ }^{214}$. Aires Carneiro, porém, a partir do questionamento da necessidade de realizar o ofício divino e do conteúdo dos salmos de Davi, refletiu sobre as relações entre a Igreja e o poder secular: assim, por um lado, assegurou ao pároco que "nem Davi disse isso" (a obrigação de realizar o ofício), nem a Igreja o mandava e, por outro lado, acrescentou que seu dever era obedecer "em primeiro lugar a Deus, em segundo lugar ao Rei, e no seu lugar o Marquês de Pombal". Nas proposições de Aires, assim, exprime-se não apenas a incredulidade de alguns textos Ilustrados em relação à Bíblia (os mencionados "livros proibidos"), como também o regalismo que caracterizou o Reformismo Ilustrado português - aliás, Aires mostrou-se não apenas regalista, como também "pombalista", alçando o bravo marquês à posição de destaque, que ele ocupava de fato, mais do que de direito.

Eivado de pombalismo - da mesma forma exacerbada que Aires Carneiro e, por isso mesmo, ferindo as prerrogativas papais - revelou-se o pardo Vicente Ferreira Guedes, advogado no mesmo Estado do Maranhão, em 1779. Guedes elogiava o livro "intitulado Tentativa Theologica”, de Antônio Pereira de Figueiredo, obra que, como foi discutido no Capítulo 3, procurava conciliar o regalismo e o antiromanismo exacerbado pelas circunstâncias (o livro foi escrito num momento de ruptura entre Portugal e o papado) à afirmação da primazia da autoridade pontifícia, mantendo aos bispos, contudo, o direito de fazerem dispensas quando houvesse conflitos entre a monarquia e o papado. Perante duas pessoas, o advogado maranhense afirmou que a autoridade dos Papas era a mesma que a dos demais bispos, pois a primazia dada "ao Pontífice era uma currutela deduzida de Roma ter sido a cabeça e dominadora de todo o mundo em seus princípios" e "não porque

${ }^{214}$ IANTT, Inquisição de Lisboa, Cadernos do Promotor, Livro 319. 
Cristo fizesse [o Papa] maior" ${ }^{215}$. Guedes, portanto, movendo-se dentro da ambigüidade contida no próprio texto entre a primazia do papa e os direitos dos bispos, optou por postar-se inteiramente contra o Sumo Pontífice, desvirtuando o sentido original do texto. Assim, no âmbito das práticas de leituras, na inventividade de um leitor do Estado do Maranhão, desenhavam-se os riscos derivados da ambigüidade do Reformismo Ilustrado português: a subversão da ordem, no caso, não estritamente política, mas político-religiosa, referente às relações entre o Estado e a Igreja.

Os livros, em resumo, foram, ao menos até meados do século XVIII, motivo de apreensão por parte das autoridades portuguesas e dos intelectuais da ordem, sendo compreendidos de algum modo como um perigo para os poderes constituídos, visão essa superada parcialmente sob o impacto das Luzes e do Reformismo Ilustrado. Se essa modificação não implicou o fim do controle sobre os livros e as leituras, expressou e, certamente, afetou a relação da sociedade com a cultura livresca no século XVIII. A distribuição da posse de livros, os usos que motivavam, as formas de apropriação de que eram objeto, os ambientes em que se encastelaram sua posse e sua leitura: tudo isso parece sinalizar uma modificação sensível na relação entre os grupos sociais, o livro e a leitura, demonstrando um progressivo interesse dos primeiros pelos últimos.

O exame da distribuição da posse de livros na América Portuguesa ao longo período colonial, no entanto, embora demonstre os progressos do apreço pelo livro e pela leitura na medida em que se aproxima da Independência, aponta para seus limites. Os livros eram possuídos por poucas pessoas, por gentes que, via de regra, aliavam a propriedade de bens de raiz e escravos ao exercício de ofícios que requeriam o uso dos livros, como sacerdócio, advocacia, medicina-cirurgia, botica, navegação e docência, fazendo-se presente, além disso, entre os que se dedicavam às atividades militares. Essa distribuição, por si mesma, já indica um dos usos do livro: os livros serviam como fonte de saberes indispensáveis para o exercício profissional.

A composição das bibliotecas coloniais, tão diferentes nas dimensões umas das outras, por seu turno, do século XVI a 1822, aponta para o predomínio das obras de religião, embora já no século XVIII as obras de cunho profissional revelem-se muito próximas em termos numéricos. Fontes de conhecimentos necessários para o

${ }^{215}$ Ibidem. 
exercício profissional, assim, os livros municiavam os leitores com saberes e informações utilizadas na vivência religiosa. Ao mesmo tempo, ainda tendo a composição das bibliotecas como ponto de partida, é possível identificar que havia espaço no interior delas para o recreio e o deleite: os livros serviam também como objeto de diversão. Os livros, ademais, eram revestidos de outra utilidade: como objetos materiais prestavam-se para ornamentar as casas; como fontes de saber, eram índices e adereços de privilégios e distinções sócio-profissionais. A posse de livros, assim como os seus usos, permeava-se pela idéia de privilégio, inerente a uma sociedade de cunho estamental. A composição das bibliotecas, ainda, segredava algo mais: a posse de livros, concentrando-se no interior das elites econômicas e/ ou intelectuais, comportando diferenciação conforme o grupo sócio-profissional, apresentava uma outra clivagem, evidente a partir do século XVIII, que separava, no interior dessa elite proprietária de livros, um segmento, uma "elite dentro da elite", que não resumia os seus interesses às obras profissionais, ou mesmo religiosas, cultivando expectativas de, em seu recreio literário, refletir sobre o homem, a natureza, a divindade e o Estado.

Esses usos implícitos do livro foram confirmados por uma primeira abordagem dos usos explícitos, aquela desenvolvida a partir das apreciações constituídas pelos próprios leitores, mormente em requerimentos enviados à censura a partir de 1768, sobre as utilidades que atribuíam aos livros. Os livros, nesses documentos, são explicitamente assumidos pelos leitores como fonte de saber, freqüentemente, de cunho profissional, como meios de acesso ao sagrado e objetos de entretenimento, prestando-se, ainda, a ornamentar e a servir em estratégias de poder, usos esses todos não excludentes, mas complementares. Nos usos explícitos também sobressai algo que era particular desse passado, uma sociedade colonial e estamental, típica do Antigo Regime: o uso do livro como um privilégio, não apenas no sentido econômico, mas como um bem cuja posse podia constituir um direito exclusivo de grupos sociais determinados e seletos.

Engastados em relações de poder, os livros, tão temidos pelas autoridades no início da colonização e motivo de controle e zelo por parte das autoridades sob o Reformismo Ilustrado, de fato, prestaram-se a servir se não de origem, ao menos como suporte para a formulação de proposições heréticas. Na América Portuguesa, desde o século XVI, além disso, o livro acompanhava a elaboração e explicitação de 
heresias: alguns leitores, demonstrando inventividade, desrespeitando as interdições censórias, as verdades estabelecidas pela Igreja, pelo Estado e/ou contidas nos livros, apropriavam-se das idéias dos livros para questionar a autoridade do Papa, a Escritura Sagrada, as interdições da censura, os santos, os milagres, os sacramentos, o Inferno e, como um todo, a religião cristã; em muitos casos, reincidiam, com o apoio dos livros, nas suas crenças judaicas.

Se esse panorama verificou-se desde o século XVI, a partir de meados do Setecentos, assistiu-se à amalgamação dessa herança secular de proposições heréticas e iconoclastas e de blasfêmias, às idéias trazidas pelas Luzes. Nem sempre é possível identificar até onde vai essa herança e em que ponto começam as Luzes, mas, de qualquer forma, ambos os elementos, tendo como suportes os livros, contribuíram para que os leitores repensassem a religião católica, duvidassem de seus dogmas, afrontassem suas autoridades. Essa vaga de irreligiosidade, tendo por epicentro Paris, derramando-se em Lisboa e atingindo a América, teve em Antônio de Morais Silva o seu mais autêntico representante: como leitor, o grande dicionarista luso-brasileiro, revelava afinação com as posturas deístas, anti-católicas e anti-inquisitoriais de Voltaire, ao mesmo tempo em que se deixava seduzir pela pró-tolerância e pela refutação de Rousseau à idéia da Queda do Homem, essencial no cristianismo. Conciliando essa postura com a rejeição à existência de autoridades inquestionáveis, confrontando as informações colhidas nos livros aos dados retirados da observação da realidade, Morais Silva concretizava aquele uso do livro inferido a partir da composição das bibliotecas e sugerido nas utilidades dos livros pensadas pelos leitores: o livro enquanto suporte de estratégias de poder, enquanto referência para refletir sobre o homem, o mundo natural e a divindade. Por isso mesmo, assim, Morais encarnava o perigo de subversão, ainda que restrito ao âmbito da religião, tão temido pelas autoridades. Se Morais era o emblema do leitor Ilustrado e inventivo, Bento Álvares, o herético de Taubaté, parecia fundir as Luzes às proposições heréticas que vicejavam na colônia desde o século XVI, juntando materialismo e ateísmo à incredulidade tributária de nossas raízes culturais, tão marcadas pela presença dos cristãos-novos, como vem defendendo insistentemente Anita Novinsky.

Nas leituras inventivas e heréticas do final do Setecentos, por fim, insinua-se e agudiza-se a própria ambigüidade do Reformismo Ilustrado Português: no longínquo Maranhão ouviam-se murmúrios regalistas que ultrapassam as fronteiras 
definidas pelo próprio marquês de Pombal, em seu embate contra a Igreja católica: se Pombal queria simplesmente sobrepor a Coroa à instituição eclesiástica, dois leitores "pombalistas" maranhenses esticavam a corda ao ponto de questionarem a própria Igreja e a primazia da autoridade papal no interior dela. A política, portanto, insinuase na heresia.

E da heresia, pode-se começar a adentrar pelo terreno da política, abrindo espaço para o uso do livro com fins sediciosos. A heresia, mesmo antes das Luzes, confluiu com a política. Pedro Rates Henequim, na primeira metade do século XVIII, personifica essa fusão, misturando a visão edênica e o milenarismo vieirista à proposição de instalar na América portuguesa o Quinto Império do Mundo, sob a chefia de D. Manuel, irmão de D. João V. No próximo capítulo, procurar-se-á analisar como, nas Minas Gerais do século XVIII, as Luzes vieram a se amalgamar ao realismo do padre Antônio Vieira, às interpretações correntes sobre a Restauração portuguesa de 1640 e à Independência dos Estados Unidos, no pensar de uma sedição, tudo isso tendo como suporte os livros. 


\section{Capítulo 8:}

\section{Leituras e Inconfidência Mineira (1789)}

A historiografia da Inconfidência de Minas Gerais, como bem sublinhou Adriana ROMEIRO, ressente-se "do silêncio sobre as tradições de contestação política disseminadas entre os mineiros: à valorização do genial, sucedeu a valorização do perfil letrado de seus integrantes, sobretudo das relações desses com a obra do abade Raynal, como se a idéia de revolução devesse ser necessariamente importada dos círculos europeus ante a existência de uma tradição revolucionária local". . Dessa forma, os historiadores tornaram a filosofia das Luzes o "catalizador par excellence da tomada de consciência", considerando que o sistema conceitual por ela oferecido fez os colonos capazes "de promover uma interpretação cristalina da realidade colonial"2. Embora este capítulo não tenha por propósito discutir a Inconfidência Mineira enquanto movimento político, mas investigar apenas as leituras feitas por seus protagonistas, convém dizer que as conclusões a serem aqui apresentadas vêm corroborar, em parte, a crítica feita por Adriana Romeiro. Todavia, foge aos propósitos desta tese quer realizar uma crítica minuciosa da historiografia referente à Conjuração de Minas, quer fazer algo mais do que uma radiografia das suas origens intelectuais.

\footnotetext{
${ }^{1}$ ROMEIRO, Adriana, op. cit., p. 247.

2 Ibidem, p. 274. Um representante desta vertente interpretativa da Inconfidência criticada por Romeiro é Sérgio Paulo Rouanet. Esse autor faz a seguinte afirmação, referindo-se à Conjuração de Minas: "As idéias da Ilustração funcionaram como a grade intelectual dentro da qual os revolucionários viam e pensavam sua realidade. O mundo era percebido segundo categorias descritivas extraídas do direito natural e do empirismo, sobre um fundo normativo que incluía pressupostos subjacentes e não questionados, como a autonomia e a universalidade da razão, o poder da educação para arrancar os homens da treva, a perfectibilidade do homem, a onipotência da política e a fé na dignidade e liberdade do homem" (ROUANET, Sérgio Paulo. As Minas Iluminadas: a Ilustração e a Inconfidência Mineira. In: NOVAES, Adauto (org.). Tempo e história. São Paulo: Companhia das Letras, 1992, p. 330). É preciso reconhecer que já defendemos posições similares, enfatizando a influência do abade Raynal sobre os Inconfidentes. Veja, por exemplo: VILLALTA, Luiz Carlos. Bibliothèques privées et pratiques de lecture au Brésil colonial, op. cit., p. 331-332 e Idem, O que se fala e o que se lê: língua, instrução e leitura, op. cit., p. 379-380.
} 


\section{Historiografia e Inconfidência: das Luzes à Lusitânia}

A unanimidade historiográfica criada em torno da associação da Inconfidência de Minas à Ilustração tem sido motivo de críticas nos últimos anos. Dentre os estudos que apontam para novas perspectivas de interpretação da Conjuração das Gerais, podem ser destacados os realizados por Ronald POLITO ${ }^{3}$ e, mais recentemente, por Joaci Pereira FURTADO ${ }^{4}$. Tais historiadores, é bem verdade, não se detêm numa análise propriamente da Inconfidência, voltando-se apenas para o exame da obra de Gonzaga, no caso do primeiro, e para as Cartas Chilenas, no caso do segundo. Mesmo assim, seus trabalhos apresentam evidências de que havia uma mentalidade tradicional e conservadora por trás do Inconfidente Tomás Antônio Gonzaga. Na mesma tendência, inscreve-se nossa dissertação de mestrado, A "Torpeza diversificada do vícios”, em que se analisam as posições morais sexuais do grande poeta da Inconfidência e dos demais conjurados, concluindo-se também que o ouvidor de Vila Rica pautava-se, em seus escritos e em sua vida, por valores tradicionais e conservadores, embora incorporasse elementos Ilustrados: associava o sexo à Queda, subordinando-o aos fins procriativos; defendia a indissolubilidade do matrimônio; propugnava o recato para as mulheres; admitia relações sexuais com prostitutas, considerando necessário, porém, a preservação das aparências no trato com as mesmas e com as "vis mulatas"; mas ao mesmo tempo apreendia o sexo como uma "lei da Natureza", fugindo assim da perspectiva teológica, e acabava por curvar-se às mudanças que, então, afetavam as relações entre homens e mulheres, em benefício dessas 5 .

No Tratado de Direito Natural, segundo POLITO, funde-se uma visão teologal com o jusnaturalismo moderno. Teologal, na medida em que Gonzaga consideraria que Deus, criador de todas as coisas, para o fim de delas receber uma glória acidental, teria dotado o homem de inteligência para conhecê-la, dando-lhe,

\footnotetext{
${ }^{3}$ POLITO, Ronald. A persistência das idéias e das formas: um estudo sobre a obra de Tomás Antônio Gonzaga. Niterói: Universidade Federal Fluminense, 1990 (Dissertação de mestrado).

${ }^{4}$ FURTADO, Joaci Pereira. Uma república de leitores: história e memória na recepção das 'Cartas Chilenas' (1845-1989). São Paulo: Hucitec, 1997.

${ }^{5}$ VILLALTA, Luiz Carlos. A “torpeza diversificada dos vícios”: celibato, concubinato e casamento no mundo dos letrados de Minas Gerais (1748-1801), op. cit., p. 207-214.
} 
para tanto, leis e liberdades; essas leis, infundidas por Deus, seriam conhecidas por Direito Natural, uma vez que sua apreensão se daria naturalmente por intermédio da razão e do discurso. Nisso tudo parece haver uma reprodução do jusnaturalismo tomista, analisado no Capítulo 1, das teorias corporativas de poder da Segunda Escolástica - POLITO, entretanto, não faz referência a elas, preferindo usar apenas o termo "teologal".

Prosseguindo em sua análise do Tratado de Direito Natural, POLITO afirma que, para Gonzaga, o poder absoluto do rei derivaria de Deus, sendo por isso ilimitado, não submetido à responsabilidade alguma. Ao mesmo tempo, contudo, Gonzaga distanciar-se-ia de Maquiavel, para quem ao Rei "era lícito tudo quanto lhe agradava"6 e opor-se-ia "a todo ideal de igualdade político-jurídica problematizado e latente em parte do direito natural moderno"7. Com base nessas constatações, POLITO conclui que Gonzaga seria, do ponto de vista doutrinário, mais conservador do que o próprio Pombal. Isso, no entanto, não procede: o maquiavelismo, enquanto doutrina, era severamente condenado pelos tribunais censórios portugueses, sendo tal rejeição explícita, como se viu nos Capitulos 3 e 4.

Joaci Pereira FURTADO, em grande parte inspirado na dissertação de Polito, considera que Gonzaga, nas Cartas Chilenas, ao criticar Luís da Cunha Menezes, propõe uma parábola sobre o bom governo, recorrendo a referenciais cristãos sem pôr em xeque o absolutismo. As Cartas chocar-se-iam, por isso, com as "propensões da filosofia política moderna, marcada por acentuada laicização e pelo naturalismo racionalista" e, malgrado tivessem pontos de coincidência com os teóricos absolutistas, partiriam de princípios excludentes, na medida em que se fundavam em pressupostos estritamente teológicos ${ }^{8}$. Filiar-se-iam ao "passado", defendendo os antigos sinais de distinção e a etiqueta tradicional; estabelecendo uma relação direta entre vida privada e o exercício do poder; reivindicando a obediência às leis régias; e, ainda, referendando a política geral da Coroa para a Colônia. "O máximo de mudanças" preconizado pelas Cartas seriam: a justiça na cobrança dos impostos, o equilíbrio nos gastos públicos e a necessidade de conciliação entre virtude e nobreza

\footnotetext{
${ }^{6}$ Tomás Antônio Gonzaga. apud. POLITO, Ronald. A persistência das idéias e das formas: um estudo sobre a obra de Tomás Antônio Gonzaga. Niterói: Universidade Federal Fluminense, 1990, p. 95 (dissertação de mestrado).

${ }^{7}$ POLITO, Ronald, p. 95.
} 
por parte daqueles que exercessem cargos a serviço da realeza ${ }^{9}$. Nessa defesa da conjugação entre a virtude e a nobreza como critério para o preenchimento de cargos públicos, tanto POLITO quanto Joaci FURTADO identificam um posicionamento conservador, insistindo que Gonzaga norteava-se por uma visão aristocrática ${ }^{10}$. Joaci FURTADO, contudo, enxerga na mesma proposição a "reforma" "mais inovadora" defendida por Gonzaga. Por inovação, esse autor compreende a "crítica reformista do Estado absolutista português que nasce pelo menos desde Antônio Vieira - passando, ironicamente, pela casa dos bisavós de [Luís da Cunha] Meneses - até culminar em Verney e Pombal" ${ }^{, 11}$.

De fato, o padre Antônio Vieira advogou a necessidade dos representantes da Coroa reunirem competência e nobreza, e D. Luís de Menezes, o Conde da Ericeira, ancestral do governador Luís da Cunha Menezes, foi refratário a um poder que se exercesse de forma despótica, como se viu no Capítulo 1; de fato, Verney sublinhava que os nobres deviam ser virtuosos, instruídos, não bastando sua origem de sangue, como se evidenciou no Capítulo 2; de fato, ainda, as reformas defendidas por Vieira foram em parte implementadas por Pombal, e Verney, embora crítico mordaz dos jesuítas, recomendava o uso das Cartas do nosso padre milenarista nas escolas, como também se apontou nos Capítulos 1 e $\mathbf{3}$ - mas não se pode esquecer que Verney e Pombal procuraram demolir boa parte do edifício cultural construído em Portugal nos séculos XVI e XVII, mormente pelos jesuítas, tendo o poderoso ministro de D. José I se esmerado em destruir a memória do maior orador sacro luso-brasileiro. Escapa ao autor, além disso, a percepção de que a defesa — talvez mais aparente do que real - que Gonzaga faz da obediência ao monarca colide não apenas com a filosofia política moderna, naturalista e racionalista, mas também, em parte e aparentemente, com os próprios ensinamentos jusnaturalistas escolásticos, teológicos, corporativos, em voga em Portugal desde o século XVI e familiares a Gonzaga, enquanto estudante da Universidade de Coimbra, em período anterior à reforma pombalina, e como magistrado. Enfim, o que se quer dizer é que, no mosaico das idéias de Gonzaga, Joaci FURTADO, com muita perspicácia, soube identificar suas origens no atacado,

\footnotetext{
${ }^{8}$ Ibidem, p. 81.

${ }^{9}$ FURTADO, Joaci Pereira. Uma república de leitores: história e memória na recepção das 'Cartas Chilenas' (1845-1989), op. cit., p. 77-78.

${ }^{10}$ Ibidem, p. 79-80 e POLITO, Ronald, op. cit., p. 199.
} 
mas embaralhou-as. Não atentou, de um lado, para as permanências da cultura política portuguesa que se expressam na obra do poeta - isto é, para o passado que era presente - e, de outro, para as contradições existentes entre suas fontes de inspiração: onde o historiador em questão vê "inovação", na realidade, existiam apenas idéias que sobreviviam ao tempo; onde ele enxerga unidade, havia igualmente agudas antinomias; aquilo que classifica como antagônico com as correntes políticofilosóficas modernas, aparentemente colidia também com as teorias corporativas de poder.

João Pinto FURTADO, ao apresentar conclusões parciais de sua pesquisa de doutorado ainda em curso, afirma que Tiradentes é insistentemente lembrado na historiografia por "importunar alguns de seus interlocutores, para que traduzissem e lessem trechos" de livros, um deles o Recueil des Lois Constitutives des Colonies Anglaises, Confédérées sous la Dénomination D'États-Unis de l'Amérique Septentrionale. Adverte o autor que a presença de tal livro poderia ser interpretada como indício de influência Ilustrada no movimento, todavia, tal hipótese não seria plausível, na medida em que o referido documento encontra-se fortemente "inscrito na tradição anglo-saxônica de organização política comunitária e representativa", o que não era conjugável "aos projetos autonomistas de tradição ibérica ou aos planos dos Inconfidentes tal como se tornaram conhecidos" ${ }^{12}$. João FURTADO, portanto, resvala num mesmo ponto tangenciado por Joaci, variável quase esquecida nas interpretações da Inconfidência Mineira: suas possíveis raízes ibéricas, mais precisamente lusitanas. É essa senda que se procurará seguir neste capítulo, buscando compreender as afinidades entre as idéias dos Inconfidentes e aquelas defendidas pelos teólogos da Segunda Escolástica, pelo padre Antônio Vieira e, ainda, pelo Conde da Ericeira, D. Luís da Cunha Menezes, autor da obra História do Portugal Restaurado; vai-se procurar avaliar como tal legado luso-brasileiro, mediado pelos livros e pelas leituras, imbricou-se nas falas dos Inconfidentes, amalgamando-se com as Luzes e relacionando-se com as notícias da Independência dos Estados Unidos da América.

\footnotetext{
${ }^{11}$ Ibidem, p. 77.

${ }^{12}$ Os resultados parciais dessa pesquisa encontram-se em: FURTADO, João Pinto. Inconfidência e Inconfidentes em múltiplos registros: história e historiografia do movimento mineiro de 1789. In:
} 


\section{Tensões e perspectivas sob Dona Maria I: apropriações possíveis}

A apropriação que os Inconfidentes de Minas Gerais fizeram dos textos que leram é indissociável das condições econômicas, políticas e sociais da Capitania ao final do século XVIII, no quadro geral das medidas reformistas implementadas pela Coroa no do império português, sob o Reformismo Ilustrado. Nessa época, Minas Gerais encontrava-se em meio à crise da produção aurífera; assistia a uma mudança de eixo sócio-econômico, que se deslocava da região central para o sul, em consonância com um processo de diversificação econômica que produzia demonstrações de relativa auto-suficiência ${ }^{13}$. Como se viu no Capítulo 3, a política colonial definida por Dona Maria I, ao final da década de 1780, sofria uma guinada "neomercantilista", procurando impedir o desenvolvimento manufatureiro da Colônia e reservar o mercado dessa para os produtos do Reino e, para tanto, determinando, em 1785, a proibição das manufaturas de tecidos na América. Sob o governo mariano, passou-se a estabelecer no seio da elite mineira, cujos interesses estavam profundamente enraizados localmente, uma percepção dual, que combinava termos contraditórios: de um lado, a constatação de que a Colônia possuía uma natureza cheia de riqueza, certa auto-suficiência e, por outro, a consciência de que "só a condição de colônia podia explicar a pobreza e a miséria"14, de que "a riqueza, drenada para fora, engendrava pobreza"15. Esse distanciamento em relação à metrópole agravou-se quando muitos dos membros da elite local foram afastados de posições e possibilidades lucrativas durante o governo de Luís da Cunha Menezes e, mais ainda, quando a Fazenda Real impôs o pagamento imediato dos débitos aos arrematadores de direitos e rendas ${ }^{16}$. Toda essa situação afetou a leitura que os Inconfidentes fizeram dos livros, Ilustrados ou não; ao mesmo tempo, tais obras

DELGADO, Lucília de Almeida Neves (org.). Tiradentes: um herói para a República. Belo Horizonte: Imprensa Oficial, 1999, p. 150-162.

13 MAXWELL, Kenneth. A devassa da Devassa: a inconfidência mineira, Brasil - Portugal, 17501808, op. cit., p. 110-111.

${ }^{14}$ NOVAIS, Fernando Antônio, op. cit., p. 174.

${ }^{15}$ SOUZA, Laura de Mello e. Desclassificados do Ouro: a pobreza mineira no século XVII. 2 ed., Rio de Janeiro: Graal, 1986, p. 41.

${ }^{16}$ MAXWELL, Kenneth. A devassa da Devassa: a inconfidência mineira, Brasil - Portugal, 17501808, op. cit., p.74 e 132-133, e Idem. Conjuração Mineira: novos aspectos, Estudos Avançados, São Paulo, 3 (6): 6-23, mai/ ago. 1989. 
favoreceram o desenvolvimento da percepção dual que vinculava a pobreza da rica colônia à exploração metropolitana, bem como a formulação de alternativas para a superação dessa situação.

Reorientação mercantilista da política imperial portuguesa sob o Reformismo Ilustrado, crise do ouro, diversificação econômica, vexação fiscal... A essas modificações materiais palpáveis somavam-se idéias que guardavam em si potencialidades de fomento de uma consciência crítica. Tais idéias devem ser examinadas, num primeiro momento, nas suas potencialidades, sem que se admita, $a$ priori, que tenham exercido influência sobre os ânimos dos conjurados. Pode-se principiar justamente por aquelas idéias às quais costumeiramente se atribui a origem intelectual da Inconfidência Mineira: as Luzes. Como se viu no Capítulo 2, malgrado a diversidade de idéias dos "filósofos", muitas posições defendidas pelos mesmos, em princípio, estimulariam o desenvolvimento de uma percepção crítica a respeito da situação colonial. De um ponto de vista mais geral, a recusa a uma idéia de autoridade exterior, não justificada pela razão, poderia suscitar o questionamento do domínio colonial; idêntica possibilidade guardaria o emprego daquela inversão metodológica realizada para a constituição das idéias de muitos de seus pensadores (a abolição das certezas fundamentais e, inversamente, o apelo à observação e à experiência como marcos iniciais do processo de conhecimento, partindo-se desse procedimento indutivo para a elaboração de leis). O anti-despotismo, defendido por vários pensadores, destacando-se dentre eles Raynal e Rousseau e, no caso desse último, também a concepção de vontade geral como fundamento da constituição dos Estados, permitiam, ademais, uma aplicação direta às relações travadas entre a metrópole e a América, instigando, de um lado, a consciência de que, na última, se vivia numa situação de opressão, cujas origens encontravam-se no estatuto colonial e, de outro, oferecendo elementos teóricos que justificavam uma rebelião da Colônia.

A caracterização da colonização como uma situação de opressões diversas, denunciando-se suas mazelas e postulando sua superação, além disso, foi algo que, como se viu no Capítulo 2, se achava presente em escritos de alguns pensadores da Ilustração. Tais "filósofos" questionavam claramente o colonialismo europeu em geral, bem como os elementos que o fundamentavam, inclusive na América: o monopólio comercial, a escravidão, o extermínio das populações indígenas, o tráfico 
negreiro e a administração colonial. Essas idéias, como sublinhou Fernando NOVAIS, lidas em situação colonial, dificilmente não levariam à consciência sobre as contradições do sistema de colonização ${ }^{17}$. Um dos "filósofos" das Luzes, acrescente-se, debruçou-se sobre a história das regiões então colonizadas pelos países europeus, dentre elas a América: o abade Raynal. Em sua análise da colonização portuguesa, pode-se destacar, de um lado, a apologia das riquezas brasileiras e, de outro, a denúncia dos males e da pobreza que o monopólio comercial metropolitano e que a vexação fiscal causavam a essa terra tão rica, que poderia vir a ser uma das mais felizes colônias do globo, se fossem executadas reformas que levassem a uma recolonização, segundo os princípios da economia de mercado (análise que, como se viu no Capítulo 3, serviu de fonte de inspiração para as reformas propostas por D. Rodrigo de Souza Coutinho, ministro do príncipe D. João). Os colonos não precisavam fazer grandes esforços para depreender que essas críticas e sugestões de mudanças aplicavam-se à própria realidade específica em que se encontravam imersos. O mesmo Raynal, além disso, narrou um feito que poderia se afigurar, aos olhos das gentes coloniais, como a concretização, na realidade da história, de uma alternativa possível a seus padecimentos, constituindo um exemplo a ser seguido: a Independência das Treze Colônias Inglesas da América do Norte. Nessa narrativa, a vexação fiscal com que o governo inglês queria gravar os povos da América é apontada como a origem da sedição, do processo de conquista da Independência. Segundo RAYNAL, tudo "se reduzia a saber se a metrópole tinha ou não o direito de cobrar, direta, ou indiretamente, um leve imposto sobre as colônias"18; ponderando, porém, mais adiante, que isso era pouco para animar os norte-americanos a lutar contra a metrópole, considerando o acordo que estabeleceram com a França a razão da continuidade de sua audácia (nesse entendimento vê-se uma autêntica manifestação de chauvinismo) ${ }^{19}$.

Até aqui vem se esboçando um leque de possibilidades consagrado tradicionalmente pela historiografia da Inconfidência, procedimento que foi alvo de críticas na abertura deste capítulo; e, de fato, é preciso acrescentar idéias cujas origens encontram-se no próprio mundo luso-brasileiro e cujo potencial subversivo

\footnotetext{
${ }^{17}$ NOVAIS, Fernando Antônio, op. cit., p. 169.

${ }^{18}$ GUILLAUME, Thomas François Raynal. A revolução da América, op. cit., p. 113.

${ }^{19}$ Ibidem, p. 117.
} 
era temido pela Coroa sob o Reformismo Ilustrado, motivando proibições e ações por parte dos tribunais censórios, conforme vem sendo apontado insistentemente nesta tese. A primeira menção deve ser feita às teorias corporativas de poder. Se as Luzes, lidas em situação colonial, podiam engendrar uma consciência acerca das contradições entre a América e o Reino, as teorias corporativas ofereciam subsídios para se questionar, não propriamente as relações entre os dois lados do Atlântico, mas entre as gentes, a comunidade, e a soberana. Como se analisou no Capítulo 1, embora, em última instância, as teorias corporativas da Segunda Escolástica atribuíssem o poder político à divindade, concebiam que o mesmo era instituído através de um pacto, mediante o qual a comunidade, buscando a realização do bem comum, abdicaria do poder, depositando-o nas mãos do governante, o qual, em contrapartida, deveria respeitar a religião cristã, o direito natural e divino, não se transformando em tirano. Azpilcueta Navarro, Suárez, Bellarmino, João Azor, Molina, Lacroix, Busembaum e Mariana - os três primeiros distinguindo o poder in $a c t u$, exercido pelo governante, do poder in habitu, em potência, conservado pelo povo que lhe derrogara o poder que originalmente detinha - compreendiam, ademais, que a comunidade poderia retomar o poder nos casos de tirania, chegando alguns a admitir o regicídio. Essas teorias, portanto, conteriam germes para uma possível legitimação de investidas contra a situação de opressão em que viviam os colonos, expressa na vexação fiscal, no afastamento dos cargos públicos e na guinada "neo-mercantilista": caracterizando-se o governo como tirânico, abria-se a possibilidade de restituir o poder in actu a quem tinha o poder in habitu... Essas teorias, é importante frisar, não eram sobrevivências ${ }^{20}$, mas algo vivido e enraizado na vida e na história das gentes. Como se constatou nos Capítulos 5, 6 e 7, embora

\footnotetext{
${ }^{20}$ A antropologia, desde o funcionalismo de Boas, Radcliffe-Brown e Malinowski, questiona o uso da noção de survival - isto é, a interpretação de determinados costumes e práticas culturais como sobrevivência de estágios anteriores — preferindo, antes, apreendê-los como vivências, como elementos que fazem parte de um determinado sistema cultural, não se encontrando fora deles, num outro tempo, anterior, muitas vezes meramente hipotéticos (DURHAM, Eunice Ribeiro. $A$ reconstituição da realidade: um estudo sobre a obra etnográfica de Bronislaw Malinowski. São Paulo: Ática, 1978; HARRIS, Marvin. El desarrollo de la teoría antropológica: uma história de las teorias de la cultura. Madrid: Siglo Veintiuno, 1979, p. 456-467 e 478; RADCLIFFE-BROWN, Alfred Reginald. Estrutura e função na sociedade primitiva. Petrópolis: Vozes, 1973, p. 236-237; Idem, O método comparativo em Antropologia Social. In: MELLATI, Júlio César (org.). RadcliffeBrown/Antropologia. São Paulo: Ática, 1978, p. 29-30). A perspectiva abraçada neste tese, pelo contrário, procura apreender tais elementos no interior dos contextos histórico-culturais específicos em
} 
os livros que as traziam fossem em grande parte proibidos, os mesmos figuravam nas bibliotecas coloniais do século XVIII e, de um lado, constituíam objeto de retenções por parte dos órgãos censórios e, de outro, motivavam pedidos de licença de leitura (grande parte das solicitações encaminhadas aos tribunais censórios, em que se especificavam nomes de autores e títulos defesos, como se viu no Capítulo 6, referia-se a livros afinados com as teorias corporativas de poder).

Tais teorias, acrescente-se, talvez encontrassem suportes na própria na história de Minas Gerais. Primeiro, porque, no próprio Reino, num parecer elaborado para o Conselho Ultramarino pelo desembargador frei Sebastião Pereira de Castro, nos idos de 1747, as mencionadas teorias são o fundamento teórico a partir do qual o parecerista tipifica os governadores Martinho de Mendonça e Gomes Freire de Andrade como tirânicos e cruéis, e combate a proposta de cobrança do direito real dos quintos pela capitação e a sua contratação por arrematação em Minas Gerais ${ }^{21}$. Em segundo lugar, porque, como mostra Carla ANASTASIA, na primeira metade do século XVIII, a Capitania foi palco de motins, de escopos heterogêneos, é bem verdade, alguns deles não afrontando o domínio colonial, buscando apenas a restauração de um equilíbrio na relação com as autoridades; outros, pelo contrário, implicando um desrespeito à soberania régia; mas em grande parte, uns e outros, marcando-se por motivações fiscais ${ }^{22}$.

Luciano FIGUEIREDO, por seu turno, estendendo seu olhar para além das sedições mineiras - dentre as quais deu destaque para a do sertão do rio São Francisco, em $1736^{23}$-, analisando rebeliões ocorridas na Bahia, em 1711, e no Rio de Janeiro, em 1660, constata que tais movimentos ameaçaram as autoridades reais na Colônia, exigindo a remoção das mesmas ou o fim de alguns impostos. Observa, ainda, que essas rebeliões possuíam um ritual comum, que passava pela deposição das autoridades nos locais de sedição, por gritos em defesa da liberdade, por vivas ao rei e à monarquia e por menções ao apoio de potências estrangeiras (Espanha,

que se encontravam, compreendendo-os, portanto, como vivências, recusando-se a percebê-los, a partir de um modelo a priori, como meros indícios de "atraso".

21 VILLALTA, Luiz Carlos. El-Rei, os Vassalos e os Impostos: Concepção Corporativa de Poder e Método Tópico num Parecer do Códice Costa Matoso. Varia Historia, Belo Horizonte (inédito).

22 ANASTASIA, Carla Maria Junho. Vassalos rebeldes: violência coletiva nas Minas Gerais na primeira metade do século XVIII. Belo Horizonte: C/ Arte, 1998, p. 42-43.

${ }^{23}$ FIGUEIREDO, Luciano. Furores sertanejos na América portuguesa: rebelião e cultura política no sertão do rio São Francisco, Minas Gerais (1736). Oceanos, Lisboa (40): 128-144, out./dez. 1999. 
Inglaterra e França). Conclui, por fim, que as mudanças preconizadas pelos sediciosos realizavam-se dentro da ordem, "no reconhecimento mesmo do lugar do exercício do poder político por excelência, conforme a mais reta tradição portuguesa", com os rebeldes reocupando os postos e as instâncias de poder, reafirmando o pacto com o soberano e apenas atacando seus delegados como tiranos e opressores ${ }^{24}$. Sublinha, porém, que, sob os olhos das autoridades coloniais, a sedição do sertão do São Francisco, de 1736, cujo alvo foi a cobrança do quinto pela capitação, rompeu com esses limites ${ }^{25}$. A sedição marcou-se pela intensa violência das manifestações populares, pela tomada de medidas de auto-governo pelos rebeldes e pela suspeita de envolvimento dos grandes do sertão, tendo todos esses elementos levado as autoridades a acreditar que "a rebelião propunha algo maior que a suspensão de um direito ilegítimo", rompendo-se, portanto, com a soberania portuguesa. De qualquer forma, tais rebeliões mostram que uma máxima era consagrada pelos povos: o direito a insurgir-se contra o poder instituído classificado como tirânico ou contra alguma medida que assim o tipificasse e, no limite, a legitimidade de voltar-se contra o próprio poder régio em casos de tirania.

As teorias corporativas de poder serviram, ademais, como fundamentos para a legitimação e a interpretação de uma rebelião que constituía um marco importante da história portuguesa: a Restauração Portuguesa de 1640, como se mostrou no Capítulo 1. À luz das citadas teorias, o Conde da Ericeira, ascendente de Luís da Cunha Menezes, compreendeu a Restauração como um movimento através do qual as gentes portuguesas, oprimidas por um governo tirânico que desrespeitava o pacto primeiro estabelecido por Felipe II, vexadas por excessos tributários, restituíram a Coroa ao seu herdeiro legítimo, o Duque de Bragança, El-Rei D. João IV. A Restauração, assim, poderia vir a constituir-se aos olhos dos Inconfidentes, em situação colonial, num contexto de acirramento das tensões entre colonos e Coroa, como um exemplo histórico concreto de luta, consagrada como legítima, contra um governo tirânico.

\footnotetext{
${ }^{24}$ FIGUEIREDO, Luciano. Práticas políticas e idéias ilustradas na América portuguesa (quando os motins tornam-se inconfidências - 1640-1817). $10^{\mathrm{TH}}$ INTERNATIONAL CONGRESS ON THE ENLIGHTENMENT, 7, 1999, Anais, Dublin. (inédito).

${ }^{25}$ Idem, Furores sertanejos na América portuguesa, op. cit., p. 134.
} 
O probabilismo seria igualmente um outro fator potencialmente subversivo ou legitimador de subversões. Abrindo espaço para a aceitação de uma opinião provável, mesmo que não fosse a mais provável e a mais aceita; justificava a opção pelo caminho menos provável e menos seguro, mas provável, da sedição. Um último elemento que poderia segredar uma potencialidade, se não crítica, talvez sediciosa, eram os milenarismos, quanto mais que há indícios de que os mesmos haviam sido apropriados em Minas Gerais com esse sentido por Pedro Rates Henequim. Como se observou no Capítulo 7, Henequim, tendo vivido na Capitania nas duas primeiras décadas do Setecentos, reconheceu na mesma o Paraíso Terreal e, sob o impacto de escritos do padre Antônio Vieira, sonhou em torná-la o berço do Quinto Império do Mundo, tendo, com esse objetivo, conspirado para fazer de D. Manuel, irmão de D. João V, seu fundador. Os próprios escritos milenaristas e realistas do padre Antônio Vieira, como se mostrou no Capítulo 7, faziam-se presentes nas bibliotecas das Minas Gerais da segunda metade do século XVIII; o juiz de fora de Sabará, como se viu no Capítulo 5, chegou a enviar aos arraiais ordens para que se denunciassem as pessoas que possuíssem os livros condenados pela censura de autoria do citado padre, classificando-os como sediciosos. Nos seus escritos realistas, o padre Antônio Vieira, estava longe de propugnar levantes contra tiranos, mas fazia críticas corrosivas à administração colonial, discorria, nos mesmos, sobre o bom governo, defendendo a concórdia das gentes e ordens do reino; a suavidade e a proporcionalidade dos impostos; a honestidade e a proficiência dos ministros, e a exemplaridade dos atos do governo.

Se em Minas havia tensões em relação às medidas da Coroa e as idéias em circulação referendavam ou apontavam possíveis alternativas de orquestração de um levante, tal potencialidade era percebida e especulada pelos Inconfidentes, às vezes em tom fantasioso. José Álvares Maciel, segundo o poeta Alvarenga Peixoto, por exemplo, teria dito

"que era matéria sem dúvida, que nas Cortes [européias] por onde ele tinha andado nada se falava mais do que na moleza e indolência, com que o Brasil se tinha portado, sem fazer o menor movimento, nem à vista das Américas inglesas, e que estas conversas eram triviais até em Lisboa e Coimbra, e que estando ele em Londres se publicara que no Rio de Janeiro tinham matado ao Ilmo. Exmo. Vice-Rei, cuja notícia até na Gazeta saíra, e logo os negociantes quiseram armar em 
defesa da cidade, e só um armava dois navios em guerra à sua custa; mas que em poucos dias se soube a falsidade da novela, foi mandado recolher a gazeta pelo Estado, e todos os negociantes ficaram ardente, 26 .

Disso, concluíra Alvarenga Peixoto que "as Cortes estrangeiras" tinham interesse em secundar "os projetos do Rio de Janeiro", 27.

Diante das tensões geradas sob o governo de Dona Maria I e das possibilidades dadas pelas idéias então em circulação, os Inconfidentes não ficaram a fantasiar. Mas quais foram as opções efetivamente feitas pelos Conjurados? Como e o que possivelmente eles leram? Como se apropriaram desses escritos, confrontandoos com sua realidade? Como, ainda, a partir disso, identificaram seus alvos e suas estratégias de intervenção na realidade em que viviam? Para responder a essas questões, primeiramente, serão examinados alguns escritos deixados pelos mesmos: as Cartas Chilenas de Gonzaga, as Poesias de Alvarenga Peixoto; a Oração fúnebre pronunciada pelo cônego Luís Vieira da Silva nas exéquias do Dr. Lourenço José de Queirós Coimbra, em 1784; e, finalmente, de modo marginal e ligeiro, os escritos de Cláudio Manuel da Costa.

\footnotetext{
${ }^{26}$ AUTOS de Devassa da Inconfidência Mineira (ADIM). 2 ed. Brasília: Câmara dos Deputados; Belo Horizonte: Imprensa Oficial de Minas Gerais, 1980, vol. 5, p. 115-116.

27 Ibidem, vol. 5, p. 116. José Álvares Maciel desmentiu a versão de seu diálogo com Peixoto apresentada por este, dizendo que: "naquele reino [a Inglaterra] não ouvira falar nunca em pretensão de levante desta América, a única coisa que ouviu que respeitasse à América foi dar-se a novidade em uma gazeta de Oxford, que tinha falecido o Ilmo. e Exmo. Vice-Rei do Brasil, Luís de Vasconcelos e Sousa, e logo disseram alguns negociantes, que ali se achavam, e ele Respondente [Maciel] não conhece, que se fosse certa a notícia, que era boa ocasião de mandar quatro navios para a costa do Brasil, porque governando ele se não podia passar contrabando algum” (Ibidem, vol. 5, p. 322).
} 


\section{Escritos Inconfidentes: das "potências" aos "atos"}

Analisando-se os escritos dos conjurados de Minas Gerais que legaram obras à posteridade — isto é, Tomás Antônio Gonzaga, Cláudio Manuel da Costa, Alvarenga Peixoto e cônego Luís Vieira da Silva - com efeito, observam-se, ao mesmo tempo, traços Ilustrados e proposições que remetem a outras origens culturais.

Nas Cartas Chilenas, ao mesmo tempo em que satiriza e denuncia os desmandos de Luís da Cunha Menezes, o Fanfarrão Minésio, caracterizando-o como um tirano, Tomás Antônio GONZAGA desenha as linhas gerais do bom governo. Enquanto Fanfarrão usa o temor como fundamento do seu governo, o "bom monarca honra o vassalo,"28; enquanto Menezes não bota sequer "abaixo um livro”, “da sua sempre virgem livraria" 29 , sabendo apenas "ler redonda letra" 30 e sendo incapaz de acompanhar as discussões acadêmicas, "quem rege os povos" "deve ler, de contínuo, os doutos livros" ${ }^{\prime 31}$; enquanto o governador não pune os insultos de seus soldados, os bons "chefes descobriram [que] para terem os corpos [militares] em sossego" deviam repartir, "com mão reta", "os prêmios e os castigos"32; enquanto o capitão-general de Minas só cuidava das milícias, um "reino bem regido", pelo contrário, "tem de tudo, tem milícia, lavoura, e tem comércio" 33 . Ao governador, ainda, são atribuídas várias atitudes reprováveis: a violação das leis, sob as mais variadas formas; a cobrança dos impostos, não levando em conta a capacidade de pagamento dos governados, bem como as desigualdades havidas entre esses; a desconsideração das formas diferenciadas de tratamento hierárquico; a prática de injustiças; o desperdício de dinheiro público em festas ou o seu uso para pagar dívidas pessoais; a aplicação das leis, desconsiderando as distinções estabelecidas nas mesmas entre os diferentes membros do corpo social ${ }^{34}$. Por isso tudo, Critilo dirige-se a Fanfarrão, classificando-

\footnotetext{
28 PROENÇA FILHO, Domício (Org.). A poesia dos Inconfidentes: poesia completa de Cláudio Manuel da Costa, Tomás Antônio Gonzaga e Alvarenga Peixto, op. cit., p. 792.

${ }^{29}$ Ibidem, p. 811.

${ }^{30}$ Ibidem, p. 848.

${ }^{31}$ Ibidem, p. 825.

${ }^{32}$ Ibidem, p. 860.

${ }^{33}$ Ibidem, p. 865 .

${ }^{34}$ Ibidem, p. 822, 831, 833, 854-856, 868, 873
} 
o como tirano e tomando-o como castigo divino pelas matanças de gentios realizadas anteriormente pelos europeus na América:

\author{
"Bárbaro, tu praticas tudo junto \\ quanto obraram, no mundo os maus tiranos!" \\ [...] Talvez [...] que nós, hoje, \\ sintamos o castigos dos insultos \\ que nossos pais fizeram: estes campos \\ estão cobertos de insepultos ossos \\ de inumeráveis homens que mataram. \\ Aqui os europeus se divertiam \\ em andarem à caça dos gentios, \\ Que muito, pois, que Deus levante o braço, \\ e puna os descendentes de uns tiranos \\ que, sem razão alguma e por capricho, \\ espalharam na terra tanto sangue!"35
}

Fanfarrão, tirano, castigo divino aos descendentes dos protagonistas das matanças que acompanharam a colonização - eis a conclusão de Gonzaga! Examinando-se atentamente as imagens do bom governo e da tirania constituídas pelo poeta de Vila Rica, fica evidente a sua filiação à Segunda Escolástica e, ainda, a sua proximidade com as críticas realistas feitas por Antônio Vieira, também elas escolásticas. O governante não pode tudo; deve respeitar as leis, as diferenças de direito e as hierarquias havidas no interior dessa sociedade, a capacidade dos povos de pagar os tributos; necessita procurar a felicidade do Reino, repartir com justiça prêmios e castigos. Inversamente, é tirano o governante que age de forma oposta a esses princípios. Todas essas idéias são defendidas ou pelos grandes pensadores da Segunda Escolástica ou por aqueles que aplicam suas concepções ao interpretarem fatos históricos. Gonzaga, no entanto, parece inovar num ponto: caracteriza como tirânico um correlato da colonização, a matança do gentio. Essa operação intelectual, portanto, concretiza aquela possibilidade aventada anteriormente: a aplicação das teorias corporativas de poder à análise da situação colonial. Resta, então, uma pergunta: Gonzaga aceitaria a distinção entre poder in actu e poder in habitu, reconhecendo o direito de resistência dos povos à tirania? Antes de responder a essa pergunta, convém observar como o poeta coroa a caracterização de Fanfarrão como

\footnotetext{
${ }^{35}$ Ibidem, p. 845e 876-877.
} 
tirano. O governador de Chile seguia a máxima de fingir zelo pela religião, assemelhando-se a Maomé:
"Mafoma, o vil Mafoma, astuto, segue também este sistema: ao seu ouvido acostuma a chegar-se a mansa pomba. A nação ignorante se convence de que este seu profeta conhecia os segredos do céu, por este meio" ${ }^{\text {"36. }}$.

Mafoma, isto é, Maomé, como se sabe, era tido como o grande adversário da cristandade, constituindo, sob o prisma escolástico, a negação dos fundamentos éticoreligiosos que deveriam reger a ação dos soberanos. Essa caracterização de Fanfarrão como um tirano perfeito, ao final das Cartas, poderia sugerir a aceitação do direito de resistência popular à tirania pelo ouvidor de Vila Rica; no entanto, a posição dele é ambígua: aborda o problema, mas rejeita a insurgência como possibilidade legítima, em função da "heróica virtude". Assim, em trecho imediatamente anterior ao supracitado, equipara Fanfarrão a Calígula e Chile a Roma, concluindo ser pior a sorte do Chile, pois se a Cidade Eterna teve que aceitar um cavalo-senador, Chile foi obrigado a submeter-se a um chefe que de homem só tinha "figura"; enquanto aquela podia acautelar-se para não levar um coice, em Chile se teria que obedecer ao chefe de "injusta espada", o que seria um castigo pelos erros dos antepassados, isto é, pela morte dos gentios:

\footnotetext{
"Eu creio, Doroteu, que tu já leste que um César [Calígula] dos romanos pertendera vestir ao seu cavalo a nobre toga dos velhos senadores [...]Mas ah! prezado amigo, que ditosa não fora a nossa Chile, se antes visse adornado um cavalo com insígnias do general supremo, do que ver-se obrigada a dobrar os seus joelhos na presença de um chefe, a quem os deuses somente deram a figura de homem! Então, prezado amigo, o néscio povo com fitas lhe enfeitara as negras clinas, [...] mas sempre, Doroteu, aqueles néscios o que ao bruto respeitassem, poderiam servi-lo, acautelados e de sorte que dar-lhes não pudesse um leve couce. Eis aqui, Doroteu, o que nos nega
}

\footnotetext{
${ }^{36}$ Ibidem, p. 896.
} 
uma heróica virtude. Um louco chefe

o poder exercita do monarca

e os súditos não devem fugir-lhe

nem tirar-lhe da mão a injusta espada.

Mas caro, Doroteu, um chefe destes

só vem para castigo de pecados" ${ }^{\text {37. }}$.

Gonzaga, em resumo, nas Cartas Chilenas, mostra-se tributário das teorias corporativas de poder, dos seus ideais de bom governo, presentes também nos escritos realistas do padre Antônio Vieira. Todavia, nega-se a abraçar o princípio que consagra aos povos o direito de resistir à tirania. Ao mesmo tempo, aplica as teorias corporativas à situação colonial. Pode-se perguntar, então, em que medida não há ambigüidade nessa posição: o público a quem se dirigiam as Cartas certamente conhecia as concepções de poder da Segunda Escolástica e, portanto, estava familiarizado com a associação entre tirania e direito à resistência, encontrando-se em condições de tirar das premissas as consequiências, sem necessidade de que o autor semeasse claramente o propósito sedicioso. GONZAGA, bom escolástico que era, aliás, afirmava que inteligências medianas eram capazes de saber "das premissas tirar as consequiências": logo conclui-se pela ambigüidade de sua posição ${ }^{38}$, hipótese essa a ser testada à frente, através do confronto das Cartas Chilenas com o depoimento do ouvidor.

Cláudio Manuel da Costa conjugava, em seus escritos, o aprisionamento a velhos paradigmas e as novidades das Luzes e do Arcadismo. Na sua poesia, assim, convivem traços cultistas e, ao mesmo tempo, elementos classicistas: se, por um lado, é sentimental, seguindo uma convenção poética rococó, por outro, limpa as "lágrimas" dos paradoxos, agudezas, hipérboles seiscentistas; valoriza a razão e trai as influências dos clássicos Ausônio e Virgílio e da Henriade, do Ilustrado Voltaire $^{39}$. O poeta, ainda, debate-se "entre a fantasia literária, que o leva ao Velho Mundo ou, ainda melhor, a um mundo puramente ideal, e o sentimento que o tem preso por tão vivos laços à terra natal" - uma dualidade esta que nunca se resolveu satisfatoriamente $^{40}$.

\footnotetext{
${ }^{37}$ Ibidem, p. 875.

${ }^{38}$ Ibidem, p. 852.

${ }^{39}$ Sobre a influência de Ausônio, Vírgilio e Voltaire na produção poética de Cláudio Manuel da Costa, veja: HOLANDA, Sérgio Buarque de. Capítulos de literatura Colonial, op. cit., p. 156, 160 e 210.

${ }^{40}$ Ibidem, p. 231.
} 
Na Écloga em louvor ao Marquês de Pombal, vêem-se claramente, ao mesmo tempo, ecos da Ilustração e, em alguns termos, também de princípios defendidos pelos teólogos da Segunda Escolástica ${ }^{41}$ : um governo racional, topos Ilustrado; um governo também justo e virtuoso, ideal ao mesmo tempo consagrado pela Ilustração e pelos escolásticos. No "Fundamento Histórico" do poema Vila Rica, o modelo é também a Henriade, na qual há igualmente um apêndice histórico, intitulado Dissertation sur la mort de Henri IV. A referência Ilustrada, no entanto, não esgota as possibilidades abraçadas pelo autor: na obra, ele conclui "ter sido a bananeira a árvore que socorreu com a grandeza de suas folhas a nudez de nossos primeiros pais", no que Eliana Scotti MUZZI vê uma influência do Paraíso Perdido de Milton $^{42}$. Essa fruta do Paraíso, curiosamente, aproxima Cláudio de um milenarista que andou pelas Gerais nas duas primeiras décadas do século XVIII: o herético Pedro Rates Henequim. Como se viu no Capítulo 7, no Paraíso Terreal de Henequim havia "uma árvore, a qual dava uns frutos como maçãs, e como figos", árvore que nada mais era do que a bananeira. Não se está querendo postular nenhuma filiação de Cláudio Manuel da Costa às idéias de Henequim, mas apenas sublinhar que, em sua visão do Éden, cabia um lugar à bananeira, com o que se americanizava, portanto, a imagem do Paraíso e, ao mesmo tempo, edenizava-se, ainda que modestamente, a natureza brasileira, o que poderia reforçar a valorização de suas riquezas.

Dual também é o único texto que restou do cônego Luís Vieira da SILVA, professor do Seminário de Mariana, proprietário da maior biblioteca dentre os Inconfidentes, recheada com obras de autores da Ilustração. Sua Oração fúnebre, ao mesmo tempo, assenta-se no uso da analogia (e, por isso, parece remeter ao método tópico aristotélico) e convida ao uso da observação para a formulação de conclusões; esboça uma concepção de história como "mestra da vida", fornecedora de modelos de conduta a serem seguidos (visão presente de Cícero a Verney) e, ainda, exprime uma visão Ilustrada sobre a relação entre homem e Natureza.

\footnotetext{
${ }^{41}$ Sobre a presença de elementos cultistas, classicistas e ilustrados na obra de Cláudio Manuel da Costa, veja: LUCAS, Fábio. Luzes e trevas: Minas Gerais no século XVIII. Belo Horizonte: UFMG, 1998, p. 15-16.

${ }^{42}$ MUZZI, Eliana Scotti. Epopéia e história. In: PROENÇA FILHO, Domício (Org.). A poesia dos Inconfidentes: poesia completa de Cláudio Manuel da Costa, Tomás Antônio Gonzaga e Alvarenga Peixto, op. cit., p. 353.
} 
Vieira da SILVA, almejando homenagear o então falecido Dr. Lourenço José de Queirós, buscou na Bíblia argumentos / razões que dessem sustentação ao seu ponto de vista, selecionando a fuga do povo eleito do Egito para a Terra Prometida, sob a direção de Moisés. Na Oração, assim, após evocar a figura de Moisés, Vieira da SILVA, dirigindo-se ao público que o ouvia, propõe uma analogia entre este e o Dr. Lourenço:

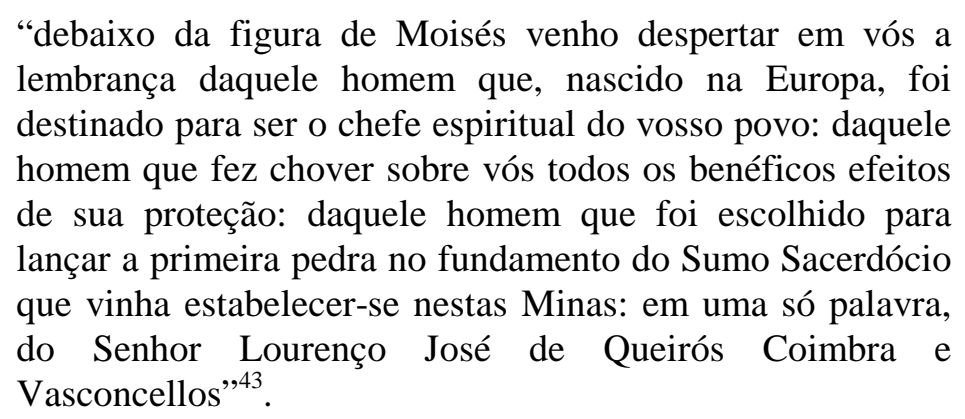

Moisés e Lourenço, assim, por analogia, enfrentaram desafios: o primeiro, de conduzir os judeus à Palestina, e o segundo, de fundar as bases da igreja mineira. Em seguida, Vieira evoca a origem nobre de Lourenço e, novamente, usando a analogia, compara o morto a Cristo: se Cristo escolhera uma família nobre para "aparecer no mundo", a estirpe de Davi, o Dr. Lourenço viera de nobres do Entre Douro e Minho. Embora de origem nobre, não lhe bastou na vida comprazer-se com a posição que lhe fora dada pelo nascimento, tendo tomado a virtude como caminho. Se até aqui vê-se a analogia como fundamento da verdade proferida pelo cônego marianense, o que remete a uma possível filiação ao método tópico; se, tal como o padre Antônio Vieira e Luís Antônio Verney, tem-se como ideal a combinação da nobreza com a virtude; o cônego Luís Vieira da Silva, para celebrar os feitos do homenageado, convoca os ouvintes a usarem também a observação, a apelarem para a memória de sua experiência, afastando explicitamente a busca de apoios em passados remotos, em histórias outras que não as dos próprios presentes nas exéquias:

"Eu, Senhores, não posso dizer coisas que não acontecessem debaixo de vossos olhos. Não vou buscar notícias às idades mais recuadas, nem às províncias mais remotas, vós mesmos, ou quando muito por tradição de vossos pais, sois

${ }^{43}$ SILVA, côn Luís Vieira da. ORAÇÃO fúnebre pronunciada pelo cônego Luís Vieira nas exéquias do Dr. Lourenço José de Queirós Coimbra, a 12 de outubro de 1784, em Sabará. In: CARVALHO, côn. José Geraldo Vidigal de. Ideologia e raízes sociais do clero da Conjuração - século XVIII, Minas Gerais. Viçosa: Imprensa Universitária, p. 54. 
as fiéis testemunhas do que vou agora perguntar-vos: Não foi ele [Lourenço] aquele zelozo Pastor que não duvidara arriscar a vida pela edificação do seu rebanho?" ${ }^{44}$

Aqui, portanto, vê-se uma dualidade: a analogia é seguida da observação, da recusa à aceitação de uma autoridade extemporânea.

Depois de criticar os políticos que ocupam os "empregos da Igreja ou da República" às custas da ruína do próximo, Vieira novamente conclama os presentes a rememorar as ações de Lourenço Queirós. Em meio a várias referências à História Antiga, depois de sublinhar a efemeridade dos impérios dos medos, caldeus, assírios, gregos e romanos, diante da ação corrosiva do tempo - "Tudo reduz a nada o tempo que gasta e que consome" -, Vieira lembra que:

"Os mesmos heróis, Senhores, os mesmos heróis, ainda aqueles que foram mais úteis à Igreja de Jesus Cristo, também estão sujeitos a esta pensão inevitável da natureza, ${ }^{, 45}$.

Ao conceber a matéria como corruptível, Vieira não está acrescentando nada de novo à visão cristã de mundo, mas ao atribuir a corruptibilidade à "pensão inevitável da natureza", sem explicitar nesse ponto o papel da divindade, o professor de filosofia de Mariana parece expressar uma visão quase materialista ou, ao menos, que toma o homem como um ser sujeito às leis da natureza. Luís Vieira, à semelhança de Gonzaga e Cláudio Manuel, bebe, assim, de duas fontes: de ensinamentos da Escolástica e das Luzes.

Restam, por fim, as Poesias de Inácio José de Alvarenga Peixoto. No "Canto Genetlíaco", como ressalta Fábio LUCAS, Peixoto sugere que a transposição da "raça portuguesa para a América estava criando uma grande civilização, capaz de bastar-se a si mesma"46. Recomendando às gentes das Minas que recordassem os "males", revolvendo o "horror das sepulturas" - no que parece haver uma crítica ao morticínio que foi correlato do processo colonizatório - , PEIXOTO faz uma apologia dos "Bárbaros filhos destas brenhas duras" (isto é, das gentes de Minas

\footnotetext{
${ }^{44}$ Ibidem, p. 56-57.

45 Ibidem, p. 59.

${ }^{46}$ LUCAS, Fábio. Luzes e trevas: Minas Gerais no Século XVIII. Belo Horizonte: UFMG, 1998, p. 17.
} 
Gerais) e, mais ainda, das próprias "brenhas"47. Exalta as riquezas das serras "na aparência feias", que:

\section{“[...] conservam nas ocultas veias}

A força das potências majestosas;

Têm as ricas entranhas todas cheias

De prata, oiro e pedras preciosas;

Aquelas brutas e escalvadas serras

Fazem as pazes, dão calor às guerras" $"$.

Terra rica, terra de onde sai a "força das potências majestosas", terra também de onde sai o "lenho" encontrado nos palácios, terra cuja "riqueza [a] todo o mundo assusta", Minas era habitada por homens:

“[...] de vários acidentes,

Pardos e pretos, tintos e tostados,

São os escravos duros e valentes;

Aos penosos trabalhos costumados" ${ }^{49}$.

O louvor às riquezas da pátria e aos seus "homens de vários acidentes" - e, aqui, talvez se possam ver ecos da crítica Ilustrada à escravidão - completa-se num outro poema - ao que tudo indica recitado diante dos demais Inconfidentes - com a idéia de miséria, exprimindo uma visão em que se assinala a dualidade da situação de Minas Gerais:

\footnotetext{
"Que fez a Natureza

Em pôr neste país o seu tesouro, das pedras na riqueza,

Nas grossas minas abundantes de ouro,

Se o povo miserável?" ${ }^{50}$.
}

No poema "Invisíveis vapores", endereçado, provavelmente da prisão, à Dona Maria I, PEIXOTO apresenta proposta de transferência da capital do império português para o Rio de Janeiro ${ }^{51}$ :

"Se o Rio de Janeiro

Só a glória de ver-vos merecesse,

\footnotetext{
${ }^{47}$ PROENÇA FILHO, Domício (Org.). A poesia dos Inconfidentes: poesia completa de Cláudio Manuel da Costa, Tomás Antônio Gonzaga e Alvarenga Peixto, op. cit., p. 976.

${ }^{48}$ Idem, p. 977.

${ }^{49}$ Idem, loc. cit.

${ }^{50}$ Ideim, p. 981.

${ }^{51}$ LUCAS, Fábio. Luzes e trevas: Minas Gerais no Século XVIII. Belo Horizonte: UFMG, 1998, p. 13.
} 
Já era vosso o Mundo Novo inteiro [...]

Vinde ver o Brasil, que vos adora [...]

A mãos seguras, vinde descansada:

De que servem dous grandes Vasconcelos?

Vinde a ser coroada

Sobre a América toda, que protesta

Jurar nas vossas mãos a lei sagrada" ${ }^{, 52}$.

Alvarenga completa seu raciocínio fazendo uma súplica à soberana, no que alguns intérpretes vêem uma alusão à Conjuração de Minas Gerais e, mais ainda, um indicativo de que essa última não implicaria um intento separatista, mas simplesmente inserir o Brasil num grande império luso-brasileiro ${ }^{53}$ :

"Da América o furor

Perdoai, grande Augusta; é lealdade,

São dignos de perdão crimes de amor, ${ }^{, 54}$.

Tais palavras evidenciam uma leitura da história luso-brasileira que, como se viu nos capítulos anteriores, tinha antecedentes no milenarismo de Pedro Rates Henequim; numa proposta "realista" (e não milenarista) de transferência de D. João IV para o Brasil, defendida pelo padre Antônio Vieira; e, ainda, de mudança da sede do Império Português feita por D. Luís da Cunha, em 1738, e por Pombal, em 1762. Seria defendida também por D. Rodrigo de Souza Coutinho, em 1801.

Avaliando, enfim, os escritos dos Inconfidentes, de um lado, observa-se a convivência de elementos de origem escolástica com idéias e princípios trazidos pela Ilustração e, de outro lado, constata-se que tais idéias então em circulação, além de potencialmente sediciosas, eram-no de fato, como parecem sinalizar ou concretizar as Cartas Chilenas de Gonzaga e as Poesias de Alvarenga Peixoto. Nas Cartas, o viés, definido pela Escolástica, é a repulsa à tirania, sutilmente colada em mazelas do processo colonizatório, o que, portanto, explica a razão de se ter afirmado no início desse capítulo que as Cartas apenas aparentemente colidem com as idéias escolásticas. Nas Poesias, impera a consciência de que nas Gerais vivia-se a

52 PROENÇA FILHO, Domício (org.) A Poesia dos inconfidentes: poesia completa de Cláudio Manuel da Costa, Tomás Antônio Gonzaga e Alvarenga Peixoto. Rio de Janeiro: Nova Aguilar, 1996., p. 986.

53 MALARD, Letícia. Notas. In: PROENÇA FILHO, Domício (org.) A Poesia dos inconfidentes: poesia completa de Cláudio Manuel da Costa, Tomás Antônio Gonzaga e Alvarenga Peixoto, op. cit., p. 1155.

54 PROENÇA FILHO, Domício (org.) A Poesia dos inconfidentes: poesia completa de Cláudio Manuel da Costa, Tomás Antônio Gonzaga e Alvarenga Peixoto, op. cit., p. 987. 
dualidade entre riqueza e pobreza, nos moldes pensados pelo abade Raynal. Vieira da Silva e Cláudio Manuel marcam-se pela dualidade de sua formação intelectual, distinguindo-se, o primeiro, por sua paixão pela história e pela combinação da analogia com a observação e, o segundo, pela tópica da bananeira como fruta do Éden e pela defesa de um governo racional e virtuoso.

\section{Leituras da Conjuração}

\subsection{Boêmias literárias}

Os livros e a inventividade dos conjurados como leitores foram fundamentais para se chegar à conspiração, tendo os contatos de caráter literário se entremeado às discussões mais estritamente políticas. Como alguns Inconfidentes, ao serem inquiridos pelos juízes da devassa, procuraram atribuir finalidades exclusivamente livresco-literárias aos seus encontros, para, com isso, esvaziar o caráter sedicioso de suas conversas (e, assim, melhorar suas condições de defesa); como, além disso, a apropriação dos livros incrustou-se nos debates políticos e, ao mesmo tempo, deu-lhe rumos, fica muito difícil discernir até que ponto vai a boêmia literária e onde começa a conspiração. Se as influências de alguns escritos sobre os conjurados ficam claras, entretanto, nem sempre é possível remeter a percepção imediata da realidade ao conteúdo dos livros. Há dificuldades, por fim, para identificar precisamente quais os livros afetaram-nos, além daqueles que os conjurados mencionam explicitamente ou cujas referências deixam escapar quando inquiridos. A repercussão dos livros sobre os Inconfidentes e o grau de inventividade dos mesmos enquanto leitores tornam-se mais evidentes quando se processa uma análise que vai dos aspectos mais estritamente literários para chegar até os elementos que remetem claramente à subversão, ou seja, quando se focalizam, num primeiro momento, as menções a empréstimos de livros, traduções, leituras etc. e, num segundo, as imbricações dessas últimas com a própria conspiração.

Alvarenga Peixoto é um dos que ressalta o conteúdo literário dos encontros realizados na casa do tenente-coronel Francisco de Paula Freire de Andrada, epicentro da conspiração, em Vila Rica. Em seus depoimentos, alegou que ia e vinha da mencionada residência "para entregar um livro, e a tirar outro da sua livraria" e 
"restituir o dito livro". Outro que alegou ter feito empréstimos de livros foi Salvador Carvalho do Amaral Gurgel, o qual revelou ter contactado o Tiradentes para pedirlhe um dicionário francês de que carecia ${ }^{55}$. Além de fazerem tais empréstimos, os Inconfidentes leram e discutiram obras e escritos: Gonzaga explicou ter estado na casa do citado tenente-coronel, encontrando lá Tiradentes, o coronel Alvarenga Peixoto e o padre Carlos Correia de Toledo, para conversar "em humanidades". Nessa ocasião, o citado Alvarenga Peixoto repetira "umas oitavas feitas ao batizado de um filho do Excelentíssimo Dom Rodrigo" (ao que parece, o "Canto Genetlíaco"), examinaram-se livros do anfitrião, dentre os quais uma obra que fazia referências elogiosas a Gonçalo Annes Bandarra, referência fundamental dos milenarismos no mundo português: seria algum livro de autoria do padre Antônio Vieira ou de D. João de Castro? ${ }^{56}$. Cláudio Manuel da Costa, à época da conjuração, "estava lendo e emendando as poesias" escritas por Gonzaga ${ }^{57}$.

Os Inconfidentes, contudo, pareciam não medir esforços para encontrar nos textos elementos que municiassem suas expectativas de sedição, mesmo quando seu potencial subversivo era acanhado. Assim, lidas em situação colonial, lidas em situação de tirania, as Gazetas foram um desses suportes em que os conjurados encontraram elementos para pensar. Alvarenga Peixoto, discutindo sobre a estratégia e os riscos do levante com Francisco Lopes, ouviu desse uma advertência sobre a falta de gente e pólvora, munições, respondendo-lhe que a terra defendia-se por si. Lopes, então, disse-lhe que, se viesse um exército de dez mil homens tudo estaria perdido, mas Peixoto falou-lhe que, "pelo Rio de Janeiro, nada podia entrar; por São Paulo, que levava meses", havendo, portanto, condições de enfrentar os invasores. A isso Lopes retrucou, com base nas informações da Gazeta, provavelmente de Lisboa, que a Rainha tinha recursos para custear a repressão ao levante, dizendo que:

\footnotetext{
"ouvira contar que, necessitando a Imperatriz da Rússia três milhões, os pedira a El-Rei de França, que lhos não emprestava. E que a Rainha N. Sra. generosamente o fizera, por cujo obséquio se lhe oferecera a dita Imperatriz. E que, se isto assim era, que vissem bem em que se metiam. Ao que respondeu o dito Alvarenga: - 'Ora, não creia nisso!
}

\footnotetext{
${ }^{55}$ Ibidem, vol. 2, p. 218.

${ }^{56}$ Ibidem, vol. 5, p. 223.

${ }^{57}$ Ibidem, vol. 5, p. 217.
} 
Primeiro que lá vá e venha, em que termos estamos nós?' Contando mais outras histórias de gazetas e sucessos de que se não recorda" ${ }^{\text {"58. }}$.

Noutra oportunidade, Alvarenga Peixoto envolveu-se de novo numa polêmica cujo ponto de partida eram as Gazetas. Em conversa com o Visconde de Barbacena, comentou uma notícia sobre o "Sr. Infante que ficou na Espanha", dizendo:

"- 'Quem o desse cá, que o haviam de criar muito bem!..." Ao que respondeu aquele Senhor: - 'Isto era o que Vms. queriam, mas não o hão de apanhar!",59.

Essa notícia talvez tenha sido colhida na Gazeta de Lisboa, aos 11 de abril de 1788, onde se lê:

"Madrid 10. de Abril. Havendo a Ser"ma. Princeza das Asturias sesta $\mathrm{f}^{\mathrm{ra}}$. passada à boca da noite principiado a experimentar algumas dores, q' annunciavão estar proximo o seu parto, e havendo-se as mesmas avivado pela huã hora e meia da manhã segte., pelas 3 e tres quartos dee S. A. felizm $^{\text {te }}$. à luz hum fermoso Infante, o qual S. M., trazendo-o nos braços o mostrou na salla aonde se achavão congregados pa. este acto os Chefes de Palacio, Prelados, Grandes, Conselheiros [etc ...] Acabado este acto se passou ao do Sagrado Baptismo o qual the foi administrado pelo Patriarca das Indias pondo the os nomes de Carlos Maria, Isidro e outros: foi padrinho seu augusto Avô, e testemunhas especiais o Ser ${ }^{\text {mos }}$ Infantes" ${ }^{\text {60 }}$.

O diálogo travado entre Barbacena e Peixoto deixa entrever a existência de alguma intencionalidade por parte do último, tendo como alvo um Infante, intenção essa que merecia a reprovação por parte do primeiro. Se isso parece estranho, mais ficaria se houvesse confirmação para a identificação da notícia da Gazeta que serviu de suporte ao diálogo: estaria Alvarenga Peixoto fazendo alguma galhofa diante do governador sobre a possibilidade de "criar" um Infante espanhol para que ele viesse a reinar nas Minas Gerais?

\footnotetext{
${ }^{58}$ Ibidem, vol. 2, p. 52.

${ }^{59}$ Ibidem, vol. 2, p. 51.

${ }^{60}$ GAZETA de Lisboa. Lisboa, 1785-1790 [IANTT, Real Mesa Censória, Caixas 468-469].
} 
Alvo de polêmica ou de galhofa, a Gazeta trazia notícias sobre a América Inglesa. Segundo o cônego Vieira da Silva, "como anda[va] escrita e impressa a história da América Inglesa, e a nossa Gazeta continuamente fala[va] nela”, e ele tinha

\begin{abstract}
"curiosidade de examinar as referidas Gazetas, podia muito bem suceder que - em alguma ocasião, sem reserva de pessoas, porque se não dirigia a fim algum particular fizesse algum discurso ou conversasse sobre uma e outra América, persuadido que nisso não cometia delito algum, por ser fato muito próprio em sujeitos que têm alguma aplicação e versados na história"61.
\end{abstract}

Acrescentou ainda que a Independência da América Inglesa ameaçava as possessões espanholas. Embora se possa enxergar nesse depoimento do cônego uma tentativa de aliviar e justificar sua empolgação com os sucessos dos norte-americanos (afinal, a Gazeta de Lisboa circulava livremente, não sendo proibida como a obra do abade Raynal, que, como se verá mais à frente, foi uma das principais fontes de inspiração dos conjurados), demonstra-se que os jornais, dependendo da inventividade dos leitores, podiam fornecer informações que vinham a reforçar as expectativas de subversão.

Nas permutas de obras feitas pelos Inconfidentes entre si, insinua-se, além de preferências literárias, também o interesse pela América Inglesa, no que se pode ver uma perspectiva sediciosa. O Alferes Joaquim José andava "buscando pelas livrarias uns livros que tratavam do levante dos ingleses" da América do Norte ${ }^{62}$. O cônego Luís Vieira da Silva, se passara ao intendente Bandeira livros de Metastásio e os Contos Morais, de Marmontel ${ }^{63}$, obras literárias, emprestara dele três livros com conteúdo histórico, um deles referentes aos Estados Unidos da América: De l'Étude de l'Histoire e Observations sur le Gouvernement de les États Unis de l'Amérique, de Mably e Dell'Istoria Civile de Regno di Napoli, de Giannone. José Álvares Maciel comprou em leilão, em Birmingham, a História da América Inglesa, pensando "que tinha feito uma grande compra", percebeu depois que adquirira "uns poucos de folhetos - e tudo mutilado" ${ }^{\text {". }}$. Acrescentava, ainda, Maciel que o referido livro e As

\footnotetext{
${ }^{61}$ Ibidem, vol. 2, p. 150 e 154.

${ }^{62}$ Ibidem, vol. 1, p. 206.

${ }^{63}$ Ibidem, vol. 6, p. 88 e 322 e vol. 8, p. 253.

${ }^{64}$ Ibidem, vol. 2, p. 282.
} 
leis constitutivas dos Estados Unidos se encontravam "encaixotados no Rio de Janeiro, em poder de Francisco José Freire, negociante naquela praça"65.

A Independência dos Estados Unidos, de fato, despertou enorme interesse nos Conjurados. Além de emprestarem obras sobre a América e sobre a sedição, houve quem quisesse fazer traduções: o Tiradentes vivia a pedir a amigos, a conhecidos e aos conjurados, para traduzirem um capítulo de Recueil des Lois Constitutives des Colonies Anglaises, Confédérées sous la Dénomination D'États-Unis de l'Amérique Septentrionale ${ }^{66}$ e passagens de "um diário que declara como foi o levante da América Inglesa", o livro de Raynal ${ }^{67}$. Simão Pires Sardinha, segundo consta nos autos da devassa, associou a prisão do Tiradentes à posse do livro de Raynal fazendo o seguinte comentário: "Que o leve [Tiradentes] o diabo com o seu enredo, que por isso está aqui [no Rio de Janeiro] retido"68. Isso revela as contigüidades existentes, aos olhos de então, entre o "enredo" do livro e o "enredo" do Alferes.

O cônego Luís Vieira mostrava "gosto" e "complacência" "quando praticava com outros, e liam a história do levante da América Inglesa"69. Segundo Vicente Vieira da Mota, havia nos "filhos da América tal gosto e complacência em ler a história da liberdade das Américas Inglesas, que lhe parecia que se eles tivessem outra tal ocasião, a abraçariam,"70. Tal afirmação sugere que, para esses leitores dos rincões das Minas Gerais, a história da América Inglesa servia para ler a própria história da América Portuguesa e para intervir nela.

Os Estados Unidos converteram-se num exemplo a ser seguido. Tendo a América Inglesa insurreta como modelo, os Inconfidentes atribuíram um sentido claramente subversivo à literatura numa determinada ocasião: na casa de Cláudio Manuel ou de Gonzaga, falou-se, segundo Alvarenga Peixoto, em "umas bandeiras, que o Alferes Joaquim José da Silva Xavier tinha ideado para servirem na nova premeditada República, que eram três triângulos enlaçados em comemoração da Santíssima Trindade"71. Então, "se lembrou o Doutor Cláudio Manuel da Costa das bandeiras da República Americana Inglesa, que era um gênio da América, quebrando

\footnotetext{
${ }^{65}$ Ibidem, vol. 2, p.282.

${ }^{66}$ Ibidem, vol. 1, p. 189-190 e vol. 2, p. 493.

${ }^{67}$ Ibidem, vol. 1, p. 308.

${ }^{68}$ AUTOS de Devassa da Inconfidência Mineira, op. cit., vol. 1, p. 308.

${ }^{69}$ Ibidem, vol. 5, p. 417.

${ }^{70}$ Ibidem, vol. 5, p. 410.
} 
as cadeias com a inscrição - Libertas aquo Spiritus - e que podia servir à mesma",72. Divergindo da sugestão, Alvarenga Peixoto "disse que seria pobreza" o uso dessa inscrição, tendo, então, Cláudio replicado que "podia servir a letra - Aut libertas, aut nihil",73. Alvarenga, no entanto, apresentou aquilo que pareceu agradar aos demais: "se lembrou do versinho de Virgílio - Libertas quae sera tamem - que ele achou, e todos os que estavam presentes, muito bonito"74. "Liberdade ainda que tardia", versos a serem inscritos numa bandeira, derrotando outras inscrições latinas, inclusive uma que se fazia presente numa bandeira da América Inglesa, o modelo dos conjurados - tais versos, inseridos nessa discussão, referidos à nascente república norte-americana, traduzem não apenas sentimentos poéticos, mas principalmente a expectativa política guardada pelos conjurados no sentido de romper os grilhões que atrelavam Minas a Portugal. Revelam, ainda, que se os Estados Unidos eram objeto de boêmia literária e fonte de inspiração quanto ao devir das Gerais, isso não significava que os Inconfidentes guardavam a expectativa de copiá-los: enquanto agentes históricos refutavam a "pobreza" da imitação, obrando no sentido de deixar suas próprias marcas.

Curiosos em relação aos Estados Unidos da América, não sendo meros imitadores do que sabiam sobre o novo país, os Inconfidentes receberam outras influências sediciosas. Numa afirmação de Gonzaga pode-se perceber aquela ambigüidade observada nas Cartas Chilenas sobre o direito dos povos de resistirem à tirania e, por conseguinte, depreender que, se os escritos da Segunda Escolástica não foram discutidos pelos Inconfidentes, ao menos permearam a visão de mundo de alguns deles e afetaram suas apreciações sobre os planos de sedição. Segundo depoimento do cônego Luís Vieira da Silva, ele teria se encontrado com Alvarenga Peixoto e com Gonzaga na casa desse e, perguntando-lhe "por esta matéria da conjuração, e levante premeditado por curiosidade", Gonzaga respondeu com "estas formais palavras - a ocasião para isso perdeu-se". Gonzaga apresentou outra versão para este diálogo, reconhecendo: "Que não duvida, que alguma vez se podia falar em se poderem levantar os povos do Brasil e que ele Respondente poderia dizer que se

\footnotetext{
${ }^{71}$ Ibidem, vol. 5, p. 122.

${ }^{72}$ Ibidem, loc. cit.

${ }^{73}$ Ibidem, loc. cit.

${ }^{74}$ Ibidem, loc. cit.
} 
perdera um boa ocasião em se não pôr a derrama, mas que esta prática, de que nem de certo se lembra, não podia ser senão em uma hipótese de potência e não de ato"75. Potências e atos, como se sabe, remetem à Escolástica, e a circunstância a que tais termos são referidos - a desistência de se fazer um levante - lembra as distinções entre poder in actu e poder in habitu, do que se pode supor que a Segunda Escolástica influenciou no pensar da conjura e, ainda, que Gonzaga admitia o direito dos povos resistirem à tirania.

\subsection{Apropriações sediciosas dos livros e das histórias}

Nas apropriações que os Inconfidentes fizeram da história, o referencial primeiro foi a história de Portugal. Como afirma Adriana ROMEIRO, é "através da mitologia das origens da nação portuguesa que o Brasil ganha o seu lugar na história; o descobrimento inaugura a sua efetiva entrada naquela história mais vasta que emana da Metrópole. Antes dele, existe apenas a suspensão do tempo num continuum imóvel"76 . Isso não exclui, no entanto, a incorporação da história da América Inglesa como referência para se pensar a história da América portuguesa.

O cônego Luís Vieira da Silva era um apaixonado pela história. Além de possuir muitos livros sobre o assunto, vivia a especular sobre os fatos históricos. A paixão do cônego pela história e pelo seu "país" levou-o a fazer conjecturas sobre como seria a América se, no passado, se instalasse cá Dom João IV — figura pela qual parecia ter certa fixação - , ou se, no futuro, a Coroa portuguesa tomasse semelhante decisão. As palavras do cônego de Mariana denunciam o conhecimento da proposta de transferência do rei Português, feita ao tempo da Restauração e que teve no padre Antônio Vieira um de seus artífices. Assim, o cônego afirmou que, "se no tempo da aclamação do Senhor Rei Dom João IV, viesse esse Príncipe para o Brasil"77, "a esta hora se acharia a América constituindo um formidável Império; e que ainda seria felicíssimo este continente se viesse para ele algum dos príncipes portugueses; mais, que a suceder assim, sempre corria risco de o quererem cá

\footnotetext{
${ }^{75}$ Ibidem, vol. 5, p. 223.

${ }^{76}$ ROMEIRO, Adriana, op. cit., p. 482.

${ }^{77}$ AUTOS de Devassa da Inconfidência Mineira, op. cit., vol. 1, p. 158
} 
aclamar; e que o melhor de tudo seria mudar a Rainha a sua corte para a América"78. Portanto, além de fazer especulações retrospectivas, o cônego realizava projeções para o futuro, revelando-se neste sentido um verdadeiro e certeiro profeta (afinal, suas previsões se concretizaram em 1808 e em 1822).

A proposta de transferência da sede do Império português para a América foi formulada inicialmente no século XVI, sendo retomada em outros termos ao tempo de D. João IV - transferir o rei para o Brasil, dividindo o Império português em dois reinos - e acalentada, no século XVIII, por ilustrados portugueses como D. Luís da Cunha, o Marquês de Pombal e D. Rodrigo de Souza Coutinho. Já se disse que Pedro Rates Henequim fez proposta de teor similar, embora com tons sediciosos e milenaristas. Todavia, o cônego Luís Vieira da Silva não alude às iniciativas dos últimos - não poderia, obviamente, conhecer a proposta de D. Rodrigo, pois esta foi posterior. Menciona apenas àquela em cuja formulação participou o padre Antônio Vieira, sem contudo citar o nome desse. Onde o cônego obteve esta informação? Eis aí um mistério ${ }^{79}$. As palavras do cônego, de qualquer forma, iam ao encontro da proposta de transferência do soberano português para o Brasil, convergindo com o que Alvarenga Peixoto expõe no poema "Invisíveis Vapores", certamente escrito depois da Conjura.

A conjectura sobre a instalação de "um formidável Império", por sua vez, remete à tópica milenarista, incorporada de modo laico por alguns Ilustrados portugueses. Em plena América Lusitana, portanto, ela se enraizava e se laicizava como no Reino. A incorporação da tópica, se mostra que o cônego Luís Vieira era

\footnotetext{
${ }^{78}$ Ibidem, loc. cit.

${ }^{79}$ Não foi possível localizar o livro em que o Cônego Vieira obteve essa informação (se é que ele não chegou até ela através da tradição oral). Na Deducção Chronologica, libelo anti-jesuíta e anti-Vieirista de J. Seabra da Silva, nenhuma referência se encontrou. O Conde da Ericeira faz menção à ação diplomática do padre Antônio Vieira na França, a mando de D. João IV, lançando dúvidas sobre a eficácia delas, como seu viu no Capítulo 1, mas não menciona o seu teor (ERICEIRA, Conde da [D. Luís de Menezes], op. cit., vol. II, p. 243). O padre Vieira, em suas Cartas, se defende da acusação de incompetência feita por Ericeira, sem também, contudo, explicitar o teor das negociações travadas na França. O livro que mais se aproxima de revelar isso, que parece ser um segredo, é o de La Clède, cuja edição francesa poderia ter chegado às mãos do cônego. Para La Clède, em termos muito próximos aos de Ericeira, o padre Antônio Vieira era um "homem célebre pelas suas pregações, mas pouco capaz para manear negociações, em que além da actividade, e intelligencia, he necessario servir-se da dobleza, e ter noticia das cousas do mundo. Este Religioso fez grandes promessas ao Cardeal Mazarin, e Sua Eminencia por zombar deste empenho, pedia cousas exorbitantes. Em fim o Padre Vieira chegou a tal excesso com suas promessas que o Conde da Vidigueira vio-se obrigado a tolher a sua negociação, dizendo que antes queria que lhe cortassem as mãos do que assignar o que o Jesuíta tinha
} 
um homem afinado com seu tempo, talvez explique porque os Inconfidentes leram e/ou fizeram comentários sobre uma obra referente a Gonçalo Annes Bandarra. Sinaliza também que os Inconfidentes não eram hostis à possibilidade de estabelecimento de um príncipe português na América. A opção pela superação de uma situação de tirania sem ferir os direitos dinásticos, por seu turno, encaixava-se perfeitamente no feitio que as teorias corporativas de poder assumiram em Portugal, onde se procurava conciliar a "soberania popular" aos direitos da dinastia reinante, tendo sido isso o que se verificou em relação a D. João IV, entendido como o legítimo herdeiro da Coroa lusitana.

As posições do cônego Luís Vieira da Silva, no entanto, não eram isentas de contradições. Num diálogo mantido com Basílio de Brito Malheiros, um dos denunciantes da conjuração, Vieira da Silva, em primeiro lugar, expôs sua crença no direito dos naturais da América constituírem um governo próprio, uma república, e, por conseguinte, de libertarem-se do jugo da Coroa Portuguesa, dizendo que "um príncipe europeu não podia ter nada com a América que é um país livre" e considerando o Tiradentes "homem animoso e que, se houvesse muitos como ele", o Brasil seria "uma república florente" ${ }^{~} 80$. Por outro lado, a partir da história pregressa da Colônia (conhecida certamente através dos livros, provavelmente a obra do Conde da Ericeira), Luís Vieira questionou os direitos da Coroa portuguesa e, ao mesmo tempo, reforçou a capacidade e a luta dos naturais da América contra a dominação de outros povos, do que se deduzia que possuíam um histórico que alicerçava e legitimava a realização de um levante contra o domínio português. Segundo suas palavras, "El-Rei de Portugal nada gastou nesta conquista [a América]", enquanto “os nacionais já a tiraram dos holandeses, fazendo sua guerra sem El-Rei contribuir com dinheiro algum para ela; depois disto, os franceses tomaram o Rio de Janeiro, que os habitadores da cidade lha compraram com o seu dinheiro" ${ }^{\prime 81}$.

Nesse raciocínio parecem combinar-se a analogia entre duas situações (a dos povos em Minas com os de Pernambuco) a um axioma (um rei deve investir em suas conquistas para ter o direito de mantê-las), ambos os elementos funcionando como

consentido" (LA CLÈDE, [Nicolas de]. História geral de Portugal. traduzida em vulgar, op. cit., vol. IV, p. 101-102).

${ }^{80}$ AUTOS de Devassa da Inconfidência Mineira, op. cit., vol. 1, p. 102. Veja também: Ibidem, vol. 5, p. 264. 
premissas para se chegar às conclusões de que os reis não tinham direito à América e de que os povos possuíam capacidade para se rebelar. Para defender-se quando foi interrogado na devassa sobre tais afirmações, o cônego apelou para a dedução, recorrendo à indução apenas para confirmar a máxima; parte, portanto, de uma certeza fundamental, máxima, extraindo dela derivações. Assim, diz, primeiramente, que "alguém há de ter direito a estes países [isto é, à América Portuguesa]; os nacionais não, que são oriundos da Europa, e já nasceram vassalos; logo todo o direito do país pertence ao seu soberano" ${ }^{" 82}$. Reconstruindo o raciocínio, o primeiro ponto é o direito que o soberano tem em relação à posse da "Europa" (essa é a máxima). Como os "nacionais", habitantes desses "países" da América, vêm da Europa, eles, portanto, já nascem vassalos. A "história", além disso, confirmaria essa dedução, pois a "Bahia, ou Pernambuco foi restaurado dos holandeses com as armas do mesmo soberano", concluindo daí o cônego que "por todas estas razões têm os monarcas portugueses todo o direito a estes países" $" 83$. O cônego, enfim, além de profético, era sagaz, manipulando as formas de raciocínio conforme as circunstâncias, as conveniências: era um leitor inventivo e sedicioso.

Feita a ressalva sobre as contradições e a inventividade do cônego marianense, pode-se retornar à tópica de Império, cara ao padre Antônio Vieira e laicizada pelo abade Raynal. Ela era, com efeito, compartilhada por outros envolvidos na Conjuração. Pode-se suspeitar que contaminava a visão do Tiradentes e mesmo de Joaquim Silvério dos Reis. Segundo o Tiradentes, "este país [Minas Gerais] podia ser um Império; e que se achasse quem o ajudasse, havia de pô-lo livre da sujeição da Europa, encarecendo as suas produções, maiormente de ouro e diamantes" ${ }^{84}$. Na casa de Resende Costa, Joaquim Silvério dos Reis teria dito, quando passava em revista aos auxiliares, "que estes países pela sua grandeza e extensão eram adequados para se fundar neles um império se não fossem sujeitos, o que se estranhara por ser diante do dito ajudante de ordens" ${ }^{, 85}$. Em princípios de março falara-lhe que em Minas estava para "se fazer um levante, entrando muitas pessoas nele; e que posto ele, dito Coronel, fosse de Portugal, estava pronto a seguir,

\footnotetext{
${ }^{81}$ Ibidem, loc. cit.

${ }^{82}$ AUTOS de Devassa da Inconfidência Mineira, op. cit., vol. 5, p. 245.

${ }^{83}$ Ibidem, loc. cit.

${ }^{84}$ Ibidem, vol. 1, p.201.
} 
porquanto bem podia ser esta terra um Império pelas riquezas que tinha" ${ }^{\text {"86 }}$. Antônio de Afonseca Pestana, sargento-mor do regimento de cavalaria auxiliar de São José, fala o mesmo sobre Joaquim Silvério dos Reis, mencionando a expressão "florente Império" ${ }^{87}$. Por fim, o Coronel Freire de Andrada possuía um escrito sobre Gonçalo Annes Bandarra, e Gonzaga afirmou que tal livro foi examinado nas conversas e que o mesmo "contava ao sapateiro Bandarra entre os primeiros poetas portugueses" Não se quer afirmar obviamente que os Inconfidentes eram milenaristas, mas apenas que, como os Ilustrados do Reino, laicizaram a idéia de Império, aplicando-a a Minas Gerais. O mesmo ocorreu nos Estados Unidos da América. Lá, as tradições milenaristas e os mitos edênicos laicizaram-se: no século XVIII, passou-se do combate a Roma à luta pela liberdade; da esperança num milênio próximo, a ser instalado no Novo Mundo e rumando na direção da Europa,,ao anseio de construir na América uma "sociedade livre de todas as tiranias religiosas e civis"; do estabelecimento do Reinado de Cristo na Terra à crença no papel da República dos Estados Unidos na defesa da liberdade e na redenção do mundo, "império de 'paz, de justiça e de liberdade ${ }^{,, 89}$.

A visão de Império estava indissociavelmente ligada às potencialidades dadas pelas riquezas existentes na terra. Todavia, os Inconfidentes percebiam que se, de um lado, havia riqueza, de outro, existia miséria. O Tiradentes, num de seus momentos de mais aguda lucidez, sintetizou aquela consciência antevista nas Poesias de Alvarenga Peixoto e, mais do que isso, amalgamou as Luzes às idéias do padre Antônio Vieira. As idéias expostas pelo Tiradentes revelam-se, assim, muito similares às de Raynal, e, sobretudo, quase idênticas às encontradas no sermão feito pelo padre Antônio Vieira em homenagem ao primeiro vice-rei que chegava ao Brasil, já analisado no Capítulo 1: segundo o alferes, “era pena, que uns países tão ricos como estes [isto é, as capitanias da América Portuguesa] estivessem reduzidos à maior miséria, só porque a Europa, como esponja, lhe estivesse chupando toda a substância, e os exmos. Generais de três em três anos traziam uma quadrilha, a que chamavam criados, que depois de comerem a honra, a fazenda, e os ofícios, que

\footnotetext{
${ }^{85}$ Ibidem, vol. 5, p. 125 .

${ }^{86}$ Ibidem, vol. 1, p. 203.

${ }^{87}$ Ibidem, vol. 1, p. 169.

${ }^{88}$ Ibidem, vol. 5, p. 223.
} 
deviam ser dos habitantes, se iam rindo deles para Portugal"90. Em acréscimo, dizia que era preciso Restaurar. Se Raynal associava a vexação dos impostos e o monopólio à pobreza do Brasil, uma terra potencialmente bela, o Tiradentes falava numa pobreza sendo engendrada pela Europa e pela ação dos governadores e seus “criados", sua "quadrilha". Se o padre Antônio Vieira falava em ministrosgovernadores, que de três em três anos desembarcavam no Brasil, e que, como “nuvens", "chupavam" a riqueza do Brasil, uma terra que então estava pobre, carreando-a para Lisboa e Madrid e propunha a Restauração do Brasil; o Tiradentes repetia os mesmos elementos: falava em governadores, em período de três anos, em riqueza chupada... Falava, ainda, em Restaurar! Substituía apenas "nuvens" por “esponja" (cujo formato, aliás, lembra o de uma nuvem); acrescentava "quadrilha" e “criados" aos governadores e pensava numa riqueza que seria natural se não houvesse a espoliação colonial. As similitudes com o sermão de Vieira são enormes para que se considere que se trata de mera coincidência; os elementos novos são bastante próximos aos de Raynal para que não se conclua que o alferes colou um ao outro. É bem verdade que entre Raynal e Vieira havia mais do que uma coincidência: Raynal tinha Vieira em alta conta, como se mostrou ao final do Capítulo 1.

No livro de RAYNAL, os conjurados, além de encontrar algumas idéias que legitimavam e estimulavam a rebelião - que era justo voltar-se contra um soberano, fosse ele despótico ou não; que os governos não eram imutáveis; que os povos da América deviam cultuar a pátria; que a América era rica, mas que a Europa a devastava -, os Inconfidentes leram, como já se observou, que o problema dos impostos tinha estimulado os norte-americanos a se rebelarem e que o apoio da França havia sido essencial para o sucesso ${ }^{91}$.

Os Inconfidentes procuravam comparar o que liam nos livros — não só de Raynal, como já se procurou mostrar na análise sobre a mistura de algumas idéias desse com as do padre Antônio Vieira - com sua realidade imediata, sendo bastante inventivos. Da associação que Raynal faz entre a Independência da América Inglesa e a questão tributária, os Inconfidentes concluíram que o problema fiscal em Minas,

${ }^{89}$ DELUMEAU, Jean. Mil anos de felicidade: uma história do paraíso, op. cit., p. 241-246.

${ }^{90}$ AUTOS de Devassa da Inconfidência Mineira, op. cit., vol. 5, p. 117.

${ }^{91}$ GUILlAUME, Thomas François Raynal. A revolução da América, op. cit., p. 64-66 e p. 113 e 117). 
materializado na derrama, poderia surtir os mesmos efeitos, despertando o ódio nos povos e tornando-os aliados da sedição - a derrama era a "outra tal ocasião" mencionada por Vicente Vieira da Mota! - e que era importante conquistar o apoio das "potências estrangeiras", sendo isso motivo de preocupações e de contatos, como o feito por José Joaquim Maia com um ministro norte-americano ${ }^{92}$. Por isso, o apoio da França e dos Estados Unidos da América é mencionado pelos Inconfidentes, seja como possibilidade, seja como uma certeza, seja como um elemento de propaganda $^{93}$. Por isso, também, o padre Toledo, Freire de Andrade, Tiradentes, Alvarenga Peixoto e o padre Rolim consideraram "que o Abade Raynal tinha sido um escritor de grandes vistas, porque prognosticou o levantamento da América Setentrional, e que a Capitania de Minas Gerais com o lançamento do tributo da derrama estaria nas mesmas circunstâncias" "94. Assim, se, por um lado, a obra de Raynal subsidiava os Inconfidentes teórica e praticamente na luta contra o domínio colonial, por outro, esses últimos foram leitores inventivos ao ponto de buscarem as especificidades de Minas e de mostrarem-se capazes de se apropriar das idéias desse livro e de outras obras Ilustradas, usando-as para criticar e intervir na própria realidade histórica imediata em que viviam.

O Alferes, assim como outros, exacerbava o raciocínio de Raynal sobre a riqueza da América portuguesa, cruzando-o com a Independência dos Estados Unidos e, ainda, depreendendo desse confronto melhores possibilidades para Minas Gerais. Se, para Raynal, a riqueza da América do Norte preparara a ruptura dos laços com a Inglaterra, para Tiradentes, em Minas, essas condições eram ainda melhores. Numa conversa com Vicente Vieira da Mota, ele "começou a exagerar a beleza, formosura e riqueza deste país de Minas Gerais, asseverando que era o melhor do mundo, porque tinha em si ouro e diamantes, acrescentando que bem podia ser uma república livre e florente; ao que lhe respondeu” Vicente: “Pois que? Assim como sucedeu com a América Inglesa?' Ao que lhe tornou o dito Alferes: - 'Justamente.

\footnotetext{
${ }^{92}$ AUTOS de Devassa da Inconfidência Mineira, op. cit., vol. 1, p. 213, vol. 5, p. 43, 112 e 203. Veja também: MAXWELL, Kenneth. A devassa da Devassa: a Inconfidência Mineira, Brasil - Portugal, 1750-1808, op. cit., p. 211.

${ }^{93}$ Como já se apontou, Alvarenga Peixoto concluiu, de uma exposição de Álvares Maciel sobre as impressões que este teve a respeito das posições de França e da Inglaterra em relação a uma possível rebelião no Brasil, "conhecer a vontade com que as Cortes estrangeiras estavam de secundar os projetos do Rio de Janeiro", que poderia rebelar-se (Ibidem, vol. 5, p. 116).

${ }^{94}$ Ibidem, vol. 5, p. 149-150 e 173.
} 
E ainda melhor, pelas maiores comodidades que tem""95. Joaquim José da Silva Xavier, possuidor de um nível de educação elementar e de uns poucos livros, leitor atrevido mas não muito sofisticado, fruiu e propagou intensamente os saberes aos quais teve acesso, levando-os aos caminhos, às estalagens, às lojas e às casas das meretrizes; graças a ele, a notícia do levante chegou, segundo as palavras do já citado Basílio de Brito Malheiros, às "pessoas da última classe da gente desta terra, como são os negros e mulatos" $" 96$.

O Tiradentes embriagava-se com os sucessos dos norte-americanos, debruçava-se sobre sua pátria: "muito curioso de mapas", conversara com José Joaquim da Rocha sobre "quantas almas teria a Capitania de Minas", obtendo como resposta que "teria trezentas e tantas mil almas", concluindo disso que "com tanta gente bem se podia fazer uma República" 97 . Andava por Vila Rica "com uma lista de todas as almas" — o "Mapa da Capitania “ elaborado por José Joaquim da Rocha — que "trazia na algibeira e mostrava sem temor" e quando a "mostrava dizia aflito: 'Ora aqui tem todo este povo açoitado por um só homem, e nós a chorarmos como negros, ai, ai; e de três em três anos, vem um e leva um milhão, e os criados levam outro tanto; e como hão de passar os pobres filhos da América? Se fosse outra nação já se tenha levantado" "98. Diante de um moço de Congonhas acrescentou que não se tratava de "levantar", mas de "restaurar". Portanto, o mapa de José Joaquim da Rocha foi exibido por Tiradentes de forma a denunciar a riqueza das Minas e instigar a rebelião 99 . O "restaurar", além de conectado ao sermão do padre Antônio Vieira, talvez explique o "modo de fazer os levantes", mostrando as vinculações da Inconfidência com a Restauração Portuguesa de 1640 e, ainda, com as sedições coloniais que lhe antecederam...

\section{3 "Modo[s] de se fazerem os levantes"}

\footnotetext{
${ }^{95}$ Ibidem, vol. 1, p. 156 (negrito nosso).

${ }^{96}$ Ibidem, vol. 1, p. 98.

${ }^{97}$ Ibidem, vol. 5 , p. 38 e 48

${ }^{98}$ Ibidem, vol. 1, p. 103-104.

${ }^{99}$ RESENDE, Maria Efigênia Lage de. Estudo crítico, In: ROCHA, José Joaquim da. Geografia histórica da Capitania de Minas Gerais, Belo Horizonte: Fundação João Pinheiro; Centro de Estudos Históricos e Culturais, 1995, p. 27.
} 
As leituras realizadas pelos Inconfidentes e que, de alguma forma, afetaram a compreensão dos mesmos sobre a sua realidade, bem como a definição de estratégias de ação para a sua transformação, compreendiam um amplo espectro de textos. Alguns deles claramente nomeados; outros, pelo contrário, só identificáveis através da comparação entre as falas dos Inconfidentes e seus conteúdos. Assim, ao tão explicitamente festejado abade Raynal, a Virgílio, o Recueil des Lois Constitutives des Colonies Anglaises, Confédérées sous la Dénomination D'États-Unis de l'Amérique Septentrionale, às Gazetas, podem-se somar os Sermões do Padre Antônio Vieira e, muito provavelmente, textos de pensadores da Segunda Escolástica e de algum autor milenarista - quem sabe o próprio Vieira - que tenha escrito sobre Gonçalo Annes Bandarra. Isso sem contar o "Mapa" de José Joaquim da Rocha e os poemas dos próprios Inconfidentes, em ambos os casos, textos manuscritos. No conjunto desses escritos sobressaíam dois fatos históricos: a Restauração Portuguesa e a Independência dos Estados Unidos. Nesse rol, no entanto, está faltando um livro que parece ter sido fundamental, ao menos para um dos Inconfidentes, o cônego Luís Vieira da Silva, e que se refere à Restauração: a História do Portugal Restaurado, do Conde da Ericeira. Tal livro e o "livrinho" de Raynal e, com isso, somando a Restauração Portuguesa de 1640 à Independência dos Estados Unidos, constituíram os elementos essenciais para que os Inconfidentes pensassem no modo de fazer os levantes e, quem sabe, evocassem as experiências anteriores de rebelião da própria Capitania.

A participação do livro de Raynal ficou clara a esse propósito. Numa passagem obscura dos autos de devassa, o padre Carlos Toledo afirma que Raynal ensinava como fazer a rebelião, alegando ter ouvido dizer "a Francisco Antônio de Oliveira Lopes que havia um livro de um autor francês, que estava na mão de um doutor na Cidade de Mariana, o qual no fim trazia o modo de se fazerem os levantes" (o que é um tanto fantasista, segundo Rouanet ${ }^{100}$ ): "era cortando a cabeça do Governador e fazendo uma fala ao povo e repetida por um sujeito erudito, e que este livro tinha sido mandado queimar por Sua Majestade"101 . De fato, pode-se vasculhar a parte da obra de Raynal sobre a Independência da América Inglesa sem que se

\footnotetext{
${ }^{100}$ ROUANET, Sérgio Paulo. As Minas Iluminadas: a Ilustração e a Inconfidência, op. cit., p. 336.

${ }^{101}$ AUTOS de Devassa da Inconfidência Mineira, op. cit., vol. 5, p. 149-150.
} 
possa encontrar nenhuma referência que lembre esse "cortando a cabeça do Governador". Porém, aqui quer-se lançar a hipótese de que uma pista para esse ensinamento encontra-se em outra parte da obra do incendiário abade: no tomo referente à América Portuguesa. Logo após transcrever um sermão do padre Antônio Vieira e celebrar a Restauração Portuguesa, RAYNAL rapidamente descreve o domínio filipino e narra como os portugueses se libertaram do jugo espanhol: uma conspiração preparada durante três anos, proscreve Filipe IV, leva ao poder o Duque de Bragança, espalha-se de Lisboa para o Reino e para as Colônias, tudo isto sem que corresse uma gota de sangue sequer, com exceção de Miguel de Vasconcelos, secretário de Estado:

"Un si grand changement ne coûta de sang que celui de Michel Vasconcelos, lâche et vil instrument de la tyranie" 102 .

A narrativa, advirta-se, é sucinta demais para que se possa acreditar que os Inconfidentes se inspiraram nessa passagem para cogitar em cortar a cabeça do governador da Capitania, Visconde de Barbacena. Todavia, a narrativa encontrada em História de Portugal Restaurado, bem como em outros livros sobre a Restauração, parece dar mais colorido a essa conjectura. Conta o Conde da ERICEIRA que os conspiradores:

"Assentaram por conclusão que sábado, primeiro de Dezembro, com o menor rumor que fosse possível, se achassem todos juntos no Paço, repartidos em vários postos, e que, tanto que o relógio desse nove horas, saíssem das carroças ao mesmo tempo; que uns ganhassem o corpo da guarda, onde estava uma companhia de infantaria castelhana, outros subissem à sala dos Tudescos a deter a guarda de archeiros alemães, que assistia nela; outros apelidassem, pelas janelas do Paço, liberdade, e aclamassem o Duque de Bragança, Rei de Portugal; outros entrassem a matar o Secretário de Estado, Miguel de Vasconcelos, diligência, que julgavam importantíssima assim por atalhar as ordens, que a sua resolução podia distribuir, como para incitar o povo com aquele merecido castigo, e persuadi-lo ao empenho da Nobreza, para que não duvidasse de a seguir [...]: "Disparou-lhe [em Miguel de Vasconcelos] D. António Telo uma pistola; sentindo-se ferido, saiu à casa, onde recebeu outras feridas mortais de que caiu. Porém, ainda vivo o lançaram ao terreiro por uma das janelas. Aguardava-

102 RAYNAL, G. T. [Guillaume-Thomas François]. Histoire philosophique et politique des etablissements et du commerce des européens dans les Deux Indes, op. cit., vol. 5, p. 47. 
o quantidade de gente que havia concorrido, daquela que sem atenção busca o rumor. Ao mesmo tempo que caiu o miserável corpo moribundo, se empregou nele toda aquela desconcertada ira, sem perdoar a algum excesso, e ficou em um instante desprezo comum o mesmo que havia sido respeito universal; e parecendo a todos uma só vida naquele cadáver a sua ira, como se estivera capaz de sentimento ${ }^{103}$.

Na narrativa de Ericeira, a morte de Miguel de Vasconcelos é apresentada como recurso para incitar o povo e como castigo por seus serviços ao domínio espanhol; ela é cercada por gritos em defesa da liberdade e em aclamação a D. João IV; Vasconcelos é, ainda, lançado à fúria da multidão. Essa narrativa está muito mais próxima do "modo de se fazer os levantes" vislumbrado pelo padre Carlos Correia de Toledo na obra do abade Raynal. Essa narrativa, ademais, está mais próxima daquilo que os Inconfidentes cogitaram e, depois, desistiram de fazer: enviar o Alferes Joaquim José à Cachoeira do Campo para matar o Capitão General, o Visconde de Barbacena, trazendo sua cabeça à Vila Rica para mostrá-la ao povo, "subindo a um lugar alto e dizendo: 'Este era quem nos governava; de hoje em diante viva a República'. E que logo subiria um [Freire de Andrada] a fazer uma oração ao povo, anunciando-lhe a futura felicidade" ${ }^{104}$. Essa narrativa encontrava ecos também nas próprias rebeliões anteriormente ocorridas em Minas Gerais, tal como as caracteriza Luciano Figueiredo. Aqui, menos do que defender essa hipótese, quer-se mostrar como a Restauração constituiu um dos modelos de sedição abraçados pelos Inconfidentes, ao menos para dois deles: o cônego Luís Vieira da Silva e o Tiradentes.

Luís Vieira da Silva, segundo Vicente Vieira da Mota, era o "mestre da aula", isto é, das práticas de leitura e da discussão sobre o sucesso dos insurretos da América Inglesa ${ }^{105}$. Mas ele não ficava apenas nisso: seu pensamento demonstra afinidades também com a Segunda Escolástica e, marca-se, pelo conhecimento e interesse pela história portuguesa. Expressa, ainda, uma criatividade ímpar na apropriação desse conjunto de informações tão distintas. Por um lado, tomando-se como referência a Ilustração, nota-se a combinação dos métodos resolutivo e

\footnotetext{
${ }^{103}$ ERICEIRA, Conde da [D. Luís de Menezes]. História de Portugal restaurado, op. cit., vol. 1, p. 118-121.

${ }^{104}$ AUTOS de Devassa da Inconfidência Mineira, op. cit., vol. 1, p. 215-216.

${ }^{105}$ Ibidem., vol. 5, p. 418.
} 
compositivo: a procura do estabelecimento das condições que provocam os fenômenos e, depois, a descoberta das regularidades que se fazem presentes em fenômenos similares, formulando-se leis. Por outro, ampliando-se o leque de origens culturais, remetendo-se à Ilustração, à Segunda Escolástica e, ainda, a um conjunto de interpretações históricas sobre a Restauração Portuguesa, há a aceitação do princípio que considera legítima a insurreição dos povos contra seus governantes tirânicos. Uma e outra presenças, é importante frisar, dão-se não só em relação às análises encontradas nos livros, mas na própria interpretação que o cônego constrói sobre a situação das Minas Gerais, sobre a América Portuguesa e sobre a Inconfidência.

A presença dos métodos e do princípio citados é perceptível nas respostas que o cônego Luís Vieira da Silva deu na primeira inquirição que lhe foi feita na devassa da Inconfidência, na Ilha das Cobras, em 1789. Interrogado sobre sua posição favorável a respeito da revolta dos norte-americanos, depois de algumas tergiversações:

\begin{abstract}
"Respondeu, que não é de presumir que ninguém obre mal somente por querer obrar mal; esses povos, que se rebelaram, conhecendo que obravam mal, algum interesse haviam de ter, com que pretendessem patrocinar a sua causa, como "verbi gratia", o livrarem-se de alguma opressão, o que não aparece na Capitania de Minas Gerais [...]" 106
\end{abstract}

A rebelião, portanto, tinha uma causa, a opressão, a qual inexistia nas Gerais - com o que Vieira da Silva procurava enganar os inquiridores, denunciando uma visão sobre o poder que consagrava o direito, presente tanto nos autores da Segunda Escolástica quanto em alguns Ilustrados, dos povos resistirem a um governo opressor. Questionado sobre a inexistência de diferenças entre os povos rebelados do norte e os mineiros:

"Respondeu que há diferença muito grande entre alguns povos, que se rebelaram nas causas, que para isso tiveram, e os da Capitania de Minas Gerais, pois a que se assina da derrama na instância não podia influir pela Carta a todas as Câmaras, do Ilmo. e Exmo. Visconde de Barbacena, em que lhes segurava o não lançar-se sem dar conta a S. Majestade, e por isso, como ele Respondente não vai atrás do

${ }^{106}$ AUTOS de Devassa da Inconfidência Mineira, op. cit., vol. 5, p. 246-248. 
maravilhoso, não podia pensar que pudesse mover os ânimos dos povos a uma sublevação, o qual não se move senão com fatos de presente [...]"107.

Os povos, desse modo, podiam rebelar-se por diferentes causas; em Minas Gerais, o problema dos impostos, motivo da sedição dos norte-americanos, inexistia, pois o Visconde de Barbacena havia noticiado que só faria a derrama depois de ouvir Sua Majestade $^{108}$. E o cônego, não acreditando no "maravilhoso" — guiando-se pela Razão! - sabia que para os povos rebelarem-se eram necessários fatos de presente. Nas entrelinhas desse raciocínio, vêem-se a presença da derrama na estratégia dos conspiradores e, ainda, a confirmação de sua importância pelo cônego quando este tenta ocultá-la, dizendo que a mesma fora suspensa.

Contraditado nas suas respostas pelo inquiridor, o cônego, então, expôs uma teoria geral sobre as condições que tornam exequiível uma rebelião, chegando até ela a partir de um exemplo concreto. Com isso, pretendia mostrar — enganando o inquiridor - que em Minas Gerais era impossível pensar em sedição e que ele não poderia cogitar em realizá-la:

"as respostas dele respondente só tendem a mostrar os fundamentos, por que não seguiria semelhante partido, quando fosse para isso convocado, prescindindo inteiramente de que houvesse, ou não, quem tivesse semelhantes idéias: Sabe que na feliz aclamação de El-Rei D. João o quarto, sendo uma causa tão justa, e tanto da vontade dos povos, perguntou, segundo sua lembrança, D. João da Costa, quais eram os generais, as armas, as alianças, os soldados, que tinham prontos para se levantarem contra

\footnotetext{
${ }^{107}$ Ibidem, loc. cit.

${ }^{108} \mathrm{O}$ fato do cônego postular a existência de diferentes causas para os povos se rebelarem e, mais ainda, de frisar a distinção neste aspecto da capitania de Minas Gerais, encontrando depois a regularidade existente entre mais de uma rebelião, pode corroborar a hipótese de que ele usaria fundamentalmente a indução - e não a dedução - ao interpretar a história. Isso porque seu ponto de partida seria a identificação das diferentes "causas" das rebeliões, procedendo em seguida a busca do que haveria de comum entre elas. Há, porém, que se ter em vista que o raciocínio do cônego é sempre sinuoso e matreiro: ele, com toda essa argumentação, não procura senão ocultar que se lançara numa rebelião contra Portugal, fazendo tudo, portanto, para desviar os que o interrogavam da similitude por ele próprio postulada entre a sedição das Minas e as outras rebeliões. Assim, sob a "diferença" nas "causas", pode estar oculta aquela epistemologia escolástica: nos termos de Richard Morse, como se disse no Capítulo 1, uma epistemologia racional formal-objetiva, que "vai de um dado concreto a uma classe de coisas, e então retorna para interpretar o dado" (MORSE, Richard M., op. cit., p. 47). Dessa forma, a Inconfidência não seria nada mais que algo pertencente a uma classe, a classe das "sedições", já constituída e dada. Essa classe seria o ponto de partida para se interpretar o dado concreto, a conjuração de Minas Gerais.
} 
as armas de Castela, e que isto foi bastante para se suspender a ação por oito dias, e talvez se não executasse, se nisso não estivesse o maior perigo; e como poderia pensar que tivesse efeito a sublevação de Minas falta de tudo o necessário, e cercada de outras Capitanias: Em segundo lugar, ele Respondente não vê interesse nenhum próprio na sublevação; porque não foi para isso convidado, nem aceitaria o partido, quando o fosse, e menos evitar o dano se este é obedecer aos superiores, e evitar tributos" ${ }^{\prime 109}$.

A Restauração Portuguesa, como se vê, era para o cônego "uma causa tão justa, e tanto da vontade dos povos". Na medida em que o cônego classificava uma rebelião como justa, pode-se presumir, primeiramente, que para ele os povos tinham o direito de resistir aos governantes que os oprimiam. A analogia entre a Inconfidência e a Restauração, por seu turno, permite inferir que, para Vieira da Silva, a Inconfidência encontrava-se no mesmo plano que a Restauração e, nessas condições, era também uma causa justa, da vontade dos povos, enfim, uma sedição legítima. Do exemplo concreto da Restauração portuguesa, protagonizada por Dom João IV, ademais, o cônego concluiu que só era possível pensar em rebelar-se se houvesse condições para tanto — isto é, generais, armas, alianças, soldados — ou se fosse mais perigoso manter-se na sujeição. Uma rebelião, portanto, podia ser uma causa justa, mas, para realizá-la, era preciso reunir condições objetivas. Nesse ponto, porém, Vieira da Silva recua e, esforçando para safar-se dos inquiridores, nega a existência das condições mencionadas em Minas Gerais, alegando que "tudo isso faltava" e que, além disso, obedecer aos superiores e pagar tributos não poderiam ser motivos de uma rebelião.

Na longa exposição do cônego Luís Vieira, notam-se a afirmação da Razão, a negação do "maravilhoso", das certezas absolutas, e uma análise do real que, tendo como referência a própria experiência (o que habilidosamente se procurava negar), compara três situações distintas: de um lado, a própria da Conjuração das Gerais, algo vivido pelo cônego e, de outro, a Independência das Treze Colônias Inglesas da América do Norte e a Restauração Portuguesa de 1640. O cônego as decompõe e, depois, chega a uma idéia geral sobre a ocorrência das rebeliões, engenhosamente atingindo a conclusão de que seria impensável uma rebelião em Minas. Nas

\footnotetext{
${ }^{109}$ AUTOS de Devassa da Inconfidência Mineira, op. cit., vol. 5, p. 246-248.
} 
entrelinhas, porém, há a afirmação do princípio Ilustrado e Escolástico que consagrava o direito à rebelião e, ao mesmo tempo, a expressão do lugar estratégico ocupado pela derrama na realização do levante. Isso mostra que o cônego de Mariana familiarizava-se com as teorias políticas em circulação à sua época, tanto as que remetiam a uma origem anterior — isto é, as da Segunda Escolástica —, quanto as adventícias da Ilustração. Sugere, além disso, que Vieira da Silva era um leitor inventivo: da leitura de livros, certamente diferentes, e da percepção do que ocorria no seu entorno, o cônego formulou um posicionamento diante das rebeliões que portugueses e norte-americanos realizaram num passado próximo e distante. Mais do que isso, das leituras e da observação, Vieira retirou subsídios para orquestrar uma rebelião contra a Coroa portuguesa na Capitania de Minas Gerais e, por fim, para ensaiar, nas entrelinhas, uma explicação para essa sedição que estava a protagonizar.

Onde lera o cônego as notícias que deu sobre a Restauração Portuguesa e a Independência dos Estados Unidos? Sobre a última, não é preciso ir muito longe: ele próprio e seus comparsas citam abundantemente o livro do abade Raynal; o cônego, ainda, acrescenta as Gazetas. Sobre a Restauração, todos os indícios conduzem à suposição de que Vieira lera a História de Portugal Restaurado, de D. Luís de Meneses, Conde da Ericeira, obra em que, conforme se demonstrou no Capítulo 1, é perceptível uma sutil adesão às teorias de poder da Segunda Escolástica, mais precisamente ao princípio que defendia o direito dos povos de resistirem à tirania.

O confronto de passagens do texto de Ericeira com o depoimento do cônego leva a esta suposição, ao mesmo tempo em que a comparação do último com as referências encontradas em outros livros indica que estes não foram a fonte usada pelo cônego marianense. Segundo Ericeira, estando "a empresa [a Restauração] tanto adiante que faltavam só três dias para se executar, se deu conta dela a D. João da Costa" e, então, este, depois de ouvir "com muita atenção a proposta" declarou em discurso pronunciado diante do Duque de Bragança (D. João IV) e outros nobres portugueses:

\footnotetext{
“"Nunca pus em dúvida a justiça que o Duque de Bragança tem para se lhe entregar esta coroa, nem ignoro o rigor com que a tiraniza o governo de Castela. Porém, a razão do Duque e a ofensa do reino, ainda que são fundamentos para nos mostrarmos justificados, não são forças para nos considerarmos vitoriosos, porque esta causa [...] hão de sentenciá-las as armas [...] Há mister muitas experiências
} 
que faltam ao Duque, não só políticas, senão militares; porque, no estado presente, é necessário a Portugal que quem empunhar o cetro saiba exercitá-lo como bastão [...] sendo a maior queixa que temos dos castelhanos a extremidade a que têm reduzido este reino com o fim de o fazer província, tirando dele gente, dinheiro, armas e cavalos, esta mesma falta impossibilita o que intentamos [...] Quais são os exércitos, quais as armadas que temos para nos opor ao poder de Castela? [...] Sendo todos estes discursos (a meu parecer) sem contradição, não nos fica para que apelar senão para milagres; e milagres, senhores, é justo que se creiam, é bom que se mereçam, mas não é razão que se esperem [...] Porém, fiando-se-me a tempo que é tão pouco o que temos do intento à execução, o que me parece é se não dilate, porque não achemos na falta do segredo o maior inimigo'

[Do que conclui Ericeira:]

"Estas razões de D. João da Costa, argüidas do seu entendimento e desprezadas do seu valor, perturbaram muito os ânimos de todos os confederados [...] E foi a causa de saírem os confederados do embaraço proposto discorrerem o empenho em que estavam, e conhecerem que o maior perigo consistia na dilação, porque, descoberto o que estava tratado, experimentariam desunidos o castigo que receavam armados" $" 110$.

Segundo Ericeira, portanto, aos olhos da D. João da Costa, a tirania dos castelhanos e a "justiça", embora justificassem a ação de entrega da coroa portuguesa ao Duque de Bragança, não garantiriam a vitória dos portugueses. Para tanto, seriam necessárias ao Duque experiências políticas e militares e, mais, gente, dinheiro, armas e cavalos, que justamente os dominadores vinham tirando de Portugal; nessas condições, quais os exércitos e armadas que os portugueses tinham, enfim, para opor aos castelhanos? Essa última interrogação de D. João da Costa, contida no livro de Ericeira, parece-se bastante com aquelas pronunciadas pelo cônego Luís Vieira da Silva (“quais eram os generais, as armas, as alianças, e os soldados...”). Além disso, há que se acrescentar a similitude dos epílogos dados ao episódio por Ericeira e Vieira da Silva: segundo Ericeira, após o desânimo, os confederados lançaram-se à rebelião, cientes de que "o maior perigo consistia na dilação"; para Vieira, 
suspendeu-se a ação por oito dias e "talvez se não executasse, se nisso não estivesse o maior perigo". As narrativas de Ericeira e Vieira da Silva, enfim, são muito semelhantes. Há, contudo, a menção, pelo cônego a um intervalo de 8 dias, que, em Ericeira, é apresentado como sendo de 3. Uma questão de memória, provavelmente.

O mesmo discurso, é bem verdade, está no livro de Vertot, Histoire des Révolutions de Portugal; mas, apenas na edição de 1809, dentre as várias edições localizadas, aparece o nome de D. João da Costa como a pessoa que o pronunciou ${ }^{111}$. Nas outras, a identidade não é revelada. Outros livros falam também do episódio. O historiador francês La Clède, autor de Histoire Générale de Portugal, obra já mencionada no Capítulo 1 e da qual o cônego Luís Vieira possuía um volume, cita o discurso de D. João da Costa. Entretanto, o teor do mesmo é bem diferente do conteúdo do depoimento de Vieira nos Autos de Devassa:

\begin{abstract}
"Car, lui dit-il [D. João da Costa a D. António de Almada], vous n'avez ni armée de terre, ni armée de mer pour la soutenir. Au moindre mouvement que vous ferez, vous serez inondés de troupes Castillanes; le peuple sur qui vous comptez, vous abandonnera lâchement; le Duc de Bragance lui-même trouvera de moyen de se reconcilier avec la Cour de Castille, \& nous, nous demeurerons les victimes qu'elle sacrifiera à sa vengeance, sous prétexte d'assurer le repos de l'Etat. Je regarde donc votre entreprise comme un précipice que vous vous creusez, \& et dans lequel vous allez vous perdre infailliblement" $" 112$.
\end{abstract}

Como se pode ver, para La Clède, D. João da Costa falava da falta de exército e de marinha para sustentar a rebelião e aventava a possibilidade do Duque de Bragança se reconciliar com a Corte de Castela. Em outro livro encontrado na biblioteca do cônego Vieira, História Genealógica da Casa Real Portuguesa, de D. António Caetano de Souza, faz-se referência à opinião sobre Dom João da Costa em

\footnotetext{
${ }^{110}$ ERICEIRA, Conde da [D. Luís de Menezes]. História de Portugal restaurado, op. cit., vol. 1, p. 115-117.

111 VERTOT, L' Abbé. Histoire des révolutions de Portugal par... continuée jusqu'au temps présent, op. cit., p. 52.

${ }^{112}$ LA CLÈDE, Mr. [Nicolas de]. Histoire Générale de Portugal, op. cit., vol. II, p. 411. Na tradução portuguesa (para o volume referido data de $1790 \mathrm{e}$, por conseguinte, não tendo sido acessível ao cônego Vieira em 1789, assim se escreve: “Porque, disse ele, vós não tendes trópas, nem armas para sustentar. Ao menor movimento, que fizerdes, vêr-vos-heis cercados de trópas Castelhanas; o Povo, de quem vos fiais, desamparar-vos-ha vergonhosamente; o mesmo Duque de Bragança dará traça para reconciliar-se com a Corte de Castela, e nós viremos a ser as victimas que ella houver de sacrificar á sua vingança sob pretexto de assegurar o socego do Estado. Pelo que tenho a vossa empreza por hum
} 
termos bem próximos aos de Ericeira - curiosamente, o autor critica explicitamente La Clède. Porém, o conteúdo do trecho distancia-se em alguns pontos tanto do que se encontra no "História do Portugal Restaurado", quanto da fala do cônego mineiro, havendo como semelhante apenas a conclusão de D. João da Costa segundo a qual seria pior demorar a realizar o levante do que concretizá-lo, apesar dos perigos e inconvenientes:

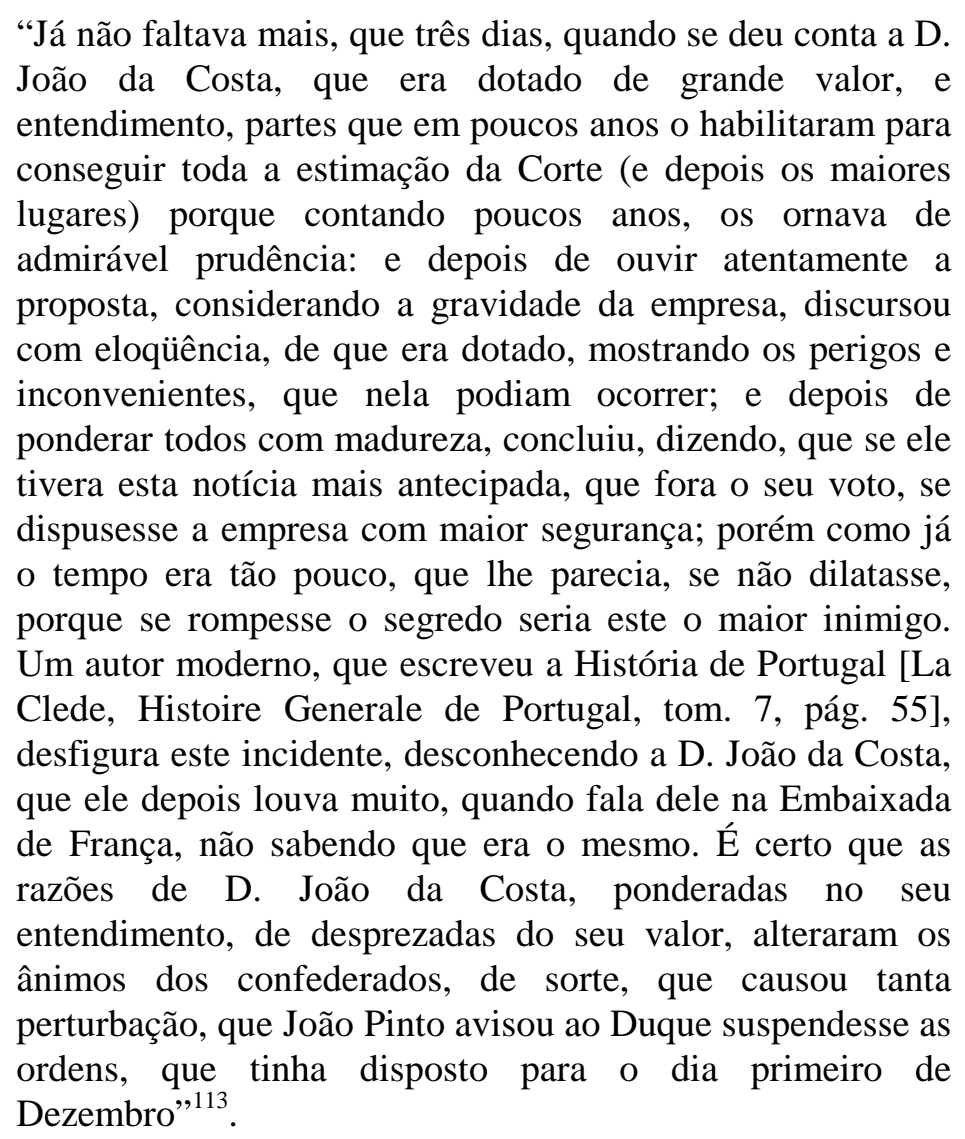

A hipótese que se mostra mais viável, portanto, é a de que o cônego leu a obra do Conde da Ericeira. Ele, no entanto, não a possuía, assim como acontecia com o livro de Raynal; ao menos nenhuma dessas obras foi arrolada no seqüestro de seus bens. Talvez ele a tenha emprestado de Ana Joaquina de São Boaventura, que, como se mostrou no Capítulo 7, a possuía em sua biblioteca, ou de um cônego seu contemporâneo, José Ferreira de Souza, que também a tinha.

precipicio, em que vos hides metter, e infalivelmente ficareis perdido." (Idem, História Geral de Portugal. traduzida em vulgar, op. cit., tomo XIII, p. 63-64).

${ }^{113}$ SOUZA, D. Antônio Caetano de. História genealógica da Casa Real Portuguesa. Coimbra: Atlântida Livraria Editora, 1949, tom. 7, p. 44. 
Atentos às transformações que ocorriam em Minas Gerais, perturbados com as alterações da política colonial metropolitana, inquietos com as perdas de postos e posições lucrativas, entusiasmados com o sucesso dos norte-americanos, os Inconfidentes passaram a pensar em rebelar-se contra a metrópole; começaram também a discutir, emprestar e ler livros, traduzir passagens desses, deixando-se influenciar pelas obras Ilustradas e, ainda, reinterpretando, se não os escritos dos teólogos escolásticos, ao menos os do padre Antônio Vieira e de D. Luís de Menezes, o $3^{\circ}$ conde da Ericeira. Tudo isso os levou a perceber que Minas era rica, mas o vínculo colonial engendrava pobreza... A conspiração contra a Coroa portuguesa nasceu, assim, em meio à percepção das contradições que separavam colônia e metrópole, na esteira da Restauração Portuguesa de 1640, sob o impacto das obras Ilustradas e atiçada pela Independência das Treze Colônias Inglesas da América do Norte. Os Inconfidentes, na verdade, conceberam o futuro de Minas Gerais e sua própria ação no sentido de rebelar-se, por um lado, como uma reiteração, ainda que subvertida, dos mitos e das mazelas da nação portuguesa e, por outro, como realização de uma aventura equiparável àquela protagonizada pelos Estados Unidos da América. A Conspiração de Minas, examinada sob o prisma de suas origens literárias, era uma luta de portugueses contra portugueses, que não se furtava a conjecturar sobre a coroação de um rei português como soberano na América. Usando da analogia ou da indução ao relacionarem América e Reino, esses homens se apropriaram da história e dos mitos lusitanos para rebelar-se contra Portugal e, ao mesmo tempo, laicizaram-nos e fundiram-nos com as Luzes e com a Independência dos Estados Unidos, concretizando os fantasmas que a censura portuguesa esmerouse em atacar: amalgamaram as teorias corporativas de poder, os milenarismos e as idéias Ilustradas radicais. Resta saber se, nessa mistura, não incorporaram elementos das revoltas anteriores ocorridas na Capitania. 


\section{CONCLUSÕES}

A censura portuguesa e os leitores sob o Reformismo Ilustrado no mundo luso-brasileiro tiveram, em suas práticas em relação aos livros, alguns parâmetros e alvos fundamentais.

De um lado, livros, textos, movimentos e correntes político-culturais que se marcavam pela defesa de concepções corporativas de poder, pelo anti-cientificismo, pelos milenarismos e pelo realismo, e cuja longevidade avançava pelo século XVIII. A Segunda Escolástica fixava limites ético-políticos ao poder absoluto e, em graus variáveis, defendia a legitimidade da resistência à tirania e, no caso de Portugal subordinava-a ao respeito aos direitos hereditários da dinastia reinante. Ao mesmo tempo o aristotelismo escolástico, seu método tópico e dedutivo e o probabilismo "jesuítico" conferiam a Portugal uma configuração cultural peculiar em relação ao Além-Pirineus. Mantendo-se distante, sem contudo estar completamente fechado à revolução científica então em andamento, Portugal e seus domínios assistiram à proliferação da crença na constituição de um Quinto Império, liderado por um príncipe lusitano, marco de uma Era de Felicidade. Dentro dos milenarismos portugueses, sobressaiu o nome do padre Antônio Vieira, homem cuja influência se estendeu aos dois lados do Atlântico e que foi, ao mesmo tempo, defensor de reformas e promotor de críticas "realistas".

De outro lado, assistia-se à influência da Ilustração. As Luzes refutavam toda autoridade exterior, não justificada pela razão, e implicavam uma inversão metodológica, ainda que não absoluta ou generalizada, mediante a qual se recusava, no processo de conhecimento, partir de certezas fundamentais, em relação às quais se fariam deduções, e se defendia a tomada da experiência e da observação como marcos iniciais, chegando-se, ao final, à descoberta de leis. A Ilustração realizava, ainda, um amplo questionamento das estruturas do Antigo Regime e, no caso do mundo luso-brasileiro, confrontava as imensas riquezas do Brasil à degradação em que se encontrava Portugal, preconizando uma série de reformas, que iam da supressão da Inquisição às modificações nas relações entre Portugal e suas possessões na América, rompendo-se com o exclusivismo metropolitano, diminuindo a opressão fiscal, dinamizando o comércio inter-colonial com as Índias Orientais. As 
vertentes mais radicais das Luzes, ademais, fustigavam o despotismo, a religião católica, a intolerância religiosa, a Inquisição, o fanatismo, a escritura sagrada, as exorbitâncias do poder real, os privilégios do rei e da nobreza e a infalibilidade papal, o monopólio comercial, o escravismo, o peso fiscal, levando, em alguns casos, ao deísmo, ao ateísmo, ao materialismo e, ainda, pondo em risco a estabilidade do trono e o colonialismo.

A Coroa portuguesa, a partir de 1750, iniciou um conjunto de reformas, sob a influência da Ilustração, empreendendo um esforço para firmar o poder régio face à igreja e à sociedade; para alterar as estruturas sócio-econômicas com o intuito de desenvolver a acumulação de capital em Portugal, fomentando as atividades manufatureiras, o comércio com as colônias e entre as mesmas, bem como as atividades produtivas no Ultramar; para desenvolver as ciências e a educação, que passaram a constituir alvos de apoios e intervenções incisivas dos governos, embora em grande parte fossem marcadas pelo pragmatismo e pela distância entre lei e prática. Valorizando o desenvolvimento científico e a Razão, movido por um forte regalismo, por uma fúria absolutista, o governo combateu aqueles elementos até então predominantes na cultura portuguesa. Procurou, ainda, executar todo esse programa de reformas, dentro dos quadros do Antigo Regime.

O resultado dessa orientação, dentro da qual se misturavam reformismo Ilustrado, regalismo, absolutismo e pragmatismo, foi a perseguição aos jesuítas e a tudo aquilo que se compreendia como seu legado no âmbito da educação e da cultura, destacando-se, as teorias corporativas de poder (e, em correlação com elas, algumas interpretações históricas da Restauração Portuguesa de 1640), os milenarismos e o anti-cientificismo. Ao mesmo tempo, os reinados que se sucederam desde 1750 procuraram conter, com ímpeto variado, de modo oscilante, com titubeios e ambigüidades, em função mesmo de sua perspectiva Ilustrada, a onda revolucionária que tinha como epicentro a França.

Os órgãos censórios portugueses, a partir de 1768, com a criação da Real Mesa Censória, seguiram essas diretrizes governamentais que procuravam conciliar Reformas Ilustradas à manutenção do Antigo Regime, ao regalismo, ao absolutismo e ao colonialismo. O aparato censório, nos quadros do Antigo Regime, sob a influência das Luzes, então, reprimiu a circulação e a posse de livros que contivessem concepções corporativas de poder ou que as referendassem na 
interpretação de episódios da história portuguesa; tentou extirpar os milenarismos e o anti-cientificismo que grassavam na cultura lusitana; e não poupou esforços, ainda, para impedir a entrada das idéias trazidas pelas Luzes que afrontassem o absolutismo, a religião cristã, a Inquisição e o colonialismo.

No que se referia à fixação de interdições, à físcalização da circulação e da posse de livros, e à concessão de licenças para a leitura de livros proibidos, a atuação da censura demonstrou coerência com a política desenvolvida num âmbito mais geral pela Coroa portuguesa. Os resultados das iniciativas censórias no âmbito da circulação e da propriedade de livros em geral, não foram, entretanto, coroados de êxito, tendo contribuído para o relativo fracasso a ambigüidade da própria situação governamental sob o Reformismo Ilustrado, em que se aliavam Luzes e Antigo Regime, reformas e repressão. Levaram ao mesmo resultado, ademais, o enraizamento, nas práticas de censura e dos leitores em geral, de uma relação com o livro e com a leitura marcada pela idéia de privilégio; a desarticulação, o descompasso, a fragilidade e as contradições estabelecidas entre os vários órgãos da burocracia estatal; e a má vontade dos leitores, que não se curvavam aos ditames régios.

No que concernia especificamente à concessão de licenças para a leitura de livros proibidos, a censura também revelou afinidade com as diretrizes governamentais e com os parâmetros fixados por ela própria. As licenças implicavam uma abertura modulada e seletiva das proibições. Embora levassem à suspensão da vigência de proibições no âmbito das leituras, as licenças não o faziam de forma absoluta, preservando, isolada ou conjuntamente, algumas proibições: as relativas a obras religiosas e as fixadas nos editais censórios de 10 de junho de 1768, 24 de julho de 1769, 04 de dezembro de 1769 e 24 de setembro de 1770. Tais editais tinham em mira a eliminação da interferência da igreja em negócios julgados seculares, a extirpação de toda uma herança cultural atribuída aos jesuítas (isto é, os milenarismos, o anti-cientificismo, o sigilismo, as teorias corporativas de poder e suas derivações) e a contenção dos efeitos "irreligionários" e revolucionários das Luzes.

A prática de concessão de licenças para a leitura de livros proibidos pelos órgãos censórios, porém, conviveu com os mesmos obstáculos que afetaram o controle da circulação e da posse de livros em geral. As licenças beneficiavam, direta 
ou indiretamente - isto é, através de instituições educativas e monásticas ou pessoalmente - uma amostra reduzida do conjunto dos leitores, um segmento elitizado formado em grande parte por clérigos e, em menor proporção, por leigos, ambos, clérigos e leigos, em sua imensa maioria, com formação de nível superior em Leis e Cânones ou Teologia, envolvidos em atividades monásticas e/ou de ensino, e/ou exercendo cargos de alguma importância no aparato judicial-administrativo. Permeadas por privilégios de cunho estamental e profissional, as licenças apresentavam-se em tipos distintos e concediam regalias diferenciadas aos leitores que contemplavam, manifestando maior ou menor rigor em relação à manutenção da validade dos editais e das interdições. Às diferentes espécies de leitores, ofereceramse variados tipos de licenças e mantiveram-se ou suspenderam-se, de forma diversa, a vigência das proibições fundamentais, beneficiando-se com as maiores regalias as instituições monásticas e de ensino e os clérigos com formação em teologia que desenvolviam atividades educativas ou que viviam em mosteiros. Isso, no entanto, sofreu uma variação no tempo, havendo entre 1790 e 1794, últimos anos de funcionamento da Real Mesa da Comissão Geral para a censura, período de revoluções e de transformações econômico-sociais profundas, uma flexibilização. Por um lado, contemplou-se um expressivo número de leigos com licenças outrora reservadas a indivíduos que exercessem atividades ligadas à teologia e ao ensino e, por outro lado, suspenderam-se, para grande parte dos beneficiários de licenças, as proibições até então resguardadas, preservando a vigência apenas do edital de 04 de dezembro de 1769, mantendo, assim, o regalismo, mas em grande parte abandonando o anti-jesuitismo, o anti-milenarismo, a oposição às teorias corporativas de poder e aos ventos radicais das Luzes. Essas concessões vieram a facilitar a disseminação das Luzes no seio das elites, bem como a sobrevivência da influência das teorias corporativas de poder e do probabilismo.

Se essas foram as linhas gerais da imposição da ortodoxia do texto, do ponto de vista da diversidade de leituras, dos usos do livro, o quadro revelou-se igualmente complexo. Se houve mudanças na apreciação que as autoridades faziam a respeito dos livros a partir de meados do século XVIII, verificando-se uma valorização do saber e do conhecimento livresco, sem porém haver suspensão dos controles e das interdições, do ponto de vista dos leitores verificou-se igualmente um crescimento do apreço pelos livros, que se evidenciou na distribuição de sua posse, nos usos que 
motivavam, nas formas de apropriação de que eram objeto, nos ambientes em que se desenvolveram sua posse e sua leitura..

Na América Portuguesa, do século XVI até 1822, os progressos do apreço pelo livro e pela leitura, embora evidentes, tiveram seus limites. Os livros eram possuídos por poucas pessoas, por gentes que, via de regra, aliavam a propriedade de bens de raiz e escravos ao exercício de ofícios que requeriam o uso dos livros, como sacerdócio, advocacia, medicina-cirurgia, botica, navegação e ensino, fazendo-se presente, além disso, entre os que se dedicavam às atividades militares, categorias de ofício e profissão essas que tinham nos livros um elemento essencial para o seu desenvolvimento, conferindo, portanto, aos mesmos, uma utilidade enquanto fonte de saberes profissionais.

A composição das bibliotecas coloniais, tão diferentes nas dimensões umas das outras, por seu turno, do século XVI a 1822, aponta para o predomínio das obras de religião, embora já no século XVIII as obras de cunho profissional revelem-se muito próximas em termos numéricos. Fontes de conhecimentos necessários para o exercício profissional, assim, os livros também municiavam os leitores com saberes e informações utilizadas na vivência religiosa. As bibliotecas, contudo, conservavam em sua composição de títulos e autores um espaço para o recreio e o deleite: os livros serviam também como objeto de diversão. Como objetos materiais que eram, além disso, funcionavam como enfeites; eram igualmente índices e adereços de privilégios e distinções sócio-profissionais. A posse de livros, assim como seus usos, permeavase pela idéia de privilégio, inerente a uma sociedade de cunho estamental. A composição das bibliotecas, ainda, comportando uma diferenciação conforme o grupo sócio-profissional, apresentava uma outra clivagem, evidente a partir do século XVIII, que separava, no interior dessa elite proprietária de livros, um segmento, uma "elite dentro da elite", que não resumia seus interesses às obras profissionais, ou mesmo religiosas, cultivando expectativas de, em seu recreio literário, refletir sobre o homem, a natureza, a divindade e o Estado.

Os leitores assumiam explicitamente os usos dos livros supracitados. Compreendiam-nos como fonte de saber, freqüentemente, de cunho profissional, como meios de acesso ao sagrado e objetos de entretenimento; como objeto que se prestava a servir para ornamentar e como elemento útil para o desenvolvimento de estratégias de poder. Encaravam, ademais, o uso do livro como um privilégio, não 
apenas no sentido econômico, mas como um bem cuja posse podia constituir um direito exclusivo de grupos sociais determinados e seletos.

Engastados em relações de poder, os livros, tão temidos pelas autoridades no início da colonização e motivo de controle e zelo por parte do aparato censório sob o Reformismo Ilustrado, prestaram-se a servir se não de origem, ao menos como suporte para a formulação de proposições heréticas. Na América Portuguesa, desde o século XVI, o livro veio a acompanhar as heresias: alguns leitores, demonstrando inventividade, desrespeitando as interdições censórias, as verdades estabelecidas pela Igreja, pelo Estado e/ou contidas nos livros, apropriavam-se das idéias dos livros para questionar a autoridade do Papa, a Escritura Sagrada, as interdições da censura, os santos, os milagres, os sacramentos, o Inferno e, como um todo, a religião cristã e, em muitos casos, os leitores reincidiam, com o apoio dos livros, nas suas crenças judaicas.

A partir de 1750, a herança secular de proposições heréticas e iconoclastas e de blasfêmias amalgamou-se às idéias trazidas pelas Luzes. Tendo como suportes os livros, assistiu-se a uma vaga de irreligiosidade, que levou os leitores a repensar a religião católica, a duvidar de seus dogmas, a desrespeitar suas autoridades. Nesse movimento de transformação, destacou-se, dos dois lados do Atlântico, a figura de Antônio de Morais Silva. Como leitor, Morais revelou afinação com as posturas deístas, anti-católicas, pró-tolerância e anti-inquisitoriais de Voltaire, ao mesmo tempo em que foi seduzido pela refutação de Rousseau à idéia da Queda do Homem. Conciliando essa postura com a rejeição à existência de autoridades inquestionáveis, confrontando as informações colhidas nos livros aos dados retirados da observação da realidade, Morais Silva concretizava aquele uso do livro inferido a partir da composição das bibliotecas e sugerido nas utilidades pensadas pelos leitores: o livro enquanto suporte de estratégias de poder, enquanto referência para refletir sobre o homem, o mundo natural e a divindade. Encarnando o perigo de subversão no âmbito restrito da religião, Morais, no entanto, mostrou-se politicamente conservador. Se Morais era o emblema do leitor Ilustrado e inventivo, Bento Álvares, denunciado ao Santo Ofício por defender proposições heréticas na Vila de Taubaté, amalgamava as Luzes às proposições heréticas que vicejavam na colônia desde o século XVI, juntando materialismo e ateísmo à incredulidade tributária de nossas raízes culturais marcadas pela presença dos cristãos-novos. 
A ambigüidade do Reformismo Ilustrado Português, por seu turno, repercutiu no âmbito das práticas de leitura, abrindo espaço para que a inventividade dos leitores pervertesse o equilíbrio que com tanto esforço as autoridades procuravam alcançar entre a preservação do Antigo Regime e a realização de reformas modernizantes. Houve leitores que fizeram do regalismo pombalino passaporte para o combate à instituição eclesiástica e ao papado, afrontando a primazia da autoridade papal no interior da igreja.

Aos usos do livro para o questionamento da ordem religiosa, para uma reflexão sobre a relação do homem com seus semelhantes, com a natureza e com Deus, veio a se somar o uso que subvertia a ordem política. Tendo-se elegido nesta tese a Inconfidência Mineira como objeto para análise dessa potencialidade do livro enquanto elemento que estimulava ou legitimava iniciativas que tinham em vista mudar a ordem política, pôde-se observar, de um lado, a sobrevivência de elementos culturais e literários que datavam de séculos anteriores ao Setecentos e que correspondiam em grande parte aos alvos privilegiados do Reformismo Ilustrado: as teorias corporativas de poder da Segunda Escolástica e as interpretações históricas da Restauração Portuguesa de 1640. Tais elementos mesclaram-se às influências das Luzes, em particular a obra do abade Raynal sobre a colonização européia e a Independência da América Inglesa. Amalgamando esses elementos de origem diversa no tempo, no espaço e em termos de suas filiações teóricas, num quadro de tensões entre os interesses de setores das elites mineiras e a política da Coroa, os Inconfidentes pensaram uma rebelião tomando como modelos a Restauração Portuguesa e a Independência dos Estados Unidos, mesclando a luta contra a tirania ao anti-colonialismo. Se com essa fusão concretizavam os temores do aparato censório, os Inconfidentes, por outro lado, mostravam-se, embora de forma confusa, pouco clara, simpáticos parcialmente a um projeto que implicava a Independência da Colônia sem contudo romper com a dinastia reinante. Evocavam, assim, sem o saber, a experiência igualmente malograda e, ainda, muito mais obscura, de Pedro Rates Henequim e faziam referências, essas sim mais explícitas, às proposições defendidas pelo maior orador sacro-luso brasileiro: o padre Antônio Vieira. Vieira, realista e milenarista, homem profético, em meio a tantas fronteiras, teve parte de suas idéias e escritos apropriados por Henequim e pelos Inconfidentes de Minas Gerais. 
Fontes Primárias e Bibliografia 


\section{Fontes Manuscritas}

Instituto dos Arquivos Nacionais da Torre do Tombo - IANTT (Lisboa)

Real Mesa Censória (1768-1787)/ Real Mesa da Comissão Geral Sobre o Exame e Censura dos Livros (1787-1794)

Registro de Bulas Pontifícias, Breves Apostólicos e de Licenças / Registro de Leis, Decretos, Alvarás, Cartas e Avisos:

Livro 2

Registro de licenças, provisões, avisos, ordens e editais expedidos pela Mesa (1768-1795)

1768-1770, Livro 9

1775-1794, Livro 18

1795, Livro 21

Requerimentos sobre vários assuntos (de 1760 a 1825)/ Decretos e avisos recebidos pela mesa, Cx 188

Registro de consultas

1768-1773, Livro 19

1775-1794, Livro 22

Editais de proibição de livros (1768-1816), Cx 1 e série preta

Ofícios relativos a editais de proibição de livros (1770-1816), Cx 185

Requerimentos para obtenção de licença de leitura e posse de livros proibidos (1770-1821)

S.d., 1770-1772, Cx 112

$1773-1825$, Cx 113

Registro de provisões concedendo licenças de leitura e posse de livros proibidos

1770-1772, Livro 13

1775-1794, Livro 14

Catálogos das livrarias particulares recebidos pela Mesa em cumprimento do edital de 10 de Julho de 1769
$2741-2835$
Cx 134
2887-3019
Cx 136
$3020-3126$
Cx 137

Requerimentos para entrega de livros retidos nas Alfândegas, na Casa da Revisão e na Secretaria da Mesa (Livros vindos da América Portuguesa)

1769-1821

Cxs. 149 e 144

Catálogos dos livros retidos nas Alfândegas, na Casa da Revisão e na Secretaria da Mesa S.d Cx. 169

Registro de entrada e saída de livros da Casa da Revisão 1788-1791

Livro 15

$1792-1794$

Livro 16

Livros destinados aos Domínios Ultramarinos 


$\begin{array}{lll}\text { Brasil } & 1769-1821 & \text { Cx. 151, 153-163 } \\ \text { Baía } & 1769-1815 & \text { Cx. } 157 \\ \text { Ceará } & 1799-1820 & \text { Cx. } 163 \\ \text { Espírito Santo } & 1802 & \text { Cx. } 163 \\ \text { Goiás } & 1796 & \text { Cx. } 163 \\ \text { Maranhão } & 1773-1821 & \text { Cx. } 159 \\ \text { Mato Grosso } & 1796-1803 & \text { Cx. } 163 \\ \text { Minas Gerais } & 1796-1819 & \text { Cx. } 163 \\ \text { Pará } & 1790-1821 & \text { Cx. } 160 \\ \text { Paraíba } & 1795-1815 & \text { Cx. } 163 \\ \text { Pernambuco } & 1769-1807 & \text { Cx. } 161 \\ \text { Rio de Janeiro } & 1769-1801 & \text { Cx. } 153 \\ \text { Rio Grande } & 1799-1816 & \text { Cx. } 163 \\ \text { São Paulo } & 1796-1819 & \text { Cx. } 163 \\ \text { Local não especificado } & 1795-1821 & \text { Cx. } 151\end{array}$

Periódicos, Caixa 491, Correio de Londres - 1793 (março-abril), nº 26 e 27 [versão manuscrita]

Biblioteca - Códice 4353 (manuscrito) - Historia Geral de Portugal por Mr. de La Clede, Traduzida em vulgar e ilustrada com notas Historicas, Geograficas e Criticas, e com algumas Dissertações singulares [tradução do Capitão Manuel de Souza: o que foi riscado na página de rosto]. Tomo 1o. Origem, costumes, guerras dos antigos Lusitanos. Dominio dos Romanos. Invasão dos Godos e Mouros.

\section{Inquisição de Lisboa}

Processos (n ${ }^{\circ}$ e nome dos réus):

2015 (Antônio de Morais Silva)

5640 (Francisco de Mello Franco)

13369 (Manoel Joaquim Henriques de Paiva)

13303 (Antônio Caetano de Freitas)

1557 (João Laureano Nunes Leger)

4259 (Henrique da Silva).

3754 (Dionísio da Silva)

8032 (Isabel de Fonseca Rego)

12 (Floriana Rodrigues)

436 (Francisco Pereira)

9397 (Teresa Barbalha de Jesus)

2919 (Simão Rodrigues da Fonseca)

1530 (Maria de Valença)

Cadernos do Promotor ( $\mathrm{n}^{\mathrm{o}}, \mathrm{n}^{\mathrm{o}}$ do livro, anos):

19, 220, 1639

90,283

$92,285,1723$

$93,286,1718$

130, 319, 1778-1790.

131, 320, 1779-1796:

133, 321, 1792-1800: e

134, 322, 1797-1802.

Correspondência Recebida

Livro 20

Livro 21

Livro 22 
Livro 931 - "Livro de Contas pertencente ao Pe. Francisco Justiniano Pereira de Carvalho. Va. de São João de El'Rey, 18 de Fevro. de 1786 [p. 1]

Desembargo do Paço (Corte, Extremadura e Ilhas)

maço n ${ }^{\circ} 1335,1783-1785$

\section{Biblioteca Nacional de Lisboa}

\section{Seção de Reservados}

[Exame e crítica da história das Revoluções de Portugal do abade Vertot, e de alegação jurídica de José Joaquim da Cunha de Azeredo Coutinho], Caixa nº 217, MSS 16, Ano 1807.

\section{$\underline{\text { Arquivo da Casa Setecentista de Mariana }}$}

Cartório do $2^{\circ}$ ofício (Ano, Códice, Auto)

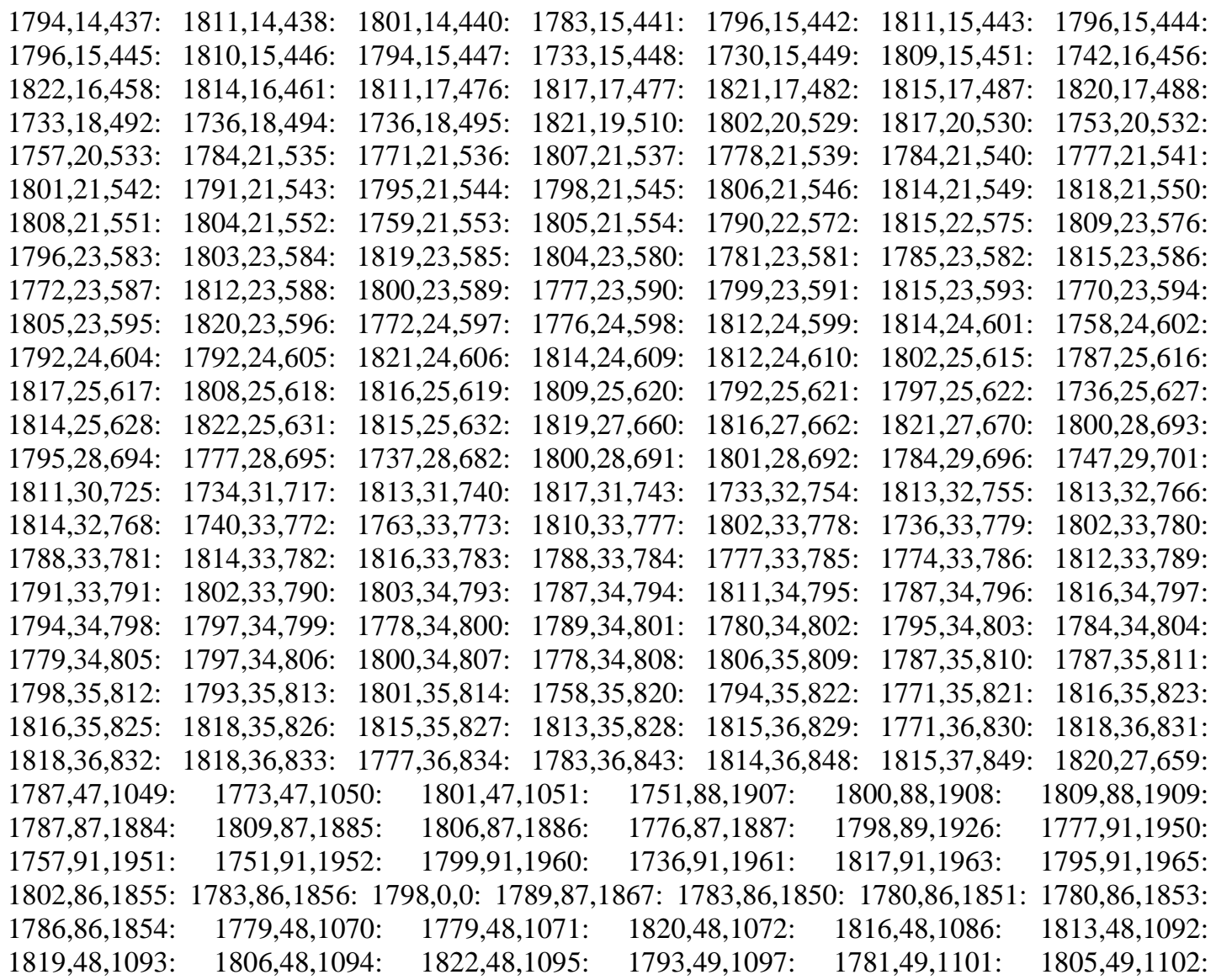


1793,49,1105: $1797,49,1106: \quad 1714,49,1108: \quad 1812,49,1109: \quad 1771,49,1110: \quad 1790,49,1114$ : 1778,49,1118: 1814,50,1136: 1818,38,894: 1767,38,896: 1811,38,897: 1771,38,890: 1817,38,891: 1817,38,893: 1817,37,850: 1820,37,851: 1761,37,855: 1779,37,862: 1795,38,877: $1810,38,878$ : 1810,38,881: 1804,38,882: 1802,38,883: 1801,38,884: 1791,38,885: 1793,38,886: 1807,38,876: 1781,38,879: 1787,38,880: 1790,38,889: 1773,38,888: 1789,38,887: 1776,39,911: 1816,39,912: 1798,39,913: 1814,39,908: 1817,39,909: 1806,39,910: 1817,39,905: 1814,39,906: 1816,39,907: 1760,45,1016: 1764,45,1017: 1758,45,1018: 1758,45,1015: $1802,45,1013: \quad 1812,45,1014$ : 1812,44,996: 1817,44,997: 1793,46,1030: 1798,46,1031: 1788,46,1032: 1743,41,936: 1746,41,937: 1812,41,938: 1808,77,1651: 1789,77,1652: 1793,77,1653: 1788,77,1654: 1778,43,980: 1785,54,1231: 1797,79,1706: $1804,79,1709: \quad 1804,80,1711: \quad 1807,80,1714: \quad 1810,80,1719: \quad 1804,81,1740$ : 1781,81,1741: $1789,81,1742: \quad 1779,81,1743: \quad 1791,76,1640: \quad 1822,76,1641: \quad 1792,76,1642$ : 1800,76,1643: $1794,76,1644: \quad 1803,76,1645: \quad 1790,76,1646: \quad 1785,76,1647: \quad 1796,77,1667$ : 1786,77,1668: $1793,77,1669: \quad 1768,77,1670: \quad 1786,77,1663: \quad 1786,77,1664: \quad 1777,77,1665:$ 1807,77,1666: 1808,77,1656: 1809,88,1906: 1792,50,1138: 1810,53,1200: 1806,93,2005: 1805,96,2052: 1814,96,2059: $1783,77,1659$ : 1793,77,1660: 1794,77,1657: $1783,77,1658$ : 1803,50,1139: $1800,50,1140$ : 1804,77,1661: 1782,77,1662: 1761,88,1899: $1730,88,1901$ : 1805,52,1178: 1810,53,1195: 1765,53,1196: 1793,53,1198: 1809,47,1058: $1797,47,1059$ : 1818,95,2028: $1813,96,2042$ : 1794,47,1060: $1749,93,1999$ : 1810,96,2053: $1800,96,2054: \quad 1804,96,2055: \quad 1788,96,2056$ : 1777,77,1655: 1793,88,1904: 1818,50,1137: 1808,53,1199: $1810,93,2002:$ 1793,96,2048: 1789,140, 1839: 1810,140,2840: 1817,140,2841: 1805,140,2831: 1801,140,2832: 1777,140,2838: 1805,93,1995: 1815,93,1996: 1819,129,2609: 1815,129,2610: 1820,129,2612: 1757,129,2613: 1809,126,2527: 1794,126,2528: 1806,126,2529: 1794,126,2543: 1818,74,1605: 1821,74,1608: 1818,74,1611: 1806,75,1621: 1809,75,1630: 1781,57,1287: 1810,73,1589: 1790,74,1600: 1815,70,1531: 1816,66,1453: 1798,68,1488: 1815,65,1439: 1799,57,1290: 1815,59,1325: 1798,61,1364: 1817,63,1417: 1820,88,1894: 1804,94,2019: $1817,74,1613$ 1809,75,1622: 1785,75,1631: 1786,57,1288: 1814,73,1598: 1784,75,1625: 1814,73,1599: 1787,75,1626: 1791,75,1624: $1800,76,1632$ : 1806,73,1591: 1796,57,1289: 1811,73,1582: 1792,73,1592: 1773,74,1601: 1815,70,1532: 1816,74,1604: 1801,73,1593: 1818,70,1538: 1746,70,1535: 1815,66,1454: 1815,68,1482: 1775,70,1536: 1787,68,1483: 1798,68,1489: 1784,68,1491: 1761,65,1440: 1785,57,1292: 1808,81,1744: 1814,59,1327: 1793,61,1367: 1763,57,1295: 1791,68,1492: 1817,81,1746: 1822,57,1301: 1756,59,1345: 1800,61,1369: 1821,63,1419: 1814,88,1892: 1780,63,1421: 1811,59,1347: 1821,61,1373: 1778,63,1423: 1791,88,1898: $1802,94,2014$ : 1808,92,1988: $1755,92,1989$ : 1760,92,1990: 1804,75,1619: 1809,75,1628: 1820,76,1634: 1793,73,1583: 1783,73,1594: 1816,70,1539: 1813,66,1451: 1779,68,1486: 1765,64,1435: 1758,81,1747: 1817,57,1303: 1804,62,1384: 1820,63,1411: 1791,63,1424:

1776,94,2017: 1816,92,1968: 1812,92,1974: $1810,92,1975$ :

1784,80,1728:

1786,94,2011: 1809,75,1620: 1767,75,1629: 1817,76,1636: 1789,73,1584: 1752,72,1578: 1786,60,1352: 1814,66,1452: 1798,68,1487: 1787,64,1437: 1822,85,1816: 1763,57,1306: 1814,62,1386: 1815,63,1413: 1784,88,1893: 1812,94,2018: 1798,90,1949: 1819,80,1732: 1805,44,988. 1818,44,989. 1814,44,991: 1814,44,992. 1820,44,994: 1813,44,995: 1787,43,983: 1798,43,984: 1800,43,987: 1810,46,1023: 1802,46,1024: 1810,46,1026: 1817,42,955: 1816,42,965: 1781,43,967: 1798,43,968: 1803,43,969: 1802,43,970: 1792,43,971: 1776,43,972: 1784,43,973: 1781,43,974: 1791,43,975: 1784,43,976: 1796,43,977: 1793,43,978: 1805,43,979: 1805,43,981: 1778,43,982: 1765,45,1019: 1737,45,1020: 1782,45,1022: 1815,79,1692: 1767,79,1694: 1766,79,1696: 1804,79,1697: 1787,79,1698: 1778,79,1699: 1807,79,1700: 1805,79,1701: 1822,79,1704: 1789,79,1705: 1775,46,1047: 1803,46,1048: 1818,39,901: 1815,39,903: 1814,39,904: 1817,38,898: 1820,38,899: 1817,38,900: 1820,117,2358: 1818,117,2359: 1816,118,2364: 1794,101,2136: 1810,101,2137: 1815,101,2141: 1815,101,2142: 1774,129,2602: 1746,129,2603: 1814,129,2606: $1822,129,2608$ : $1777,84,1812: \quad 1811,84,1814: \quad 1798,84,1815: \quad 1812,90,1932$ : 1727,77,1672: $1740,77,1673: \quad 1805,81,1736: \quad 1776,81,1739: \quad 1807,97,2076: \quad 1794,99,2094$ : 1781,99,2095: 1804,99,2096: 1816,123,2474: 1813,123,2475: 1813,123,2478: 1802,123,2488: 1812,117,2341: 1796,117,2351: 1816,117,2354: 1822,117,2356: 1795,82,1757: 1770,82,1763: 1806,82,1764: $\quad 1774,83,1774: \quad 1789,87,1869: \quad 1817,87,1870: \quad 1788,87,1871: \quad 1787,87,1877$ : 1817,86,1844: $1806,86,1847$ : $1791,86,1848: \quad 1777,86,1849: \quad 1819,83,1776: \quad 1813,83,1777$ : 1727,83,1786: 1767,83,1787: 1811,136,2761: 1815,136,2762: $1780,136,2763: 1815,136,2764$ : 1784,49,1119: $1814,49,1127: \quad 1798,51,1162: \quad 1803,76,1648: \quad 1814,76,1633: \quad 1783,76,1650$ : 1798,76,1649: 1765,67,1474: 1761,67,1475: 1796,69,1505: 1761,69,1507: 1819,60,1351: 
1821,60,1350: 1748,71,1543: 1781,61,1358: 1762,57,1284: 1783,74,1615: 1822,72,1565: 1728,72,1567: 1802,92,1977: 1753,85,1826: 1743,116,2327: 1816,91,1956: 1809,47,1053: 1797,47,1063: 1804,53,1204: 1818,54,1211: 1757,55,1255: 1748,92,1985: 1759,94,2024: 1821,99,2101: 1809,101,2130: 1805,101,2144: 1785,118,2373: 1820,121,2446: 1805,126,2521: 1783,127,2566: 1800,127,2561: 1816,129,2615: 1785,133,2682: 1810,136,2741: 1768,64,1434: 1735,67,1472: 1777,67,1469: 1795,68,1494: 1758,68,1501: 1775,71,1545: 1751,73,1581: 1819,84,1791: 1777,84,1809: 1785,85,1833: 1793,86,1840: $1781,89,1915$ : 1749,89,1925: 1800,90,1941: 1793,90,1948: 1807,136,2757: 1808,140,2847: 1724,136,2748: 1739,39,915: 177 1821,59,1337: 1775,39,918: 1734,39,919: 1762,40,924: 1722,40,925: 1728,40,930: 1764,41,942: 1810,41,944: 1727,42,945: 1815,42,949: 1813,42,951: 1785,25,614: 1790,101,2143: 1817,32,767: 1818,108,2229: 1810,53,1203: 1813,116,2332: $1807,84,1810$ : 1803,53,1202: $1817,50,1134: \quad 1822,50,1133: \quad 1782,59,1332: \quad 1821,120,2411$ : 1813,81,1745: $1817,32,770$ : $1814,49,1128: \quad 1801,95,2030: \quad 1816,120,2421$ : 1822,70,1541: $1819,70,1534: \quad 1819,79,1690: \quad 1804,124,2495: \quad 1822,70,1540$ : 1777,46,1045: 1806,86,1852: 1812,49,1109: 1770,140,2815: 1810,33,788.

1762,69,1514: $1764,69,1516$ : 1814,56,1283: $1747,58,1318$ : 1822,54,1222: $1786,54,1230$ : 1783,95,2032: $1822,95,2033$ : 1796,68,1503: $1814,72,1562$ : 1784,66,1459: $1780,66,1460$ : 1820,54,1221: $1815,54,1220$ : 1785,92,1981: $1814,85,1823$ : 1738,78,1675: $1805,78,1681$ : 1786,117,2336: 1760,91,1953: 1802,46,1028: $1796,46,1029$ : $1796,47,1054: \quad 1807,47,1055: \quad 1809,47,1056: \quad 1810,47,1057:$ 1797,47,1064: 1798,53,1205: 1817,54,1223: 1739,56,1256: 1750,92,1986: 1734,94,2025: 1820,99,2105: $1798,101,2131$ : 1813,108,2226: 1814,121,2434: 1800,121,2447: $1756,126,2522$ : 1820,127,2570: 1813,127,2565: 1815,129,2607: 1794,133,2685: 1745,136,2742: 1816,66,1447: 1734,67,1471: 1809,66,1461: 1805,68,1495: $1762,69,1508$ : 1812,71,1549: 1804,80,1733: 1774,84,1800: 1811,85,1818: 1793,85,1834: 1811,87,1878: 1757,89,1920: 1817,90,1934: 1791,90,1942: 1789,92,1983: 1789 $1803,136,2758$ : $1781,140,2818$ : $1803,140,2825$ : 1811,140,2848: 1810,140,2849: 1755,140,2855: 1724,53,1207: $1816,53,1208: \quad 1822,55,1238$ : $1753,92,1987:$ 1781,97,2064: 1814,99,2107: 1788,101,2132: 1737,116,2325: 807,121,2439: 1813,127,2547: $1818,128,2574$ : 1812,128,2579: 1766,128,2580: 1781,128,2591: 1732,136,2743: $1805,64,1428: \quad 1762,64,1430$ : 1813,66,1448: $1821,66,1449$ : $1816,66,1450$ : 1734,67,1473: $1742,63,1426: \quad 1768,67,1463$ : 1773,66,1462: $1771,68,1476: \quad 1730,68,1480$ : 1787,68,1496: $1759,69,1509:$ $1769,80,1735$ : 1822,84,1801: 1756,85,1819: 1779,85,1835: 1812,87,1881: $1737,89,1921$ : 1803,90,1935: 1787,68,1497: 1764,69,1510: 1776,71,1556: 1790,82,1752: $1797,84,1804$. 1790,85,1821: $802,87,1882$ : $1763,89,1922$ : 1817,90,1938: 1805,68,1498: 1816,69,1512: 1770,71,1557: 1743,82,1756: 1795,84,1807: 1809,85,1822: 1741,83,1789: 1785,87,1883: $1769,89,1923$ : 1814,90,1939: 1807,90,1945: 1768,136,2755: 1782,140,2826: ,39,916: 1783,39,917: 1816,44,998: 1811,44,999: 1729,45,1046: 1818,59,1326: 1722,45,1012: : $1775,41,943$ : 1796,88,1905: 807,134,2708: 1821,127,2556: 1822,54,1215: 1814,55,1234:
1771,69,1517: 1809,58,1323: $1817,51,1166$ : (8), $1821,54,1225$ : 1816,85,1825: 1787,79,1688: 1790,91,1954: 1799,95,2033: 1805,53,1201: 1785,54,1212: 1749,55,1254: 1802,94,2022: 1816,97,2074: 1804,101,2129: 1797,101,2135: 1778,118,2372: $1821,121,2445$ : 1816,127,2557: 1816,127,2559: $1817,129,2601:$ $1740,64,1431$ : 1737,67,1470: 1727,67,1467: 1778,68,1493: 1798,68,1499: 1820,71,1544: 1744,73,1579: 1718,84,1790: 1797,84,1808: 1817,85,1832: $1762,89,1924:$ 1812,90,1940: 1771,90,1946: 1807,136,2756: 1816,140,2846: $1819,136,2753$ : 1738,58,1322: 1773,136,2747: 


\section{$\underline{\text { Arquivo Eclesiástico da Arquidiocese de Mariana }}$}

Livro de Autos de Querelas (1764-1792), p. 12v-14v.

Inventário de Dom Frei Domingos da Encarnação Pontével, códice 105, 1793, arm. 1, gav. 4, pasta 17.

Juízo Eclesiástico (1738-1826).

\section{$\underline{\text { Arquivo Nacional do Rio de Janeiro }}$}

Inventários (respectivamente, ano, $\mathrm{n}^{\mathrm{o}}$ do processo, caixa ou estante, maço e/ ou galeria):

1785, 2368, -, A/2296: 1790, 45, 8864, 2254: 1795, 9147, 7159, 475: 1800, 5622, 6992, 308: 1795, 9335, A/5149: 1800, 2549, A/6624: 1800, 2, 3634, 508: 1790, 187, A/5436: 1795, 8719, 7140, 8719: 1795, 9102, 7158, 474: 1791, 2046, 8897, 2288: 1795, 9109, 1106, 5128: 1795, 9121, 7159, 475: 1795, 9115, 7159, 475: 1800, 9080, 7158, 474: 1795, 13, 3650, -: 1783, 22, 3629, A: 1800, 5875, 7002, 318: 1800, 5632, 6992, 308: 1820, 6890, 7072, 388: 1821, 21, 3637, 508: 1815, 88, 3621, 7145: 1800, 5611, 6987, 303: 1820, 9163, 355, A: 1801, 1594, 1115, A: 1795, 6753, -, 381: 1805, 9326, 1126, -:1795, 9216, 7162, -: 1810, 7166, 629, A: 1801, 1405, 1106, A: 1795, 8, 3615, -: 1783, 2428, , A-2298: 1786, 5702, 2755, B: 1820, 137, 3619, -: 1810, 8975, 7154, 470: 1810, 236, 1392, -: 1815, 2012, 6791, 106: 1786, 2438, -, A-2298: 1800, 5623, 6992, 308: 1795, 9113, 7159, 475: 1815, 6518, 7058, 374: 1810, 18, 872, 1: 1790, 9077, 5128, 474: 1790, 5630, 6992, 308: 1781, 9024, 5158, -: 1810, 6690, 349, C: 1791, 456, 8904, 2295: 1791, 1970, 8894, 2285: 1796, 9215, 7162, 478: 1775, 2091, 8898, 2289: 1801, 8853, -, 462: 1811, 9629, 1141, -: 1820, 4145, 368, -: 1795, 8462, 7123, 439: 1794, 9263, 5915, A: 1753, 663, 8958, 2350: 1786, 418, 8904, 2295: 1794, 9027, 5157, A: 1794, 8932, 5139, -: 1796, 8917, 5139, A: e 1798, 8398, 7118, 434. 


\section{Fontes Impressas:}

01.ABBEVILlE, Claude de. História da missão dos Padres Capuchinhos na Ilha do Maranhão e terras circunvizinhas. Belo Horizonte: Itatiaia: São Paulo: Edusp, 1975.

02.A INCONFIDÊNCIA da Bahia: devassas e seqüestros. Separata de Anais da Biblioteca Nacional Rio de Janeiro: Biblioteca Nacional, 2 v., 1931.

03.ANCHIETA, José de. Cartas, informações, fragmentos históricos e sermões. Belo Horizonte: Itatiaia: São Paulo: Edusp, 1988.

04. Teatro de Anchieta. São Paulo: Edições Loyola, 1977.

05.ANDRADE, Gomes Freire de. Instrução e Norma. In: LOPES, Eliane Marta Teixeira. Colonizador-Colonizado: uma relação educativa no movimento da história. Belo Horizonte: Editora UFMG, 1985, p. 252-259.

06.ANNO de 1791/ Autos Crimes/ Juízo da Comissão/ contra os Reos Ecclesiasticos/ da Conjuração, formada em Minas/ Gerais. Anuário do Museu da Inconfidência, Ouro Preto, (1): 72-101, 1952.

07.AUTOS de devassa: prisão dos letrados do Rio de Janeiro (1794). Niterói: Arquivo Público do Estado do Rio de Janeiro: Rio de Janeiro: UERJ, 1994.

08.AUTOS de devassa da Inconfidência Mineira. 2 ed. Brasília: Câmara dos Deputados: Belo Horizonte: Imprensa Oficial de Minas Gerais, 1980. 10 v.

09.AZPILCUETA NAVARRO, [et al.] Cartas avulsas: 1550-1568. Belo Horizonte: Itatiaia: São Paulo: Edusp, 1978.

10.BARLÉUS, Gaspar. História dos feitos recentemente praticados durante oito anos no Brasil. Belo Horizonte: Itatiaia: São Paulo: Edusp, 1974.

11.BIELFELD, Le Baron de. Institutions Politiques, par Monsieur... Leide: Samuel et Jean Luchtmans, 1772, tomo 3.

12.BLUTEAU, D. Rafael. Dicionario da Língua Portuguesa. Lisboa: Officina de Simão Thaddeo Ferreira, 1789.

13.CASTRO, Damião Antônio de L. F. História geral de Portugal e suas conquistas offerecida á Rainha Nossa Senhora D. Maria I. Lisboa: Typografia Rollandiana, 1786 -1804. 20 v.

14.CATALOGO dos livros defesos neste Reino, desde o dia da Criação da Real Mesa Cençoria athé ao prezente. In: MARQUES, Maria Adelaide Salvador. A Real Mesa Censória e a cultura nacional. Coimbra: Universidade de Coimbra, s/d., p. 118-206.

15.COELHO, José João Teixeira. Instrução para o governo da capitania de Minas Gerais. Belo Horizonte: Fundação João Pinheiro, Centro de Estudos Históricos e Culturais, 1994.

16.COLEÇAM das leys decretos, e alvarás que compreende o feliz reinado D’El Rey Fidelíssimo D. José I Nosso Senhor desde o anno de 1765 até 1770. Lisboa: Miguel Rodrigues, 1771, 7 v.

17. COLLEÇÃO de Leis. [s.1.], [s.d.] 8v.

18.COMPÊNDIO Histórico do Estado da Universidade de Coimbra (1771). Coimbra, Universidade de Coimbra, 1972. 
19.COUTO, José Vieira. Memória sobre a capitania das Minas Gerais: seu território, clima e produções metálicas. Belo Horizonte: Fundação João Pinheiro, Centro de Estudos Históricos e Culturais, 1994.

20.DISCURSO Histórico e Político sobre a sublevação que nas Minas houve no ano de 1720. Belo Horizonte: Fundação João Pinheiro: Centro de Estudos Históricos e Culturais, 1995.

21.ERICEIRA, Conde da [D. Luís de Menezes]. História de Portugal restaurado. Livraria Civilização Editora: $1945.4 \mathrm{v}$.

22.ESTATUTOS da Academia Brazilica dos Academicos Renascidos. Revista Trimestral do Instituto Histórico, Geographico e Ethnographico do Brasil, Rio de Janeiro, (45): 7-67, 1882.

23.FERREIRA, Luís Gomes. Erário mineral dividido em 12 tratados. Lisboa, 1735.

24.FIGUEIREDO, Antônio Pereira de. Tentativa teológica. Lisboa, 1769.

25.FRANCO, Francisco de Mello. Reino da estupidez: poema. Hambourg: 1820.

26.GAZETA de Lisboa. Lisboa, 1785-1790, 1792 e 1793 [IANTT, Real Mesa Censória, Caixas 468469].

27.GONZAGA, Tomás Antônio. Marilia de Dirceu. Rio de Janeiro: Livraria Garnier, 1992.

28.LA CLÈDE, Mr. [Nicolas de]. Histoire générale de Portugal. Paris: 1735. v. II.

29. História geral de Portugal. traduzida em vulgar e illustrada com muitas notas históricas, geograficas, e criticas: e com algumas dissertações singulares. Lisboa: Typografia Rollandiana, 1781-1790. 15 v.

30.LEITE, Serafim. Cartas dos primeiros Jesuítas do Brasil. São Paulo: Comissão do IV Centenário, 1954. $3 \mathrm{v}$.

31.LÉRY, Jean de. Viagem à terra do Brasil. trad. Sérgio Milliet. Belo Horizonte: Itatiaia: São Paulo: EDUSP, 1980.

32.LIVRO da visitação do Santo Ofício da Inquisição ao estado do Grão-Pará: 1763-1769. Petrópolis: Vozes, 1978.

33.LUCCOCK, John. Notas sobre o Rio de Janeiro e partes meridionais do Brasil. Belo Horizonte: Itatiaia: São Paulo: Edusp, 1975.

34.MADRE DE DEUS, Frei Gaspar. Memórias para a história da capitania de São Vicente. Belo Horizonte: Itatiaia: São Paulo: Edusp, 1975.

35.MACHADO, Diogo Barbosa. Bibliotheca lusitana. Lisboa: Biblioteca Nacional, [1998]. (CDROM)

36.MELlO, José Antônio Gonsalves de. Confissões de Pernambuco (1594-1595): primeira visitação do Santo Ofício às partes do Brasil. Recife: Universidade Federal de Pernambuco, 1970.

37.NÓBREGA, Manuel da. Cartas do Brasil: cartas jesuíticas I: 1549-1560. Belo Horizonte: Itatiaia: São Paulo: Edusp, 1988.

38.NOVINSKY, Anita. Inquisição: inventários de bens confiscados a cristãos-novos: fontes para a história de Portugal e do Brasil. Lisboa: Imprensa Nacional/ Casa da Moeda: Rio de Janeiro: Camões, [1976].

39.ORDENAÇÕES Filipinas. Lisboa: Fundação Calouste Gulbenkian, 1985.5 v. 
40.PITTA, Sebastião da Rocha. História da América Portuguesa desde o ano MD. até o de MDCCXXIV. 2 ed. rev. Lisboa: Livraria Guimarães \& C. ${ }^{\text {a }} 1880$.

41.PROENÇA FILHO, Domício (org.) A Poesia dos inconfidentes: poesia completa de Cláudio Manuel da Costa, Tomás Antônio Gonzaga e Alvarenga Peixoto. Rio de Janeiro: Nova Aguilar, 1996.

42.RAYNAL, Guillaume-Thomas François. A Revolução da América. Trad. de Regina Clara Simões Lopes. Rio de Janeiro: Arquivo Nacional, 1993.

43. O estabelecimento dos portugueses no Brasil. Trad.

Mônica F. Campos de Almeida e Flávia Roncari Gomes. Rio de Janeiro: Arquivo Nacional: Brasília: Editora UnB, 1998.

44.RAYNAL, G. T. [Guillaume-Thomas François]. Histoire philosophique et politique des etablissements et du commerce des européens dans les Deux Indes:. nouvelle edition, corrigée et augmentée d'après les manuscrits autographés de l'auteur... par M. Peuchet. Paris, Amable Costes et C.ie., 1820. tomo 5.

45.ROBERTSON, William. Histoire de L'Amérique. Trad. J. B. Suard et Morellet, 5 ed. Paris: Didier, Libraire-Éditeur, 1848. 2 v.

46.ROCHA, José Joaquim da. Geografia histórica da capitania de Minas Gerais. Belo Horizonte: Fundação João Pinheiro: Centro de Estudos Históricos e Culturais, 1995.

47.ROUSSEAU, Jean-Jacques. Emílio ou da educação. São Paulo: Martins Fontes, 1995.

48.SAINT-HILAIRE, Auguste de. Segunda viagem do Rio de Janeiro a Minas Gerais e São Paulo, 1822. Belo Horizonte: Itatiaia: São Paulo: Edusp, 1974.

49. . Viagem pelas Províncias do Rio de Janeiro e Minas Gerais. Belo Horizonte: Itatiaia: São Paulo: Edusp, 1975. 50. . Viagem pelo distrito dos Diamantes e pelo litoral do Brasil. Belo Horizonte: Itatiaia: São Paulo: Edusp, 1974.

51.SEGUNDA visitação do Santo Ofício às partes do Brasil pelo inquisidor e visitador o licenciado Marcos Teixeira. Livro das Confissões e Ratificações da Bahia - 1618-1620. (Introd. Eduardo d’Oliveira França e Sônia A.Siqueira). Anais do Museu Paulista, São Paulo (17): 123-547, 1963.

52. SILVA, Antônio de Moraes. História de Portugal composta em Inglez por huma sociedade de litteratos, trasladada em vulgar. com as addições da versão franceza, e notas do traductor portuguez, Antonio de Moraes Silva. Lisboa: Typografia da Academia Real das Sciencias de Lisboa, 1802. $5 \mathrm{v}$.

53. SILVA, côn Luís Vieira da. ORAÇÃO fúnebre pronunciada pelo cônego Luís Vieira nas exéquias do Dr. Lourenço José de Queirós Coimbra, a 12 de outubro de 1784, em Sabará. In: CARVALHO, côn. José Geraldo Vidigal de. Ideologia e raízes sociais do clero da Conjuração - século XVIII, Minas Gerais. Viçosa: Imprensa Universitária, p. 52-61.

54.SOUZA, D. Antônio Caetano de. História genealógica da Casa Real Portuguesa. Coimbra: Atlântida Livraria Editora, 1949. tomo VII. 
55.SYLVA, Jozeph de Seabra da. Dedução chronologica e analytica. Lisboa: Officina de Miguel Manescal da Costa, 1767.

56.SPIX, Johann Baptist von. Viagem pelo Brasil: 1817-1820. Belo Horizonte: Itatiaia: São Paulo: Edusp, 1981.

57.VAINFAS, Ronaldo (org.). Confissões da Bahia: santo ofício da inquisição de Lisboa. São Paulo: Companhia das Letras, 1997.

58.VERNEY, Luís Antônio. Verdadeiro método de estudar. 3 ed. Porto: Domingos Barreira, [s/d].

59.VERTOT, L' Abbé. Histoire des révolutions de Portugal par... continuée jusqu'au temps présent: enrichie de notes historiques et critiques, d'une table historique et chronologique des Rois de Portugal, et d'une description du BRÉSIL par Louis de Boisgelin, chevalier de Malthe. Londres: R. Juigné, 1809.

60. . The revolutions of Portugal written in French by the... London: William Chetwood, 1721.

61. Histoire des révolutions de Portugal par... Amsterdã: Etienne Roger, 1749.

62. Histoire des révolutions de Portugal par... sixiéme edition, revue \& augmentée par l'Auteur. Londres: Jean Nourse, 1765.

63. VIEIRA, Padre Antônio. Por Brasil e Portugal. São Paulo: Companhia Editora Nacional, 1938. v. 108.

64. Sermões do Padre Antônio Vieira. São Paulo: Anchieta, 1944. (Edição facsimilada da edição de 1683)

65. Cartas. Lisboa: Editores J. M. C. Seabra \& T. Q. Antunes, 1854-5. 4 tomos.

66. . Escritos históricos e políticos. São Paulo: Martins Fontes, 1995.

67.VIOTTI, Hélio A.(org). Cartas: correspondência ativa e passiva. São Paulo: Edições Loyola, 1984.

68. VOLTAIRE. Cândido. Lisboa: Publicações Europa-América, s/d. 70 . Dicionário Filosófico. Trad. de Bruno da Ponte, João Paulo Alves e Marilena Chauí. São Paulo: Nova Cultural, 1988, p. 1-211. 


\section{Bibliografia}

Artigos e Capítulos de livros:

01.ABREU, Márcia. Cordéis portugueses e folhetos nordestinos em confronto. Centre de Recherches Latino-Américaines, da Université de Poitiers (mimeograf.).

02. Leituras Coloniais. CONGRESSO LUSO-BRASILEIRO DE HISTÓRIA DA EDUCAÇÃO, 2, 1998, São Paulo. Anais, São Paulo, [1999]. (Inédito).

03.ALCALÁ, Angel. La censura inquisitorial de la literatura del siglo de oro en España y en Portugal: comparación de sus 'indices' y sus resultados. In: NOVINSKY, Anita, CARNEIRO, Maria Luiza Tucci. [org.].Inquisição: ensaios sobre mentalidade, heresias e arte. Rio de Janeiro: Expressão e Cultura: São Paulo: EDUSP, 1992. 421-456.

04.ALGRANTI, Leila Mezan. Os livros de devoção e a religiosa perfeita: normatização e práticas religiosas nos recolhimentos femininos no Brasil colonial. In: SILVA, Maria Beatriz Nizza da [Coord.]. Cultura portuguesa na Terra de Santa Cruz. Lisboa: Editorial Estampa, 1995. p. 109124.

05.ALMEIDA, Ângela Mendes de. Casamento, sexualidade e pecado: os manuais portugueses de casamento dos séculos XVI e XVII. Ler História, Lisboa, (12): 3-21, 1988.

06.ALMEIDA, Luís Ferrand de. D. João V e a Biblioteca Real. Revista da Universidade de Coimbra, Coimbra, (36): 413-438, 1991 [separata].

07.ANDRADE, Antônio Alberto Banha de. A reforma pombalina dos estudos menores em Portugal e no Brasil: linhas gerais de um livro que importa escrever. Revista de História, São Paulo, 56 (112): 459-498, 1977

08.ANTUNES, Álvaro de Araújo. Resquícios de leitura nas práticas advocatórias setecentistas em Minas Gerais. In: CONGRESSO DE HISTÓRIA DA LEITURA E DO LIVRO NO BRASIL, I, 1998, Campinas. (inédito).

09.ARAÚJO, Jorge de Souza. O perfil do leitor colonial. Artes e Literatura: Revista de Cultura Vozes, Petrópolis, (4): 439-457, jul./ag. 1989.

10.ARIÈS, Philippe. Por uma História da Vida Privada. In: ARIÈS, Philippe, CHARTIER, Roger. História da vida privada: da Renascença ao século das Luzes. Trad. Hildegard Feist. São Paulo: Companhia das Letras, 1991, p. 9-23.

11.BAUGHER, Sherene, VENABLES, Robert W. Ceramics as indicators of status and class in eighteenth-century New York. In: WOOD, S. M. Spencer. Consumer choice in historical archaeology. New York: Plenum Press, 1987, p. 31-53.

12.BEAUDRY, Mary. C. Words for things: linguistic analysis of probate inventories. In: BEAUDRY, Mary [ed.]. Documentary archaeology in the New World. Cambridge: Cambridge University Press, 1988. p. 43-50. 


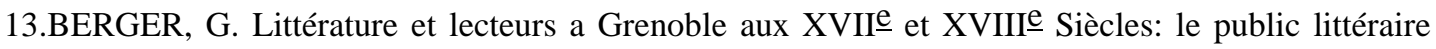
dans une capitale provinciale. Revue d'Histoire Moderne et Contemporaine, Paris, (33): 132, jan./mar. 1986.

14.BOSCHI, Caio César. A Universidade de Coimbra e a formação intelectual das elites mineiras coloniais. Estudos Históricos, Rio de Janeiro, 4 (7): 100-111, 1991.

15. Debate da conferência 'O Imaginário Republicano do Século XVIII e Tiradentes'. In: TIRADENTES hoje: imaginário e política na república brasileira. Belo Horizonte: Fundação João Pinheiro, 1994, p. 143-145.

16.BREWER, John. Reading and readers in 18 th century Britain. Cultura: Revista de História das Idéias. Lisboa, (9): 159-185, 1997.

17.BURNS, E. Bradford. O Iluminismo em duas bibliotecas do Brasil Colônia. Universitas, Salvador (8/9): 5-13, jan./ago. 1971.

18.CAEIRO, Francisco da Gama. Livros e livreiros franceses em Lisboa, nos fins de setecentos e no primeiro quartel do século XIX. Boletim da Biblioteca da Universidade de Coimbra, Coimbra, (35): 139-167, 1980 [separata].

19.CALAFATE, Pedro. Gramática e filosofia no século XVIII em Portugal. Revista da Faculdade de Letras, 5ª́rie, Lisboa, (15): 145-154, 1993.

20.CARDOZO, Manoel Silveira. O desembargador João Fernandes de Oliveira. Revista da Universidade de Coimbra, Coimbra, (27): 303-318, 1979 [separata].

21.CARRATO, José Ferreira. O Marquês de Pombal e a reforma dos estudos menores em Portugal. Boletim da Biblioteca da Universidade de Coimbra, Coimbra, 3 (34): 5-45, 1980 [separata].

22.CARVALHO, Augusto da Silva. As academias científicas no Brasil no século XVIII. Memórias da Academia das Ciências de Lisboa, classe de ciências. Lisboa, (2): 349-377, 1939.

23.CARVALHO, Feu de. Instrução pública: primeiras aulas e escolas de Minas Gerais. Revista do Arquivo Público Mineiro, Belo Horizonte, 24 (1): 345-391, 1933.

24.CARVALHO, Joaquim. A livraria de um letrado do século XVI: Fr. Diogo de Murça. In: CARVALHO, Joaquim. Obra completa de Joaquim de Carvalho II: história da cultura (19221948). Lisboa: Fundação Calouste Gulbenkian, 1982, p. 569-633.

25.CARVALHO, Laerte Ramos de. A Educação e Seus Métodos. In: HOLLANDA, Sérgio Buarque de [org.]. História geral da colonização Brasileira I: a época colonial). São Paulo: Difel, 1985.

26.CASTELO-BRANCO, Fernando. Tentativa de criação de uma universidade no Brasil do século XVII. Anais da Academia Portuguesa de História, Lisboa, (21): 621-631, 1972.

27.CASTRO, Zília Osório de. Poder régio e direitos da sociedade no reinado de D. Maria I. Ler História, Lisboa, (23): 11-22, 1992.

28.CAVALCANTE, Berenice. Os 'letrados' da sociedade colonial: as academias e a cultura do Iluminismo no final do século XVIII. Acervo, Rio de Janeiro, 8 (1/2): 53-66, jan./dez. 1995.

29.CAVALCANTI, Nireu Oliveira. A livraria do Teixeira e a circulação de livros na cidade do Rio de Janeiro. Acervo, revista do Arquivo Nacional, Rio de Janeiro, 8 (1-2): 183-194, jan./ dez. 1995. 
30.CHARTIER, Roger. 'Cultura popular': retorno a un concepto historiográfico. Manuscrits, (12): 43 62, jan. 1994.

31 . Introdução: A cultura do objeto impresso. In: CHARTIER, Roger (Coord.). As Utilizações do Objecto Impresso. Algés [Portugal]: Difel, 1998, p. 9-21.

32.CURTIS, Bruce. Some recent work on the history of literacy in Canada. History of Education Quaterly, University of Wisconsin-Madison, 4 (30): 613-624, inv. / 1990.

33.D’AZEVEDO, M. D. Moreira. Instrução pública nos tempos coloniaes do Brasil. Revista do Instituto Histórico-Geográfico Brasileiro, Rio de Janeiro, 2 (55): 141-158, 1892.

34.DIAS, Maria Odila Leite Silva. Aspectos da Ilustração no Brasil. Revista do Instituto Histórico e Geográfico Brasileiro, Rio de Janeiro, (278):105-170, jan./mar. 1968.

35.DINIZ, Sílvio Gabriel. Biblioteca setecentista nas Minas Gerais. Revista do Instituto Histórico e Geográfico de Minas Gerais, Belo Horizonte, (6): 333-344, 1959. 36. Um livreiro em Vila Rica no meado do século XVIII. Kriterion. Belo Horizonte, (47/48): 180-198, jan./jun de 1959.

37.DOMINGOS, Manuela D. Visitas do Santo Ofício às naus estrangeiras: regimentos e cotidianos. Revista da Biblioteca Nacional, Lisboa, 2, 8 (1): 117-229, 1993.

38. Para a história da biblioteca da Real Mesa Censória. Revista da Biblioteca Nacional, Lisboa, 2, 7 (1): 137-153, 1992.

39. Contratos e sociedades de um livreiro do setecentos: João Baptista Reycend. Revista da Biblioteca Nacional, Lisboa, (1-2): 195-219, 1995 [separata]. 40. Colporteurs ou livreiros: acerca do comércio livreiro em Lisboa: 17271754. Revista da Biblioteca Nacional, S 2, Lisboa, 6 (1): 109-142, 1991.

41.ELLIS, Myriam. Documentos sobre a primeira biblioteca pública oficial de São Paulo. Revista de História, São Paulo, (30): 387-447, abr/ jun. 1957.

42.ENNES, Ernesto. Autos crimes contra os réus eclesiásticos da conspiração de Minas Gerais. Anuário do Museu da Inconfidência, Ouro Preto, 9-70, 1952.

43.FALCON, Francisco Calazans. O imaginário republicano do século XVIII e Tiradentes. Tiradentes Hoje: Imaginário e Política na República Brasileira. Belo Horizonte: Fundação João Pinheiro, 1994

44.FARIA, Maria Isabel Ribeiro de. Diderot: carta histórica e política sobre o comércio do livro. Boletim da Biblioteca da Universidade de Coimbra, Coimbra, (34): 4-88, 1978 [separata].

45.FEITLER, Bruno. Les nouveaux-chrétiens dans la Capitainerie du Paraíba au XVIIIe siècle. Cahiers du Brésil Contemporain, Paris, (32): 89-106, 1997.

46. FIGUEIREDO, Luciano Raposo de Almeida. Furores sertanejos na América portuguesa: rebelião e cultura política no sertão do rio São Francisco, Minas Gerais (1736). Oceanos, Lisboa (40): 128-144, out./dez. 1999.

47. Práticas políticas e idéias ilustradas na América portuguesa (quando os motins tornam-se inconfidências - 1640-1817). 10 ${ }^{\mathrm{TH}}$ INTERNATIONAL CONGRESS ON THE ENLIGHTENMENT, 7, 1999, Anais, Dublin. (inédito). 
48. MUNTEAL FILHO, Osvaldo. Prefácio. In: RAYNAL, Gillaume - Thomas François. A revolução da América. Trad. Regina Clara Simões Lopes. Rio de Janeiro: Arquivo Nacional, 1993, p. 1-47.

49.FILGUEIRAS, Carlos Alberto Lombardi. Saberes acadêmicos e populares na prática médica do século XVIII em Portugal e em Minas Gerais. In: CONGRESSO LATINO-AMERICANO DE HISTÓRIA DA CIÊNCIA E DA TECONOLOGIA, 5, 1998, Rio de Janeiro. Anais... Rio de Janeiro, [1999]. (inédito).

50.

A revolução química de lavosier: uma verdadeira revolução?. Química Nova, São Paulo, 18 (2): 219-224, 1995.

51. Bartolomeu de Gusmão: um eco da revolução científica no Brasil colonial. In: GOLDFARB, Ana Maria, MAIA, C. A. [org.]. História da ciência: o mapa do conhecimento. São Paulo: Expressão e Cultura: Edusp, 1995, p. 381-390.

52. Voltaire e a natureza do fogo: uma controvérsia do século dezoito. (mimeograf.).

53. . O conhecimento científico no Brasil setecentista (mimeograf.).

54. João Manso Pereira, químico empírico do Brasil colonial. Química Nova, São Paulo, 16 (2): 155-160, 1993.

55. A ciência e a sociedade brasileira: do Iluminismo na Colônia ao positivismo no Império. In: SEMINÁRIO NACIONAL DE HISTÓRIA DA CIÊNCIA, 4, 1993, Caxambu. Anais... Caxambu, 1993, 104-109.

56. The mishaps of peripheral science: the life and work of Manoel Joaquim Henriques de Paiva, Luso-Brazilian chemist and physician of the late eighteenth century. Ambix, 2 (39): 75-90, july 1992.

57. Origens da ciência no Brasil. Química Nova, São Paulo, 13 (3): 222-229, 1990.

58. Vicente de Seabra Telles (1764-1804), the first Brazilian chemist.

NTM-Schriftenr. Gesch. Naturwiss., Technik, Med., Leipzig, 2 (27): 27-44, 1990. 59. Newton e a alquimia. Ciência e Cultura, 40 (1): 41-44, jan. 1988.

60. A química de José Bonifácio. Química Nova, 9 (4): 263-268, 1986.

61.FRANCO, Márcia Maria de Arruda. A Correspondência Entre Sá de Miranda e Jorge de Montemor. Caligrama, Belo Horizonte, 3: 129-146, novembro/ 1998.

62.FURTADO, João Pinto. Inconfidência e Inconfidentes em múltiplos registros: história e historiografia do movimento mineiro de 1789. In: DELGADO, Lucília de Almeida Neves (org.). Tiradentes: um herói para a República. Belo Horizonte: Imprensa Oficial, 1999, p. 150-162.

63.GROVER, Mark L. The book and the conquest: Jesuit libraries in colonial Brazil. Libraries and Culture, Austin, 28 (3): 266-283, 1993.

64.GUEDES, Fernando. Lotarias ou rifas de livros no século XVIII. Revista da Biblioteca Nacional, $S$ 2, Lisboa, 3 (1): 49-64, 1995. 
65.HANSEN, João Adolfo. Teatro da memória: monumento barroco e retórica. Revista do IFAC, Ouro Preto, (2): 40-54, dez. 1995.

66. Prefácio. In: PÉCORA, Alcir. Teatro do Sacramento: a unidade teológico-retórico-política dos sermões de Antônio Vieira.. São Paulo: Edusp: Campinas: UNICAMP, 1994. p. 13-36.

67.HIGGS, David. Linguagem perigosa e a defesa da religião no Brasil da segunda metade do século XVIII. In: SILVA, Maria Beatriz Nizza da (coord.). Cultura portuguesa na Terra de Santa Cruz. Lisboa: Editorial Estampa, 1995, p. 155-169.

68.JOBIM, Leopoldo Collor. A difusão da obra de Diderot em Portugal e no Brasil. Acervo: Revista do Arquivo Nacional, Rio de Janeiro, 4 (1): 99-111, jan. jun. 1989.

69.

O Santo Ofício da Inquisição no Brasil setecentista: estudo de uma denúncia. Revista de Estudos Ibero-Americanos, Porto Alegre, 13 (2): 195 - 213, dez. 1987.

70.KLUT, Duarte. O momento pedagógico pombalino: referências bibliográficas. In: PAIM, Antônio (org.). Pombal e a cultura Brasileira. Rio de Janeiro: Fundação Cultural Brasil-Portugal: Tempo Brasileiro, 1983, p. 32-43.

71.KOCHAKOWICZ, Leszek. Libertino. In: ENCICLOPÉDIA Einaudi: Mythos/ logos: sagrado/ profano. Lisboa: Imprensa Nacional/ Casa da Moeda, 1987.

72.LAJOLO, Marisa. Sociedade e literatura: parceria sedutora e problemática. In: ORLANDI, Eni Puccinelli (org.). Sociedade e linguagem. Campinas: Unicamp, 1997, p. 63-92.

73.LEITE, Paulo Gomes. Revolução e heresia na Biblioteca de um advogado de Mariana. Acervo, Revista do Arquivo Nacional, Rio de Janeiro, 8 (1-2): 153-166, jan./ dez. 1995.

74. . A propagação do Iluminismo em Minas Gerais. Revista Minas Gerais, Belo Horizonte, 2 (13): 24-27, jan. 1989.

75. A cultura no Tijuco no resgate do Iluminismo em Minas. Revista Minas Gerais, Belo Horizonte, (14): 22-26, mar. 1989.

76. A maçonaria, o Iluminismo e a Inconfidência Mineira. Revista Minas Gerais, Belo Horizonte, (33): 18-23, jan. 1991.

77. Contestação e revolução na biblioteca de Vieira Couto. Revista Minas Gerais, Belo Horizonte, (27): 23-29, jul. 1990.

78. Um Iluminista holandês na biblioteca de Vieira Couto. Revista Minas Gerais, Belo Horizonte, (32): 24-29, 1990. 79. Convulsões e histeria de Paris à Serra da Piedade. Revista Médica de Minas Gerais, Belo Horizonte, 3 (4): 243-247, out./ dez. 1993.

80.LEITE, Serafim. O curso de filosofia e tentativas para se criar a universidade do Brasil no século XVII. Verbvm, Rio de Janeiro, 2 (5): 107-148, jun./1948.

81.LESSA, Clado Ribeiro de. As bibliotecas brasileiras dos tempos coloniais: apontamentos para um estudo histórico. Revista do Instituto Histórico e Geográfico Brasileiro, Rio de Janeiro, (191): 339-345, 1946.

82.LIMA, Lana Lage da Gama. Aprisionando o desejo: confissão e sexualidade. In: VAINFAS, Ronaldo (org.). História e sexualidade no Brasil. Rio de Janeiro: Graal, 1986, p. 67-88. 
83.LISBOA, João Luís. O papel da história entre os leitores do século XVIII. Ler História, Lisboa, (24): 5-15, 1993.

84.LOUREIRO, Olímpia Maria da Cunha. Uma leitura de sucesso no século XVIII: 'Mestre da Vida que ensina a viver e morrer santamente'. Poligrafia, Porto, (3): 33-40, 1994.

85. . Bibliotecas e leituras do clero do Porto: 1769-1770. Actas do Congresso de História no IV Centenário do Seminário de Évora. Évora, 1994.

86.MACEDO, Jorge Borges de. Livros impressos em Portugal no século XVI: interesses e formas de mentalidade. Arquivos do Centro Cultural Português, Lisboa (9): 183-221, 1975.

87. Formas e premissas do pensamento luso-brasileiro do século XVIII. Revista da Biblioteca Nacional, Lisboa, 1 (1): 74-84, 1981.

88.MAGALHÃES, Beatriz R. Inventários e seqüestros: fontes para a história social. Revista do Departamento de História, Belo Horizonte, (9): 31-45, 1989.

89.MALARD, Letícia. Notas. In: PROENÇA FILHO, Domício (org.) A Poesia dos inconfidentes: poesia completa de Cláudio Manuel da Costa, Tomás Antônio Gonzaga e Alvarenga Peixoto. Rio de Janeiro: Nova Aguilar, 1996. p. 1155.

90.MARQUILHAS, Rita. 'Muito fistijei oubir bosas que tam desconsolada vibo e sem novas vosas': práticas da escrita na sociedade portuguesa de seiscentos In: CONGRESSO LUSOBRASILEIRO DE HISTÓRIA DA EDUCAÇÃO, 1, Lisboa, 1996. Lisboa, [s.d.]. (inédito). 91. 'Que todas as pessoas, fação rol de todos os livros que tiverem'...: testemunhos seiscentistas de uma leitura privada em Portugal. Cultura: revista de história das idéias. Lisboa, (9): 45-74, 1997.

92.MARTINS, Teresa Payan. 'Verdadeiro método de estudar'. Cultura: revista de história das idéias. Lisboa, (9): 221-248, 1997.

93.MASSIMI, Marina. As idéias psicológicas de Francisco de Melo Franco, médico e Iluminista brasileiro. Psicologia: Teoria e Pesquisa, Brasília, 7 (1): 83-90, 1991.

94.MATTOSO, Katia de Queirós. Bahia 1798: os panfletos revolucionários: proposta de uma nova leitura. In: COGGIOLA, Osvaldo. A Revolução Francesa e seu impacto na América Latina. São Paulo: Edusp/ Novastela: Brasília: CNPq, 1990, p. 341-356.

95.MAXWELL, Kenneth. Conjuração Mineira: novos aspectos. Estudos Avançados, São Paulo, 3 (6): 6-23, mai/ ago. 1989.

96.MONTUEAL FILHO, Oswaldo, KURY, Lorelai Brilhante. Cultura científica e sociabilidade intelectual no Brasil setecentista: um estudo acerca da sociedade literária do Rio de Janeiro. Acervo, revista do Arquivo Nacional, Rio de Janeiro, 8 (1-2): 105-122, jan./ dez. 1995.

97.MOTT, Luiz. A inquisição em Ilhéus. Revista FESPI, Ilhéus - Bahia, (10): 74-75, jul./ dez. 88/89.

98.MOUREAU, François. L'épisode brésilien dans l'histoire philophique et politique des deus Indes de l'abbé Raynal: un éclairage des Lumières. In: MATTOSO, Katia de Queiros: SANTOS, Idelette Muzart Fonseca dos, ROLLAND, Denis (Org.). Naissance du Brésil moderne: 15001808. Paris: Presses de l'Université de Paris-Sorbonne, 1998, p. 119-129. 
99.MUZZI, Eliana Scotti. Epopéia e história. In: PROENÇA FILHO, Domício (org.) A Poesia dos inconfidentes: poesia completa de Cláudio Manuel da Costa, Tomás Antônio Gonzaga e Alvarenga Peixoto. Rio de Janeiro: Nova Aguilar, 1996.p. 353.

100.NALLE, Sara T. Litteracy and culture in Early Modern Castile. Past \& Present, Oxford, (125): 65-96, nov. 1989.

101.NEVES, Guilherme Pereira das. Bahia, 1798: uma leitura colonial da Revolução Francesa: a propósito da tradução portuguesa de um texto de Jean-Louis Carra. Acervo: Revista do Arquivo Nacional, Rio de Janeiro, 4 (1): 121-125, jan. jun. 1989.

102. Do império Luso-Brasileiro ao império do Brasil. Ler História, Lisboa, (27-28): 75-102, 1995.

103.NEVES, Lúcia Maria Bastos Pereira. Corcundas e constitucionais: a cultura política no mundo Luso-Brasileiro: 1820-1822. In: SILVA, Maria Beatriz Nizza da (coord.). Cultura Portuguesa na Terra de Santa Cruz. Lisboa: Editorial Estampa, 1995, p. 265-280.

104. Comércio de livros e censura de idéias no Brasil. Ler História, Lisboa, (23): 61-78, 1992.

105. , BESSONE, Tânia. O medo dos 'abomináveis princípios franceses': a censura dos livros nos inícios do século XIX no Brasil. Acervo: Revista do Arquivo Nacional, Rio de Janeiro, 4 (1): 113-119, jan. jun. 1989.

106.NOVINSKY, Anita Waingort, Estudantes brasileiros 'afrancesados' da Universidade de Coimbra. a perseguição de Antônio de Morais Silva - 1779-1806. In: COGGIOLA, Osvaldo [org.]. A revolução francesa e seu impacto na América Latina. . São Paulo: Edusp/ Novastela: Brasília: CNPq, 1990, p. 357-371.

107.OLIVEIRA, António de. A livraria de um teólogo do século XVI. In: MARTINEZ MARTIN, Jesus A. Lectura y Lectores en el Madrid del siglo XIX. Madrid, CSIC, 1992, p. 541-588.

108.PÉCORA, Alcir. Prefácio: tópicas políticas dos escritos de Antônio Vieira. In: PÉCORA, Alcir (org.). Escritos históricos e políticos. São Paulo: Martins Fontes, 1995.

109.PEDROSA, Manoel Xavier de Vasconcellos. Estudantes brasileiros na faculdades de medicina de Montpellier no fim do século XVIII. Revista do Instituto Histórico e Geográfico Brasileiro, Rio de Janeiro, (243): 35-71, abr./ jun. 1959.

110.PICARD, Evelyne. Une bibliothèque conventuelle aux XVIII e. siècle: les théatins de SainteAnne-La-Royale. Revue d'Histoire Moderne et Contemporaine. Paris, (27): 235-255, abr./jun. 1979.

111.RADCLIFFE-BROWN, Alfred Reginald. O método comparativo em Antropologia Social. In: MELLATI, Júlio César (org.). Radcliffe-Brown/Antropologia. São Paulo: Ática, 1978, p. 2735.

112.RESENDE, Maria Efigênia Lage de. Estudo crítico. In: ROCHA, José Joaquim da. Geografia histórica da capitania de Minas Gerais. Belo Horizonte: Fundação João Pinheiro: Centro de Estudos Históricos e Culturais, 1995. 
113.REVEL, Jacques. Os usos de civilidade. In: ARIÈS, Philippe, CHARTIER, Roger. História da vida privada: da Renascença ao século das Luzes. Trad. Hildegard Feist. São Paulo: Companhia das Letras, 1991, p. 186-94.

114.RIBEIRO, Ângelo. De Montijo à morte de D. João IV. In: PERES Damião, CERDEIRA, Eleutério (dir.). História de Portugal. Barcelos: Portucalense, 1934, vol. 6, p. 65-83.

115.ROUANET, Sérgio Paulo. As minas Iluminadas: a Ilustração e a Inconfidência. In: NOVAES, Adauto (org.). Tempo e história. São Paulo: Companhia das Letras: Secretaria Municipal de Cultura, 1992, p.329-345.

116.SANTOS FILHO, Lycurgo. Francisco de Melo Franco. In: SILVA, Maria Beatriz Nizza da (coord.). Dicionário da história da colonização portuguesa no Brasil. Lisboa: Verbo, 1994, p. 357.

117.SARAIVA, Antônio J.. Padre Antônio Vieira. Dicionário da história de Portugal. Porto: Inic. Edit., 1970, v. 6, p. 298-302.

118.SILVA, Maria Beatriz Nizza da. Sociedade, instituições e cultura. In: JOHNSON, Harold, SILVA, Maria Beatriz Nizza da (coord.). Nova história da expansão portuguesa: o império brasileiro: 1500-1620. Lisboa: Editorial Estampa, 1992, p. 305-546.

119. SILVA, Antonio de Morais. In: SILVA, Maria Beatriz Nizza da (coord.). Dicionário da história da colonização portuguesa no Brasil. Lisboa: Verbo, 1994., p. 763.

120. A livraria pública da Bahia em 1818: obras de história. Revista de História, São Paulo, 43 (87): 225-239, 1971.

121. Educacão masculina e educação feminina no Brasil colonial. Revista de História, São Paulo, 55 (109): 150, jan./mar. 1977.

122. Livro e sociedade no Rio de Janeiro: 1808-1821. Revista de História, São Paulo, 46 (94): 441-457, 1973.

123. Uma biblioteca científica brasileira no início do século XIX. Revista do Instituto de Estudos Brasileiros, São Paulo, (14): 137-148, 1973.

124. Um brasileiro nas malhas da inquisição: o mineiro José Joaquim Vieira Couto e a maçonaria. In: SILVA, Maria Beatriz Nizza da (coord.). Cultura portuguesa na Terra de Santa Cruz. Lisboa: Editorial Estampa, 1995, p. 249-264.

125.SOUZA, Laura de Mello e. Estudo Crítico. In: DISCURSO Histórico e Político sobre a sublevação que nas Minas houve no ano de 1720. Belo Horizonte: Fundação João Pinheiro: Centro de Estudos Históricos e Culturais, 1995.

126.VAINFAS, Ronaldo. Sodomia, mulheres e inquisição: notas sobre sexualidade e homossexualismo feminino no Brasil colônia (mimeograf.).

127.VENTURA, Roberto. Leituras do Abade Raynal na América Latina. In: COGGIOLA, Osvaldo (org.). A Revolução Francesa e o seu impacto na América Latina. São Paulo: Edusp/ Novastela: Brasília: CNPq, 1990, p. 165-179.

128.VILLALTA, Luiz Carlos. Bibliothèques privées et pratiques de lecture au Brésil colonial. In: MATTOSO, Katia, , SANTOS, Idellete Muzart Fonseca dos, ROLLAND, Denis (org.). 
Naissance du Brésil moderne: (1500-1808). Paris: Presses de L’Université de ParisSorbonne, 1998, p. 319-336.

129. El-Rei, os Vassalos e os Impostos: Concepção Corporativa de Poder e Método Tópico num Parecer do Códice Costa Matoso. Varia Historia, Belo Horizonte (inédito).

130. O que se fala e o que se lê: língua, instrução e leitura. In: SOUZA, Laura de Mello e (org.). História da vida privada no Brasil: vida privada e cotidiano na América Portuguesa. São Paulo: Companhia das Letras, 1997, p. 331-385.

131. O cenário urbano em Minas Gerais setecentista: outeiros do sagrado e do profano. In: TERMO de Mariana: história e documentação. Belo Horizonte: BDMG; Ouro Preto: UFOP, 1998, p. 67-85.

132. A 'América', a Ilustração e os inconfidentes mineiros. Registro: Informativo do Centro Nacional de Referência Historiográfica, Mariana, 2 (4): 15-17, set. 1995/ fev. 1996 (notas de pesquisa).

133. O Diabo na livraria dos inconfidentes. In: NOVAES, Adauto (org.). Tempo e História. São Paulo: Companhia das Letras: Secretaria Municipal de Cultura, 1992. 134. . Os clérigos e os livros nas Minas Gerais da segunda metade do século XVIII. Acervo, Rio de Janeiro, 8 (1/2): 19-52, jan./dez. 1995.

135. XAVIER, Ângela Barreto, HESPANHA, Antônio Manuel. A representação da sociedade e do poder. In: HESPANHA, Antônio Manuel (coord.). História de Portugal. Lisboa: Editorial Estampa, 1998, p. 113-140. 
Livros e Teses:

01.ALBUQUERQUE, Luís de. Para a história da Ciência em Portugal. Lisboa: Horizonte, 1973.

02. ALEXANDRE, Valentim. Os sentidos do império: questão nacional e questão colonial na crise do antigo regime português. Porto: Edições Afrontamento, 1993.

03. ALMEIDA, Ângela Mendes de. O gosto do pecado: casamento e sexualidade nos manuais de confessores dos séculos XVI e XVII. Rio de Janeiro: Rocco, 1992.

04.ALVES, Gilberto Luiz. O pensamento burguês no seminário de Olinda: 1800-1836. Ibitinga: Humanidades, 1993.

05.ANASTASIA, Carla Maria Junho. Vassalos rebeldes: violência coletiva nas Minas na primeira metade do Século XVIII. Belo Horizonte, C/ Arte, 1998.

06.ANDRADE, Antônio Alberto Banha de. A reforma pombalina dos estudos secundários no Brasil. São Paulo: Saraiva: Edusp, 1978.

07.ARAÚJO, Emanuel. O teatro dos vícios: transgressão e transigência na sociedade urbana colonial. Rio de Janeiro: José Olympio, 1993.

08.ARAÚJO, Jorge de Souza. Perfil do leitor colonial. Rio de Janeiro: UFRJ, 1988 (Tese de doutorado) 3 vol.

09.ARIÈS, Philippe. História social da criança e da família. Rio de Janeiro: Zahar, 1978.

10. CHARTIER, Roger. História da vida privada: da renascença ao século das luzes. São Paulo: Companhia das Letras, 1991.

11.AVELLAR, Hélio de Alcântara. História administrativa do Brasil; a administração pombalina. 2 ed., Brasília: Fundação Centro de Formação do Servidor Público/ Universidade de Brasília, 1983.

12.AZEVEDO, J. Lúcio de. História de António Vieira. 2 ed. Lisboa: Livraria Clássica Editora, 1931. 2.v.

13.BAIÃO, Antônio. Episódios dramáticos da Inquisição portuguesa. 3 ed. Lisboa: Seara Nova, $1973.3 \mathrm{v}$.

14.BAILYN, Bernard. Los orígenes ideológicos de la revolución norteamericana. Buenos Aires: Paidós, [199?].

15.BAKHTIN, Mikhaïl. Questões de literatura e de estética: a teoria do romance. 3 ed. São Paulo: Editora da Universidade Estadual Paulista, 1993.

16.BASTOS, José Timóteo da Silva. História da censura intelectual em Portugal: ensaio sobre a compreensão do pensamento português. 2 ed. Lisboa: Moraes Editores, 1983.

17.BELMONTE. No tempo dos bandeirantes. São Paulo: Governo do Estado, 1980.

18.BESSELAAR, José van den. O sebastianismo: história sumária. Lisboa: Instituto de Cultura e Língua Portuguesa/ Ministério da Educação e Cultura, 1987.

19.BOSCHI, Caio César. Roteiro-sumário dos arquivos portugueses de interesse para o pesquisador da história do Brasil. São Paulo: Edições do Arquivo do Estado, 1986. 
20.BOTO, Carlota. A escola do homem novo: entre o Iluminismo e a Revolução Francesa. São Paulo: Editora da Universidade Estadual Paulista, 1996.

21.CÂNDIDO, Antônio. Formação da literatura Brasileira: momentos decisivos. 6 ed. Belo Horizonte: Itatiaia, 1981.

22.CARNEIRO, Maria Luiza Tucci. Preconceito racial no Brasil colônia: os cristãos-novos. São Paulo: Brasiliense, 1983.

23.CARRATO, José Ferreira. Igreja, Iluminismo e escolas mineiras coloniais. São Paulo: Companhia Editora Nacional: Edusp, 1968.

24.CARREIRA, Laureano. O teatro e a censura em Portugal na segunda metade do século XVIII. Lisboa: Imprensa Nacional, 1988.

25.CARVALHO, Rômulo de. História do ensino em Portugal: desde a fundação da nacionalidade até o fim do regime de Salazar-Caetano. Lisboa: Fundação Calouste Gulbenkian, 1986.

26.CASSIRER, Ernst. Filosofia de la Ilustración. 2 ed. Madrid: Fondo de Cultura Económica, 1993.

27.CÉSAR, Guilhermino. História do Rio Grande do Sul: período colonial. Porto Alegre: Globo, 1970.

28.CHARTIER, Roger. As utilizações do objecto impresso. Lisboa: Difel, 1998.

29. (org.). Práticas de leitura. São Paulo: Estação Liberdade, 1996.

30 . A ordem dos livros: leitores, autores e bibliotecas na Europa entre os séculos XIV e XVIII. Brasília: UnB, 1994.

31. A história cultural: entre práticas e interpretações. Lisboa: Difel: Rio de Janeiro: Bertrand Brasil, 1990.

32. Lectures et lecteurs dans la France D'Ancien Régime. Paris: Éditions du Seuil, 1987.

33.CHIARAMONTE, José Carlos. Ciudades, provincias, Estados: orígenes de la nación Argentina 1800-1846. Buenos Aires: Ariel Historia, 1997.

34.CIDADE, Hernâni. Antônio Vieira. Lisboa: Editorial Presença, 1985.

35.CIOCCHINI, Hector: BURUCÚA, José E., BAGNOLI, Omar H. La Revolución Francesa: libros/ historia/ ideas. Buenos Aires: Hermathena: Editorial Biblos, 1989.

36.DARNTON, Robert. Boêmia literária e revolução: o submundo das letras no Antigo Regime. São Paulo: Companhia das Letras, 1989.

37. Edição e sedição: o universo da literatura clandestina no século XVIII. São Paulo: Companhia das Letras, 1992.

38. O beijo de Lamourette: mídia, cultura e revolução. São Paulo: Companhia das Letras, 1990.

39. O grande massacre de gatos e outros episódios da história cultural francesa.

2ed. Rio de Janeiro: Paz e Terra, 1986.

40.DAVIS, Natalie Zemon. Culturas do povo. Rio de Janeiro: Paz e Terra, 1990.

41.DELUMEAU, Jean. A confissão e o perdão. São Paulo: Companhia das Letras, 1991.

42 . Mil anos de felicidade: uma história do paraíso. São Paulo: Companhia das 
43. . La Reforma. Barcelona: Editorial Labor, 1967.

44.DINES, Alberto. Vínculos do fogo: Antônio José da Silva, o Judeu, e outras histórias da Inquisição em Portugal e no Brasil. São Paulo: Companhia das Letras, 1992.

45.DOMINGUES, Francisco Contente. Ilustração e catolicismo: Teodoro de Almeida. Lisboa: Edições Colibri, 1994.

46.DUCHET, Michèle. Anthropologie et histoire au siècle des Lumières. Paris: Albin Michel, 1995.

47.DUPRONT, Alphonse. Qu'est-ce que les lumières? Paris: Gallimard, 1996.

48.DURHAM, Eunice Ribeiro. A reconstituição da realidade: um estudo sobre a obra etnográfica de Bronislaw Malinowski. São Paulo: Ática, 1978

49.ENCONTRO DE HISTÓRIA DA EDUCAÇÃO EM PORTUGAL, 1, Lisboa, 1988. Anais... Lisboa: Fundação Calouste Gulbenkiam, 1988.

50.FALCON, Francisco Calazans. A época pombalina: política econômica e monarquia ilustrada. São Paulo: Ática, 1982.

51.FERNANDES, Rogério. Os caminhos do ABC: sociedade portuguesa e ensino de primeiras letras. Porto: Porto Editora, 1994.

52.FREIRE, Gilberto. Casa grande \& senzala: formação da família brasileira sob o regime da economia patriarcal. 21 ed. Rio de Janeiro: José Olympio, 1981.

53.FRIEIRO, Eduardo. O Diabo na livraria do cônego. 2 ed. rev. e aum. São Paulo: EDUSP: Belo Horizonte: Itatiaia, 1981.

54.FURTADO, Joaci Pereira. Uma república de leitores: história e memória na recepção das 'Cartas Chilenas' (1845-1989). São Paulo: Hucitec, 1997.

55.FURTADO, Júnia. O livro da capa verde: o regimento diamantino de 1771 e a vida no distrito diamantino no período da Real Extração. São Paulo: Anna Blume, 1996.

56.GAY, Peter. The Enlightenment: the science of freedom. New York: W. W. Norton \& Company, 1996.

57. The Enlightenment: the rise of modern paganism. New York: W. W. Norton \& Company, 1995.

58.GINZBURG, Carlo. O queijo e os vermes: o cotidiano e as idéias de um moleiro perseguido pela Inquisição. São Paulo: Companhia das Letras, 1986.

59.GINZBURG, Carlo. Os andarilhos do bem: feitiçarias e cultos agrários nos séculos XVI e XVII. São Paulo: Companhia das Letras, 1988.

60.GOMES, João Ferreira. Para a história da educação em Portugal. Porto: Porto Editora, 1995.

61.GOMES, Plínio Freire. Um herege vai ao paraíso: Cosmologia de um ex-colono condenado pela Inquisição (1680-1744). São Paulo: Companhia das Letras, 1997.

62.GRANDE Enciclopédia Portuguesa e Brasileira. Lisboa/ Rio de Janeiro: Editorial Enciclopédia Limitada, s/d, vol. 16.

63.GUEDES, Fernando. O livro e a leitura em Portugal: subsídios para a sua história (séculos XVIII e XIX). Lisboa: Verbo, 1987.

64.HARRIS, Marvin. El desarrollo de la teoría antropológica: uma história de las teorias de la cultura. Madrid: Siglo Veintiuno, 1979. 
65.HAZARD, Paul. La crise de la conscience européenne (1680-1715). Paris: Fayard, 1994. . O pensamento europeu no século XVIII. Lisboa: Presença, 1989.

67.HERMANN, Jacqueline. No reino do desejado: a construção do sebastianismo em Portugal (séculos XVI e XVII). São Paulo: Companhia das Letras, 1998.

68.HOLANDA, Sérgio Buarque de. Capítulos de literatura colonial. São Paulo: Brasiliense, 1991. 69. . Raízes do Brasil. 19 ed. Rio de Janeiro: José Olympio, 1987.

70 . Visão do paraíso: os motivos edênicos no descobrimento e colonização do Brasil. 3 ed. São Paulo: Ed. Nacional: Secretaria de Cultura, Ciência e Tecnologia, 1977.

71.HOORNAERT, Eduardo: AZZI, Riolando: VAN DER GRIJP, Klaus, BROD, Benno. História da igreja no Brasil: ensaio de interpretação histórica a partir do povo (primeira época). 3 ed. Petrópolis: Vozes: Paulinas, 1983.

72.JANCSÓ, István. Na Bahia, contra o império: história do ensaio de sedição de 1798. São Paulo: Hucitec: Salvador: UFBA, 1996.

73.JOHNSON, Harold, SILVA, Maria Beatriz Nizza da (coord.). Nova história da expansão portuguesa: o império brasileiro: 1500-1620. Lisboa: Editorial Estampa, 1992.

74.LAJOLO, Marisa, ZILBERMAN, Regina. A leitura rarefeita: livro e literatura no Brasil. São Paulo: Brasiliense, 1991.

75.LEITE, Serafim. História da Companhia de Jesus no Brasil. Lisboa: Portugália: Rio de Janeiro: INL, 1938-1950. $10 \mathrm{v}$.

76.LIMA JR., Augusto de Lima. A capitania de Minas Gerais. Belo Horizonte: Itatiaia: São Paulo: Edusp, 1978.

77.LIRA, Maria de Lourdes Viana. A utopia do poderoso império. Rio de Janeiro: Sette Letras, 1994.

78LISBOA, João Luís. Ciência e política: ler nos finais do Antigo Regime. Lisboa: INIC/ Centro de História da Cultura da Universidade Nova de Lisboa, 1991.

79.LOPES, Eliane Marta Santos Teixeira. Colonizador-colonizado: uma relação educativa no movimento da história. Belo Horizonte: Editora UFMG, 1985.

80.LOUREIRO, Olímpia Maria da Cunha. O livro e a leitura no Porto no século XVIII. Porto: Centro de Estudos D. Domingos de Pinho Brandão/ Fundação Eng. ${ }^{\circ}$ António de Almeida, 1994.

81.LUCAS, Fábio. Luzes e trevas: Minas Gerais no século XVIII. Belo Horizonte: UFMG, 1998.

82.MACHADO, Alcântara. Vida e morte do bandeirante. Belo Horizonte: Itatiaia: São Paulo: Edusp, 1980.

83.MANACORDA, Mario Alighiero. História da educação: da antigüidade aos nossos dias. São Paulo: Cortez: Autores Associados, 1989.

84.MARQUES, Maria Adelaide Salvador. A Real Mesa Censória e a cultura nacional. Coimbra: Universidade de Coimbra, [s. d.].

85.MARQUILHAS, Rita. A faculdade das letras: leitura e escrita em Portugal no século XVII. Lisboa: Faculdade de Letras da Universidade de Lisboa, 1996 (Tese de Doutorado).

86.MARTINS, Wilson. História da inteligência brasileira. São Paulo: Cultrix: Edusp, 1977-78, v. 1.

87.MATTOSO, Katia de Queirós. Presença francesa no movimento democrático baiano de 1798. Salvador: Itapuã / Secretaria de Educação e Cultura do Estado da Bahia, 1969. 
88.MAURO, Frédéric (coord.). O império Luso-Brasileiro: 1620-1750. Lisboa: Editorial Estampa, 1991.

89.MAXWELL, Kenneth. A devassa da devassa: a Inconfidência Mineira, Brasil - Portugal, 17501808. 3 ed. Rio de Janeiro: Paz e Terra, 1985.

90. Pombal: paradox of the Enlightenment. New York: Cambridge University Press, 1995.

91. MELLO, Evaldo Cabral de. O nome e o sangue: uma fraude genealógica no Pernambuco Colonial. São Paulo: Companhia das Letras, 1989.

92.MIRANDA, Tiago Costa Pinto dos Reis. Ervas de ruim qualidade: a expulsão da Companhia de Jesus e a aliança anglo-portuguesa: 1750-1763. São Paulo: FFLCH-USP, 1991 (Dissertação de mestrado).

93.MORA, Adelina Sarrión. Sexualidad y confesión: la solicitación ante el tribunal del Santo Oficio (siglos XVI-XIX). Madrid: Alianza Editorial, 1994.

94.MORAES, Rubens Borba de. Bibliografia brasileira do período colonial: catálogo comentado das obras dos autores nascidos no Brasil e publicadas antes de 1808. São Paulo: IEB, 1969.

95. . Livros e bibliotecas no Brasil colonial. São Paulo: Secretaria da Cultura, Ciência e Tecnologia do Estado de São Paulo, 1979.

96.MOTA, Carlos Guilherme. Idéia de Revolução no Brasil: (1789-1801) - Estudo das Formas de Pensamento. Petrópolis: Vozes, 1979.

97.MOTT, Luiz. A inquisição no Maranhão. São Luiz: Edufma, 1995. 98. $O$ sexo proibido: escravos, gays e virgens nas garras da Inquisição. Campinas: Papirus, 1988.

99.MULLET, Michael. A Contra-Reforma. Lisboa: Gradiva, 1985.

100.NEGRONI, Barbara de. Lectures interdites: le travail des censeurs au XVIIIe siècle, 1723-1774. Paris: Albin Michel, 1995.

101.NEVES, Guilherme Pereira das. O seminário de Olinda: educação, cultura e política nos tempos modernos. Rio de Janeiro: Universidade Federal Fluminense. Niterói, 1984. 2 v. (Dissertação de mestrado)

102.NEVES, Luiz Felipe Baêta. O combate dos soldados de Cristo na Terra dos Papagaios: colonialismo e repressão cultural. Rio de Janeiro: Forense-Universitária, 1978.

103.NOVAIS, Fernando Antônio. Portugal e Brasil na crise do antigo sistema colonial: 1777-1808. 2 ed. São Paulo: Hucitec, 1981.

104.OUTRAM, Dorinda. The Enlightenment. Cambridge: Cambridge University Press, 1995.

105.PAIVA, José Maria de. Colonização e catequese: 1549-1600. São Paulo: Autores Associados/ Cortez, 1982.

106.PÉCORA, Alcir. Teatro do sacramento: a unidade teológico-retórico-política dos sermões de Antônio Vieira. São Paulo: Edusp: Campinas: Universidade de Campinas, 1994.

107.PIANZOLA, Maurice. Os Papagaios Amarelos: os franceses na conquista do Brasil. São Luís: Secretaria da Cultura do Estado do Maranhão, 1992. 
108.PIRES, Maria do Carmo. Juízes e infratores: o tribunal eclesiástico do bispado de Mariana (17481800).Franca: Faculdade de História, Direito e Serviço Social da Unesp, 1997 (Dissertação de mestrado).

109.PIZARRO, Ana (org.). América Latina: palavra, literatura e cultura. São Paulo: Memorial: Campinas: Unicamp, 1993.

110.POLITO, Ronald. A persistência das idéias e das formas: um estudo sobre a obra de Tomás Antônio Gonzaga. Niterói: Universidade Federal Fluminense, 1990 (dissertação de mestrado).

111.PRIORE, Mary del. Ao sul do corpo: condição feminina, maternidades e mentalidades no Brasil colônia. Rio de Janeiro: José Olympio: Brasília: Edunb, 1993.

112.RADCLIFFE-BROWN, Alfred Reginald. Estrutura e função na sociedade primitiva. Petrópolis: Vozes, 1973.

113.RIBEIRO, Márcia Moisés. A ciência dos trópicos: a arte médica no Brasil no século XVIII. São Paulo: Hucitec, 1997.

114.RIBEIRO, Maria Luísa Santos. História da educação brasileira. 5 ed. São Paulo: Moraes, 1989.

115.RIZZINI, Carlos. O livro, o jornal e a tipografia no Brasil, 1500-1822: com um breve estudo geral sobre a informação. São Paulo: Imprensa Oficial do Estado, 1988.

116.RODRIGUES, José Carlos. Idéias filosóficas e políticas em Minas Gerais no século XIX. Belo Horizonte: Itatiaia: São Paulo: Edusp, 1986.

117.ROMEIRO, Adriana. Um visionário na corte de D. João V: revolta e milenarismo em Minas Gerais. Campinas: Unicamp, 1996 [Tese de doutoramento].

118.SANTOS, Afonso Carlos Marques dos. No rascunho da nação: Inconfidência no Rio de Janeiro. Rio de Janeiro: Secretaria Municipal de Cultura, Turismo e Esportes, Departamento Geral de Documentação e Informação Cultural, Divisão de Editoração, 1992.

119.SILVA, Maria Beatriz Nizza da (coord.). Cultura portuguesa na Terra de Santa Cruz. Lisboa: Editorial Estampa, 1995.

120. (coord.). Dicionário da história da colonização portuguesa no Brasil. Lisboa: Verbo, 1994.

121 (coord.). O Império Luso-Brasileiro (1750-1822). Lisboa: Editorial Estampa, 1986.

122. Cultura e sociedade no Rio de Janeiro (1808-1821). 2 ed. São Paulo: Companhia Editora Nacional, 1978.

123. Sistema de casamento no Brasil colonial. São Paulo: T. A. Queiroz: Edusp, 1984.

124.SIQUEIRA, Sônia Apparecida. A inquisição portuguesa e a sociedade colonial. São Paulo: Ática, 1978.

125.SKINNER, Quentin. As fundações do pensamento político moderno. Trad. Renato Janine Ribeiro e Laura Teixeira Motta. São Paulo: Companhia das Letras, 1996.

126.SOUZA, Laura de Mello e. Inferno atlântico: demonologia e colonização: séculos XVI e XVIII. São Paulo: Companhia das Letras, 1993. 
127. O Diabo e a Terra de Santa Cruz: feitiçaria e religiosidade popular no Brasil colonial. São Paulo: Companhia das Letras, 1986.

128. Desclassificados do ouro: a pobreza mineira no século XVIII. 2 ed. Rio de Janeiro: Graal, 1986.

129.TAVARES, Luís Henrique Dias. História da sedição intentada na Bahia em 1798: a conspiração dos alfaiates. São Paulo: Pioneira, 1975.

130. Introdução ao estudo das idéias do movimento revolucionário de 1798. Salvador: Livraria Progresso Editora/ União Baiana dos Escritores, 1959.

131.TORGAL, Luís Reis. Ideologia política e teoria do estado na restauração. Coimbra: Biblioteca da Universidade, 1982. 2 v.

132. VARGUES, Isabel Nobre. A revolução de 1820 e a instrução pública. Porto: Paisagem Editora, 1984.

133.TREVOR-ROPER, H. R. De la réforme aux Lumières. Trad. Laurence Ratier. Paris: Éditions Gallimard, 1996.

134.TRINDADE, côn. Raymundo. Breve notícia dos seminários de Mariana. Mariana: Arquidiocese de Mariana, 1951.

135.VAINFAS, Ronaldo. Trópico dos pecados: moral, sexualidade e inquisição no Brasil. Rio de Janeiro: Campus, 1989.

136.VIGUERIE, Jean de. Histoire et dictionnaire du temps des Lumières (1715-1789). Paris: Robert Laffont, 1995.

137.VILLALTA, Luiz Carlos. A "torpeza diversificada dos vícios": celibato, concubinato e casamento no mundo dos letrados de Minas Gerais (1748-1801). São Paulo: FFLCH-USP, 1993. (Dissertação de mestrado).

138.WEBSTER'S Biographical Dictionary. Springfield [Mass.]: G. \& C. Merriam, 1943.

139.WERNET, Augustin. A igreja paulista no século XIX: a reforma de D. Antônio Joaquim de Melo (1851-1861). São Paulo: Ed. Ática, 1978.

140.XAVIER, Ângela Barreto. “El Rei aonde póde, \& não aonde quér”: razões da política no Portugal seiscentista. Lisboa: Colibri, 1998. 